UNIVERSIDADE DE SÃO PAULO

FACULDADE DE FILOSOFIA, LETRAS E CIÊNCIAS HUMANAS DEPARTAMENTO DE TEORIA LITERÁRIA E LITERATURA COMPARADA

PROGRAMA DE PÓS-GRADUAÇÃO EM TEORIA LITERÁRIA E LITERATURA COMPARADA

THIAGO RHYS BEZERRA CASS

\title{
Ossian e o crepúsculo da epopeia
}

São Paulo

2015 


\section{THIAGO RHYS BEZERRA CASS}

\section{Ossian e o crepúsculo da epopeia}

Tese apresentada ao Programa de PósGraduação do Departamento de Teoria Literária e Literatura Comparada, da Faculdade de Filosofia, Letras e Ciências Humanas, da Universidade de São Paulo, como requisito à obtenção do título de Doutor em Letras.

Orientadora: Professora Doutora Sandra Guardini T. Vasconcelos

São Paulo 


\section{FOLHA DE APROVAÇÃO}

Thiago Rhys Bezerra Cass

Ossian e o crepúsculo da epopeia

Tese apresentada ao Programa de PósGraduação do Departamento de Teoria Literária e Literatura Comparada, da Faculdade de Filosofia, Letras e Ciências Humanas, da Universidade de São Paulo, como requisito à obtenção do título de Doutor em Letras.

Aprovado em:

BANCA EXAMINADORA

Professor(a) Doutor(a)

Instituição Assinatura:

Professor(a) Doutor(a)

Instituição Assinatura:

Professor(a) Doutor(a)

Instituição Assinatura:

Professor(a) Doutor(a)

Instituição Assinatura:

Professor(a) Doutor(a)

Instituição Assinatura: 
À memória de meu pai, MARK JULIAN Richter CASS. 


\section{AGRADECIMENTOS}

Os Agradecimentos são uma instância inescapável para a legitimação intelectual e acadêmica de uma obra como esta. Por vias indiretas, toma-se de empréstimo a credibilidade dos grandes mestres e pesquisadores, metonimicamente inscrita em seus nomes, na esperança de desarmar as inevitáveis objeções que aparecerão no decorrer da leitura. Como observaria Samuel Johnson, a referência aos figurões constitui uma insinuação velada de que alguém muito importante endossa ao menos parte do que se encontrará nas próximas páginas. Estes Agradecimentos, no entanto, não devem ser lidos assim. Trata-se apenas do reconhecimento de que, sem a ajuda das pessoas listadas abaixo, jamais conseguiria completar este trabalho.

Minha maior dívida é com minha orientadora, Professora Sandra Guardini Teixeira Vasconcelos. Ao longo de quase uma década, ela me guiou em meus estudos com sua imensa generosidade intelectual, sempre disposta a mostrar o caminho das pedras, sem abrir mão de seu proverbial rigor. Sua expertise foi complementada pela do Professor Thomas Keymer, meu orientador durante meu estágio de pesquisa junto ao Departamento de Inglês da Universidade de Toronto, no Canadá. Seus padrões inalcançáveis de excelência acadêmica mostraram-me a importância de substanciar qualquer discussão teórica com dados empíricos. A forma que tomou minha hipótese de trabalho se deve muito às correções minuciosas e pertinentes dos Professores Eduardo Vieira Martins e John Corbett durante o exame de qualificação.

Sinto-me privilegiado pelas condições em que pude conduzir minha pesquisa. Aprendi muito: com meus Professores de pós-graduação, Marta Kawano e Franklin de Matos; nos seminários da associação de dix-huitièmistes da Universidade de Toronto, sob a coordenação do Professor Simon Dickie; e em grupos de estudo sobre romantismo (comandado pelo meu amigo e landlord Daniel Lago Monteiro) e poesia setecentista 
(sob a direção de Matt Risling). Foi de fundamental importância o auxílio que recebi dos serviços de apoio das bibliotecas da FFLCH, IEB, Thomas Fisher, Robarts e John W. Graham. Contei com a ajuda dos funcionários e coordenadores das comissões de cooperação internacional daqui e do Canadá, com a receptividade dos Professores Claudio Possani e Heather Murray e com a presteza dos funcionários do Departamento de Teoria Literária e Literatura Comparada, em especial do inigualável Luiz de Mattos Alves. Nada se compara, entretanto, ao apoio que recebi da Fundação de Amparo à Pesquisa do Estado de São Paulo - Fapesp, que subvencionou meu trabalho de 2011 a 2015, por meio da concessão de duas bolsas de estudo, sob a rubrica dos Processos Fapesp de número 2010/18863-7 e 2012/17474-2.

Queria pedir desculpas aos amigos pelas ausências, pelo silêncio recorrente e pelos cancelamentos de última hora, sempre por conta desta tese interminável. Estou em falta com Bruno, Carlão, Fabiana, Flávio, Guilherme, Kanitz, Liane, Marcus, Maurício, Paulo, Pedro e Rodrigo. Mando um abraço especial ao meu grande amigo Luís Fernandes dos Santos Nascimento, conselheiro, irmão mais velho e companheiro de longas conversas madrugada adentro. Ele saberá encontrar nestas páginas a influência das suas ideias.

Teria ficado pelo caminho sem a compreensão e o encorajamento da minha família, especialmente da minha mãe, Quezia Cass. Gostaria de ter passado mais tempo com cada um deles: Bia, Drica, John, Marthinha, Pedro, Susie e Tainá.

Ao longo desta trajetória, ninguém foi tão importante quanto minha mulher, Ingrid Braido, a quem dedicaria esta tese não fossem as circunstâncias. 
Homer's world, not ours.

(W. H. AudEn, "Memorial for the city") 


\section{RESUMO}

Correlaciona-se a síntese antitética havida nas narrativas longas de Ossian, Fingal e Temora, com a ascensão do romance no século XVIII. Conforme Hugh Blair inadvertidamente nos mostra em sua Dissertação sobre os Poemas de Ossian, as "traduções" de James Macpherson combinam os discursos incompatíveis do primitivismo e do neoclassicismo, a emergir como epopeias fraturadas, caso leiamos tais obras sob o signo de sua designação genérica ostensiva. No entanto, postula-se que a forma contraditória de Fingal e Temora captura a instabilidade intrínseca às narrativas novelísticas do século XVIII, que problematizam a distância entre o narrador e o narrado.

PALAVRAS-CHAVE: Ossian; James Macpherson; epopeia; romance; Fingal e Temora. 


\section{ABSTRACT}

This dissertation is invested in correlating the antithetical synthesis brought about by Ossian's longest narratives, Fingal and Temora, to the rise of the eighteenth-century novel. As Hugh Blair inadvertently showed in his Dissertation on the Poems of Ossian, James Macpherson's most ambitious 'translations' conflate opposing primitivistic and neoclassical discourses, thereby emerging as unredeemably fractured and unstable epics, if one reads them in compliance with their ostensive generic label. Instead, I argue that the contradictory form of Fingal and Temora re-enacts that of eighteenthcentury novelistic narratives, which problematize the distance between narrator and narrated.

KEYWORDS: Ossian; James Macpherson; epics; the novel; Fingal and Temora. 


\section{PREFÁCIO}

Este Prefácio não contém considerações teóricas. A abordagem ensaística torna um tanto absurda a compartimentalização da teoria à prática crítica. Entretanto, creio que quatro observações se fazem necessárias, para que se clarifiquem alguns dos procedimentos adotados ao longo desta tese. Em primeiro lugar, tomo os gêneros literários como construções históricas, uma afirmação que pressupõe a conjunção das circunstâncias sociais à paisagem crítica e criativa do período estudado, num regime de codeterminação. Um corolário desse tipo de abordagem é a exposição da longa sedimentação de um gênero literário: as questões estéticas mobilizadas, os impasses composicionais e o quadro social em que se inseria. Diante disso, dediquei-me consideravelmente à discussão de fontes primárias, de escritos críticos e ficcionais virtualmente esquecidos fora dos círculos de dix-huitièmistes. Embora as referências sejam um tanto obscuras, procurei sempre incorporá-las ao texto, por meio de citações, para que se possa acompanhar a argumentação.

Escrever sobre os Poemas de Ossian sob uma perspectiva histórica implica digladiar-se com uma terminologia que varia do embaraçoso ao opaco. Muitas das categorias correntes à época se tornaram inaceitáveis hoje, como primitivo, efeminado e selvagem. No entanto, nelas se enfeixa um repertório indispensável a qualquer tentativa séria de se mergulhar no universo cultural e literário do século XVIII. Obviamente, busquei sempre manter distanciamento crítico, mas sei que, por mais que se tenha revisado estas páginas, sempre haverá alguém a imputar um preconceito que é dos textos - e nunca, jamais, meu. Por outro lado, as composições ossiânicas constituem um teste de fogo para o manuseio do vocabulário crítico e teórico. O lamaçal das questões de autenticidade e originalidade do corpus ossiânico transforma, de saída, termos como autor, tradutor, editor e narrador, dentre outros, em designações inescapavelmente 
parciais, redutoras e capciosas, mesmo para aqueles que não beberam de águas pósestruturalistas. Tentei dar alguma sistematicidade à terminologia empregada, mas com resultados duvidosos.

Num outro nível, a virada dialética que se empreende do capítulo 1 para o capítulo 2 proporciona constrangimentos. Em muitos pontos, é necessário repetir trechos ou passagens já analisadas, na tentativa de ressignificá-las à luz de novas considerações. Por outro lado, seria por demais tedioso recapitular paráfrases e definições feitas muitas páginas antes. Buscou-se um difícil equilíbrio entre inteligibilidade e fluidez. Novamente, não é possível dizer que se obteve sucesso.

Por fim, cabe uma palavra sobre as lacunas da tese que se abre nas páginas subsequentes. Minha aproximação dos épicos ossiânicos com o romance é inevitavelmente seletiva. Interesso-me sobretudo pelas narrativas em que julgo enxergar a corporificação do processo de especificação do gênero novelístico, deixando de lado algumas obras e subgêneros cujas afinidades estilísticas e temáticas com o experimento ossiânico talvez demandassem um olhar mais detido. Passa-se ao largo, por exemplo, da consolidação do dito romance sentimental, da refiguração do romanesco pelo romance gótico e do crescente interesse pelo idioma do sublime na segunda metade do século XVIII. São caminhos que têm sido explorados de maneira consistente e convincente pela crítica. Não se questiona nem se contrapõe a nenhuma dessas abordagens. Penso apenas que se as incorporasse ao meu argumento talvez obscurecesse ou inviabilizasse a exposição das contradições que saturam Fingal e Temora e o romance setecentista. 


\section{SUMÁRIO}

Prefácio

Ponto de PARTIDA

1. DISJUNÇÃo ÉPICA

1. O problema da forma 21

2. Neoclássicos 34

3. Primitivistas 54

4. De volta a Fingal e Temora 63

4.1 Anotações à margem 63

4.2 Poemas heroicos 65

4.3 Poemas épicos 90

4.3.1 Fingal 93

4.3.2 Temora 123

2. CONCILIAÇÃo NOVELÍSTICA 136

1. Totalidades paralelas 136

2. A síntese do heterogêneo 160

2.1 Forma à instabilidade 163

2.2 Aphra Behn 185

2.3 Love in excess 194

2.4 Defoe 204 
2.5 Clarissa

3. Sir Fingal Grandison

REFERÊNCIAS BIBLIOGRÁFICAS 


\section{PONTO DE PARTIDA}

O fervor com que os Poemas de Ossian (1760-1763) foram recebidos na Europa e nas Américas é notório. ${ }^{1}$ Atribuídas a um velho bardo celta do século III d. C., essas composições supostamente traduzidas pelo escocês James Macpherson encontraram a acolhida de leitores como Goethe, Thomas Jefferson e José de Alencar.

Menos conhecida é a fortuna da Dissertação crítica sobre os poemas de Ossian, de Hugh Blair, publicada como anexo às traduções de Macpherson a partir de 1765. É difícil exagerar o interesse com que esse opúsculo foi lido por seus contemporâneos, sendo saudado por gente das mais diversas latitudes teóricas, tanto na Grã-Bretanha quanto no Continente. David Hume, por exemplo, afirmaria estar diante da melhor peça crítica da língua inglesa. E Johann Gottfried Herder aguardaria ansioso por sua tradução. ${ }^{2}$ Afirma-se que parte da reputação alcançada pela poesia ossiânica deveu-se à Dissertação de Blair. ${ }^{3}$

\footnotetext{
${ }^{1}$ Ver, dentre outros: GASKILL, Howard (ed.). The reception of Ossian in Europe. Londres: Continuum, 2008, passim; GASKILL, Howard. "Ossian in Europe". Canadian review of Comparative Literature, v. 21, n. 4 (dezembro, 1994), p. 643-675; VAN TIEGHEM, Paul. Ossian et l'ossianisme dans la littérature européenne aux XVIII siècle. Haia: J. B. Wolters, 1920, passim; VAN TIEGHEM, Paul. Ossian en France. Paris : F. Rieder, 1917. 2 t., passim; CARPENTER, Frederic. "The vogue of Ossian in America". American literature, v. 2, n. 4 (janeiro, 1931), p. 405-417; MONTIEL, Isidoro. "Ossián en la literatura argentina”. Revista interamericana de bibliografia, v. 19, n. 2 (abril - junho, 1969), p. 146-179; AGUIAR, Ofir Bergemann. Ossian no Brasil. Goiânia: UFG, 1999, passim; HENRIQUES, Ana Lucia de Souza. "Machado de Assis, leitor de Ossian". In: JOBIM, José Luís (org.). A biblioteca de Machado de Assis. Rio de Janeiro: Academia Brasileira de Letras - Topbooks, 2001, p. 277-287; BÄR, Gerald. Poesias de Ossian: antologia das traduções em português. Lisboa: Universidade Católica, 2010, passim.

${ }^{2}$ Cf. RIZZA, Steve. "A bulky and foolish treatise? Hugh Blair's Critical dissertation reconsidered". In: GASKILL, Howard (ed.). Ossian revisited. Edimburgo: Edinburgh University, 1991, p. 129-146, especialmente p. 129.

${ }^{3}$ GASKILL, Howard. "Blair's A critical dissertation on the poems of Ossian". In: MACPHERSON, James. The poems of Ossian and related works. Ed. Howard Gaskill. Edimburgo: Edinburgh University, 1996, p. 542-543, nota 1. Antonio Candido e Eduardo Vieira Martins atestam a ressonância da obra mais importante de Blair, as Lições sobre Retórica e Belas Letras, em Portugal e no Brasil (ver CANDIDO, Antonio. Formação da literatura brasileira. 9. ed. Belo Horizonte - Rio de Janeiro: Itatiaia, 2000, v. 2, p. 308; MARTINS, Eduardo Vieira. A fonte subterrânea: José de Alencar e a retórica oitocentista. Londrina:
} 
Tamanha simpatia não era sem fundamento. $O$ texto impressiona pelas referências que mobiliza, ${ }^{4}$ cuja multiplicidade se antecipa logo na sucinta Advertência que precede a primeira edição, de 1763:

Nesta dissertação, propõe-se: fazer algumas observações quanto à poesia antiga das nações, especialmente a rúnica e a celta; assinalar que traços de antiguidade portam as obras de Ossian; dar ideia do espírito e estilo de sua poesia; e, após aplicar as regras da crítica a Fingal, na condição de poema épico, examinar o mérito das composições de Ossian em geral, considerando-se descrições, imagens e sentimento. ${ }^{5}$

Com efeito, o professor da Universidade de Edimburgo ${ }^{6}$ percorre uma longa trajetória argumentativa, em que postula generalidades sobre a poesia antiga e aprecia uma obra conforme o gênero literário a que se filia. Sente-se à vontade para discorrer sobre a língua das ditas sociedades antigas, seu modo de vida e como tais são propícios à produção de poemas heroicos. Quando necessário, transcreve literatura gótica extraída da coletânea Literatura Runica, de Olaus Wormius. Na sua exposição sobre a sociedade celta, colige abalizadas fontes romanas, como César e Lucano. E, não satisfeito em rastrear a presença das características que atribui à poesia antiga nos poemas de Ossian, decide determinar seu mérito à luz do que chama de "regras da crítica".

Eduel - São Paulo: Edusp, 2005, p. 12 e ss.). Para uma listagem mais ou menos global das edições, antologias e adaptações dos escritos de Hugh Blair nos séculos XVIII e XIX, ver: SCHMITZ, Robert Morell. Hugh Blair. Morningside Heights, NY: King's Crown, 1948, p. 143-145. Nos Estados Unidos, pode-se detectar o uso das Lições como ferramenta de ensino até as primeiras décadas do século XX. Com efeito, uma edição condensada de seus ensinamentos viria a público em 1911 (STAFFORD, Fiona. STAFFORD, Fiona. "Blair's Ossian, romanticism, and the teaching of literature". In: CRAWFORD, Robert (ed.). The Scottish invention of English literature. Cambridge: Cambridge University, 1998, p. 6888, especialmente p. 68).

${ }^{4}$ Para uma discussão da Critical dissertation, ver RIZZA, Steve. "A bulky and foolish treatise? Hugh Blair's Critical dissertation reconsidered" cit., p. 130-131.

5 "In this Dissertation, it is proposed, to make some Observations on the ancient Poetry of Nations, particularly the Runic and the Celtic; to point out those characters of Antiquity, which the works of Ossian bear; to give an Idea of the Spirit and Strain of his Poetry; and after applying the Rules of Criticism to Fingal, as an Epic Poem, to examine the Merit of Ossian's compositions in general, with regard to Description, Imagery, and Sentiment" (BLAIR, Hugh. A critical dissertation on the poems of Ossian, the son of Fingal. Londres, 1763, paginação sem número). Todas as outras citações serão da segunda edição da Critical dissertation (publicada em 1765 e incorporada à terceira edição, do mesmo ano, dos poemas ossiânicos), reproduzida na edição sob os cuidados de Howard Gaskill: BLAIR, Hugh. "A critical dissertation on the poems of Ossian, the son of Fingal". In: MACPHERSON, James. The poems of Ossian and related works cit., p. 343-408. Salvo menção em contrário, todas as traduções contidas nesta tese são de minha autoria.

${ }^{6}$ Blair foi o primeiro professor de literatura inglesa numa universidade britânica (cf. STAFFORD, Fiona. STAFFORD, Fiona. "Blair's Ossian, romanticism, and the teaching of literature" cit., p. 68).

${ }^{7}$ Uma versão resumida e preliminar da Dissertação de Blair pode ser encontrada na transcrição de uma aula sua sobre os Poemas de Ossian (ver SUDO, Yoshiaki. "An unpublished lecture of Hugh Blair on the Poems of Ossian". The Hiyoshi review of English studies, v. 25 (março, 1995), p. 160-94). Sobre as transcrições estudantis dos cursos de Blair, ver HATCH, Gary Lane. "Sudent Notes on Hugh Blair's 
Uma leitura atenta dos autores citados por Blair, no entanto, indica que a imensa erudição demonstrada trai a conciliação de abordagens radicalmente distintas. A primeira está calcada na aferição "dos traços de antiguidade que portam as obras de Ossian”. A segunda é marcada pela mobilização de normas ou prescrições estabelecidas por um conjunto de doutrinadores, conforme se depreende da formulação "regras da crítica". ${ }^{8}$ Noutras palavras, uma análise que apela a critérios universalistas é jungida ao interesse pela particularidade histórica de seu objeto.

Logo no parágrafo de abertura da Dissertação, argumenta-se que as composições imaginativas constituem dos maiores monumentos que os antigos nos legaram. Oferecem-nos acesso a seu modo de vida, aos objetos que admiravam e às ideias e emoções que cultivavam. Para os "observadores filosóficos da natureza humana", 9 poesia e outras formas ficcionais teriam muito mais importância que qualquer narrativa historiográfica, porquanto os antigos registrariam os eventos de maneira esparsa, pouco instrutiva e sob o véu de uma "confusão fabulosa". ${ }^{10}$ Para as "pessoas de gosto", no entanto, as composições dos antigos teriam um "mérito" ainda maior, dado que seriam depositárias de qualidades como "entusiasmo", "veemência" e "fogo":

Irregulares e não refinadas, é-nos lícito supor que sejam as produções de tempos incultos; porém, ao mesmo tempo, abundantes daquele entusiasmo, daquela veemência e daquele fogo que são a alma da poesia. ${ }^{11}$

Correlacionam-se os traços "irregulares" das "produções dos tempos incultos" a atributos que "são a alma da poesia", num expediente em que se tomam as circunstâncias sociais e históricas como as forças definidoras da aptidão à criação literária. Entusiasmo, veemência e fogo não são apenas qualidades que se encontram com frequência nas obras de antanho. São, em verdade, atributos da expressividade "não refinada", que se manifestam mesmo em ocasiões relativamente banais, uma vez que "[u]m cacique americano, hoje em dia, perora defronte de sua tribo num estilo

lectures on Rhetoric". In: GAILLET, Lynee Lewis (ed.). Scottish Rhetoric and its influences. Mahwah, NJ: Hermagoras, 1998, p. 79-94.

${ }^{8}$ Sobre esse diálogo, ver SWEDENBERG JR., H. T. The theory of the epic in England: 1650-1800. Berkeley - Los Angeles: University of California, 1944, p. 114-118. Ver também RUBEL, Margaret Mary. Savage and barbarian: historical attitudes in the criticism of Homer and Ossian in Britain, 17601800. Amsterdã - Oxford - Nova Iorque: North Holland, 1978, p. 70-101, especialmente p. 91-94.

9 “[...] philosophical observers of human nature" (BLAIR, Hugh. "A critical dissertation on the poems of Ossian, the son of Fingal" cit., p. 343).

10 "[...] fabulous confusion" (idem, ibidem).

11 "Irregular and unpolished we may expect the productions of uncultivated ages to be; but abounding, at the same time, with that enthusiasm, that vehemence and fire, which are the soul of poetry" (idem, p. 345). 
muito mais arrojado e metafórico que um europeu moderno se aventuraria a usar num poema épico". ${ }^{12}$ A origem de tamanha inclinação à eloquência, segundo Blair, encontrava-se na conformação do ânimo dos antigos. Quando mudam as condições históricas, mudam-se os predicados da mente humana. Por exemplo: a inventividade seria um atributo coetâneo à barbárie. O homem moderno seria demasiado cioso do pensamento metódico e regrado, o que o tornava desdenhoso de incursos na fantasia: ${ }^{13}$

Com o progresso da sociedade, o gênio e os hábitos humanos passam por mudanças mais favoráveis à acuidade que a vivacidade $\mathrm{e}$ sublimidade. Conforme o mundo avança, o entendimento toma o lugar da imaginação: o entendimento é mais exercitado; a imaginação, menos. ${ }^{14}$

Postula-se uma continuidade entre a organização social, o feitio das faculdades mentais e os elementos distintivos da expressão literária. Tem-se uma análise na qual se subsume a "imaginação humana" aos "objetos e paixões" correntes num determinado “estágio [...] de costumes":

É provável [...] que uma extensa busca descobriria certa semelhança entre todas as produções poéticas mais antigas, independentemente do país de sua procedência. Num estágio similar de costumes, objetos e paixões semelhantes, ao operarem sobre a imaginação humana, imprimirão a suas produções o mesmo caráter geral. Algumas diferenças, sem dúvida, serão ocasionadas pelo clima e pelo gênio. ${ }^{15}$

Blair esboça a "extensa busca" de semelhanças "entre as produções poéticas mais antigas”. Efetivamente, arrola os elementos definidores do que julga ser o estilo “inculto". Tais elementos, contudo, não são elencados como se faria num manual de retórica: por exemplo, um capítulo dedicado a aliterações, outro às assonâncias e um terceiro às hipérboles. Não: a discussão das figuras de linguagem é implexa numa exposição que poderíamos chamar de antropológica, na qual se dá amplo destaque ao modo de vida dos povos antigos. Vejamos como se dá essa discussão.

\footnotetext{
12 "An American chief, at this day, harangues at the head of his tribe, in a more bold and metaphorical style, than a modern European would adventure to use in an Epic poem" (idem, p. 346).

${ }^{13}$ Ver RIZZA, Steve. “A bulky and foolish treatise?” cit., p. 129-146.

14 "In the progress of society, the genius and manners of men undergo a change more favourable to accuracy than to sprightliness and sublimity. As the world advances, the understanding gains ground upon the imagination; the understanding is more exercised; the imagination, less" (BLAIR, Hugh. "A critical dissertation on the poems of Ossian, the son of Fingal" cit., p. 346).

15 "It is probable [...] that an extensive search would discover a certain degree of resemblance among all the most ancient poetical productions, from whatever country they have proceeded. In a similar state of manners, similar objects and passions, operating upon the imaginations of men, will stamp their productions with the same general character. Some diversity will, no doubt, be occasioned by climate and genius" (idem, p. 347).
} 
No início, não haveria agrupamentos sob os quais as pessoas pudessem se congregar. Vagavam dispersas, em frequente isolamento. Travando pouco contato com seus semelhantes, seu principal afazer era contemplar a natureza. Sem meios para explicar os fenômenos com que se defrontavam, os antigos sentiam-se acuados num mundo terrivelmente vasto e desconhecido, permeado por surpresas e temores. Suas vidas eram instáveis, pois inexistiam anteparos institucionais ou materiais que os protegessem de imprevistos. Sucessivos reveses encheriam o espírito de furor, a obnubilar a razão. ${ }^{16}$

Tamanho estado de desordem emocional inevitavelmente afetava a linguagem. A excitação que se agita à mente demanda ser extravasada num tom carregado de sentimentalidade. Isso, por si só, confere ao discurso um aspecto poético. Essa sentimentalidade, no entanto, tem livre curso, porquanto não tem de transpor convenções sociais ou é tolhida por regras de comportamento. Os antigos de Blair eram francos e diretos, não escondiam o que se passava em seus corações. E como seu léxico era pouco desenvolvido, o uso de tropos fazia-se recorrente. Afinal, era preciso comunicar o emaranhado de impressões que não encontravam tradução adequada na fala ordinária. O recurso a símiles e comparações se tornava inevitável:

Homens nunca usaram tantas figuras de estilo quanto naqueles tempos rudes, quando, além do poder de uma imaginação cálida para sugerir imagens animadas, a falta de termos próprios e precisos para as ideias que iriam expressar obrigou-os a recorrer a perífrases, metáforas, comparações e todas aquelas formas substitutivas que dão um ar poético à linguagem. ${ }^{17}$

Como se pode notar, o procedimento de amarrar a exegese textual ao comentário antropológico tem certa dificuldade em determinar a especificidade de seu objeto de estudo. A obra literária se converte num decalque de condicionantes sociais e históricas, das quais, em tese, o autor não teria como abstrair. Os traços distintivos que a Dissertação atribui à literatura antiga se estendem a "todos os países num certo período", ${ }^{18}$ inclusive às composições ossiânicas. Assim, Blair parece menos interessado

\footnotetext{
${ }^{16}$ Ver idem, p. 345.

17 "Men never have used so many figures of style, as in those rude ages, when, besides the power of a warm imagination to suggest lively images, the want of proper and precise terms for the ideas they would express, obliged them to have recourse to circumlocution, metaphor, comparison, and all those substituted forms of expression, which give a poetical air to language" (idem, p. 346).

18 "[...] all nations at a certain period" (idem, p. 347).
} 
em apreender os Poemas de Ossian em sua integridade morfológica (Gestalt) que, propriamente, derivar seus "caracteres" de uma "era bem remota": 19

As composições de Ossian são tão fortemente marcadas com os caracteres de antiguidade que, embora não haja nenhuma prova externa que confirme essa antiguidade, dificilmente algum leitor com discernimento ou gosto poderia hesitar em reportá-las a uma era bem remota. ${ }^{20}$

Prefigura-se o repertório ossiânico pela realidade a ser representada pela criação literária. Tomam-se forma e estilo como extensões naturais de um "gênio poético" moldado pelos "hábitos da época", isentos dos "vícios [...] aos quais Longino imputa o declínio da poesia". ${ }^{21}$ Nesse diapasão, os "méritos" da poesia de Ossian seriam largamente creditáveis à "vida errante e indolente" dos antigos celtas, em que "a caça e a guerra eram as principais preocupações":

Os hábitos da época de Ossian, na medida em que podemos coletá-los de seus escritos, eram abundantemente favoráveis ao gênio poético. Os dois vícios desanimadores, aos quais Longino imputa o declínio da poesia, cupidez e efeminação, eram ainda desconhecidos. As preocupações humanas eram poucas. Vivia-se uma vida errante e indolente; a caça e a guerra eram as suas principais ocupações [...]. O grande objeto buscado pelos espíritos heroicos era "receber a sua fama", ou seja, tornar-se digno de ser celebrado nas canções dos bardos $[\ldots]$. Em tempos como esses, num país em que a poesia fora cultivada por tanto tempo, causa alguma surpresa que, dentre a raça e a linhagem de bardos, um Homero avultaria $[\ldots] ?^{22}$

Depois de discutir as obras atribuídas a Ossian por meio de observações históricas e generalizações quanto ao assim chamado espírito antigo, Blair intenta examinar "o

\footnotetext{
${ }^{19}$ Sobre a circularidade do argumento de Blair, ver: DENTITH, Simon. Epic and empire in nineteenthcentury Britain. Cambridge: Cambridge University, 2006, p. 24. Ver também: MANNING, Susan. "Ossian, Scott, and nineteenth-century Scottish nationalism". Studies in Scottish Literature, v. 17 (1982), p. 39-54.

20 "The compositions of Ossian are so strongly marked with characters of antiquity, that although there were no external proof to support that antiquity, hardly any reader of judgment and taste, could hesitate in referring them to a very remote æra" (BLAIR, Hugh. "A critical dissertation on the poems of Ossian, the son of Fingal" cit., p. 353).

${ }^{21}$ Ver LONGINUS, Dionysius. On the sublime. Trad. William Smith. 2. ed. London, 1747, p. 102-108. Sempre que puder, utilizarei traduções correntes quando da publicação da Dissertação de Blair.

22 "The manners of Ossian's age, so far as we can gather them from his writings, were abundantly favourable to the poetical genius. The two dispiriting vices, to which Longinus imputes the decline of poetry, covetousness and effeminacy, were as yet unknown. The cares of men were few. They lived a roving indolent life; hunting and war were their principal employments [...]. The great object pursued by heroic spirits, was "to receive their fame", that is, to become worthy of being celebrated in the songs of bards [...]. In such times as these, in a country where poetry had been so long cultivated, is it any wonder that among the race and succession of bards, one Homer should arise [...]?" (BLAIR, Hugh. "A critical dissertation on the poems of Ossian" cit., p. 352-353).
} 
primeiro grande poema desta coleção": ${ }^{23}$ Fingal. Neste ponto, todavia, sua abordagem sofre uma inesperada inflexão argumentativa. ${ }^{24} \mathrm{Seu}$ método de análise parece confrontar-se com um súbito esgotamento. São postas à parte quase todas as premissas que vinham guiando a Dissertação. Apela-se à autoridade de Aristóteles. Propõe-se demonstrar como Fingal seria (inconscientemente) construído em consonância com as regras para a produção de uma epopeia:

Recusar o título de poema épico a Fingal porque este não é, em cada detalhe, exatamente coincidente à prática de Homero e Virgílio, nada mais é que pedantismo e meticulosidade da crítica. Examinado mesmo de acordo com as regras de Aristóteles, ver-se-á que tem todos os requisitos de um épico verdadeiro e típico - e que os tem num grau tão elevado que, inicialmente, suscita nossa admiração ao descobrirmos a composição de Ossian tão conforme às regras das quais ele era completamente ignorante. $^{25}$

O apelo a Aristóteles - e, por conseguinte, a regras das quais Ossian "era completamente ignorante" - constitui uma violenta e surpreendente alteração nos rumos da Dissertação. Recorre-se a um receituário gestado em condições alheias tanto ao objeto que se intenta estudar quanto ao tempo em que se realizará o estudo. Aquiesce-se à existência de métodos gerais para apreciação literária, que permitem tomar uma obra como a encarnação "verdadeira" e "típica" de um modelo ubiquamente reconhecido, dotado de "regras fundamentais":

As regras fundamentais legadas por Aristóteles quanto a um poema épico são estas: que a ação, que é a base do poema, deve ser una, completa e grande; que deve ser fingida, [e] não meramente histórica; que deve ser avivada com personagens [caracteres] e hábitos; e elevada pelo maravilhoso. ${ }^{26}$

Adere-se tacitamente a uma abordagem que se pretende adstrita a critérios universais não só para a análise, mas, sobretudo, para a criação literária - aplicável, por exemplo, às composições de Homero, Virgílio e Ossian.

\footnotetext{
23 "[...] the first great poem in this collection" (idem, p. 358).

${ }^{24}$ Ver SWEDENBERG JR., H. T. The theory of the epic in England cit., p. 114.

25 "To refuse the title of an epic poem to Fingal, because it is not in every little particular, exactly conformable to the practice of Homer and Virgil, were the mere squeamishness and pedantry of criticism. Examined even according to Aristotle's rules, it will be found to have all the essential requisites of a true and regular epic; and to have several of them in so high a degree, as at first view to raise our astonishment on finding Ossian's composition so agreeable to rules of which he was entirely ignorant" (BLAIR, Hugh. A critical dissertation on the poems of Ossian cit., p. 358).

26 "The fundamental rules delivered by Aristotle concerning an epic poem, are these: That the action which is the groundwork of the poem, should be one, compleat, and great; that it should be feigned, not merely historical; that it should be enlivened with characters and manners; and heightened by the marvellous" (idem, ibidem).
} 
Diante disso, a Dissertação avulta como uma conciliação esquizofrênica de premissas incompatíveis, em que um amplo vocabulário crítico e teórico é mobilizado sem que se chegue a uma análise dotada de coerência. Se lermos os Poemas de Ossian com cuidado, no entanto, tamanha fratura argumentativa não parecerá despropositada. Ao contrário: ela expõe os compromissos antitéticos que se sedimentam na forma das traduções de Macpherson. 


\section{DISJUNÇ̃̃O ÉPICA}

\section{O problema da forma}

A Dissertação de Blair é uma peça de antologia. ${ }^{1}$ É um registro eloquente das tendências contraditórias da crítica setecentista na Grã-Bretanha: uma crítica interessada no que há de subjetivo na criação literária, porém insegura para se desfazer de parâmetros de análise que se querem gerais. ${ }^{2} \mathrm{O}$ aspecto exemplar desse opúsculo, todavia, tende a obscurecer sua intelecção. Com efeito, é fácil nos perdermos em adjetivos e deixarmos de enxergar aquilo que o retor escocês nos provê. Seu recurso às ditas regras da crítica em meio a uma exposição marcada por referências ao gênio poético desvenda as premissas da empreitada de Macpherson e deslinda o arranjo do experimento ossiânico.

Blair nos revela uma obra cuja fratura formal constitui sua primeira fundamentação estética. A afirmação talvez soe um tanto especiosa, dado que nos habituamos a enxergar toda obra como tentativa de resolução formal das tensões e contradições da realidade. ${ }^{3}$ Contudo, esse distanciamento analítico pode obscurecer as categorias literárias plasmadas nos Poemas de Ossian. O público setecentista decerto não as ignorava. A prosa poética de Ossian - em que se sucedem instâncias líricas, dramáticas e narrativas - jamais poderia ser entendida como um tecido textual coeso e

\footnotetext{
${ }^{1}$ Ver, por exemplo, ELLEDGE, Scott (ed.). Eighteenth-century critical essays. Ithaca, NY: Cornell University, 1961, v. 2, p. 1170-1171.

${ }^{2}$ Para uma explicação das tendências da crítica setecentista, ver BUTT, John; CARNALL, Geoffrey. The mid-eighteenth century. Oxford: Clarendon, 1979, p. 7 e 495-513. Para a conciliação das premissas analíticas de Blair, ver SWEDENBERG JR., H. T. The theory of the epic in England: 1650-1800. Berkeley - Los Angeles: University of California, 1944, p. 114-118 e RUBEL, Margaret Mary. Savage and barbarian: historical attitudes in the criticism of Homer and Ossian in Britain, 1760-1800. Amsterdã - Oxford - Nova Iorque: North Holland, 1978, p. 70-101, especialmente p. 91-94. Ver também DUFF, David. Romanticism and the uses of genre. Oxford: Oxford University, 2009, p. 21.

${ }^{3}$ Para essa discussão, ver JAMESON, Frederic. Marxism and form: twentieth-century dialectical theories of literature. Princeton, NJ: Princeton University, 1974, p. 328 e ss.
} 
uniforme. ${ }^{4} \mathrm{E}$ é essa percepção que faz com que as reações às traduções de Macpherson, tanto as positivas quanto as negativas, frequentemente tenham a forma como ponto focal.

Para nomes como Samuel Johnson, as composições ossiânicas eram quase um sinônimo - quando não de fraude - de imaturidade e descontrole artísticos. Fingal nada mais seria que "uma mera rapsódia desconexa, uma repetição tediosa das mesmas imagens". 5 Segundo Boswell, o célebre dicionarista não só negava a autenticidade das traduções de Macpherson; de modo ainda mais ofensivo, ele "sustentava que não tinham mérito algum". 6 Johnson diria, numa conversa com o próprio Hugh Blair, que qualquer um, inclusive mulheres e crianças, poderia escrever como Ossian. ${ }^{7}$ Diante de Joshua Reynolds, afirmaria que os Poemas podem ser dilatados indefinidamente, caso alguém se entregasse a esse exercício. ${ }^{8}$

Outros demonstravam um misto de confusão e entusiasmo em face dos Poemas. $^{9}$ No Gentleman's Magazine de julho de 1760, por exemplo, publicaram-se variações em dísticos heroicos dos "Fragmentos" V e XII, assinadas por F. M. e endereçadas a Sylvanus Urban. ${ }^{10}$ Pondera-se que, se algo se perdeu com essa "distração de duas manhãs", muita coisa se ganhou. A abertura do "Fragmento V",

O outono é sombrio nas montanhas; a névoa cinzenta descansa nas colinas. O rodamoinho está na charneca. Sombrio, o rio erra pela

\footnotetext{
${ }^{4}$ Sobre a percepção do público setecentista quanto à mistura de gêneros nos Poemas de Ossian, ver GASKILL, Howard. "Introduction: 'Genuine poetry... like gold"”. In: GASKILL, Howard (ed.). The reception of Ossian in Europe. Londres: Continuum, 2004, p. 1-20, especialmente p. 4.

5 "[...] a mere unconnected rhapsody, a tiresome repetition of the same images" (BOSWELL, James. Life of Johnson. Ed. R. W. Chapman. Oxford - Nova Iorque: Oxford University, 1980, p. 443)

${ }^{6}$ No original: "Johnson had all along denied their authenticity; and, what was still more provoking to their admirers, maintained that they had no merit" (idem, p. 280).

${ }^{7}$ Idem, ibidem.

${ }^{8}$ Idem, p. 1207. Para disputa entre Johnson e Ossian, ver STAFFORD, Fiona. "Dr. Johnson and the Ruffian: new evidence in the dispute between Samuel Johnson and James Macpherson". Notes and Queries, n. 36 (1989), p. 70-77 e, sobretudo, CURLEY, Thomas M. Samuel Johnson, the Ossian fraud and the Celtic revival in Great Britain and Ireland. Cambridge: Cambridge University, 2009, p. 82 e SS.

${ }^{9}$ Para Corina Laughlin, as adaptações com que lidaremos nas próximas páginas talvez constituam a melhor abordagem crítica da poesia ossiânica, dado que oferecem uma resposta aos problemas de linguagem e sentimento plasmados nas traduções de Macpherson (cf. LAUGHLIN, Corinna. "The Lawless Language of Macpherson's Ossian”. SEL, v. 40, n. 3 (verão, 2000), p. 511-537, especialmente p. 511). Da mesma autora, ver também: LAUGHLIN, Corinna. The Ossianic novel. Tese de Doutorado (PhD Dissertation). Seattle, WA: Washington University, 1998, p. 107 e ss.

${ }^{10}$ Pseudônimo do editor da Gentleman's Magazine.
} 
planície estreita. Uma árvore eleva-se solitária na colina e indica o túmulo de Connal. ${ }^{11}$

converte-se em

Agora, em trevas outonais, dobram-se as montanhas

E a névoa que se adensa acastanha as escuras colinas.

Sobre a parda charneca, brame o crescente rodamoinho

$\mathrm{E}$ as corredeiras, enegrecendo, transbordam suas margens lúgubres:

Sobre a colina verde, feito para erguer-se solitário,

$\mathrm{O}$ velho carvalho trai a jazida de Connal ${ }^{12}$

Com tal exercício, substituem-se períodos curtos e justapostos em parataxe por uma sequência caudalosa, coordenada em grande parte por conjunções aditivas. Verbos existenciais, como em "o outono é sombrio", são trocados por verbos actanciais, com que a sucessão de imagens silenciosas, perturbada somente pelo curso das águas, é engolfada por uma nova tensão dos elementos. Ademais, o ritmo fluido, em que se temperam pés iâmbicos com substituições anapésticas e inversões trocaicas, é abandonado em prol da marcha precisa do pentâmetro heroico. O escopo disso parece bastante claro: domesticar Ossian em fórmulas conhecidas. ${ }^{13}$ Impulso semelhante está na paródia Three beautiful and important passages omitted by the translator of Fingal, assinada por Donald Macdonald. ${ }^{14}$ Conforme indica o título, alega-se a descoberta de três excertos de poesia ossiânica, supostamente ignorados por Macpherson. Ressalvado o meio da prosa poética, entretanto, os achados de Macdonald pouco têm em comum com a parte, por assim dizer, canônica do corpus. Seu molde é o da Oriental tale: comparam-se os highlanders aos árabes e injeta-se nos excertos dose considerável de sensualidade luxuriante, uma das marcas do gênero:

Ó Shangger, filha de Conner-ea, ${ }^{15}$ quão traiçoeiros são teus beijos! Quão terríveis são teus abraços! Teus abraços são como as articulações de uma víbora juntando suas forças para precipitar sua

\footnotetext{
11 "Autumn is dark on the mountains; grey mist rests on the hills. The whirlwind is on the heath. Dark rolls the river thro' the narrow plain. A tree stands alone on the hill, and marks the grave of Connal" (MACPHERSON, James. "Fragment V". The poems of Ossian and related works cit., p. 13).

12 "Now with autumnal glooms the mountains frown,/ And settling mists the dusky hills imbrown; O'er the dun heath the gath'ring whirl-wind roars/ And the streams, black'ning, dash their sullen shores:/ On the green hill ordain'd alone to rise,/ The time-worn oak betrays where Connal lies" (F. M. "Poetical essays; July 1760". Gentleman's Magazine (1. ' de julho de 1760), p. 335-336, especialmente p. 335).

${ }^{13}$ LAUGHLIN, Corinna. The Ossianic novel cit., p. 111.

${ }^{14}$ Idem, ibidem.

${ }^{15}$ Conner-ea: quase homofonia para "gonorrhœa" - gonorreia. Agradeço o Professor John Corbett pela dica.
} 
fúria; teus beijos são como a grande voragem de Malstrom, nos mares da Noruega, a tragar-nos para o golfo da destruição. ${ }^{16}$

E havia aqueles para os quais o suposto descontrole das composições de Ossian constituía a sua verdadeira potência literária. A irregularidade dos Poemas seria a condição que lhes permitiria propiciar o máximo de sublimidade e sentimento. Dentre os partidários dessa abordagem, figuravam - ao menos nos primeiros anos da década de 1760 - o jovem Edmund Burke e Tobias Smollett. ${ }^{17}$ Em artigo não assinado para o Annual Register de 1761, o irlandês versa sobre o assunto em termos laudatórios. Descreve as poesias de Ossian como "extraordinárias" e como "relíquias inestimáveis do espírito genuíno da poesia". Ao vertê-las para o inglês, Macpherson teria, com "indústria e gosto", preservado o "ar majestoso" e a "simplicidade nativa" dos originais. Com isso, “o autor venerável e seu tradutor elegante mutuamente conferiram imortalidade um ao outro". ${ }^{18}$ Todos esses encômios fundam-se na avaliação de que o estilo e as ideias de Ossian, "tão diferentes dos modos modernos de expressão e pensamento", perfazem um tecido que nos afeta "com tudo que há de patético" e eleva "com tudo que há de sublime". 19

Para Smollett, caso levássemos em conta o juízo dos críticos, seriam inegáveis as falhas na execução das composições ossiânicas. Em Fingal, por exemplo, Ossian concedia pouca voz às suas personagens e quase não esparzia o maravilhoso em sua narrativa. Esses defeitos estruturais, contudo, não diminuiriam a beleza da obra. Surpreendentemente, eles esvaziariam o poema de instâncias conflituosas e imorais. As personagens ossiânicas não dariam curso a insultos ou comandos imperiosos, nem tampouco entidades sobrenaturais interveriam de maneira caprichosa, com o único propósito de resguardar seus interesses escusos. A forma de Fingal, portanto, seria

\footnotetext{
16 "O Shangger, Daughter of Conner-ea, how deceitful are thy Kisses! how dreadful are thy Embraces! Thy Embraces are like the Foldings of an Adder collecting her Strength to dart forth her Fury: thy Kisses are like the great Whirl-pool of Malstrom in the Ocean of Norway, sucking Man into the Gulph of Destruction" (MACDONALD, Donald. Three beautiful and important passages omitted by the translator of Fingal. Londres, 1762, p. 6).

${ }^{17}$ Para a leitura de Smollett, ver MOORE, Dafydd. "The reception of The Poems of Ossian in England and Scotland". In: GASKILL, Howard (ed.). The reception of Ossian in Europe cit., p. 21-39, especialmente p. 25. Ver também SAUNDERS, Bailey. The life and letters of James Macpherson: containing a particular account of his famous quarrel with Dr. Johnson, and a sketch of the origin and influence of the Ossianic poems. Nova Iorque: Haskell House, 1968, p. 170-172.

18 "The venerable author, and his elegant translator, thus have mutually conferred immortality on each other" ([BURKE, Edmund.] "An account of books for 1761". The annual register, or a view of the history, politicks, and literature of the year 1761. Londres, 1762, p. 276-286, especialmente p. 276).

${ }^{19}$ Idem, p. 278.
} 
propícia à representação dos heróis com toda a ternura e delicadeza da natureza humana, ${ }^{20}$ diante do que Smollett tece inequívocos elogios:

A peça diante de nós abunda com tantas imagens poéticas, tantos devaneios, tantos caracteres interessantes, toques patéticos e sentimentos sublimes, que não podem deixar de excitar a admiração do gosto, enquanto despertam a alma de sensibilidade. ${ }^{21}$

Os artigos de Burke e Smollett põem em relevo as forças contraditórias que organizam os Poemas de Ossian. De um lado, a poesia é tida como a extensão de "modos [...] de expressão e pensamento" historicamente determinados, como a materialização da consciência poética de um autor bastante específico. De outro lado, subsistem categorias como o gosto, a que, no século XVIII, dava-se valoração (mais ou menos) objetiva. ${ }^{22}$ Essa síntese entre subjetividade e objetividade se cristaliza na abertura de "Carthon":

Um conto de outrora! Os feitos de outrora! - O murmúrio de teus riachos, ó Lora, traz de volta a memória do passado. O som de teus bosques, Garmallar, é amável aos meus ouvidos. Não divisas, Malvina, uma rocha com sua coroa de urzes? De sua face, vergam três abetos envelhecidos. Verde é a planície ao sopé. Lá, cresce a flor da montanha e agita sua coroa branca na brisa. Lá, o cardo está só e resguarda sua barba envelhecida. Duas pedras, semienterradas no chão, exibem suas coroas de musgo. O cervo da montanha evita o lugar, pois avista o fantasma cinza que o guarda: pois os grandes jazem, ó Malvina, na estreita planície da rocha. Um conto de quadras antigas! Os feitos de outrora! $!^{23}$

Aqui, tão importante quanto a narrativa das glórias de antanho é o aflorar da elocução poética. Estiola-se a autonomia das personagens que desempenharam os grandes "feitos de outrora", porquanto se convertem em vivência do sujeito poético. O eixo temporal original, o passado, é inequivocamente atualizado ao momento da

${ }^{20}$ [SMOLLETT, Tobias]. “Article I". "The critical review for the month of December, 1761". The critical review: or, Annals of literature. Londres, 1762, v. 12, p. 405-418, especialmente, p. 411-412.

21 "The piece before us abounds with such poetical images, such flights of fancy, such interesting characters, pathetic touches, and sublime sentiments, as cannot fail to excite the admiration of taste, while they wake the soul of sensibility" (idem, p. 405).

${ }^{22}$ BATE, Walter Jackson. From classic to romantic: premises of taste in eighteenth-century England. Cambridge, MA: Harvard University, 1949, p. 43 e ss.

23 "A tale of the times of old! The deeds of days of other years!- The murmur of thy streams, O Lora, brings back the memory of the past. The sound of thy woods, Garmallar, is lovely in mine ear. Dost thou not behold, Malvina, a rock with its head of heath? Three aged firs bend from its face; green is the narrow plain at its feet; there the flower of the mountain grows, and shakes its white head in the breeze. The thistle is there alone, and shades its aged beard. Two stones, half sunk in the ground, shew their heads of moss. The deer of the mountain avoids the place, for he beholds the gray ghost that guards it: for the mighty lie, O Malvina, in the narrow plain of the rock. A tale of the times of old! the deeds of days of other years!" (MACPHERSON, James. "Carthon: a poem”. The poems of Ossian and related works. Ed. Howard Gaskill. Edimburgo: Edinburgh University, 1996, p. 127). 
enunciação, como o rememorar de Ossian. A incerteza quanto ao status da voz narrativa - se pertencente ao autor, ao narrador ou mesmo a uma personagem potencializa o efeito dessas oscilações. Estamos diante de "poesia pura"? Ou do registro do estado psicológico de um antigo celta? Não está claro se se deve integrar o eu do bardo ao objeto da narrativa ou se se deve analisar esse eu de maneira isolada, nos estritos termos de sua externalização. ${ }^{24}$

Formulam-se tais indagações, como se mencionou acima, porque o experimento ossiânico tende a construir no próprio texto seu sistema formal. Moldes externos, que orientem a priori a intelecção de sentido, existem apenas fugazmente. Cada poema, bem como os Poemas em seu conjunto, parecem amalgamar fragmentos genéricos num tecido cujo princípio organizador não se revela em nenhum desses fragmentos. Podemos exemplificar com a abertura de "Calthon and Colman":

Filha do céu, és bela! Agradável é o silêncio em tua face. Surges cheia de encanto: as estrelas observam teus passos azuis no leste. As nuvens se regozijam em tua presença, ó lua, e iluminam suas faces castanhas. Quem nos céus é como tu, filha da noite? As estrelas se envergonham em tua presença e escondem seus olhos verdes e brilhantes. - Para onde te retiras do teu curso, quando cresce a escuridão do teu semblante? Tens o teu salão, como Ossian? Habitas nas sombras do pesar? As tuas irmãs caíram do céu? Não mais existem aquelas que contigo se rejubilavam à noite? - Sim! elas tombaram, bela luz! e muitas vezes te retiras para lamentar. Mas tu mesma te extinguirás um dia, e deixarás teu caminho azul nos céus. As estrelas erguerão então as suas coroas verdes: aquelas que se encabulavam em tua presença rejubilarão.

Agora estás trajada com tua claridade: olha para os portões do céu. Rompe a nuvem, ó vento, para que a filha da noite possa olhar adiante, para que as ásperas montanhas se clareiem e o oceano agite suas ondas azuis sob a luz.

Nathos está no pélago, e [também] Athos, aquele feixe de juventude. Ardan está próximo a seus irmãos. Movem-se nas trevas de seu curso. Os filhos de Usnoth movem-se na escuridão, da fúria do aurígico Cairbar. ${ }^{25}$

\footnotetext{
${ }^{24}$ Sobre a presença ostensiva do eu ossiânico e a configuração de uma dupla perspectiva, ver MOORE, Dafydd. "The Ossianic revival, James Beattie and primitivism”. In: MANNING, Susan (ed.). The Edinburgh history of Scottish literature: Enlightenment, Britain and Empire (1707-1918). Edimburgo: Edinburgh University, 2007, p. 90-98, especialmente p. 94.

25 "Daughter of heaven, fair art thou! the silence of thy face is pleasant. Thou comest forth in loveliness: the stars attend thy blue steps in the east. The clouds rejoice in thy presence, $\mathrm{O}$ moon, and brighten their dark-brown sides. Who is like thee in heaven, daughter of the night? The stars are ashamed in thy presence, and turn aside their green, sparkling eyes.- Whither dost thou retire from thy course, when the darkness of thy countenance grows? Hast thou thy hall like Ossian? Dwellest thou in the shadow of grief? Have thy sisters fallen from heaven? Are they who rejoiced with thee, at night, no more?-Yes! - they have fallen, fair light! and thou dost often retire to mourn.-But thou thyself shalt fail, one night; and leave thy blue path in heaven. The stars will then lift their green heads: they who were ashamed in thy presence, will rejoice. Thou art now clothed with thy brightness: look from thy
} 
Percebe-se um percurso da apóstrofe lírica à narrativa. No primeiro parágrafo, a lua e todo seu entorno despontam mediados pela interioridade do sujeito poético. Este é feito, de maneira explícita, medida das coisas, tal qual demonstra a singela pergunta: “Tens o teu salão, como Ossian?”. Toda a sequência de indagações, aliás, traz a procedência da elocução para o primeiro plano. Embora personificados, os corpos celestes se dispõem como projeção do eu ossiânico: resquício de um mundo em eclipse, Ossian duvida da perenidade das translações lunares.

A persona do sujeito poético começa a se retrair no segundo parágrafo. É verdade que interpela o vento e a lua, mas se promove uma abstração do campo de experiência de Ossian para o da lua. Deveras, vemos o mar através dos olhos dela e, juntos, divisamos as três personagens. Deste ponto em diante, o que se apresenta são as interações de Nathos, Athos e Ardan. Ao final desse processo, está-se no campo da narração pura. ${ }^{26}$

A análise da organização da "Calthon e Colman", portanto, priva-nos de atalhos interpretativos, com que parte do sentido seria ostensivamente pré-configurado e préapreendido. ${ }^{27}$ De fato, não estamos diante de um epílio, balada ou qualquer outra forma narrativa curta. A observação de que contém elementos de todos esses gêneros não nos permite, entretanto, classificar o todo. Assim, o subtítulo da composição "um poema" - torna-se quase uma etiqueta em branco, dado que tal "poema" funda, delimita, explora e, possivelmente, esgota seu próprio gênero, bem como as suas convenções fundamentais. ${ }^{28}$

Mas é para as mais ambiciosas composições ossiânicas que a Dissertação de Blair se torna um prisma realmente revelador. Estamos a falar de Fingal e Temora.

gates in the sky. Burst the cloud, $\mathrm{O}$ wind, that the daughter of night may look forth, that the shaggy mountains may brighten, and the ocean roll its blue waves, in light. Nathos is on the deep, and Althos that beam of youth, Ardan is near his brothers; they move in the gloom of their course. The sons of Usnoth move in darkness, from the wrath of car-borne Cairbar" (MACPHERSON, James. "Dar-thula: a poem". The poems of Ossian and related works cit., p. 140).

${ }^{26}$ A terminologia, por óbvio, é de GENETTE, Gérard. Discurso da narrativa. Trad. Fernando Cabral Martins. 3. ed. Lisboa: Vega, 1995, p. 27.

${ }^{27}$ Sobre a falta de instrumental crítico para a intelecção dos Poemas de Ossian, ver: STAFFORD, Fiona. "Romantic Macpherson". In: PITTOCK, Murray (ed.). The Edinburgh companion to Scottish Romanticism. Edimburgo: Edinburgh University, 2011, p. 27-37, especialmente p. 32.

${ }^{28}$ Sobre a mistura de gêneros nos Poemas de Ossian, vejam-se os comentários quase bicentenários de HEGEL, Georg Wilhelm. Cursos de estética Trad. Marco A. Werle. São Paulo: Edusp, 2004, v. 4, p. 146 e LAING, Malcolm (ed.). The poems of Ossian, containing the poetical works of James Macpherson. Edimburgo, 1805, v. 1, p. 410, nota. Ver também SIMONSUURI, Kirsti. Homer's original genius: eighteenth-century notions of the early Greek epic. Cambridge: Cambridge University, 1979, p. 114. 
São obras diferentes das demais. Só elas têm a indicação de gênero: "um poema épico". Só elas são tratadas como "epopeia" ou "poema heroico". Todo o resto do repertório de Ossian, salvo os Fragmentos de poesia antiga, "Comála" e "The songs of Selma", é designado apenas como "um poema".

Basta folhear qualquer das edições dos Poemas de Ossian ${ }^{29}$ para que se perceba a singularidade de Fingal e Temora. Primeiro, eram as peças mais longas. Fingal se estende por cinquenta páginas, dividindo-se em seis livros. Temora é trinta por cento maior, repartindo-se em oito livros. "Cath-loda" fica numa distante terceira posição; seus três episódios (duans) perfazem quatorze páginas. Em segundo lugar, o próprio tradutor fizera das epopeias as mais conspícuas de suas obras. Foi sob a sombra delas que, inicialmente, apareceu a maior parte do corpus ossiânico. ${ }^{30}$ Inicialmente, as traduções de Macpherson vieram à luz em três momentos. A estreia foi com os Fragmentos de poesia antiga, em 1760, a conter quinze poemas curtos. A segunda edição sairia no mesmo ano, a conter mais um poema. Em dezembro de 1761 (mas com data de 1762), foi publicado Fingal, an ancient epic poem in six books, together with several other poems, que reúne quinze composições, além do poema epônimo e um trecho de Temora, an epic poem. Este outro épico surgiria em sua inteireza em março de 1763, em Temora an ancient epic poem in eight books, together with several other poems, ao lado de "Cathlin of Clutha", "Sul-malla of Lumon", "Cathloda", "Oina-Morul”, "Colna-dona" e um texto gaélico, "espécime original” do "Livro Sétimo" de Temora.

Tamanha proeminência não foi perdida nem mesmo quando se reuniu todo o inventário em Works of Ossian, em 1765. Aliás, foi realçada. Cada volume dessa edição era capitaneado por um dos épicos. E uma intervenção editorial mudou completamente a percepção de como os textos ossiânicos se relacionam. Em 1763, lêse "Uma dissertação" como o prefácio de Temora an ancient epic poem in eight

\footnotetext{
${ }^{29}$ Utilizaremos a seguinte edição: MACPHERSON, James. The poems of Ossian and related works. Ed. Howard Gaskill. Edimburgo: Edinburgh University, 1996.

${ }^{30}$ Quanto às edições dos Poemas de Ossian, ver GASKILL, Howard. "About this edition”. In: MACPHERSON, James. The poems of Ossian and related works cit., p. xxii-xvi; GASKILL, Howard. "Ossian na Europa". In: BÄR, Gerald (coord.). Poesias de Ossian: antologia da poesia ossiânica traduzida em português. Lisboa: Universidade Católica, 2010, p. 15-53 e GASKILL, Howard. “Ossian in Europe". Canadian Review of Comparative Literature, v. 21, n. 4 (dezembro, 1994), p. 643-675. Também consultamos as seguintes edições setecentistas: OSSIAN. Fingal, an ancient epic poem in six books, together with several other poems. Trad. James Macpherson. Londres, 1762 e OSSIAN. Temora an ancient epic poem in eight books, together with several other poems. Trad. James Macpherson. Londres, 1763.
} 
books, together with several other poems. Afinal, está antes mesmo do sumário. Em 1765, move-se a dissertação para depois do sumário, para ficar colada a Temora. Agora, "Uma dissertação" parece ligada exclusivamente à epopeia. O efeito é o mesmo que se tem em relação a Fingal, que desde 1761 era precedido por "Uma dissertação sobre a antiguidade etc. dos poemas de Ossian, o filho de Fingal". ${ }^{31} \mathrm{O}$ resultado desse tipo de expediente é óbvio: confere solenidade (e, por isso, importância) às obras, inteligíveis apenas aos que se aventurarem pelos prolegômenos. $^{32}$

Todos esses expedientes parecem pôr fim, nos casos de Fingal e Temora, ao curto-circuito formal que distingue o restante das composições ossiânicas. Afinal, o épico é um gênero poético dos mais antigos, cujas manifestações usualmente se situam (ou se situavam) no centro do cânone literário. ${ }^{33}$ Nomes como Homero, Virgílio e Milton estiveram dentre os mais reverenciados ao longo do século XVIII. Para John Dennis, por exemplo, a epopeia é a primeira manifestação da "poesia maior". É nela que se encontrariam os modelos mais óbvios da sublimidade e inocência às quais o crítico almejava restaurar a literatura de seus contemporâneos. ${ }^{34}$ $\mathrm{Na}$ mesma linha, o influente crítico e professor Joseph Trapp diria que o épico é a melhor e mais perfeita forma poética. ${ }^{35}$ Tal tipo de avaliação se faz presente até mesmo em obras generalistas, como a Cyclopcedia, de Chambers, publicada em 1728. Aqui, o poema épico também é a primeira ocorrência do que se chama de "grande poesia". 36

\footnotetext{
${ }^{31}$ Reformulada em 1765.

${ }^{32}$ A proeminência dada aos épicos seria um tanto diluída na edição de 1773 (cf. MOORE, Dafydd. "The critical response to Ossian's Romantic bequest". In: CARRUTHERS, Gerard; RAWES, Alan (ed.). English Romanticism and the Celtic world. Cambridge: Cambridge University, 2003, p. 38-53, especialmente p. 48).

${ }^{33}$ FOWLER, Alastair. Kinds of literature: an introduction to the theory of genres and modes. Cambridge, MA: Harvard University, 1982, p. 221 e ss.

${ }^{34}$ DENNIS, John. "The grounds of criticism in poetry". In: HOOKER, Edward Niles (ed.). The critical works of John Dennis. Baltimore: Johns Hopkins, 1939, v. 1, p. 325-373, especialmente p. 328331.

${ }^{35}$ TRAPP, Joseph. Lectures on poetry: read in the School of Natural Philosophy at Oxford. Londres, 1742 , p. 328.

${ }^{36}$ CHAMBERS, Ephraim. Cyclopcedia, or, An universal dictionary of arts and sciences: containing the definitions of the terms, and accounts of the things signify'd thereby, in the several arts, both liberal and mechanical, and the several sciences, human and divine: the figures, kinds, properties, productions, preparations, and uses, of things natural and artificial: the rise, progress, and state of things ecclesiastical, civil, military, and commercial: with the several systems, sects, opinions, \&c: among philosophers, divines, mathematicians, physicians, antiquaries, criticks, \&c: the whole intended as a course of antient and modern learning. Londres, 1728, v. 2, p. 832.
} 
E há um conjunto de invariantes na longa e venerável tradição da poesia épica ocidental, ${ }^{37}$ que vem à mente tão logo tomamos Fingal e Temora como epopeias.

Estritamente, a epopeia é obra de um epopoiios (produtor ou fabricador de narrativas em versos), posta como fala primordial (épos). Convivem com a noção de epopeia, as expressões “épico" e "poema heroico". Épico significa "relativo à epopeia", sendo, portanto, de uso originalmente adjetivo. Poema heroico, por sua vez, é uma definição derivada do conteúdo. E opõe-se à definição centrada no modo de enunciação - epopeia. Essa dicotomia indica os núcleos das definições usuais: a narratividade e a excepcionalidade dos temas e da estória. ${ }^{38}$

Tal combinação de modos de enunciação e traços temáticos faz-se presente sobretudo nos épicos canônicos - nomeadamente, Ilíada, Odisseia, Eneida, Jerusalém libertada, Os lusíadas e Paraíso perdido. ${ }^{39}$ Bowra afirma que há um consenso de que são narrativas longas em que se representam eventos grandiosos e importantes, advindos de uma vida de ação, especialmente de ação violenta, como se dá na guerra. Seus pressupostos são o apreço aos feitos humanos e convicção na dignidade e na nobreza do homem. ${ }^{40}$

Ademais, os épicos canônicos são (ou foram) reconhecidos, de um lado, pela seriedade do tema e da linguagem e, de outro lado, por seu controle formal. Sua predeterminação exclui o aberrante, dado que o desvio sempre é medido pela norma, cuja vigência se tem como inequívoca. ${ }^{41} \mathrm{~A}$ organicidade de sua cosmologia faz com que se vislumbre nas epopeias de Homero, Virgílio, Tasso, Camões e Milton uma totalidade, um movimento contínuo, que não se esgota num verso ou num trecho do poema. Tais composições são (ou foram) associadas às grandes instituições humanas, com que se lhes atribui (ou atribuía) uma qualidade córica. ${ }^{42}$

A nomeação de Fingal e Temora como epopeias, portanto, jamais pode ser tida como casual ou inocente. Macpherson afirma, logo na primeira nota a Temora, que o

\footnotetext{
${ }^{37}$ MADELÉNAT, Daniel. L'épopée. Paris: PUF, 1986, p. 14 e ss.

${ }^{38}$ Idem, p. 17-18.

${ }^{39}$ Ver idem, p. 14-15 e TILLYARD, E. M. W. The English epic and its background. Nova Iorque: Oxford University, 1966, p. 5 e ss.

${ }^{40}$ BOWRA, C. M. From Virgil to Milton. Londres: Macmillan, 1945, p. 1.

${ }^{41}$ TILLYARD, E. M. W. The English epic and its background cit., p. 8-9.

${ }^{42}$ Idem, p. 12-13.
} 
“título de Épico foi imposto por mim mesmo". 43 Já na página de rosto, inserem-se as obras ossiânicas num sistema de referências e expectativas que lhes antecede. Se fossem consideradas manifestações plenas e genuínas de tal sistema, cobririam de glória seu autor - e, por extensão, seus paisanos.

Fazendo as vezes de editor, Macpherson opera para que a associação de Fingal e Temora à estirpe da Ilíada e Odisseia não passe desapercebida de seus leitores. Coteja copiosamente as epopeias ossiânicas com os escritos de Homero, Virgílio e Milton. Evidencia, com isso, semelhanças no manejo de figuras de linguagem, na caracterização das personagens e na concepção da fábula. ${ }^{44}$ Suas "descobertas" são, de fato, numerosas.

Quanto à linguagem, aduzem-se símiles e mais símiles como aparentados, por exemplo, daqueles encontrados no Paraíso perdido. Tal parentesco residiria na coincidência de comparantes e conformidade nas imagens evocadas. É o que se dá quando o estandarte de Fingal é comparado a uma chama que ilumina o horizonte ${ }^{45}$ e, ao pé da página, há uma pequena citação, a remeter-nos ao "Livro I" do épico miltônico:

\section{A bandeira imperial que no ar subida Qual meteoro que os ventos arrebatam, Brilhou $[\ldots]^{46}$}

E é o que sé dá em uma passagem no "Livro II" de Fingal, na qual os soldados do exército de Cuchullin são convertidos em carvalhos - ou robles - açoitados pela ventania:

O som se dissemina; os heróis se levantam, como o rebentar de uma errante onda azul. Mantiveram-se na charneca, como carvalhos

\footnotetext{
43 "The title of Epic was imposed on the poem by myself" (MACPHERSON, James. "Temora: an epic poem". The poems of Ossian and related works cit., p. 479, nota 2).

${ }^{44}$ Essas semelhanças residem naquilo que a crítica renascentista costumava chama de as "partes de qualidade" da epopeia (HANSEN, João Adolfo. "Notas sobre o gênero épico". In: TEIXEIRA, Ivan (org.). Épicos. São Paulo: Universidade de São Paulo - Imprensa Oficial do Estado de São Paulo, 2008, p. 15-91, especialmente p. 45 e ss.).

${ }^{45}$ MACPHERSON, James. "Fingal: an epic poem". The poems of Ossian and related works cit., p. 86.

${ }^{46}$ MILTON, John. O paraíso perdido. Trad. António José Lima Leitão. Belo Horizonte - Rio de Janeiro: Villa Rica, 1994, p. 45. No original: “Th' Imperial Ensign, which full high advanc't/ Shone like a Meteor streaming to the Wind (I, 536-537) (MILTON, John. "Paradise lost". Complete poems and major prose. Ed. Merritt Y. Hughes. Indianápolis - Cambridge: Hackett, 1957 (reimpressão 2003), p. 225). A passagem foi citada em MACPHERSON, James. "Fingal: an epic poem". The poems of Ossian and related works cit., p. 431, nota 22.
} 
rodeados de galhos: quando ecoam para o córrego de gelo e suas folhas secas farfalham para o vento. ${ }^{47}$

Em nota, confronta-se o tropo ao "Livro I" do Paraíso perdido, em que os demônios são equiparados às árvores desfolhadas em terras inóspitas:

- quais se mostram

Na selva o roble, na montanha o pinho,

Depois que os estragou do Céu o lume,

Crestada a rama inteira, mas erguidos

Com toda a corpulência nua e enorme

Muito por cima das queimadas urzes! $!^{48}$

No que concerne à caracterização, trata-se de um elemento das epopeias ossiânicas cuja consonância com as medidas canônicas também se encontra fartamente documentada. Inserem-se muitos dos campeões de Ossian em linhagens fundadas, dentre outras, por personagens homéricas. É o caso de Gaul, do qual “os heróis fugiam como duas nuvens sombrias". ${ }^{49}$ Seu valor em combate aliado à ânsia desmedida por renome torná-lo-iam semelhante a Ajax, cuja imensa fortitude era despida de sabedoria. ${ }^{50}$ Já Cathmor, o pensativo antagonista de Temora, é associado a Aquiles, pois "prefere uma vida curta e gloriosa a uma sequência obscura de anos em repouso e descanso". ${ }^{51}$ Tratava-se de uma linhagem em que se incluem até os que tombaram em batalha. Logo no início do "Livro II" de Fingal, irmana-se o fantasma de Crugal ao de Pátroclo. ${ }^{52}$ Ambos aparecem à noite para seus companheiros de armas, respectivamente Connal e Aquiles. E ambos desaparecem com um símile em que sua evanescência é evocada em fenômenos naturais transitórios. ${ }^{53}$

\footnotetext{
47 "The sound spreads wide; the heroes rise, like the breaking of a blue-rolling wave. They stood on the heath, like oaks with all their branches round them; when they eccho to the stream of frost, and their withered leaves rustle to the wind" (idem, p. 66).

${ }^{48}$ MILTON, John. O paraiso perdido cit., p. 48. No original: "As when Heaven's fire/ Hath scath'd the Forest Oaks, or Mountain Pines, / With singed top thir stately growth, though bare, Stands on the blasted Heath (I, 612-615) (MILTON, John. "Paradise lost". Complete poems and major prose cit., p. 227). A passagem foi citada em MACPHERSON, James. "Fingal: an epic poem". The poems of Ossian and related works cit., p. 426, nota 17.

49 "[...] the heroes flew like two dark clouds" (idem, p. 78).

${ }^{50}$ Ver idem, p. 429, nota 52. Em nota ao "Livro Terceiro" de Temora, a associação a Ajax é retrabalhada. Agora, Gaul tem a mesma "taciturnidade masculina" ["manly taciturnity"] do herói grego (MACPHERSON, James. "Temora: an epic poem". The poems of Ossian and related works cit., p. 493 , nota 7$)$.

51 "[...] prefers a short and glorious life, to an obscure length of years in retirement and ease" (idem, p. 500, nota 43).

${ }^{52}$ MACPHERSON, James. "Fingal: an epic poem". The poems of Ossian and related works cit., p. 425 , nota 1 .

${ }^{53}$ Ver idem, p. 425 , nota 8.
} 
Macpherson ainda aproximaria os poemas heroicos de Ossian daqueles de Homero, Virgílio e Milton na maneira como se ordena a fábula épica. Mais uma vez, o bardo caledônio parece dominar os mesmos princípios na execução de uma epopeia que seus colegas mais célebres. Sintomaticamente, o tradutor e editor desvenda uma ordenação comum, em que o início, o meio e o encerramento são realizados de modo similar. Não raro, contudo, julgam-se as soluções literárias de Ossian até mesmo como superiores às dos demais. A título de ilustração, leia-se a última nota a Fingal. Aposta ao parágrafo conclusivo -

Assim eles passaram a noite a cantar e trouxeram a manhã de volta com alegria. Fingal ergueu-se na charneca e agitou sua lança reluzente em sua mão. - Dirigiu-se para as planícies de Lena, e seguimo-lo como uma serrania de fogo. Içai a vela, disse o rei de Morven, e pegai o vento que sopra a partir de Lena. - Elevamonos nas ondas com canções e lançamo-nos, com alegria, através da espuma do oceano. ${ }^{54}$

-, a nota contém a observação de que Fingal termina de maneira elevada, assim como a Ilíada, a Eneida e o Paraíso perdido. ${ }^{55}$ Ao contrário destes, todavia, Ossian não nos deixa com sentimentos contraditórios, um misto de satisfação e amargura. Afinal, um se despede do leitor nas exéquias de um príncipe: "Os funerais estes foram de Heitor, domador de cavalos". 56 O outro, na morte prematura de um herói:

No peito aqui lhe esconde o iroso ferro:

Gelo solve-lhe os órgãos, e num gemido

A alma indignada se afundou nas sombras. ${ }^{57}$

E o terceiro, na solidão de um mundo despovoado:

Dando-se as mãos os pais da humana prole, Vagarosos lá vão com passo errante

\footnotetext{
54 "Thus they passed the night in the song; and brought back the morning with joy. Fingal arose on the heath, and shook his glittering spear in his hand.-He moved first toward the plains of Lena, and we followed like a ridge of fire. Spread the sail, said the king of Morven, and catch the winds that pour from Lena.-We rose on the wave with songs, and rushed, with joy, through the foam of the ocean" (MACPHERSON, James. "Fingal: an epic poem". The poems of Ossian and related works cit., p. 104).

${ }^{55}$ MACPHERSON, James. "Fingal: an epic poem". The poems of Ossian and related works cit., p. 435 , nota 54.

${ }^{56}$ HOMERO. Ilíada. Trad. Carlos Alberto Nunes. Rio de Janeiro: Ediouro, 2004, p. 548. Na tradução de Pope: "Such Honours Ilion to her Hero paid,/ And peaceful slept the mighty Hector's Shade" (XXIV, 1015-1016) (POPE, Alexander. The Iliad of Homer. Ed. Maynard Mack. Londres: Metheun - New Haven: Yale University, 1967, v. 2, p. 577). Sempre que puder, utilizarei traduções correntes quando da publicação dos Poemas de Ossian.

${ }^{57}$ VIRGÍlLIO. Eneida. 2. ed. Trad. Odorico Mendes. Cotia: Ateliê, 2010, p. 265. Na versão de Dryden da Eneida, lê-se: "Deep in his Bosom drove the shining Sword./ The streaming Blood distain'd his Arms around:/ And the disdainful Soul came rushing thro' the Wound" (XII, 1375-1377) (VIRGÍLIO. "Virgil's AEneis". Trad. John Dryden. In: KINSLEY, James (ed.). The poems of John Dryden. Oxford: Clarendon, 1958, v. 3, p. 1423).
} 
Afastando-se do Éden solitários. ${ }^{58}$

À primeira vista, o recurso a obras paradigmáticas indica clareza e confiança nos critérios de criação e análise poéticas. Uma leitura mais atenta a Fingal e Temora evidencia, todavia, que a consciência das invariantes do gênero épico e os precedentes dos autores canônicos convivem com noções inextrincavelmente circunscritas ao debate literário do século XVIII. O período testemunhou a erosão do referencial legado pelo Renascimento, num processo que resultaria na ascensão do romantismo. ${ }^{59}$ Nesses anos de transição, não raro coexistiam dentro do mesmo círculo intelectual noções inconciliáveis acerca da natureza da literatura e da arte em geral. A poesia épica, gênero no centro do sistema literário de então, era o campo privilegiado para contenciosos. Ao plasmar na forma de Fingal e Temora posições divergentes quanto à natureza do poema heroico, Macpherson talvez tenha criado uma "epopeia para todos os gostos". ${ }^{60}$ Contudo, como veremos adiante, o resultado são obras cuja epicidade é desconstituída pelo mesmo arranjo que a constitui.

\section{Neoclássicos}

Para parcela considerável dos críticos, "épico" e "epopeia” referiam-se a uma forma literária ideal. Era uma forma que não se definia por suas condicionantes históricas. Pelo contrário: seria a materialização poética de regras gerais sobre estilo,

\footnotetext{
${ }^{58}$ MILTON, John. O paraíso perdido cit., p. 48. No original: "They hand in hand with wand'ring steps and slow/ Through Eden took thir solitary way" (XII, 648-649) (MILTON, John. "Paradise lost". Complete poems and major prose cit., p. 469).

${ }^{59}$ Para uma análise das categorias críticas no século XVIII, bem como a sua relação, sobretudo, com aquelas estabelecidas pelo romantismo: PATEY, Douglas Lane. "The institution of criticism in the eighteenth century". In: NISBET, H. B.; RAWSON, Claude (ed.) The Cambridge History of Literary Criticism: the eighteenth century. Cambridge: Cambridge University, 2005, p. 3-31, especialmente p. 8 e ss.

${ }^{60}$ Cf. FOLKENFLIK, Robert. "Folklore, antiquarianism, scholarship and high literary culture". In: RICHETTI, John (ed.). The Cambridge History of English Literature, 1660-1780. Cambridge: Cambridge University, 2005, p. 602-622, especialmente p. 605. Num estudo monográfico, Dafydd Moore contesta a persistência do referencial épico para a análise dos Poemas de Ossian. Prefere a noção de estória romanesca, que melhor acomodaria as diversas partes do texto. Talvez sua leitura seja, de fato, a mais adequada para uma abordagem en bloc do corpus ossiânico (ver MOORE, Dafydd. Enlightenment and romance in James Macpherson's The Poems of Ossian: myth, genre and cultural change. Aldershot: Ashgate, 2003, p. 1-43 e passim). Contudo, a leitura de Moore me parece indiferente à especificidade de Fingal e Temora. Em diversos países, as composições de Ossian muitas vezes chegavam em prestações. A tradução portuguesa de Fingal, feita por Maria Adelaide Fernandes Prata, por exemplo, não veria acompanhada de nenhuma outra peça (ver OSSIAN. Fingal: poema em seis cantos. Seguido de duas cartas dos poetas Pinto Ribeiro e Sousa Viterbo. Trad. Maria Adelaide Fernandes Prata. Porto: Typographia Commercial, 1867). Para o leitor português, os princípios construtivos configurados em Fingal não se confundem com aqueles plasmados noutras composições ossiânicas. Trata-se de uma constatação que talvez não seja tão óbvia a um britânico, dada a maneira conjunta como Macpherson publicou suas traduções.
} 
enredo, personagens etc. Tais regras serviriam tanto para os antigos quanto para os modernos: orientavam o estudo de obras consagradas e orientavam criações futuras. ${ }^{61}$ Assim, esperava-se que a análise da Odisseia, d'Os Lusíadas e da Jerusalém libertada fosse conduzida a partir de critérios idênticos. A título de ilustração, veja-se esta passagem, escrita por Addison:

A primeira coisa a ser considerada num poema épico é a fábula, que é perfeita ou imperfeita, na medida em que a ação que relata é mais ou menos assim [perfeita]. Essa ação deve ter três qualificações. Primeiramente, deve ser apenas uma ação única. Em segundo lugar, deve ser uma ação inteira. E, em terceiro lugar, deve ser uma ação grande. Consideremos a ação de Ilíada, Eneida e Paraíso perdido sob essas três diferentes luzes. ${ }^{62}$

Aqui, Homero, Virgílio e Milton são tidos como poetas de uma mesma linhagem, praticantes do mesmo ofício. ${ }^{63}$ Seus escritos demandariam, portanto, uma abordagem uniforme. E é o que Addison providencia. ${ }^{64}$ Os requisitos que vislumbra para a ação épica têm existência autônoma, que não se esgota em nenhuma obra literária. Como se pode notar, esses requisitos servem até para julgar o primeiro poema épico de que se tem notícia no Ocidente: a Ilíada.

Addison filia-se a uma tradição que se convencionou chamar de neoclássica. Associada à França seiscentista, é uma tradição que julgava ter encontrado o fundamento comum para a apreciação e a criação poéticas: a razão humana, muitas vezes apresentada como "bom-senso", "gosto" ou "discernimento". Trata-se de uma entidade metafísica, atemporal, imutável e incorruptível, a partir da qual seria possível apreender e, por fim, universalizar os elementos constitutivos da obra literária. ${ }^{65}$

${ }^{61}$ TILLYARD, E. M. W. The English epic and its background cit., p. 2-4 e 452 e 464. SWEDENBERG JR., H. T. The theory of the epic in England cit., p. 63-75. Num quadro mais amplo, ver WELLEK, René. A history of modern criticism: 1750-1950. New Haven: Yale University, 1955, v. 1, p. 12-40.

62 "The first Thing to be consider'd in an Epic Poem, is the Fable, which is perfect or imperfect, according as the Action which it relates is more or less so. This Action should have three Qualifications in it. First, It should be but one Action. Secondly, It should be an entire Action; and Thirdly, It should be a great Action. To consider the Action of the Iliad, Aeneid, and Paradise Lost, in these three several Lights" (ADDISON, Joseph. "No. 267”. The Spectator. Ed. Gregory Smith. Londres - Nova Iorque: Everyman, 1958, v. 2, p. 294-298, especialmente p. 295).

${ }^{63}$ Cf. TILLYARD, E. M. W. The English epic and its background cit., p. 1.

${ }^{64}$ SWEDENBERG JR., H. T. The theory of the epic in England cit., p. 65-68. Ver também DAMROSCH JR., Leopold. “The significance of Addison's criticism”. Studies in English Literature, 1500-1900, v. 19, n. 3 (Restoration and Eighteenth Century) (verão, 1979), p. 421-430.

${ }^{65}$ BRAY, René. La formation de la doctrine classique en France. Paris: A. G. Nizet, 1966, p. 99 e 114-139. Ver também: DUFF, David. Romanticism and the uses of genre cit., p. 24-57. 
A recusa em analisar a poesia em termos individuais, forçosamente, diminui a distância entre o leitor e o autor. Este não era visto como o criador de escritos inacessíveis, cujo sentido profundo escaparia àqueles que não foram agraciados pelas Musas. A ênfase estaria, antes, num código partilhado por ambos os polos, bifronte. Primeiramente, as categorias críticas seriam também preceitos de composição. Voltemos ao exemplo da ação perfeita, da passagem que citamos há pouco: é tanto a medida analítica de Addison quanto o princípio a ser realizado nos épicos de Homero, Virgílio e Milton. Em segundo lugar, não havia licença para divergir. O referido código é imposto pelo público - e seu teor é entendido como prescritivo. ${ }^{66}$

O cerne da doutrina neoclássica é, portanto, seu normativismo. Dominava a ideia de que um poeta não poderia prescindir das regras. ${ }^{67}$ Arte e regra, aliás, eram entendidas como termos quase sinônimos. Rapin, por exemplo, tomaria o "método" (i.e., conjunto de regras) como elemento definidor do que entende por arte, que "nada mais é que o bom-senso reduzido ao método". ${ }^{68}$ Esse método, por sua vez, é apresentado como dedutivo, estribado em verdades autoevidentes e fundado em preceitos estabelecidos desde a Antiguidade. ${ }^{69}$ Era o único caminho possível. Sintomaticamente, costumava-se dizer que a arte poderia levar até mesmo um gênio medíocre a um triunfo moderado, ao passo que aqueles que a desconheciam só poderiam incorrer em fracasso. ${ }^{70}$

Das normas de composição, aquela que se tinha em mais alta conta era de que a poesia deveria instruir. ${ }^{71}$ Com isso, tem-se um entendimento utilitário da arte, ${ }^{72}$ cujas origens são relativamente remotas. ${ }^{73}$ No Renascimento, os humanistas haviam estabelecido uma equivalência ideal entre as esferas moral e intelectual do homem. Assim, o verdadeiro, o bom e o belo são noções que muitas vezes se confundem. A criação literária deveria, então, fazer-se impregnada desses três valores. ${ }^{74}$

\footnotetext{
${ }^{66}$ BRAY, René. La formation de la doctrine classique en France cit., p. 99 e ss.

${ }^{67}$ Idem, p. 108.

68 "[...] Art [...] is nothing else, but good Sense reduc'd to Method" (RAPIN. "Reflections on Aristotle's Treatise of poesie". Trad. Thomas Rymer. The whole critical works of Monsieur Rapin. Vários tradutores. Londres, 1706. v. 2, p. 135-244, especialmente p. 240).

${ }^{69}$ BRAY, René. La formation de la doctrine classique en France cit., p. 126 e BATE, Walter Jackson. From classic to romantic cit., p. 29 e ss.

${ }^{70}$ Cf. BRAY, René. La formation de la doctrine classique en France cit., p. 93-94.

${ }^{71}$ Idem, p. 62-84.

${ }^{72}$ Idem, p. 84.

${ }^{73}$ BATE, Walter Jackson. From classic to romantic cit., p. 29 e ss.

${ }^{74}$ Idem, p. 4-14.
} 
A verdade seria acessível se a obra abstraísse o que é contingente, efêmero ou particular. Com isso, revelar-se-ia algo pertinente a todos. Recupera-se a ideia aristotélica de que a poesia comunica o universal, diferentemente da história, que nos conta o circunstancial $(1451 \mathrm{a}-1451 \mathrm{~b}) .{ }^{75} \mathrm{O}$ conteúdo dessa verdade, todavia, não deve ser aleatório. Requer-se que tenha o condão de ensinar a virtude. De tal feita, a obra é concebida para satisfazer esse fim: funda-se numa alegoria; torna-se permeada de ditos sentenciosos; contrapõe vícios e virtudes de maneira inequívoca; recompensa os justos quando do desenlace da ação; purga as paixões; e tem assunto e personagens adequados. ${ }^{76} \mathrm{~A}$ esses ensinamentos, dá-se uma roupagem condizente com a sua dignidade: prescreve-se a busca pela perfeição da obra literária, dotando-a de harmonia, proporção, unidade etc. ${ }^{77}$

Diante desse quadro, as categorias com que lidarão os neoclássicos têm inequívoco conteúdo moral. Tomemos como exemplos a verossimilhança e o decoro.

Num primeiro momento, a verossimilhança parece ser um mandamento da razão. ${ }^{78}$ Com ela, interdita-se a representação de tudo que não seja justo, adequado e natural. Alguns neoclássicos chegarão mesmo a condenar a representação de eventos extraídos da Bíblia: embora verdadeiros, não eram verossímeis. A ação e as personagens deveriam ser críveis por elas mesmas - e não porque uma entidade divina assim o determinara. A justificativa para tamanha estreiteza estaria, todavia, na moral: a poesia deveria incutir o apreço à verdade. ${ }^{79}$

Para respeitar o decoro, uma obra tem de ser "conveniente". A conveniência é uma qualidade complexa, em que critérios de moral e verdade se confundem. Pressupõe a adequação a uma tipologia abstrata de estilos, gêneros, temas e pessoas. Assim, são convenientes as obras em que: se excluem assuntos e situações

\footnotetext{
${ }^{75}$ ARISTÓTELES. "Poetics". Trad. Stephen Halliwell. In: HENDERSON, Jeffrey (ed.). The Loeb Classical Library: Aristotle XXIII. 2. ed. Cambridge, MA - Londres: Harvard University, 1995, p. 4951.

${ }^{76}$ BRAY, René. La formation de la doctrine classique en France cit., p. 74 e ss.

${ }^{77}$ BATE, Walter Jackson. From classic to romantic cit., p. 29 e ss.

${ }^{78}$ De maneira expressa, afirmaria Rapin: "É apenas pelas [...] regras que a verossimilhança nas ficções é mantida, que é a alma da poesia. [...] é por essas regras que tudo se torna justo, adequado e natural; pois elas são fundadas no bom-senso e na razão segura" ("Tis only by [...] Rules that the Verisimility in Fictions is maintained, which is the Soul of Poesie. [...] 'tis by these Rules that all becomes just, proportionate, and natural; for they are founded upon good Sense and sound Reason") (RAPIN. "Reflections on Aristotle's Treatise of poesie" cit., p. 146).

${ }^{79}$ Ver BRAY, René. La formation de la doctrine classique en France cit., p. 192 e 197-207 e WILLIAMS, Ralph C. "Two studies in epic theory”. Modern philology, v. 22, n. 2 (novembro, 1924), p. 133-158, especialmente p. 133-141.
} 
indesejáveis; a caracterização das personagens está acordo com sua idade, sorte, condição de vida, nacionalidade e sexo; o tom e a linguagem condizem com as paixões suscitadas etc. ${ }^{80}$

Ao aportar na Grã-Bretanha, o neoclassicismo era um corpo doutrinário há muito investido de autonomia teórica, detentor de um inventário de conceitos firmemente estabelecidos. A base estaria numa leitura bastante seletiva da Poética, ${ }^{81}$ de Aristóteles, filósofo ao qual se atribuía a autoridade da razão. ${ }^{82} \mathrm{~A}$ temperar a leitura do estagirita, fazia-se menção ao pseudo Longino, que tratara do sublime, e a Horácio, que discorrera sobre decoro, abertura in medias res e o propósito da poesia, que seria o de instruir com deleite. Além disso, coligiam-se exemplos de Homero, Virgílio, Sófocles etc.

O apelo a uma abordagem aristotélica faz com que a crítica neoclássica tome as formas literárias em abstrato. $\mathrm{Na}$ Antiguidade, a obra era comumente definida por seu veículo, ou seja, por sua prosódia. Eram considerados épicos, portanto, todos os poemas escritos em hexâmetros, mesmo os que tinham um conteúdo didático. ${ }^{83}$ Já no início da Renascença, tinha-se que aqueles que desejassem escrever um poema épico deveriam seguir os exemplos de Homero e Virgílio. Conforme se consolida a abordagem que, depois, será chamada de neoclássica, a epopeia, a tragédia e a comédia serão estudadas de maneira autônoma, num esforço de se delimitar a sua natureza específica. Isso não quer dizer que, por óbvio, o prestígio dos escritos antigos fora abalado. $\mathrm{O}$ que mudou foi a justificativa para sua leitura. Cada vez mais, seriam tidos como as melhores corporificações de um ideal de forma literária. ${ }^{84}$

Todas essas formas ideais tinham um fundo moral. Seguindo Aristóteles (1448a), ${ }^{85}$ diferenciava-se a tragédia da comédia conforme a qualidade das personagens: na tragédia, elas são melhores do que nós; na comédia, piores. ${ }^{86}$ Mais

\footnotetext{
${ }^{80}$ BRAY, René. La formation de la doctrine classique en France cit., p. 215-230; BATE, Walter Jackson. From classic to romantic cit., p. 14 e ss.; e WILLIAMS, Ralph C. "Two studies in epic theory" cit., p. 142 e ss.

${ }^{81}$ Cf. WEINBERG, Bernard. "From Aristotle to pseudo-Aristotle". Comparative literature, v. 5, n. 2 (primavera, 1953), p. 97-104.

${ }^{82}$ BRAY, René. La formation de la doctrine classique en France cit., p. 124.

${ }^{83}$ TILLYARD, E. M. W. The English epic and its background cit., p. 181 e ss.

${ }^{84}$ Idem, p. 223.

${ }^{85}$ ARISTÓTELES. "Poetics" cit., p. 33.

${ }^{86}$ Ver HALLIWELL, Stephen. "The importance of Plato and Aristotle for Aesthetics". In: GERSON, Lloyd P. (ed.). Aristotle: critical assessments. Routledge: Londres - Nova Iorque, 1999, v. 4, p. 289-312, especialmente p. 305.
} 
importante: as formas seriam divididas em imitativas e não imitativas, conforme contivessem - ou não - uma ação. Noutras palavras: supunha-se que formas como a tragédia, a comédia e a epopeia operavam como instrumentos para a apresentação e a cognição verdadeiras da realidade. ${ }^{87} \mathrm{~A}$ atribuição desse poder não era aleatória. Em primeiro lugar, depende de uma definição estreita do que seria realidade: restringe-se ao dito mundo natural, perceptível aos sentidos, excluindo aquilo que é interior ao sujeito poético. ${ }^{88} \mathrm{E}$, em segundo lugar, funda-se na percepção de que nem todos os modos de enunciação (dramático, narrativo ou lírico) permitem configurar um universo aparentemente destacado do sujeito poético no qual personagens individualizadas tomam parte de uma ação. Os únicos modos que permitiriam tal destacamento seriam o narrativo e o dramático. ${ }^{89}$

Sendo assim, a ode e a elegia não eram tratadas como formas imitativas, como espelhos efetivos do real. Boileau, por exemplo, separa-as da noção de objeto “imitado pela arte" (par l'art imité ou, na tradução infeliz de Dryden, well disposed by art). Essas formas líricas eram vistas como ineptas a conceder vida independente a tudo aquilo que é exterior ao sujeito poético. Com efeito, argumentava-se que seu conteúdo e seus limites não eram hauridos do mundo sensível, mas sim da expressividade do próprio poeta. ${ }^{90}$

\footnotetext{
${ }^{87} \mathrm{O}$ sentido que Aristóteles atribui à imitação (mimese) é bastante diverso daquele desenvolvido por Platão. Em primeiro lugar, a definição de Aristóteles é dotada de generalidade. Platão, por sua vez, vê a mimese como um dos modos do discurso poético, ao lado da narrativa direta (diegese), em que o poeta fala com a sua própria voz. A mimese, para Platão, consiste na criação de uma voz ficcional, das personagens, por meio da qual o poeta então falaria (cf. KOSMAN, Aryeh. "Drama as the mimeses of praxis". In: RORTY, Amélie Oskenberg (ed.). Essays on Aristotle's Poetics. Princeton, NJ: Princeton University, 1992, p. 51-72).

${ }^{88}$ Para uma discussão das formulações do que viria a ser o dito mundo natural que adentra na arte, segundo as releituras da Poética, de Aristóteles, a partir do fim da Idade Média, ver: SCHMITT, Arbogast. "Mímesis em Aristóteles e nos comentários da Poética no Renascimento: da mudança do pensamento sobre a imitação no começo dos tempos modernos". Trad. Luiz Costa Lima. In: COSTA LIMA, Luiz (org.). Mímesis e a reflexão contemporânea. Rio de Janeiro: Uerj, 2010, p. 137-189.

${ }^{89}$ Ver HANSEN, João Adolfo. "Notas sobre o gênero épico". In: TEIXEIRA, Ivan (org.). Épicos cit., p. 26-27.

${ }^{90}$ Consulte-se o original e a mencionada tradução, lado a lado, em BOILEAU-DESPRÉAUX, Nicolas. "L'art poétique". Trad. como "The art of poetry" por John Dryden e Sir William Soame. In: ELLEDGE, Scott; SCHIER, Donald (ed.). The continental model cit., p. 208-269, especialmente p. 232-233. Para uma discussão sobre a presença e a ausência de imitação nas diferentes formas literárias, segundo a crítica neoclássica, ver: GENETTE, Gérard. "Introduction à l'architexte". In: TODOROV, Tzvetan; GENETTE, Gérard (org.). Théorie des genres. Paris: Seuil, 1986, p. 108-111; GUILLÉN, Claudio. Literature as a system: essays toward the theory of literary history. Princeton, NJ: Princeton University, 1971, p. 394 e ss. e, sobretudo, ABRAMS, M. H. The mirror and the lamp: romantic theory and critical tradition. Londres - Oxford - Nova Iorque: Oxford University, 1953, p. 30-72. Ver também WELLEK. René. A history of modern criticism cit., v. 1, p. 19.
} 
Esse tipo de divisão supõe uma hierarquia. As formas imitativas são consideradas as mais elevadas. Para Aristóteles $(1461 b-1462 b)$, a tragédia era superior. ${ }^{91}$ Com os neoclássicos, a preferência desloca-se para a epopeia. ${ }^{92}$ Como diria Samuel Johnson, o poema épico é a forma mais eminente porque satisfaz, como nenhuma outra, a definição de que a poesia deve instruir por meio do deleite: transmite as mais importantes verdades com recurso aos feitos mais extraordinários. ${ }^{93}$

Todas essas formulações chegaram relativamente tarde à Grã-Bretanha. O tratado aristotélico havia sido redescoberto para o Ocidente pelas mãos dos mestres italianos quase dois séculos antes, a partir da chegada dos egressos de Bizâncio. ${ }^{94}$ Conquanto a Poética fosse discutida no período isabelino por nomes como Harrington e Philip Sidney, ela só passou a ser vista como sumo manancial das leis da crítica e da composição a partir do neoclassicismo, por força do prestígio de autores franceses. As interpretações destes últimos - como aquelas de $\operatorname{Rapin}^{95}$ e Dacier $^{96}$ - gozaram de imensa ressonância. Aliás, é da tradução francesa de Dacier que foi feita a primeira versão inglesa, em $1705 .^{97}$

Findo esse quadro geral, podemos lidar especificamente com os preceitos neoclássicos da epopeia. Aparentemente, sua introdução na Inglaterra data de 1650, a partir de discussões suscitadas por Hobbes e Davenant. ${ }^{98}$ Todavia, aqui, o que há de neoclássico é uma concepção estanque das formas literárias, além de uma preocupação horaciana em conciliar a realização estética ao didatismo. A maneira como se concebe a imitação literária ainda é muito diferente da abordagem do Continente.

Cabe ressaltar que a ênfase aos escritos de Hobbes e Davenant não deve ser entendida como uma afirmação implícita de que a epopeia não houvera suscitado o interesse de críticos e escritores antes de 1650. Num proêmio à sua tradução de

\footnotetext{
${ }^{91}$ ARISTÓTELES. "Poetics" cit., p. 137-141.

${ }^{92}$ FOWLER, Alastair. Kinds of literature cit., p. 221 e ss.

${ }^{93}$ JOHNSON, Samuel. The lives of the poets. Ed. John H. Minddendorf. New Haven - Londres: Yale University, 2010, v. 1, p. 182-183.

${ }^{94}$ Ver COOPER, Lane. The Poetics of Aristotle: its meaning and influence. Boston: Marshall Jones, 1923 , p. 112 e ss.

${ }^{95}$ RAPIN. "Reflections on Aristotle's Treatise of poesie" cit., p. 135-244.

${ }^{96}$ ARISTÓTELES. La poëtique d'Aristote traduit en français avec des remarques. Trad. André Dacier. Paris, 1692, passim.

${ }^{97}$ Cf. HALLIWELL, Stephen. "The Poetics and its interpreters". In: RORTY, Amélie Oskenberg (ed.). Essays on Aristotle's Poetics cit., p. 409-419, especialmente p. 416.

${ }^{98}$ Cf. SWEDENBERG JR., H. T. The theory of the epic in England cit., p. 44-45.
} 
Orlando furioso, Harrington submetera o poema de Ariosto a uma avaliação de acordo com o que julgava serem as normas relativas ao gênero. ${ }^{99}$ Spenser, por sua vez, discorrera sobre a alegoria na poesia heroica (sobretudo a de sua autoria) numa carta a Walter Raleigh, que serve de posfácio a Faerie queene. ${ }^{100} \mathrm{E}$ o próprio Milton, anos antes de finalizar o Paraíso perdido, no seu tratado sobre a educação, esboçara suas opiniões sobre a relação entre a poesia (épica e dramática) e outros campos do conhecimento. $^{101}$

Em 1650, Davenant e Hobbes elegem o aspecto moral da epopeia e das outras formas como verdadeiro elemento definidor do gênero literário. Tal aspecto é aferido em diversas esferas: nos valores encerrados; nos feitos desempenhados; na adequação da conduta à condição das personagens; e na influência que os ensinamentos contidos na obra terão sobre o leitor.

Ao publicar Gondibert, an heroick poem, Davenant dedica o Prefácio a Thomas Hobbes. Compromete-se a delinear os elementos inerentes à forma a que se filia seu poema. ${ }^{102}$ Para Davenant, a epopeia é o maior e mais instrutivo dos gêneros poéticos, pois canta os "fundadores divinos" do povo - seus generais, estadistas e legisladores , envoltos em questões pertinentes a religião, armas, política e direito. ${ }^{103}$ Assim, argumenta-se que a poesia épica não é destinada ao vulgo. É destinada àqueles que comandam o vulgo, que podem instruir-se dos exemplos dos heróis. ${ }^{104}$ De tal feita, diz-se que as perfídias não devem ser atribuídas às pessoas de baixa extração, pois se crê que a vinculação de vícios a pessoas abjetas será inservível aos leitores. ${ }^{105}$ Por outro lado, Davenant rechaça a ideia de que os valores cristãos sejam estranhos a um

\footnotetext{
${ }^{99}$ Ver HARRINGTON, John. “An apology for Ariosto: poetry, epic, morality”. In: VICKERS, Brian (ed.). English Renaissance literary criticism. Oxford: Clarendon, 1999, p. 302-324.

${ }^{100}$ SPENSER, Edmund. "A letter of the Authors [sic] expounding his whole intention in the course of his worke: which for that it giueth great light to the Reader, for the better vnderstanding is heunto annexed". The Faerie Queene. Ed. A. C. Hamilton. 2. ed. Harlow: Pearson Longman, 2007, p. 714718. Sobre a alegoria em Faerie Queene, ver COOK, Patrick J. Milton, Spenser and the epic tradition. Aldershot: Ashgate, 1999, p. 114 e ss.

${ }^{101}$ MILTON, John. "Of education: to Master Samuel Hartlib". Complete poems and major prose cit, p. 630-639, especialmente p. 636.

${ }^{102}$ DAVENANT, William. "Preface to Gondibert, an heroick poem". In: SPINGARN, J. E. (ed.). Critical essays of the seventeenth century. Oxford: Clarendon, 1908, vol. 2, p. 1-53. Sobre as teorias esposadas no mencionado Prefácio, ver SWEDENBERG JR., H. T. The theory of the epic in England cit., p. 43-44 e TILLYARD, E. M. W. The English epic and its background cit., p. 428-429.

${ }^{103}$ DAVENANT, William. "Preface to Gondibert" cit., p. 35-44.

${ }^{104}$ Idem, p. 14.

${ }^{105}$ Idem, p. 16-17.
} 
poema épico, uma vez que pregam a virtude, a honra e o respeito aos seus. ${ }^{106}$ No que tange à relação entre a obra e a realidade, defende uma representação literária que se atenha mais à essência do objeto que às suas minúcias, pois a verdade estaria na razão, e não na matéria. Vê como desnecessário o zelo excessivo aos fatos históricos. $^{107}$

Ainda no mesmo ano, Hobbes responde ao Prefácio. ${ }^{108}$ Mais do que uma retomada dos pontos suscitados por Davenant, Hobbes esquematiza um amplo painel dos gêneros literários, no qual a conceituação da epopeia emerge ao longo de um arrazoado contrastivo. Recupera a noção medieval - representada graficamente na famosa "roda de Virgílio" - de continuidade da poesia pastoril até a epopeia, num percurso baseado não só em formas literárias, mas também nas classes sociais das personagens, nos cenários e nas espécies de estilo desenvolvidos. ${ }^{109}$

Para Hobbes, exatamente como fizeram os filósofos - que teriam dividido o mundo nas partes celestial, aérea e terrestre -, os poetas repartiram "as regiões da humanidade" em corte, cidade e campo. Os poetas assim procedem porque seu objeto é a vida humana, imitada pela poesia. ${ }^{110} \mathrm{~A}$ vida humana, por seu turno, seria constituída de: príncipes, outrora denominados heróis, cujo poder sobre seus súditos se assemelha àquele que emana dos céus; insinceridade e inconstância, que lembram os pútridos ares da cidade; e uma singeleza, ainda que tida como pouco inteligente, mas bastante digna, dos rústicos homens que trabalham a terra. ${ }^{111}$

Dessa divisão, procederiam três classes de poesia: heroica, sarcástica (scommatique) e pastoral. Cada uma delas se dá num modo diferente de representação, que pode ser narrativa, em que o próprio poeta relata, ou dramática, em que a personagem é adornada e trazida para falar em seu nome. ${ }^{112}$ Hobbes conclui que há seis classes de poesia, que são as três originais combinadas aos modos de representação. São elas: o poema heroico narrativo, chamado de poema épico; o

\footnotetext{
${ }^{106}$ Idem, p. 10-11.

${ }^{107}$ Idem, p. 11.

${ }^{108}$ HOBBES, Thomas. "Answer to Davenant's Gondibert". In: SPINGARN, J. E. (ed.). Critical essays of the seventeenth century cit., vol. 2, p. 54-67. Ver SWEDENBERG JR., H. T. The theory of the epic in England cit., p. 44-45.

${ }^{109}$ Cf. FOWLER, Alastair. Kinds of literature cit., p. 239-241. Ver também CURTIUS, Ernst Robert. European literature and the Latin Middle Ages. Trad. William Trask. Princeton, NJ: Princeton University, 1990, p. 231-232.

${ }^{110}$ HOBBES, Thomas. "Answer to Davenant's Gondibert" cit., p. 54-55.

${ }^{111}$ Idem, p. 54.

${ }^{112}$ Idem, p. 55.
} 
poema heroico dramático, que é a tragédia; o poema sarcástico narrativo, que é a sátira; o poema sarcástico dramático, que é a comédia; o poema pastoral narrativo, antes chamado de bucólico, mas hoje conhecido simplesmente como pastoral; o poema pastoral dramático, conhecido como comédia pastoral. ${ }^{113}$

Esboçada a teoria geral hobbesiana sobre a poesia, restam alguns comentários esporádicos acerca da epopeia. Aqui, percebe-se que a preocupação com o decoro é a linha-mestra do pensamento de Hobbes, tanto na adequação do estilo ao tema quanto à atribuição dos feitos às personagens. Censura as ações daqueles cuja condição moral ou social - não nos autoriza a pensar que pudessem realizá-las. ${ }^{114}$ Tampouco o agradam as ficções desbragadas, carregadas de castelos encantados, cavalos voadores, corpos invulneráveis e homens de ferro. ${ }^{115}$

O moralismo de Davenant e Hobbes teria enorme sobrevida na Inglaterra e na Escócia. ${ }^{116}$ Seus critérios analíticos, no entanto, não detinham a sistematicidade necessária para que pudessem se converter numa espécie de mapa infalível a seus contemporâneos. Embora mencionassem categorias caras ao aristotelismo neoclássico, como ação, forma e imitação, tais menções estavam subordinadas ao esquema horaciano de deleitar para instruir. Seriam os franceses que serviriam como guias a muitas das inquirições acerca da poesia épica. Sua presença na Grã-Bretanha seria enorme a partir da Restauração, após uma longa temporada dos Stuarts e seus seguidores na França. Lá, apreciaram o papel desempenhado pela poesia e a crítica como instrumentos da estabilidade social e política alcançada sob o reinado de Luís XIV. $^{117}$

Dentre os franceses, o mais importante teórico da epopeia era Le Bossu. É difícil exagerar a importância de suas ideias nos dois lados do Canal da Mancha. Desde o ano de publicação, em 1675, até quase o final do século XVIII, seu Traité du poëme épique $^{118}$ foi referência obrigatória em quase todas as discussões a respeito do gênero

\footnotetext{
${ }^{113}$ Idem, ibidem. De passagem, Hobbes menciona a teoria de tripartição dos gêneros, que seria amplamente difundida a partir do romantismo. No entanto, ele rapidamente a descarta (ver idem, p. 5556).

${ }^{114}$ Idem, p. 64.

${ }^{115}$ Idem, p. 61-62.

${ }^{116}$ SWEDENBERG JR., H. T. The theory of the epic in England cit., p. 44-45.

${ }^{117}$ Cf. TILLYARD, E. M. W. The English epic and its background cit., p. 453.

${ }^{118}$ Utilizamos a seguinte edição: LE BOSSU, René. Traité du poëme épique. Paris, 1705.
} 
épico. ${ }^{119}$ Para muitos, foi visto como uma espécie de codificação definitiva. Na GrãBretanha setecentista, usar a expressão "as regras da poesia épica” era o equivalente a dizer "as regras de Le Bossu". ${ }^{120}$ Notem-se os laudatórios termos com que Mulgrave, em seu An essay upon poetry, recobre a obra de Le Bossu: sem ela, a Ilíada e a Odisseia seriam mistérios insondáveis:

Lê Homero uma vez, e não poderás tornar a ler.

Pois todo o resto se parecerá tão pobre e enfadonho.

Tu o desejarás não lido; mas com frequência o examina

E dificilmente precisarás de outro livro.

Se Bossu não tivesse escrito, o mundo ainda estaria

Como índios a ver esse maravilhoso produto de destreza;

A admirar a obra tal qual algo [procedente] do Divino,

Refinada não para instruir, mas inspirar:

Até que ele, desvendando mistérios sagrados,

Mostrou onde repousa a poderosa mágica,

Descreveu as sementes (e em que ordem [foram] semeadas),

Que se elevaram em tão vasta proporção.

Certamente, aprendeu tal segredo de um anjo,

Que por esse labirinto forneceu-lhe o novelo! ${ }^{121}$

O tom de reverência empregado por Mulgrave é complemente estranho à sobriedade e discrição afetadas por Le Bossu ao longo de seu tratado. Ao invés de arvorar-se em intérprete do sagrado, o crítico francês se credencia como um racionalista. Promete emprestar à arte uma abordagem semelhante àquela dispensada à ciência, pois vê em ambas um fundamento comum, a saber: a razão. Por outro lado, diz que, além de confiar na razão, é importante orientar-se pelos antigos, uma vez que foram eles os criadores da poesia. Assim, sua análise da epopeia se valerá tanto de verdades "autoevidentes" quanto dos ensinamentos de Aristóteles e Horácio e

\footnotetext{
${ }^{119}$ Cf. DOUGLAS, Loyd. "A severe animadversion on Bossu”. PMLA, v. 62, n. 3 (setembro, 1947), p. 690-706.

${ }^{120}$ CLARK, A. F. B. Boileau and the French classical critics in England (1660-1830). Nova Iorque: Russell \& Russell, 1965, p. 246.

121 "Read Homer once, and you can read no more./ For all things else will seem so dull and poor,/ You'l wish 't unread; but oft upon him look,/ And you will hardly need another book./ Had Bossu never writ, the world had still/ Like Indians view'd this wondrous piece of Skill;/ As something of Divine the work admired,/ Moped not to be Instructed, but Inspired:/ Till he, disclosing sacred Mysteries,/ Has shewn where all the mighty Magick lyes,/ Describ'd the Seeds, and in what order sown,/ That have to such a vast proportion grown./ Sure from some Angel he the secret knew,/ Who through this Labyrinth has given the clue!" (SHEFFIELD, John (Earl of Mulgrave, Duke of Buckinghamshire). "An essay upon poetry". In: SPINGARN, J. E. (ed.). Critical essays of the seventeenth century cit., vol. 2, p. 286-296, especialmente p. 295-296).
} 
exemplos de Homero e Virgílio. ${ }^{122} \mathrm{O}$ resultado é um texto cujo teor é, indubitavelmente, prescritivo. Le Bossu está a todo instante a dizer o que os poetas devem e não devem fazer.

Esse aristotelismo racionalista, como é de se esperar, não pôde prescindir da aplicação de um arranjo dedutivo quando do desenvolvimento de sua exposição. A partir de uma ampla suposição, propõe-se estudar uma forma literária sob todos os critérios analíticos que distinguem a crítica neoclássica. Para tanto, tem-se uma definição da epopeia em que a moral é entrelaçada ao conceito de ação, elemento definidor das ditas formas imitativas:

A epopeia é um discurso inventado com arte, para formar os hábitos por meio de instruções ocultas sob as alegorias de uma ação importante, que é narrada em verso de uma maneira verossimilhante, deleitosa \& maravilhosa. ${ }^{123}$

Confere-se à ação - mais precisamente, a uma "ação importante" - centralidade na conceituação do poema épico. Todavia, retira-se dessa mesma "ação importante" sua autonomia. Ainda que extraída de eventos reais, sua estruturação subordina-se a uma ideia ou ensinamento que se almeja passar ao leitor. Conseguintemente, as personagens de uma epopeia são, acima tudo, alegóricas e universais. ${ }^{124}$ A narrativa da ira de Aquiles e da sua disputa com Agamenon não teria nenhum valor per se. Sua importância estaria em demonstrar, de "maneira verossimilhante, deleitosa \& maravilhosa", que a desinteligência entre os príncipes leva o Estado à ruína. ${ }^{125} \mathrm{Ou}$ seja: o estabelecimento de uma moral antecede a configuração da ação. Com isso, reforça-se a teoria aristotélica de que a poesia diferencia-se da história por transcender o circunstancial. $^{126}$

Desse compromisso, dá-se azo à fábula, que é uma narração que imita alegoricamente uma ação, com o propósito de instruir. Ante o exposto, entende-se que a moral é a finalidade da epopeia e a ação, a matéria sobre a qual trabalha o poeta. ${ }^{127}$ É a ação que prevalece sobre a caracterização dos heróis. Portanto, a unidade da obra

\footnotetext{
${ }^{122}$ LE BOSSU, René. Traité du poëme épique cit., p. 1-3.

123 "L'Epopée est un discours inventé avec art, pour former les mœurs par des instructions déguisées sous les allégories d'une action importante, qui est racontée en Vers d'une manière vraisemblable, divertissante, \& marveilleuse" (idem, p. 14). Sobre a importância da alegoria para Bossu, ver BRAY, René. La formation de la doctrine classique en France cit., p. 212-214.

${ }^{124}$ LE BOSSU, René. Traité du poëme épique cit., p. 8.

${ }^{125}$ Idem, p. 43 e ss.

${ }^{126}$ Ver idem, p. 16.

${ }^{127}$ Idem, p. 131-132.
} 
não advém das personagens nem do evento narrado. Deriva da própria ação. Sendo assim, na Ilíada, não se representa o passado de Heitor ou toda a Guerra de Tróia. ${ }^{128}$ Não se dispensa a unidade da ação mesmo para os poemas fundados em fatos históricos.

A construção dos episódios é tida como ponto fundamental para se alcançar a unidade. ${ }^{129}$ Le Bossu estabelece que devem ter origem na própria ação, que se reparte em incidentes particulares que lhe dão colorido e interesse. A inserção de episódios autônomos estilhaçaria a ação. ${ }^{130}$ Haveria, portanto, três tipos de erro que violam a unidade da ação. São eles: episódios que não derivam da ação; episódios que não têm relação com o resto do poema; a ação ser trazida a cabo independentemente da personagem principal. ${ }^{131}$ Embora a ação seja unitária, isso não quer dizer que não deva possuir obstáculos ou nós. ${ }^{132}$

Além da unidade, a ação épica deteria outras três condições: integridade, importância e duração. ${ }^{133}$

A integridade se perfaria quando a ação produz um todo, no qual avulta a presença de um começo, um meio e um fim. Para que esse objetivo seja atingido, é aconselhável reduzir a ação, para que possa apresentá-la convenientemente. Contudo, é necessário que essa ação reduzida não seja apresentada como parte de uma ação maior. Ainda que se aluda a feitos que não são apresentados, a ação deve desenvolver-se por si mesma, de acordo com critérios internos de necessidade. ${ }^{134}$ Em face disso, o poema tem de começar de maneira que não sejam necessárias explicações prévias. E deve encerrar como consequência da ação desenvolvida, sem que seja preciso apor qualquer outro evento para a compreensão do sentido total da fábula. $^{135}$

Em síntese, o começo não deve exigir nada antes e o fim não deve exigir nada depois. $\mathrm{O}$ começo demanda continuidade e o fim demanda eventos que o precedam. $\mathrm{O}$

\footnotetext{
${ }^{128}$ Idem, p. 133-136.

${ }^{129}$ Sobre os episódios no Traité, ver BRAY, René. La formation de la doctrine classique en France cit., p. 246-250.

${ }^{130}$ LE BOSSU, René. Traité du poëme épique cit., p. 158-166.

${ }^{131}$ Idem, p. 184.

${ }^{132}$ Idem, p. 174.

${ }^{133}$ Idem, p. 184.

${ }^{134}$ Idem, p. 195-204.

${ }^{135}$ Idem, p. 208-209.
} 
meio deve ser fruto do que lhe antecedeu e implicar continuidade para que se desatem os conflitos que nele se delinearam. ${ }^{136}$

A importância da ação decorre dos feitos narrados. Le Bossu prescreve que sejam desempenhados por pessoas ilustres, cujos atos tenham consequência política. Não há necessidade de que sejam reis, como escreve Horácio, mas é relevante que sejam magníficos e admirados por todos. A guerra seria o meio por excelência em que se demonstra a grandeza do herói. Alguns dos recursos retóricos utilizados para realçar tal grandeza são a amplificação - da força, estatura ou idade - e o exagero. ${ }^{137}$

No que concerne ao tempo, afirma-se que as ações épicas são mais longas que as dramáticas. Ao contrário, do que se daria com a tragédia, na qual predominaria a unidade de tempo, há epopeias de diferentes extensões. ${ }^{138}$ Tamanha diferença se justifica pelo objeto representado: a tragédia lida com paixões, que se exaurem, e a epopeia, com hábitos, que precisam ser expostos. ${ }^{139}$ Apesar de não se dispor a formular uma lei geral, Le Bossu crê que a ação da epopeia não deva delongar-se por mais de um ano, numa analogia à ação do drama, que dura um dia. Demora-se numa digressão, sem resolução satisfatória, acerca do que é razoável entender pela expressão "um ano": se compreende o inverno ou se deve ser interpretada como uma campanha. $^{140}$

O Traité não se esgota na análise da moral e da ação épicas. Versa ainda sobre a narração, os hábitos retratados (i.e., a caracterização das personagens), as divindades e a expressão poética. É importante lidarmos com esses quesitos com algum vagar, como maneira de expor a minúcia prescritiva de Le Bossu e da crítica neoclássica.

Sob a rubrica da narração, discutem-se as fórmulas retóricas, como a proposição e a invocação, e a estruturação que considera apropriada ao enredo de uma epopeia. ${ }^{141}$

A proposição deveria resumir a ação, de molde que haja informações suficientes para que se saiba o assunto do poema. Le Bossu concorda com Horácio quanto à necessidade de não se iniciar um poema de modo muito grandiloquente, fazendo-se promessas que não podem ser cumpridas. Censura nomes como Estácio, cuja

\footnotetext{
${ }^{136}$ Idem, p. 210.

${ }^{137}$ Idem, p. 273-280.

${ }^{138}$ Idem, p. 265-266.

${ }^{139}$ Idem, p. 266-267.

${ }^{140}$ Idem, p. 379-390.

${ }^{141}$ Idem, p. 284 e ss.
} 
Aquilíada promete tratar da magnanimidade de Aquiles, numa proposição contrariada pelos feitos narrados. ${ }^{142}$

A invocação, por seu turno, consiste na atribuição à Musa dos poderes do canto. Homero não diz que cantará os feitos de Aquiles ou Ulisses. Pede auxílio à Musa. A invocação das Musas distinguiria os deuses da Poesia dos deuses que presidem a ação do poema. ${ }^{143}$

Findas a proposição e a invocação, passa-se ao "corpo do poema" ou o que Le Bossu toma como a narração em si. No que tange às suas "qualidades", deve ser agradável, verossímil, tocante, admirável e ativa. São qualidades que tornam prazerosa a leitura da epopeia, permitindo a transmissão da instrução que encerra. Assim, retomando-se as observações de Horácio, a epopeia deve ser agradável para que possa ser útil. A utilidade não seria uma qualidade da narração, mas da natureza da fábula ou da epopeia como um todo. ${ }^{144}$

A verificação da verossimilhança se daria sob o escrutínio da teologia, da moral, da natureza, da razão, da experiência e da opinião. Segundo a teologia, tudo é verossímil, pois nada é impossível para Deus. Essa seria uma saída de que os poetas se têm valido com frequência. Mas a verossimilhança mais importante é aquela ditada pela opinião comum - a saber, o decoro. ${ }^{145}$ Contudo essa verossimilhança não pode implicar uma asfixia do admirável. ${ }^{146}$

Para que possa deleitar e instruir, a epopeia precisa ser tocante e incitar as paixões, como a piedade, o terror e, sobretudo, a admiração. Cada epopeia, no entanto, tem uma paixão particular, determinada pelo caráter do herói. Recomenda-se evitar a mistura de paixões contraditórias. ${ }^{147}$

Requer-se também vivacidade na narrativa épica. Citando Aristóteles, Le Bossu afirma ser importante conceder a palavra às personagens. Ademais, faz-se mister submeter as instruções, alegorias e descrições ao curso da ação. Para falar que o sal preserva cadáveres, deve-se colocar tal lição no meio do desenvolvimento da ação. ${ }^{148}$

\footnotetext{
${ }^{142}$ Idem, p. 291-305.

${ }^{143}$ Idem, p. 306-311.

${ }^{144}$ Idem, p. 314-316.

${ }^{145}$ Idem, p. 326-334. WILLIAMS, Ralph C. “Two studies in epic theory” cit., p. 141.

${ }^{146}$ LE BOSSU, René. Traité du poëme épique cit., p. 340. Ver BRAY, René. La formation de la doctrine classique en France cit., p. 208-209.

${ }^{147}$ LE BOSSU, René. Traité du poëme épique cit., p. 346-354.

${ }^{148}$ Idem, p. 357-368.
} 
No penúltimo capítulo a tratar da narração, Le Bossu distingue a fábula do enredo, conquanto não formule tais conceitos de maneira explícita. Assevera que a ação e a narração são contínuas, mas que a narração o é de uma maneira bastante peculiar. Permite inverter a ordem de apresentação dos fatos, omitir situações tediosas e concentrar-se em eventos mais interessantes. Esses procedimentos costumam acontecer no caso de poemas cujas ações são muito longas. Aqui, a narração é "artificial": seleciona apenas o que é digno da epopeia, num expediente que, no entanto, esconde seu engenho e quer soar natural. Contrasta-se a Ilíada à Odisseia. No primeiro caso, diz-se que a ordem da narrativa é a mesma da ação. No segundo caso, não. ${ }^{149}$

Um dos tópicos mais interessantes ao longo do estudo de Le Bossu é aquele acerca das personagens, porquanto explicita o escopo instrutivo entrevisto na poesia épica.

Conforme se depreende do que foi dito páginas atrás, requer-se que a escolha das personagens obedeça à fábula. Sua idade, sua posição e seus hábitos têm de se subsumir à alegoria que se almeja comunicar com o poema épico. ${ }^{150}$ Ressalte-se que caráter não é apenas uma virtude (ou vício), mas composição de diversas virtudes e vícios, misturados em diferentes graus. Cada personagem precisa ter uma mistura única, o que torna o poema animado e variado. ${ }^{151}$

Recomenda-se que os hábitos de cada personagem também sejam apropriados à sua inclinação e que sejam semelhantes àqueles que a opinião comum reconhece em tais figuras. Tampouco deve haver espaço para dubiedade moral: as personagens devem ser constantes. A unidade do caráter da personagem seria obtida com recurso a alguns expedientes. Primeiramente, é preciso que o herói tenha um caráter preciso, apto a se manifestar em diversas ocasiões. Depois, sugere-se que esse mesmo herói seja completamente livre e independente, de molde que não haja obstáculos para que se possa dar vazão à sua personalidade. Recomenda-se que tais obstáculos sejam introduzidos por meio de episódios. ${ }^{152}$

\footnotetext{
${ }^{149}$ Idem, p. 368-378. Para um estudo sobre a dita ordem artificial na epopeia inglesa, ver DELASANTA, Rodney. The epic voice. Haia - Paris: Mouton, 1967, p. 11 e ss.

${ }^{150}$ LE BOSSU, René. Traité du poëme épique cit., p. 444-457.

${ }^{151}$ Idem, p. 485.

${ }^{152}$ Idem, p. 507-508.
} 
Estabelece-se uma distinção entre bondade moral e bondade poética. ${ }^{153} \mathrm{~A}$ primeira relaciona-se aos ensinamentos derivados da religião. A segunda, por sua vez, à função desempenhada ao longo da ação. ${ }^{154}$ Mirando-se sobretudo no exemplo de Aquiles, Le Bossu argumenta que o herói poético não precisa ser necessariamente virtuoso. Na poesia, "heroico" não é (ou nem sempre é) sinônimo de "virtuoso". É um termo que pode referir-se a um tipo de metro ("verso heroico") ou que pode designar uma genealogia divina: heróis são os filhos dos deuses. Como havia deuses maus entre os gregos, a linhagem sagrada não se traduziria em virtudes.

Le Bossu explica que a não coincidência do heroísmo com virtude tem origem na própria natureza da epopeia. Dotada de uma fábula, muitas vezes há necessidade de se ter um herói com vícios a fim de instruir o público. É pelo fato de Aquiles entrar em conflito com seu rei que surgem problemas para os gregos. A Ilíada recomendaria, portanto, que se evitasse essa sorte de conflito. ${ }^{155}$

Ao discutir o papel reservado às divindades, Le Bossu mostra-se um ardoroso defensor de sua intervenção. Presta-se à instrução, porquanto propicia ensinamentos sobre as virtudes divinas. Ademais, torna o poema interessante e variado. ${ }^{156}$

Le Bossu encerra seu Traité com uma discussão sobre a expressão poética. Contudo, o assunto desta parte não é só o estilo, mas também como incutir na audiência os sentimentos que se quer que ela tenha. ${ }^{157}$ Assim, o crítico se detém não apenas nos ensinamentos das regras da epopeia relativas a descrições, comparações, hipérboles etc. ${ }^{158}$ Devota grande atenção à transmissão tanto de pensamentos úteis "à condução da vida" ${ }^{159}$ quanto de conhecimentos artísticos ou científicos. ${ }^{160}$

Ao falar propriamente do estilo, Le Bossu diz que, na epopeia, deve ser belo, nobre e elevado, tal qual se dá na tragédia. No entanto, requer-se adequação ao tema. Na Ilíada, em que abunda a cólera, o estilo é inflamado. Na Odisseia, em que se cantam a prudência e a sabedoria, o estilo é mais fleumático. Na Eneida, o estilo é

\footnotetext{
${ }^{153}$ BRAY, René. La formation de la doctrine classique en France cit., p. 223.

${ }^{154}$ LE BOSSU, René. Traité du poëme épique cit., p. 416-426.

${ }^{155}$ Idem, p. 426-436.

${ }^{156}$ Idem, p. 563-568.

${ }^{157}$ Idem, p. 577.

${ }^{158}$ Idem, p. 586-602.

${ }^{159}$ Idem, p. 603.

${ }^{160}$ Idem, p. 627.
} 
mais doce. Por fim, deve-se adequar o tom ao episódio e os sentimentos àquilo que se descreve. $^{161}$

Vinte anos depois de sua publicação na França, o Traité du poëme épique ganhou tradução anônima para o inglês, dedicada a Richard Blackmore. ${ }^{162}$ Contudo, seu conteúdo já era conhecido na Grã-Bretanha mesmo antes de 1695. São contínuas e sucessivas as referências que os neoclássicos ingleses, de John Dryden até Samuel Johnson, fazem à obra de Le Bossu. ${ }^{163}$ Vejamos alguns exemplos.

Notável é a reformulação por que passaram as ideias de Dryden sobre a epopeia. ${ }^{164}$ E é possível perceber a sombra de Le Bossu ao longo desse processo, que se faz sentir a partir do prefácio a Troilus and Cressida, quando Dryden expressamente cita o crítico francês, a respeito do caráter alegórico da ação épica. ${ }^{165}$ A partir de então, Dryden vislumbra o autor do Traité como alguém sem o qual não seria possível se aventurar na escrita de uma epopeia:

[...] um poeta épico, se se trata de alguém digno desse nome, além de um gênio universal [...], precisa ter estudado Homero e Virgílio como seus padrões; Aristóteles e Horácio como seus guias; e Vida e Bossu como seus comentadores [...]. ${ }^{166}$

E é pelas lentes de Le Bossu que Dryden avalia a Eneida, ${ }^{167}$ por ele traduzida, no que tange ao seu estilo e ao tempo da ação. Ademais, saúda a alegoria do poema de Virgílio, sobre a importância de um governo centralizado e como a instituição de um governo não eletivo propiciava a paz, uma vez que as pessoas se conformavam com a

\footnotetext{
${ }^{161}$ Idem, p. 632-635.

${ }^{162}$ Cf. ELLEDGE, Scott; SCHIER, Donald (ed.). The continental model cit., p. 396. Utilizaremos a presente edição inglesa: LE BOSSU, René. Monsieur Bossu's treatise of the epick poem: containing many curious reflexions, very useful and necessary, for the right understanding and judging of the excellencies of Homer and Vergil. Trad. W. J. Londres, 1719, 2 vols.

${ }^{163}$ Sobre a importância de Le Bossu na Inglaterra, ver CLARK, A. F. B. Boileau and the French classical critics in England (1660-1830) cit., p. 243-261.

${ }^{164}$ Ver SWEDENBERG JR., H. T. The theory of the epic in England cit., p. 54 e ss.

${ }^{165}$ DRYDEN, John. "Preface to Troilus and Cressida, containing the grounds of criticism in tragedy”. In: KER, W. P. (ed.). Essays of John Dryden. Oxford: Clarendon, 1900, v. 1, p. 202-229, especialmente p. 213.

166 " [...] an epic poet if one who is worthy of that name, besides an universal genius, is required universal learning [...], he must have exactly studied Homer and Virgil as his patterns; Aristotle and Horace as his guides; and Vida and Bossu as their commentators [...]" (DRYDEN, John. "A discourse concerning the original and progress of satire". In: KER, W. P. (ed.). Essays of John Dryden cit., v. 2, p. 15-114, especialmente p. 36).

${ }^{167}$ DRYDEN, John. "The dedication of the AEneis". In: KINSLEY, James (ed.). The poems of John Dryden cit., v. 3, p. 1003-1064.
} 
sociedade em que nasceram. ${ }^{168}$ Apenas lamenta que Spenser não tenha conhecido as regras do Traité.

No prefácio à sua primeira malfadada epopeia, ${ }^{169}$ Prince Arthur, Richard Blackmore destila uma síntese do pensamento de Le Bossu. ${ }^{170}$ Ao que parece, Blackmore compôs seu poema de acordo com as regras do crítico francês. Toma a poesia épica como uma forma em que agem personagens de origem nobre, cujos feitos servem de lição ao público. Assim, repete-se o mantra de que a ação deve ser alegórica:

Um poema épico é uma estória fingida ou inventada de uma ação ilustre, relatada em verso, numa maneira alegórica, provável, deleitosa e admirável, a fim de cultivar a mente com instruções de virtude. ${ }^{171}$

Curiosamente, John Dennis se valerá da autoridade de Le Bossu para demolir a reputação de Blackmore. ${ }^{172}$ Estabelece que:

Um poema épico é um discurso inventado com arte, para formar os hábitos por meio de instruções disfarçadas sob a alegoria da ação, que é importante, e que é relatado em verso de uma maneira deleitosa, provável e maravilhosa. ${ }^{173}$

Empenha-se em demonstrar que a ação de Prince Arthur é desprovida de integridade, moralidade ou universalidade, o que retira qualquer insinuação da presença de uma fábula e torna insubsistentes as tentativas de qualificá-lo como poema heroico. Depois, expõe os vícios da narrativa, que não seria nada deleitosa, provável ou repleta de maravilhas. Sobre as personagens, assevera que lhes faltam unidade de caráter, constância ou moralidade poética. Quanto às divindades, reclama daquelas insertas no

\footnotetext{
${ }^{168}$ Creio que as preferências políticas de Dryden, desgostoso com a Revolução Gloriosa, fazem-se sentir aqui.

${ }^{169}$ BLACKMORE, Richard. "Preface to Prince Arthur, an heroick poem". In: SPINGARN, J. E. (ed.). Critical essays of the seventeenth century cit., v. 3, p. 227-241.

${ }^{170}$ Sobre Blackmore e Le Bossu, ver TILLYARD, E. M. W. The English epic and its background cit., p. 483.

171 “An Epick Poem is a feign'd or devis'd Story of an Illustrious Action, related in Verse, in an Allegorical, Probable, Delightful, and Admirable manner, to cultivate the Mind with Instructions of Virtue" (BLACKMORE, Richard. "Preface to Prince Arthur, an heroick poem" cit., p. 235).

${ }^{172}$ Ver SWEDENBERG JR., H. T. The theory of the epic in England cit., p. 52-54 e CLARK, A. F. B. Boileau and the French classical critics in England (1660-1830) cit., p. 244-245.

173 “An Epick Poem is a Discourse invented with Art, to form the Manners by Instructions disguis'd under the Allegory of Action, which is important, and which is related in Verse in a delightfull, probable and wonderfull manner" (DENNIS, John. "Remarks on a book entitled, Prince Arthur, an heroick poem. With some general critical observations, and several new remarks upon Virgil". In: HOOKER, Edward Niles (ed.). The critical works of John Dennis cit., v. 1, p. 46-144, especialmente p. $55)$.
} 
poema. Ao fim, questiona o estilo do poema, marcado por uma dicção baixa e pelo mau emprego dos tropos. ${ }^{174}$ Há de se notar que a análise de Dennis segue até mesmo a ordem dos tópicos discutidos pelo crítico francês em seu tratado.

Como se pode perceber, as teses de Le Bossu se haviam convertido numa espécie de régua comum, com que se avaliavam desde obras provenientes da Antiguidade até produções vindas a lume no alvorecer do século XVIII. Embora o Paraíso perdido seja um poema cuja estruturação dista do receituário neoclassicista francês, ${ }^{175}$ é ao idioma comum das categorias analíticas de Le Bossu que Addison apelará numa série de ensaios, que citamos páginas atrás, devotados a comprovar os méritos literários de John Milton. ${ }^{176}$

Assim, Addison se detém na moral do poema, que seria: a obediência a Deus traz alegria e a desobediência, tristeza. ${ }^{177}$ A relação dessa moral com a ação é esmiuçada, com o que se tem a fábula. ${ }^{178}$ Elencam-se, então, as qualidades da ação, que deve ser una, inteira e dotada de magnitude. Ao tratar do que chama de magnitude, Addison está, na verdade, a ocupar-se de um conceito amplo, que abarca vários daqueles de Le Bossu: refere-se ao assunto do poema, à duração da narrativa e ao tempo da ação. ${ }^{179} \mathrm{O}$ assunto grandioso é tido como adequado à elevação de sentimentos e pensamentos miltonianos ${ }^{180} \mathrm{e}$ à caracterização dos heróis. ${ }^{181}$

Ao lidarem com premissas tão amplamente aceitas, os ensaios de Addison encontraram imensa ressonância junto ao público leitor, a contribuir decisivamente para a maneira como o público setecentista passaria a apreciar o Paraíso perdido. ${ }^{182}$

174 Idem, p. 46 e ss.

${ }^{175}$ As referências de Milton não the são exatamente contemporâneas. Estão, sim, mais nos renascentistas italianos que nos neoclassicistas franceses. É interessante notar, contudo, que o épico miltônico é sumamente neoclássico, pautado pelo respeito à unidade da ação (TILLYARD, E. M. W. The English epic and its background cit., p. 430).

${ }^{176}$ ADDISON, Joseph. Notes upon the twelve books of Milton's Paradise lost cit., passim. Sobre o método crítico de Addison e a relação de seus ensaios sobre o Paraiso perdido com as teses de Le Bossu, ver DAMROSCH JR., Leopold. "The significance of Addison's criticism”. Studies in English Literature, 1500-1900, v. 19, n. 3 (Restoration and Eighteenth Century) (verão, 1979), p. 421-430, especialmente p. 425 e CLARK, A. F. B. Boileau and the French classical critics in England (16601830) cit., p. 253.

${ }^{177}$ ADDISON, Joseph. Notes upon the twelve books of Milton's Paradise lost cit., p. 133-143.

${ }^{178}$ Idem, p. 3-8.

${ }^{179}$ Idem, ibidem. CLARK, A. F. B. Boileau and the French classical critics in England (1660-1830) cit., p. 253.

${ }^{180}$ ADDISON, Joseph. Notes upon the twelve books of Milton's Paradise lost cit., p. 13-24.

${ }^{181}$ Idem, p. 8-13.

${ }^{182}$ Cf. DAMROSCH JR., Leopold. “The significance of Addison's criticism” cit., p. 421-430. 
O nome de Le Bossu passaria a ser invocado ainda por muitos e muitos anos. Pope diria que o "admirável" tratado do crítico francês sobre a epopeia é um bom guia para compreender o propósito e a condução do ofício poético por Homero. ${ }^{183} \mathrm{E}$ já no final do século XVIII, Johnson se basearia nos ensinamentos de Le Bossu para avaliar o Paraíso perdido, de molde que versa sobre a precedência do elemento moral em face da ação, dotada de unidade e integridade; os sentimentos, pensamentos e lições éticas; emprego dos símiles e manejo de amplificações etc. ${ }^{184}$

\section{Primitivistas}

Apesar da força da crítica neoclássica, tomava corpo uma corrente para a qual as discussões normativistas sobre a poesia épica eram apontadas como ociosas. $\mathrm{O}$ próprio Pope se permitiria debochar de Le Bossu. Em Peri Bathous: of the art of sinking in poetry, de 1728, o pedante charlatão Martinus Scriblerus distorce a ideia do crítico francês de que a ação épica seja alegórica. Ironicamente, dá o seguinte conselho aos futuros Homeros e Virgílios: conceber uma alegoria bastante lata, na qual seja possível atafulhar qualquer coisa. ${ }^{185}$

Muitos argumentavam que uma abordagem prescritiva era estéril porque em todo poema épico se veem as marcas da cultura e da sociedade que o geraram. Delineavase um método que hoje chamaríamos de historicista, ${ }^{186}$ porquanto presume a descontinuidade de modelos e convenções literárias. ${ }^{187} \mathrm{O}$ interesse, com isso, deslocase de um suposto código comum entre o autor e o leitor para a gestação do dito gênio poético, bem como para a sua potencialidade e a sua interação com o mundo. ${ }^{188} \mathrm{~A}$ maneira como o poeta percebe, interpreta e reage ao entorno ganha cada vez mais importância nas tentativas de se entender suas escolhas estéticas. E mais: todo esse

\footnotetext{
${ }^{183}$ POPE, Alexander. "Preface". The Iliad of Homer cit., v. 1, p. 23.

${ }^{184}$ JOHNSON, Samuel. The lives of the poets cit., v. 1, p. 99-205, especialmente p. 183-192.

${ }^{185}$ POPE, Alexander. "Peri Bathous: of the art of sinking in poetry". In: GOLDGAR, Bertand A. (ed.). Literary criticism of Alexander Pope. Lincoln: University of Nebraska, 1965, p. 43-90, especialmente p. 85. Ver SWEDENBERG JR., H. T. The theory of the epic in England cit., p. 68-70 e CLARK, A. F. B. Boileau and the French classical critics in England (1660-1830) cit., p. 247 e ss.

${ }^{186}$ Ver FOERSTER, Donald M. Homer in English criticism: the historical approach in the eighteenth century. New Haven: Yale University, 1947, passim; e LEERSEN, Joep. "Ossian and the rise of literary historicism". In: GASKILL, Howard (ed.). The reception of Ossian in Europe cit., p. 109-125, especialmente p. 113. André Leme Lopes, no entanto, considera impróprio o uso do adjetivo "historicista" para o conjunto de ideias que discutiremos logo mais (LEME LOPES, André. O poeta que não existiu: James Macpherson e os poemas de Ossian. Tese de Doutorado. Brasília: Universidade de Brasília, 2009, p. 135 e ss.).

${ }^{187}$ Cf. SIMONSUURI, Kirsti. Homer's original genius cit., p. 77-79 e 84-87.

${ }^{188}$ Idem, p. 121-122.
} 
processo de apreensão da realidade estaria sujeito a contingências individuais e históricas. ${ }^{189}$ Logo, seria inapropriado avaliar Faerie Queene com a mesma régua do Paraíso perdido. São as palavras de Hurd: ${ }^{190}$

Sob essa ideia [...] de um poema gótico, e não clássico, é que Faerie Queene deve ser lido e criticado. E, com esses princípios, não seria difícil revelar seu mérito de um modo diferente do que se tem feito até agora.

Milton, é verdade, preferiu o modelo clássico ao gótico. ${ }^{191}$

Para Hurd, Spenser e Milton não são mestres da mesma arte, embora ambos sejam conhecidos como poetas épicos. Com suas digressões e caracteres fantásticos, Faerie Queene requer uma leitura bastante diversa daquela que suscita o Paraíso perdido. Cabe ao crítico reconhecer essa diferença e encontrar ou desenvolver o instrumental necessário para dar conta de sua análise. De tal sorte, postula-se a legitimidade de cada uma das formas poéticas. Todas elas podem ser compreendidas e explicadas:

Nada na natureza humana [...] é despido de motivos. Os usos e padrões de outros tempos podem parecer, à primeira vista, fantásticos e injustificáveis. Mas aqueles que os olham de perto descobrem uma causa latente para sua produção. ${ }^{192}$

Esse tipo de abordagem era bastante comum na Grã-Bretanha. Em nenhum lugar do reino, contudo, teve tanto apelo quanto na Escócia. Aqui, as formulações de Giambattista Vico sobre uma História Ideal Eterna tiveram ampla penetração. Em Aberdeen e Edimburgo, discutiram-se as teses do pensador napolitano, que atribuía a cada uma das Idades do mundo uma configuração exclusiva. Vico providenciou um esquema filosófico para o qual governos, religiões, sistemas morais e códigos linguísticos são transitórios, porque peculiares ao tempo em que foram gestados. ${ }^{193}$

${ }^{189}$ Ver LACERDA, Sonia. Metamorfoses de Homero: história e antropologia na crítica setecentista da poesia épica. Brasília: UnB, 2003, p. 158-162.

${ }^{190}$ SWEDENBERG JR., H. T. The theory of the epic in England cit., p. 106-111 e SIMONSUURI, Kirsti. Homer's original genius cit., p. 121-122.

191 "Under this idea [...] of a Gothic, not classical poem, the Faery Queen is to be read and criticized. And on these principles, it would not be difficult to unfold its merit in another way than has been hitherto attempted. Milton, it is true, preferred the classic model to the Gothic" (HURD, Richard. Letters on chivalry and romance: with the Third Elizabethan dialogue. Ed. Edith J. Morley. Londres: Henry Frowde, 1911, p. 115).

192 "Nothing in human nature [...] is without its reasons. The modes and fashions of different times may appear, at first sight, fantastic and unaccountable. But they, who look nearly into them, discover some latent cause of their production" (HURD, Richard. Letters on chivalry and romance cit., p. 79).

${ }^{193}$ VICO, Giambattista. Ciência nova. Trad. Jorge Vaz de Carvalho. Lisboa: Calouste Gulbekian, 2005, p. 58-59 e 668. Sobre a repercussão do esquema viquiano dentre os escoceses, ver: PITTOCK, Murray. "Historiography". In: BROADIE, Alexander (ed.). The Cambridge companion to the Scottish 
Adaptadas à crítica literária, essas ideias permitiram o desenvolvimento de uma espécie de teoria sobre como o gênio poético - em face das circunstâncias naturais e históricas - era gestado. Essa teoria é hoje conhecida como primitivismo, ${ }^{194}$ sendo Thomas Blackwell reconhecido como seu mais importante articulador.

Professor da Universidade de Aberdeen, Blackwell publica, em 1735, An enquiry into the life and writings of Homer. ${ }^{195}$ Trata-se de um estudo sobre Homero, em que se tenciona responder à seguinte indagação:

Que destino ou conjuntura fez que ninguém o tenha igualado na poesia épica em dois mil e setecentos anos, desde o tempo em que ele escreveu, nem jamais o havia superado antes. [?] $]^{196}$

Blackwell diria que a solução de sua indagação se encontrava no que chamou de Fortuna. Esta seria a reunião de condições (de ordem política, climática, geográfica ou religiosa) propícias - ou não - ao florescimento de certas potencialidades humanas. Assim, as qualidades extraordinárias da poesia homérica decorreriam não de uma inspiração sagrada, mas sim do ambiente em que se cultivou o aedo.

[...] os poemas de Homero são de composição humana; inspirados por nenhum outro poder que as suas faculdades naturais, e as oportunidades de sua educação: em suma: que um concurso de causas naturais conspirou para produzir e cultivar aquele gênio poderoso $[\ldots] .{ }^{197}$

Enlightenment. Cambridge: Cambridge University, 2003, p. 258-279, especialmente p. 259-260 e SIMONSUURI, Kirsti. Homer's original genius cit., p. 120.

${ }^{194}$ Por razões óbvias, o termo "primitivismo" encontra-se hoje um tanto fora de moda. A noção do "primitivo" presume alteridade, com que o moderno se vê como medida do outro, tido como diferente, bárbaro, cultural e temporalmente remoto (cf. STAFFORD, Fiona. "Primitivism and the 'primitive' poet: a cultural context for Macpherson's Ossian”. In: BROWN, Terence (ed.). Celticism: studia imagologica. Amsterdã - Atlanta, GA: Rodopi, 1996, p. 79-96). Entretanto, os termos "primitivo" e "primitivista" me parecem inescapáveis, pois só eles dão dimensão do contraponto à modernidade embutido nas discussões de Blackwell e seus seguidores (ver DENTITH, Simon. Epic and empire in nineteenth-century Britain. Cambridge: Cambridge University, 2006, p. 1-15).

${ }^{195}$ Sobre o pensamento de Blackwell, ver: SIMONSUURI, Kirsti. Homer's original genius cit., p. 99 e ss.; LACERDA, Sonia. Metamorfoses de Homero cit., p. 155-231; HAUGEN, Kristine Louise. "Ossian and the invention of textual history". Journal of the History of Ideas, v. 59, n. 2 (abril, 1998), p. 309-327; e KERSEY, Mel. "Addison's Indian, Blackwell's bard and the voice of Ossian". History of European Ideas, v. 31, n. 2 (setembro, 2005), p. 265-275. Sobre como as ideias de Blackwell sobre a natureza da epopeia diferiam daquelas de críticos neoclássicos, ver SWEDENBERG JR., H. T. The theory of the epic in England cit., p. 77 e ss.

196 "By what Fate or Disposition of things it has happened, that None have equalled him in EpicPoetry for two thousand seven hundred Years, the Time since he wrote; Nor any, that we know, ever surpassed him before" (BLACKWELL, Thomas. An enquiry into the life and writings of Homer. Londres, 1735, p. 2).

197 “[...] Homer's Poems are of Human Composition; inspired by no other Power than his own natural Faculties, and the Chances of his Education: In a word, That a Concourse of natural Causes, conspired to produce and cultivate that mighty Genius [...]" (idem, p. 4). 
Habitantes de um país montanhoso, dotado de solo relativamente pobre, os primeiros gregos viveriam de maneira frugal, sem supérfluos e afastados do ócio, sem grande apego a qualquer tipo de propriedade. Todos os seus bens, inclusive suas moradias, seriam perecíveis e, por isso mesmo, transitórios. Para Blackwell, era uma situação que não permitia o desenvolvimento de hábitos ditos refinados, que, segundo ele, refreiam os pendores inatos do espírito humano. A sinceridade, em seus diversos níveis, seria comum a todos. ${ }^{198}$

Aventureiros do mar, os contemporâneos de Homero frequentemente se teriam dedicado à pirataria. Era uma atividade que, por óbvio, demandaria coragem para enfrentar sucessivos confrontos, que se repetiriam no campo militar. Politicamente fragmentada, a Grécia conviveria com oscilações entre guerra e paz, dividida entre as cidades-Estado onde florescia o comércio e aquelas isoladas de qualquer contato exterior. ${ }^{199}$ A desordem grega deve ter forçado Homero a ir buscar instrução no Egito, pois somente lá existiria uma classe de sacerdotes letrados apta a lhe ensinar os mistérios da escrita, religião, arte, filosofia e política. ${ }^{200}$

Como viajante, teria aprendido a interessar-se pelas realizações dos estrangeiros. Ademais, o clima da Ásia Menor lhe teria incutido uma disposição de ânimo equilibrada, sem os excessos de ferocidade dos nórdicos nem a indolência de egípcios e babilônios. Esse clima ameno, temperado pelas brisas do Egeu, contribuiria para o desenvolvimento de um caráter inclinado à fruição equilibrada das graças do mundo sensível e imaginoso, mas não efeminado. ${ }^{201}$

A conjunção desses fatores teria possibilitado o surgimento de alguém apto a dar vazão à verdadeira poesia heroica. Seus tempos rústicos e belicosos teriam ensinado o aedo a apreciar genuinamente as virtudes guerreiras e a desdenhar dos prazeres materiais. Com efeito, a Fortuna de Homero não só o teria iniciado em conhecimentos arcanos e lhe concedido sensibilidade poética: ela lhe teria proporcionado uma afeição sincera por valores como bravura, temperança e frugalidade, que são, em última instância, os valores emulados em todas as epopeias. Na Ilíada e na Odisseia, eles

\footnotetext{
${ }^{198}$ Idem, p. 24.

${ }^{199}$ Idem, p. 15-23.

${ }^{200}$ Idem, p. 83.

${ }^{201}$ Idem, p. 6-7.
} 
seriam representados com realismo, porquanto não seriam o produto artificial de um poeta que passou recluso toda a sua vida. ${ }^{202}$

O método blackwelliano logo foi expandido para além da poesia homérica. Para tanto, seria conjugado à teoria social de Montesquieu, de ampla penetração na Escócia iluminista. ${ }^{203}$ Em seu Espírito das leis, de 1748, o filósofo francês descarta o estudo das sociedades com base em critérios universais - ou no que chama de lei geral, advinda da razão humana -, em prol de uma análise das contingências sob as quais essas mesmas sociedades se organizam.

Para Montesquieu, a interação dessas contingências acaba por determinar como se configuram as múltiplas instituições sob as quais vivem os povos. Cada nação ou agrupamento humano teria um caráter peculiar, moldado por uma série de fatores, como religião, regime de governo, meio físico, modo de subsistência, grau de liberdade desfrutado, riquezas e costumes. ${ }^{204}$ Assim, ao longo do Espírito das leis, sucedem-se observações de como se tende a cultivar: o amor à pátria nas democracias, ${ }^{205}$ a indústria em países ilhéus, ${ }^{206} \mathrm{o}$ espírito republicano no protestantismo etc. ${ }^{207}$ Dentre as conclusões a que chega Montesquieu, está a de que o modo de subsistência dos povos selvagens (caçadores) e bárbaros (pastores) ${ }^{208}$ seria mais propício à liberdade:

O que mais garante a liberdade dos povos que não cultivam as terras é que a moeda lhes é desconhecida. Os frutos da caça, da pesca ou dos rebanhos não podem ser reunidos em quantidade suficiente nem guardados o suficiente, para que um homem se veja em situação de corromper todos os outros, ao passo que, quando se têm sinais de riqueza, eles podem ser amontoados e distribuídos a quem se quiser.

${ }^{202}$ Ver idem, p. 26-27 e 69.

${ }^{203}$ Sobre a importância do pensamento de Montesquieu para os primitivistas escoceses, ver WHITNEY, Lois. "English primitivistic theories of epic origins". Modern philology, v. 21, n. 4 (maio, 1924), p. 337-378, especialmente p. 348-353. Para a relação entre os iluministas escoceses e a obra de Montesquieu, ver: SHER, Richard B. "From Troglodytes to Americans: Montesquieu and the Scottish Enlightenment on liberty, virtue, and commerce". In: WOOTTON, David (ed.). Republicanism, liberty, and commercial society, 1649-1776. Stanford, CA: Stanford University, 1994, p. 368-402; MOORE, James. "Montesquieu and the Scottish Enlightenment". In: KINGSTON, Rebecca E. (ed.). Montesquieu and his legacy. Albany: State University of New York, 2009, p. 179-195; e BERRY, Christopher J. Social theory of the Scottish Enlightenment. Edimburgo: Edinburgh University, 1997, p. 7.

${ }^{204}$ MONTESQUIEU. O espírito das leis. Trad. Cristina Murachco. São Paulo: Martins Fontes, 1996, p. 16-17.

${ }^{205}$ Idem, p. 54.

${ }^{206}$ Idem, p. 295.

${ }^{207}$ Idem, p. 469.

${ }^{208}$ Idem, p. 299. 
Entre os povos que não possuem moeda, cada um tem poucas necessidades e as satisfaz fácil e igualmente. Assim, a igualdade é forçada; por isso seus chefes não são despóticos. ${ }^{209}$

E que os hábitos guerreiros dessas sociedades também seriam favoráveis à honra e à coragem:

A prova pelo combate singular tinha alguma razão fundada na experiência. Numa nação unicamente guerreira, a covardia supõe outros vícios; ela prova que se resistiu à educação que se recebeu e que não se foi sensível à honra, nem conduzido pelos princípios que governaram os outros homens; ela demonstra que não se teme o desprezo deles e que não se faz grande caso de sua estima: por pouco que se seja bem-nascido, não se deixará normalmente de ter a habilidade que se deve aliar com a força, nem a força que deve concorrer com a coragem; porque aquele que dá importância à honra se terá exercitado durante toda a vida em coisas sem as quais não se pode obter a honra. Além do mais, numa nação guerreira, onde a força, a coragem e a proeza são honradas, os crimes verdadeiramente odiosos são aqueles que nascem da trapaça, da malícia e da astúcia, ou seja, da covardia. ${ }^{210}$

Esse olhar relativamente simpático a certas qualidades do que hoje chamamos de sociedades tradicionais era coetâneo a uma crítica aos hábitos artificiais da França setecentista, que já houvera ganhado forma nas suas Cartas persas, de 1721. Aqui, o olhar espantado do estrangeiro escrutiniza instituições e indivíduos, dessacralizados numa exposição que retira as máscaras e os simulacros que ornavam os salões do século XVIII. $^{211}$

Dessa conjunção das teses de Blackwell à teoria social de Montesquieu, emerge uma espécie de teoria geral da crítica à poesia primitiva, desdobrada em três axiomas: cada povo tem uma configuração peculiar; toda forma de criação literária é culturalmente dependente da sociedade que a gerou; e as melhores condições para a produção poética encontravam-se em tempos primitivos. ${ }^{212}$ Ínsita a essa maneira de pensar, está a noção de gênio natural.

${ }^{209}$ Idem, p. 302.

${ }^{210}$ Idem, p. 555.

${ }^{211}$ Ver STAROBINSKI, Jean. As máscaras da civilização: ensaios. Trad. Maria Lúcia Machado. São Paulo: Companhia das Letras, 2001, p. 86-118, especialmente p. 93-95. Cabe mencionar que os escritos de Rousseau também gozaram de acolhida favorável nos círculos ilustrados da Escócia. Dentre a sua bibliografia crítica ao advento do mundo moderno, destacamos sua obra de estreia, em que afirma que, no passado, "nossos hábitos eram rústicos, mas naturais" ("nos mœurs étoient rustiques, mais naturelles"): ROUSSEAU, Jean-Jacques. Discours sur les sciences et les arts. Gallimard: Paris, 1964, p. 32.

${ }^{212}$ Ver WHITNEY, Lois. "English primitivistic theories of epic origins" cit., p. 337-378. Ver também SIMONSUURI, Kirsti. Homer's original genius cit., p. 77 e ss. 
De difícil definição, tal expressão relaciona-se, para citarmos um célebre ensaio de Addison, aos

[...] prodígios da humanidade, os quais, pela mera força de suas partes naturais, e sem a ajuda de arte ou estudo, produziram obras que foram o deleite de seu tempo e as maravilhas da posteridade. ${ }^{213}$

Como se pode notar, estamos diante de uma espécie de conceito-valise, que alude tanto às potencialidades poéticas do homem selvagem quanto ao modo como este se relaciona com o ambiente. As potencialidades poéticas adviriam de uma vida desfrutada em isolamento, na qual o espírito se torna impressionável em face de qualquer novidade. Veja-se a citação lapidar de William Duff:

O primeiro motivo que devemos atribuir ao fato de o Gênio Poético original manifestar-se de maneira mais notável no período prematuro e inculto da sociedade advém da própria antiguidade desse período e do aspecto novel dos objetos que o gênio contempla [...], que, num período mais cultivado, em grande medida se perdem, mas que, naquele [período] de que falamos, excitam atenção, curiosidade e surpresa - altamente favoráveis à aplicação do gênio. ${ }^{214}$

Em certo sentido, compara-se a mente selvagem à de uma criança que começa a conhecer o mundo. Trazemos à colação uma passagem do famoso Elements of criticism, de Lord Kames:

Durante a infância, todo objeto novo provavelmente dá azo, em alguma medida, à admiração. Porque, durante a infância, cada objeto é, à primeira vista, tão estranho quanto novo. No entanto, conforme os objetos tornam-se familiares com o costume, deixamos, aos poucos, de nos admirarmos com novos eventos, se eles guardam alguma semelhança com aquilo que conhecemos, pois uma coisa deve ser tão singular quanto nova para suscitar nossa admiração. ${ }^{215}$

213 " [...] Prodigies of Mankind, who by the mere Strength of natural Parts, and without any Assistance of Art or Learning, have produced Works that were the Delight of their own Times, and the Wonder of Posterity" (ADDISON, Joseph. "No. 160". The Spectator cit., v. 1, p. 482-485, especialmente p. 482). Addison, obviamente, não era primitivista nem escocês. Ademais, seu ensaio é anterior ao Enquiry, de Blackwell.

214 "The first reason we shall assign of ORIGINAL POETIC GENIUS being most remarkably displayed in an early and uncultivated period of society, arises from the antiquity of the period itself, and from the appearance of novelty in objects which Genius contemplates [...], which, in a more cultivated period, they in a great measure loose; but which, in that we are speaking of, excites an attention, curiosity and surprise, highly favourable to the exertion of Genius" (DUFF, William. An essay on original genius, and its various modes of exertion in philosophy and the fine arts, particularly in poetry. 2. ed. Londres, 1767, p. 265-266).

215 "During infancy, every new object is probably the occasion of wonder, in some degree; because, during infancy, every object at first sight is strange as well as new: but as objects are rendered familiar by custom, we cease by degrees to wonder at new appearances, if they have any resemblance to what we are acquainted with; for a thing must be singular as well as new, to raise our wonder" (HOME, 
Num tempo em que a língua era simples e destituída de recursos, o uso de símiles e metáforas torna-se inevitável para dar conta do turbilhão de sensações que inundam a alma:

[...] cada objeto lhe é novo e tem o poder de afetá-lo com surpresa e prazer. E ele não está familiarizado com descrições anteriores das cenas que contempla: estas fulguram em sua mente com toda a força, e a imaginação, atônita e arrebatada com a visão do vasto, do indômito e do belo na natureza, transmitidos pelos sentidos, espontaneamente expressa suas ideias vívidas em metáforas audazes e ardentes, em descrições sublimes, animadas e pitorescas. ${ }^{216}$

O núcleo da citação acima está no advérbio “espontaneamente”. É ele que define a maneira como flui a elocução selvagem: das sensações que vêm à alma, sem travas ou receios. O sentido que esse termo adquiriu para os primitivistas mostra a ruptura com a poética neoclássica. Antes, espontâneo era o estilo simples e nobre, sem os excessos retóricos que haviam caracterizado a poesia isabelina ou a Plêiade. ${ }^{217}$ Agora, é o estilo sem constrições, que oscila conforme as emoções do poeta.

Essas oscilações seriam influenciadas pelo ambiente. A mente primitiva se relacionaria com seu entorno de maneira direta, sem a mediação de preconceitos ou especulações filosóficas. $\mathrm{O}$ incurso em abstrações tende a contribuir para o declínio das faculdades expressivas, conforme observava Adam Ferguson:

Para falar ou escrever apropriadamente a partir da observação da natureza, é necessário ter experimentado os sentimentos da natureza.

[...] Mas dentre todas as maneiras em que o ser humano se prepara para os empenhos do estilo e da [boa] conduta, desponta como a mais fulgurante das decepções, buscar as aptidões de uma pessoa nos meros feitos da especulação $\left[\ldots . .{ }^{218}\right.$

Henry (Lord Kames). Elements of criticism. Ed. Peter Jones. Indianápolis, IN: Liberty Fund, 2005, v. 1, p. 185). Kames assevera que as pessoas de gosto refinado tendem a ter a um interesse menor por coisas novas (idem, p. 191).

216 “ $[. .$.$] every object is new to him, and has the power to affect him with surprise and pleasure; and$ as he is not familiarised by previous description to the scenes he contemplates, these strike upon his mind with their full force; and the imagination astonished and enraptured with the survey of the vast, the wild, and the beautiful in nature, conveyed through the medium of sense, spontaneously expresses its vivid ideas in bold and glowing metaphors, in sublime, animated and picturesque description" (DUFF, William. An essay on original genius cit., p. 267).

${ }^{217}$ Ver BRAY, René. La formation de la doctrine classique en France cit., p. 8 e ss.

218 "To speak or to write justly from an observation of nature, it is necessary to have felt the sentiments of nature. [...] But in whatever manner men are formed for great efforts of elocution or conduct, it appears the most glaring of all other deceptions, to look for the accomplishments of a human character in the mere attainments of speculation [...]" (FERGUSON, Adam. An essay on the history of civil society. Ed. Fania Oz-Salzberger. Cambridge: Cambridge University, 1995, p. 171). 
Haveria, então, um continuum entre a realidade, o gênio humano e sua elocução poética. Categorias como decoro ou verossimilhança teriam de esperar anos para ser formuladas, de molde que nada compelia o bardo ou o aedo a refrear a expressão de seus sentimentos. ${ }^{219}$ Sua poesia seria, a um só tempo, irregular e genuína, o que lhe conferia uma vitalidade que nos seria estranha. Leiam-se os (prolixos) termos com que Robert Wood qualifica as composições homéricas:

A essa investigação imparcial dos diferentes poderes da natureza e dos diversos mananciais de ação - não como são fantasiados num gabinete, transcritos de sistemas especulativos e copiado dos livros, mas conforme se testemunhou o seu exercício na vida real -, somos gratos pela mais correta história das paixões e afeições humanas a ter vindo a lume. Tão imparcialmente temperada por boas e más qualidades, as quais adentram, em várias proporções, a composição de cada personagem, [de molde] que ele não nos legou um padrão uniforme de beleza ou deformidade moral. ${ }^{220}$

A ausência de entraves tanto à interação com a natureza quanto à conversão desta em objeto da poesia primitiva fazia desta um instrumento legítimo de cognição da realidade - e, em última análise, da verdade. Para Ferguson, somente a leitura desse tipo de composição nos permitia efetivamente apreender os valores caros aos tempos heroicos:

Sob as supostas desvantagens de um conhecimento limitado e de uma apreensão rude, o poeta simples obtém impressões as quais mais do que compensam as deficiências de sua habilidade. Os melhores assuntos para a poesia, o caráter dos [homens] violentos e bravos, generosos e intrépidos, grandes perigos, desafios à fortitude e fidelidade, exteriorizam-se diante de seus olhos ou são repassados pela tradição, que é tida como verdadeira, porque é integralmente aceita. Ele não se empenha em recordar, como Virgílio ou Tasso, os sentimentos ou cenários de uma idade remota à sua: ele não precisa ser instado pelo crítico a se lembrar do que outro haveria pensado ou de que maneira outro haveria expressado sua concepção. [...]. ${ }^{221}$

\footnotetext{
${ }^{219}$ Ver WHITNEY, Lois. "English primitivistic theories of epic origins" cit., p. 357.

220 "To this unbiassed [sic] investigation of the different powers of Nature, and the various springs of action, not as they are fancied in the Closet, transcribed from speculative Systems, and copied from books, but as they were seen exerted in real life, we owe the most correct history of human passions and affections, that have ever yet been exhibited under one view; so impartially checquered with the good and bad qualities, which enter, in various proportions, into the composition of every character, that he has not left us one compleat pattern of moral beauty or deformity" (WOOD, Robert. An essay on the original genius of Homer. Londres, 1769, p. 69).

221 "Under the supposed disadvantage of a limited knowledge, and a rude apprehension, the simple poet has impressions that more than compensate the defects of his skill. The best subjects of poetry, the characters of the violent and the brave, the generous and the intrepid, great dangers, trials of fortitude and fidelity, are exhibited within his view, or are delivered in traditions which animate like truth, because they are equally believed. He is not engaged in recalling, like Virgil or Tasso, the sentiments or scenery of an age remote from his own: he needs not to be told by the critic, to recollect what
} 
A relação entre a literatura e a realidade era uma das pedras angulares da poética neoclássica. Junto com a tragédia e a comédia, a epopeia era uma das formas imitativas. Sem embargo, essa relação opera de outra maneira para Ferguson. O poeta selvagem não apenas representaria o mundo em seus épicos; ele o apresentaria. Sim, pois faz com que seu quotidiano de heroísmo, batalhas e coragem emerja em suas composições. $^{222}$ Para o poeta refinado, isso não passa de mera convenção poética, um universo nunca vivenciado, porque acessado apenas pela poesia. Embora se reconheçam os méritos de um Virgílio, eles seriam derivados, artificiais e de segunda ordem. $^{223}$ Como afirma Edward Young, “[...] originais são as flores mais belas; imitações crescem mais depressa, mas sua flor é mais efêmera". ${ }^{224}$ A verdadeira poesia heroica seria, portanto, uma via há muito interditada.

\section{De volta a Fingal e Temora}

\subsection{Anotações à margem}

O fosso entre as abordagens normativa e historicista é transposto nas epopeias ossiânicas. ${ }^{225}$ Basta ler os prefácios, ensaios introdutórios e notas de rodapé de Fingal e Temora, nos quais se intervém a fim de direcionar a recepção das obras. Parte considerável dessas intervenções buscava determinar a relação entre a poesia de Ossian e o ambiente sociocultural que a gestara. Por outro lado, o tradutor não hesitava em indicar como seus poemas satisfaziam expectativas neoclássicas para a execução de um épico.

Talvez em nenhum lugar a conjunção de premissas salte tanto aos olhos quanto numa nota ao "Livro Oitavo" de Temora. De início, rejeitam-se abstrações formais e

another would have thought, or in what manner another would have expressed his conception [...]" (FERGUSON, Adam. An essay on the history of civil society cit., p. 166).

${ }^{222}$ Ver SIMONSUURI, Kirsti. Homer's original genius cit., p. 133 e ss.

${ }^{223}$ Idem, p. 125; TILLYARD, E. M. W. The English epic and its background cit., p. 494 e ss. e FOERSTER, Donald M. The fortunes of epic poetry cit., p. 16 e 25.

224 “[...] Originals are the fairest Flowers: Imitations are of quicker growth, but fainter bloom" (YOUNG, Edward. Conjectures on Original Composition, in a Letter to the Author of Sir Charles Grandison. Londres, 1759, p. 9).

${ }^{225}$ Uma síntese dessa conciliação pode ser encontrada em BYSVEEN, Josef. Epic tradition and innovation in James Macpherson's Fingal. Uppsala: Acta Universitatis Upsaliensis, 1982, p. 130-134. Ver também STAFFORD, Fiona. "Romantic Macpherson" cit., p. 32. Para análises da poesia de Ossian, em especial a de Blair, que conciliam primitivismo e neoclassicismo, ver MOORE, Dafydd. "The reception of The Poems of Ossian in England and Scotland" cit., p. 27-28; CARBONI, Pierre. "Ossian and belles lettres: Scottish influence on J.-B.-A. Suard and late-eighteenth-century French taste and criticism". In: DAWSON, Deidre; MORERE, Pierre (ed.). Scotland and France in the Enlightenment. Lewisburg: Bucknell University - Londres: Associated University Presses, 2004, p. 7489. 
abjura-se da primazia de Aristóteles. Modelos críticos são tidos como construções históricas, adstritos aos "hábitos das nações", sendo errôneo aplicá-los irrestritamente. Os preceitos aristotélicos deveriam ser entendidos, portanto, na conjuntura específica da literatura grega. Formulados da Ilíada e da Odisseia, satisfaziam as concepções locais do que seria a alta poesia heroica. Logo, seria forçoso admitir que a Poética talvez fosse um guia pouco adequado à apreciação de uma epopeia celta.

[...] todos os preceitos que Aristóteles extraiu de Homero não devem ser aplicados à composição de um bardo celta. Tampouco se deve questionar o direito deste último à epopeia, ainda que divirja, em algumas circunstâncias, de um poeta grego. Deve-se dar alguma margem aos diferentes hábitos das nações. O gênio de gregos e celtas era muito dissimilar. Os primeiros eram muito animados e loquazes; uma concisão viril de expressão distinguia os últimos. Acreditamos, portanto, que as composições de Homero e Ossian são marcadas pelos caracteres gerais e opostos de suas respectivas nações; e, consequentemente, que é impróprio comparar as minúcias de seus poemas em conjunto. ${ }^{226}$

Macpherson parece dar pouca importância ao fato de que o poema não se adéqua por inteiro às regras usualmente aceitas para uma epopeia. Impostas por Aristóteles, tais regras teriam sido prescritas a partir das composições homéricas, numa acusação velada de que seriam arbitrárias. Poucas linhas abaixo, no entanto, reverte-se a lógica da argumentação e o tradutor aquiesce à validade de um código universal. Postulamse "regras gerais" na elaboração de um poema épico, em face dos quais seria possível aferir o mérito de Ossian:

Há, todavia, regras gerais na condução de um poema épico, que, como são naturais, são iguais, universais. Nessas, ambos os poetas concordam. Essa similaridade, que não poderia provir de imitação, é mais decisiva, com respeito aos mais relevantes princípios da epopeia, do que todos os preceitos de Aristóteles. ${ }^{227}$

Na poesia de Ossian, contudo, inexiste uma separação muito clara ou segura entre o entrecho ficcional e as intervenções do editor e tradutor. As constantes intromissões

\footnotetext{
226 " [...] all the precepts, which Aristotle drew from Homer, ought not to be applied to the composition of a Celtic bard; nor ought the title of the latter to the epopcea to be disputed, even if he should differ in some circumstances, from a Greek poet. - Some allowance should be made for the different manners of nations. The genius of the Greeks and Celtæ was extremely dissimilar. The first were lively and loquacious; a manly conciseness of expression distinguished the latter. We find, accordingly, that the compositions of Homer and Ossian are marked with the general and opposite characters of their respective nations, and, consequently, it is improper to compare the minutice of their poems together" (idem, p. 522, nota 1).

227 "There are, however, general rules, in the conduct of an epic poem, which, as they are natural, are likewise, universal. In these the two poets exactly correspond. This similarity, which could not possibly proceed from imitation, is more decisive, with respect to the grand essentials of the epopøa, than all the precepts of Aristotle" (idem, ibidem).
} 
assinadas por Macpherson integram a construção do sentido que emerge das partes cuja voz organizadora se atribui a Ossian. Obtém-se, com isso, uma triangulação dos poemas para as notas e das notas de volta para os poemas. Veja-se o que se dá, por exemplo, em "Colna-dona". Tão logo a donzela epônima é mencionada, dicionarizase seu nome como "o amor dos heróis". ${ }^{228}$ Tendo-se esta definição em mente, o desenvolvimento da historieta ganha em profundidade: agora, a paixão desenfreada de Toscar por Colna-dona avulta menos caprichosa e mais justificada. Ademais, a inserção da nota problematiza a linguagem do sujeito poético. De acordo com a sistemática estabelecida pela nota de rodapé, uma passagem singela à primeira vista, como "Toscar escureceu em seu lugar, diante do amor dos heróis", ${ }^{229}$ não contém apenas um epíteto, mas também uma tradução literal em língua inglesa, inescapavelmente perifrástica, do nome de Colna-dona. ${ }^{230}$

A supressão do aparato paratextual, como faziam muitos dos tradutores portugueses no século XIX, certamente simplifica a experiência estética e intelectual proporcionada por Ossian. Trata-se de aparato que elabora e teoriza a poesia primitiva - e decerto orientou a recepção e a fortuna crítica imediatas de Ossian na Europa e nas Américas. Por outro lado, é inegável que as dissertações e os prefácios de Macpherson, e muito menos as suas notas, não se sustentam sozinhos. ${ }^{231}$ De tal feita, nossa análise de como Fingal e Temora conjugam noções neoclássicas e primitivistas da poesia épica buscará evitar seccionamentos artificiais entre as epopeias propriamente ditas e os comentários do tradutor.

\subsection{Poemas heroicos}

De saída, o liame estabelecido entre a configuração de Fingal e Temora e seu contexto insere-se na complexa - porém necessária - tentativa de se proporcionarem "provas internas" ${ }^{232}$ de autenticidade dos Poemas de Ossian.

\footnotetext{
${ }^{228}$ MACPHERSON, James. "Colna-dona: a poem”. The poems of Ossian and related works cit., p. 540 , nota 2.

229 "Toscar darkened in his place, before the love of heroes" (idem, p. 328).

${ }^{230}$ GASKILL, Howard. "Introduction: "Genuine poetry... like gold'” cit., p. 4.

${ }^{231}$ Ver GENETTE, Gérard. Paratextos editoriais. Trad. Álvaro Faleiros. Cotia - SP: Ateliê, 2009, p. 17.

${ }^{232}$ Tomamos essa distinção entre as ditas provas internas e externas dos Poemas de Ossian de SHAW, W. An enquiry into the authenticity of the poems ascribed to Ossian. Londres, 1761, p. 2. Sobre Shaw, ver SHER, Richard B. "Percy, Shaw and the Ferguson 'cheat': national prejudice in the Ossian wars”. In: GASKILL, Howard (ed.). Ossian Revisited. Edimburgo: Edinburgh University, 1991,
} 
Macpherson estava muito longe de ser um tradutor judicioso das relíquias que coletara em suas andanças pelos Highlands. Com efeito, manipularia o expressivo material coletado na sua expedição de agosto de 1760 , que resultaria na publicação Fingal, an ancient epic poem in six books, together with several other poems e Temora an ancient epic poem in eight books, together with several other poems. ${ }^{233}$ Em todas as composições atribuídas a Ossian, o eminente poeta e celtista Derick Thomson conseguiu detectar os vestígios de quinze ou dezesseis baladas gaélicas, pertencentes sobretudo aos ciclos de Finn e Cù Chulainn. ${ }^{234}$ Às vezes, como em "The Battle of Lora", há correspondências consideráveis com a tradição oral celta, dado que o enredo de fuga conjugal, vingança e morte é decalcado de "Teanntachd Mhòr Fèinne". ${ }^{235}$ Ainda assim, há variações substantivas nos procedimentos retóricos, nos nomes e no ponto de vista das personagens. ${ }^{236}$ Noutros poemas, existe uma verdadeira colagem a fim de se obter algo maior e mais impressivo. Em Fingal, fundem-se no enredo "Garbh mac Stairn" e "Magnus", enquanto os episódios advêm de "Fingal's visit to Norway", "Duan na h-Inghinn” e "Ossian’s Courtship”. Ademais, há ecos de “Sliabh nam Ban Fionn”, "Praise of Goll”, “Táin Bó Cùalnge” e, provavelmente, de uma balada sobre o carro de Cù Chulainn. ${ }^{237}$ Temora, por sua vez, é uma composição para a qual quase não se reclamam origens legítimas. O "Livro Primeiro" provém da

p. 207-245. Para uma análise das "provas internas" apontadas por Blair, ver: DENTITH, Simon. Epic and empire in nineteenth-century Britain cit., p. 24.

${ }^{233}$ Sobre a relação de Macpherson com suas fontes, ver, de saída, o relatório da Highland Society, de 1805, coordenado por Henry Mackenzie, sobre a autenticidade dos Poemas de Ossian (MACKENZIE, Henry (coord.). Report of the Committee of the Highland Society of Scotland, Appointed to Inquire into the Nature and Authenticity of the Poems of Ossian: Drawn Up, according to the Directions of the Committee, by Henry Mackenzie, Esq. Edimburgo: Constable - Londres: Hurst, Rees and Orme, 1805, passim). Ver também: THOMSON, Derick S. The Gaelic sources of Macpherson's 'Ossian'. Edimburgo - Londres: Oliver and Boyd (published for the University of Aberdeen), 1951, passim; O'HALLORAN, Clare. "Irish re-creations of the gaelic Past: the challenge of Macpherson's Ossian". Past and Present, n. 124 (agosto, 1989), p. 69-95; MEEK, Donald E. "The Gaelic ballads of Scotland: creativity and adaptation". In: GASKILL, Howard (ed.). Ossian revisited cit., p. 19-48; MAC CRAITH, Mícheál. "The 'forging' of Ossian". In: BROWN, Terence (ed.). Celticism cit., p. 125-142; THOMSON, Derick S. "James Macpherson: the Gaelic dimension". In: GASKILL, Howard; STAFFORD, Fiona (ed.). From Gaelic to romantic: Ossianic translations. Amsterdã - Atlanta, GA: Rodopi, 1998, p. 17-26; e CURLEY, Thomas M. Samuel Johnson, the Ossian fraud and the Celtic revival in Great Britain and Ireland cit., p. 34-36. Sobre o tour de Macpherson pelos Highlands, ver STAFFORD, Fiona. The sublime savage: a study of James Macpherson and The Poems of Ossian. Edimburgo: Edinburgh University, 1988, p. 113-128.

${ }^{234}$ THOMSON, Derick S. The Gaelic sources of Macpherson's 'Ossian' cit., p. 10.

${ }^{235}$ Cf. THOMSON, Derick S. "James Macpherson: the Gaelic dimension” cit., especialmente p. 21.

${ }^{236}$ Cf. idem, p. 22.

${ }^{237}$ Ver THOMSON, Derick S. The Gaelic sources of Macpherson's 'Ossian' cit., p. 14 e ss. 
reformulação das baladas "Death of Oscar" e "Battle of Gabhra", mas o resto é, aparentemente, de sua própria lavra. ${ }^{238}$

Mesmo diante disso, Macpherson até que demonstrara empenho em fazer disponíveis algumas de suas fontes, como o "Book of the Dean of Lismore", e providenciar testemunhos quanto à honestidade do trabalho. ${ }^{239} \mathrm{Na}$ mesma toada, rechearam-se as composições ossiânicas de extenso aparato crítico, destinado a tanto demonstrar a seriedade da pesquisa quanto situar o leitor nas especificidades da poesia gaélica. E, se isso não fosse o bastante, tachavam-se eventuais reticências como decorrentes de

[...] preconceitos de nosso tempo contra os antigos habitantes da Grã-Bretanha, os quais são tidos como incapazes dos sentimentos generosos a serem encontrados nos poemas de Ossian. ${ }^{240}$

Contudo, de acordo com o tradutor, a antiguidade dos Poemas e, mais especificamente, dos épicos seria discernível na sua própria configuração. Temas, estilo e linguagem denunciariam uma origem remota, com que a produção de evidências empíricas, externas, tornava-se desnecessária. Já no "Prefácio" aos Fragmentos de poesia antiga, escrito por Hugh Blair, ${ }^{241}$ tem-se que a mera leitura das composições desnudaria a conjuntura em que foram geradas:

A tradição, no país em que foram escritos, refere-se a uma era das mais antigas. Essa tradição é sustentada pelo espírito e o estilo dos próprios poemas, que abundam daquelas ideias - e pintam aqueles hábitos - que pertencem aos mais antigos estágios da sociedade. ${ }^{242}$

Quando da publicação de Fingal, expande-se o mesmo argumento para descrever eventuais suspeitas de fraude como desarrazoadas:

Essa ideia poderia induzir alguém, desconfiado de suas habilidades, a atribuir suas composições a uma pessoa, cuja antiguidade remota e circunstâncias, quando viva, poderiam muito bem responder pelas

\footnotetext{
${ }^{238}$ Idem, p. 59-69.

${ }^{239}$ Ver GASKILL, Howard. "What did James Macpherson really leave on display at his publisher's shop in 1762?". Scottish Gaelic Studies, v. 16 (1990), p. 67-89.

240 " [...] prejudices of the present age, against the ancient inhabitants of Britain, who are thought to have been incapable of the generous sentiments to be met with in the poems of Ossian" (MACPHERSON, James. "Preface to $1^{\text {st }}$ edition of Fingal". The poems of Ossian and related works cit., p. 35-36).

${ }^{241}$ Cf. BLAIR, Hugh. "Appendix no. IV". In: MACKENZIE, Henry (coord.). Report of the Committee of the Highland Society of Scotland cit., p. 57-58.

242 "Tradition, in the country where they were written, refers them to an æra of the most remote antiquity: and this tradition is supported by the spirit and strain of the poems themselves; which abound with those ideas, and paint those manners, that belong to the most early state of society" (MACPHERSON, James. "Preface". The poems of Ossian and related works cit., p. 5) (grifo nosso).
} 
falhas que seriam indesculpáveis num escritor desse tempo. Um cavalheiro engenhoso fez essa observação, antes que conhecesse qualquer coisa além do nome do poema épico impresso nesta coleção [Fingal]. Quando ele o leu, sua opinião mudou. Julgou-o abundante daquelas ideias que pertencem somente aos mais antigos estágios da sociedade, para que fosse a obra de um poeta moderno. ${ }^{243}$

"Falhas indesculpáveis" em escritos contemporâneos são vinculadas às ideias comuns às eras primevas da sociedade. É uma associação em que o arranjo da obra é um meio para se conhecer as circunstâncias em que tal obra foi gerada. O pressuposto, obviamente, é de que o poema é poroso aos estímulos do meio.

Seria errôneo, contudo, afirmar que a postulação de um vínculo entre Fingal e Temora e o contexto do século III d. C. se esgota em mostras engenhosas de autenticidade. Nos ditos épicos ossiânicos, a vida nas Terras Altas é o substrato de sua dimensão estética. Não é à toa que o tradutor, nas suas dissertações, muitas vezes substitua suas considerações sobre os méritos de Ossian por arrazoados sobre a sociedade celta. Nos ensaios introdutórios e nas notas de rodapé aos poemas, há comentários sobre os valores dos highlanders, bem como sobre sua religião, língua, clima, sistema jurídico, atividades econômicas e organização política, familiar e social. Muito embora essas intervenções tenham um quê de antiquariato postiço, o elenco não é aleatório. Com efeito, ele contém os elementos que, para os primitivistas, perfazem o que Blackwell chama de Fortuna - e, por isso, prefiguram a criação literária. $^{244}$

Trata-se a realidade caledônia como contígua ao universo ficcional de Fingal e Temora. No aparato crítico-editorial, a caracterização heroica das personagens é examinada com base em dados sociais e antropológicos. Na dissertação a Fingal, afirma-se que a conduta dos antigos escoceses era fortemente influenciada pelos bardos, que comandariam uma espécie de "poetocracia". ${ }^{245}$ Numa sociedade iletrada,

\footnotetext{
243 "This consideration might induce a man, diffident of his abilities, to ascribe his own compositions to a person, whose remote antiquity and whose situation, when alive, might well answer for faults which would be inexcusable in a writer of this age. An ingenious gentleman made this observation, before he knew any thing but the name of the epic poem, which is printed in the following collection. When he had read it, his sentiments were changed. He found it abounded too much with those ideas, that only belong to the most early state of society, to be the work of a modern poet" (MACPHERSON, James. "Preface to $1^{\text {st }}$ edition of Fingal". The poems of Ossian and related works cit., p. 35).

${ }^{244}$ KERSEY, Mel. “Addison's Indian, Blackwell’s bard and the voice of Ossian” cit., p. 265-275.

${ }^{245}$ Retirei a expressão "poetocracia”, em outro contexto, de CARPEAUX, Otto Maria. História da literatura ocidental. São Paulo: Leya, 2011, v. 3, p. 1978.
} 
eles eram tanto os guardiães quanto os árbitros da memória. Por mais valoroso que fosse um guerreiro, seus feitos seriam esquecidos caso não fossem eternizados em poesia. ${ }^{246}$ Nenhum temor assombra mais as personagens ossiânicas que o do esquecimento. É o destino reservado aos covardes, aos derrotados na guerra e àqueles que morreram cedo demais. ${ }^{247}$ Cuchullin, campeão irlandês, teme que o triunfo de Swaran sobre seus homens no campo de batalha o condene ao oblívio:

Lá longe, ignorado do mundo, hei de jazer. Nenhum bardo ouvirá falar de mim. Nenhuma pedra cinza será levantada para meu renome. Pranteia-me com os mortos, ó Bragéla!, [pois] minha fama se foi. ${ }^{248}$

E Fingal lamenta o fim prematuro de seu filho Ryno, antes de tornar-se renomado: “[...] Ryno, estás mesmo morto. - não recebeste a tua fama. Ullin, tange a harpa para Ryno, conta o que o chefe teria sido". ${ }^{249}$ De tal sorte, a maior glória para um guerreiro seria irmanar-se a seus antepassados nas canções dos bardos. É o que se depreende da fala do rei de Morven, ao consolar seu exército após a morte de Oscar, seu neto: "Nossos jovens heróis, ó guerreiros, são como o renome de nossos pais. — Eles lutam na juventude. Eles tombam: seus nomes estão nas canções". ${ }^{250}$

$\mathrm{Na}$ "Dissertação" que antecede Temora, mobilizam-se com bastante clareza o método analítico de Blackwell e o historicismo de Montesquieu. Defende-se que os tempos primitivos de Ossian são propícios às paixões e às inclinações viris da alma, constantemente defrontada com todo tipo de provação. O resultado dessas provações seria, de acordo com o tradutor, um povo dotado de atributos extraordinários, bastante diversos daqueles dos modernos. Os séculos ditos refinados, argumenta-se, eram marcados pela pusilanimidade. Longe das circunstâncias que demandariam verdadeiras demonstrações de fortitude e mérito, o caráter dos contemporâneos de Macpherson se esconderia atrás de mesuras e afetações, perdendo o viço. As

\footnotetext{
${ }^{246}$ MACPHERSON, James. "A dissertation concerning the antiquity, \&c. of the poems of Ossian the son of Fingal". The poems of Ossian and related works cit., p. 48-49.

${ }^{247}$ Sobre o temor do esquecimento nos Poemas de Ossian, ver STAFFORD, Fiona J. The last of the race: the growth of a myth from Milton to Darwin. Oxford: Clarendon, 1997, p. 104.

248 “There, far remote, I shall lie unknown. No bard shall hear of me. No gray stone shall rise to my renown. Mourn me with the dead, O Bragéla! departed is my fame" (MACPHERSON, James. "Fingal: an epic poem". The poems of Ossian and related works cit., p. 76).

249 " [...] Ryno, thou art low indeed, - thou hast not received thy fame. Ullin, strike the harp for Ryno; tell what the chief would have been" (idem, p. 93).

250 "Our young heroes, O warriors, are like the renown of our fathers. - They fight in youth; they fall: their names are in song" (MACPHERSON, James. "Temora: an epic poem". The poems of Ossian and related works cit., p. 234).
} 
exigências da vida primitiva, contudo, seriam propícias a um comportamento espontâneo, no qual não se cerceiam as paixões humanas. Como consequência, ter-seia uma sociedade livre, cujo comando está invariavelmente nas mãos de seus melhores. Condensam-se essas ideias num trecho lapidar:

As paixões mais nobres da mente nunca brotaram tão livres e irrestritas quanto naqueles tempos que chamamos de bárbaros. Aquele modo de vida irregular e aquelas ocupações varonis das quais a barbárie toma seu nome são altamente favoráveis para uma força de vontade desconhecida em tempos refinados. Numa sociedade avançada, os caracteres humanos são uniformes e encobertos. As paixões humanas se quedam, de certa maneira, ocultas por formas e modos artificiais - e os poderes da alma, sem a oportunidade de exercê-los, perdem seu vigor. Os tempos de hábitos refinados e regulares devem, portanto, ser desejados por aqueles de vontade débil e fraca. Circunstâncias conturbadas - e as convulsões que lhes são próprias - são o campo adequado para um caráter exaltado e para o exercício de grandes feitos. $\mathrm{O}$ mérito sempre avulta superior; nenhum evento fortuito é capaz de levar os tímidos e covardes ao poder. ${ }^{251}$

Essas formulações reaparecem numa nota de rodapé a uma fala de Cathmor, no "Livro Quarto" de Temora. Aqui, o tradutor louva a intensidade com que os contemporâneos de Ossian desprezavam uma vida indolente e pacífica. Desdenha dos filósofos que recomendam a solidão e a quietude, porquanto enfraquecem e rebaixam a mente humana, coarctada por ideias destituídas de nobreza. Somente uma vida agitada, com todas as suas vicissitudes, pode conferir grandeza e energia. Seria por isso, conclui Macpherson, que dificilmente nos deparamos com o vigor mental dos antigos dentre os membros de uma nação opulenta. ${ }^{252}$

Tamanho contraponto entre primitivos e modernos não seria apenas moral, mas também físico. Recuperam-se os topoi sobre a velhice do mundo e o passado edênico para revesti-los com o historicismo primitivista. O século XVIII seria um tempo de decrepitude, de pessoas débeis e fragilizadas. Seu sedentarismo thes teria exaurido a

\footnotetext{
251 "The nobler passions of the mind never shoot forth more free and unrestrained than in these times we call barbarous. That irregular manner of life, and those manly pursuits from which barbarity takes its name, are highly favorable to a strength of mind unknown in polished times. In advanced society the characters of men are more uniform and disguised. The human passions lie in some degree concealed behind forms, and artificial manners; and the powers of the soul, without opportunity of exerting them, lose their vigor. The times of regular, and polished manners, are therefore to be wished for by the feeble and weak in mind. An unsettled state, and those convulsions which attend it, is the proper field for an exalted character, and the exertion of great parts. Merit there rises always superior; no fortuitous event can raise the timid and mean into power" (MACPHERSON, James. "A dissertation". The poems of Ossian and related works cit., p. 205).

${ }^{252}$ MACPHERSON, James. "Temora: an epic poem". The poems of Ossian and related works cit., p. 500 , nota 44 .
} 
saúde. Em compensação, a existência ativa dos highlanders lhes teria livrado de qualquer tipo de doença. ${ }^{253}$

Em suma, a "Dissertação" a Temora é perpassada pela noção de que as circunstâncias têm o condão para moldar por completo as sociedades humanas e, por extensão, os indivíduos. Sua compleição e seu ânimo não são frutos do acaso ou de atributos pessoais: são, antes, creditados a uma entidade autônoma, cujo movimento se pode apreender à revelia de seus agentes: a História. É a conformação de cada um de seus "estágios" que está por trás dos caracteres humanos. Escreve o tradutor:

Há três estágios na sociedade humana. O primeiro é resultado da consanguinidade, e a afeição natural dos membros de uma família entre si. O segundo começa quando a propriedade é estabelecida, e os homens entram em associações para defesa mútua contra as invasões e injustiças de vizinhos. A humanidade se submete, no terceiro, a certas leis e subordinações de governo, ao qual ela confia a segurança de suas pessoas e propriedade. Como o primeiro é formado na natureza, é, então, obviamente, o mais desinteressado e nobre. Os homens, no último, têm tempo livre para cultivar a mente - e restaurá-la, com reflexão, a uma dignidade de sentimento primeva. O intermediário é a província de completa barbárie e ignorância. ${ }^{254}$

Vejamos como as condicionantes históricas são tematizadas nas epopeias ossiânicas.

Em primeiro lugar, os celtas de Macpherson viveriam num período em que o ser humano é destituído de qualquer controle sobre o mundo natural. As personagens experimentam sem anteparos um clima extremo, repleto de nevascas e tempestades, como demonstra esta passagem lapidar de "The songs of Selma":

É noite. Estou só, abandonada na colina das tempestades. Ouve-se o vento na montanha. A torrente guincha ao pé da rocha. Nenhuma cabana me abriga da chuva. Abandonada na colina dos ventos.

\footnotetext{
${ }^{253}$ MACPHERSON, James. "Temora: an epic poem". The poems of Ossian and related works cit., p. 526, nota 13 .

254 "There are three stages in human society. The first is the result of consanguinity, and the natural affection of the members of a family to one another. The second begins when property is established, and men enter into associations for mutual defence, against the invasions and injustice of neighbours. Mankind submit, in the third, to certain laws and subordinations of government, to which they trust the safety of their persons and property. As the first is formed on nature, so, of course, it is the most disinterested and noble. Men, in the last, have leisure to cultivate the mind, and to restore it, with reflection, to a primeval dignity of sentiment. The middle state is the region of complete barbarism and ignorance” (MACPHERSON, James. "A dissertation”. The poems of Ossian and related works cit., p. 211).
} 
Levanta, ó lua!, de trás das tuas nuvens! Estrelas da noite, aparecei! Guiai-me, com alguma luz, ao lugar onde meu amado descansa dos labores da caça! ${ }^{255}$

Conquanto não haja qualquer cena remotamente comparável a essa nos ditos épicos ossiânicos, a brutalidade dos elementos é aqui um tema recorrente. Em Fingal, a neblina "navega sobre as planícies do outono e traz morte às pessoas"; 256 o espírito da tempestade "senta-se indistinto nas nuvens de Gormal e contempla a morte do marinheiro"; ${ }^{257}$ e o raio "trespassa os filhos do vale", "quando as pessoas são arrasadas e morrem e todas as colinas queimam ao redor". ${ }^{258}$ E em Temora, evocamse as ondas invernais que os barcos singram de uma ilha para outra. ${ }^{259}$ Para sobreviver a forças tão maiores que o homem, eram necessárias firmeza e coragem. A relação entre o ambiente inóspito e a índole heroica dos celtas ossiânicos é feita, como no Espírito das Leis, explícita nas palavras do jovem Calmar, em diálogo com Cuchullin:

Cormar era o primeiro de minha raça. Divertia-se pelas tempestades das ondas. Seu esquife negro agitava-se sobre o oceano e viajava nas asas da borrasca. Certa vez, um espírito enredou a noite. Os mares ondejam e as rochas ressoam. Ventos arrastam as nuvens. O raio voa em asas de fogo. Ele temeu e voltou à terra. Então, enrubesceu por ter temido. Apressou-se de volta às ondas para encontrar o filho do vento. Três jovens guiam o barco tormentoso; ele se ergueu com a espada desembainhada. Enquanto passava o nimbo, agarrou-o pela cabeça eriçada e perfurou seu ventre negro com a espada. O filho do vento deixou os céus. A lua e as estrelas retornaram.

Tal era a intrepidez da minha raça. E Calmar é como seus pais. O perigo foge da espada empunhada. Quem ousa sempre triunfa. ${ }^{260}$

255 "It is night; - I am alone, forlorn on the hill of storms. The wind is heard on the mountain. The torrent shrieks down the rock. No hut receives me from the rain; forlorn on the hill of winds. Rise, moon! from behind thy clouds; stars of the night appear! Lead me, some light, to the place where my love rests from the toil of the chace!" (MACPHERSON, James. "The songs of Selma". The poems of Ossian and related works cit., p. 166).

256 " [...] sails over the plains of autumn and brings death to the people" (MACPHERSON, James. "Fingal: an epic poem". The poems of Ossian and related works cit., p. 57).

257 “[...] sits dim, on the clouds of Gormal, and enjoys the death of the mariner" (idem, p. 60).

258 " [.... it pierces the sons of vale; when the people are blasted and fall, and all the hills are burning around" (idem, ibidem).

${ }^{259}$ MACPHERSON, James. "Temora: an epic poem". The poems of Ossian and related works cit., p. 265.

260 "Cormar was the first of my race. He sported through the storms of the waves. His black skiff bounded on ocean, and travelled on the wings of the blast. A spirit once embroiled the night. Seas swell and rocks resound. Winds drive along the clouds. The lightning flies on wings of fire. He feared and came to land: then blushed that he feared at all. He rushed again among the waves to find the son of the wind. Three youths guide the bounding bark; he stood with the sword unsheathed. When the low-hung vapour passed, he took it by the curling head, and searched its dark womb with his steel. The son of the wind forsook the air. The moon and stars returned. Such was the boldness of my race; and Calmar is like his fathers. Danger flies from the uplifted sword. They best succeed who dare" (MACPHERSON, 
A rusticidade do ambiente encontraria equivalência nas condições materiais dos antigos escoceses. Em sua sociedade, pequena e dedicada sobretudo à guerra, inexistiria uma aguda divisão de trabalho. A base da subsistência era a caça, uma atividade de que todos tomavam parte, inclusive os membros mais ilustres das casas reais. Ao final de Fingal, o herói epônimo pede ao neto, Oscar, para que traga "o cervo e prepare a festa das conchas". ${ }^{261}$ Uma base econômica tão simples e uma organização social tão pouco complexa, obviamente, nada proporcionariam além do mínimo necessário à subsistência. Os reis e senhores de Morven, Lochlin e Erin desconheciam o fausto e a opulência. Temora, o palácio dos reis irlandeses, é feito de madeira. Tais hábitos austeros, contudo, estão longe de ser valorados negativamente. Nas digressões sócio-históricas de Macpherson, talvez influenciadas por seu contato com Adam Ferguson, ${ }^{262}$ o eclipse dessa era do mundo é tratado com inequívoco pesar. Quando os caledônios, sobretudo os do sul, deixaram de frequentar os ermos em busca de caça e passaram a se dedicar à agricultura, seu "caráter nacional" mudou inapelavelmente. ${ }^{263}$ As demandas daquela vida venatória produziriam o máximo da virilidade. Neste trecho do "Livro VI" de Fingal, em que o bardo Ullin celebra os feitos de Trenmor, bisavô de Fingal, a caçada é um ato que exige o mesmo destemor que enfrentar os mares revoltos:

Trenmor, disse a voz das canções, viveu em épocas antigas. Singrava as ondas do norte: companheiro da tempestade. As altas rochas da terra de Lochlin e os bosques murmurantes despontavam para o herói através da bruma. - Içou suas velas de alvo colo. Trenmor perseguiu o javali que rugia pelas florestas de Gormal. Muitos fugiram de sua presença, mas a lança de Trenmor o matou. ${ }^{264}$

James. "Fingal: an epic poem". The poems of Ossian and related works cit., p. 75). Consultei com proveito: OSSIAN. "Fingal. Poema em seis cantos". Trad. Maria Adelaide Fernandes Prata. In: BÄR, Gerald (coord.). Poesias de Ossian cit., p. 171-212, especialmente p. 189.

${ }^{261}$ No original: "Bring hither, Oscar, the deer, and prepare the feast of shells" (MACPHERSON, James. "Fingal: an epic poem". The poems of Ossian and related works cit., p. 104).

${ }^{262}$ Sobre a proximidade de Macpherson e Ferguson, ver MOORE, Dafydd. "James Macpherson and Adam Ferguson: an Enlightenment encounter". Scottish Literary Journal, v. 24, n. 2 (novembro, 1997), p. 5-23.

${ }^{263}$ No original: "national character" (MACPHERSON, James. "A dissertation". The poems of Ossian and related works cit., p. 212).

264 "Trenmor, said the mouth of the songs, lived in the days of other years. He bounded over the waves of the north: companion of the storm. The high rocks of the land of Lochlin, and its groves of murmuring sounds appeared to the hero through the mist; - he bound his white-bosomed sails. Trenmor pursued the boar that roared along the woods of Gormal. Many had fled from its presence; but the spear of Trenmor slew it" (MACPHERSON, James. "Fingal: an epic poem". The poems of Ossian and related works cit., p. 99). Consultei: OSSIAN. "Fingal. Poema em seis cantos" cit., p. 207. 
É a guerra que se toma, entretanto, como a contingência seminal do caráter primitivo. A caracterização de todas as personagens ossiânicas - em todas as composições, das mais breves às mais extensas - dá-se sob o pressuposto do confronto e da violência. E, no caso específico das epopeias, a conflagração é generalizada. Em Temora, por exemplo, instaura-se uma guerra civil, em que o jovem monarca, Cormac II, chega a ser assassinado:

Ele passou em sua escuridão e tomou a mão do rei. Cormac anteviu sua morte e a raiva transbordou de seus olhos. - Retira-te, ó sombrio chefe de Atha: Nathos vem com a batalha. - És valente no salão de Cormac, pois seu braço é fraco. - A espada penetrou no flanco do rei: ele tombou no salão de seus pais. Seus cabelos claros estão no pó. Seu sangue fumega ao redor. ${ }^{265}$

Nesse quadro, as virtudes e os vícios das personagens derivam, em sua maioria, de seu comportamento no campo de batalha, locus no qual só há dois papéis a desempenhar: vítima e algoz. Quanto às vítimas, os conflitos recorrentes nas Terras Altas teriam proporcionado exemplos ímpares de amor e devoção, ainda que em face das mais extremas situações. Mulheres, jovens e crianças sacrificam-se por seus entes queridos, a despeito de sua debilidade. É o que ocorre com Agandecca, uma princesa escandinava e irmã de Swaran. Teve de pagar com a própria vida por salvar Fingal dos planos de Starno, o pai dela, para atocaiar o rei de Morven.

Ela veio com seus olhos vermelhos de lágrimas. Ela veio com o negro cabelo em desalinho. Seu alvo colo palpitava em suspiros, como a espuma da flumínea Lubar. Starno perfurou seu flanco com a espada. Ela tombou como uma coroa de neve que desliza pelas rochas de Ronan, quando as árvores estão silentes e o eco ressoa no vale. $^{266}$

Em cenas desse tipo, Macpherson cobre de elogios a beleza dos sentimentos daqueles que, muitas vezes inutilmente, dão a vida pelos seus. E, não raro, reconta estórias semelhantes que supostamente coletara em suas andanças. ${ }^{267}$

\footnotetext{
265 "He passed on in his darkness, and seized the hand of the king. Cormac foresaw his death, and the rage of his eyes arose.-Retire, thou gloomy chief of Atha: Nathos comes with battle.-Thou art bold in Cormacs hall, for his arm is weak.-The sword entered the side of the king: he fell in the halls of his fathers. His fair hair is in the dust. His blood is smoking round" (MACPHERSON, James. "Temora: an epic poem". The poems of Ossian and related works cit., p. 233).

266 "She came with the red eye of tears. She came with her loose raven locks. Her white breast heaved with sighs, like the foam of the streamy Lubar. Starno pierced her side with steel. She fell like a wreath of snow that slides from the rocks of Ronan; when the woods are still, and the echo deepens in the vale" (MACPHERSON, James. "Fingal: an epic poem". The poems of Ossian and related works cit., p. 74). Consultei: OSSIAN. "Fingal. Poema em seis cantos" cit., p. 189.

${ }^{267}$ Ver MACPHERSON, James. "Temora: an epic poem". The poems of Ossian and related works cit., p. 279-280 e p. 517, nota 16 .
} 
Quanto aos algozes, tem-se que suas qualidades heroicas só se realizam plenamente no conflito armado. Nenhuma demonstração de valentia em face dos elementos ou de animais selvagens seria comparável àquela exibida em face do inimigo. Isso se torna claro na cena do "Livro III" de Fingal em que Colmar se vangloria por descender de Cormar, que desafiara os mares. Após apresentar a sua linhagem, exorta Cuchullin a reunir as tropas dispersas de Erin, enquanto ele se postará sozinho contra o inimigo. Cuchullin rejeita a oferta e brada que jamais desertará Calmar. Mostra-se superior ao jovem ao vincular seu heroísmo exclusivamente a meios militares:

Minha alegria está no campo desigual: minha alma avulta no perigo. Connal e Carril de outrora, levai os tristes filhos de Erin. E, quando a batalha acabar, procurai por nossos corpos pálidos nesta passagem estreita, pois próximos a este carvalho estaremos na torrente da batalha dos milhares. ${ }^{268}$

A verdadeira honra também só emerge no combate. Mantendo-se firme mesmo diante da derrota inevitável e da debandada de seu exército, Cuchullin nega-se a aquiescer à paz oferecida por Swaran, ${ }^{269}$ cujos termos transcrevo:

Aceita a paz de Swaran - disse o guerreiro - , a paz que ele dá aos reis quando os povos se curvam diante dele. Deixa-nos as amáveis planícies de Ullin e dá-nos tua esposa e teu cão. Tua bela esposa, de alvo colo palpitante. Teu cão que supera o vento. Dá-nos para provar a fraqueza do teu braço e vive sob nosso poder. ${ }^{270}$

A condição guerreira de Cuhullin o impede de aceitar a oferta. Ainda que se renda num diálogo, sua espada nunca deixaria que se consumasse essa rendição. ${ }^{271} \mathrm{~A}$ necessidade de sempre lutar - e, se preciso for, tombar lutando - sobrepõe-se a eventuais escolhas e hesitações da personagem.

A movimentação das tropas é apresentada como o teste supremo de liderança. Cuchullin mostra-se um herói inferior a Swaran e Fingal exatamente porque não

\footnotetext{
268 "My joy is in the unequal field: my soul increases in danger. Connal, and Carril of other times, carry off the sad sons of Erin; and when the battle is over, search for our pale corses in this narrow way. For near this oak we shall stand in the stream of the battle of thousands" (MACPHERSON, James. "Fingal: an epic poem". The poems of Ossian and related works cit., p. 75).

${ }^{269}$ Sobre os episódios de Fingal em que transparece o zelo de Cuchullin por sua honra, ver BYSVEEN, Josef. Epic tradition and innovation in James Macpherson's Fingal cit., p. 64.

270 "Take Swaran's peace, the warrior spoke, the peace he gives to kings, when the nations bow before him. Leave Ullin's lovely plains to us, and give thy spouse and dog. Thy spouse high-bosom'd heaving fair. Thy dog that overtakes the wind. Give these to prove the weakness of thine arm, and live beneath our power" (MACPHERSON, James. "Fingal: an epic poem". The poems of Ossian and related works cit., p. 67).

${ }^{271}$ No original: "In words I yield to many, Morla; but this sword shall yield to none” (idem, p. 67).
} 
consegue evitar a fuga de seus soldados. ${ }^{272}$ Sozinho, é uma ameaça irrelevante ao avanço de Swaran, o que leva o rei de Lochlin a ignorá-lo para lidar com os homens vindos de Morven. Sem seguidores, resta a Cuchullin refugiar-se nas florestas de Cromla. A figura de Swaran no campo de batalha, por outro lado, é colossal. A vastidão do oceano é o símbolo apropriado para a sua ascendência, como se pode notar nesta ordem proferida a seus comandados: "Erguei-vos para a batalha, meus milhares! Despejai-vos ao meu redor, como o mar retumbante". ${ }^{273}$ Fingal, no entanto, impõe-se sobre os demais pela sua grandeza marcial, materializada no esplendor de suas armas. De tal feita, a luminosidade é símbolo que convém à sua majestade: "Fingal, como um feixe de luz vindo dos céus, reluziu em meio a seu povo. Seus heróis se juntam ao seu redor e ele emite a voz de seu poder". ${ }^{274}$

Embora a guerra seja a ocasião na qual os selvagens ossiânicos se fazem heróis, seria errôneo interpretar o conflito armado em Fingal e Temora apenas como um palco organizado para extrair o máximo de rendimento de tipologias já estabelecidas. A guerra, aqui, é tratada também como experiência formadora. Para o polo que denominamos dos algozes, o estado permanente de desordem implica a consciência de que seus feitos e conquistas são efêmeros. Diz Fingal:

Swaran - disse o rei das montanhas - hoje nossa fama é imensa.
Passaremos como um sonho. Som nenhum permanecerá no campo
de batalha. Nossos túmulos se perderão na charneca. O caçador não
reconhecerá o local de nosso repouso. Nossos nomes poderão até
ser ouvidos na canção, mas cessará a força de nossos braços. ${ }^{275}$ A proximidade da morte é por demais eloquente para ser desconsiderada. Sua ubiquidade, contudo, impede-nos de diferenciar as reações das vítimas daquelas dos algozes. A morte é, também nas epopeias ossiânicas, uma inequívoca equalizadora. Ainda assim, cabe ressaltar que se espera resignação por parte dos guerreiros ao

\footnotetext{
${ }^{272}$ Sobre a relativa inferioridade de Cuchullin, ver BYSVEEN, Josef. Epic tradition and innovation in James Macpherson's Fingal cit., p. 78-79. Bysveen, no entanto, atribui a superioridade de Fingal e Swaran a sua idade e experiência.

273 "Rise to the battle, my thousands; pour round me like the echoing main" (MACPHERSON, James. "Fingal: an epic poem". The poems of Ossian and related works cit., p. 59). Sobre este símile, ver BYSVEEN, Josef. Epic tradition and innovation in James Macpherson's Fingal cit., p. 78.

274 "Fingal, like a beam from heaven, shone in the midst of his people. His heroes gather around him, and he sends forth the voice of his power" (MACPHERSON, James. "Fingal: an epic poem". The poems of Ossian and related works cit., p. 86). Ver BYSVEEN, Josef. Epic tradition and innovation in James Macpherson's Fingal cit., p. 85.

275 "Swaran, said the king of hills, to-day our fame is greatest. We shall pass away like a dream. No sound will remain in the fields of battle. Our tombs will be lost in the heath. The hunter shall not know the place of our rest. Our names may be heard in song, but the strength of our arms will cease" (MACPHERSON, James. "Fingal: an epic poem". The poems of Ossian and related works cit., p. 101).
} 
partirem ao seu encontro. Antes da batalha final de Fingal, o rei exorta seus filhos e netos a protegerem os amigos, mas os adverte: "aqui em Erin tombareis. Logo nossos espectros frios e pálidos se encontrarão nas nuvens e voarão sobre as colinas de Cona". ${ }^{276}$ Ademais, parece-nos evidente que, para as personagens destituídas de agência, os desdobramentos das carnificinas tendem a dar ensejo a lamúrias e a outras expressões ritualizadas de sofrimento. As viúvas e os velhos constantemente se ressentem da marcha dos acontecimentos e anseiam por uma redenção que jamais virá. ${ }^{277}$ É o caso do rei Cormac I, pai de Ros-crána, ${ }^{278}$ num episódio contado por Fingal, em Temora. Incapaz de repelir os inimigos, chora por sua impotência. São as suas palavras ao rei de Morven:

Cinzento, com sua lança sem ponta, vieram os passos idosos de Cormac. Ele sorriu por entre suas madeixas esvoaçantes, mas o pesar estava em sua alma. Ele divisou poucos de nós diante de si, e seu suspiro elevou-se. - Vejo os braços de Trenmor, ele disse. E estes são os passos do rei! Fingal, tu és um feixe de luz para a sombria alma de Cormac. - Precoce é a tua fama, meu filho: mas fortes são os inimigos de Erin. Eles são como o rugido das torrentes sobre a terra, filho do aurígico Comhal.

[...] Escorreram as lágrimas em que rebentou o rei. Em silêncio, ele tomou minha mão. ${ }^{279}$

Esse desespero lamentoso, todavia, não é exclusivo das vítimas. Mesmo aqueles que presidem a ação violenta, como Fingal e Cathmor, são acometidos pela tristeza e pelo desespero ao contemplar o exício de seus companheiros, embora sejam indiferentes quanto ao próprio destino. Em Temora, Fingal pranteia a morte de seu neto, Oscar, e declara que a guerra já cobrara uma fatura alta demais, ceifando a vida de vários de seus descendentes. O futuro que vislumbra para si é desolado e solitário:

Tombaste, Oscar, no meio de tua trajetória? O coração do velho se agita ao pensar em ti! Ele vê as tuas guerras vindouras! As guerras que deverão vir ele vê, mas elas foram removidas de tua fama! Quando a alegria habitará em Selma? Quando a tristeza deixará Morven? Um a um tombam meus filhos: Fingal será o último de sua

\footnotetext{
276 “ $[. .$.$] here ye should fall in Erin. Soon shall our cold, pale ghosts meet in a cloud, and fly over the$ hills of Cona" (idem, p. 85).

277 STAFFORD, Fiona. The sublime savage cit., p. 106.

${ }^{278}$ Primeira esposa de Fingal.

279 "Grey, on his pointless spear, came forth the aged steps of Cormac. He smiled, from his waving locks, but grief was in his soul. He saw us few before him, and his sigh arose.- I see the arms of Trenmor, he said; and these are the steps of the king! Fingal! thou art a beam of light to Cormac's darkened soul.-Early is thy fame, my son: but strong are the foes of Erin. They are like the roar of streams in the land, son of car-borne Comhal. [...] The bursting tears of the king came down. He seized my hand in silence" (MACPHERSON, James. "Temora: an epic poem". The poems of Ossian and related works cit., p. 255$)$.
} 
raça. A fama que recebi desaparecerá: minha velhice será sem amigos. Sentar-me-ei como uma nuvem cinzenta em meu salão: tampouco ouvirei o regresso de um filho em meio ao clangor de suas armas. Chorai, ó heróis de Morven! Nunca mais Oscar se levantará! $!^{280}$

A "revolta contra o despotismo dos fatos"281 extrapola o campo de experiência das personagens inflecte a voz do próprio sujeito poético. Enquanto Oscar agoniza e pede para que Ossian erga um monumento em sua homenagem, a narrativa personaliza-se. Inicialmente, parece ser o herói, a personagem, que responde ao filho. No quarto período, "O musgo está em tuas pedras cinzentas [...]”, irrompe a voz do narrador. Da contemplação de um futuro desolado, passa-se à expressão do sentimento presente:

E tombaste, ó filho de minha fama! E jamais te verei, Oscar! Quando outros ouvirem de seus filhos, não ouvirei de ti. O musgo está em tuas pedras cinzentas; o vento lamentoso está lá. Lutar-se-á a batalha sem ele: ele não perseguirá as corças castanho-escuras. Quando o guerreiro retornar das batalhas e contar de outras terras: eu vi um túmulo, ele dirá, próximo à torrente estrondosa, a morada sombria de um chefe. Ele tombou pelas mãos de Oscar, o primeiro dentre os mortais. - Eu, então, ouvirei a sua voz. E um feixe de alegria se erguerá em minha alma. ${ }^{282}$

As provações com que se defrontariam os antigos caledônios não seriam, portanto, apenas condicionantes de caracteres. Como se pode notar na passagem acima, a História seria também a força a moldar a consciência poética. Como Blackwell, Macpherson assevera explicitamente, na "Dissertação" a Temora, que as

\footnotetext{
280 "And art thou fallen, Oscar, in the midst of thy course? the heart of the aged beats over thee! He sees thy coming wars. The wars which ought to come he sees, but they are cut off from thy fame. When shall joy dwell at Selma? When shall grief depart from Morven? My sons fall by degrees: Fingal shall be the last of his race. The fame which I have received shall pass away: my age will be without friends. I shall sit a grey cloud in my hall: nor shall I hear the return of a son, in the midst of his sounding arms. Weep, ye heroes of Morven! never more shall Oscar rise!" (MACPHERSON, James. "Temora: an epic poem". The poems of Ossian and related works cit., p. 230). Sobre a morte de Oscar, ver STAFFORD, Fiona J. The last of the race cit., p. 105.

${ }^{281}$ Ver ARNOLD, Matthew. On the study of Celtic literature. Nova Iorque: Macmillan, 1904, p. 115-6 e p. 118 e STAFFORD, Fiona J. "Fingal and the fallen angels: Macpherson, Milton and romantic titanism". In: GASKILL, Howard; STAFFORD, Fiona (ed.). From Gaelic to romantic cit., p. 164-182.

282 "And fallest thou, son of my fame! And shall I never see thee, Oscar! When others hear of their sons, I shall not hear of thee. The moss is on thy four grey stones; the mournful wind is there. The battle shall be fought without him: he shall not pursue the dark-brown hinds. When the warrior returns from battles, and tells of other lands; I have seen a tomb, he will say, by the roaring stream, the dark dwelling of a chief. He fell by car-borne Oscar, the first of mortal men.-I, perhaps, shall hear his voice; and a beam of joy will rise in my soul" (MACPHERSON, James. "Temora: an epic poem". The poems of Ossian and related works cit., p. 231).
} 
ideias e a sensibilidade de Ossian são próprias de seu tempo. ${ }^{283}$ Por conseguinte, sua mente e seu coração seriam, como tudo do "primeiro estágio da sociedade", "formados na natureza". Sua poesia seria progênie dessa mesma natureza, não conteria arte. ${ }^{284}$ Afinal, os antigos celtas

[...] dão-nos a linguagem genuína do coração, sem nenhum daqueles ornamentos afetados de fraseologia, os quais, embora projetados para embelezar sentimentos, despojam-nos de força natural. ${ }^{285}$

O único ornamento dos épicos ossiânicos seria a verdade, ${ }^{286}$ entendida como fidelidade tanto à maneira como o mundo se apresenta à mente do poeta quanto às sensações decorrentes dessa relação entre o eu e seu entorno. Trata-se de um entendimento, como é possível notar, para o qual as distinções entre representação e expressão se tornam irrelevantes.

A adesão primitiva aos impulsos da interioridade eliminaria qualquer distância entre o narrador e o narrado. ${ }^{287}$ As emoções suscitadas pela rememoração do passado constituiriam a grande matriz estrutural de Fingal e Temora. ${ }^{288}$ Da assunção de que estamos diante de um texto espontâneo, decorre que a temporalidade do poetar é visível no tecido textual. Explico: inexistiriam, aqui, instâncias de uniformização e harmonização da obra, devotadas a conceder-lhe unidade e organicidade. Não haveria, com o perdão dos pleonasmos, nem um molde genérico anterior nem uma decorosa revisão posterior. Por conseguinte, toda composição selvagem seria (também) o registro das sucessivas disposições de ânimo da consciência do bardo. De tal feita, as epopeias ossiânicas se definiriam por descontinuidades e modulações: o sujeito poético iria reagindo ex tempore à sua própria narrativa e deixaria as marcas dessas reações na forma de Fingal e Temora. Essas marcas eram, sobretudo, oscilações

\footnotetext{
${ }^{283}$ Macpherson escreve: "Suas [de Ossian] ideias, embora notavelmente apropriadas para os tempos em que viveu, são tão contrárias ao presente estágio avançado da sociedade [...]" ("His ideas, though remarkably proper for the times in which he lived, are so contrary to the present advanced state of society" (MACPHERSON, James. "A dissertation". The poems of Ossian and related works cit., p. 214).

284 "It is the offspring of nature, not of art" (BLAIR, Hugh. "A critical dissertation on the poems of Ossian the son of Fingal". In: MACPHERSON, James. The poems of Ossian and related works cit., p. 395).

285 “....] give us the genuine language of the heart, without any of those affected ornaments of phraseology, which, though intended to beautify sentiments, divest them of their natural force" (MACPHERSON, James. "A dissertation". The poems of Ossian and related works cit., p. 214).

${ }^{286}$ No "Prefácio" à primeira edição de Fingal, diz-se que "A estória deste poema é tão pouco misturada à fabula [...]" ("The story of this poem is little interlarded with fable") (MACPHERSON, James. "Preface to $1^{\text {st }}$ edition of Fingal". The poems of Ossian and related works cit., p. 37).

${ }^{287}$ Ver POPE, Alexander. "Preface". The Iliad of Homer cit., v. 1, p. 12.

${ }^{288}$ Ver STAFFORD, Fiona J. The sublime savage cit., p. 141.
} 
rítmicas e estilísticas. ${ }^{289}$ Há modulações rítmicas na cena inicial do "Livro Terceiro" de Temora, ao longo da qual se reúne o conselho dos guerreiros de Morven. Quando se focalizam Fingal e Gaul (depois do rei, “a personagem mais renomada introduzida por Ossian em seus poemas" ${ }^{290}$ ), há uma clara uniformidade de cadência. Com alguma boa vontade, é possível até decompor parágrafos inteiros em versos com quase o mesmo padrão métrico. ${ }^{291}$ Abaixo, o momento em que Gaul, sem proferir palavra, toma para si a missão de liderar o exército dos caledônios:

The chiefs bend towards the king: each darkly seems to claim the war. They tell, by halves, their mighty deeds: and turn their eyes on Erin. But far before the rest the son of Morni stood: silent he stood, for who had not heard of the battles of Gaul? They rose within his soul. His hand, in secret, seized the sword. The sword which he brought from Strumon, when the strength of Morni failed. ${ }^{292}$

[Os chefes curvam-se em direção ao rei: cada um parece, sombriamente, reclamar a guerra para si. Eles contam, em metades, seus feitos poderosos: e voltam seus olhos em direção a Erin. Mas muito à frente dos outros ficou o filho de Morni: silente ele ficou, pois quem não ouvira das batalhas de Gaul? Elas avultaram em sua alma. Sua mão, em segredo, agarrou a espada - a espada que trouxera de Strumon, quando a força de Morni falhou.]

Podemos enxergar unidades de sete pés, a sua maioria iambos, com que se obtém um arranjo métrico-formal semelhante ao da Ilíada de Chapman, descontadas as rimas:

The chiefs bend towards the king: each darkly seems to claim the [war.

They tell, by halves, their mighty deeds: and turn their eyes on $\left[\right.$ Erin. $^{293}$

But far before the rest the son of Morni stood: silent he stood, for who had not heard of the battles of Gaul? They rose within his soul. His hand, in secret, seized the sword. The sword which he brought from Strumon, when the strength

[of Morni failed.

\footnotetext{
${ }^{289}$ Seguimos de perto idem, p. 85 e ss.

${ }^{290}$ No original: "next to Fingal, is the most renowned character introduced by Ossian in his poems" (MACPHERSON, James. "Temora: an epic poem". The poems of Ossian and related works cit., p. 493 , nota 7).

${ }^{291}$ Seguimos o exemplo de STAFFORD, Fiona J. The sublime savage cit., p. 90. Stafford, contudo, escande os parágrafos em trímetros e tetrâmetros alternados.

${ }^{292}$ MACPHERSON, James. "Temora: an epic poem". The poems of Ossian cit., p. 245. Como o arranjo métrico e acentual da passagem é o objeto da análise, decidi abrir uma exceção e transcrever o texto original no corpo do trabalho, e não meramente em nota de rodapé.

${ }^{293}$ Lê-se "E'in".
} 
Contudo, esse arranjo se dissolve logo no parágrafo seguinte, em que Fillan, filho de Fingal com sua segunda esposa, Clatho, chora por lhe ser negada a oportunidade de alcançar a glória que, até então, não possuía.

On his spear stood the son of Clatho in the wandering of his locks. Thrice he raised his eyes to Fingal: his voice thrice failed him, as he spoke.-Fillan could not boast of battles; at once he strode away. Bent over a distant stream he stood: the tear hung in his eye. He struck, at times, the thistle's head, with his inverted spear. ${ }^{294}$

[Apoiado em sua lança ficou o filho de Clatho, no esvoaçar de suas madeixas. Três vezes levantou seus olhos em direção a Fingal: sua voz três vezes lhe faltou, ao falar. - Fillan não podia vangloriar-se de batalhas. Num instante, ele se afastou. Curvado sobre um córrego distante ele ficou: a lágrima pendia de seu olho. Cutucava, às vezes, a fronde do cardo, com sua lança invertida.]

Nos três primeiros segmentos, o narrador está colado a Fillan. Revela-nos o que se passa em sua mente, formula os pensamentos que em vão tentou expressar. Essa proximidade na focalização permite que o desalento do neófito reverbere na voz de Ossian. Os momentos de maior intensidade são assinalados pela variação métrica, coincidentemente situados na abertura de cada um dos segmentos. Nos dois últimos períodos, o narrador guarda certa distância de Fillan e descreve apenas a sua conduta exterior. O distanciamento se cristaliza no emprego preciso dos iambos, novamente num esquema análogo ao da Ilíada de Chapman. Por vias oblíquas, o próprio Macpherson chama a atenção do leitor para a inconstância das cadências. Embora silencie sobre as escolhas de sua tradução, assevera, em nota, que o original é irregular e desigual, com que os números traem agitação mental. ${ }^{295}$

Para o primitivismo, a fidelidade às emoções também acarreta uma retórica peculiar. Em suas famosas aulas sobre a poesia sagrada dos hebreus, Robert Lowth afirma que, originalmente, a linguagem poética deriva das afecções veementes da alma. ${ }^{296}$ Uma ideia ou um sentimento simples, ainda que expresso sem quaisquer adornos, muitas vezes se apoderaria da elocução, derramando-se sobre ela. Assenhoreados por esse sentimento, os hebreus tendiam a repeti-lo, amplificá-lo ou variá-lo em estruturas paralelísticas. ${ }^{297}$

\footnotetext{
${ }^{294}$ MACPHERSON, James. “Temora: an epic poem”. The poems of Ossian cit., p. 245.

${ }^{295}$ Ver idem, p. 492, nota 1.

${ }^{296}$ LOWTH, Robert. Lectures on the sacred poetry of the Hebrews. Trad. G. Gregory, Londres, 1787, p. 79. Sobre Lowth e Ossian, ver STAFFORD, Fiona. The sublime savage cit., p. 86 e ss.

${ }^{297}$ LOWTH, Robert. Lectures on the sacred poetry of the Hebrews cit., p. 100.
} 
Nos épicos ossiânicos, a intensidade do sentimento também se convertia em imagens persistentes, frequentemente decalcadas em termos sinônimos ou em índices idênticos, mas em função semântica diversa. ${ }^{298}$ No encontro climático entre os reis de Morven e Lochlin, em Fingal, a tensão do momento é verbalizada no uso dobrado de “terrível” e de seu sinônimo, "horrível”: "Terrível é a batalha do rei, e horrível o olhar de seus olhos". E o cataclismo provocado pelo embate dos chefes, quando "balançaram a colina com seus calcanhares; as rochas caem do alto; os arbustos de verde coroa são arrancados", não se esgota na descrição exagerada. É retomado pelo narrador numa evocação metafórica, também paralelística, em que os reis se convertem em torrentes cuja força arrasta as próprias colinas: ${ }^{299}$

Assim eu vi em Cona (mas Cona já não diviso), assim eu vi duas colinas sombrias serem removidas pela força de uma corredeira prestes a transbordar. Movem-se de um lado para outro e seus imensos carvalhos se encontram no alto. Então eles caem, com todas as suas rochas e árvores. ${ }^{300}$

Os efeitos hiperbólicos da luta, que convulsiona o ambiente, podem ser atribuídos à noção, depois elaborada por Duff e Kames, de que a mente selvagem era por demais impressionável, tendente sempre ao exagero no registro de sua experiência. ${ }^{301}$

No que tange à fidelidade à apresentação do mundo à mente de Ossian, há uma série de procedimentos editoriais e narrativos com vistas a apontar a adesão do poeta à sua realidade. Linguagem, objeto e, em última instância, a forma de Fingal e

${ }^{298}$ STAFFORD, Fiona. The sublime savage cit., p. 91.

${ }^{299}$ Vale a pena transcrever o combate inteiro, para que se evidenciem outros paralelismos imagéticos, como os das armas caídas, dos membros sinuosos etc.: "Essas foram as palavras de Connal, quando os heróis se encontraram em meio a seus homens caídos. Houve um ressoar das armas! Cada golpe, como centenas de martelos na fornalha! Terrível é a batalha do rei, e horrível o olhar de seus olhos. Seus escudos castanho-escuros estão partidos ao meio e suas espadas voam, quebradas, de seus elmos. Deitam fora as suas armas. Cada um se precipita ao atracar de seu inimigo. Seus braços sinuosos envolvem um ao outro: viram-se de um lado a outro e, abaixo, forçam e esticam suas pernas grandes e longas. Mas quando o orgulho de sua força elevou-se, balançaram a colina com seus calcanhares; as rochas caem do alto; os arbustos de verde coroa são arrancados. Ao fim, vacilou a força de Swaran e o rei dos arvoredos é preso". No original: "Such were the words of Connal, when the heroes met in the midst of their falling people. There was the clang of arms! there every blow, like the hundred hammers of the furnace! Terrible is the battle of the kings, and horrid the look of their eyes. Their dark-brown shields are cleft in twain; and their steel flies, broken, from their helmets. They fling their weapons down. Each rushes to the grasp of his foe. Their sinewy arms bend round each other: they turn from side to side, and strain and stretch their large spreading limbs below. But when the pride of their strength arose, they shook the hill with their heels; rocks tumble from their places on high; the green-headed bushes are overturned. At length the strength of Swaran fell; and the king of the groves is bound" (MACPHERSON, James. "Fingal: an epic poem". The poems of Ossian cit., p. 91).

300 "Thus have I seen on Cona; (but Cona I behold no more) thus have I seen two dark hills removed from their place by the strength of the bursting stream. They turn from side to side, and their tall oaks meet one another on high. Then they fall together with all their rocks and trees" (idem, ibidem)

${ }^{301}$ Ver MOORE, Dafydd. "The Ossianic revival, James Beattie and primitivism” cit., p. 91. 
Temora nada mais seriam que prolongamentos incontornáveis dos originais com que operaria o bardo caledônio. Com efeito, a mente e o verbo primitivos seriam uma espécie de receptáculo transparente, em que seu substrato concreto poderia ser apreendido de modo puro, pleno e incondicionado. Isso se daria porque Ossian conheceria o mundo e a ele se referiria, como o Homero de Robert Wood, sem a mediação de sistemas filosóficos, doutrinas morais ou até mesmo expectativas religiosas.

Quanto à linguagem, vincular-se-iam os tropos empregados por Ossian a elementos imediatamente sensíveis à sua experiência. Para usarmos uma expressão do próprio Macpherson, as figuras de Fingal e Temora seriam "colhidas na natureza". 302 Os epítetos dos heróis, por exemplo, adviriam do clima de sua terra ou da ordem social a que pertencem. Starno, pai de Swaran e Agandecca, é denominado "rei da neve" a partir, explica Macpherson, "das grandes quantidades de neve que caem em seus domínios". ${ }^{303}$ E Allad, um druida, é chamado de o "filho da rocha" por habitar uma caverna. $^{304}$

Mas talvez seja na construção de símiles que se encontra a maior aposta de Macpherson para naturalizar a linguagem ossiânica. Para retores setecentistas, como Lord Kames, a função precípua do símile é instruir. ${ }^{305}$ Efetuar-se-ia uma comutação, com que um objeto é oferecido como equivalente epistêmico do outro. ${ }^{306}$ Nos épicos ossiânicos, o comparante advém, sobretudo, da paisagem e dos fenômenos naturais de um cenário bastante específico. Em certa passagem do "Livro V" de Fingal, escolhida quase que de maneira aleatória, estabelece-se, por exemplo, que a força do rei de Morven "é como a torrente de Lubar ou o vento da ressoante Cromla, quando as ramadas florestas da noite são derrubadas". ${ }^{307}$ Noutros pontos, conquanto se se abstenha de nomear a localidade, especifica-se o comparante por meio de minuciosa

\footnotetext{
${ }^{302}$ Veja-se, por exemplo, MACPHERSON, James. "A dissertation". The poems of Ossian and related works cit., p. 499 , nota 37.

${ }^{303}$ No original: "Starno is here poetically called the king of snow, from the great quantities of snow that fall in his dominions" (MACPHERSON, James. "Fingal: an epic poem". The poems of Ossian and related works cit., p. 428 , nota 13$)$.

${ }^{304}$ No original: "Allad is plainly a druid: he is called the son of the rock, from his dwelling in a cave" (idem, p. 433, nota 37).

${ }^{305}$ HOME, Henry (Lord Kames). Elements of criticism cit., v. 2, p. 184.

${ }^{306}$ DUBOIS, J. et al. Retórica geral. Trad. Carlos Felipe Moisés. São Paulo: Cultrix - USP, 1974, p. 162.

${ }^{307}$ No original: "His strength is like the stream of Lubar, or the wind of the echoing Cromla; when the branchy forests of night are overturned" (MACPHERSON, James. "Fingal: an epic poem". The poems of Ossian and related works cit., p. 91).
} 
descrição. É o que se dá na abertura do último livro de Temora, naquele que, segundo o editor, é o mais longo de todos os símiles de Ossian.

Tais quais os ventos invernais agarraram as ondas do lago montanhês, agarraram-nas na noite tempestuosa e cobriram-nas de gelo. Brancas, aos olhos do caçador, as vagas ainda parecem se agitar. Ele volta seu ouvido para o som de cada uma das elevações irregulares. Mas todas se encontram silenciosas, cintilantes, cobertas de ramos e tufos de grama, que balançam e assoviam para o vento, sobre seus cinzentos bancos de gelo. - Assim brilharam silenciosamente para a manhã as elevações das hostes de Morven $[\ldots] .{ }^{308}$

Numa primeira leitura, esses expedientes retóricos fazem do comparado - no primeiro caso, Fingal; no segundo, o exército de Morven - uma extensão do ambiente, com que se realiza literariamente a assertiva primitivista de que há identidade entre o caráter dos antigos e o quadro ambiental que o gerou. Caso as comparações fossem menos precisas, talvez a importância das condicionantes não restasse evidente. Seria errôneo, entretanto, tomar o tropo apenas como um juízo acerca do comparado. De acordo com o método blackwelliano, toda técnica literária é também um indício de uma maneira determinada de pensar e, por conseguinte, de poetar. $\mathrm{O}$ uso recorrente de símiles calcados na natureza imediata trai uma mente que, para compreender algo, precisa encontrar um equivalente perceptível aos sentidos, cuja existência é una, dotada de materialidade, não universalizável e, por isso mesmo, inadulterável.

A própria língua de Ossian teria um lastro no real. Seria motivada, adâmica. ${ }^{309} \mathrm{~A}$ designação de pessoas, coisas e lugares teria um sentido palpável, o que impele o tradutor a dicionarizar os nomes de quase todas as personagens. Assim, no "Livro Primeiro" de Temora, com a menção de Mór-lath, Hildalla, Cor-mar, Málth-os e Foldath, há nota em que o teor desses nomes é dado como, respectivamente, "grande

\footnotetext{
308 "As when the wintry winds have seized the waves of the mountain-lake, have seized them, in stormy night, and cloathed them over with ice; white, to the hunter's early eye, the billows still seem to roll. He turns his ear to the sound of each unequal ridge. But each is silent, gleaming, strewn with boughs and tufts of grass, which shake and whistle to the wind, over their grey seats of frost.- So silent shone to the morning the ridges of Morven's host [...]" (MACPHERSON, James. "Temora: an epic poem". The poems of Ossian and related works cit., p. 287). A análise que o tradutor faz deste símile se encontra em: idem, p. 522, nota 1.

${ }^{309}$ Sobre as concepções primitivistas da linguagem, ver NOVAK, Maximillian E. "Primitivism". In: NISBET, H. B.; RAWSON, Claude (ed.) The Cambridge History of Literary Criticism: the eighteenth century cit., p. 456-469, especialmente p. 464.
} 
no dia de batalha", "herói de olhar calmo", "experto no mar", "lento no falar" e "generoso". 310

A adesão dos poemas ossiânicos à realidade os fariam heroicos quase que por definição. Ao representarem a sociedade highlander sem qualquer fantasia literária, Fingal e Temora não teriam outro objeto senão os caracteres, para retomarmos os termos de uma citação de Macpherson, "nobres" e "desinteressados" que habitavam essa sociedade. ${ }^{311}$ Episódios, diálogos e até elementos constitutivos da forma dos épicos de Ossian são-nos apresentados pelo tradutor e editor como meras manifestações dos valores heroicos dos celtas, fielmente registrados em tom solene e reverencial pelo bardo. Por exemplo, em Temora, quando Oscar comparece às festividades de Cairbar, seu inimigo, há uma nota que nos explica por que se aceitou um convite tão temerário:

Nenhuma nação do mundo empenhava-se tanto na hospitalidade quanto os antigos escoceses. Era até mesmo desonroso, por muito tempo, para um homem de posses sequer fechar a porta de sua casa, POR RECEIO DE QUE, como dizem os bardos, O FORASTEIRO VENHA E CONTEMPLE SUA ALMA CONTRAÍDA. ${ }^{312}$

Outro exemplo em que a hospitalidade do herói e a exposição dos costumes locais se confundem pode ser encontrado no "Livro I" de Fingal. A magnificência do banquete recepcionado por Cuchullin, em que centenas de jovens vão à cata de combustível, dez guerreiros fazem o fogo e outros trezentos escolhem a pedra polida, é justificada por uma descrição pormenorizada de como os antigos celtas promoviam suas celebrações. $^{313}$

Nessas intervenções, o tradutor desvincula a representação literária de quaisquer preocupações quanto à economia da obra. Prevalece a lógica do conteúdo sobre a lógica da forma. As cenas se desenrolariam da maneira como desenrolam porque assim demandaria o objeto da mimese, indiferente ao evolver da ação. É o que

310 "Mór-lath, great in the day of battle. Hidalla, mildly looking hero. Cor-mar, expert at sea. Málthos, slow to speak. Foldath, generous" (MACPHERSON, James. "Temora: an epic poem". The poems of Ossian and related works cit., p. 480, nota 6).

${ }^{311}$ Macpherson associa diretamente os costumes do "primeiro estágio da sociedade" ao "heroísmo, que subsistia nos dias de Ossian" ("[...] heroism, which subsisted in the days of Ossian") (MACPHERSON, James. "A dissertation". The poems of Ossian and related works cit., p. 211).

312 "No nation in the world carried hospitality to a greater length than the antient Scots. It was even infamous, for many ages, in a man of condition, to have the door of his house shut at all, LEST, as the bards express it, THE STRANGER SHOULD COME AND BEHOLD HIS CONTRACTED SOUL" (MACPHERSON, James. "Temora: an epic poem". The poems of Ossian and related works cit., p. 482, nota 29).

${ }^{313}$ MACPHERSON, James. "Fingal: an epic poem". The poems of Ossian and related works cit., p. 423, nota 90 . 
ostensivamente ocorreria no "Livro Segundo" de Temora, o qual "embora [...] tenha pouca ação, não é a parte menos importante" da epopeia. ${ }^{314}$ Igualmente, pode-se interromper a narrativa de um conselho de guerra para a introdução de um episódio de desventuras amorosas, como no "Livro I" de Fingal. Quando todos estão prontos para o combate, Cuchullin pergunta onde estão seus amigos Cathbat e Duchomar, que não compareceram à reunião dos chefes irlandeses. Mesmo com Swaran e os escandinavos no horizonte, sustam-se os preparativos para a batalha para que Connal conte a estória do fatal triângulo amoroso entre os guerreiros e Morna, uma donzela. Ao final, Cuchullin deseja paz às almas dos heróis, pois "seus feitos foram grande no perigo. Que cavalguem nas nuvens ao meu redor e mostrem suas feições de guerra". ${ }^{315}$ Feita a intervenção, os irlandeses marcham então para o campo de batalha. Se o narrador (ou alguma personagem, fazendo as vezes de narrador delegado) sentese compelido a introduzir um excurso episódico, nada o impedirá.

Fundamentam-se muitas reviravoltas do enredo e elementos constitutivos da narrativa no éthos guerreiro dos caledônios. Em Temora, diz-se que são os laços de parentesco que obrigam Cathmor a levar adiante a guerra iniciada por seu falecido irmão, Cairbar, ainda que discorde de seus motivos. ${ }^{316}$ A concepção da maquinaria, por sua vez, teria algo a ver com o esprit de corps dos campeões celtas. Diferentemente dos poemas homéricos, os deuses não intervêm nas epopeias ossiânicas. O motivo de tal ausência, no entanto, não seria de ordem religiosa. Segundo Macpherson, dizer que um povo era destituído de religião era a mesma coisa que dizer que um povo é desprovido de razão. E esse decerto não seria o caso dos heróis de Ossian. Sua largueza de espírito é inegável, de molde que seria injusto supor que desconhecessem a mais elementar das verdades. O tradutor explica a falta de deuses pelo fato de que, de acordo com as noções de honra de então, a ajuda de um ente externo - qualquer que seja - retiraria a honra daqueles que a recebessem.

\footnotetext{
${ }^{314}$ Eis o inteiro teor da passagem citada: "Tho' this book has little action, it is not the least important part of Temora" (MACPHERSON, James. “Temora: an epic poem”. The poems of Ossian and related works cit., p. 487, nota 1 ).

315 " [...] their deeds were great in danger. Let them ride around me on clouds; and shew their features of war" (MACPHERSON, James. "Fingal: an epic poem". The poems of Ossian and related works cit., p. 58).

${ }^{316}$ MACPHERSON, James. "Temora: an epic poem". The poems of Ossian and related works cit., p. 486 , nota 90 .
} 
Ademais, o uso desse recurso poético poderia ser interpretado como uma concessão à odiada, porém quase extinta, classe druídica. ${ }^{317}$

Entrelaçada a forma de Fingal e Temora à realidade dos antigos celtas, abria-se caminho para que as narrativas configuradas em tais composições fossem tratadas como autênticas crônicas históricas. ${ }^{318}$ No "Prefácio" à primeira edição de Fingal, diz-se, por exemplo, que nenhum evento naquele poema era inventado; tudo seria, isso sim, o relato genuíno, ainda que poetizado, da expedição do rei de Morven à Irlanda. ${ }^{319}$ Esse tipo de assertiva tem, certamente, o condão de alterar o estatuto dos ditos épicos ossiânicos. Não mais estamos diante de obras ficcionais, mas de documentos históricos. Num primeiro momento, esses documentos tanto trariam fatos conhecidos por todos quanto conteriam o registro de um tempo para além do alcance da memória. Argumenta-se, assim, que é possível datar Fingal como uma composição do século III d. C. em razão das alusões a eventos que sabidamente teriam ocorrido no período. ${ }^{320} \mathrm{E}$, de maneira ainda mais ousada, diz-se que o valor das composições ossiânicas não reside apenas na sua realização poética, mas também na maneira como permitem entrever o modo de vida dos antigos escoceses e irlandeses. ${ }^{321}$ Em Temora, haveria ocorrências que implicariam a reescrita da historiografia convencional da Grã-Bretanha. Trar-se-iam a lume acontecimentos então ignorados quanto à origem dos povos da Escócia e da Irlanda. Leia-se a "Dissertação" que antecede o poema:

[...] Temora [...] ilumina a história daquela época. A primeira população da Irlanda, seus primeiros reis e diversas circunstâncias que dizem respeito a sua antiga conexão com o norte e o sul da GrãBretanha: são-nos [todos] apresentados em diversos episódios. ${ }^{322}$

\footnotetext{
${ }^{317}$ MACPHERSON, James. "A dissertation concerning the antiquity, \&c. of the poems of Ossian the son of Fingal". The poems of Ossian and related works cit., p. 45-46.

${ }^{318}$ Ver HAYWOOD, Ian. The making of history: a study of the literary forgeries of James Macpherson and Thomas Chatterton in relation to eighteenth-century ideas of history and fiction. Londres - Toronto: Associated University Presses, 1986, passim.

${ }^{319}$ Ver MACPHERSON, James. "Preface to $1^{\text {st }}$ edition of Fingal". The poems of Ossian and related works cit., p. 37.

${ }^{320}$ MACPHERSON, James. "A dissertation concerning the antiquity, \&c. of the poems of Ossian the son of Fingal". The poems of Ossian and related works cit., p. 46-47.

${ }^{321}$ MACPHERSON, James. "Preface to $1^{\text {st }}$ edition of Fingal". The poems of Ossian and related works cit., p. 37.

322 Trecho integral: "But what renders Temora infinitely more valuable than Fingal, is the light it throws on the history of the times. The first population of Ireland, its first kings, and several circumstances, which regard its connection of old with the south and north of Britain, are presented to us, in several episodes" (MACPHERSON, James. "A dissertation". The poems of Ossian and related works cit., p. 215).
} 
Aqui, os irlandeses são feitos descendentes dos caledônios num episódio do "Livro Segundo". Após a morte de Oscar, Fingal exorta a Fillan para que não arrefeça no campo de batalha, apesar de todo o sofrimento. Fingal afirma que assim procediam seus antepassados, como Conar, o primeiro rei de Erin, que prosseguira na luta contra os inimigos do sul a despeito da morte de seu filho, Colgar. Conar, de acordo com a narrativa, seria filho de Trenmor e teria vindo, juntamente com o resto de seu povo, da terra das corças - i.e., Morven.

Conar era o irmão de Trathal, o primeiro dentre os mortais. Suas batalhas estavam em toda a costa. Mil torrentes levavam o sangue de seus inimigos. Sua fama tomou conta de Erin, como uma agradável brisa. As nações se reuniam em Ullin e abençoavam o rei: o rei da raça de seus pais, da terra das corças. ${ }^{323}$

Ossian não só teria preservado a história da migração dos caledônios para a Irlanda, como ainda teria clarificado alguns pontos obscuros da trajetória dos povos da região. Para Macpherson, as evidências de Temora provavam definitivamente que o primeiro líder a unificar a Irlanda não poderia ter vivido antes do século I d.C., o que punha por terra uma extensa linhagem de reis que os antiquários da Escócia e Irlanda diziam ter começado quase mil anos antes. ${ }^{324}$ Hoje se sabe, no entanto, que a historiografia ossiânica era, no mínimo, imprecisa. O fluxo migratório, por exemplo, deu-se em sentido contrário. Macpherson, contudo, ataca ferozmente aqueles que apresentam versões diversas das suas. Não passariam de delírios romanescos, baseados em relatos "crédulos e pueris". 325

A conversão de Fingal e Temora à condição de documentos históricos decerto aumentou a sua ressonância perante o público setecentista. Foram obras passíveis de instrumentalização no debate intelectual de então, coisa que o próprio Macpherson não se furtou em fazer. Contudo, a suposição de que a criação literária é mero prolongamento de seu contexto nega a individualidade e a singularidade da consciência ossiânica e destitui a obra de sua dimensão estética. Ao se rejeitar a ficcionalidade da narrativa, toma-se um juízo estético como análogo a um juízo de verdade, num procedimento no qual a apreciação literária é substituída pela

\footnotetext{
323 "Conar was the brother of Trathal, first of mortal men. His battles were on every coast. A thousand streams rolled down the blood of his foes. His fame filled green Erin, like a pleasant gale. The nations gathered in Ullin, and they blessed the king; the king of the race of their fathers, from the land of hinds" (MACPHERSON, James. "Temora: an epic poem". The poems of Ossian and related works cit., p. 238).

${ }^{324}$ MACPHERSON, James. "A dissertation”. The poems of Ossian and related works cit., p. 210.

${ }^{325}$ No original: "credulous and puerile" (idem, p. 210-211).
} 
perquirição de condicionantes socioculturais. ${ }^{326}$ Ademais, fazem-se problemáticas quaisquer especificidades atribuídas a Fingal e Temora - inclusive a sua designação, “poema épico". Afinal, onde residiria a diferença entre essas obras e o restante do repertório ossiânico? Decerto não seria nas personagens: Oscar, Fingal e Ossian aparecem desde os Fragmentos de poesia antiga até "Colna-dona", o último poema da coleção Temora an ancient epic poem in eight books, together with several other poems. Tampouco estaria na crônica de acontecimentos passados. Com efeito, muitos dos outros Poemas de Ossian seriam um manancial de informações históricas. Em nota ao segundo duan de "Cath-Loda", por exemplo, escreve o tradutor que o estabelecimento da monarquia na Caledônia é recontado no seguinte episódio:

De sua própria colina musgosa veio Trenmor de escudo anilado. Conduziu a batalha de largas margens - e os forasteiros fracassaram. Em seu entorno, vieram pardos guerreiros: vibraram o escudo da alegria. Como uma brisa prazerosa, as palavras de poder precipitaram-se dos reis de Selma. Mas em turnos os chefes conduziram a guerra, até que assomou o perigo: então era a hora de o rei conquistar o campo. ${ }^{327}$

Já em “Sul-malla of Lumon”, assevera-se que a similitude dos costumes de Inis-huna (hoje, País de Gales) aos da Caledônia atesta que os habitantes de ambos os territórios perfaziam um só povo. ${ }^{328} \mathrm{E}$, num corolário a essas hipóteses, não seria possível atribuir a epicidade Fingal e Temora à representação fiel da realidade celta do século III d. C. ou à presença de caracteres heroicos: todas as composições ossiânicas, que nada mais são que o registro fidedigno dos eventos e da mentalidade de um tempo, necessariamente têm de se igualar nesses quesitos.

Macpherson parece logo se ter dado conta do impasse. Na versão de 1761 da dissertação a Fingal, assevera que “o primeiro poema desta coleção é verdadeiramente épico. Os caracteres são fortemente demarcados e os sentimentos [as

\footnotetext{
${ }^{326}$ Noutro contexto, André Leme Lopes aponta a indistinção entre fato e ficção nos Poemas de Ossian (LEME LOPES, André. O poeta que não existiu cit., passim).

327 "From his own mossy hill blue-shielded Trenmor came down. He led wide-skirted battle, and the strangers failed. Around him the dark-browed warriors came: they struck the shield of joy. Like a pleasant gale the words of power rushed forth from Selma of kings. But the chiefs led by turns, in war, till mighty danger rose: then was the hour of the king to conquer in the field" (MACPHERSON, James. "Cath-Loda: a poem". The poems of Ossian and related works cit., p. 313 e 537, nota 1).

${ }^{328}$ MACPHERSON, James. "Sul-malla of Lumon: a poem". The poems of Ossian and related works cit., p. 531, nota 1 .
} 
opiniões?] respiram heroísmo". ${ }^{329}$ Levam-se as premissas do primitivismo às últimas consequências. Ao fazer da forma uma função do conteúdo, o conteúdo se torna, em última instância, forma: Fingal é um poema épico porque é um poema heroico, ${ }^{330}$ numa definição que prescinde de modelos e invariantes canônicos. Como se justifica, então, o zelo de Macpherson em cotejar Ossian com Milton, Homero e Virgílio? Em 1765, com The works of Ossian: todo o trecho que acabamos de citar foi silenciosamente suprimido. Para tratar Fingal e Temora como epopeias, o primitivismo à moda de Blackwell decerto não dispunha de instrumental teórico adequado.

\subsection{Poemas épicos}

A sequência editorial das traduções de Macpherson trai uma crescente conscientização de um obstáculo para que Ossian fosse aceito como poeta épico. Se levados às últimas consequências, os preceitos críticos e criativos do primitivismo, que interditavam o seccionamento de forma e conteúdo, negavam a intelecção em abstrato dos gêneros literários. E, sem uma tipologia de pretensões universais, as justificativas para hierarquizar obras e autores ficavam sem lastro. Como Ossian se beneficiaria do imenso prestígio outorgado pelo qualificativo "épico" se a conformação de sua criação poética era derivada exclusivamente de fatores circunstanciais? Ou ainda: seria possível apresentar Fingal e Temora como composições sem paralelo na tradição ocidental e, ao mesmo tempo, argumentar que mereciam a mesma reverência devotada aos escritos que figuram no centro dessa tradição? ${ }^{331}$

Obviamente, não havia um roteiro de elementos imprescindíveis para a composição de um épico primitivo. A suposição de que um gênio como o de Homero pudesse ser tutelado por convenções é completamente estranha à argumentação de

\footnotetext{
329 "The poem which stands first in the collection is truly epic. The characters are strongly marked, and the sentiments breathe heroism" (MACPHERSON, James. "A dissertation". The poems of Ossian and related works cit., p. 419, nota 53).

${ }^{330}$ Conforme definição feita páginas atrás, épico é adjetivo que significa "relativo à epopeia", o produto de um fabricador de narrativas em versos. Poema heroico, por sua vez, é uma definição derivada do conteúdo (MADELÉNAT, Daniel. L'épopée cit., p. 17-18).

${ }^{331}$ Sobre a perda de parâmetros críticos decorrente da abordagem blackwelliana, ver FOERSTER, Donald M. The fortunes of epic poetry cit., p. 34.
} 
Thomas Blackwell. Macpherson teve de buscar sozinho ${ }^{332}$ uma transcriação formal para a dita poética primitivista. Nessa operação, parece-me claro que o tradutor de Ossian se defrontou com complicadores que uma abordagem teórica tem grandes chances de mascarar. O método blackwelliano removia os alicerces sobre os quais o neoclassicismo conceitua gêneros literários. Seu historicismo, contudo, não o levou a questionar a validade, a pertinência ou até mesmo o valor dessa abstração chamada poema épico. ${ }^{333}$ Com efeito, no Enquiry por vezes se descola a forma de seu substrato histórico. Fala-se, por exemplo, de uma linhagem de quase três milênios para a epopeia. ${ }^{334}$ Homero seria uma espécie de primus inter pares: o indiscutível fundador de um sistema literário, mas, ainda assim, ligado a seus epígonos pelo cultivo de uma mesma forma poética. Nem mesmo Hurd, que apontava o equívoco de se comparar Milton a Spenser, deixava de emprestar ao termo "épico" uma conotação simultaneamente concreta e universal. ${ }^{335}$ Embora rejeite definir o gênero a partir da Ilíada e da Eneida, seria errôneo dizer que tomasse a epopeia como um conceito vazio. Pelo contrário: empenha-se em revalorizar esse conceito, por meio da dilatação da terminologia neoclássica, para que pudesse englobar composições "góticas", como as de Spenser.

Ao contrário dos poetas estudados por Hurd e Blackwell, Ossian não era um nome que circulava há muito tempo, coisa que, segundo o próprio Macpherson, ${ }^{336}$ tende a extrair concessões até mesmo dos juízes mais severos. Para o bardo celta, não se poderia contar com a deferência reservada a gente como Spenser, cuja Faerie Queene comandava reverência inclusive em expoentes do neoclassicismo, que, no mais, deploravam sua narrativa difusa. O próprio Thomas Rymer, talvez o mais

\footnotetext{
${ }^{332}$ Macpherson obviamente não foi o primeiro a tentar configurar literariamente uma voz primitiva. De seus predecessores, Thomas Gray, com The bard (1757), talvez seja o nome mais notório. Entretanto, nem Gray nem qualquer outro legou uma receita da qual eventuais epígonos pudessem se beneficiar.

${ }^{333}$ Para Foerster, o relativismo e a inclusividade dos ditos primitivistas matam ou anulam os elementos definidores do gênero épico, sem que, no entanto, abalassem seu imenso prestígio, porquanto o público costumava enxergá-lo pelas lentes do neoclassicismo (FOERSTER, Donald M. The fortunes of epic poetry cit., p. 15).

${ }^{334}$ BLACKWELL, Thomas. An enquiry into the life and writings of Homer cit., p. 2. Citamos o trecho páginas atrás (ver supra, p. 55).

${ }^{335}$ FOERSTER, Donald M. The fortunes of epic poetry cit., p. 15.

${ }^{336}$ Ver MACPHERSON, James. "Temora: an epic poem". The poems of Ossian and related works cit., p. 479 , nota 2
} 
acerbo e normativista ${ }^{337}$ dos críticos da Restauração, era pródigo em elogios ao "equivocado" poeta isabelino.

Spenser, penso eu, pode ser considerado o primeiro de nossos poetas heroicos. Ele tinha um largo espírito, um discernimento aguçado e um gênio para poesia heroica provavelmente acima do de qualquer escritor desde Virgílio. Mas o nosso infortúnio é que lhe faltou uma ideia verdadeira - e se perdeu ao seguir um guia infiel. Embora, além de Homero e Virgílio, tenha lido Tasso, permitiu-se ser desencaminhado por Ariosto, com quem, perambulando cegamente por aventuras maravilhosas, não teve quaisquer escrúpulos quanto à probabilidade. ${ }^{338}$

Sem as regras para conduzir sua criação, Spenser seria tratado como um talento desperdiçado. Seguindo exemplos errados, convertera a matéria heroica, que dominava como poucos, numa sucessão de incidentes romanescos. De tal feita, Rymer mostra-se reticente em chamar Faerie Queene de épico ou epopeia. Qualificaa pelo conteúdo, como poema heroico. Embora muito mais flexível que Rymer, Dryden também demonstra um misto de admiração e frustração pelo "colosso informe". Até mesmo especula se, noutras circunstâncias, o autor de Faerie Queene poderia ter composto a grande epopeia inglesa.

[...] a poesia heroica não é nativa da França, como pode ser da Inglaterra, se cultivada. A Spenser faltou apenas ter lido as regras de Bossu, pois jamais houve alguém com um gênio tão grande - ou teve mais conhecimento para sustentá-lo. ${ }^{339}$

Infelizmente para os ingleses, a obra de Spenser antecedia à introdução da poética do aristotelismo moderno. Sem compreender as formas em abstrato, Spenser teria

\footnotetext{
${ }^{337}$ Sobre o método crítico de Rymer, ver: ZIMANSKI, Curt A. (ed.). The critical works of Thomas Rymer. New Haven: Yale - Londres: Geoffrey Cumberlege - Oxford: Oxford University, 1956, p. viili e EADE, J. C. Aristotle anatomised: the Poetics in England, 1674-1781. Oxford - Berna - Berlim Bruxelas - Frankfurt - Nova Iorque - Viena: Peter Lang, 1988, p. 7-28. Além de acerbo e normativista, Rymer poderia ser descrito também como histriônico - ou, para citarmos Leopold Damrosch, como "feroz, mas tolo" ("ferocious but silly") (DAMROSCH JR., Leopold. "The significance of Addison's criticism" cit., p. 422).

338 "Spencer [sic], I think, may be reckon'd the first of our Heroick Poets; he had a large spirit, a sharp judgment, and a Genius for Heroick Poesie, perhaps above any that ever writ since Virgil. But our misfortune is, he wanted a true Idea; and lost himself by following an unfaithful guide. Though besides Homer and Virgil, he had read Tasso, yet he rather suffer'd himself to be misled by Ariosto; with whom blindly rambling on marvellous adventures he makes no Conscience of Probability" (RYMER, Thomas. "Reflections on Aristotle's treatise of poesie. Containing the necessary, rational, and universal rules for epick, dramatick, and the other sorts of poetry. With reflections on the works of the ancient and modern poets and their faults noted by R. Rapin: The preface of the translator". In: ZIMANSKI, Curt A. (ed.). The critical works of Thomas Rymer cit., p. 1-16, especialmente p. 5).

339 " [...] Heroick Poetry is not of the growth of France, as it might be of England, if it were Cultivated. Spencer [sic] wanted only to have read the rules of Bossu: for no Man was ever Born with a greater Genius, or had more Knowledge to support it" (DRYDEN, John. "Dedication of the Æneis". In: KINSLEY, James (ed.). The poems of John Dryden cit., v. 3, p. 1049).
} 
falhado em organizar literariamente a multiplicidade de assuntos que concebera. Resta, então, glorificar o homem e seu potencial poético - e lamentar que tal potencial jamais se tenha realizado plenamente.

Rymer e Dryden tiveram de lidar com um fait accompli. Buscam conciliar uma reputação já consolidada antes da revolução neoclássica. É provável que não fossem tão benevolentes com um estreante, sobretudo um escocês, mesmo que do século III d. C. Diante disso, é possível identificar, dos Fragmentos de poesia antiga até a publicação de Temora an ancient epic poem in eight books, together with several other poems, uma certeza crescente de que só se concederia a palma de poeta épico a Ossian caso seus poemas fossem indubitavelmente chancelados pelo único código então disponível para outorgar tamanha honraria: o neoclássico. ${ }^{340}$

\subsubsection{Fingal}

No "Prefácio" aos Fragmentos, de 1760, escrito por Hugh Blair, solicita-se, por vias oblíquas, "encorajamento" 341 para uma missão nas mesmas terras em que se coletaram as peças ora publicadas. O tradutor afirma haver indícios de "uma obra de extensão considerável, e que merece ser chamada de um poema heroico". ${ }^{342}$ Embora haja uma alusão casual aos "fragmentos [...] desse poema épico", ${ }^{343}$ o enquadramento genérico da nova composição é apenas tateante. Macpherson (ou Blair) silencia sobre sua estrutura nem discorre sobre a natureza de sua ação, se una ou múltipla. Aponta, todavia, seu modo presentacional: "o autor fala de si mesmo como presente na expedição de Fingal". ${ }^{344}$ Como a referência ao heroísmo indica, é ao assunto do poema que Macpherson devota a maior parte de suas energias. Disposto a comprovar a excepcionalidade da narrativa, o tradutor nos fornece uma curiosa paráfrase dessa composição que, em tese, ainda precisava vir à tona:

\footnotetext{
${ }^{340}$ Para Howard Weinbrot, os épicos ossiânicos são muitas vezes familiares e seguramente neoclássicos (WEINBROT, Howard D. Britannia's issue: the rise of British literature from Dryden to Ossian. Cambridge: Cambridge University, 1993, p. 542). Dafydd Moore, por sua vez, afirma que "Ossian palpavelmente não é um "épico neoclássico"” ("Ossian is palpably not a 'neo-classical epic") (MOORE, Dafydd. Enlightenment and romance in James Macpherson The Poems of Ossian cit., p. 29).

${ }^{341}$ Ou seja, dinheiro. Sobre a rapacidade de Macpherson, ver MURPHY, Peter T. "Fool's gold: the Highland treasures of Macpherson's Ossian”. ELH, v. 53, n. 3 (outono, 1986), p. 567-591.

342 "[...] one work of considerable length, and which deserves to be styled an heroic poem" (MACPHERSON, James. "Preface". The poems of Ossian and related works cit., p. 6).

343 "[...] fragments [...] of this Epic poem" (idem, ibidem).

344 " [...] the author speaks of himself as present in the expedition of Fingal" (idem, ibidem)
} 
O assunto é uma invasão da Irlanda por Swarthan, Rei de Lochlyn, que é o nome da Dinamarca na língua ersa. Cuchulaid, o general ou chefe das tribos irlandesas, ao saber da invasão, reúne suas forças; realizam-se conselhos; e lutam-se batalhas. ${ }^{345}$

Em cinco ou seis orações, confere-se qualidade heroica à futura "obra de extensão considerável" com a menção persistente, mas discreta, de caracteres e temas que Le Bossu tomava como ínsitos à epopeia. Entreveem-se eventos momentosos, presididos por personagens ilustres, de alta patente. Invasões instauram um palco de intensa conflagração militar, com que se demanda o máximo das forças dos que detêm consequência política, como reis, chefes e generais. ${ }^{346}$ Ademais, insinua-se uma identidade tópica entre os escritos ossiânicos e os lugares-comuns do gênero épico. Com a promessa de conselhos de guerra, por exemplo, associa-se imediatamente Cuchulaid à linhagem de Agamenon, que deliberava os rumos da guerra de Tróia com Nestor e Ulisses ${ }^{347}$

A diva Aurora, entrementes, já estava a caminho do Olimpo, para que a Zeus e às demais divindades o dia anunciasse, quando Agamémnone ordena aos divinos arautos que chamem para a assembleia os Acaios de soltos cabelos nos ombros. Gritam, sem mora, o pregão; apressados, aqueles concorrem. Primeiramente, o conselho reuniu dos magnânimos velhos junto da nave do sábio Nestor, que reinava nos Pílios. (II, 48-54)

— ou de Satã, que se reunia com os anjos caídos no Pandemônio para tramar vingança contra os céus:

Os arautos alígeros no entanto,

Cumprindo as ordens do infernal monarca,

Ao som pregoam de canoras tubas,

E em préstito pomposo, um grão conselho

Que logo deve em Pandemônio unir-se,

Paços imensos do tirano do Orco. ${ }^{349}$

\footnotetext{
345 "The subject is, an invasion of Ireland by Swarthan [sic] King of Lochlyn [sic]; which is the name of Denmark [sic] in the Erse language. Cuchulaid [sic], the General or Chief of the Irish tribes, upon intelligence of the invasion, assembles his forces; councils are held; and battles fought" (idem, ibidem).

${ }^{346}$ Ver LE BOSSU, René. Traité du poëme épique cit., p. 273-280.

${ }^{347}$ Para uma análise dos conselhos em Fingal à luz dos conselhos da Ilíada, ver BYSVEEN, Josef. Epic tradition and innovation in James Macpherson's Fingal cit., p. 99.

${ }^{348}$ HOMERO. Iliada cit., p. 79. Na versão de Pope: "Now rosie Morn ascends the Court of Jove,/ Lifts up her Light, and opens Day above./ The King dispatch'd his Heralds with Commands/ To range the Camp, and summon all the Bands:/ The gath'ring Hosts the Monarch's Word obey;/ While to the Fleet Atrides bends his way./ In his black Ship the Pylian Prince he found,/ There calls a Senate of the Peers around" (II, 59-67) (POPE, Alexander. The Iliad of Homer cit., v. 1, p. 130).
} 
A vinculação de Ossian aos lugares-comuns da epopeia ocidental deixaria as entrelinhas quando os frutos da missão de Macpherson vieram a lume, em dezembro de $1761,{ }^{350}$ com Fingal, an ancient epic poem in six books, together with several other poems. Preliminarmente, a epígrafe anuncia um contrato genérico diferente daquele proposto pelos Fragmentos. ${ }^{351}$ Antes, havia uma transcrição da Farsália, de Lucano, obra à qual costumeiramente se negava a designação de epopeia. Tida como uma sucessão de passagens sublimes, porém desconexas, a Farsália era usualmente classificada como um poema histórico. ${ }^{352}$ Agora, a epígrafe é da Eneida, de Virgílio, que por séculos e séculos foi lida na Grã-Bretanha como o épico paradigmático. ${ }^{353}$ Quando se começava efetivamente a folhear o volume, saltavam aos olhos intertítulos que emulavam a prática das autoridades do gênero ao qual se queria filiar Fingal. ${ }^{354} \mathrm{~A}$ obra se repartia em "Livros" (Books), como as versões de Chapman e Pope dos poemas homéricos, a tradução de Fairfax da Jerusalém libertada, a Eneida de Dryden e o Paraíso perdido, de Milton. Não havia qualquer traço da sistemática romanesca ou "gótica", como a de Faerie Queene, que, na Grã-Bretanha, ensejava a divisão em "Cantos" (Cantos). ${ }^{355}$ Ademais, o número de "Livros" era sintomático: metade da Eneida e do Paraíso perdido ou um quarto da Ilíada e da Odisseia.

$\mathrm{Na}$ "Dissertação" que abre a coleção, a que aludimos ao final do item 4.2 Poemas heroicos, parafraseia-se "o antigo poema épico em seis livros”. De saída, nota-se que Macpherson não errara quando pedira "encorajamento" para um tour pelos Highlands em busca de uma "obra de extensão considerável". O assunto do poema, conforme se

\footnotetext{
${ }^{349}$ MILTON, John. O paraiso perdido cit., p. 54. No original: "Meanwhile the winged Heralds by command/ Of Sovran power, with awful Ceremony/ And Trumpets' sound throughout the Host proclaim/ A solemn Council forthwith to be held/ At Pandcemonium, the high Capitol/ Of Satan and his Peers" (I, 752-757) (MILTON, John. "Paradise lost". Complete poems and major prose cit., p. 230).

${ }^{350}$ Datada, como dissemos páginas atrás, de 1762 (ver supra, p. 27).

${ }^{351}$ Sobre o uso de epígrafes para se estabelecer um contrato genérico, ver GENETTE, Gérard. Paratextos editoriais cit., p. 143-144. Para Genette, muitas vezes é menos importante o teor da epígrafe que o nome do autor da citação.

${ }^{352}$ QUINT, David. Epic and empire. Princeton, NJ: Princeton University, 1993, p. 134-151. Ver TRAPP, Joseph. Lectures on poetry cit., p. 349.

${ }^{353}$ Cf. QUINT, David. Epic and empire cit., p. 21-46 e MARESCA, Thomas. Epic to novel. Columbus: Ohio State University, 1974, p. 26 e ss.

${ }^{354}$ Sobre os intertítulos, ver GENETTE, Gérard. Paratextos editoriais cit., p. 259-279. Para o uso de intertítulos para identificação genérica na Grã-Bretanha, sobretudo no que concerne à epopeia, ver FOWLER, Alastair. Kinds of literature cit., p. 95-99.

${ }^{355}$ Essas distinções entre "livros" e "cantos" não subsistem em português. Os lusíadas, por exemplo, repartem-se em dez "cantos". Sintomaticamente, a tradução feita por Maria Adelaide Fernandes Prata de Fingal não mantém a sistemática do original: divide o poema em seis "cantos" (OSSIAN. "Fingal. Poema em seis cantos". Trad. Maria Adelaide Fernandes Prata. In: BÄR, Gerald (coord.). Poesias de Ossian cit., p. 171-212).
} 
previra, era mesmo uma invasão da Irlanda por Swaran, rei de Lochlin, "que é o nome da Escandinávia na língua gaélica". ${ }^{356}$ Cuchullin, o comandante das forças irlandesas, reúne suas tropas contra o invasor. Assim, "realizam-se conselhos, lutam-se batalhas". 357

Todo esse aparato paratextual inequivocamente induz à identificação de Fingal com os expoentes máximos do gênero épico. Mas é nas margens que esse processo de identificação opera de maneira mais frutífera e complexa. Nas notas à principal peça da coleção, há, salvo engano, vinte e sete remissões a Ilíada, Eneida e Paraíso perdido. Menciona-se o primeiro poema homérico doze vezes, em todas as seções de Fingal. ${ }^{358}$ A epopeia inglesa viria em segundo lugar, com nove citações, distribuídas ao longo de todo o poema, exceto no "Livro III". ${ }^{359}$ Virgílio, por sua vez, deixa de ser citado em dois "Livros", com uma aparição nos "Livros" I, IV e VI e três no "Livro II". 360

Idealmente, intercala-se a leitura das notas de rodapé à do entrecho ficcional. Estabelece-se uma relação de codeterminação, em que a variação do registro, do autoral para o editorial, pode complicar os sentidos que emergiriam exclusivamente da economia narrativa. ${ }^{361}$ Quase que por uma saturação metonímica, o acúmulo de referências a Homero, Virgílio e Milton sugere que a "obra de extensão considerável [...] mere[ça] ser chamada de um poema heroico". Adotando uma versão avant la lettre do método crítico de Matthew Arnold, o tradutor confronta passagens de Fingal com manifestações prototípicas de uma maneira de escrever, com o escopo, muitas vezes explícito, de mostrar a adequação do bardo celta às técnicas literárias dos expoentes máximos do gênero épico. A pedra de toque canônica resgata Ossian de sua excepcionalidade histórica e poética para avaliá-lo por um metro cuja vigência se presume indiscutível. Detenhamo-nos nas mais ilustrativas ocorrências desse procedimento. No "Livro II", interrompe-se o embate entre Swaran e Cuchullin com a

\footnotetext{
356 "[...] which is the name of Scandinavia in the Galic [sic] language" (MACPHERSON, James. "A dissertation". The poems of Ossian and related works cit., p. 419, nota 53).

357 "[...] councils are held, battles fought" (idem, ibidem).

${ }^{358}$ Quatro vezes no "Livro I", duas no "Livro II", duas no "Livro III", uma no "Livro IV", duas no "Livro V" e uma no Livro "VI".

${ }^{359}$ Haveria três citações no "Livro I", duas no "Livro II", uma no "Livro IV", duas no "Livro V" e uma no "Livro VI". Três dessas citações a Milton cairiam, no entanto, na edição de 1765.

${ }^{360}$ As Geórgicas, de Virgílio, ainda seriam mencionadas duas vezes. Além disso, citam-se a Tebaida, de Estácio, e os cânticos de Salomão.

${ }^{361}$ Sobre a lógica e as relações estabelecidas pelas notas de rodapé, ver GENETTE, Gérard. Paratextos editoriais cit., p. 281-301.
} 
informação de que Virgílio e Milton se valeram de comparações semelhantes àquela que fecha esta passagem:

[...] Swaran avançava como uma corredeira que irrompe do deserto. As pequenas colinas estão revolvidas em seu curso e as rochas, quase submersas às suas margens. Mas Cuchullin se postou diante dele como uma colina que apanha as nuvens do céu. ${ }^{362}$

Indicam-se, então, os antecedentes em que se compara uma personagem a um monte enevoado. Na Eneida, ao se avizinhar a batalha final, o narrador equipara o herói troiano a montanhas da Grécia, Sicília e Itália:

[...] o Atos, o Érix,

Mesmo o Apenino padre, assim bramindo

Folga, e azinhos balança coruscantes

E alteia às auras o nivoso cume.

$(\mathrm{XII}, 677-681)^{363}$

No Paraíso Perdido, Satã torna-se imenso ao deparar-se com as sentinelas do Éden, como as montanhas que, na mitologia, sustentavam os céus:

Assombrado dalém, Satã assume

Quanto possui de brio e de vigor;

Imenso cresce nos sentidos todos,

E firme em pé se tem, assemelhando

De Atlante ou Tenerife a vasta mole.

Sua estatura o firmamento alcança; ${ }^{364}$

A nota editorial, contudo, não é apenas informativa. Numa intervenção em primeira pessoa, pede-se para que o leitor julgue "qual desses dois grandes poetas teve mais êxito". ${ }^{365} \mathrm{O}$ elemento oculto desse cotejo é, obviamente, o tropo geológico presente no Fingal. ${ }^{366}$ Como se dá em toda nota de rodapé, seu espaço discursivo é enquadrado pelo segmento a que se refere. ${ }^{367}$ As cinco montanhas de Enéas e Satã são mediadas

\footnotetext{
362، “...] Swaran advanced, as a stream that bursts from the desart. The little hills are rolled in its course; and the rocks are half-sunk by its side. But Cuchullin stood before him like a hill, that catches the clouds of heaven" (MACPHERSON, James. "Fingal: an epic poem". The poems of Ossian and related works cit., p. 68).

${ }^{363}$ VIRGÍlLIO. Eneida cit., p. 262. Na versão de Dryden: "Like Eryx, or like Athos, great he shows,/ Or Father Apennine, when, white with Snows,/ His Head Divine obscure in Clouds he hides:/ And shakes the sounding Forest on his sides" (XII, 375-379) (VIRGÍLIO. "Virgil's ÆEneis". Trad. John Dryden cit., v. 3, p. 1414).

${ }^{364}$ MILTON, John. O paraíso perdido cit., p. 175. No original: “On th' other side Satan allarm'd/ Collecting all his might dilated stood,/ Like Teneriff or Atlas unremov'd:/ His stature reacht the Sky [...]" (IV, 985-988) (MILTON, John. "Paradise lost". Complete poems and major prose cit., p. 301).

365 "I shall lay both before the reader, and let him judge for himself which of these two great poets have best succeed" (MACPHERSON, James. "Fingal: an epic poem". The poems of Ossian and related works cit., p. 427, nota 41).

${ }^{366}$ Cf. STAFFORD, Fiona J. The sublime savage cit., p. 138.

${ }^{367}$ Cf. GENETTE, Gérard. Paratextos editoriais cit., p. 281 e ss.
} 
(e medidas) pela montanha solitária de Cuchullin. O convite, portanto, é para que se avalie qual dos três poetas "teve mais êxito". Por cuidar de uma figura retórica e dispensar considerações quanto a especificidades históricas, o juízo decorrente dessa avaliação possui como que um selo de objetividade. Insinua-se que, postos os preconceitos de lado, Ossian talvez ombreie com Virgílio e Milton. A régua empregada para mensurar tais realizações, o símile, não era aleatória. Conforme escreveu Addison em sua famosa série de estudos sobre o Paraíso perdido: trata-se do "tipo sublime de entretenimento" que mais se adéqua à natureza de um poema épico. $^{368}$

As intervenções à margem não se satisfazem apenas com colações dedutivas. Algumas das notas assinadas pelo tradutor chegam a pedir diretamente para que se ponderem as realizações de Ossian e as de seus colegas assuntivos. É o caso em que se interpela o leitor para que confronte a conflagração inaugural entre os exércitos de Tura e Lochlin com uma passagem da Ilíada. ${ }^{369}$ Nos excertos fornecidos, evoca-se a violência do combate com recurso a imagens de confusão, em que as partes se tornam um amálgama. Em Fingal, as tropas se convertem em torrentes a escoar uma ao encontro da outra:

Assim como as tempestades sombrias do outono caem de duas colinas ribombantes, rumo ao outro precipitaram-se os heróis. Como duas corredeiras sombrias de altas rochas se encontram, e misturam-se e bramem na planície, sonoras, rudes e sombrias na batalha se encontram Lochlin e Innis-fail. Os chefes batiam-se com os chefes, e os guerreiros com os guerreiros. O aço, a clangorar, ressoava contra o aço. Elmos fendem-se no ar. O sangue irrompe e fumega o redor. ${ }^{370}$

$\mathrm{Na}$ Ilíada, as armas dos esquadrões se fundem para verter uma tempestade metálica e banhar o campo de sangue:

lanças e escudos se chocam bem como a coragem dos homens
com armaduras de bronze; broquéis abaulados se chocam
uns contra os outros; estrépito enorme se eleva da pugna.

\footnotetext{
${ }^{368}$ ADDISON, Joseph. "No. 303”. The Spectator cit., v. 2, p. 405-410, especialmente p. 409.

${ }^{369}$ MACPHERSON, James. "Fingal: an epic poem". The poems of Ossian and related works cit., p. 423, nota 77.

370 “As autumn's dark storms pour from two echoing hills, towards each other approached the heroes.-As two dark streams from high rocks meet and mix and roar on the plain; loud, rough and dark in battle meet Lochlin and Inis-fail. Chief mixed his strokes with chief, and man with man; steel, clanging, sounded on steel, helmets are cleft on high. Blood bursts and smoaks around" (MACPHERSON, James. "Fingal: an epic poem". The poems of Ossian and related works cit., p. 59). De acordo o OED, "man" pode designar os membros de uma força de militar. Tendo isso em mente, traduzi "man" como "guerreiro". Consultei: OSSIAN. "Fingal. Poema em seis cantos" cit., p. 176.
} 
Dos vencedores os gritos de júbilo se ouvem e as queixas dos que tombavam vencidos; de sangue se encharca o chão duro. $(\mathrm{IV}, 447-451)^{371}$

O comando direto ao leitor está longe de ser gratuito. Aqui, consiste num apelo tão enfático quanto sutil para que nos atentemos à proximidade entre Fingal e alguns versos especialmente notórios da Ilíada. "[E]xcedidos por nenhum outro em Homero", ${ }^{372}$ esses versos eram saudados por Pope, que os identificava em "feliz imitação" na Thebaida, de Estácio. ${ }^{373}$ Macpherson traz o pano de fundo da fortuna crítica para o primeiro plano - e opera para que o aspecto canônico da citação homérica não passe despercebido. Recuperam-se as palavras de Pope, ao nos lembrar da "feliz imitação" de Estácio, ${ }^{374}$ e ressoa um eco miltônico de imagens de indistinção armada, em que a artilharia infernal e as montanhas arremessadas pelos anjos convergem numa espiral de fogo, que envolve os combatentes:

Com feroz confusão tinem, retinem

Umas contra outras férvidas as armas,

E hórridas rangem das carroças brônzeas

As arrojadas rodas furibundas;

Rechinam as descargas flamejantes

De ígneos dardos que inúmeros cobriam

Todo o Céu co'uma abóbada de fogo. ${ }^{375}$

O encadeamento dos excertos contrapõe a natureza fortuita do contato entre Fingal e a Ilíada à apropriação consciente de Estácio e Milton. Por caminhos próprios, Ossian chegara a um topos persistente na tradição épica. As diferentes trilhas, no entanto, parecem todas levar à conversão da guerra numa entidade que sobrepaira, perpassa e determina a experiência humana - e organiza a narrativa. Nos trechos transcritos acima, a batalha erige uma dimensão à parte, um locus demarcado exclusivamente pelos espólios da contenda. Pelo alto, os estilhaços das armaduras e abóbodas de fogo.

\footnotetext{
${ }^{371}$ HOMERO. Ilíada cit., p. 130. Na versão de Pope: "Now Shield with Shield, with Helmet Helmet clos'd,/ To Armour Armour, Lance to Lance oppos'd,/ Host against Host with shadowy Squadrons drew,/ The sounding Darts in Iron Tempests slew,/ Victors and Vanquish'd join promiscuous Cries,/ And shrilling Shouts and dying Groans arise;/ With streaming Blood the slipp'ry Fields are dy'd,/ And slaughter'd Heroes swell the dreadful Tide" (IV, 508-515) (POPE, Alexander. The Iliad of Homer cit., v. 1, p. 245-246).

372 “[...] excell'd by none other in Homer" (idem, v. 1, p. 245, nota n. 508).

${ }^{373}$ Idem, ibidem.

${ }^{374}$ MACPHERSON, James. "Fingal: an epic poem". The poems of Ossian and related works cit., p. 423, nota 77 .

${ }^{375}$ MILTON, John. O paraíso perdido cit., p. 224. No original: “[...] Arms on Armor clashing bray'd/ Horrible discord, and the madding Wheels/ Of brazen Chariots rag'd; dire was the noise/ Of conflict; over head the dismal hiss/ Of fiery Darts in flaming volleys flew,/ And flying vaulted either host with fire" (VI, 209-214) (MILTON, John. "Paradise lost". Complete poems and major prose cit., p. 328).
} 
Pelos lados, o evolar do sangue e as labaredas. Pelo chão, a maré vermelha. São limites que aprisionam o eu dos três narradores, a inundá-lo de impressões de morte e destruição, por meio da intoxicação de (quase) todos os sentidos. Bramidos, clangores, tinir das armas, gritos de júbilo e alegria se sucedem. Oscila-se da sombra ao brilho das armas e do sangue, que, respectivamente, encobre ou se reflete em superfícies rudes, espadas férvidas ou corpos abaulados.

De Ossian a Milton, essa percepção englobante da guerra tem uma posição privilegiada: eclode na primeira batalha generalizada do poema, ${ }^{376}$ invariavelmente aquela que imprime o teor e a marcha dos eventos por narrar. Tamanha inflexão é marcada na versão poperiana da Ilíada pela inserção de um ensaio de quase doze páginas acerca das batalhas de Homero:

Talvez seja necessário, neste lugar, diante da abertura das batalhas de Homero, fazer algumas observações gerais sobre elas [...], que ensejam um melhor entendimento dessas descrições que perfazem uma parte tão grande do poema. ${ }^{377}$

Para citarmos o próprio Prefácio de Pope à tradução: com esse conflito, teriam início as "descrições de suas [de Homero] batalhas, que ocupam nada menos do que metade da Ilíada". ${ }^{378}$ Institui-se um crescendo, em que "cada batalha supera a anterior em grandiosidade, horror, e confusão". 379

É nesse estado de guerra contínua e total que estão as coordenadas para a configuração plena do herói. Exclui-se a possibilidade de descompasso entre a ação e as personagens, porque estas, na tautológica formulação de Joseph Trapp, ${ }^{380}$ serão sempre compelidas a agir como heróis. Assim como para Aquiles e Jesus, não haveria atividades indignas no horizonte de Fingal. O rei de Morven jamais se veria como Ulisses, na (nunca citada por Macpherson nas notas a Fingal e Temora) Odisseia, forçado a rebaixar-se à condição de pastor. ${ }^{381}$

\footnotetext{
${ }^{376}$ No caso dos poemas homérico e ossiânico, situa-se ao fim do primeiro sexto da obra. Em Fingal, no final do "Livro I" (total de seis "Livros"). Na Ilíada, ao cabo do "Livro IV", de um total de vinte e quatro. O caso do Paraíso perdido é excepcional, pois se trata da única cena de batalha generalizada.

377 "Perhaps it may be necessary in this Place at the Opening of Homer's Battels [sic], to premise some Observations upon them in general [...], that tend to a more distinct understanding of those Descriptions which make so large a Part of the Poem" (POPE, Alexander. The Iliad of Homer cit., v. 1, p. 252).

378 “[...] the Descriptions of his Battels, which take up no less than half the Iliad" (POPE, Alexander. "Preface". The Iliad of Homer cit., v. 1, p. 9).

379 “[...] every Battel rises above the last in Greatness, Horror, and Confusion” (idem, ibidem).

380 TRAPP, Joseph. Lectures on poetry cit., p. 334.

${ }^{381}$ Cf. idem, p. 334-335.
} 
Como se pode perceber, o apontamento de afinidades tópicas entre Fingal e as epopeias canônicas acabava por iluminar - ou melhor: ressignificar - a estruturação do poema ossiânico. Multifacetado, o comentário paratextual muitas vezes condensa em referências coruscantes a codificação do gênero épico. De tal maneira, algumas das identificações metonímicas de lugares-comuns da epopeia operam como metáforas da forma. ${ }^{382}$ É o que se dá com as notas que propõem liames entre Fingal e passagens (tidas como) especialmente sublimes das epopeias de Homero, Virgílio ou Milton, sobretudo aquelas relativas ao sagrado. Até o século XVIII, não era incomum que os britânicos lessem esses épicos como narrativas de uma trajetória de revelação e iluminação, em que fantasmas de antepassados e descidas ao submundo (nekuia) constituíam, em suma, um encontro com o divino. ${ }^{383}$ Ao se entrelaçar Fingal a referências em que, no limite, se ambiciona "Justificar o proceder do Eterno/ E demonstrar a providência aos homens", ${ }^{384}$ institui-se um protocolo para a recepção da composição ossiânica, nos termos da poética de então, como uma obra elevada. ${ }^{385}$ Uma simples glosa miltônica, por exemplo, dá ao último parágrafo do "Livro V" um esteio de solenidade que o próprio universo ficcional não tem condições de configurar. ${ }^{386}$ Ao pedir para que o bardo Carril rememore quadras antigas, sem no entanto mencionar a estória de Everallin, o Ossian-personagem acaba por conjurar os fantasmas dos Highlands:

Não tragas, Carril, respondi, sua memória à minha mente. Minha alma há de se despedaçar diante da lembrança. Meus olhos haverão de ter suas lágrimas. Pálida na terra ela está, a corada e formosa senhora de meu amor. Mas senta-te na charneca, ó Bardo, e escutemos a tua voz. É agradável como vento da primavera que

\footnotetext{
${ }^{382}$ A analogia é de Peter Brooks. Valendo-se do binômio de Jakobson, afirma que lemos os incidentes da narrativa como promessas e anunciações de uma coerência final, uma metáfora obtida por uma cadeia de metonímias (BROOKS, Peter. Reading for the plot: design and intention in narrative. Nova Iorque: Alfred A. Knopf, 1984, p. 94).

${ }^{383}$ Cf. MARESCA, Thomas E. Epic to novel cit, p. 29-49.

${ }^{384}$ MILTON, John. O paraíso perdido cit., p. 22. No original: "I may assert Eternal providence,/ And justify the ways of God to man" (I, 24-25) (MILTON, John. "Paradise lost". Complete poems and major prose cit., p. 212). Em alguns círculos religiosos, tomava-se o Paraíso perdido como complementar à Bíblia (ver FOERSTER, Donald M. The fortunes of epic poetry cit., p. 102).

${ }^{385}$ A introdução de elementos religiosos na poesia era vista por Dennis como a única maneira de a literatura dos modernos se equiparar à dos antigos (DENNIS, John. "The advancement and reformation of modern poetry". In: HOOKER, Edward Niles (ed.). The critical works of John Dennis cit., v. 1, p. 197-278, especialmente p. 207 e ss.

${ }^{386}$ Para a nostalgia do divino no Paraíso perdido, ver STAFFORD, Fiona. The last of the race cit., p. $12-33$.
} 
suspira no ouvido do caçador, quando ele desperta de sonhos de alegria ao ouvir a música dos espíritos da colina. ${ }^{387}$

Sem a nota, a canção vernal dos "espíritos da colina" nada mais seria que uma referência mais ou menos en passant ao sobrenatural. Evocando a música dos anjos caídos, os versos miltônicos revestem o canto que ulula nas Terras Altas de uma nostalgia do divino, que, a rigor, não está no vento que "suspira no ouvido do caçador":

Outros, dotados de índole mais branda,

Em retirado vale silencioso

Cantam, de harpas ao som, com vozes de anjos,

[...] Contudo (e que menor seria o efeito,

Quando imortais espíritos cantavam?!)

A harmonia deixou suspenso o Inferno

E extasiou do concurso a mó imensa. ${ }^{388}$

Quando os espíritos efetivamente descem à terra para conversar com os mortais, o editor de imediato proporciona um enquadramento na tradição. No início do "Livro II", o fantasma de Crugal (cuja "túnica é [feita] das nuvens das colinas"), ${ }^{389}$ que fora morto por Swaran, aparece nos sonhos de Connal, um dos chefes irlandeses. Logo na abertura dessa cena, somos mandados para os espectros de Pátroclo e Heitor, que visitaram o sono de seus amigos em, respectivamente, a Ilíada e a Eneida. O parceiro de Aquiles não parece mudado; surge com o mesmo porte e os mesmos trajes que usava enquanto vivia:

aproximou-se-lhe o espectro do mísero Pátroclo, ao morto em tudo igual, na estatura gigante, nos fúlgidos olhos e no agradável da voz; iguais vestes, também, tinha o espectro.

Fica-lhe junto à cabeça e lhe diz as seguintes palavras:

"Dormes, Aquiles [...]?"

(XXIII, 65-69)

\footnotetext{
387 "Bring not, Carril, I replied, bring not her memory to my mind. My soul must melt at the remembrance. My eyes must have their tears. Pale in the earth is she the softly-blushing fair of my love. But sit thou on the heath, O Bard, and let us hear thy voice. It is pleasant as the gale of spring that sighs on the hunter's ear; when he wakens from dreams of joy, and has heard the music of the spirits of the hill" (MACPHERSON, James. "Fingal: an epic poem". The poems of Ossian and related works cit., p. 96).

${ }^{388}$ MILTON, John. O paraíso perdido cit., p. 79. No original: “[...] Others, more mild,/ Retreated in a silent valley, sing/ With notes Angelical [....] the harmony/ (What could it less when Spirits immortal sing?)/ Suspended Hell, and took with ravishment/ The thronging audience [...]" (II, 545-547, 551-554) (MILTON, John. "Paradise lost". Complete poems and major prose cit., p. 245).

389 "[...] his robes are of the clouds of the hill" (MACPHERSON, James. "Fingal: an epic poem". The poems of Ossian and related works cit., p. 65).

${ }^{390}$ HOMERO. Ilíada cit., p. 499. Na versão de Pope: "When lo! the Shade before his closing Eyes/ Of sad Patroclus rose, or seem'd to rise;/ In the same Robe he living wore, he came,/ In Stature, Voice,
} 
O príncipe de Tróia, por seu turno, aparece completamente coberto de poeira e sangue:

Tétrico Heitor em sonhos se me antolha, Debulhando-se em pranto; como outrora, Negro do pó cruento a biga o arrasta, Os loros arrochando os pés tumentes. Ai! quão mudado! aquele Heitor não era Que no espólio volveu do próprio Aquiles, E lançou teucra flama às popas graias.

Pegada a grenha em sangue, a barba esquálida, Crivam-no golpes cem, que junto aos muros Paternos recebeu. [...] $(\text { II, 279-289) })^{391}$

O cruzamento de Fingal com a fantasmagoria clássica liminarmente absolve Ossian de qualquer acusação de crendice ou superstição, sobremodo comuns nessa época tão enamorada da razão. Sob as sombras de Pátroclo e Heitor, Crugal se torna um elemento de maquinaria épica, uma manifestação do maravilhoso, uma parte constitutiva da forma epopeia. Exatamente como nos precedentes de Homero e Virgílio, a aparição celta fala do futuro e exorta seu interlocutor para que aja. Se Pátroclo pede a Aquiles que lhe faça honras fúnebres, e Heitor avisa a Enéas que os gregos se infiltraram em Tróia, Crugal aconselha Connal a desertar o campo de batalha:

Meu espírito, ó Connal, está em minhas colinas nativas, mas meu corpo está nas areias de Ullin. Tu jamais conversarás com Crugal ou encontrarás seus passos solitários na charneca. Estou leve como o vento e me movo como a sombra da neblina. Connal, filho de Colgar, vejo a nuvem negra da morte: ela paira sobre as planícies de Lena. Os filhos da verde Erin tombarão. Arreda-te do campo de fantasmas. - Como a lua escurecida, ele se retirou em meio ao vento sibilante. ${ }^{392}$

and pleasing Look, the same./ The Form familiar hover'd o'er his Head,/ And sleeps Achilles, (thus the Phantom said)" (XXIII, 78-83) (POPE, Alexander. The Iliad of Homer cit., v. 2, p. 490).

${ }^{391}$ VIRGÍlLIO. Eneida cit., p. 63. Na versão de Dryden: "When Hector's Ghost before my sight appears:/ A bloody Shrowd he seem'd, and bath'd in Tears./ Such as he was, when, by Pelides slain,/ Thessalian Coursers drag'd him o're the Plain./ Swoln were his Feet, as when the Thongs were thrust/ Through the bor'd holes, his Body black with dust./ Unlike that Hector, who return'd from toils/ Of War Triumphant, in Eacian Spoils:/ Or him, who made the fainting Greeks retire,/ And launch'd against their Navy Phrygian fire./ His Hair and Beard stood stiffen'd with his gore;/ And all the Wounds he for his Country bore" (II, 352-363) (VIRGÍLIO. "Virgil's Æneis". Trad. John Dryden cit., v. 3, p. 1101).

392 "My ghost, O Connal, is on my native hills; but my corse is on the sands of Ullin. Thou shalt never talk with Crugal, or find his lone steps in the heath. I am light as the blast of Cromla, and I move like the shadow of mist. Connal, son of Colgar, I see the dark cloud of death: it hovers over the plains of Lena. The sons of green Erin shall fall. Remove from the field of ghosts.-Like the darkened moon 
Qualificando-se essa exortação pelo apelo às autoridades, é possível enxergar em Crugal uma figura de prolepse, tão comum nas epopeias ocidentais, ${ }^{393}$ em que os desdobramentos das empreitadas aventurosas são, com a ajuda do sobrenatural, descortinados para os heróis.

Noutros pontos, o diálogo paratextual não somente reinterpreta o sobrenatural ele se presta à sacralização do ostensivamente profano, num expediente que infunde a narrativa ossiânica de simbologia. Obtém-se esse efeito com o entremear de uma fala do rei de Morven com uma pergunta de Adão ao arcanjo Miguel. Após a vitória sobre Swaran, Fingal exorta seu neto Oscar para que aja como os que tombaram: renomados entre os vivos, mas prontos para morrer e terem sua glória celebrada por gerações e gerações de bardos. Sua ferocidade é o que os distinguia na batalha. No entanto, Fingal se lembra de Ryno, o mais jovem de seus filhos, que acabara de morrer. Compara-o a um arco-íris:

[...] calmo era Ryno nos dias de paz. Era como o arco da chuva, visto de longe, sobre o riacho, quando o sol se põe em Mora e [há] silêncio na colina do cervo. Descansa, ó Ryno, o mais jovem de meus filhos, em Lena. ${ }^{394}$

Somos remetidos, então, ao penúltimo "Livro" do Paraíso perdido. Expulso do Éden, porém agraciado com uma visão do futuro da humanidade, Adão pergunta ao arcanjo qual a finalidade das "listradas cores" que, depois do Dilúvio, passariam a riscar o céu:

[...] arco se debuxa amplo e formoso

Com três listradas cores refulgente.

[...] que indicam as listradas cores

Que, pelo Céu arqueadas, mostram visos

Dos sobrolhos do Eterno serenado?

Servirão elas de festão florido

Que as abas feche das aquosas nuvens

he retired, in the midst of the whistling blast" (MACPHERSON, James. "Fingal: an epic poem". The poems of Ossian and related works cit., p. 65).

${ }^{393}$ Cf. BOWRA, C. M. From Virgil to Milton cit., p. 16-17 e QUINT, David. Epic and empire cit., p. 135. Ver também MITCHELL, Sebastian. "Macpherson, Ossian, and Homer's Iliad". In: BÄR, Gerald; GASKILL, Howard (ed.). Ossian and national epic. Oxford - Berna - Berlim - Bruxelas Frankfurt - Nova Iorque - Viena: Peter Lang, 2012, p. 55-71, especialmente p. 56.

394 “ [...] calm was Ryno in the days of peace. He was like the bow of the shower seen far distant on the stream; when the sun is setting on Mora, and silence on the hill of deer. Rest, youngest of my sons, rest, O Ryno, on Lena" (MACPHERSON, James. "Fingal: an epic poem". The poems of Ossian and related works cit., p. 95). 
Para não ser de novo o Mundo imerso? ${ }^{395}$

A resposta de Miguel está calcada no ensinamento bíblico de que o arco-íris simboliza a promessa divina de que o mar, a chuva e as águas subterrâneas "nunca jamais alagarão o mundo" outra vez. ${ }^{396}$ Com toda essa carga religiosa, de uma aliança inquebrantável entre Deus e o homem, a citação a Milton põe Fingal à parte das convenções literárias setecentistas. Por meio do prisma newtoniano, o arco-íris ganhara o século XVIII como o topos de uma natureza desencantada, decomponível em linguagem cientificista. ${ }^{397}$ Diversas obras se referem à excitação e à surpresa de olhar para o céu e, pela primeira vez, enxergar as cores apenas como refração da luz, dando adeus a milênios de interpretações sacralizadas. Em The pleasures of imagination (1744), Mark Akenside didaticamente recria essa sensação ao cadenciar o estilo árido dos tratados científicos nos números do verso branco miltônico:

Brilharam para mim tão deleitosos

Os tons vernais do modulado arco-íris, como quando

A mão da ciência apontou o caminho

Em que os raios solares, brilhando no ocidente,

Precipitam-se numa nuvem d'água, cujo véu sombrio

Envolve o oriente; e aquele feixe intermitente,

A trespassar cada cristalino convexo

Das multidões de gotas de orvalho que ao seu trajeto se opõem,

Ao fim reflui onde a concavidade atrás

Da superfície interna de cada orbe vítreo

Repele seu avanço direto pelo $\mathrm{ar}^{398}$

${ }^{395}$ MILTON, John. O paraíso perdido cit., p. 441. No original: “[...] a Bow/ Conspicuous with three lifted colors gay, $[\ldots] / /[\ldots]$ what mean those color'd streaks in Heav'n/ Distended as the Brow of God appeas'd/ Or serve they as a flow'ry verge to bind/ The fluid skirts of that same wat'ry Cloud" (XI, 865-866 e 879-883) (MILTON, John. "Paradise lost". Complete poems and major prose cit., p. 453).

${ }^{396}$ MILTON, John. O paraíso perdido cit., p. 442.

${ }^{397}$ Sobre o lugar do arco-íris na poesia de língua inglesa no século XVIII, acompanhamos de muito perto a argumentação de EPSTEIN, Julia L.; GREENBERG, Mark L. "Decomposing Newton's Rainbow". Journal of the History of Ideas, v. 45, n. 1 (janeiro - março, 1984), p. 115-140, especialmente p. 122 e 124.

398 “'...] Nor ever yet/ The melting rainbow's vernal-tinctur'd hues/ To me have shown so pleasing, as when first/ The hand of science pointed out the path/ In which the sun-beams gleaming from the west/ Fall on the watry cloud, whose darksome veil/ Involves the orient; and that trickling show'r/ Piercing thro' ev'ry crystalline convex/ Of clustering dew-drops to their flight oppos'd,/ Recoil at length where concave all behind/ Th' internal surface of each glassy orb/ Repels their forward passage into air" (II, 103-114) (AKENSIDE, Mark. "The pleasures of imagination". The poetical works of Mark Akenside. Ed. Robin Dix. Cranbury, NJ - Londres - Mississauga, ON: Associated University Presses, 1996, p. 114). Como se pode notar, sinesteticamente se representa a luz de maneira aquosa, como uma "chuva gotejante" (trickling shower), que reflui (recoil) ao passar por uma superfície convexa. Quando possível, mantive essas imagens em minha tradução. Noutros pontos, deixei-as de lado. Ainda: ancorado no $O E D$ (melting, ppl. a., 1c), traduzi "melting" por "modulado". Em minha solução, contudo, perde-se ambivalência do termo original, derivado do verbo to melt, derreter. Assim como no caso da luz, o arco-íris de Akenside tem algo de líquido. 
E é possível encontrar alusões à óptica newtoniana até mesmo em pastorais, pertencentes a um gênero em que, por convenção, o sujeito poético retroage a um estado de simplicidade idealizada. Talvez a mais notória das pastorais setecentistas, The seasons $(1730,1744,1746)$, do escocês James Thomson, integra à anunciação celeste da primavera o vocabulário das ciências naturais. Outrora o símbolo máximo de um tempo cíclico, ${ }^{399}$ o arco-íris agora traduz o início de uma nova era, de razão e entendimento. Doravante, o "olho instruído pelo sábio" Newton reconhece o desdobrar "refratado" de cada cor, do vermelho ao violeta, no "emaranhado de luz" do "arco etéreo":

[...] Refratado da distante nuvem oriental,

Montando a terra, o grande arco etéreo Irrompe imenso; e cada tom se desdobra, Em justa proporção, indo do vermelho Até onde o violeta se esmaece no céu. Aqui, venerável Newton, as nuvens liquefeitas Formam, defrontando-se ao sol, teu prisma irradiante;

$\mathrm{E}$, ao olho instruído pelo sábio, descortina

$\mathrm{O}$ variegado emaranhado de luz, por ti revelado

Na misturada cor branca. $[\ldots]^{400}$

Supostamente escrito duzentos e poucos anos depois de Cristo, Fingal não teria como partilhar do entusiasmo dos contemporâneos de Macpherson pela física do "venerável Newton". Com efeito, a narrativa ossiânica claramente se socorre de fantasmas, espíritos e outras entidades que escapam à observação científica. Ao amarrar a religiosidade miltônica a Fingal, busca-se assegurar que o cético público setecentista leia os eventos numa chave sublime. A explicação mecânica dos fatos embute o risco de deflacionar relações humanas e naturais, de cuja representação magnificada depende o épico para se constituir como o mais elevado dos gêneros literários. ${ }^{401}$ Trata-se de um perigo que o próprio Paraíso perdido tematiza, no "Livro VIII". 402 Tão logo Rafael termina seu relato sobre a origem da Terra, Adão afirma que

\footnotetext{
${ }^{399}$ FRYE, Northrop. Anatomy of criticism. Londres: Penguin, 1990, p. 163 e ss.

400 " [...] refracted from yon eastern cloud,/ Bestriding earth, the grand ethereal bow/ Shoots up immense; and every hue unfolds,/ In fair proportion running from the red/ To where the violet fades into the sky./ Here, awful Newton, the dissolving clouds/ Form, fronting on the sun, thy showery prism;/ And to the sage-instructed eye unfold/ The various twine of light, by thee disclosed/ From the white mingling maze. [...]" (THOMSON, James. "The seasons". The seasons and The castle of indolence. Ed. James Sambrook. Oxford: Clarendon, 1972, p. 8-9).

${ }^{401}$ HEGEL, Georg Wilhelm. Cursos de estética cit., v. 4, p. 145.

${ }^{402}$ Para uma leitura que busca reconsiderar o dito reacionarismo científico de Milton, ver MARTIN, Catherine Gimelli. “'What if the sun be centre to the world?': Milton's epistemology, cosmology, and Paradise of Fools reconsidered". Modern Philology, v. 99, n. 2 (novembro, 2001), p. 231-265 e GILLIES, John. "Space and place in Paradise lost". ELH, v. 74, n. 1 (primavera, 2007), p. 27-57.
} 
ainda lhe resta uma dúvida, que o arcanjo poderia resolver. Para o primeiro homem, a Terra parece "um grão, um ponto, um átomo". ${ }^{403}$ Tão insignificante na imensidão do espaço, como poderia esse ponto ser o centro de toda a Criação, em torno do qual tudo revolve? Teria a Providência, sempre tão sábia, feito com que milhões e milhões de corpos percorressem distâncias incalculáveis apenas para prestar homenagem a esta Terra, que nem luz própria tem? Conquanto saúde a ânsia por conhecimento demonstrada por Adão ante o livro da natureza, Rafael não endossa suas especulações copernicanas. Deus não revelou aos homens e aos anjos os segredos de sua arquitetura; prefere que simplesmente a admirem, rindo-se de suas hipóteses. O anjo aconselha, então, para que

Esse oculto problema não te canse:

Deus na altura dos Céus mui bem o entende.

$[\ldots]$

São para ti os Céus muito elevados

Para o que neles possa conheceres:

Sê modesto, coa ciência não te ufanes;

Tua existência e cômodos só busca:

Se outros mundos existem não indagues,

Nem se neles habitam criaturas,

Qual delas seja o grau, estado ou sorte:

Satisfaça-te o quanto, à larga e franco,

Da Terra e do alto Céu te hei revelado. ${ }^{404}$

Se não cabe num épico a representação mecânica do mundo, as notas a Fingal mostram que suas armas e barões assinalados não se esgotam no profano. Indicam, ademais, que Ossian imbrica a política e a guerra em questões fundamentais do sagrado. ${ }^{405}$ Morto em combate, Ryno e seu arco-íris evocariam "a graça” de um "varão perfeito", “[q]ue Deus por ele seu furor aplaca/ Deixando inda viver a humana prole". ${ }^{406}$ Com isso, a trajetória do herói implica oferecer-se em holocausto. O autossacrifício é, todavia, uma promessa de paz e redenção aos que ficam. Como se pode perceber, esse tipo de interpretação atende à teleologia do neoclassicismo, para a

${ }^{403}$ MILTON, John. O paraíso perdido cit., p. 285.

${ }^{404}$ MILTON, John. O paraíso perdido cit., p. 290. No original: "Solicit not thy thoughts with matters hid, /Leave them to God above; [...]/ [...] Heav'n is for thee too high/ To know what passes there; be lowly wise:/ Think only what concerns thee and thy being;/ Dream not of other Worlds, what Creatures there/ Live, in what state, condition or degree,/ Contented that thus far hath been reveal'd/ Not of Earth only but of highest Heav'n" (VIII, 167-168, 172-178) (MILTON, John. "Paradise lost". Complete poems and major prose cit., p. 367). Lembre-se que Milton conheceu Galileu pessoalmente, e chegou a homenageá-lo num símile do "Livro I" do Paraíso perdido.

${ }^{405}$ Deliberadamente, valho-me das categorias e dos termos mobilizados por Davenant em seu prefácio ao Gondibert, endereçado a Thomas Hobbes (ver DAVENANT, William. "Preface to Gondibert" cit., p. 35-44).

${ }^{406}$ MILTON, John. O paraíso perdido cit., p. 442. 
qual a literatura dita séria necessariamente comunica ensinamentos que podem ser parafraseados numa prosa expositiva. ${ }^{407}$ Com essa moldura platônico-horaciana, reverte-se em grande medida o impulso de identificar cada nota editorial de contextualização histórica como uma intervenção de corte blackwelliano. Sem o diálogo paratextual com o cânone, fiando-se apenas aos índices primitivistas, a nota a esta passagem -

Chora sobre a rocha dos ventos ensurdecedores, ó donzela de Inistore! Verga tua bela cabeça sobre as vagas, tu que és mais bela que o espírito das colinas, quando se move num raio de sol pelo silêncio de Morven. Ele tombou! Pálido, teu amado jaz sob a espada de Cuchullin. Não mais a coragem incitará o rapaz a enfrentar o sangue real. - Trenar, o amável Trenar morreu, ó donzela de Inistore! Seus cães uivam em casa e veem seu fantasma transitório. Seu arco está distendido no salão. Não há som na charneca de suas corças. $^{408}$

- seria facilmente lida como uma reiteração da contiguidade entre o ambiente e a criação poética ossiânica. Afinal, afirma-se que Ossian e seus contemporâneos acreditavam que, com a morte, as almas dos heróis regressassem para as colinas de sua terra e para as paisagens que visitavam nos dias mais felizes de sua vida. Cães e cavalos, dizia-se, podiam enxergar fantasmas. ${ }^{409} \mathrm{~A}$ menção a espectros, sob esta chave, tratar-se-ia meramente do registro espontâneo e irrefletido de uma crença: um dado sociocultural, cuja repercussão estética teria interessado mais ao leitor setecentista que ao próprio autor. A glosa editorial em análise, no entanto, opera claramente de maneira diversa quando inserta num sistema de referências em que o gênero épico e a doutrinação metafísica se confundem. A apóstrofe à donzela de Inistore e as imagens de xamanismo canino agora avultam carregadas de ensinamentos sobre o destino dos mortos. De curiosidade antropológica, a alusão a

\footnotetext{
${ }^{407}$ Para uma discussão sobre o que se entende por "literatura séria", ver: FRYE, Northrop. The secular scripture: a study of the structure of romance. Cambridge, MA - Londres: Harvard University, 1976 , p. 24 e ss.

408 "Weep on the rocks of roaring winds, O maid of Inistore, bend thy fair head over the waves, thou fairer than the spirit of the hills; when it moves in a sun-beam at noon over the silence of Morven. He is fallen! thy youth is low; pale beneath the sword of Cuchullin. No more shall valour raise the youth to match the blood of kings. — Trenar, lovely Trenar died, thou maid of Inistore. His gray dogs are howling at home, and see his passing ghost. His bow is in the hall unstrung. No sound is in the heath of his hinds" (MACPHERSON, James. "Fingal: an epic poem". The poems of Ossian and related works cit., p. 60). Traduzi o termo "youth" por "amado". Embora a tradução seja imprecisa, as alternativas literais - moço, rapaz, jovem, efebo ou mancebo - tampouco me pareceram satisfatórias. Nenhuma delas me soa idiomática na notícia da morte de uma pessoa amada. Outra coisa: seguindo o $O E D$ (valour, 1c), traduzi "valour" por "coragem".

${ }^{409}$ Idem, p. 423, nota 84.
} 
espíritos converte-se em articulação consciente de um bardo que enxerga em seu ofício uma finalidade bastante específica.

Não é preciso muito esforço para demonstrar a incompatibilidade das interpretações arroladas acima. Uma delas, como discutido páginas atrás, põe em xeque o status ficcional da narrativa ossiânica, tomando-a como "a história genuína da expedição de Fingal, embelezada pela poesia". ${ }^{410}$ Pressupõe que a criação literária é, repitamos, moldada por forças e circunstâncias alheias à vontade do poeta. Seu gênio, porque natural, tão somente canalizaria, sem falseamento ou modificação, os impulsos da Fortuna, cantando o que vê e sente, nas exageradas cores em que apreende o mundo. Por essas lentes, fábula se torna uma palavra proscrita, uma categoria inservível à análise de Fingal. No "Prefácio" ao poema, fábula, sintomaticamente, é tratada como sinônimo de mentira, algo em que Ossian seria incapaz de incorrer. Verdade, aqui, presume a comunicação fiel e não mediada de uma maneira contingente - porque historicamente determinada - de perceber e reagir ao entorno.

Uma obra cujo propósito é ensinar enquanto deleita possui pontos cardeais estranhos à poética primitivista. Em primeiro lugar, requer-se o reconhecimento de uma terceira variável, o leitor. ${ }^{411}$ No método de Blackwell, praticamente só há lugar para a relação do texto com a realidade e com o autor, o qual se identifica com o sujeito poético. Quando categorias como conveniência e utilidade são levadas em conta, enfatizando-se a dimensão pragmática da obra, o foco se desloca do emissor para o receptor. No caso de Ossian, promove-se, no limite, um deslocamento de quinze séculos, em que breviários sobre a cultura e a sociedade dos antigos são empacotados como lições ao público setecentista. Ao se tomar a literatura como uma espécie de magistério, transmissão e cognição da verdade tornam-se elementos nucleares da forma. A verdade na literatura, portanto, seria diferente daquela na historiografia. ${ }^{412}$ Os escritores se valem de um expediente de duplicação alegórica, ${ }^{413}$

\footnotetext{
410 “[...] the genuine history of Fingal's expedition, embellished by poetry" (MACPHERSON, James. "Preface to $1^{\text {st }}$ edition of Fingal". The poems of Ossian and related works cit., p. 37).

${ }^{411}$ Ver BRAY, René. La formation de la doctrine classique en France cit., p. 99 e ss.

${ }^{412}$ Ver ARISTÓTELES. "Poetics" cit., p. 59-61 e LE BOSSU, René. Traité du poëme épique cit., p. 16.

${ }^{413}$ Doravante, seguiremos de muito perto a leitura de E. M. Ancekewicz das categorias mobilizadas no Traité de Le Bossu (ANCEKEWICZ, E. M. "De la poétisation de l'histoire à la politisation de la poétique: histoire et poésie dans le Traité du poème épique (1675) du Père Le Bossu". MLN, v. 107, n. 4, (setembro, 1992), p. 698-729, especialmente p. 705 e ss.
} 
com que inventam caracteres e eventos para condensar ensinamentos ao leitor, que os apreende mesmo sem se dar conta. Num esquema didático, em que a poesia se torna demasiado próxima da filosofia (Poética, 1451a - 1451b), as lições dos escritores deixariam uma impressão bem mais duradoura que aquela haurida de tediosos tratados de ideias.

Se Fingal engendra a verdade por meio da ficção, designá-lo de "história genuína" resta evidentemente inadequado. ${ }^{414}$ De maneira ainda mais interessante, o século XVIII costumava vislumbrar objetos diferentes para a imitação da narrativa histórica e para a da epopeia. Quando da publicação de Annus Mirabilis, em 1667, Dryden já argumentava que uma narrativa demasiado presa às leis da história não poderia aspirar à condição de epopeia. Trata-se, como no caso da Farsália de Lucano, de um "poema histórico". ${ }^{415}$ Sem dúvida, o relato histórico teria algo de amorfo, porque presumiria atenção precípua àquilo que em inglês se chama de character, as condutas e costumes humanos. Já o agenciamento da verdade por meio da ficção se daria pela fábula, que presumiria a imitação de uma ação. ${ }^{416}$ Nos termos do aristotelismo neoclássico, a ação - entendida aqui como ação una e inteira - daria à obra um plano ou sequência lógica, a ordenar episódios conforme relações de causa e consequência. Seria esse arranjo que tornaria inteligível a representação literária, de molde a permitir que o leitor dela extraísse uma moral, um ensinamento. ${ }^{417}$

Inteligibilidade, unidade e integridade da ação são expressões que condensam um conjunto de procedimentos formais com os quais se configuram relações de necessidade, até uma conclusão que, retrospectivamente, concede coerência e supercodifica a cadeia de eventos narrados. ${ }^{418}$ Dentre esses procedimentos, talvez o mais importante seja a concentração temporal, obtida sobretudo pelo uso da dita ordem artificial, com que se abre a narrativa in medias res e clarifica-se a estória por meio de flashbacks. ${ }^{419}$ A triangulação do presente (das personagens) para passado e,

\footnotetext{
${ }^{414}$ Quaisquer que sejam as dúvidas do pós-estruturalismo quanto ao estatuto da ficção e da historiografia, elas decerto não encontram paralelo entre os teóricos setecentistas da poesia épica.

${ }^{415}$ DRYDEN, John. "Annus Mirabilis: the year of wonders, 1666”. KINSLEY, James (ed.). The poems of John Dryden cit., v. 1, p. 44. Ver também TRAPP, Joseph. Lectures on poetry cit., p. 349.

${ }^{416}$ LE BOSSU, René. Traité du poëme épique cit., p. 131-132.

${ }^{417}$ BRAY, René. La formation de la doctrine classique en France cit., p. 74 e ss. e LE BOSSU, René. Traité du poëme épique cit., p. 131-132.

${ }^{418}$ Para os procedimentos formais que caracterizam a voz épica, sobretudo na literatura de língua inglesa, ver DELASANTA, Rodney. The epic voice cit., p. 11-36. Nossa discussão também é informada pelas categorias apresentadas em BROOKS, Peter. Reading for the plot cit., p. 94.

${ }^{419}$ DELASANTA, Rodney. The epic voice cit., p. 29-36.
} 
depois, de volta para o presente estabelece uma hierarquia. $\mathrm{O}$ acontecimento pretérito, pela maneira como é apresentado, é esvaziado de autonomia, porquanto qualificado e valorado pelo que veio depois. Paralelamente a isso, teleologiza-se o presente com anunciações e profecias, verbalizadas por caracteres sobrenaturais ou que transitam pelo sobrenatural. Explicitam-se, com todas essas idas e vindas, os elos do destino e, no nível hermenêutico, possibilita-se a paráfrase, o recapitular sem hiatos da estória, com que se descortinaria seu sentido profundo. ${ }^{420}$

Temia-se que, sem esse controle formal, o herói parecesse seguir ao sabor das contingências e o leitor não conseguisse enxergar o propósito das múltiplas aventuras. O épico resvalaria no romanesco, sem instrução para oferecer, apenas entretenimento ou efusões retóricas. ${ }^{421}$ Em última instância, a maioria das epopeias canônicas nada representa senão o processo de aquisição - ou melhor, tomada - desse controle. Em Eneida, Os lusiadas, Jerusalém libertada e Paraíso perdido, o triunfo do herói é, sobretudo, uma vitória sobre os caprichos da Fortuna. Ao final, vencem-se as circunstâncias adversas e a comunidade do herói realiza uma dupla conquista: sobre os derrotados e sobre o próprio tempo. Sua vitória lhe dá poder para reinterpretar o passado e outorga-lhe domínio sobre o futuro. ${ }^{422}$

Realiza-se essa conquista de maneira fundamental (e, por isso, exemplar) na Eneida, de Virgílio. ${ }^{423}$ Nos primeiros seis "Livros", Enéas e os troianos erram pelos mares, em sucessivas e infrutíferas tentativas de restabelecer seu reino. Há, portanto, um padrão romanesco de narrativa, em que o fim é sempre postergado por aventuras sem propósito. ${ }^{424} \mathrm{O}$ modelo se encontra obviamente na Odisseia, em que Ulisses é obrigado a navegar sem rumo por dez longos anos até finalmente aportar em Ítaca. ${ }^{425}$ Só quando Enéas aceita os mandamentos do Destino e conduz seu povo para a Itália é que se rompe com o paradigma da repetição. Deixa-se o vagar das águas para trás e

\footnotetext{
${ }^{420}$ Ver ANCEKEWICZ, E. M. "De la poétisation de l'histoire à la politisation de la poétique” cit., p. 704.

${ }^{421}$ Ver QUINT, David. Epic and empire cit., p. 9 e FRYE, Northrop. The secular scripture cit., p. 5 e ss.

${ }^{422}$ QUINT, David. Epic and empire cit., p. 30 e ss. Nas próximas páginas, seguiremos de perto o argumento de Quint.

${ }^{423}$ Idem, p. 21-46.

${ }^{424}$ Idem, p. 9 e 50.

${ }^{425}$ Para Northrop Frye, pode-se definir a Odisseia uma história romanesca de um herói que, após escapar milagrosamente de uma série incrível de perigos, consegue chegar na undécima hora para reclamar a noiva e surpreender os vilões (FRYE, Northrop. Anatomy of criticism cit., p. 319).
} 
parte-se para a conquista militar. Enéas inequivocamente assume as rédeas de sua trajetória e caminha, portanto, da Odisseia para a Ilíada. ${ }^{426}$

Na economia da Eneida, a partida com a circularidade da História se dá em termos imperiais. Enquanto os troianos se veem como uma nação vencida, sua experiência é destituída de linearidade, tanto que o sábio Nautes exorta para que "[d]a fortuna aos vaivéns nos resignemos" $(\mathrm{V}, 731) .{ }^{427}$ Contudo, a vitória na Itália elimina o imponderável e investe seus feitos de finalidade. Os descendentes de Enéas não se limitarão a conquistar um espaço tão vasto quanto a distância entre leste e oeste, ${ }^{428}$ mas domarão também o próprio tempo. O Júpiter de Virgílio concede aos romanos um domínio eterno:

Rômulo há de erigir mavórcios muros

E à recebida gente impor seu nome.

Metas nem tempos aos de Roma assino;

O império dei sem fim. [...]

$(\mathrm{I}, 292-295)^{429}$

N'Os lusíadas, a sobreposição ao acaso enfeixa-se na figura de Tétis, deusa do mar. É a ela que Adamastor, entidade que parece extraída dos romanzi de Boiardo e Ariosto, vota inutilmente a sua paixão. Ao ser associado ao romanesco, o mar, portanto, evoca o esforço cíclico e baldado. Cabe a Vasco da Gama subjugar seus caprichos, conforme deixa claro o episódio da Ilha dos Amores: afinal, é Tétis quem faz as "deleitosas honras" ao capitão. As implicações imperiais desse intercurso logo são trazidas à tona. No "Canto Décimo", Tétis miniaturiza o mundo aos olhos de Vasco da Gama, "pera que vejas/ Por onde vás e irás, e o que desejas” (X, LXXIX, 78). ${ }^{430}$ Nomeiam-se, com isso, os locais em que chegarão os portugueses, do Timor à Terra de Santa Cruz, passando pelo Sri Lanka. Sintomaticamente, essa ampla

${ }^{426}$ QUINT, David. Epic and empire cit., p. 50.

${ }^{427}$ VIRGÍLIO. Eneida cit., p. 133.

${ }^{428}$ Parafraseei a fala do Oráculo que prevê a chegada de Enéas ao Lácio: "De fora outros virão que o nosso nome/ Exaltem com seu sangue, e em netos brotem/ A cujos pés se curve e rode quanto/ De um oceano ao outro o Sol perlustra.” (VII, 100-104) (VIRGÍlLIO. Eneida cit., p. 167). Na tradução de Dryden: "A foreign Son upon thy Shore descends,/ Whose Martial Fame from Pole to Pole extends./ His race in Arms, and Arts of Peace renown'd,/ Not Latium shall contain, nor Europe bound:/ 'Tis theirs what e're the Sun surveys around" (VII, 142-146) (VIRGÍLIO. "Virgil's Æneis". Trad. John Dryden cit., v. 3, p. 1237).

${ }^{429}$ VIRGÍLIO. Eneida cit., p. 42. Na versão de Dryden: “Then Romulus his Grandsire's Throne shall gain,/ Of Martial Tow'rs the Founder shall become,/ The people Romans call, the City Rome./ To them, no Bounds of Empire I assign;/ Nor term of Years to their immortal Line" (I, 375-379) (VIRGÍLIO. "Virgil's Æneis". Trad. John Dryden cit., v. 3, p. 1074). Sobre a conquista do tempo, ver QUINT, David. Epic and empire cit., p. 30.

${ }^{430}$ CAMÕES, Luís Vaz de. Os lusíadas. Ed. Antônio Soares Amora et al. Belo Horizonte: Itatiaia São Paulo: Universidade de São de Paulo, 1980, p. 377. 
cartografia imperial é acompanhada também pela promessa de domínio através das eras:
Vês corre a costa célebre indiana
Pera o sul, até o cabo Comori,
Já chamado Cori, que Taprobana
(Que ora é Ceilão) defronte tem de si.
Por este mar a gente lusitana,
Que com armas virá despois de ti,
Terá vitórias, terras, e cidades,
Nas quais hão de viver muitas idades.
$(\mathrm{X}, \mathrm{CVII})^{431}$

Na Jerusalém libertada, obtém-se a linearidade com o resgate de Rinaldo do bosque da feiticeira Armida. O cavaleiro dirige-se a esse locus amoenus, tão semelhante à Ilha de Calipso, após renunciar ao projeto cruzado-missionário, sob o comando de Godofredo de Bulhão, e decidir trilhar seu próprio caminho. Com tal movimento, abandona-se a empreitada épica, de conquista temporal e secular, em prol da descontinuidade romanesca. Carlo e Ubaldo incumbem-se de trazer Rinaldo de volta ao seu destino. Simboliza-se essa passagem da contingência à teleologia pela jornada dos cavaleiros. Seu barco é guiado por uma donzela, símbolo da volúvel Fortuna:

Donde logo descobrem na água pura Uma barquinha, e junto à popa dela A que os há de levar fatal donzela.

$\mathrm{O}$ rosto the compõe basto cabelo; No doce olhar a mansidão lhe mora; É seu semblante como de anjo belo, Tanta luz de si deita abrasadora. Já cerúleo o vestido crereis vê-lo, Já rubro; de mil modos se colora; De sorte que se muda e se transtorna Em cada vez que a examinar-se torna.

Tal a coleira que, da pomba amante $O$ pescoço gentil enfeita e cinge, Nunca se mostra ao que era semelhante, $\mathrm{E}$ ao dar-lhe o sol de vária cor se tinge; Qual colar de rubins ora é brilhante; Ora no verde as esmeraldas finge, Ora as cores mistura; e assim com tanta Inconstância aprazível nos encanta. $(\mathrm{XV}, \mathrm{III}-\mathrm{V})^{432}$

\footnotetext{
${ }^{431}$ Idem, p. 386. Ver, por tudo, QUINT, David. Epic and empire cit., p. 99-125, especialmente p. $118-119$.
} 
Sua "inconstância aprazível" representa os perigos daqueles que dão as costas aos desígnios da religião. Entretanto, quando se investido de propósitos maiores, superam-se as artimanhas da donzela, e a Fortuna se converte em instrumento da Providência. Uma fala da própria Fortuna, ao tratar dos perigos do Atlântico, tematiza a necessidade de se escolher entre navegar sem rumo ou seguir o rumo traçado pela religião. Ela diz que o mar além das Colunas de Hércules (estreito de Gibraltar) é o túmulo de heróis como Ulisses, presas dos ventos e das tempestades. A transposição desses fenômenos só teria sido alcançada por um evangelizador, Colombo, cuja glória é imorredoura:

Colombo, tu do mundo a nova parte

Conduzirás tão longe a feliz vela, Que a fama de asas mil acompanhar-te

Só poderá co'os olhos. Cante ela

Embora Alcides, Baco; para honrar-te

Basta esboçar a tua ação tão bela,

Porque esse esboço valerá memória,

De um poema digníssima e da história.

$(\mathrm{XV}, \mathrm{XXXII})^{433}$

No Paraíso perdido, a graça divina põe termo ao ciclo interminável de contradições morais e religiosas. Banido do Éden, o primeiro casal passaria a viver num mundo de constante e insuperável sofrimento. $O$ padrão repetitivo e incontornável desse sofrimento se articula no paralelismo da sentença que Deus impõe a Adão:

Por causa tua a terra está maldita.

Dela tens de tirar o teu sustento,

${ }^{432}$ TASSO, Torquato. Jerusalém libertada. Trad. José Ramos Coelho. Org. Marco Lucchesi. Rio de Janeiro: Topbooks, 1998, p. 451-452. Na tradução isabelina de Fairfax, o trecho citado fica assim: "And gasing round, a little barke they spide,/ Wherein a damsell sate the stern to guide;// Vpon her front her lockes were curled new,/ Her eies were curteous, full of peace and loue;/ In looke a saint, an Angell bright in shew, So in her visage grace and vertue stroue;/ Her raobe seem'd sometimes red, and sometimes blew,/ And changed still as shee did stirre or moue;/ That looke how oft mans eie beheild the same,/ So oft the colours changed, went and came.// The feathers so (that tender, soft, and plaine,/ About the doues smooth necke close couched beene)/ Doe in one colour neuer long remaine,/ But change their hew, gainst glimse of Phobus sheene;/ And now of rubies bright a vermile chaine,/ Now make a Carknet rich of Emrauldes greene;/ Now mingle both, now alter, turne and change/ To thousand colours, rich, pure, faire, and strange" (XV, III-V) (TASSO, Torquato. Godfrey of Bulloigne. Trad. Edward Fairfax. Ed. Kathleen M. Lea e T. M. Gang. Oxford: Clarendon, 1981, p. 432).

${ }^{433}$ TASSO, Torquato. Jerusalém libertada cit., p. 458. Eis a versão de Fairfax para o trecho citado: "Thy ship (Columbus) shall her canuasse wing/ Spread ore that world that yet concealed lies,/ That scant swift fame her lookes shall after bring,/ Though thousand plumes she haue, and thousand eies;/ Let her of Bacchus and Alcides sing,/ Of thee to future age let this suffies,/ That of thine actes she some forewarning giue,/ Which shall in verse and noble story liue" (XV, XXXII) (TASSO, Torquato. Godfrey of Bulloigne cit., p. 439). Sobre a maneira como lida com a contigência romanesca, a Fortuna e a Providência na Jerusalém libertada, ver QUINT, David. Epic and empire cit., p. 248-253, especialmente p. 252. 
Enquanto vivas, a poder de angústias:

Há de ela produzir-te espinhos, cardos,

E terás que comer do campo as ervas:

Só comerás teu pão quando o ganhares

Co'o suor de tuas faces escorrendo,

- Até que tornes outra vez à terra

De que és feito: conhece a tua origem;

E, pois que és pó, ao pó tornar te incumbe. ${ }^{434}$

Para o primeiro casal, que deixará o Paraíso com "passo errante" (em inglês, "wand'ring steps"), o futuro é completamente destituído de direção e expectativas. ${ }^{435}$

Promete-se, todavia, a superação dessa amarga peregrinação romanesca. Jesus voltará, diz o arcanjo Miguel, e, com ele, haverá a instituição de um novo tempo, em que o futuro regenerado se abre para o infinito:

Nele "a progênie da Mulher" (que dantes

Anunciado te foi entre mistérios

E prometido como teu socorro,

Mas que teu salvador vês hoje às claras)

Torna a descer ao globo, - e no éter amplo,

Todo adornado coa paterna glória,

Vê-lo-ão talhar das trevas o tirano

$\mathrm{E}$ as pervertidas turmas que o seguirem.

Depois, tendo a matéria conflagrada

Obtido a sua prístina pureza,

Dela tem de formar o Nume-Filho

Novos Céus, nova Terra; e infindos tempos,

Que paz, justiça e amor, terão por bases,

Darão de ovante dita eternos frutos. ${ }^{436}$

De Virgílio a Milton, o saneamento da desordem social se traduz em saneamento da narrativa. ${ }^{437}$ Enquanto a ação se encontra, para usarmos uma expressão de Dryden,

${ }^{434}$ MILTON, John. O paraíso perdido cit., p. 368. No original: "Curs'd is the ground for thy sake, thou in sorrow/ Shalt eate thereof all the days of thy Life;/ Thorns also and Thistles it shall bring thee forth/ Unbid, and thou shalt eate th' Herb of the Field,/ In the sweat of thy Face shalt thou eat Bread,/ Till thou return unto the ground, for thou/ Out of the ground wast taken, know thy Birth,/ For dust thou art, and shalt to dust return" (X, 201-208) (MILTON, John. "Paradise lost". Complete poems and major prose cit., p. 411).

${ }^{435}$ Ver STAFFORD, Fiona J. The last of the race cit., p. 13-33, especialmente p. 33.

${ }^{436}$ MILTON, John. O paraiso perdido cit., p. 464-465. No original: "Of him so lately promis'd to thy aid,/ The Woman's seed, obscurely then foretold,/ Now amplier known thy Saviour and thy Lord,/ Last in the Clouds from Heav'n to be reveal'd/ In glory of the Father, to dissolve/ Satan with his perverted World, then raise/ From the conflagrant mass, purg'd and refin'd,/ New Heav'ns, new Earth, Ages of endless date/ Founded in righteousness and peace and love/ To bring forth fruits Joy and eternal Bliss" (XII, 542-551) (MILTON, John. "Paradise lost". Complete poems and major prose cit., 466). Sobre a maneira como Milton combina a narrativa romanesca à narrativa épica no Paraíso perdido, ver QUINT, David. Epic and empire cit., p. 325-340, especialmente p. 340.

${ }^{437}$ Idem, p. 33 e $45-46$. 
"amarrada às leis da História", ${ }^{438}$ ela se perde em episódios desconexos. Contudo, no momento em que a coletividade nacional ou religiosa se liberta do eterno presente e passa a divisar um destino glorioso, essa mesma ação parece investir-se de unidade. Prolepses dão uma dimensão transcendente às circunstâncias imediatas, doravante enredadas numa causa maior, de ampla repercussão através do tempo. ${ }^{439}$ Feitos até então definidos como inúteis tornam-se uma etapa indispensável numa marcha de conquista imperial, seja esse o império dos homens, da Igreja ou até mesmo de Jesus Cristo. Com essa estruturação unitária, a narrativa obtém inteligibilidade ou sentido: converte-se em alegoria. Assim, equipara-se a conquista do porvir à conquista de todos os poderes da narrativa. Um poema que não alcançasse essa plenitude, avisava Dryden, não poderia ser considerado (nem julgado) como épico. Seria, no máximo, um "poema histórico": ${ }^{440}$ uma forma digna e apreciável, mas inquestionavelmente menor.

É possível enxergar em Fingal um movimento semelhante de unificação narrativa, com que os ensinamentos esporádicos, ministrados por meio de notas de rodapé, confluem para uma estrutura coesa, descodificável numa alegoria. Embora se tenha recebido Ossian como uma versão celta de Homero, a organização de seu primeiro poema longo não pode ser creditada exclusivamente à Ilíada. A oposição entre a desordem inicial e a conquista militar do futuro é claramente informada pelo modelo da Eneida.

Podemos reconhecer dois momentos bastante distintos em Fingal. Até o "Livro III", os irlandeses enfrentam o risco de se tornarem vítimas da Fortuna. Os escandinavos chegam pelo mar e tencionam subjugar Erin. Inúmeros são os indícios de que o exército de Cuchullin, guardião do rei Cormac em sua minoridade, será trucidado. Connal teme o pior e aconselha "o filho de Semo" a zelar "pelo antigo trono de Cormac", dando "riquezas e metade da terra em troca de paz". ${ }^{441}$ Os receios de Connal são reforçados pela introdução do maravilhoso. Como mostramos páginas atrás, o fantasma de Crugal o visita para prenunciar a queda de Cuchullin. Quando a

\footnotetext{
${ }^{438}$ DRYDEN, John. "Annus Mirabilis: the year of wonders, 1666”. KINSLEY, James (ed.). The poems of John Dryden cit., v. 1, p. 44.

${ }^{439}$ BOWRA, C. M. From Virgil to Milton cit., 16-17.

${ }^{440}$ DRYDEN, John. "Annus Mirabilis: the year of wonders, 1666”. KINSLEY, James (ed.). The poems of John Dryden cit., v. 1, p. 44.

${ }^{441}$ Trecho completo: "[...] son of Semo, hear my voice, regard the ancient throne of Cormac. Give wealth and half the land for peace [...]" (MACPHERSON, James. "Fingal: an epic poem". The poems of Ossian and related works cit., p. 56).
} 
profecia finalmente se confirma, os irlandeses fogem do campo de batalha e debandam para as colinas. Nesse instante, os escoceses chegam em seu socorro. Swaran, o rei de Lochlin, desdenhosamente dá as costas ao campeão irlandês e vai ao encontro de Fingal, o único oponente à sua altura. Cuchullin então se retira envergonhado e esconde-se numa caverna, um local sem saída, talvez o emblema mais óbvio para ausência de perspectivas. Entrega-se ao desespero e vê-se aprisionado num eterno presente de malogro e insucesso: ${ }^{442}$

Quantos lá jazem de meus heróis, os chefes de Innis-fail - eles que estavam contentes no salão quando ecoou o som das conchas? Não mais encontrarei seus passos na relva ou sua voz na caçada às corças. Pálidos, silenciosos e abatidos, meus amigos estendem-se em leitos cobertos de sangue! Ó espíritos dos que acabaram de morrer, vinde ao encontro a Cuchullin na sua charneca. Conversai com ele através do vento, quando a árvore farfalhante da caverna de Tura ressoa. ${ }^{443}$

Ainda que almeje recuperar a sua condição de herói épico, as vias para o heroísmo lhe parecem irremediavelmente interditadas. Connal o avisa que essa condição, de agora em diante, seria imerecida:

Sua mão está na espada de seus pais: seus olhos vermelhos e errantes, no inimigo. Três vezes ele tentou correr para a batalha, e três vezes Connal o deteve. - Chefe da ilha da neblina - ele disse -, Fingal subjuga o inimigo. Não busques um quinhão da fama do rei $[\ldots] .444$

As repetidas tentativas - três vezes ele tentou e três vezes Connal interveio - de romper com esse ciclo de impotência mostram-se frustradas. A trajetória de Cuchullin não é mais linear, seu enredo não mais pertence à epopeia. Esse novo enredo, aliás, parece inenarrável: evanescente, fugidio e sem qualquer expectativa de desenlace. Privado de sua fama, Cuchullin desiste de regressar para sua Penélope, "Bragéla de alvo colo":

Nunca mais serei renomado dentre os grandes da terra. Sou como a luz que brilhou, como a neblina soprada para longe, quando veio a

\footnotetext{
${ }^{442}$ STAFFORD, Fiona. The last of the race cit., p. 93.

443 "How many lie there of my heroes! the chiefs of Innis-fail! they that were cheerful in the hall when the sound of the shells arose. No more shall I find their steps in the heath, or their voice in the chace of the hinds. Pale, silent, low on bloody beds are they who were my friends! O the spirits of the lately dead, meet Cuchullin on his heath. Converse with him on the wind, when the rustling tree of Tura's cave resounds" (MACPHERSON, James. "Fingal: an epic poem". The poems of Ossian and related works cit., p. 76).

444 "His hand is on the sword of his fathers: his red-rolling eyes on the foe. He thrice attempted to rush to battle, and thrice did Connal stop him. Chief of the isle of mist, he said, Fingal subdues the foe. Seek not a part of the fame of the king [...]" (idem, p. 88)
} 
borrasca da manhã e iluminou o flanco escarpado da colina. [...] E tu, Bragéla de alvo colo, pranteia a perda da minha fama, pois, derrotado, jamais retornarei para ti, ó raio de sol de Dunscaich. ${ }^{45}$

O surgimento de Fingal no horizonte está longe de ser fortuito. Sua chegada é copiosamente antecipada. Desde as primeiras páginas, é anunciada num conselho de chefes, quando Connal pede para que Cuchullin tente apaziguar o invasor, ao menos "até que Fingal venha com a batalha". ${ }^{446}$ E, no "Livro II", o campeão irlandês avista, ainda no mar, a frota caledônia. Prenuncia-se a redenção de Erin:

Os navios - ele gritou —, os navios da ilha solitária! Lá vem Fingal, o primeiro dentre os homens, arrebentador de escudos! As ondas espumam diante de suas proas negras. Seus mastros com as velas são bosques nas nuvens.

Soprai - disse Cuchullin —, ó ventos que açoitam a minha ilha de amável neblina. Vem para a morte de milhares, ó chefe das colinas das corças! Tuas velas, meu amigo, são para mim como as nuvens da manhã e teus navios, como a luz do firmamento. E tu és como um pilar de fogo que ilumina a noite! $!^{447}$

De saída, antes mesmo que se anuncie sua intervenção, o rei de Morven despontava como único herói que teria como rivalizar com Swaran. Em seu primeiro diálogo, com uma jovem sentinela da Irlanda, o soberano de Lochlin menciona um duelo que (talvez) teria perdido para Fingal:

[...] quem nesta terra desponta como eu? Os heróis não param em pé em minha presença: eles caem por terra sob minha mão. Ninguém pode se igualar a Swaran na luta a não ser Fingal, rei das tempestuosas colinas. Certa vez nos batemos na charneca de Malmor, e nossos calcanhares reviraram as árvores. Rochas despencaram e riachos, mudando seu curso, fugiram murmurantes de nossa luta. Por três dias retomamos nossa luta, e os heróis ficavam a distância e tremiam. No quarto [dia], Fingal diz que o rei do oceano foi ao chão. Mas Swaran diz: ele permaneceu em pé. ${ }^{448}$

\footnotetext{
445 "For never more shall I be renowned among the mighty in the land. I am like a beam that has shone, like a mist that fled away; when the blast of the morning came, and brightened the shaggy side of the hill. [...] And thou, white-bosom'd Bragela, mourn over the fall of my fame; for, vanquished, I will never return to thee, thou sun-beam of Dunscaich" (idem, ibidem).

446 “[...] till Fingal come with battle" (idem, p. 56).

447 "The ships, he cried, the ships of the lonely isle! There Fingal comes the first of men, the breaker of the shields. The waves foam before his black prows. His masts with sails are like groves in clouds. Blow, said Cuchullin, all ye winds that rush over my isle of lovely mist. Come to the death of thousands, $\mathrm{O}$ chief of the hills of hinds. Thy sails, my friend, are to me like the clouds of the morning; and thy ships like the light of heaven; and thou thyself like a pillar of fire that giveth light in the night" (idem, p. 68).

448 " [...] who in this land appears like me? Heroes stand not in my presence: they fall to earth beneath my hand. None can meet Swaran in the fight but Fingal, king of stormy hills. Once we wrestled on the heath of Malmor, and our heels overturned the wood. Rocks fell from their place; and rivulets, changing their course, fled murmuring from our strife. Three days we renewed our strife, and
} 
Quando os escoceses aportam em Erin, inaugura-se um segundo momento em Fingal. Inicia-se o processo de resgate dos irlandeses de sua vergonha, que haveria de reconfigurar o universo épico. Ao cabo de ataques malsucedidos capitaneados por Gaul e Oscar, os dois maiores campeões de Morven, Fingal finalmente intervém. Após peleja renhida, vence o combate singular com o chefe inimigo. Sua vitória é total, ao ponto de se ver obrigado a pedir para que seus homens suspendam a perseguição dos rivais. Magnânimo, Fingal acaba por soltar Swaran mediante a promessa de que nunca mais invadirá a Irlanda. $\mathrm{O}$ escandinavo concorda e iça suas velas de volta para Lochlin. Fingal então se encontra com Cuchullin, que, humilhado pela derrota, evita sua presença. Alguns, como Connan, repreendem o "filho de Semo", perguntando-lhe: "onde estão teus feitos nas armas? Por que cruzamos o oceano para auxiliar a tua débil espada? Tu foges para tua caverna de pesar [...]". 449 Contudo, o triunfo de Fingal, além de libertar a Irlanda, absolve seu comandante (e, por extensão, seu povo) das acusações de covardia: "Cuchullin é renomado na batalha e terrível ao longo do deserto. Muitas vezes ouvi da tua fama, ó tormentoso chefe de Innis-fail" ${ }^{450} \mathrm{E}$, o que é mais interessante, resgatará Cuchullin de sua estase, de seu confinamento na caverna escura, a partir da qual, dizia, "Nenhum bardo ouvirá falar de mim. Nenhuma pedra cinza será levantada para meu renome". ${ }^{451}$ Fingal reconduzirá Cuchullin de volta à epopeia. Antecipa-lhe um futuro glorioso, em que suas vitórias militares inspirarão as canções dos bardos:

E doravante serás vitorioso - disse Fingal, rei das conchas. - A fama de Cuchullin crescerá como a árvore frondosa de Cromla. Muitas batalhas te esperam, ó chefe, e muitos serão os ferimentos de tua mão. ${ }^{452}$

E libera-o para retornar para a sua amada, Bragéla:

Desfralda agora as tuas velas brancas para a ilha da neblina. E vê Bragéla apoiada em sua rocha: seus tenros olhos em lágrimas - e de seu colo palpitante os ventos levantam seus longos cabelos. Ela

heroes stood at a distance and trembled. On the fourth, Fingal says, that the king of the ocean fell; but Swaran says, he stood" (idem, p. 55)

449 “[...] son of Semo [...] where are thy deeds in arms? Why did we come, over the ocean, to aid thy feeble sword? Thou flyest to thy cave of sorrow [...]" (idem, p. 103).

450 "Cuchullin is renowned in battle, and terrible over the desart. Often have I heard thy fame, thou stormy chief of Inisfail" (idem, ibidem).

451 "No bard shall hear of me. No gray stone shall rise to my renown" (MACPHERSON, James. "Fingal: an epic poem". The poems of Ossian and related works cit., p. 76). Trecho citado supra, p. 68.

452 "And hereafter thou shalt be victorious, said Fingal king of shells. The fame of Cuchullin shall grow like the branchy tree of Cromla. Many battles await thee, O chief, and many shall be the wounds of thy hand" (idem, p. 104). 
escuta os ventos da noite para ouvir a voz de teus remadores, para ouvir a canção do mar e o som da harpa distante. ${ }^{453}$

Reconciliado com a sua trajetória original, Cuchullin se junta a Fingal num banquete de celebração à vitória. Ao final, o rei parte de volta para Morven.

O movimento de retorsão da guerra para a concórdia, da desordem para a ordem, traduz estruturalmente a simbologia do arco-íris, enxertada no último "Livro" de Fingal por meio de Milton. ${ }^{454}$ Depois do dilúvio, há a expectativa de paz, reconciliação e glória. O arranjo simétrico clarifica os dois polos e torna inequívoca a passagem de um extremo a outro, sobretudo para um público familiarizado com o cânone épico, com o qual os paratextos de Macpherson tanto queriam dialogar. Com uma estrutura tão fácil de se reconhecer, Fingal se presta sem maiores dificuldades à paráfrase. Daí para a atribuição de uma mensagem ao poema é, convenhamos, apenas um pequeno passo hermenêutico. ${ }^{455} \mathrm{Na}$ Dissertação de Blair, por exemplo, a constatação de que a ação de Fingal é una e inteira forçosamente levaria o retor a inferir - ainda que a contragosto ${ }^{456}$ - um ensinamento do dito épico ossiânico, tal qual preconizava Le Bossu: “[...] Sabedoria e bravura sempre triunfam sobre a força bruta” ou, melhor ainda, "a vitória mais completa sobre um inimigo é obtida por aquela moderação e generosidade que o convertem num amigo". ${ }^{457}$ Tendo-se em mente o referencial canônico de inteligibilidade imperial, tem-se também uma alegoria da independência celta frente às forças estrangeiras, assegurada principalmente pela bravura dos caledônios. Não custou muito para que se tomasse Fingal como um lembrete de que a recente União dos Parlamentos (1707) não significava capitulação

453 "Spread now thy white sails for the isle of mist, and see Bragéla leaning on her rock. Her tender eye is in tears, and the winds lift her long hair from her heaving breast. She listens to the winds of night to hear the voice of thy rowers; to hear the song of the sea, and the sound of thy distant harp" (idem, $p$. 103-104).

${ }^{454}$ Cf. supra, p. 103.

${ }^{455}$ Sobre o impulso de se identificar uma mensagem na estrutura parafraseável, ver BROOKS, Peter. Reading for the plot cit., p. 4.

${ }^{456}$ Blair afirma que a teoria de Bossu, de que a ação épica comunica uma alegoria, é frígida e pedante. Contudo, sente-se compelido a aquiescer a ela e propõe uma moral para Fingal (BLAIR, Hugh. "A critical dissertation on the poems of Ossian". In: MACPHERSON, James. The Poems of Ossian and related works cit., p. 359-360).

457 “[...] Wisdom and Bravery always triumph over brutal force" e "[...] the most compleat victory over an enemy is obtained by that moderation and generosity which convert him into a friend" (idem, ibidem). 
e, num segundo nível, de que não seria prudente confundir escoceses com irlandeses. $^{458}$

Para ser desencavada da fábula, a alegoria requer uma ação una e integral. Assim, a ação de Fingal começa de maneira que não sejam necessárias explicações prévias e encerra como consequência da ação desenvolvida. ${ }^{459} \mathrm{~A}$ abertura do poema coincide com a instauração do conflito, i.e., a chegada dos escandinavos nas praias da Irlanda. Nada se requer senão os desdobramentos desse ato hostil. Com efeito, tudo aquilo que antecede a invasão de Swaran é introduzido retrospectivamente. Só depois, com a reunião do conselho de guerra, é que Connal nos informa que já se despachara um pedido de socorro a Fingal. Noutra extremidade, coloca-se termo à narrativa tão logo se resolve o último desdobramento do conflito, o aviltamento de Cuchullin. Nada mais se precisa apor para a compreensão da fábula. ${ }^{460}$ Contraindo-se ao máximo o objeto da representação literária, encaixam-se os episódios por meio de delegação narrativa, com a qual uma personagem (quase sempre um bardo) ou supre informações sobre passado, presente e futuro de outras personagens ou providencia um pano de fundo histórico para a questão em jogo. Dessa maneira, mantém-se a unidade temporal de Fingal, cuja ação dura míseros seis dias, bem menos que os quarenta e oito da Ilíada e um ano da Eneida.

Há até episódios que se integram plenamente à economia narrativa, prefigurando o desenlace das querelas formadas ao longo do enredo. No "Livro III", logo após os irlandeses distinguirem as embarcações de Morven, Carril canta uma antiga desavença entre Fingal e os soberanos de Lochlin. Quando jovem, o pai de Ossian fora convidado para a Escandinávia a fim de receber a mão de Agandecca, filha de Starno e irmã de Swaran. ${ }^{461} \mathrm{O}$ convite era uma armadilha para atrair o herói e matá-lo à traição. No entanto, Agandecca, "a filha da neve", enamora-se do "rei do deserto" e revela-lhe as reais intenções de seus familiares:

Fingal, chefe de alta linhagem, não confies no orgulhoso coração de Starno. Naquele bosque ele pôs seus chefes. Cuidado com o bosque

\footnotetext{
${ }^{458}$ Sobre Ossian e a União, ver SHIELDS, Juliet. Sentimental literature and Anglo-Scottish identity, 1745-1820. Cambridge: Cambridge University, 2010, p. 24-55 e DAVIS, Leith. Acts of Union: Scotland and the literary negotiation of the British nation, 1707-1830. Stanford : Stanford University, 1998, p. 74-106.

${ }^{459}$ Ver LE BOSSU, René. Traité du poëme épique cit., p. 208-210.

${ }^{460}$ Idem, ibidem.

${ }^{461}$ Ver supra, p. 74.
} 
da morte! Mas lembra-te, filho da colina, lembra-te de Agandecca: salva-me da ira de meu pai, ó rei da ventosa Morven. ${ }^{462}$

Prevenido pela donzela, Fingal facilmente subjuga os inimigos. Enfurecido pela delação de sua filha, Starno apunhala-a até a morte. O rei de Morven nada pode fazer senão trazer o corpo para sua terra e lá enterrá-lo:

Pálido em seu navio tormentoso, ele velou a donzela de negros cabelos. Seu túmulo se ergue em Ardven, e o mar ressoa ao redor da escura morada de Agandecca. ${ }^{463}$

Falas e discursos ao longo de Fingal dão mostras indubitáveis de que essa desventura amorosa ainda ocuparia a mente do rei de Morven. Quando o exército escocês se prepara para enfrentar Swaran, Fingal apostrofa o espectro da "filha da neve". Se estiver por perto, em meio a seu povo, que apareça em sonhos e mostre sua "face luminosa". ${ }^{464} \mathrm{O}$ fantasma de Agandecca efetivamente aparece para Fingal. "Sua face era pálida como a névoa de Cromla e escuras eram as lágrimas em suas bochechas". ${ }^{465}$ Ela estende sua mão translúcida para o rei, que lhe pergunta por que chora. Sem responder, ela parte nas asas do "vento de Lena". ${ }^{466}$ O narrador afirma que ela, profeticamente, "lamentava as crianças de seu povo que tombariam pelas mãos de Fingal". ${ }^{467}$ Após o início efetivo das hostilidades, o pai de Ossian se arrependeria de ter matado um dos guerreiros de Lochlin. Ao ver seu rosto desfalecido, reconhece-o como um "amigo de Agandecca" e afirma ter visto suas "lágrimas pela donzela de meu amor nos salões do sanguinolento Starno". ${ }^{468}$ Tantas reminiscências se justificam formalmente no último "Livro", em que o nome de Agandecca é outra vez trazido à tona. Ao celebrar sua vitória sobre Swaran, Fingal é tomado pela lembrança da filha de Starno. Enternecido, manda soltar o irmão de sua primeira amada, "para que possa partir renomado como o sol poente no oeste". 469

\footnotetext{
462 "Fingal, high-descended chief, trust not Starno's heart of pride. Within that wood he has placed his chiefs; beware of the wood of death. But, remember, son of the hill, remember Agan|decca: save me from the wrath of my father, king of the windy Morven!" (MACPHERSON, James. "Fingal: an epic poem". The poems of Ossian and related works cit., p. 74).

463 "Pale, in his bounding ship he closed the maid of the raven hair. Her tomb ascends on Ardven, and the sea roars round the dark dwelling of Agandecca" (idem, ibidem).

${ }^{464}$ Idem, p. 79.

465 "Her face was pale like the mist of Cromla; and dark were the tears of her cheek" (idem, p. 84).

466 Trecho integral: "She departed on the wind of Lena" (idem, ibidem).

${ }^{467}$ Trecho integral: "She mourned the sons of her people that were to fall by Fingal's hand" (idem, ibidem).

468 "I have seen thy tears for the maid of my love in the halls of the bloody Starno" (idem, p. 88).

469 "[...] that thou mayest depart renowned like the sun setting in the west" (idem, p. 101)
} 


\subsubsection{Temora}

O acúmulo de referências e as coincidências estruturais havia concedido um lastro canônico à designação genérica aposta a Fingal: um poema épico em seis livros. Em 1761, Macpherson parecia suficientemente seguro de sua estratégia criativa, crítica e mercadológica. Tanto é que ela se estende a um fragmento incluso na coleção daquele ano, intitulado "Temora: an epic poem". De acordo com o tradutor, não era uma narrativa completa, mas apenas sua abertura. Pelo que ouvira falar, tratava-se de uma composição extensa, que "proporciona exemplos da mais alta bravura, misturados a atos e sentimentos incomparavelmente generosos". ${ }^{470}$ Assim como fizera em 1760, Macpherson curiosamente demonstra conhecer o inteiro teor de uma composição que declarava perdida:

Imediatamente depois da morte de Cuchullin, Cairbar, senhor de Atha, estabeleceu-se em Connaught, e, tendo privadamente matado o jovem rei Cormac, tornou-se, sem oposição, o único monarca da Irlanda. O homicídio de Cormac foi tão deplorado por Fingal que ele decidiu por uma expedição para a Irlanda contra Cairbar. Informações antecipadas de seus desígnios chegaram a Cairbar e ele reuniu as tribos no Ulster para se opor ao desembarque de Fingal. Entrementes, seu irmão Cathmor ficou com um exército próximo a Temora. ${ }^{471}$

De saída, o vocabulário denuncia uma tópica épica. Faz-se menção a reis, monarcas, senhores, exércitos, mortes e expedições. A temática bélica, com regicídios e invasões, salta aos olhos. E o desfile de títulos e dignidades indica a consequência social das personagens. Atrás dos estandartes reais, seguem tropas e tribos. Nas entrelinhas, há um referencial intertextual intra-ossiânico. A ambientação na Irlanda e a alusão a dois dos três personagens principais de Fingal indicam semelhanças profundas entre esses dois poemas designados épicos. Até este ponto da coleção Fingal, an ancient epic poem in six books, together with several other poems, Cuchullin e o rei de Morven só são reunidos - vivos ou mortos - em "Darthula: a poem", a peça imediatamente anterior a "Temora: an epic poem", com a qual,

\footnotetext{
470 “[...] affords instances of the greatest bravery, mixed with incomparably generous actions and sentiments" (MACPHERSON, James. "Temora: an epic poem" [1761/1762]. The poems of Ossian and related works cit., p. 456 , nota 1$)$.

471 "Immediately after the death of Cuchullin, Cairbar, lord of Atha, openly set up for himself in Connaught, and having privately murdered young king Cormac, became, without opposition, sole monarch of Ireland. The murder of Cormac was so much resented by Fingal, that he resolved on an expedition into Ireland against Cairbar. Early intelligence of his designs came to Cairbar, and he had gathered the tribes together into Ulster, to oppose Fingal's landing; at the same time his brother Cathmor kept himself with an army near Temora" (idem, ibidem).
} 
segundo Macpherson, compartilha o pano de fundo histórico. ${ }^{472}$ Para modular essa associação, novamente há um aparato paratextual que equipara Ossian aos maiores expoentes do gênero épico. Seria falso dizer, todavia, que noutros poemas da coleção não haja referências a epopeias paradigmáticas. Elas existem e em grande quantidade. Entretanto, ocupam um espaço de bem menos destaque que as citações estranhas ao repertório heroico. Aqui, são muito numerosas as remissões à Bíblia, sobretudo a partes menos narrativas, como os Cânticos de Salomão e o Livro de Isaías. No fragmento "Temora: an epic poem", por sua vez, não há nada disso: apenas os nomes de Homero e Virgílio. Assim, nesta passagem, em que “o jovem rei Cormac” está prestes a ser avisado da morte de Cuchullin -

Mil luzes se acenderam, cem bardos tangeram a harpa. Cormac estava no meio, como uma estrela da manhã, quando ela se regozija na colina oriental e seus jovens raios são banhados pela chuva.

— há uma referência a Palante, no "Livro VIII" da Eneida, em que é comparado às luzes (salpicadas por gotículas de água) de uma estrela:

De arnês pintado e clâmide vistoso;

Qual, do oceano orvalhada, a estrela d'alva,

A quem sobre os mais astros Vênus ama,

Alteia aos céus a fronte e solve as trevas. ${ }^{473}$

(VIII, 581-584)

À primeira vista, estamos diante de uma coincidência no manejo de símiles, uma constatação que contribuía para aumentar o valor de face de Ossian. Se Virgílio tivera Homero como guia, o bardo celta fiara-se exclusivamente em seu próprio engenho. Num segundo momento, insinua-se uma semelhança entre a caracterização de Cormac e a de Palante: jovens e inexperientes, encontrarão a morte pelas mãos de oponentes formidáveis, respectivamente Cairbar e Turno. Como se pode notar, mais uma vez o diálogo paratextual nos lança numa espiral de associações que aprofunda e complica os sentidos sugeridos pelo entrecho ficcional. No limite, poderíamos perguntar se Fingal, ao vingar a morte de Cormac, assemelha-se a Enéas, que vingou a morte de Palante? E em que medida se dá essa semelhança? Como ela nos permite enxergar a expedição dos escoceses para a Irlanda? Trata-se, como no caso dos troianos, de um

\footnotetext{
${ }^{472}$ Ver idem, ibidem.

${ }^{473}$ VIRGÍlLIO. Eneida cit., p. 193. Na versão de Dryden: "So, from the Seas, exerts his radiant head/ The Star, by whom the lights of Heav'n are led:/ Shakes from his rosie Locks the perly Dews; Dispels the darkness, and the Day renews" (VIII, 778-781) (VIRGÍLIO. "Virgil’s Æneis”. Trad. John Dryden cit., v. 3, p. 1283).
} 
processo de conquista imperial? Como estamos diante de um fragmento, a nenhuma dessas perguntas se oferece uma resposta satisfatória.

Ainda que sejam ilusórias as tentativas de apreender a estrutura de uma narrativa épica numa peça de poucas páginas, é nítida a propositura de uma ação que, quando configurada, será una e inteira. Logo na primeira intervenção editorial, chama-se atenção para o uso da dita "ordem artificial":

O presente poema abre pela manhã. Cairbar é representado à parte do resto dos chefes irlandeses - e atormentado pelo homicídio de Cormac -, quando chega a notícia do desembarque de Fingal. O que aconteceu, antes daquele dia, e é necessário saber para continuar com o poema, é depois introduzido por meio de episódios. ${ }^{474}$

O arranjo lembra muito o de Fingal. Ali, Cuchullin sentava-se só ao pé de uma árvore, até que uma sentinela chega esbaforida para avisar-lhe que Swaran aportara. Apavorada, exorta o campeão de Erin a fugir. O filho de Semo repreende a covardia de seu subordinado. Ao invés de correr, convoca um conselho. Agora, Cairbar perambula sozinho, quando vê os "batedores do oceano" tomados pelo pavor. Sabendo que "os poderosos estavam perto", convoca "seus chefes sombrios". Como no poema anterior, uns sugerem lutar e outros sugerem a rendição. Herói que é, Cairbar opta pela batalha.

A guerra começa com traição. Cairbar convida Oscar, o neto de Fingal, para um banquete. Desonrando as leis da hospitalidade, ataca o escocês. Os dois morrem em combate. Ao longe, os guerreiros de Morven ouvem o clamor das armas e partem em socorro de um dos seus. Contudo, chegam a tempo apenas de ouvir as últimas palavras de Oscar. Ullin parte de volta para Morven com seu corpo, encarregado de confortar Malvina. Fingal e os outros ficam para lutar contra o exército de Erin, cujo comando passou para Cathmor.

À noite, Althan conta aos escoceses como se deu a tomada de poder, em que Cairbar matou Cormac. Dentro dessa narrativa, trata-se também da morte de Cuchullin, cujo fantasma apareceu para Althan. Analepticamente, suprem-se as informações sobre a origem do conflito.

\footnotetext{
474 "The present poem opens in the morning. Cairbar is represented as retired from the rest of the Irish chiefs, and tormented with remorse for the murder of Cormac, when news was brought him of Fingal's landing. What passed, preceding that day, and is necessary to be known for carrying on the poem, is afterwards introduced by way of episode" (MACPHERSON, James. "Temora: an epic poem" [1761/1762]. The poems of Ossian and related works cit., p. 456, nota 1).
} 
O velho Althan estava no meio e contou a estória do tombado Cormac. Althan, o filho de Conachar, o amigo do aurígico Cuchullin. Ele morava com Cormac na ventosa Temora, quando o filho de Semo lutava ao lado do generoso Torlath. - A estória de Althan era pesarosa, e lágrimas estavam em seus olhos. ${ }^{475}$

Com a retrospectiva, estabelecem-se ainda as bases da caracterização daquele que será o inimigo de Fingal e que, com o rei de Morven, presidirá os desdobramentos do enredo. No relato de Althan, Cathmor diferencia-se de Cairbar repreendendo-o pelo derramamento de sangue inocente. Teme que esse ato covarde conspurque a sua glória:

Chefe de Atha - ele disse - , por quanto tempo machucarás a minha alma? Teu coração é como a rocha do deserto e sombrios são teus pensamentos. - Mas tu és o irmão de Cathmor, e ele lutará as tuas batalhas. - Mas a alma de Cathmor não é como a tua, ó débil mão na guerra! A luz de meu peito é maculada pelos teus feitos: os bardos não cantarão meu renome. Decerto eles dirão: "Cathmor era bravo, mas lutou pelo sombrio Cairbar".

Ao cabo da narrativa de Althan, Fingal elogia seu antagonista e afirma deleitar-se com a oportunidade de lutar contra alguém como Cathmor. Pouco depois, os escoceses decidem guardar forças para o embate do dia seguinte. Fillan, a sentinela, divisa no horizonte a marcha dos irlandeses, mas "Temora: an epic poem" chega ao fim.

O complicado jogo de marchas e contramarchas constitui indício bastante sólido de que Macpherson planejava publicar um segundo épico caso Fingal e, de modo geral, Fingal, an ancient epic poem in six books, together with several other poems obtivessem êxito crítico e, sobretudo, comercial. ${ }^{476}$ Suas expectativas, como se sabe, não foram frustradas. Mais de quarenta anos depois que Fingal despontou na cena literária da década de 1760, e depois das investidas de Samuel Johnson e Malcolm Laing contra a autenticidade das traduções de Macpherson, as vendas de Ossian aparentemente só ficaram atrás da Bíblia e Shakespeare. ${ }^{477}$ Diante de uma acolhida

475 "Old Althan stood in the midst, and told the tale of fallen Cormac. Althan the son of Conachar, the friend of car-borne Cuchullin: he dwelt with Cormac in windy Temora, when Semo's son fought with generous Torlath.- The tale of Althan was mournful, and the tear was in his eye" (idem, p. 153).

${ }^{476}$ Ver comentário de Howard Gaskill em idem, p. 456, nota 1. De acordo com Laing, Macpherson provavelmente escreveria um épico por ano caso Temora tivesse sido recebido com o mesmo entusiasmo que Fingal (LAING, Malcolm (ed.). The poems of Ossian, containing the poetical works of James Macpherson cit., v. 2, p. 264, nota). Para uma cronologia de Ossian, ver GASKILL, Howard. "Ossian in Europe" cit., p. 644.

${ }^{477}$ Cf. STAFFORD, Fiona. The sublime savage cit., p. 171. Ver também GASKILL, Howard. "Introduction: 'Genuine poetry... like gold"” cit., p. 2. 
tão calorosa, logo viria a lume o terceiro lote de peças ossiânicas, em Temora an ancient epic poem in eight books, together with several other poems, em março de 1763.

Precedida por uma epígrafe à Eneida, Temora, a principal obra da coleção, era intitulada "um épico em oito livros". ${ }^{478}$ Tratava-se, isso é claro, de uma versão expandida (ou acabada) de "Temora: an epic poem". Em pouco mais de um ano, Macpherson dizia ter coletado todos os fragmentos dispersos da narrativa, que antes lhe faltavam. Como já conhecia a história do poema, pôde "reduzi-la à ordem em que ora aparece". ${ }^{479}$ Em quase tudo, o "Livro Primeiro" de Temora repete "Temora: an epic poem". Eventuais diferenças, segundo o tradutor, advêm de novas cópias do poema, mais corretas, que vieram parar em suas mãos desde a publicação anterior. Para se livrar de interpolações, Macpherson garante ter-se fiado sobretudo ao "espírito do contexto". 480

A relativa parcimônia na revisão do entrecho ficcional pode ser enganosa. Se atentarmos somente à voz ossiânica, a procedência de Temora é indisputável: é um texto derivado de "Temora: an epic poem". Contudo, ao integrarmos as instâncias paratextuais à intelecção da obra, nota-se que algo mudou radicalmente entre uma publicação e outra. Ao contrário do que se dera em volumes anteriores, os prolegômenos não subministram rudimentos críticos para o enquadramento de Temora. Tampouco se discutem seus temas ou sua tópica, com que se justificaria, ainda que obliquamente, a designação genérica desse novo poema longo de Ossian. $\mathrm{O}$ teor de "Uma dissertação", que faz as vezes de prefácio, é, acima de tudo, histórico. Com excruciante minúcia, almeja-se mostrar como

Ossian não apenas preservou a história da primeira migração dos Caledônios para a Irlanda; ele também nos legou alguns fatos

\footnotetext{
${ }^{478}$ Curiosamente, Temora tem suscitado muito menos análises críticas que Fingal. Os propósitos claramente mercadológicos de Macpherson e seu interesse em reescrever a história das relações entre os povos de Escócia e Irlanda fazem com que, ainda hoje, Temora seja levado ainda menos a sério que o poema anterior. Contudo, a segunda epopeia ossiânica é bem mais ambiciosa que a primeira e expõe com mais clareza como seu dito "tradutor" buscou conciliar correntes críticas antagônicas na confecção de épicos primitivos (ver MOORE, Dafydd. "Heroic incoherence in James Macpherson's The Poems of Ossian". Eighteenth-century studies, v. 34, n. 1 (outono, 2000), p. 43-59.

479 "[...] to reduce it into that order in which it now appears" (MACPHERSON, James. "Temora: an epic poem". The poems of Ossian and related works cit., p. 479, nota 2).

${ }^{480}$ No original: "spirit of the context" (sobre as alterações, ver idem, ibidem).
} 
importantes a respeito dos primeiros assentamentos dos Firbolg, ou Belgce da Bretanha, naquele reino. ${ }^{481}$

Numa análise que se quer rente aos episódios de Temora, Macpherson decreta que "a história preservada por Ossian" põe em suspeição as certezas dos cronistas e historiadores escoceses, irlandeses e até mesmo romanos. ${ }^{482}$

Dada a ambição da empreitada, antecipa-se o sacrifício da forma em prol das determinações do conteúdo, com vistas à transmissão de uma "história genuína". Isso se depreende até mesmo da maneira em que se emprega o vocabulário crítico em "Uma dissertação". Significativamente, termos como "assunto" (subject), "catástrofe" (catastrophe) e "episódios" (episodes) são reduzidos a meros procedimentos narrativos para o registro factual. ${ }^{483}$

No que concerne às anotações à margem, abandona-se a tentativa de cristalização genérica a partir de uma moldura canônica. Nas extensas notas a Temora, não há qualquer tipo de citação literária, exceto aquelas atribuídas ao próprio Ossian. Existem, é verdade, menções ocasionais a Homero e Virgílio. No caso do grego, são, salvo engano, sete: duas no "Livro Primeiro", uma no "Livro Segundo", três no “Livro Quarto" e um no "Livro Oitavo". O poeta latino, por sua vez, é citado em dois momentos: uma no "Livro Primeiro" e outra no "Livro Quarto". Entretanto, pouca coisa restou do sistema desenvolvido em Fingal, pois não mais se coteja a escrita ossiânica à pedra de toque dos clássicos. Muitas vezes, deflaciona-se a autoridade poética de Virgílio e Homero, tomando-os tão somente como fontes de informação antropológica:

[...] as ideias daqueles tempos, a respeito dos espíritos dos mortos, não eram tão sombrias e desagradáveis, como aquelas de eras subsequentes. Os espíritos das mulheres, supunha-se, retinham a beleza que possuíam quando vivas e transportavam-se de um lugar para outro com aquele movimento deslizante que Homero atribuía aos deuses. ${ }^{484}$

481 "Ossian has not only preserved the history of the first migration of the Caledonians into Ireland, he has also delivered some important facts, concerning the first settlement of the Firbolg, or Belgae of Britain, in that kingdom [...]" (MACPHERSON, James. "A dissertation". The poems of Ossian and related works cit., p. 210). Para uma análise minuciosa dos "eventos históricos" narrados em Temora, ver LEME LOPES, André. O poeta que não existiu cit., p. 168 e ss.

482 "[...] the history preserved by Ossian" (idem, p. 211)

${ }^{483}$ Ver idem, p. 215.

484 " [...] the ideas of those times, concerning the spirits of the deceased, were not so gloomy and disagreeable, as those of succeeding ages. The spirits of women, it was supposed, retained that beauty, which they possessed while living, and transported themselves, from place to place, with that gliding 
A ausência de excertos da Ilíada e da Eneida (para não falar do Paraíso perdido) está longe de ser acidental. Tampouco pode ser creditada a algum tipo de enfado inconfessável, uma preguiça em sair à cata de equivalências estilísticas, imagéticas e formais - ou, como diriam os cínicos, a um receio bastante compreensível de tornar demasiado óbvias as fontes, por assim dizer, não gaélicas de Ossian. ${ }^{485}$ Macpherson, na sua primeira nota a Temora, declara ter evitado a transcrição, "neste volume, das passagens correlatas de outros autores". ${ }^{486}$ Alega que jamais quisera comparar "seu autor" aos "nomes célebres da antiguidade". ${ }^{487}$ Pondera que nem os eventuais méritos de Ossian, mesmo se superiores aos de Homero ou Virgílio, poderiam fazer com que o público divergisse de uma estima já consolidada há muitos e muitos séculos. ${ }^{488}$

Noutras palavras, Macpherson dispensa a chancela dos antigos para adequar Temora aos "termos técnicos da crítica", que eram "totalmente ignorados por Ossian". ${ }^{489}$ Sua estratégia consistirá em reabilitar categorias que a dinâmica do pensamento primitivista inevitavelmente desacredita, por meio da naturalização dos requisitos neoclássicos para a configuração do poema épico. ${ }^{490}$ Por conseguinte, descrevem-se "os grandes fundamentos da epopeia" "491 - das três unidades à abertura in medias res - como formulações exaradas dos poemas de Homero. Ao invés de denunciar tais fundamentos como inservíveis à poética ossiânica, o tradutor toma-os como provenientes da natureza. A intermediação homérica, porque feita pelo gênio natural par excellence, outorgar-lhes-ia universalidade. Assim, se "na forma de seus poemas, e em diversas passagens de sua dicção, ele [Ossian] se assemelha a Homero, a similaridade tem de proceder da natureza, o original do qual ambos retiraram suas

motion, which Homer ascribes to the gods" (MACPHERSON, James. "Temora: an epic poem". The poems of Ossian and related works cit., p. 497, nota 12).

${ }^{485}$ Nesse sentido, Laing argumenta que a publicação, assinada por Webb, de Fingal reclaimed (que, infelizmente, não conseguimos localizar), levou Macpherson a suprimir as citações canônicas. De acordo com Laing, Webb havia identificado várias imitações grosseiras de Macpherson ao Homero de Pope (cf. LAING, Malcolm (ed.). The poems of Ossian, containing the poetical works of James Macpherson cit., v. 2, p. 8-9, nota).

${ }^{486}$ Trecho completo: "I have avoided, in this volume, to give parallel passages from other authors [...]" (MACPHERSON, James. "Temora: an epic poem". The poems of Ossian and related works cit., p. 479 , nota 2 ).

${ }^{487}$ Trecho completo: "It was far from my intention to raise my author into a competition with the celebrated names of antiquity" (idem, ibidem).

${ }^{488}$ Idem, ibidem.

489 “[...] technical terms of criticism [...] totally unknown to Ossian” (idem, ibidem).

${ }^{490}$ Ver FOERSTER, Donald M. The fortunes of epic poetry cit., p. 25.

491 "[...] the grand essentials of the epopcea" (MACPHERSON, James. "Temora: an epic poem". The poems of Ossian and related works cit., p. 479, nota 2). 
ideias". ${ }^{492}$ Gestada em tempos rudes e incultos, a criação literária ossiânica atendia às principais exigências do aristotelismo neoclássico:

Embora este poema de Ossian não tenha todas as minúcias que Aristóteles, a partir de Homero, formula como necessárias ao desenvolvimento de um poema épico, ainda assim, presume-se, ele detém os grandes fundamentos da epopeia. A unidade de tempo, lugar e ação é preservada do começo ao fim. O poema abre in medias res - o que é necessário saber de acontecimentos anteriores é introduzido, depois, por meio de episódios [...] As circunstâncias são grandiosas e a dicção, animada. ${ }^{493}$

Tamanha ginástica conceitual e argumentativa vira do avesso a terminologia primitivista. Em muitas das notas a Temora, a razão, e não mais os sentidos, torna-se a via de acesso ao natural. Cessam as explicações antropológicas sobre as afecções do elocutor poético e introduzem-se comentários sobre como Ossian demonstra "discernimento" (judgment), "propriedade" (propriety) e "delicadeza" (delicacy). Quando seguir a natureza presume discernimento, adentra-se no sistema do Ensaio sobre a crítica, de Pope, para o qual se "forja a mente" (judgment frame) ao reconhecermos "o justo padrão" da natureza, "que nunca é diferente". ${ }^{494}$ A natureza cognoscível à razão seria "perene e universal", decomponível em “[...] leis antigas, que não são coisa inventada,/ São inda a Natureza, mas metodizada". ${ }^{495}$ Contrapõe-se, por isso, o natural ao espontâneo. A imaginação é domesticada por preocupações com a unidade da ação; e aquilo que horacianos empedernidos tachariam de monstruosa mistura de gêneros é travestido de decorosa adequação ao assunto:

Nenhum poeta desvia-se menos de seu assunto que Ossian. Nenhum ornamento longínquo é introduzido; os episódios emergem da - e são essenciais para - a estória do poema. Até mesmo as suas canções líricas, nas quais ele mais incorre em extravagâncias da fantasia, naturalmente brotam de seu assunto. Sua propriedade e conexão com o resto do poema mostram que o bardo celta era

\footnotetext{
492 " [...] in the form of his poems, and in several passages of his diction, he resembles Homer, the similarity must proceed from nature, the original from which both drew their ideas" (idem, ibidem).

493 “Tho' this poem of Ossian has not perhaps all the minulice, which Aristotle, from Homer, lays down as necessary to the conduct of an epic poem, yet, it is presumed, it has all the grand essentials of the ерорка. Unity of time, place, and action is preserved throughout. The poem opens in the midst of things; what is necessary of preceding transactions to be known, is introduced by episodes [...] The circumstances are grand, and the diction animated" (idem, ibidem).

${ }^{494}$ POPE, Alexander. "Ensaio sobre a crítica". Poemas. Trad. Paulo Vizioli. São Paulo: Nova Alexandria, 1994, p. 39. No original: "[...] your Judgment frame/ By her just Standard, which is still the same" (POPE, Alexander. "An essay on criticism". Poetry and prose of Alexander Pope. Ed. Aubrey Williams. Boston: Riverside, 1969, p. 40).

495 POPE, Alexander. "Ensaio sobre a crítica" cit., p. 39. No original: "Those RULES of old discover'd, not devis'd,/ Are Nature still, but Nature Methodiz'd" (POPE, Alexander. "An essay on criticism". Poetry and prose of Alexander Pope cit., p. 40).
} 
guiado pelo discernimento, mesmo nos mais selvagens arrebatamentos da imaginação. ${ }^{496}$

Em intervenções desse tipo, a obra do gênio natural é um produto acabado, para cuja elaboração se pressupõem etapas de planejamento, reflexão e ajuste. ${ }^{497}$ Operações como seleção de ornamentos apropriados e subsunção dos episódios às demandas do enredo subentendem uma estrutura abstrata que prefigura a criação literária, um molde dotado de uma lógica própria, o que idealmente proscreve ou cerceia a aleatoriedade. ${ }^{498}$ Intuído ou ensinado por Aristóteles, esse molde é plenamente reconhecível em Temora, como o próprio Macpherson já indicara.

No que tange à abertura, preserva-se o arranjo de "Temora: an epic poem". Reproduz-se o primeiro parágrafo quase que literalmente. Ressalvado melhor entendimento, há apenas oito alterações de um texto para outro, quase todas elas no nível da pontuação (como troca de ponto-e-vírgula para vírgula) ou das conjunções aditivas (suprime-se o "and"). Diante disso, temos de novo Cairbar no alto da colina a pensar na morte de Cormac, até que o avisam da chegada de Fingal. A “ordem artificial" concede proeminência ao embate entre irlandeses e escoceses, a partir do qual se organiza toda a narrativa. Os antecedentes do conflito são, quase que sem exceção, trazidos à tona pela boca de personagens, para as quais o narrador cede a palavra. Até mesmo causas remotas, cujo relato incidentalmente mostraria a ascendência de um povo sobre o outro, são delineadas por meio de diálogos. Numa conversa entre Fillan e o Ossian-personagem, conta-se que Conar, tio-avô de Fingal, houvera pacificado a Irlanda, coroando-se rei. ${ }^{499}$ Os chefes ao sul de Connaught que, lembre-se, é a região de Cairbar -, no entanto, rebelam-se contra o monarca estrangeiro:

Os chefes do sul reuniram-se na escuridão de seu orgulho. $\mathrm{Na}$ horrível caverna de Moma, trocaram palavras secretas. Para lá, eles diziam, iam os espíritos de seus pais, a mostrar sua pálida figura do

\footnotetext{
496 "No poet departs less from his subject than Ossian. No far-fetched ornaments are introduced; the episodes rise from, and are indeed essential to, the story of the poem. Even his lyric songs, where he most indulges the extravagance of fancy, naturally spring from his subject. Their propriety and connection with the rest of the poem, shew that the Celtic bard was guided by judgment, amidst the wildest flights of imagination" (MACPHERSON, James. "Temora: an epic poem". The poems of Ossian and related works cit., p. 514, nota 1).

${ }^{497} \mathrm{O}$ tradutor chega a escrever que há "arte" na construção da fábula de Temora (idem, p. 522, nota $1)$.

${ }^{498}$ TILLYARD, E. M. W. The English epic and its background cit., p. 8-10.

${ }^{499}$ Consulte-se a representação gráfica da genealogia dos reis escoceses e irlandeses em LEME LOPES, André. O poeta que não existiu cit., p. 173.
} 
alto de desfiladeiros, e a lembrá-los da honra de Bolga: por que deveria Conar reinar, o filho da flumínea Morven? ${ }^{500}$

Os rebeldes impõem pesadas perdas a Conar, que se vê sozinho "em meio ao túmulo de seus guerreiros". ${ }^{501}$ Depois de enterrar seu filho, Colgar, o rei finalmente reúne forças e vinga-se dos Bolgæ. Cairbar teria completado, portanto, a missão de seus antepassados. E Fingal se apresentava, gerações mais tarde, para repetir a pacificação manu militari promovida por Conar.

Configura-se o mesmo roteiro de sublevação Fir-bolg, seguida de estabilização promovida pelos escoceses, no "Livro Terceiro". Ao cabo do primeiro dia de combate, Fingal percebe que Connal, chefe de Dun-lora, tombara. Pede então para que seu filho cante sobre as outras vezes em que marcharam juntos:

Ossian, tua alma é uma chama: alumia a memória do rei. Desperta as batalhas de Connal, quando brilhou na guerra pela primeira vez. As madeixas de Connal eram cinzas, seus dias de juventude misturavam-se aos meus. ${ }^{502}$

$\mathrm{Na}$ voz do Ossian-personagem, insere-se o episódio da expedição de Connal, a mando de Fingal, para conter "os filhos de Bolga", que "se precipitaram para a guerra" sob o estandarte de Colc-ulla, contra o rei Cormac I. ${ }^{503}$ Ao lado de seu pai, Duth-caron, postou-se como uma rocha para evitar o massacre da gente de Erin. No embate, todavia, Duth-caron é trespassado por uma flecha. Morto pelo exército de Cairbar e Cathmor, Connal "vagueará pelos ventos" ${ }^{504}$ nos mesmos campos em que repousa seu pai.

Como se depreende dos exemplos acima, os mecanismos de delegação narrativa indicam o controle formal de Temora. A subordinação do tempo cronológico ao andamento da ação comprovaria que Ossian não teria incorrido no erro de confundir um poema épico com uma biografia. ${ }^{505}$ Só lhe interessariam os eventos que, de

\footnotetext{
500 "The chiefs of the south were gathered, in the darkness of their pride. In the horrid cave of Moma, they mixed their secret words. Thither often, they said, the spirits of their fathers came; shewing their pale forms from the chinky rocks, and reminding them of the honor of Bolga.-Why should Conar reign, the son of streamy Morven?" (MACPHERSON, James. "Temora: an epic poem". The poems of Ossian and related works cit., p. 238).

501 "[...] among the tomb of his warriors" (idem, ibidem).

502 "Ossian, thy soul is fire: kindle the memory of the king. Awake the battles of Connal, when first he shone in war. The locks of Connal were grey; his days of youth were mixed with mine" (idem, p. 248).

${ }^{503}$ No original: "[...] the sons of Bolga rushed to war" (idem, p. 249)

504 "[...] wander on the winds" (idem, ibidem).

${ }^{505}$ LE BOSSU, René. Traité du poëme épique cit., p. 114.
} 
maneira direta e necessária, guardam relação com a ação principal do poema. Assim, entre a chegada e o adeus de Fingal transcorrem apenas quatro dias, dois a menos que o primeiro épico ossiânico. Contraindo-se ao máximo o tempo, elimina-se a possibilidade de dissipação mimética em deslocamentos e mudanças de cenário. Como no caso da Ilíada, o próprio título nos assegura que a ação revolve em torno de um só lugar, Temora, "o palácio real dos primeiros reis irlandeses da raça caledônia, na província de Ulster". 506

Entretanto, dificilmente se teria uma narrativa una e inteira se ela também não tematizasse o embate para a imposição de um ordenamento às forças da história, com que a transposição armada das vicissitudes da Fortuna impõe sentido e transcendência da comunidade vencedora. ${ }^{507}$

Em Temora, Fingal e seus conterrâneos são o poder que livra a Irlanda do caos, aprisionada num conflito entre o norte e o sul, que se repete geração após geração. Antes da insurgência de Cairbar e Cathmor, Conar e Connal já se haviam batido com os Fir-bolg. O próprio Fingal, aliás, interferira nas questões intestinas da ilha. No "Livro Quarto", o rei de Morven conta que teve de partir em socorro de Connal, que, sozinho, não conseguira vencer Colc-ulla. Na ponta de sua lança, Cormac I finalmente supera seus oponentes, que fogem. Agradecido, o rei cede ao forasteiro a mão de sua filha, Ros-crána:

Por três dias festejamos em Moi-lena: ela se elevava luminosa em minha alma atormentada. - Cormac me viu sombrio. Ele me deu a donzela de alvo colo. - Ela me seguiu com olhos submissos, em meio ao vaguear de suas pesadas madeixas. - Ela veio. - Logo a batalha bramiu. - Colc-ulla atacou. - Peguei minha lança. Minha espada se levantou, com meu povo, contra o inimigo escarpado. Alcnema fugiu. Colc-ulla tombou. Fingal retornou com fama. ${ }^{508}$

Mas é ao término do "Livro Quarto", com recurso ao maravilhoso, que se prenuncia o fim desse ciclo de violência. O fantasma de Cairbar visita o sono de seu irmão Cathmor, que assumira o comando do exército irlandês após a sua morte. "[S]uas

\footnotetext{
506 “[...] the royal palace of the first Irish kings of the Caledonian race, in the province of Ulster" (MACPHERSON, James. "Temora: an epic poem". The poems of Ossian and related works cit., p. 479 , nota 1$)$.

${ }^{507}$ QUINT, David. Epic and empire cit., p. 93.

508 "Three days we feasted at Moi-lena: she rose bright amidst my troubled soul.—Cormac beheld me dark. He gave the white-bosomed maid.- She came with bending eye, amidst the wandering of her heavy locks. - She came.— - Straight the battle roared.—Colc-ulla rushed;- I seized my spear. My sword rose, with my people, against the ridgy foe. Alnecma fled. Colc-ulla fell. Fingal returned with fame" (MACPHERSON, James. "Temora: an epic poem". The poems of Ossian and related works cit., p. 256).
} 
débeis palavras", "meio misturadas ao barulho do riacho", anunciam a queda dos Firbolg. ${ }^{509}$ Com este ponto de inflexão, a segunda metade de Temora abre com uma conflagração generalizada. Liderados por Fillan, o caçula de Fingal, os escoceses obrigam o exército de Cathmor a bater em retirada. Hipérboles convertem o jovem Fillan num "espírito dos céus", uma força irrefreável da natureza:

Recobrindo Lubar ecoante, esparrama-se a fuga de Bolga. Fillan seguia em seu encalço e cobria, com mortos, a charneca. [...] Mergulhado na guerra vermelha, a batalha se agita ao seu redor. Ou, avançando em meio ao embate escarpado, despeja a morte de milhares. Fillan é como um espírito dos céus, que desce à frente de sua borrasca. $\mathrm{O}$ oceano atormentado sente seus passos enquanto avança de onda para onda. Seu caminho alumia atrás de si; com os mares agitados, ilhas tremem suas coroas. ${ }^{510}$

Conquanto os irlandeses consigam reverter parcialmente os rumos da batalha, Fingal assume o comando de suas tropas e parte para o confronto final. Seu alarme de guerra ritualisticamente põe termo à impotência de outrora.

$\mathrm{O}$ rei pegou sua lança mortal e golpeou o escudo ressonante: seu escudo que à noite pende no alto, o lúgubre sinal da guerra! Fantasmas fugiram por todos os lados e pelo vento deslizaram suas figuras retorcidas. - Três vezes do vale sinuoso ergueram-se as vozes da morte. As harpas dos bardos, intocadas, soaram pesarosas pelas colinas. ${ }^{511}$

Afugentam-se as sombras de outros tempos. Literalmente, as vozes da morte (eco?) tentam por três vezes reagir, mas em vão. A amada de Cathmor, Sul-malla, interpreta corretamente a ameaça e exorta o chefe irlandês para que implore clemência. Ela antes o acompanhava incógnita, mas, ao ouvir o clangor, abandona seu disfarce e vem

\footnotetext{
${ }^{509}$ Trecho completo: "Half-mixed with the noise of the stream, he poured his feeble words" (idem, p. 258)

510 "Wide-spreading over echoing Lubar, the flight of Bolga is rolled along. Fillan hung forward on their steps; and strewed, with dead, the heath. [...] Deep-folded in red war, the battle rolls against his side. Or, striding midst the ridgy strife, he pours the deaths of thousands forth. Fillan is like a spirit of heaven, that descends from the skirt of his blast. The troubled ocean feels his steps, as he strides from wave to wave. His path kindles behind him; islands shake their heads on the heaving seas" (idem, p. 266-267).

511 "The king took his deathful spear, and struck the deeply-sounding shield: his shield that hung high in night, the dismal sign of war! - Ghosts fled on every side, and rolled their gathered forms on the wind.- Thrice from the winding vale arose the voices of death. The harps of the bards, untouched, sound mournful over the hill" (idem, p. 279). Laing, com a acrimônia característica, diz que fazer um escudo "ressoar, quando golpeado, como gongo indiano" ("resound, when struck, like an Indian gong") é mais um sinal da invencionice de Macpherson (LAING, Malcolm. "An historical and critical dissertation on the supposed authenticity of Ossian's poems". The history of Scotland, from the Union of the Crowns on the accession of James VI to the throne of England, to the Union of the Kingdoms in the reign of Queen Anne. Londres: I. Cadwell Jr and W. Davies, 1800, v. 2, p. 377-453, especialmente p. 398-399).
} 
falar com Cathmor. De início, ele pensa estar diante de uma "figura de antanho", 512 uma aparição. Mas a marcha de Fingal parece ter rompido definitivamente com o passado:

Não sou nenhum viajante da noite, nem uma voz de uma nuvem espiralada: mas eu te aviso do perigo de Erin. Ouviste aquele som? Não são os fracos, rei de Atha, que rufam seus alarmes pela noite! [...] Ele, que nunca se rende, aproxima-se. Acorda o bardo da paz! $!^{513}$

Sul-malla estava certa. Novamente, os caledônios vencem os Fir-bolg. Sobrevém uma tempestade, e "o inimigo encolheu na escuridão". ${ }^{514}$ Num duelo, Fingal fere Cathmor de morte. Significativamente, equipara-se a derrota do rei à rendição de uma linhagem: "Rende-se a raça de Borbar-duthul? Ou ele ainda ergue sua lança?". ${ }^{515} \mathrm{O}$ fantasma de Cathmor se desintegra no vento. Ao contrário de outros entes sobrenaturais no universo ossiânico, ele não interage com os vivos: passa ao largo até mesmo de sua amada, sem lhe dizer palavra. Vencido o inimigo, Fingal conduz o jovem Ferad-atho ao trono, último descendente dos reis caledônios na Irlanda. Pede para que Ossian o guie pelos salões de Temora e "Lembre-o dos reis de Erin, das imponentes figuras de antanho". 516

Nas notas ao "Livro Oitavo", no entanto, não há uma referência sequer à moral ou alegoria do poema, nem mesmo por vias oblíquas, com recurso a citações etc. Blair, infelizmente, limitou-se a seguir o método de Le Bossu somente na análise de Fingal. Quanto a Temora, reservou apenas alguns termos elogiosos, mas nada de relevante. Qualquer que tenha sido o ensinamento que o Ossian de Macpherson quisera transmitir, o certo é que Temora repercute numa clave completamente diferente. Se em Fingal escoceses e irlandeses se haviam unido contra o inimigo externo, agora os caledônios eram o que chamaríamos, do século XIX em diante, de uma nação imperialista. É pena que não havia um fantasma para prometer, à moda do Júpiter de Virgílio, um domínio sem fim ou, no máximo, plantations no Ulster.

512 “[...] a form from the times of old" (idem, p. 280)

513 "Nor traveller of night am I, nor voice from folded cloud: but I warn thee of the danger of Erin. Dost thou hear that sound? It is not the feeble, king of Atha, that rolls his signs on night. [...] He, who never yields, comes forth: Awake the bard of peace!" (idem, ibidem).

514 "In darkness shrunk the foe" (idem, p. 289).

515 "Yields the race of Borbar-duthul? Or still does he lift the spear?" (idem, p. 290)

516 "Remind him of the kings of Erin; the stately forms of old" (idem, p. 292). Para Weinbrot, essa restauração monárquica tinha inequívocas tintas jacobitas (WEINBROT, Howard D. Britannia's issue cit., p. 531). 


\section{2 \\ CONCILIAÇÃO NOVELÍSTICA}

\section{Totalidades paralelas}

A Dissertação de Hugh Blair e os paratextos assinados por Macpherson, cujos métodos expositivos buscamos recriar no capítulo anterior, encenam um persuasivo exercício de hermenêutica seletiva. ${ }^{1}$ Chancelam-se como épicas as longas narrativas ossiânicas por meio da conversão da antítese entre poema heroico primitivo e epopeia neoclássica em listagens imiscíveis de referenciais genéricos. Com efeito, estes se repartem em segmentos incomunicáveis, cada qual segundo uma lógica peculiar. Conforme demonstramos páginas atrás, secciona-se a discussão do "gênio e do espírito" de Ossian da análise "de acordo com as regras de Aristóteles". ${ }^{2} \mathrm{Na}$ Dissertação, a transição é muito bem sinalizada, a barrar contaminação teórica: "Depois dessas observações gerais sobre o gênio e o espírito de nosso autor, passo a um olhar mais detido e um exame mais preciso de suas obras". ${ }^{3}$ Explicitamente, propõem-se alternativas interpretativas que estariam em pé de igualdade: a chave primitivista não impediria a chave neoclássica, nem vice-versa. ${ }^{4} \mathrm{~A}$ sugestão de que o

\footnotetext{
${ }^{1}$ Dafydd Moore nos alerta para a tendência da crítica ossiânica em compartimentalizar as referências mobilizadas nas traduções de Macpherson. Embora esse alerta seja formulado noutro contexto, ele orienta meu argumento neste item. Ver MOORE, Dafydd. "Heroic incoherence in James Macpherson's The Poems of Ossian”. Eighteenth-century studies, v. 34, n. 1 (outono, 2000), p. 43-59, especialmente p. 51.

2 "[...] according to Aristotle's rules" (BLAIR, Hugh. "A critical dissertation on the Poems of Ossian, the son of Fingal". In: MACPHERSON, James. The poems of Ossian and related works. Ed. Howard Gaskill. Edimburgo: Edinburgh University, 1996, p. 358).

3 "After these general observations on the genius and spirit of our author, I now proceed to a nearer view, and more accurate examination of his works" (idem, ibidem).

${ }^{4}$ Macpherson, em suas anotações a Temora (cf. nossa discussão supra, p. 129-130), e Blair, na Dissertação, chegariam a alegar que a poesia primitiva e o receituário aristotélico derivavam da mesma fonte. Blair afirmaria que Aristóteles, "com grande sagacidade e perspicácia", teria formulado suas regras a partir de Homero. E "[t]anto Homero quanto Ossian escreveram a partir da natureza" ("Homer and Ossian both wrote from nature") (idem, ibidem). Esse mesmo argumento também se encontra em sua aula não publicada sobre os Poemas de Ossian (ver SUDO, Yoshiaki. "An unpublished lecture of
} 
estético é uma função do histórico não se confunde com a postulação de um tipo universal. Igualmente, afirmações peremptórias sobre a veracidade das narrativas ignoram especulações sobre a sua dimensão alegórica. Coordenam-se, assim, séries sintáticas em paralelo. Por exemplo: com a representação de uma ação una obteríamos a inteligibilidade, requisito para a transmissão de um ensinamento moral. Ou, reversamente, o domínio da contingência se traduziria numa elocução imediata, que, por sua vez, levaria à eclosão da performance do eu. Idealmente, essas séries existiriam em planos diversos, cada qual a entabular um diálogo em particular com um nicho do debate setecentista sobre a poesia épica.

Talvez essa fosse a única maneira de se assegurar a Fingal e Temora o prestígio inerente à designação épica, que tanto orgulho patriótico suscitou entre os escoceses. ${ }^{5}$ Trata-se de uma estratégia que tem o mérito inegável de conferir ressonância a um experimento literário tão inovador quanto ambicioso. Possibilitava-se o estabelecimento de uma relação em que as traduções de Macpherson simultaneamente se identificavam com e diferenciavam das obras mais prestigiosas de então. No entanto, o resultado dessa operação é uma inequívoca simplificação das narrativas ossiânicas.

À distância, a desconstrução de Fingal e Temora nas convenções críticas e criativas manifestamente mobilizadas por Macpherson pode até denunciar a complexidade de seu arranjo formal. Se fossem lidas em conjunto, essas convenções inevitavelmente ressignificariam sua designação, "um poema épico antigo". Dadas as múltiplas acepções evocadas para "poema", "épico" e "antigo", prenunciar-se-ia uma colcha de referências incompatíveis - e, o que é mais importante, haveria um hiato entre, de um lado, a uniformidade que tal designação genérica dá a entender e, de outro lado, a pluralidade de sentidos que ela efetivamente encerra. Contudo, dilui-se de maneira considerável essa tensão por meio do agenciamento alternado dos

Hugh Blair on the Poems of Ossian". The Hiyoshi review of English studies, v. 25 (março, 1995), p. 160-94, especialmente p. 174).

${ }^{5}$ Sobre como Blair e sua Dissertação silenciam o debate sobre a autenticidade de Ossian ao longo da década de 1760, ver MOORE, Dafydd. "The reception of The Poems of Ossian in England and Scotland". In: GASKILL, Howard (ed.). The reception of Ossian in Europe. Londres: Continuum, 2004, p. 21-39, especialmente p. 27-28. Sobre a maneira como a conciliação empreendida nos épicos ossiânicos balizou a sua recepção, ver PITTOCK, Murray. Scottish and Irish romanticism. Oxford: Oxford University, 2008, p. 73. 
protocolos à recepção dos ditos épicos ossiânicos. ${ }^{6}$ De modo sutil, evade-se a contradição fundamental entre o que o tradutor chama de uma "narrativa histórica", governada pelas leis da Fortuna, e uma "narrativa poética", organizada sob a premissa da unidade da ação. ${ }^{7}$ A título ilustrativo, detenhamo-nos numa passagem de Temora. Com seu propósito declarado de reescrever a história da Irlanda e de "sua antiga conexão com o norte e o sul da Grã-Bretanha", 8 Temora revolve em torno de rememorações das campanhas militares dos escoceses em Erin, seja para fins de colonização, seja para subjugar movimentos insurgentes das tribos do sul, os Fir-bolg. Algumas vezes, essas rememorações parecem diretamente ligadas à sensibilidade primitiva. No "Livro Segundo", Fillan e o Ossian-personagem conversam enquanto o exército de Cathmor se aproxima. $\mathrm{O}$ irmão mais moço reclama seu direito à glória. Dentre os jovens, só Oscar lhe seria superior. Ante a menção ao filho que acabara de morrer, Ossian pergunta em tom plangente: "Por quê, Fillan, falaste de Oscar, para fazer surgir o meu suspiro?" Caberia aos pais esquecerem dos mortos enquanto persiste o combate. Como exemplo, relata como Conar, "o filho da flumínea Morven" que unificara Erin sob seu cetro, ${ }^{10}$ só fora chorar a morte de seu filho, Colgar, depois de vencer os Fir-bolg:

Seu túmulo foi erguido sem uma lágrima sequer. $\mathrm{O}$ rei vingaria seu filho. - Relampeou na batalha, até que Bolga se rendesse em seus riachos.

Quando a paz voltou à terra, e suas ondas azuis levaram o rei a Morven: então ele se lembrou de seu filho e verteu a lágrima silenciosa. ${ }^{11}$

Em sua profusão, o discurso emocional contrabandeia a sugestão de que os irlandeses descendem dos caledônios. O derramamento primitivo é, todavia, requalificado por uma nota assinada pelo editor. Nessa nota, classifica-se o excurso como um "episódio", o qual fluiria naturalmente do diálogo dos irmãos e para o qual, em

\footnotetext{
${ }^{6}$ Essas observações são informadas a partir da discussão em BENNETT, Tony. "The sociology of genres: a critique". Outside literature. Londres - Nova Iorque: Routledge, 1990, p. 78-114, especialmente p. 81 e 108-109.

${ }^{7}$ Ver MACPHERSON, James. "Temora: an epic poem". The poems of Ossian and related works cit., p. 519, nota 31 .

8 "[...] its connection of old with the south and north of Britain [...]" (MACPHERSON, James. "A dissertation". The poems of Ossian and related works cit., p. 215). Ver também supra, p. 87 e 132.

9 "Why, Fillan, didst thou speak of Oscar, to call forth my sigh?" (MACPHERSON, James. "Temora: an epic poem". The poems of Ossian and related works cit., p. 207).

10 “[...] the son of streamy Morven" (idem, p. 238). Tal passagem foi citada supra, p. 132.

11 "His tomb was raised, without a tear. The king was to revenge his son.- He lightened forward in battle, till Bolga yielded at her streams. When peace returned to the land, and his blue waves bore the king to Morven: then he remembered his son, and poured the silent tear" (idem, ibidem).
} 
insinuação alegórica, "o poeta tinha um desígnio maior em mente". ${ }^{12}$ A disjunção entre o comentário e o entrecho ficcional desvanece-se num sistema de totalidades paralelas.

Previsivelmente, observa-se a reprodução desse sistema na fortuna crítica imediata a Fingal e Temora. ${ }^{13}$ Num extremo, encontra-se o arremate da resenha de Tobias Smollett sobre o primeiro épico ossiânico, ${ }^{14}$ apresentado como a corporificação de um tipo ideal. A maneira abstrata como se concebe o gênero literário permite até mesmo uma argumentação silogística:

[...] se a epopeia foi uma espécie de poesia instituída para celebrar as ações dos heróis, para que o ouvinte seja animado pelo exemplo de seus ancestrais; ou, se foi planejada para aperfeiçoar o coração, além de confortar a imaginação, ao comunicar as melhores lições de moralidade, no deleitoso veículo da expressão poética; e se se toma a obra como perfeita quando essas intenções são eficazmente preenchidas e satisfeitas, ousaremos declarar Fingal um poema épico perfeito - e, como tal, recomendá-lo à atenção do público. ${ }^{15}$

A epopeia seria uma instituição cujo plano (ou planejamento) é usado como medida da perfeição de uma obra. Só se lhe atribui "eficazmente" o qualificativo de épico caso se preencham ou satisfaçam os diversos requisitos do gênero. E mais: conforme indica o vocabulário empregado, conjuga-se a ação heroica ao ensinamento moral, sob a roupagem do preceito horaciano de deleitar para instruir. A poesia é "veículo" para "comunicar as melhores lições de moralidade". No polo oposto à resenha de Smollett, estão as Critical observations on the writings of the most celebrated original geniuses in poetry, de William Duff. Publicadas em 1770, contêm talvez uma das últimas análises, na Grã-Bretanha, dos escritos ossiânicos que ignoram

\footnotetext{
12 "[...] the poet had a farther design in view" (idem, p. 488, nota 13).

${ }^{13}$ Para Dafydd Moore, virtualmente toda a crítica aos Poemas de Ossian reproduz a tensão entre as noções neoclássica e primitivista da epopeia (ver MOORE, Dafydd. Enlightenment and romance in James Macpherson's The Poems of Ossian: myth, genre and cultural change. Aldershot: Ashgate, 2003, p. 5).

${ }^{14}$ Ver a discussão sobre a recepção de Smollett a Ossian supra, p. 24-25.

15 " [...] if the Epopœa was a species of poetry, instituted to celebrate the actions of heroes, that the hearer might be animated by the example of his ancestors; or if it was intended to improve the heart as well as to soothe the imagination, by conveying the best lessons of morality, in the delightful vehicle of poetical expression; and if the work is allowed to be perfect, when this intentions are effectually answered or fulfilled, we will venture to pronounce Fingal a perfect Epic poem, and as such recommend it to the attention of the public" ([SMOLLETT, Tobias]. "Article VII". "The critical review for the month of January, 1762". The critical review: or, Annals of literature. Londres, 1762, v. 13, p. 45-53, especialmente p. 53). Sobre a argumentação silogística de Smollett, ver MOORE, Dafydd. "The reception of The Poems of Ossian in England and Scotland" cit., p. 26. Moore argumenta, no entanto, que a resenha de Smollett é orientada precipuamente por simpatias patrióticas. Sem discordar dessa observação, parece-me claro que o entusiasmo de Smollett também deriva da maneira como Fingal satisfaz as noções tradicionais (i. e., neoclássicas) sobre a condução de uma epopeia.
} 
questionamentos quanto à sua autenticidade. ${ }^{16}$ Promove-se, como sinaliza o título, uma discussão orientada pelo conceito de gênio natural; e, como não poderia deixar de ser, os juízos literários se confundem com a apreciação do contexto histórico em que teriam surgido as composições a que se referem tais juízos. A abordagem proposta se justifica porque "os incidentes que encontramos nos poemas de Ossian são reais" e "os caracteres humanos neles exibidos são copiados da vida, ao invés de [serem] inventados". ${ }^{17}$ Os elementos que fazem heroica uma obra são dados pelo ambiente e, por isso, precederiam o momento de composição propriamente dito. Tivesse Ossian "escrito vinte poemas épicos, eles decerto seriam dignificados com os mesmos caracteres e preenchidos com os mesmos incidentes". ${ }^{18}$ As atenções se voltam, portanto, para a figura do gênio "detentor de uma sensibilidade extraordinária", canal por que se comunicam as condicionantes históricas. Ossian é autor, personagem e narrador, e Duff lida com sua representação - que toma como apresentação - como se estivesse diante de um ser de carne e osso, devotando-lhe admiração, piedade e simpatia:

O retrato que Ossian traça de si mesmo é, de fato, uma obra-prima. Ele não aparece apenas na condição de um guerreiro condecorado, tão generoso quanto bravo, e detentor de uma sensibilidade extraordinária, mas [também] na de um velho bardo venerável, sujeitado às mais melancólicas vicissitudes da fortuna, fraco e cego: o único sobrevivente de sua família, o último da raça de Fingal. Reunidas, todas essas circunstâncias tornam sua situação profundamente comovente. É impossível para alguém dotado do mais ínfimo sentimento ler a história que conta de suas desventuras sem se condoer ternamente e, em certa medida, delas participar. ${ }^{19}$

A voz do gênio natural, tão sujeita "às mais melancólicas vicissitudes da fortuna", prescinde dos requisitos elencados por Smollett, ante os quais se toma "a obra como perfeita". Seu efeito estético, com que se alcança a condição de "obra-prima", é

\footnotetext{
${ }^{16}$ Idem, p. 28-29.

${ }^{17}$ Trecho integral: "[...] the incidents we meet in the poems of Ossian are real, not fictitious, and [...] the human characters exibited in these are copied from life, rather than created" (DUFF, William. Critical observations on the writings of the most celebrated original geniuses in poetry. Being a sequel to the Essay on original genius. Londres, 1770, p. 78).

18 "Had he written twenty epic poems, they must have been dignified with the same characters, and filled up with similar incidents" (idem, p. 72).

19 "The portrait which Ossian has drawn of himself, is indeed a master-piece. He not only appears in the light of a distinguished warriour, generous as well as brave, and possessed of exquisite sensibility, but of an aged venerable bard, subjected to the most melancholy vicissitudes of fortune, weak, and blind; the sole survivor of his family, the last of the race of Fingal. All these circumstances united, render his situation deeply affecting; and it is impossible for one who has the least feeling, to read the history which he gives of his misfortunes, without tenderly commiserating, and in some measure participating them" (idem, p. 82).
} 
obtido pelo "retrato que Ossian faz de si mesmo", nele enfeixando "circunstâncias" que, "reunidas", "tornam sua situação profundamente comovente" para os leitores dotados até "do mais ínfimo sentimento".

Concorrentes, cada uma das leituras estanca a épica ossiânica numa soma coesa de categorias estáticas, em que a postulação ou do neoclássico ou do primitivo precede o próprio texto. ${ }^{20}$ Eliminam-se dissonâncias construtivas por meio da renúncia de qualquer tentativa de formular essas categorias a partir do texto - e entender como se sedimentam, também no texto, num processo de determinação recíproca: indissociáveis entre si e do que se chama de estrutura da obra. ${ }^{21}$ Uma passagem como a seguinte, de Fingal -

Muitas foram as mortes sob meu braço; e funesto era o fulgor de minha espada. Minhas madeixas ainda não eram tão cinzentas. Meus olhos ainda não se haviam cerrado na escuridão, nem meus pés falhado na corrida. ${ }^{22}$

-, é frequentemente identificada com o discurso primitivista, em que um narrador subjetivado não consegue refrear suas emoções: o eixo temporal de Ossian, presentificado, sobrepor-se-ia àquele do campo de experiência das personagens, que ordena os eventos vivenciados pelos heróis. ${ }^{23}$ Há que se notar, entretanto, que essa

\footnotetext{
${ }^{20}$ Até o final deste item, nossa tentativa de capturar a unidade dialética dos ditos épicos ossiânicos se orienta pela discussão marxista da economia política, em que se desenvolve um método para que, ao longo da análise, identidade e diferença sejam mantidas simultaneamente diante de nossos olhos (Ver MARX, Karl. "Introdução". Grundrisse. Trad. Mario Duayer; Nélio Schneider. São Paulo: Boitempo Rio de Janeiro: UFRJ, 2011, p. 39-64, especialmente p. 54 e ss.). Para um estudo sobre o método de Marx, ver: MUSTO, Marcello. "History, production and method in the 1857 'Introduction"”. In: MUSTO, Marcello (ed.) Karl Marx's Grundrisse: foundations of the critique of political economy 150 years later. Londres - Nova Iorque, 2008, p. 3-32 e, principalmente, HALL, Stuart. "Marx's notes on method: a 'reading' of the '1857 Introduction"'. Cultural Studies, v. 17, n. 2 (2003), p. 113-149. Acompanhamos também as aplicações desse método à literatura feitas por: WILLIAMS, Raymond. Marxism and literature. Oxford - Nova Iorque: Oxford University, 1977 (reimpr. 2009), p. 88-89 e, sobretudo, McKEON, Michael. The origins of the English novel, 1600-1740. Baltimore: Johns Hopkins University, 1987, p. 1-22, especialmente p. 15 e ss.

${ }^{21}$ Ainda hoje, muitos dos estudos ossiânicos mais importantes parecem incorrer nesse tipo de armadilha (ver, por exemplo, BYSVEEN, Josef. Epic tradition and innovation in James Macpherson's Fingal. Uppsala: Acta Universitatis Upsaliensis, 1982, passim). Talvez esse seja um reflexo das intermináveis discussões sobre a autenticidade das traduções de Macpherson.

22 "Many were the deaths of my arm; and dismal was the gleam of my sword. My locks were not then so gray; nor trembled my hands of age. My eyes were not closed in darkness; nor failed my feet in the race" (MACPHERSON, James. "Fingal: an epic poem". The Poems of Ossian and related works cit., p. 77).

${ }^{23}$ Nossa análise do tempo ficcional se vale de algumas categorias delineadas por HAMBURGER, Käte. A lógica da criação literária. Trad. Margot P. Malnic. 2. ed. São Paulo: Perspectiva, 1986, p. 4457. Sobre o esvaziamento da temporalidade do epos em Ossian, ver DUNCAN, Ian. "The pathos of abstraction: Adam Smith, Ossian, and Samuel Johnson". In: DAVIS, Leith; DUNCAN, Ian; SORENSEN, Janet (ed.). Scotland and the borders of romanticism. Cambridge: Cambridge University, 2004, p. 38-56, especialmente p. 47.
} 
inflexão subjetiva encontra-se atada à lógica do enredo, que, lembremo-nos, é organizado segundo o modelo virgiliano. O trecho citado pertence ao "Livro III" do primeiro épico ossiânico, ponto em que os escoceses desembarcam em Erin, para irmanarem-se às tropas de Cuchullin contra os invasores vindos de Lochlin. Antes da entrada em cena dos guerreiros de Morven, mantinham-se onisciência e objetividade, ${ }^{24}$ a despeito da introdução de alguns episódios amorosos. No momento de retorsão e saneamento épico da narrativa, ${ }^{25}$ com que Swaran será vencido e restabelecer-se-á a paz na Irlanda, o narrador assume a persona de Ossian, que expressa as saudades de seus dias de glória. O mesmo movimento que nos permite vislumbrar Fingal como uma epopeia neoclássica prefigura uma irrupção discursiva, ${ }^{26}$ atribuída à poética selvagem, com que se descontinua a intelecção do arranjo genérico herdado da tradição. A voz do narrador se subjetiva quando o universo evocado se torna plenamente inteligível e codificado. Ossian se torna "ossiânico" à proporção que se evidencia a distância entre seu presente de velhice e solidão e o ideal do herói épico (sublinhado por citações ao cânone), que testemunhara em sua juventude. A objetividade associada à epopeia é modulada pelo lamento de alguém que se vê e sente perpetuamente aquém de um parâmetro inatingível: "Muitas vezes lutei e muitas vezes venci na batalha da lança. Mas, cego, choroso e esquecido, agora caminho entre homens inferiores". ${ }^{27}$ Por outro lado, nem todas as intromissões da persona ossiânica obstam a cristalização de um arranjo genérico convencional. Pelo contrário: o narrador em primeira pessoa desponta como engrenagem imprescindível para a consecução de uma ação unitária. A liberdade tida como ínsita a seu modo presentacional naturaliza ou suaviza o manejo de analepses e prolepses, das quais tanto depende a dita "ordem artificial". ${ }^{28}$ No "Livro IV" de Fingal, pouco antes do confronto derradeiro, suspende-se a narrativa e muda-se do passado do "som da batalha" para o presente da "donzela de braços nevados". Ossian (narrador ou autor?) apostrofa sua nora, Malvina, para perguntar-lhe por que chora. Adianta-lhe que os escoceses triunfarão e que Oscar voltará para casa:

\footnotetext{
${ }^{24}$ Ver MADELÉNAT, Daniel. L'épopée. Paris: PUF, 1986, p. 24.

${ }^{25}$ Cf. a discussão supra, p. 115-116.

${ }^{26}$ Da oposição entre récit e discours (cf. BENVENISTE, Émile. "Les relations de temps dans le verbe français". Problèmes de linguistique générale. Paris: Gallimard, 1966, t. I, p. 237-250).

27 "Often have I fought, and often won in battles of the spear. But blind, and tearful, and forlorn I now walk with little men" (MACPHERSON, James. "Fingal: an epic poem". The Poems of Ossian and related works cit., p. 79)

${ }^{28}$ Cf. supra, p. 49 e 110.
} 
Esse era o som da batalha, donzela de braços nevados. Por que essa lágrima, criança das colinas? As donzelas de Lochlin têm por que chorar. A gente de sua terra tombou, pois sanguinário era o aço azul da raça de meus heróis. ${ }^{29}$

Analogamente, o diálogo de Fingal e Carril, nas últimas páginas do primeiro épico ossiânico, parece fechar sua ação ou enredo. Emissário de Cuchullin, Carril avisa o rei de Morven que seu chefe se retirara para "a lúgubre caverna de Tura", entregue a "pensamentos sobre a batalha que perdeu". ${ }^{30}$ Humilhado, Cuchullin professa submissão e envia sua espada ao herói escocês. Fingal rejeita a oferta e, generoso, proclama a grandeza marcial do campeão de Erin, dizendo que sua glória é imorredoura: "Não — respondeu o rei —, Fingal jamais tomará a sua espada. Seu braço é poderoso na guerra; e diga para ele que sua fama jamais cessará". ${ }^{31}$ Pondera sentenciosamente, num trecho que o público setecentista decerto leria como um ensinamento moral, que "[m]uitos foram os derrotados na batalha que depois brilharam como o sol do céu". ${ }^{32}$ Após absolver Erin de sua derrota, Fingal volta-se para Swaran, que acabara de subjugar, e estende-lhe o ensinamento, a magnanimidade e o símile solar:

Ó, Swaran, rei dos bosques ressoantes, põe fim a esse pesar. - Os derrotados, se bravos, são renomados: são como o sol por trás das nuvens, ao esconder sua face no sul, para depois olhar outra vez sobre as colinas de relva. ${ }^{33}$

A cena é, de certo modo, reminiscente da reconciliação lacrimosa de Aquiles e Príamo nos últimos livros da Ilíada. ${ }^{34} \mathrm{O}$ ciclo de desordem é completamente superado e a obra oferece-se à alegoria, conforme demonstramos no item 4.3.1 do capítulo

\footnotetext{
29 "Such was the noise of battle, maid of the arms of snow. Why, daughter of the hill, that tear? the maids of Lochlin have cause to weep. The people of their country fell, for bloody were the blue blades of the race of my heroes" (MACPHERSON, James. "Fingal: an epic poem". The Poems of Ossian and related works cit., p. 87 ).

${ }^{30}$ Trecho integral: "Cuchullin, said Carril of other times, lies in the dreary cave of Tura. [...] His thoughts on the battle which he lost" (idem, p. 102). Acima, analisamos essa cena com menos vagar. Ver supra, p. 119.

31 "No: replied the king, Fingal shall never take his sword. His arm is mighty in war; and tell him his fame shall never fail" (idem, ibidem).

32 "Many have been overcome in battle, that have shone afterwards like the sun of heaven" (idem, ibidem).

33 "O Swaran, king of the resounding woods, give all thy grief away.-The vanquished, if brave, are renowned; they are like the sun in a cloud when he hides his face in the south, but looks again on the hills of grass" (idem, ibidem). Ver QUINT, David. Epic and empire. Princeton, NJ: Princeton University, 1993, p. 348.

${ }^{34}$ Idem, ibidem.
} 
anterior. ${ }^{35}$ Certamente esse era um dos trechos que Blair tinha em mente ao decifrar em Fingal um elogio à moderação frente aos derrotados, a qual converteria inimigos hereditários em amigos. ${ }^{36}$ Moderação e generosidade que talvez os conterrâneos de Macpherson esperassem dos ingleses após o fracasso do Levante de 1745 contra a União. Como sentenciara o rei de Morven, mesmo os derrotados, se corajosos, tinham a sua glória. ${ }^{37}$ No entanto, a reiteração do símile solar (“como o sol por trás das nuvens") aponta para além do molde aristotélico. Indica-se a persistência de uma linguagem que proscreve abstrações, perpetuamente instada a fazer referências a fenômenos naturais para se fazer entender. Sob o impulso de concretizar as generalizações que o didatismo de Fingal presume, a narrativa se socorre da suposta incapacidade primitiva de refrear sua elocução e mergulha em exempla do passado, de perdedores que teriam conseguido livrar-se da vergonha e provar seu valor. Delega-se a palavra ao rei de Morven, que conta a história de Grumal, um antigo chefe escocês, da região de Cona. Sanguinário, buscava a batalha em todas as paragens. "Sua alma se regozijava no sangue; seu ouvido, no estrondo das armas". ${ }^{38}$ Sua belicosidade o levara a aportar nas Shetlands (mais precisamente, na ilha de Craca) acompanhado de suas tropas, para exigir do rei, na ponta da espada, a mão de sua filha. Malogram-se, contudo, as suas intenções. Depois de quatro dias de luta, Grumal seria feito prisioneiro e conduzido ao círculo de Brumo, "onde com frequência, diziam, os espíritos dos mortos uivam ao redor da rocha". ${ }^{39}$ Porém, Grumal brilhou - atente-se para o símile - "como um pilar de luz no céu" e triunfou sobre os fantasmas, recuperando sua reputação. Ao concluir a história, Fingal ordena aos bardos que cantem os heróis do passado, para que a mente de Swaran desanuvie. Com esse episódio, a dimensão alegórica da obra, para mantermos a imagem, é clara "como um pilar de luz". É inegável, todavia, que o aprofundamento, inclusive temporal e sobrenatural, no tema do valor dos derrotados produz uma coda que esgarça a unidade

\footnotetext{
${ }^{35}$ Ver supra, p. 120.

${ }^{36}$ No original: "[...] the most compleat victory over an enemy is obtained by that moderation and generosity which convert him into a friend" (BLAIR, Hugh. "A critical dissertation on the poems of Ossian". In: MACPHERSON, James. The Poems of Ossian and related works cit., p. 359). Trecho citado supra, p. 120.

${ }^{37}$ QUINT, David. Epic and empire cit., p. 346. Ver também WEINBROT, Howard D. Britannia's issue: the rise of British literature from Dryden to Ossian. Cambridge: Cambridge University, 1993, p. 530.

38 "His soul rejoiced in blood; his ear in the din of arms" (MACPHERSON, James. "Fingal: an epic poem". The Poems of Ossian and related works cit., p. 102).

39 “[...] where often, they said, the ghosts of the dead howled round the stone [...]" (idem, ibidem).
} 
de ação. Pensemos nalguns dos modelos canônicos. A Eneida encerra-se com a morte de Turno. O Paraíso perdido, com Adão e Eva a contemplar as solidões para além do Éden.

Os bardos obedecem ao comando de Fingal e centenas de vozes se erguem em uníssono para celebrar "os poderosos chefes dos anos antigos". ${ }^{40}$ Mas não somos informados como Swaran teria reagido ao canto dos bardos, se teria sido suficiente para dissipar sua tristeza. Sintomaticamente, susta-se a narrativa. A voz do narrador se subjetiva e presentifica. Ossian se pergunta quando tornará a ouvir a canção dos bardos:

Hoje em dia, quando ouvirei o bardo ou me regozijarei na fama de meus pais? A harpa não é tangida em Morven, nem a voz da música se levanta em Cona. Morto com os grandes está o bardo e a fama morreu no deserto. ${ }^{41}$

Novamente, o irromper da subjetividade ossiânica se apresenta como uma reação à narrativa neoclássica. Quando o universo épico parece pleno, dotado de sentido e investido de uma moral universalizável, cessa a representação e dá-se início à performance. Não há mais lição ou alegoria - as harpas já não tocam, os bardos já não cantam - para se comunicar: apenas a expressão do narrador, aquilo que se toma como a vazão não mediada de seu eu. Perde-se o controle do tempo, proporcionado pelo enredo completo e decodificável, porquanto a ele se impõe a interioridade de um Ossian vitimado pela Fortuna, apartado da História e sem qualquer esperança para o futuro.

A recuperação de todo esse emaranhado de determinações pressupõe um entendimento da obra como uma unidade dialética, uma unidade contraditória de elementos heterogêneos, projetando-se um modelo imaginativo para a conjugação de antinomias. ${ }^{42}$ Para tanto, é preciso superar o enquadramento épico demandado pelos protocolos à recepção de Fingal e Temora e empregado, sob perspectivas tão

\footnotetext{
40 “[...] the mighty chiefs of other years" (idem, ibidem).

41 "When now shall I hear the bard; or rejoice at the fame of my fathers? The harp is not strung on Morven; nor the voice of music raised on Cona. Dead with the mighty is the bard; and fame is in the desart no more" (MACPHERSON, James. "Fingal: an epic poem". The poems of Ossian and related works cit., p. 102).

${ }^{42}$ A teorização ora desenvolvida dialoga com JAMESON, Fredric. The political unconscious: narrative as a socially simbolic act. Ithaca, NY: Cornell University, 1981, p. 141. Ver também McKEON, Michael. "Generic transformation and social change: rethinking the rise of the novel". In: DAMROSCH Jr., Leopold (ed.). Modern essays on eighteenth-century literature. Nova Iorque Oxford: Oxford University, 1988, p. 159-180, especialmente p. 176.
} 
diferentes, por nomes como Duff e Smollett. Voltado para o passado, esse enquadramento se mostra rígido, pouco elástico. ${ }^{43}$ Seja pela compilação da prática inscrita no cânone, seja pela investigação das condições socioculturais necessárias ao seu pleno florescimento, o longo século XVIII havia progressivamente eliminado a possibilidade de novas intervenções no campo discursivo demarcado para o épico. ${ }^{44}$ Embora os poemas épicos continuassem altamente estimados (e produzidos), no centro do sistema educacional (de elite) de então, ${ }^{45}$ ou fossilizavam-se em prescrições supostamente deduzidas da razão ou convertiam-se em matéria de investigação arqueológica. Tratava-se de um gênero que se definia, portanto, pela negação do presente. ${ }^{46}$ Mesmo para os que asseveravam a permeabilidade da criação literária ao contexto, o influxo de contingências ambientais seria circunscrito a um período específico - já soterrado pelo tempo - da história humana. ${ }^{47}$ E aqueles que propunham uma definição mais lata do épico, a englobar da Faerie Queene ao Paraíso perdido, ${ }^{48}$ faziam-no a partir de uma perspectiva obituária, demarcando, pela identidade do conteúdo heroico, a sucessão das diversas manifestações de um fenômeno literário cujos elementos distintivos da forma se tornaram irrelevantes. O próprio Blair, nas

\footnotetext{
${ }^{43}$ As premissas deste argumento foram desenvolvidas a partir de: BERNSTEIN, J. M. The philosophy of the novel: Lukács, marxism, and the dialectic of form. Brighton: Harvester, 1984, p. $46 \mathrm{e}$ ss. e, sobretudo, BAKHTIN, Mikhail M. "Epic and novel”. The dialogic imagination. Trad. Michael Holquist; Caryl Emerson. Austin: University of Texas, 1981 (reimpressão, 2008), p. 3-40, especialmente p. 22.

${ }^{44}$ Para as transformações na forma tradicional do épico, da sua vertente miltônica até as traduções e os burlescos de Dryden e Pope, ver: VENTURO, David. "Understanding genre: epic, mock epic, and some versions of heroism, from Milton to Pope". In: DeMARIA, Robert; CHANG, Heesok; ZACHER, Samantha (ed.). A companion to British Literature: the Long Eighteenth Century, 1660 - 1830. Chinchester: Wiley-Blackwell, 2014, p. 1-18. Para uma discussão sobre a ossificação do épico e o crescente interesse antiquário que passou a suscitar ao longo do século XVIII, ver: STEWART, Susan. "Notes on distressed genres". The journal of American Folklore, v. 104, n. 411 (inverno, 1991), p. 531, especialmente p. 11-15.

${ }^{45}$ Ver CURTIUS, Ernst Robert. European literature and the Latin Middle Ages. Trad. William Trask. Princeton, NJ: Princeton University, 1990, p. 36.

${ }^{46}$ Para os primitivistas, o épico primário, como o de Homero, tornar-se-ia a face visível da alteridade da barbárie (cf. DENTITH, Simon. Epic and empire in nineteenth-century Britain. Cambridge: Cambridge University, 2006, p. 1-15). Dentith argumenta que o ressurgimento do épico com os ditos poemas nacionais, em que obras como a Kalevala e Idílios do rei (1859-1885), de Lorde Tennyson, seriam escritas ou "descobertas" no século XIX, não tem como prescindir do pastiche de estilos remotos, de uma linguagem arcaizante e da pesquisa folclorista e filológica (idem, p. 11 e passim). Obviamente, as composições ossiânicas forneceriam o modelo do qual se construiriam muitos dos épicos nacionais do século XIX. Anne Marie Thiesse, aliás, chega até a elaborar uma espécie de checklist, a partir do experimento ossiânico, de elementos que seriam recorrentemente apropriados ao longo de toda a Europa, do Atlântico aos Urais (THIESSE, Anne-Marie. La création des identités nationales: Europe XVIIIe-XXe siècle. Paris : Seuil, 1999, p. 17 e ss. e passim).

${ }^{47}$ Ver STEWART, Susan. "Notes on distressed genres" cit., p. 11.

${ }^{48}$ É o caso, outras vezes citado, de Richard Hurd. Ver: HURD, Richard. Letters on chivalry and romance: with the Third Elizabethan dialogue. Ed. Edith J. Morley. Londres: Henry Frowde, 1911, p. 115. Uma análise sumária de suas teses encontra-se supra, p. 55.
} 
suas Lectures on Rhetoric and Belles Lettres (1783), publicadas duas décadas depois da Dissertação, definiria a epopeia apenas como "narrativas poéticas de grandes aventuras", numa classificação que abarca "o Paraíso perdido de Milton, a Farsália de Lucano, a Tebaida de Estácio, Fingal e Temora de Ossian, os Lusíadas de Camões, a Henriada de Voltaire, o Telêmaco de Cambray, o Leônidas de Glover e a Epigoniad de Wilkie". 49 A epopeia seria vista, portanto, como algo pronto, acabado ou não contraditório (ou cujas contradições foram há muito esquecidas) ${ }^{50}$ um gênero cuja identificação se faz de pronto, dispensando-se o exame de pormenores. ${ }^{51}$

O próprio Macpherson dava sinais bastante claros de que não ignorava a rigidez unanimemente atribuída às composições épicas. Confrontem-se as intervenções editoriais para The Highlander, que publicara anonimamente em 1758 (cerca de três anos antes do aparecimento de Fingal), àquelas feitas ao redor das narrativas ossiânicas. Salvo melhor entendimento, em nenhuma das oitenta-e-uma páginas da edição original ${ }^{52}$ há prefácios ou notas ao pé ou à margem. ${ }^{53}$ Os paratextos não identificam a filiação épica do poema. A designação é neutra: simplesmente, "um poema em seis cantos". Aliás, usa-se o romanesco "canto" ao invés de "livro". A

\footnotetext{
${ }^{49}$ Trecho integral: "I therefore have no scruple to class such poems as Milton's Paradise Lost, Lucan's Pharsalia, Statius's Thebaid, Ossian's Fingal and Temora, Camoen's [sic] Lusiad, Voltaire's Henriade, Cambray's Telemachus, Glover's Leonidas, Wilkie's Epigoniad, under the same species of Composition with the Iliad and the Eneid [...]. They are, undoubtedly, all Epic; that is, poetical recitals of great adventures; which is all that is meant by this denomination of Poetry") (BLAIR, Hugh. Lectures on rhetoric and belles lettres. Ed. Linda Ferreira-Buckley; S. Michael Halloran. Carbondale: Southern Illinois University, 2005, p. 480). Em suma, a narrativa épica é, nas Lectures, uma narrativa heroica. A amplitude da formulação permite a inclusão de obras destituídas de unidade, no sentido tradicional e aristotélico do termo, como a Farsália e a Tebaida. Por outro lado, há que se notar que Blair afirmaria que "[e]m todos os grandes poemas épicos, a unidade de ação é suficientemente aparente" ("The unity of the Epic Action is not to be so strictly interpreted") (idem, p. 482). E que citaria nominalmente Aristóteles quanto à importância de a ação épica ter um começo, um meio e um fim. E que, na mesma linha, prescreveria "regras" para a inserção de episódios. Sobre a definição generalista de Blair, ver: MARTINS, Eduardo Vieira. A fonte subterrânea : José de Alencar e a retórica oitocentista. Londrina: Eduel - São Paulo: Edusp, 2005, p. 126.

${ }^{50}$ Ver BAKHTIN, Mikhail M. "Epic and novel" cit., p. 3.

${ }^{51}$ Ver BOWRA, C. M. From Virgil to Milton. Londres: Macmillan, 1945, p. 1.

${ }^{52}$ Consultamos: [MACPHERSON, James]. The Highlander: a poem: in six cantos. Edimburgo: Printed by Wal. Ruddiman jun. and Company, 1758 e MACPHERSON, James. "The Highlander". In: LAING, Malcolm (ed.). The poems of Ossian \&c., containing the poetical works of James Macpherson, Esq. in prose and rhyme: with notes and illustrations. Edimburgo, 1805, v. 2, p. 523-587. Nossa discussão sobre The Highlander será altamente derivada da de Fiona Stafford. Muitas das passagens analisadas por ela serão retomadas aqui (STAFFORD, Fiona. The sublime savage: James Macpherson and the Poems of Ossian. Edimburgo: Edinburgh University, 1988, p. 61-76, especialmente p. 66-74).

${ }^{53}$ Sobre a ausência de comentários, ver: LINDFIELD-OTT, Kristin. 'See Scot and Saxon coalesc'd in one': James Macpherson's The Highlander in its intellectual and cultural contexts, with an annotated text of the poem. Tese de Doutorado (PhD Dissertation). Saint Andrews: University of Saint Andrews, 2011, p. 3-4.
} 
epígrafe da folha de rosto até é de Virgílio, mas das Geórgicas. Em suma, versos e estrofes do poema chegam ao leitor quase sem mediação, como se eles, por si mesmos, conseguissem balizar a sua recepção. E, de fato, o metro é o dístico heroico, o mesmo das famosas traduções de Dryden e Pope. De saída, o "Eu canto" com que se abre a composição é inequivocamente alusivo aos versos inaugurais da Ilíada, Eneida e Paraíso perdido:

O jovem eu canto, que, desconhecendo a si mesmo, Perdido para o mundo e o trono da Caledônia, Surgiu das montanhas para os braços da Fama, E, nas asas do Destino, voltou para vingar seu pai. ${ }^{54}$ (I, 1-4)

O molde, por sua vez, é claramente virgiliano. Caledônios e saxões se unem contra a invasão viking, chefiada por Magnus, para, enfim, repeli-la. ${ }^{55}$ No momento de restauração da ordem, prenuncia-se a União de 1707 e a construção de um vasto império:

Vê o escocês e o saxão, amalgamados num só, Sustentam a glória de uma coroa.

A Bretanha não mais tremerá ante tempestades nativas Mas sobre nações temerosas erguerá seus braços. ${ }^{56}$ (V, 177-180)

Apesar do inegável fracasso estético, a forma neoclássica da epopeia é cristalina, a despeito da ambientação na Idade das Trevas. O dito conteúdo medieval é dissociado do enquadramento genérico, que lhe antecede. Diante disso, o aparato paratextual torna-se dispensável. Apenas quando Macpherson abandona o verso pela prosa e deriva a inteligibilidade neoclássica da espontaneidade dos tempos heroicos é que se vê compelido a proclamar insistentemente a qualidade épica de suas composições. ${ }^{57}$

\footnotetext{
54 "The youth I sing, who, to himself unknown,/ Lost to the world and CALEDONIA's throne,/ Sprung o'er his mountains to the arms of Fame,/ And, wing'd by Fate, his sire's avenger, came" (I, 1-4) ([MACPHERSON, James]. The Highlander cit., p. 3).

${ }^{55}$ O poema "Magnus", vale lembrar, é uma das fontes gaélicas de Fingal (ver THOMSON, Derick S. The Gaelic sources of Macpherson's 'Ossian'. Edimburgo - Londres: Oliver and Boyd (published for the University of Aberdeen), 1951, p. 59-69). Ver STAFFORD, Fiona. The sublime savage cit., p. 67. Ver também supra, p. 66.

56 "See SCOT and SAXON coalesc'd in one,/ Support the glory of the common crown./ BRITAIN no more shall shake with native storms, / But o'er the trembling nations lift her arms" (V, 177-180) (idem, p. 64). Sobre esta passagem, ver: WEINBROT, Howard D. Britannia's issue cit., p. 540.

${ }^{57}$ Para Kristin Lindfield-Ott, no entanto, a ausência de anotações ao Highlander se justifica pelo fato de o argumento do poema ser extraído de crônicas históricas. Os épicos ossiânicos, por sua vez, com sua historiografia inventada, precisariam das intervenções do tradutor/editor para se legitimarem. Tratar-se-ia de uma opinião persuasiava, não fosse o fato de passar ao largo das múltiplas questões
} 
Alguns leitores partilhariam dessa desconfiança de Macpherson quanto à flexibilidade da epopeia. Em projetos independentes, John Wodrow, Richard Hole e Ewen Cameron recriariam, entre 1771 e 1776, a prosa de Fingal em dísticos heroicos, que definiam a prosódia do Virgílio de Dryden e do Homero de Pope. ${ }^{58}$ Noutras palavras, domesticariam o bardo numa forma tida há muito como própria à epopeia, ${ }^{59}$ trazendo-o para um registro canônico, em que se esfumam seus compromissos antinômicos. Wodrow, aliás, seria bastante categórico. Nas mais de cem páginas que prefaciam sua versificação de Fingal, afirma que seu propósito é tornar "meu Ossian favorito mais largamente conhecido e mais universalmente aceitável". ${ }^{60}$ Para tanto, argumenta, seria preciso transcriá-lo sob uma roupagem recitativa, com que a proeminência do metro deixaria "o fio da narrativa" 61 mais evidente: "a narrativa apareceria menos fragmentada; as transições, mais suaves; e os conectivos, mais óbvios". ${ }^{62}$ Ainda que Wodrow professe uma admiração sem restrições às traduções de Macpherson, admite-se que elas contrariam o entendimento mais largo e universal do que viria a ser uma epopeia. Aparentemente, haveria algo a macular a univocidade que se espera de um poema épico. O metro e o ritmo requereriam, por conseguinte, ampla reformulação. As pausas e as modulações anapésticas dos segmentos iniciais do "Livro I" -

Cuchullin sat by Tura's wall; by the tree of the rustling leaf.-His spear leaned against the mossy rock. His shield lay by him on the grass. As he thought of mighty Carbar, a hero whom he slew in war; the scout of the ocean came Moran the son of Fithil. ${ }^{63}$

formais e estéticas suscitadas nas notas a Fingal e Temora (LINDFIELD-OTT, Kristin. 'See Scot and Saxon coalesc'd in one' cit., p. 4).

${ }^{58}$ Seguimos de muito perto: MITCHELL, Sebastian. "Macpherson, Ossian, and Homer's Iliad". In: BÄR, Gerald; GASKILL, Howard (ed.). Ossian and national epic. Oxford - Berna - Berlim Bruxelas - Frankfurt - Nova Iorque - Viena: Peter Lang, 2012, p. 55-71, especialmente p. 60-61. Algumas das passagens discutidas por Mitchell são retomadas aqui.

${ }^{59}$ Ver LAUGHLIN, Corinna. The Ossianic novel. Tese de Doutorado (PhD Dissertation). Seattle, WA: Washington University, 1998, p. 111. Embora Laughlin discuta extensamente as adaptações de Ossian a formas mais convencionais, ela passa ao largo das recriações de Woodrow, Hole e Cameron. Ver também supra, p. 22, nota 9.

60 “[...] my favourite OSSIAN more generally known and more universally acceptable" (WODROW, John. Fingal: an ancient epic poem. In six books. Translated into English heroic rhyme. Edimburgo, 1771, v. 1, p. xciii).

61 "[...] the thread of narration" (idem, ibidem).

62 "[...] the narration would appear less broken, the transitions more easy [sic], and the connection more obvious" (idem, p. xcix).

${ }^{63}$ MACPHERSON, James. "Fingal: an epic poem". The poems of Ossian and related works cit., $\mathrm{p}$. 55. A discussão da métrica do trecho leva-nos, excepcionalmente, a transcrevê-lo em inglês no corpo do texto. 
[Cuchullin sentava-se junto à muralha de Tura, ao pé da árvore de folhagem farfalhante. - Sua lança recostava sobre a rocha musgosa. Seu escudo descansa a seu lado, sobre a grama. Enquanto pensava no poderoso Carbar, um herói que matara em combate, surge a sentinela do oceano, Moran, o filho de Fithil.]

- dão lugar à marcha iâmbica (mais ou menos) precisa do pentâmetro:

Beneath a tree, with leafy honours crown'd

Cuchullin sits, the chief in war renown'd;

His spear against a mossy rock is laid;

His heavier arms upon the grass are spread.

By Tura's lofty walls, the hero sat,

Revolving in his mind green ERIN's fate;

Careful, concern'd, its danger to prevent,

Much he inquir'd, and many a message sent;

And from his faithful friends succour sought,

And all on Cormac ran his restless thought.

To his lov'd cause, the hero still divin'd

A dire event, in his presaging mind.

Yet, with a soul resolv'd, and unapall'd,

To guard his throne whenever danger call'd,

He thinks of former conquests in the field,

How th' invading foe he fore'd to yield;

He thinks of mighty CAIRBAR, whom in fight

He lately slew, and drove his friends in flight.

His hopes arise, dispell'd is ev'ry fear,

His heart bounds high, nor dreads th' impending war.

As thus he mus'd, and in his mind forecast

The future danger, and recall'd the past,

Lo! MoRAN, breathless, terror in his face,

The scout of ocean, came with hasty pace. ${ }^{64}$

[Sob uma árvore, coroado de honras frondosas,

Senta-se Cuchullin, o chefe renomado na guerra;

Sua lança sobre a rocha musgosa recosta;

Suas armas mais pesadas sobre a grama se espalham.

Junto às elevadas muralhas de Tura, sentava-se o herói,

Ponderando em sua mente o destino da verde Erin;

Cioso, preocupado, para o perigo prevenir,

Muito perguntou e muitas mensagens mandou;

E de seus fiéis amigos buscou socorro,

Só para Cormac agitava-se seu pensamento inquieto.

Para sua amada causa o herói pressagiava

Um terrível evento, em sua mente clarividente.

Ainda assim, com uma alma resoluta, e destemido,

Protegerá seu trono diante de qualquer perigo.

\footnotetext{
${ }^{64}$ WODROW, John. Fingal cit., p. 9-10.
} 
Lembra-se de antigas conquistas no campo de batalha,

Como forçara o inimigo invasor a se render.

Pensa no poderoso Cairbar, que na luta

Acabara de matar, e levara seus amigos à fuga.

Suas esperanças se elevam, dissipa-se cada temor,

Seu coração bate forte nem teme a guerra iminente.

Enquanto assim ele cismava e em seu coração previa

O perigo futuro e recordava-se do passado,

Vede!, Moran, esbaforido, o terror em seu rosto,

A sentinela do oceano, surge num passo apressado.]

Embora longa, a citação é bastante reveladora. Não é apenas pelo ritmo que se purgará Fingal de suas incongruências estruturais. Tediosa e repetitivamente, Wodrow busca limar eventuais arestas à unidade de ação, para que a "ordem artificial" fulgure isenta de questionamentos. Analepticamente, somos informados de que, antevendo a ameaça, Cuchullin solicitara o auxílio de amigos. Desde a primeira estrofe, insinua-se que navios vindos de Morven aportarão na Irlanda. Por outro lado, a "mente clarividente" de Cuchullin pressagia a derrota dos irlandeses ("um terrível evento"). As menções a suas antigas vitórias são contrabalançadas pela alusão persistente a seus temores. É impossível tomar o Fingal de Wodrow como uma narrativa espontânea ou imediata. Não há nada que um leitor setecentista creditaria a uma sensibilidade primitiva.

Verifica-se essa tendência uniformizadora também entre encarregados de verter Ossian para outro idioma. Igualmente, não é incomum eliminarem a prosa poética e sua instabilidade rítmica, em benefício de uma dicção mais homogênea, calcada em versificação com ares classicizantes. É o caso das versões de Pedro Montegón de Fingal e Temora, em hendecassílabos. ${ }^{65} \mathrm{Ou}$, com uma repercussão bem maior, dos sciolti de Melchiore Cesarotti. ${ }^{66}$ Mais de um século depois da publicação dos Poemas de Ossian, ainda se encontra a portuguesa Maria Adelaide Fernandes Prata a recriar Fingal, em 1867, numa combinação de decassílabos heroicos e sáficos. A abertura do "Livro I", citada duas páginas atrás, converte-se em versos semelhantes aos d'O Uraguai:

Por debaixo da trémula folhagem

D’uma arvore frondosa, descançava

\footnotetext{
${ }^{65}$ MONTIEL, Isidoro. Ossián en España. Barcelona: Planeta, 1974, p. 47 e ss. De acordo com Montiel, a tradução de Montegón, ex-jesuíta, é derivada daquela de Cesarotti.

${ }^{66}$ MATTIODA, Enrico. "Ossian in Italy: from Cesarotti to the theatre". In: GASKILL, Howard (ed.). The reception of Ossian in Europe cit., p. 274-302, especialmente p. 274-288.
} 
Cuchullin recostado n'um rochedo

Alcatifado d'urzes mil floridas,

E alli scisma de Tura junto aos muros.

Ao lado seu, na relva, o escudo e lança

Pousados elle tinha, imaginando

Em seu silencio vêr esse guerreiro,

Cairbar, ${ }^{67}$ que no campo da batalha

Outr'ora assassinara entre combates.

Eis que Moran, tremendo, lhe apparece,

Moran, de vigiar encarregado pelo vasto Oceano. ${ }^{68}$

Fernandes Prata resolve o hiato entre a rigidez da epopeia e o tecido contraditório de Fingal optando pela primeira variável. Seu Ossian português consegue ser mais identificável com a linhagem de Homero a Milton que o Ossian de Macpherson. Para outro grupo de leitores, no entanto, dentre os quais se inclui Clara Reeve, a percepção do referido hiato levava-os a desacreditar a moldura ostensiva do experimento ossiânico. ${ }^{69}$ Em The Progress of Romance (1785), a personagem Euphrasia, que vocaliza a opinião autoral, ${ }^{70}$ define os Poemas de Ossian como uma coleção de "todas as histórias tradicionais dos Highlands", costuradas numa peça harmoniosa pelo tear de Macpherson. Ainda assim, as composições dessa "coleção respeitável" lhe parecem dotadas de "marcas fortes de gênio e originalidade", pois são "ousadas e figurativas", além de bastante agradáveis. ${ }^{71}$ Num primeiro momento, Euphrasia não parece enxergar nenhum empecilho na reunião de todas essas observações num mesmo arrazoado. Mas tudo muda quando se chega ao caso específico da obra mais famosa da coleção, Fingal. Aqui, a coexistência de "costura harmônica" e

\footnotetext{
${ }^{67}$ Sic.
}

${ }^{68}$ OSSIAN. "Fingal. Poema em seis cantos". Trad. Maria Adelaide Fernandes Prata. In: BÄR, Gerald (coord.). Poesias de Ossian: antologia da poesia ossiânica traduzida em português. Lisboa: Universidade Católica, 2010, p. 171. Para uma discussão sobre a tradução de Maria Adelaide Fernandes Prata, ver: BÄR, Gerald (ed.). "Ossian in Portugal”. In: GASKILL, Howard (ed.). The reception of Ossian in Europe cit., p. 351-374, especialmente p. 370-373 e BUESCU, Maria Gabriela Carvalhão. Macpherson e o Ossian em Portugal: estudo comparativo-translatológico. Lisboa: Colibri, 2001, p. 187 e ss. A despeito da prosódia classicizante, Buescu aponta a sucessão de imagens ultrarromânticas que animam a tradução de Fernandes Prata.

${ }^{69}$ Para uma discussão en passant da avaliação de Clara Reeve sobre Fingal e os Poemas de Ossian, ver SCHOLES, Robert; KELLOGG, Robert. The nature of narrative. Londres - Oxford - Nova Iorque: Oxford University, 1968, p. 7.

${ }^{70}$ Cf. SPACKS, Patricia Meyer. Desire and truth: functions of plot in eighteenth-century English novels. Chicago - Londres: University of Chicago, 1990, p. 26.

${ }^{71}$ Eis o trecho integral: "I believe that Mr. Macpherson collected all the traditional stories of the Highlands, that he put them in his own loom and wove them into a regular piece. His works bear strong marks of genius and Originality, they are bold and figurative, and some of them are highly pleasing. It is certainly a very respectable collection" ([REEVE, Clara]. The Progress of romance, through times, countries, and manners; with remarks on the good and bad effects of it, on them respectively: in a course of evening conversations. Colchester, 1785, v. 2, p. 66-67). 
"originalidade" leva Euphrasia a reavaliar os limites do enquadramento imposto pelo tradutor:

Fingal é indubitavelmente um épico, mas não um poema. Não posso dar esse nome ao que não é nem prosa nem verso. Esse tipo de escrita corrompe e estraga nossa língua e destrói a barreira, erguida pela natureza, para distinguir a poesia da prosa. ${ }^{72}$

Euphrasia descortina a dialética entre a forma ideal e a amorfia que "destrói a barreira" natural que "distingu[e] a poesia da prosa", resultando num tecido que "é indubitavelmente um épico", mas para o qual, simultaneamente, falta algo de essencial para que se lhe outorgue tal qualificativo. A flexibilidade formal de Fingal é, por assim dizer, o tiro de morte na sua epicidade.

Dentre os escritos setecentistas publicados sob a rubrica do épico, ${ }^{73}$ os de maior ressonância foram aqueles que deixaram explícito como o gênero se tornara rígido, autossuficiente e, por consequência, descolado do presente. As traduções de Virgílio e Homero, empreendidas respectivamente por Dryden e Pope, podem ser entendidas como capitulações de dois escritores que, por muito tempo, ambicionaram a conquista da musa épica. ${ }^{74}$ Essa conquista só seria possível pela tradução ou pela via do burlesco. $^{75}$ Tanto Dryden quanto Pope esvaziariam a forma do épico de sua dimensão heroica, reduzindo-a a um punhado de fórmulas que, trazidas para seu quotidiano, mostravam-se absurdas ou risíveis. Em Absalom and Achitophel (1681), recria-se um passado convenientemente remoto -

Em tempos piedosos, antes de o sacerdócio existir,

Antes de a poligamia ser feita um pecado;

Em que o homem, com muitas, multiplicava-se,

Antes que um, detestavelmente, ao outro se confinasse:

\footnotetext{
72 "Fingal is undoubtedly an Epic, but not a Poem.-I cannot give that name to what is neither prose nor verse - this sort of writing corrupts and spoils our language, and destroys, which nature has placed, to distinguish between poetry and prose" (idem, v. 2, p. 67).

${ }^{73}$ Obviamente, os épicos publicados durante o longo século XVIII, de Prince Arthur (1697), de Richard Blackmore a The Epigoniad (1757), podem ser classificados como neoclássicos.

${ }^{74}$ John Dryden publicou sua tradução da Eneida em 1697. A tradução poperiana da Ilíada apareceria entre 1715 e 1720. A da Odisseia, nos anos de 1725 e 1726. Sobre a tradução de Dryden da Eneida, ver THOMAS, Richard F. Virgil and the Augustan reception. Cambridge: Cambridge University, 2004, p. 122-153. Para os projetos épicos abandonados por Dryden e Pope, ver: BROICH, Ulrich. The eighteenth-century mock-heroic poem. Trad. David Henry Wilson. Cambridge: Cambridge University, 1990, p. 5. Quanto às ambições épicas de Pope e sua epopeia jamais terminada, intitulada Brutus, ver: TORCHIANA, Donald T. "Brutus: Pope's last hero". The journal of English and Germanic Philology, v. 61, n. 4 (outubro, 1962), p. 853-867.

${ }^{75} \mathrm{BROICH}$, Ulrich. The eighteenth-century mock-heroic poem cit., p. 5 e ss. Para Broich, as traduções de Dryden e Pope, imensamente influentes, são "as verdadeiras" epopeias do período neoclássico. Ver também idem, p. 110.
} 
Quando a natureza comandava e nenhuma lei negava

O uso promíscuo da noiva e da concubina. ${ }^{76}$

(1-6)

- para alegorizar a rebelião do Duque de Monmouth, filho bastardo do rei Carlos II, supostamente insuflado pelo Conde (Earl) de Shaftesbury, contra a ascensão de Jaime II. O tema, a ambientação e as personagens são nominalmente retirados da Bíblia. No lugar de Monmouth, Shaftesbury e Carlos II, temos Absalão, Aitofel e Davi, numa narrativa que parodia a tópica de reis, guerras e conselhos. Ao fim, triunfam as forças reais, auxiliadas pela maquinaria divina. Após um discurso inflamado de Davi, em que jura derrotar os rebeldes, Deus exibe o máximo de potência com o mínimo de esforço:

[...] O Todo-poderoso, acenando, deu consentimento;

E ribombos de trovão chacoalharam o firmamento.

Doravante, um novo tempo começou.

Em procissão perfilaram os poderosos anos:

Mais uma vez, o divino Davi foi restaurado,

E nações concordes reconheceram seu legítimo senhor. ${ }^{77}$

(1026-1031)

Como no molde virgiliano, restabelece-se a ordem e, para Carlos II, divisa-se um futuro imperial. ${ }^{78}$ Analogamente, Mac Flecknoe (1682) se vale da promessa de hegemonia para satirizar a poesia de Shadwell, a quem Dryden imputava a degeneração intelectual de seu tempo. ${ }^{79} \mathrm{O}$ domínio que Júpiter prometera a Enéas transforma-se na tirania da mediocridade: "Em prosa e verso, era tido, sem disputa,/ Por todos os reinos do absurdo, absoluto". 80

A derrocada da inteligência também é o tema de The dunciad (A Asníada), de Alexander Pope. Publicado em duas versões - a primeira de 1729 e a segunda, entre

\footnotetext{
76 "In pious times, e'r Priest-craft did begin,/ Before Polygamy was made a sin;/ When man on many multiply'd his kind,/ E'r one to one was, cursedly, confind,/ When Nature prompted, and no law deny'd/ Promiscuous use of Concubine and Bride" (1-6) (DRYDEN, John. "Absalom and Achitophel”. The poems of John Dryden. Ed. James Kinsley. Oxford: Clarendon, 1958, v. 1, p. 217).

77 “[...] Th' Almighty, nodding, gave Consent;/ And Peals of thunder shook the Firmament./ Henceforth a Series of new time began,/ The mighty Years in long Procession ran:/ Once more the Godlike David was Restor'd,/ And willing Nations knew their Lawful Lord" (1026-1031) (idem, p. 243).

${ }^{78}$ QUINT, David. Epic and empire cit., p. 30. Ver a discussão supra, p. 109-111. Tratava-se, na verdade, de uma segunda Restauração: "Mais uma vez, o divino Davi foi restaurado". Carlos II já houvera recuperado o poder real em 1660, após um interregno os onze anos de governo parlamentar e do Protetorado de Cromwell.

${ }^{79}$ MARESCA, Thomas. Epic to novel. Columbus: Ohio State University, 1974, p. 69.

80 "In Prose and Verse, was own'd, without dispute/ Through all the Realms of Nonsense, absolute" (5-6) (DRYDEN, John. "Mac Flecknoe”. The poems of John Dryden cit., v. 1, p. 265).
} 
1742 e 1743 -, esse épico burlesco-satírico "celebra" o triunfo da Estupidez (Dulness)

(Obtusidade, na tradução de Paulo Vizioli), deusa cuja causa é defendida por seu filho e sacerdote: na versão de 1742 e 1743, o ator e poetastro Colley Cibber. Na conclusão do "Livro IV", vaticinam-se a morte das ciências e o sufocamento da cultura. A Musa se curva à Estupidez:

Em vão, em vão... A criativa Hora beata

Tomba sem resistir a Musa à Deusa acata.

Ela vem! Ela vem! No trono ei-la afinal

Do Caos antigo e de sua Noite primordial!

Ante ela, as nuvens de ouro perde a Fantasia,

E a seu arco-íris variegado renuncia.

Seus momentâneos fogos lança o Engenho em vão,

O meteoro cai e expira num clarão.

[...]

Assim, à vinda dela e a seu potente açoite,

Arte após Arte vai-se embora, e tudo é Noite.

A seu antro a Verdade esquiva torna à pressa,

Com pilhas de casuísmo em cima da cabeça!

$[\ldots]$

Nenhum clarão, privado ou público, ilumina;

Não existe centelha humana nem divina.

Eis restaurado, CAOS, o teu império acerbo;

A Luz sucumbe face o teu estéril verbo;

À cortina, grande Anarca, vem fechar tua mão,

E enterra a Tudo universal Escuridão! ${ }^{81}$

(IV, 627-634, 639-644, 651-656)

O padroado da Estupidez é a perversão suprema do que tradicionalmente se entendia por epopeia. ${ }^{82}$ Disfarçada como Mentor, o amigo de Ulisses, Atena guiara Telêmaco em sua jornada à procura de seu pai. Cristo, o herói do Paraíso perdido, é usualmente identificado como o logos. A instrução moral era a finalidade que tantos, como Le Bossu, atribuíam-lhe. Agora, a degeneração cultural faz com que “[...] a farsa e o

\footnotetext{
${ }^{81}$ POPE, Alexander. “A asníada - (Do Livro IV) (1745) [sic]: O triunfo da Obtusidade”. Poemas. Trad. Paulo Vizioli. São Paulo: Nova Alexandria, 1994, p. 109. No original: "In vain, in vain,- the allcomposing Hour/ Resistless falls: the Muse obeys the Pow'r./ She comes! she comes! the sable Throne behold/ Of Night Primæval, and of Chaos old!/ Before her, Fancy's gilded clouds decay,/ And all its varying Rain-bows die away./ Wit shoots in vain its momentary fires, / The meteor drops, and in a flash expires./ [...] Thus at her felt approach, and secret might,/ Art after Art goes out, and all is Night./ See sulking Truth to her old Cavern fled,/ Mountains of Casuistry heap'd o'er her head!/ [...] Nor public Flame, nor private, dares to shine;/ Nor human Spark is left, nor Glimpse divine!/ Lo! thy dread Empire, CHAOS is restor'd;/ Light dies before thy uncreating word;/ Thy hand, great Anarch! lets the curtain fall;/ And Universal Darkness buries All” (IV, 627-634, 639-644, 651-656) (POPE, Alexander. "The dunciad". Poetry and prose of Alexander Pope. Ed. Aubrey Williams. Boston: Riverside, 1969, p. 377-378).

${ }^{82}$ MARESCA, Thomas. Epic to novel cit., p. 105, 128-129.
} 
épico corr[a]m misturados". ${ }^{83}$ Mergulham-se os lugares-comuns do gênero em sordidez e baixeza. Os embates atléticos entre guerreiros em busca de honrarias, como ocorre no "Livro XXIII" da Ilíada e no "Livro V" da Eneida, tornam-se provas obscenas, marcadas pela coprologia, em que os desafetos literários de Pope disputam competições de nado livre numa piscina de fezes e, como na citação abaixo, urina em distância: ${ }^{84}$

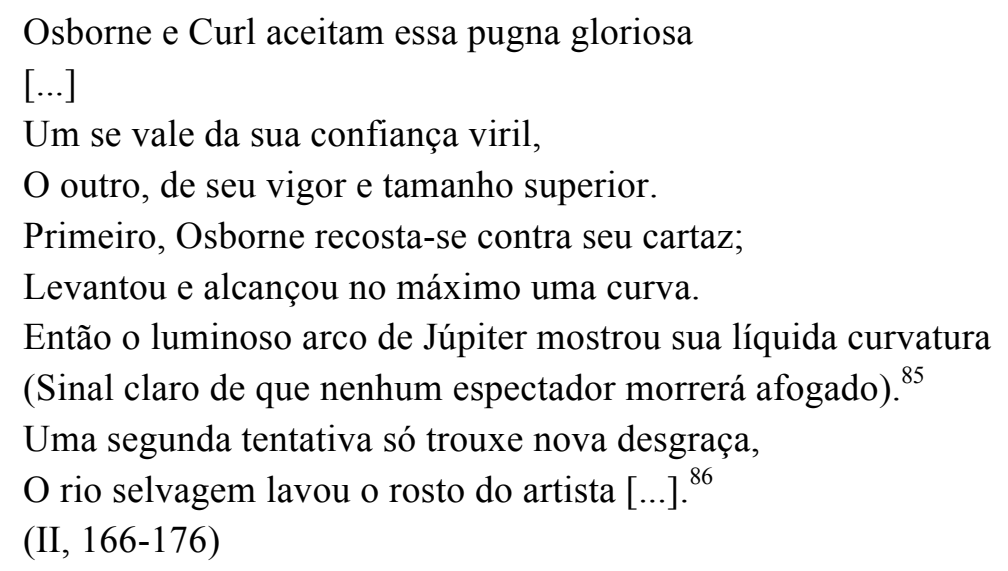

Conquanto despido do ímpeto libelista de The dunciad ou mesmo dos poemas de Dryden, pode-se considerar The rape of the lock $(1712,1714$, 1717), em razão de sua simetria formal, o mais consistente exercício de deflação da epopeia. ${ }^{87}$ Paradoxalmente, o mais bem acabado épico burlesco é exatamente aquele que mais fielmente segue os preceitos neoclássicos para a composição da epopeia. ${ }^{88}$ Já no prefácio, uma epístola dirigida a Mrs Arabella Fermor, comparam-se os antigos poetas épicos às "senhoras modernas": por mais trivial que seja a ação, sempre lhe atribuem a mais alta importância. ${ }^{89}$ A disparidade entre o modo de representação e a temática é assentada logo nos primeiros versos: "Os rancores cruéis que vêm do amor

\footnotetext{
83 "[...] Farce and Epic get a jumbled race" (I, 70) (POPE, Alexander. "The dunciad". Poetry and prose of Alexander Pope cit., p. 310).

${ }^{84}$ Ver BROICH, Ulrich. The eighteenth-century mock-heroic poem cit., p. 147.

${ }^{85}$ Sobre a tópica do arco-íris, veja-se a discussão supra, p. 104 e ss.

86 "Osborne and Curl accept the glorious strife/ [...] One on his manly confidence relies,/ One on his vigour and superior size./ First Osborne lean'd against his letter'd post;/ It rose, and labour'd to a curve at most./ So Jove's bright bow displays its wat'ry round,/ (Sure sign that no spectator shall be drown'd)/ A second effort brought but new disgrace,/ The wild Meander wash'd the artist's face" (II, 166-176) (POPE, Alexander. "The dunciad". Poetry and prose of Alexander Pope cit., p. 328).

${ }^{87}$ Ver MARESCA, Thomas. Epic to novel cit., p. 91 e ss.

${ }^{88}$ Esse paradoxo é discutido por BROICH, Ulrich. The eighteenth-century mock-heroic poem cit., $\mathrm{p}$. 112 e 120 e ss.

${ }^{89}$ POPE, Alexander. "The rape of the lock". Poetry and prose of Alexander Pope cit., p. 79.
} 
fatal,/ As contendas febris que brotam do trivial/ Eu canto [...]". ${ }^{90}$ Passo a passo, as convenções do épico vão nulificando o heroico. Ou melhor: os símbolos, as premissas sociais e, sobretudo, a tópica do heroísmo tornam-se uma função do cômico, numa simbiose que vai além da sátira ou da paródia. Ao invés do furioso Aquiles ou do piedoso Enéas, temos Belinda, uma aristocrata dada ao carteado, acompanhada de um totó a tiracolo. Ao invés de deuses, silfos e gnomos intervêm na peleja. Ao invés de uma batalha, uma partida de arrenegada (espécie de voltarete), em que os títulos nobiliárquicos e as patentes militares dão lugar às figuras do baralho.

Eis quatro Reis, em majestade venerada,

Com suíças grisalhas, barba bifurcada;

Quatro lindas Rainhas, flores sustentando,

Os claros símbolos de seu poder mais brando;

Quatro Valetes bem cingidos, fiel guarda,

Barrete na cabeça e a alabarda;

E tropas multicolores, um fulgor em tudo,

Prestes à luta na planície de veludo. ${ }^{91}$

(III, 37-44)

The rape of the lock mostra o descolamento da modernidade, ao menos das classes mais altas, de qualquer ideal de heroísmo. Os aristocratas de Pope não têm, para citarmos Le Bossu, "consequência política" 92 nem lideram tropas para além da "planície de veludo". Sua vida de luxo, lazer, "cantos, risos, olhadelas, e o que mais"93 reúne exatamente os atributos cuja ausência Blackwell via como necessária para o florescimento do gênio homérico. ${ }^{94}$ De acordo com o regime de preconceitos do século XVIII, o ambiente de recreação e frivolidade pavimentaria o caminho para a efeminação dos costumes. Aqui, a ação representada é invariavelmente pequena,

\footnotetext{
${ }^{90}$ POPE, Alexander. “A violação da madeixa”. Poemas. Trad. Paulo Vizioli cit., p. 47 (com modificações). No original: "What dire Offence from am'rous Causes springs,/ What mighty Contests rises from trivial Things/ I sing [...]" (I, 1-3) (POPE, Alexander. "The rape of the lock". Poetry and prose of Alexander Pope cit., p. 81).

${ }^{91}$ POPE, Alexander. “A violação da madeixa”. Poemas. Trad. Paulo Vizioli cit., p. 65. No original: "Behold four Kings in Majesty rever'd,/ With hoary Whiskers and a forky Beard;/ And four fair Queens, whose hands sustain a Flow'r,/ Th' expressive Emblem of their softer Pow'r;/ Four Knaves in Garbs succinct, a trusty Band,/ Caps on their heads, and Halberds in their hand/ And Particolour'd Troops, a shining Train,/ Draw forth to Combat on the Velvet Plain" (III, 37-44) (POPE, Alexander. "The rape of the lock". Poetry and prose of Alexander Pope cit., p. 88).

${ }^{92}$ LE BOSSU, René. Traité du poëme épique. Paris, 1705, p. 273-280. Ver supra, p. 47.

${ }^{93}$ POPE, Alexander. “A violação da madeixa”. Poemas. Trad. Paulo Vizioli cit., p. 63. No original: "[...] singing, laughing, ogling, and all that" (III, 18) (POPE, Alexander. "The rape of the lock". Poetry and prose of Alexander Pope cit., p. 88). Para um cometário dessa passagem, ver BROICH, Ulrich. The eighteenth-century mock-heroic poem cit., p. 115.

${ }^{94}$ BLACKWELL, Thomas. An enquiry into the life and writings of Homer. Londres, 1735, p. 26-27 e 69. Veja a discussão supra, p. 57.
} 
insignificante e privada. Por consequência, a écfrase do escudo ou da armadura de Aquiles se converte na descrição dos cosméticos, da toalete e do toucador de Belinda. E a moral, com que se alegoriza a narrativa, deixa de ser dirigida a reis e príncipes; passa a instruir as "beldades" à espera de "dândi alvi-enluvado" sobre a fragilidade da beleza:

\author{
Por que às beldades dão louvor todos os lábios, \\ O brinde dos vaidosos e a paixão dos sábios? \\ Por que com tantos dons da terra andam ornadas, \\ Chamados anjos, e como anjos adoradas? \\ Por que ao coche lhes cerca o dândi alvi-enluvado, \\ E inclina-se ao fundo do camarote ao lado? \\ Para não serem vãos tal glória e afã, convém \\ Que o bom senso preserve o que a beleza obtém; \\ Assim dirão de nós, honrando o melhor posto: \\ "Eis a primeira na virtude e pelo rosto!" \\ Oh! Se dançar a noite e se enfeitar de dia \\ Contra a varíola e a idade fossem garantia, \\ Por deveres do lar quem não teria desdém? \\ E algo de utilidade aprenderia alguém? \\ [...] \\ Mas, ai!, como a frágil beleza passar deve \\ E, frisados ou não, os cachos serão neve ${ }^{95}$ \\ (V, 9-26)
}

Recomenda-se às altivas senhoras, portanto, que não se fiem demais em sua beleza e que cultivem outras qualidades. Do contrário, poderão sofrer a mais terrível das punições: "morrer donzela".

[...] pintada ou não, definha toda bela -

E a que despreza os homens vai morrer donzela;

Que mais resta que usar nosso poder humano,

Mantendo-se o bom-humor qualquer que seja o dano?

O bom humor, querida, faz melhor trabalho

Que afetação e fuga e gritaria e ralho.

Que vire os lindos olhos a beldade em vão;

O belo atrai o olhar; mas à alma, a retidão. ${ }^{96}$

\footnotetext{
${ }^{95}$ POPE, Alexander. "A violação da madeixa”. Poemas. Trad. Paulo Vizioli cit., p. 83. No original: "Say, why are Beauties prais'd and honour'd most,/ The wise Man's Passion, and the vain Man's Toast?/ Why deck'd with all that Land and Sea afford,/ Why Angels call'd, and Angel-like ador'd?/ Why round our Coaches crowd the white-glov'd Beaus,/ Why bows the Side-box from its inmost Rows?/ How vain are all these Glories, all our Pains,/ Unless good Sense preserve what Beauty gains:/ That Men may say, when we the Front-box grace,/ Behold the first in Virtue, as in Face!/ Oh! if to dance all Night, and dress all Day,/ Charm'd the Small-pox, or chas'd old Age away;/ Who would not scorn what Huswife's Cares produce,/ Or who would learn one earthly Thing of Use?/ [...] But since, alas! frail Beauty must decay,/ Curl'd or uncurl'd, since Locks will turn to grey" (V, 9-26) (POPE, Alexander. "The rape of the lock". Poetry and prose of Alexander Pope cit., p. 97).
} 
$(\mathrm{V}, 27-34)$

De maneira sutil, constrói-se a ação unitária para a qual a alegoria é a culminância lógica. Inicia-se o poema, obviamente, in medias res, com que se explicitam as relações de causalidade que ordenam a representação. A narrativa se torna inteligível e o evolver dos acontecimentos inevitáveis. Logo na primeira cena, prenuncia-se que algo terrível recairá sobre Belinda. Enquanto ela "apertava o fofo travesseiro", 97 Ariel, seu silfo da guarda, vaticina que lhe "ameaça horrendo evento arcano", instando-a para que fique "atenta a tudo, e, mais que tudo, ao homem". ${ }^{98}$ Apesar do alerta, o coquetismo de Belinda obsta qualquer precaução. Parte para Hampton Court e lá, na terceira tentativa, o Barão consegue cortar-lhe uma madeixa. Quando ela se dá conta do ocorrido, traz à tona presságios cujo sentido falhara em interpretar: uma caixinha que caíra por três vezes, a porcelana que tremeu sem motivo aparente e os cães que não paravam de latir. A forma neoclássica da epopeia se articula plenamente, sem deixar margem para dúvidas.

A acomodação antitética promovida por Dryden e, sobretudo, Pope no interior de um gênero fixo, hereditário, acaba por desconstituí-lo. Embora a apreensão dos elementos épicos seja uma etapa incontornável de qualquer tentativa de se compreender Absalom and Achitophel e The dunciad, tais elementos se integram a um jogo de determinações na estrutura da obra, com que, em última instância, perdem sua autonomia e tornam-se peças numa outra engrenagem imaginativa. ${ }^{99}$ Fossilizado para comunicar as incertezas do presente, o épico se torna uma ferramenta essencial,

\footnotetext{
${ }^{96}$ POPE, Alexander. “A violação da madeixa”. Poemas. Trad. Paulo Vizioli cit., p. 83. No original: “[...] paint'd, or not paint'd, all shall fade,/ And she who scorns a Man, must die a Maid;/ What then remains, but well our Pow'r to use,/ And keep good Humour still whate'er we lose?/ And trust me, Dear! good Humour can prevail,/ When Airs, and Flights, and Screams, and Scolding fail./ Beauties in vain their pretty Eyes may roll;/ Charms strike the Sight, but Merit wins the Soul” (V, 27-34) (POPE, Alexander. "The rape of the lock". Poetry and prose of Alexander Pope cit., p. 97). Para uma análise da configuração da moral em The rape of the lock e a tradição neoclássica, ver: BROICH, Ulrich. The eighteenth-century mock-heroic poem cit., p. 118-119.

${ }^{97}$ POPE, Alexander. "A violação da madeixa". Poemas. Trad. Paulo Vizioli cit., p. 47. No original: "Belinda still her downy Pillow prest" (I, 19) (POPE, Alexander. "The rape of the lock". Poetry and prose of Alexander Pope cit., p. 90).

${ }^{98}$ POPE, Alexander. "A violação da madeixa". Poemas. Trad. Paulo Vizioli cit., p. 51 e 53. No original: "[...] some dread event impend" e "Beware of all, but most beware of Man!" (I, 109 e 114) (POPE, Alexander. "The rape of the lock". Poetry and prose of Alexander Pope cit., p. 82 e 83).

${ }^{99}$ Broich defende consistentemente a necessidade de tomarmos esse tipo de obra como um gênero literário autônomo. A autoconsciência formal desse gênero se daria, argumenta, com The rape of the lock. Mesmo os inimigos de Pope reconheceram de imediato as profundas implicações de sua composição, que designariam como um "poema herói-cômico" (subtítulo que Silva Alvarenga empregaria em seu $O$ desertor). Ver BROICH, Ulrich. The eighteenth-century mock-heroic poem cit., p. 128 e ss.
} 
porém preambular, na instauração de uma forma polifônica que é capaz de fazê-lo. The rape of the lock nos diz muito mais sobre o século XVIII que, por exemplo, o Prince Arthur, de Richard Blackmore. ${ }^{100}$

O entremear da epopeia neoclássica no poema heroico primitivo que se configura em Fingal e Temora força a propositura de um novo modelo genérico, que, a um só tempo, preserve sua integridade morfológica (Gestalt) e insinue sua condição de compósito. ${ }^{101}$ Produtivamente problemático, seria um modelo em que se promove o encontro (a priori inconcebível) do enredo com a subjetividade, da alegoria com a realidade e do trans-histórico com o contingente, em cuja forma pressupostos antagônicos se superam e se legitimam reciprocamente. Em suma, um modelo aberto, mas coeso; formular, mas amorfo; inteligível, mas irreproduzível; e, por fim, antigo, mas - porque contraditório - moderno.

\section{A síntese do heterogêneo ${ }^{102}$}

A estruturação do heterogêneo resgata Fingal e Temora da ossificação épica e atualiza-os do século III d. C. para a contemporaneidade do século XVIII. A atualização se dá porque a postulação de heterogeneidade vivifica uma designação genérica inerte, seja porque decomponível em prescrições imutáveis, seja porque atada ou adstrita a uma conjuntura soterrada pela História. Há uma temporalidade inacabada, ${ }^{103}$ em que se agenciam o pretérito alegorizável da ação empreendida pelos guerreiros de Morven e o presente performático do narrador, que se entrega à expressão das emoções e sensações suscitadas pelo próprio ato de narrar. Ossian emerge com uma persona singularizada, cujos atributos (estilísticos, morais e até mesmo físicos) podem ser listados por qualquer pessoa minimamente familiarizada com as traduções de Macpherson.

\footnotetext{
${ }^{100}$ Sobre Blackmore e a poética de Le Bossu, ver a discussão supra, p. 52.

${ }^{101}$ Neste ponto, estabelecemos um diálogo com HALL, Stuart. "Marx's notes on method: a 'reading' of the '1857 Introduction'” cit., p. 129.

${ }^{102}$ A expressão "síntese do heterogêneo" é empregada por Paul Ricoeur num contexto mais amplo que o deste trabalho, porquanto é relacionada a todas as narrativas de ficção (ver RICOEUR, Paul. Tempo e narrativa. Trad. Claudia Berliner e Márcia Valéria Martinez de Aguiar. São Paulo: Martins Fontes, 2012, v. 1, p. 1-2 e passim). Meu interesse, por sua vez, restringe-se a um tipo especial de narrativa em que a síntese do heterogêneo, como reconhece o próprio Ricoeur, é elevada à condição de princípio estético: o romance (ver: idem, v. 2, p. 12 e ss. e p. 166-172).

${ }^{103}$ Ver BAKHTIN, Mikhail M. "Epic and novel” cit., p. 16-22.
} 
O mesmo movimento que nos apresenta heróis admiráveis, em cujos feitos se inscrevem, para citarmos Smollett, "as melhores lições de moralidade", suscita o compartilhamento de uma interioridade autorreferente, a propiciar ao leitor uma identificação empática com aquele bardo velho e decrépito. Como observara Duff, é impossível não "se condoer ternamente" nem "participar" das desventuras daquele que é o último de sua raça. É isso que o texto demanda. Em Fingal e Temora, narramse as aventuras do rei de Morven na Irlanda, mas se configura também uma narrativa da narração ossiânica das referidas aventuras. A focalização indeterminada, no universo representado ou na voz que em tese proporciona essa representação, protela indefinidamente a solução da tensão entre inteligibilidade e contingência, decorrente do entremear do neoclássico ao primitivo - ou vice-versa. Leiam-se, por exemplo, as observações que Blair faz a respeito de Temora. O valor do poema advém, sobretudo, do contraste entre o "gênio de Ossian" e a evocação das "operações militares":

Temora talvez tenha menos fogo que o outro poema épico; mas, por sua vez, tem mais variedade, mais ternura, e mais magnificência. A ideia predominante, tantas vezes nos apresentada como "Fingal na última de suas batalhas", é venerável e comovente. Nem uma conclusão mais nobre poderia ser concebida que a de um herói idoso, depois de muitos feitos bem-sucedidos, dando adeus às armas e, com toda a solenidade daqueles tempos, renunciando a sua lança para seu filho. Os eventos são menos comprimidos em Temora que em Fingal; as ações e os caracteres são exibidos de maneira mais pormenorizada; testemunhamos as negociações dos dois exércitos; e somos informados das aventuras tanto da noite quanto do dia. $\mathrm{O}$ pathos sereno e o cenário romântico de muitas das aventuras noturnas, tão notavelmente apropriados para o gênio de Ossian, dão uma admirável diversidade ao poema - e são habilmente contrastados com as operações militares diurnas. ${ }^{104}$

\footnotetext{
104 "Temora has perhaps less fire than the other epic poem; but in return it has more variety, more tenderness, and more magnificence. The reigning idea, so often presented to us of 'Fingal in the last of his fields,' is venerable and affecting; nor could any more noble conclusion be thought of, than the aged hero, after so many successful achievements, taking his leave of battles, and with all the solemnities of those times resigning his spear to his son. The events are less crouded in Temora than in Fingal; actions and characters are more particularly displayed; we are let into the transactions of both hosts; and informed of the adventures of the night as well as of the day. The still pathetic, and the romantic scenery of several of the night adventures, so remarkably suited to Ossian's genius, occasion a fine diversity in the poem; and are happily contrasted with the military operations of the day" (BLAIR, Hugh. "A critical dissertation on the poems of Ossian". In: MACPHERSON, James. The Poems of Ossian and related works cit., p. 370-371). Para uma discussão o sentido dado por Blair a "romântico", ver: IMMERWAHR, Raymond. "'Romantic' and its cognates in England, Germany, and France in 1790". In: EICHNER, Hans (ed.). 'Romantic' and its cognates: the European history of a word. Manchester: University of Manchester, 1972, p. 17-97, especialmente p. 48-51. Seguindo o OED (host, $\left.n .{ }^{1}, \mathbf{1}\right)$, traduzi "host" como "exército".
} 
A síntese desse jogo, se é que ela é possível, é delegada para o leitor. Com efeito, o leitor - "the reader" - é o destinatário ostensivo do comentário paratextual assinado por Macpherson e também da Dissertação de Blair. Frequentemente interpelado de modo direto, esse leitor é convidado de maneira recorrente a reconhecer os princípios construtivos das composições ossiânicas, sem preocupação aparente com eventuais incompatibilidades entre as interpelações. Na Dissertação, Blair insta esse leitor abstrato a notar como Fingal é ordenado em consonância com os mais relevantes princípios aristotélicos: “A unidade da ação, que, de todas as regras de Aristóteles, é a principal e mais importante, é tão estritamente preservada em Fingal, que ela pode ser percebida por qualquer leitor". ${ }^{105}$ Blair não explica, contudo, como a percepção de uma forma cristalina harmoniza-se com uma afirmação sua, feita poucas páginas antes, quanto às "marcas da mais remota antiguidade" na épica ossiânica. A veemência do narrador, argumentara, levaria necessariamente a uma narrativa irregular e até mesmo fragmentária, cuja completude só seria alcançada na mente do leitor:

A maneira de composição leva todas as marcas da mais remota antiguidade. Nada de transições engenhosas nem de conexões arredondadas e dilatadas entre as partes, assim como encontramos nos poetas de tempos mais recentes, quando a ordem e a regularidade eram mais praticadas e conhecidas: mas, sim, um estilo sempre rápido e veemente; na narração, uma concisão quase brusca, a deixar várias circunstâncias para serem suprimidas pela imaginação do leitor". ${ }^{106}$

Celeridade é uma qualidade tanto do estilo quanto da "maneira de composição". A ausência de "ordem" e "regularidade" suprime o lapso entre o ato de compor e seu registro textual. É algo muito diferente do que presume a criação literária sob as regras de Aristóteles. A organização unitária, com suas analepses e prolepses, implica um burilar artístico, (em tese) ausente na elocução espontânea que se atribui à "mais remota antiguidade".

\footnotetext{
105 "The unity of the Epic action, which, of all Aristotle's rules, is the chief and most material, is so strictly preserved in Fingal, that it must be perceived by every reader" (BLAIR, Hugh. "A critical dissertation on the poems of Ossian". In: MACPHERSON, James. The Poems of Ossian and related works cit., p. 359).

106 "The manner of composition bears all the marks of the greatest antiquity. No artful transitions; nor full and extended connection of parts; such as we find among the poets of later times, when order and regularity of composition were more studied and known; but a style always rapid and vehement; in narration concise even to abruptness, and leaving several circumstances to be supplied by the reader's imagination" (idem, p. 354).
} 
Seja como for, as interpelações recorrentes ao leitor indicam que a síntese da dialética proposta pela épica ossiânica só pode ocorrer no presente - mais especificamente, sob as condições sociais e culturais da Grã-Bretanha da segunda metade do século XVIII. Fingal e Temora não são obras atemporais, como prescrevia o aristotelismo neoclássico, nem tampouco o registro imediato de um longínquo passado primitivo. Postulam uma estrutura que, embora estranha às teorizações correntes sobre a epopeia, encontrou imensa ressonância junto a um público disposto a atribuir-lhe coerência. Um dos maiores best-sellers de seu tempo, o sucesso das traduções de Macpherson, como dissemos no capítulo anterior, é comparável apenas ao da Bíblia. ${ }^{107} \mathrm{O}$ desconforto que muitos críticos e tradutores sentiram ao lidar com as longas narrativas de Ossian não se converteu num entrave à sua apreciação popular. O público setecentista, sobretudo se britânico, encontrava-se especialmente equipado para lidar com as contradições construtivas das ditas epopeias ossiânicas. Fazia quase cem anos que o mercado fornecia experimentos ficcionais com que se pudesse narrar a contemporaneidade, incorporando à forma a indeterminação das questões e embates ainda por resolver. Em 1761, ano da publicação de Fingal, esses experimentos se encontravam em vias de institucionalização, pela ascensão de um novo gênero: o romance.

\subsection{Forma à instabilidade}

A consolidação da narrativa novelística coincide com uma percepção generalizada de erosão das estruturas que davam valor e sentido à vida em sociedade na Inglaterra e Escócia. No período entre as experimentações de Aphra Behn (década de 1680) e a institucionalização do gênero na década de 1740, com Samuel Richardson, os dois reinos testemunhariam um conflito intermitente entre a ordem hereditária de poder e prestígio, associada à casa real dos Stuarts, e os setores ligados ao comércio e ao partido Whig. Estes últimos triunfariam decisivamente em 1688, ao deporem Jaime II por meio de uma autoproclamada Revolução Gloriosa. ${ }^{108}$ Os Stuarts ou seus partidários ainda organizariam duas contraofensivas a partir da Escócia, a primeira delas em 1715. No Levante Jacobita de 1745, chegariam a desfraldar seu

\footnotetext{
${ }^{107}$ Ver supra, p. 105.

${ }^{108}$ HILL, Christopher. A century of revolution, 1603-1714. Londres - Nova Iorque: Routledge, 1991, p. 255 e ss.
} 
estandarte em Edimburgo. No entanto, sua causa era perdida. Meses depois, a rebelião e os grupos sociais que lhe davam suporte seriam inequivocamente esmagados. ${ }^{109}$

As convulsões políticas e a revolução comercial dos séculos XVII e XVIII feriram de morte uma ideologia que preconizava a coincidência da hierarquia política e econômica com a hierarquia moral. ${ }^{110} \mathrm{O}$ ponto máximo de expressão dessa ideologia era a convergência das ordens sagrada e terrena na figura do monarca. Reis e rainhas eram, simultaneamente, a fonte do direito e o centro de comando das igrejas de Inglaterra e Escócia. Seu poder emanaria de Deus, o que lhes dava a prerrogativa de requisitar a obediência irrestrita de seus súditos. Num discurso ao Parlamento, em 1603, Jaime I diria sem meias palavras: “O estado da monarquia é a coisa suprema na terra, pois reis não são apenas os lugares-tenentes de Deus na terra, mas mesmo por Deus são chamados de deuses". ${ }^{111}$ Para além das cabeças coroadas, a ideologia em questão atribuía à aristocracia, composta por nobreza (nobility ou quality) e fidalguia (gentry), o virtual monopólio das instituições de projeção do poder estatal, como o exército, os altos cargos no clero e os assentos nas casas legislativas. A hereditariedade de sua ascendência social se justificaria por seu "interesse permanente", como proprietários de terras, na manutenção do arranjo constitucional vigente. ${ }^{112}$ Sua primazia social seria mediada para as relações intersubjetivas numa ética estruturada pelo valor da honra. Esperava-se dos patrícios uma conduta que naturalizasse sua posição social, com que inspirariam nos estamentos inferiores mais que o dever de obediência, mas também os sentimentos de deferência e respeito. Qualidades como firmeza, autocontrole, coragem, lealdade e indiferença às paixões seriam essenciais a alguém nascido para mandar, em quem virtudes marciais se combinariam ao estoicismo senatorial dos antigos romanos. ${ }^{113}$ Trata-se de um código que regulamenta a dimensão pública do indivíduo e, de imediato, separa-o dos demais

\footnotetext{
${ }^{109}$ HARRIS, Bob. “Jacobitism”. In: COOKE, Anthony et al (ed.). Modern Scottish history: 1707 to the present. Phantassie: Tuckwell, 2001, v. 1, p. 23-42, especialmente p. 39 e ss.

${ }^{110}$ McKEON, Michael. "Generic transformation and social change: rethinking the rise of the novel" cit., p. 168.

111 "The state of monarchy is the supremest thing on earth; for kings are not only God's lieutenants on earth, but even by God himself they are called gods" (apud HILL, Christopher. A century of revolution cit., p. 43).

${ }^{112}$ A ideia do interesse permanente se articula com clareza nos Debates de Putney, em meio ao movimento dos Levellers, durante a Guerra Civil. Ver a intervenção de Ireton em: SHARP, Andrew (ed.). The English Levellers. Cambridge: Cambridge University, 1998, p. 102-103.

${ }^{113}$ TAYLOR, Charles. Sources of the self: the making of the modern identity. Cambridge, MA: Harvard University, 1989, p. 152-154.
} 
ao proclamar suas origens. A desonra, como observaria Spenser, era algo semelhante a um "espinho venenoso" no nome de um aristocrata, algo que retirava a sua consequência social:

Nenhum ferimento, que a mão belicosa do inimigo

Inflige a golpe de espada, é uma chaga

Como o espinho venenoso que a infâmia

Grava no nome de nobre linhagem ${ }^{114}$

(VI, 6, 1)

Com efeito, muitos aristocratas zelariam por seu nome ainda que à custa de sua própria vida, batendo-se em duelos ante a menor imputação de desonra. ${ }^{115}$ No caso da Escócia, a ascendência da aristocracia era reforçada pelo serviço militar devido pelos camponeses. No caso específico dos Highlands, havia o reforço adicional do sistema de clãs, baseado na consanguinidade. ${ }^{116}$ Em sua The History of the Rebellion in the Year 1745, John Home resumiria a autoridade patriarcal do chefe do clã:

Essa pessoa (conhecida em inglês pelo nome de Chefe) era o magistrado, juiz e general hereditário do clã: ele resolvia todas as querelas que surgiam entre seu povo, e regulava seus negócios discricionariamente. Do seu julgamento não havia apelo: declinar do tribunal do Chefe, e apelar a qualquer uma das cortes do rei por socorro contra qualquer um dos seus, era considerado altamente criminoso, uma espécie de traição contra a constituição do clã e a majestade do Chefe. ${ }^{117}$

$\mathrm{Na}$ aurora do século XVIII, os alicerces do poder hereditário da realeza e aristocracia haviam sido irremediavelmente trincados. As Guerras Civis e a Revolução Gloriosa eliminariam a viabilidade política da noção de direito divino dos reis. Mesmo um partidário ardoroso do absolutismo, como Thomas Hobbes, precisaria encontrar uma justificava terrena para o poder monárquico. A instituição de um ente

\footnotetext{
114 "No wound, which warlike hand of enemy/ Inflicts with dint of sword, so sore doth light,/ As doth the poysnous sting, which infamy/ Infixeth in the name of noble wight" (VI, 6, 6) (SPENSER, Edmund. The faerie queene cit., p. 638).

${ }^{115}$ ANDREW, Donna T. "The code of honour and its critics: the opposition to duelling in England, 1700-1850”. Social History, v. 5, n. 3 (outubro, 1980), p. 409-434, especialmente p. 413.

${ }^{116}$ YOUNGSON, A. J. After the Forty-Five: the economic impact on the Scottish Highlands. Edimburgo: Edinburgh University, 1972, p. 11-12.

117 "This person (known in the English language by the name of Chief) was the hereditary magistrate, judge, and general of the clan: he determined all disputes that arose amongst his people, and regulated their affairs at his discretion. From his judgment there was no appeal: to decline the tribunal of the Chief, and apply to any of the king's courts for redress against one of the same kindred, was considered as highly criminal, a kind of treason against the constitution of clanship, and the majesty of the Chief" (HOME, John. The history of the rebellion in the year 1745. Londres, 1802, p. 8).
} 
soberano seria um desenvolvimento natural da vida em sociedade, uma escolha humana, em busca da autopreservação. Deus está fora desse esquema explicativo:

O fim último, causa final e o desígnio dos homens (que amam naturalmente a liberdade e o domínio sobre os outros), ao introduzir aquela restrição sobre si mesmos sob a qual os vemos viver sob Estados, é o cuidado com sua própria conservação e com uma vida mais satisfeita. ${ }^{118}$

De 1649 a 1688, Carlos I seria decapitado, experimentar-se-ia com um regime republicano e, por fim, Jaime II seria substituído por um monarca, William III, cuja ascensão ao trono seria condicionada à assinatura de uma Petição de Direitos, num inequívoco arranjo contratual. ${ }^{119} \mathrm{Na}$ formulação de Locke, submete-se o soberano ao escrutínio da meritocracia:

[...] todo poder dado para a consecução de um fim, sendo limitado por este fim, quando tal fim for manifestamente negligenciado ou oposto, a confiança deve necessariamente ser revogada, e o poder devolvido às mãos daqueles que o deram, que podem colocá-lo, então, onde julguem melhor para sua segurança e proteção. E assim a comunidade retém um poder supremo de se salvaguardar das tentativas e desígnios de qualquer um, mesmo seus legisladores, quando forem tão tolos, ou tão maus, a ponto de planejarem e executarem desígnios contra as liberdades e as propriedades de seus súditos $[\ldots] .{ }^{120}$

Opõem-se os interesses dos súditos, como liberdade e propriedade, à onipotência que Jaime I via como ínsita à prerrogativa real. Dessacralizada, a figura do monarca agora é tida como uma espécie de procurador ou encarregado de negócios, sob o risco perene de ter seu mandato revogado em caso de quebra de "confiança".

\footnotetext{
${ }^{118}$ HOBBES, Thomas. Leviatã ou matéria, forma e poder do Estado eclesiástico e civil. Trad. João Paulo Monteiro; Maria Beatriz Nizza da Silva. São Paulo: Abril Cultural, 1974, p. 85. No original: "The finall Cause, End, or Designe of men, (who naturally love Liberty, and Dominion over others,) in the introduction of that restraint upon themselves, (in which wee see them live in Commonwealths,) is the foresight of their own preservation, and of a more contented life thereby [...]" (HOBBES, Thomas. Leviathan. Revised Student Edition. Ed. Richard Tuck. Cambridge: Cambridge University, 1996, p. 85).

${ }^{119}$ Ver, por tudo, HILL, Christopher. A century of revolution cit., p. 273 e ss.

120 “ [....] all power given with trust for the attaining an end, being limited by that end: whenever that end is manifestly neglected or opposed, the trust must necessarily be forfeited, and the power devolve into the hands of those that gave it, who may place it anew where they shall think best for their safety and security. And thus the community perpetually retains a supreme power of saving themselves from the attempts and designs of any body, even of their legislators, whenever they shall be so foolish, or so wicked, as to lay and carry on designs against the liberties and properties of the subject" (LOCKE, John. "The second treatise: an essay concerning the true original, extent, and end of civil government". Two treatises of government and A letter concerning toleration. Ed. Ian Shapiro. New Haven Londres: Yale University, 2003, p. 166).
} 
As transformações ocasionadas pela ascensão da burguesia seriam ainda mais profundas. ${ }^{121}$ As reformas econômicas promovidas no Interregno (1649-1660), como os Atos de Navegação (1651), começariam a produzir efeitos ainda nas últimas décadas do período da Restauração. ${ }^{122}$ Os ingleses (e, depois, os britânicos como um todo) suplantariam os holandeses como a principal nação mercantil da Europa, a dominar rotas comerciais nos três oceanos, em quatro continentes. ${ }^{123}$ Inicia-se um processo que traria uma afluência sem precedentes para os setores médios da sociedade, ${ }^{124}$ precipuamente urbanos e alheios à hierarquia agrária, de nobility, gentry (ou lairds, na Escócia), yeomen, cottagers, husbandmen etc. Cidades portuárias como Londres, Bristol, Liverpool e, depois, Glasgow, ligadas ao comércio internacional, tornaram-se ímãs para levas de despossuídos, atraídos pela possibilidade de se beneficiarem, ainda que indiretamente, da inédita prosperidade. ${ }^{125} \mathrm{~A}$ despeito da insalubridade, insegurança e extrema miséria que compunham seu quotidiano, Londres experimentaria taxas de crescimento demográfico extremamente robustas, numa rápida marcha para se tornar a maior metrópole da Europa. Às vésperas da Restauração, em 1657, estima-se que a população da capital seria de 462.000 pessoas. Trinta e três anos depois, esse número pularia para 595.624, um crescimento de quase $29 \%$, num período em que a cidade sofreu tanto com a peste (1665-1666) quanto com um incêndio de proporções apocalípticas (1666). ${ }^{126}$ No século XVIII, a expansão se aceleraria. Calcula-se que cerca de um sexto da população inglesa tenha vivido em Londres, ao menos por um tempo. O relativo anonimato proporcionado pelas aglomerações humanas seria logo percebido como um dos elementos definidores de

${ }^{121}$ A argumentação deste parágrafo foi largamente baseada em WAHRMAN, Dror. The making of the modern self: identity and culture in eighteenth-century England. New Haven - Londres: Yale University, 2004, p. 202 e ss.

${ }^{122}$ HILL, Christopher. A century of revolution cit., p. 155 e p. 209 e ss.

${ }^{123}$ A participação dos escoceses no comércio e na colonização intercontinentais antes da União de 1707 é errática. Em alguns casos, como em Nova Jérsei, trabalhavam em parceria com os ingleses, em empreendimentos explicitamente "britânicos", antes mesmo da criação oficial do Estado chamado GrãBretanha. Noutras situações, agiam por sua própria conta e risco, como a desastrosa tentativa de estabelecerem um colônia escocesa, apesar da oposição dos ingleses, no istmo do Panamá, em Darien. Para uma discussão dessa relação nos dois séculos que precederam a União, ver: ARMINTAGE, David. "Making the Empire British: Scotland in the Atlantic World, 1542-1707". Past \& Present, n. 155 (maio, 1997), p. 34-63.

${ }^{124}$ Usarei a expressão "setores médios" ao invés do anacronismo "classe média", pertinente ao século XIX. Em inglês, a expressão corrente era "people of middling sort".

${ }^{125}$ Glasgow experimentaria altas taxas de crescimento urbano a partir de meados do século XVIII (MAVER, Irene. "Urbanisation”. In: COOKE, Anthony et al (ed.). Modern Scottish history cit., v. 1, p. 155-176, especialmente p. 166).

${ }^{126}$ Cf. VITO, George V. "A note on the population of seventeenth-century London". Demography, v. 9 , n. 3 (agosto, 1972), p. 511-514. 
uma nova maneira de viver em sociedade. Como escreveria Addison no número inaugural do Spectator, de março de 1711, era um tempo em que o cavalheiro se mistura a soldados, mercadores, judeus, artesãos e políticos sem que um, no entanto, tenha como reconhecer o outro. ${ }^{127}$

Muitos não partilhavam do entusiasmo de Addison. A hipertrofia dos centros urbanos era frequentemente percebida como um mal e descrita como uma ameaça à dita ordem natural das coisas. Seriam espaços em que homens e mulheres poderiam se reinventar, apagar seu passado e fingir o que "de fato" não eram. No mesmo ano em que apareceu o Spectator, John Dennis publicaria seu Ensaio sobre o espírito público, no qual se recorda com nostalgia da época em que roupas, costumes e hábitos claramente distinguiam as origens, a nacionalidade, a idade e até mesmo o sexo de uma pessoa. $^{128}$

A fluidez dos centros urbanos era apenas o sintoma mais visível de uma acelerada desagregação do tecido social. Dennis diagnosticaria o agigantamento de Londres como a "prova palpável e visível do luxo britânico". ${ }^{129}$ Não eram só os pobres que migravam para a capital. Lá também seria o lugar onde nobres e fidalgos, cada vez mais, buscariam as comodidades e os prazeres que o dinheiro proporcionava: roupas, mobiliário, carruagens, prostitutas. Com acrimônia, veria a crescente afluência de alguns setores como corrosiva às relações baseadas em paternalismo e deferência. A “insana profusão" dos aristocratas tornava-os "vis aos olhos do mundo". Até pouco tempo atrás, argumentaria, levavam uma vida estritamente ligada à terra, cônscios de sua posição e de seus deveres para com os que se encontram sob sua proteção:

Passavam a maior parte do tempo no campo, junto a seus inquilinos, para os quais suas casas hospitaleiras se encontravam sempre abertas. Seus inquilinos viviam sob sua proteção a alugueres módicos. Eram os deuses protetores dos pobres, os quais tinham cuidados na doença e alimento na saúde - e, em ambas, suas moradias. [...] Sua conversa se restringia na maior parte do tempo a seus iguais em nascimento ou posição, ou àqueles que superavam essa deficiência pela verdadeira nobreza de espírito. Ou se, em qualquer circunstância, [...] demonstravam intimidade com seus

\footnotetext{
${ }^{127}$ ADDISON, Joseph. "No. 1". The Spectator. Ed. Gregory Smith. Londres - Nova Iorque: Everyman, 1958, v. 1, p. 3-6.

${ }^{128}$ No original: "And their Habits, and the rest of their Customs and Manners were such, as very fairly distinguish'd their Birth, their Age, their Sex, and their Country" (DENNIS, John. An essay upon publick spirit; being a satyr in prose upon the manners and luxury of the times, the chief sources of our present parties and divisions. Londres, 1711, p. 10).

${ }^{129}$ Trecho integral: "This over-grown Town may be said to be a visible, palpable Proof of the Growth of the British Luxury" (idem, p. 11).
} 
inferiores, ao mesmo tempo se preocupavam em mostrar que sabiam baixar o nível com dignidade. ${ }^{130}$

As recompensas para esse tipo de comportamento não se mediam em dinheiro ou poder, mas em honra, fama, reputação e glória. ${ }^{131} \mathrm{O}$ "luxo britânico" teria irremediavelmente invertido essa equação. Tornara homens e mulheres indolentes, desinteressados de seus negócios, perpetuamente entregues a passatempos e recreações, como bebedeiras, glutonia e carteado. O custo de seu ruinoso estilo de vida seria apresentado a seus inquilinos, dos quais exigiam alugueres exorbitantes, levando-os à miséria e ao desespero. Carreiras outrora prestigiosas, como a militar, despertavam cada vez menos interesse, pois não mais se queria "cortejar a glória verdadeira por meio de ações heroicas". ${ }^{132}$ O luxo alterara a própria natureza das pessoas. As mulheres se masculinizariam em seus desejos e práticas, sem qualquer receio de se declararem libertinas, ao passo que os homens se tornariam doces, lânguidos e passivos. Ademais, "esquecem seu nascimento, sua posição, sua dignidade, seu entendimento, sua virtude - e são vistos a conversar com canalhas desprezíveis, que são, a um só tempo, tolos e patifes". ${ }^{133}$

A despeito do tom satírico e preconceituoso, Dennis captura a crise de valores por que passavam a Inglaterra e, depois, a Grã-Bretanha, cujas causas estavam na ascensão do comércio. Contrariamente ao que pensava, entretanto, não era o "amor ao luxo" que fizera com que a aristocracia subitamente renegasse suas obrigações hereditárias para se entregar a dissipações frívolas, a dar as costas para seu antigo código de honra. A dita crise de valores decorria do fato de que o lastro de toda a sociedade, a medida com que estabeleciam distinções sociais e econômicas, deixara de ser a terra, para ceder lugar ao dinheiro. Era a posse da terra que estruturava a relação da nobreza e fidalguia com o resto da população. Cottagers e husbandmen não só alugavam campos de cultivo em troca de alugueres ou de trabalho na porção

\footnotetext{
130 "They spent a great deal of their Time in the Country among their Tenants, to whom their Hospitable Houses were always open. Their Tenants liv'd under them at easy Rates. They were the Tutelary Gods of the Poor, who in Sickness had Physick from them, and in Health their Food, and in both their Habitations. [...] Their Conversation lay for the most part with their Equals both in Birth and Rank, or with such as supply'd the Defect of those by true Nobility of Mind: Or if at any time, [...] they were familiar with their Inferiors; at the same time they took care to shew, that they knew how to descend with Dignity" (idem, p. 8-9).

${ }^{131}$ Idem, p. 9-10.

132 "[...] courting true Glory by Heroick Actions [...]" (idem, p. 13).

133 “[...] forget their Birth, their Rank, their Dignity, their Understanding, their Virtue, and herd and converse with mean Wretches, who are often both Fools and Knaves" (idem, p. 17).
} 
senhorial: ao menos em teoria, cabia à aristocracia assistir às necessidades dos "imerecidamente pobres" (undeserving poor) e subsidiar o financiamento da paróquia e da (eventual) escola. Naturalizavam-se diferenças hierárquicas por meio de obrigações recíprocas, demarcando-se de maneira precisa o papel de cada parte na cadeia do ser. $^{134}$

Historicamente, as cidades e vilas se organizavam em corporações alheias à hierarquia do campo, como guildas e conselhos. Na última década do século XVII, mesmo esse arranjo já havia implodido ou caducado. O regime instituído pela Revolução Gloriosa, por exemplo, eliminaria os últimos monopólios comerciais. ${ }^{135} \mathrm{~A}$ promoção do livre comércio na Inglaterra e na Escócia (a partir de 1707) enterrava os últimos vestígios das ideias medievais de restringir a produção, manter preços e qualidade, ainda correntes nos primeiros governos dos Stuarts. ${ }^{136}$ Removidos os entraves institucionais, o comércio cresceria a taxas fenomenais. Vinte e cinco anos depois da deposição de Jaime II, as receitas alfandegárias mais do que dobrariam. ${ }^{137}$ Bristol seria o porto por que se exportariam os manufaturados de ferro e tecidos para as colônias. Liverpool, o centro de distribuição europeu dos produtos das colônias: nomeadamente, açúcar e escravos. E Glasgow, o entreposto do comércio de tabaco. ${ }^{138}$

O influxo sem precedentes de dinheiro poria fim à percepção de um mundo imutável. ${ }^{139}$ Mercadores e acionistas das companhias faziam fortunas da noite para o dia que rivalizavam com as dos maiores pares do reino. Produtos das partes mais distantes do globo, como café, chá, açúcar e chocolate, eram consumidos em escala cada vez maior. O crescimento do comércio com as colônias e a consequente intensificação da emigração tornariam o convívio com diferentes tipos humanos, ainda que submetidos à escravidão, algo rotineiro. Grupos étnicos antes desconhecidos na Grã-Bretanha, como o mulato, começavam a aparecer em cidades portuárias. ${ }^{140}$ Sobressaindo-se a todos esses fatores de desestabilização, todavia, estava a introdução do papel-moeda, na esteira da revolução financeira da década de

\footnotetext{
${ }^{134}$ POCOCK, J. G. A. "The classical theory of deference". The American Historical Review, v. 81, n. 3 (junho, 1976), p. 516-523.

${ }^{135}$ HILL, Christopher. A century of revolution cit., p. 260.

${ }^{136}$ Idem, p. 261.

${ }^{137}$ Idem, p. 262.

${ }^{138}$ Idem, ibidem.

${ }^{139}$ WAHRMAN, Dror. The making of the modern self cit., p. 202 e ss.

${ }^{140}$ Idem, p. 212-217.
} 
1690. ${ }^{141}$ A chegada de William III ao trono alteraria a orientação diplomática de Inglaterra e Escócia, que doravante se aliariam à Holanda na luta contra o catolicismo e o expansionismo de Luís XIV. Não podendo taxar os súditos como um governo absolutista, William e seu gabinete desenvolveriam instituições, como o Banco da Inglaterra, para canalizar para o Estado a imensa riqueza acumulada com a revolução comercial. Os mercadores emprestariam dinheiro em troca de uma remuneração a juros estratosféricos. Com isso, introduzem-se títulos, ações, anuidades, loterias e notas promissórias: um vocabulário novo para relações econômicas sem paralelo, criando medidas até então desconhecidas de riqueza. ${ }^{142}$ Numa perspectiva conservadora, Swift sintetizaria, num artigo para The examiner, em 1710, a perplexidade de muitos:

Por esse meio, a riqueza de uma nação, que costumava ser aferida pelo valor da terra, é calculada hoje pela subida e descida de ações. E embora a fundação do crédito continue a mesma, sobre um piso que jamais pode ser alterado; e embora todo juro seja pago pontualmente pelo público, mesmo assim, pelo artifício dos operadores de ações, produziu-se tanta confusão de patifaria e fraude, tanto mistério de iniquidade e tanto jargão ininteligível de termos para envolvê-lo, como jamais se viu em qualquer outra era ou país do mundo. ${ }^{143}$

As flutuações do mercado acionário são as manifestações mais óbvias de uma profunda perda de parâmetros. Como comprovam as sátiras atribuídas a Martinus Scliberus, heterônimo que Swift criara com Pope e Gay, os valores do tempo em que "a riqueza de uma nação [...] costumava ser aferida pelo valor da terra" começavam a cair em desuso. ${ }^{144}$ Muitos podiam até concordar com Spenser, para o qual "é vergonha adornar/ [...] alguém de nascimento tão baixo" (VI, 6, 36), ${ }^{145}$ mas já não

\footnotetext{
${ }^{141}$ Idem, p. 209.
}

${ }^{142}$ Ver BREWER, John. The sinews of power: war, money and the English state, 1688-1783. Cambridge, MA: Harvard University, 1988, passim.

143 "By this means the Wealth of the Nation, that used to be reckoned by the Value of Land, is now computed by the Rise and Fall of Stocks: And although the Foundation of Credit be still the same, and upon a Bottom that can never be shaken; and although all interest be duly paid by the Public, yet through the Contrivance and Cunning of Stock-Jobbers, there hath been brought in such a Complication of Knavery and Couzenage, such a Mystery of Iniquity, and such an unintelligible Jargon of Terms to involve it in, as were never known in any other Age or Country of the World" (SWIFT, Jonathan. "No 14". The Examiner (1710-11). Ed. Herbert Davis. Oxford: Blackwell, 1959, p. 6-7). Ver McKEON, Michael. The origins of the English novel cit., p. 206-207.

${ }^{144}$ Sobre a condenação de Swift às instituições de seu tempo, ver: SEIDEL, Michael. "Systems satire: Swift.com”. In: RICHETTI, John (ed.). The Cambridge history of English literature, 1660-1780 cit., p. 235-258, especialmente p. 251.

145 "[...] shame is to adorne/ [...] one so basely borne" (VI, 6, 36) (SPENSER, Edmund. The faerie queene. Ed. A. C. Hamilton. 2. ed. Harlow: Pearson Longman, 2007, p. 643). 
havia muito o que fazer. O código de honra aristocrático e sua ênfase em hierarquia, fama e renome entrava em choque com uma comunidade em que seus membros mais prósperos buscavam uma vida comum, longe das armas e do conflito, dedicada precipuamente a lucro, mobilidade social e ao que hoje chamamos de satisfação pessoal. Ademais, nesse novo mundo de instabilidade, as atribuições são menos claras e as origens do indivíduo, insuficientes para definir sua identidade. Aos poucos, suas atividades produtivas e, por extensão, reprodutivas ganhariam precedência sobre a sua linhagem. Começa a ser articulada uma ideologia, que os marxistas denominariam burguesa, com que se dá proeminência à vida do trabalho e da família. ${ }^{146} \mathrm{~A}$ transição dos paradigmas é documentada pelo Spectator, de Addison e Steele. Enfaticamente, Mr Spectator defenderia que o gosto aristocrático pela exibição pública de poder e prestígio derivava de uma noção falsa de felicidade:

A felicidade genuína tem uma natureza reservada, inimiga da pompa e da notoriedade. Advém, em primeiro lugar, do desfrute de si mesma e, depois, da amizade e conversas com um grupo seleto de companheiros. Ela ama a sombra e a solidão e naturalmente frequenta bosques e fontes, campos e prados: em resumo, busca tudo o que necessita dentro de si mesma e não recebe o incremento de aglomerações de testemunhas e espectadores. Pelo contrário: a falsa felicidade adora estar numa multidão e atrair os olhos do mundo para si. Ela não se satisfaz com os aplausos que dá a si mesma, mas da admiração que suscita nos outros. Floresce em cortes e palácios, teatros e assembleias, mas não existe quando examinada de perto. ${ }^{147}$

Talvez uma das manifestações mais eloquentes da perda de parâmetros esteja no Ensaio sobre o entendimento humano (1690), de John Locke. Procurar-se-ia desembaraçar a filosofia das coordenadas estranhas ou anteriores ao sujeito, mais ou menos como a ascensão do comércio havia feito com que a trajetória do indivíduo se sobrepusesse ao seu nascimento. Analogamente, Locke desconfiaria de qualquer

\footnotetext{
${ }^{146}$ TAYLOR, Charles. Sources of the self cit., p. 285-286. Ver também: RICHETTI, John. The English novel in history, 1700-1780. Londres: Routledge, 1999, p. 18.

147 "True Happiness is of a retired Nature, and an Enemy to Pomp and Noise; it arises, in the first place, from the Enjoyment of one's self; and, in the next, from the Friendship and Conversation of a few select Companions. It loves Shade and Solitude, and naturally haunts Groves and Fountains, Fields and Meadows: In short, it feels every thing it wants within itself, and receives no Addition from Multitudes of Witnesses and Spectators. On the contrary, false Happiness loves to be in a Crowd, and to draw the Eyes of the World upon her. She does not receive any Satisfaction from the Applauses which she gives her self, but from the Admiration which she raises in others. She flourishes in Courts and Palaces, Theatres and Assemblies, and has no Existence but when she is looked upon" (ADDISON, Joseph. "No. 15". The spectator cit., v. 1, p. 47).
} 
instância diversa das atividades reflexivas da mente. ${ }^{148} \mathrm{O}$ eu e a maneira como conhece, interpreta e avalia o mundo são o objeto exclusivo de seu interesse. Rejeitase, diante disso, a doutrina platônica e, depois, cartesiana das ideias inatas. Ideias, afirmaria, são tudo aquilo que a mente emprega enquanto pensa. ${ }^{149}$ Das percepções dos objetos sensíveis, formaríamos ideias como amarelo, dureza, amargor etc. Da percepção das operações de nossa mente, chegaríamos a ideias como dúvida, descoberta, crença etc. Assim, a experiência sempre seria a base de nosso conhecimento, seja pelas sensações, seja pela reflexão. ${ }^{150}$ Delas, chegaríamos ou a ideias simples, que são os átomos ou matéria-prima de todo nosso conhecimento, ${ }^{151}$ ou a ideias complexas, que advêm de operações ativas da mente de combinar ideias simples; estabelecer relações; e fazer abstrações. ${ }^{152}$

Ao concentrar-se somente nas operações da mente, Locke rompe com a tradição e caminha da ontologia para a epistemologia. ${ }^{153}$ Literalmente, faria do sujeito a medida do mundo, o qual, reversa e sintomaticamente, seria destituído de uma medida universal. $\mathrm{O}$ próprio tempo seria derivado exclusivamente da reflexão e das sensações. A partir da observação de que as ideias se alternam em nossa mente, chegaríamos à ideia de sucessão. Ao observarmos a distância entre cada um dos pontos dessa sucessão, chegaríamos à ideia de duração. Pela percepção de que o aparecimento e desaparecimento de ideias se pode dar em intervalos equidistantes, chegaríamos às medidas de duração, como minutos, horas, dias e anos. E assim por diante. $^{154}$

${ }^{148}$ TAYLOR, Charles. Sources of the self cit., p. 159-176. Meu débito à exposição de Taylor é bem maior do que transparece nas próximas notas de rodapé.

${ }^{149}$ LOCKE, John. An essay concerning human understanding. Ed. Peter H. Nidditch. Oxford Nova Iorque: Clarendon, 1972 (reimpressão, 2011), p. 47.

${ }^{150}$ Idem, p. 104-105.

${ }^{151}$ Idem, p. 119.

152 Idem, p. 163.

${ }^{153}$ TAYLOR, Charles. Sources of the self cit., p. 164

${ }^{154}$ Transcrevo a teoria de Locke sobre como chegaríamos à ideia de tempo: "And thus I think it is plain, that from those two Fountains of all Knowledge before mentioned, (viz.) Reflection and Sensation, we get the Ideas of Duration, and the measures of it. For First, By observing what passes in our Minds, how our Ideas there in train constantly some vanish, and others begin to appear, we come by the Idea of Succession. Secondly, By observing a distance in the parts of this Succession, we get the Idea of Duration. Thirdly, By Sensation observing certain appearances, at certain regular and seeming equidistant periods, we get the Ideas of certain Lengths or Measures of Duration, as Minutes, Hours, Days, Years, etc. Fourthly, By being able to repeat those Measures of Time, or Ideas of stated length of Duration in our Minds, as often as we will, we can come to imagine Duration, where nothing does really endure or exist; and thus we imagine to morrow, next year, or seven years hence. Fifthly, By being able to repeat any such Idea of any length of Time, as of a Minute, a Year, or an Age, as often as 
Igualmente, ideias não seriam nem falsas nem verdadeiras. ${ }^{155}$ Elas simplesmente existiriam na mente de cada um de nós e formariam, ainda que incompatíveis com a realidade, aquilo que chamamos de conhecimento, que nada mais é que a percepção de conexão ou concordância (ou disjunção ou repugnância) entre quaisquer de nossas ideias. ${ }^{156}$ Muitas das nossas ideias, aliás, teriam origem espontânea, que fogem do nosso controle. Por força da educação, hábitos e costumes, associamos naturalmente ideias umas às outras. Cabe à razão apenas explicar o porquê de tais associações. ${ }^{157}$ Diante desse quadro, não é de surpreender que Locke negue a existência ontológica do bem e do mal. Para ele, seriam abstrações que a mente formula a partir das ideias de prazer e dor, que são acompanhadas, por sua vez, de deleite e inquietação. ${ }^{158}$

Nesse amplo contexto de desagregação social, moral e intelectual, gêneros narrativos como a epopeia e a estória romanesca, ao traduzirem na forma a coesão de um sistema de valores, mostravam-se inquestionavelmente anacrônicos. No caso da epopeia, como explicado no capítulo anterior, a forma seria ou "natural", porque decorrente de uma experiência não mediada de uma realidade efetivamente heroica, ou evocaria, com a unidade da ação, a ressignificação da história por meio da conquista imperial. ${ }^{159}$ No caso das estórias romanescas, gênero que remonta, sobretudo, a Aethiopica, de Heliodoro, ${ }^{160}$ configura-se um mundo em que o desenlace de sucessivas aventuras depende exclusivamente das qualidades extraordinárias das personagens. Aqui, a caracterização não é um processo que se cristaliza ao longo da narrativa. Pelo contrário: heroínas e heróis emergem inalterados de estórias como Le Grand Cyrus (1648-1653), de Madeleine de Scudéry. À intriga cabe confirmar suas virtudes, que se encontram dadas de saída, sem que nenhuma intempérie possa

\footnotetext{
we will in our own Thoughts, and add them one to another, without ever coming to the end of such addition, any nearer than we can to the end of Number, to which we can always add, we come by the Idea of Eternity, as the future eternal Duration of our Souls, as well as the Eternity of that infinite Being, which must necessarily have always existed. Sixthly, By considering any part of infinite Duration, as set out by periodical Measures, we come by the Idea of what we call Time in general" (LOCKE, John. An essay concerning human understanding cit., p. 195-196).

${ }^{155}$ Idem, p. 384-385. Ver TAYLOR, Charles. Sources of the self cit., p. 169.

${ }^{156}$ LOCKE, John. An essay concerning human understanding cit., p. 525.

${ }^{157}$ Idem, p. 395 e ss.

${ }^{158}$ Idem, p. 229.

${ }^{159}$ Ver supra, p. 112 e ss.

${ }^{160}$ DIPIERO, Thomas. "Unreadable novels: toward a theory of seventeenth-century aristocratic fiction". Novel: a forum on fiction, v. 38, n. 2/3 (primavera-verão, 2005), p. 129-146, especialmente p. 146 e RICHETTI, John. "The novel before "the novel"'. In: CASERIO, Robert L.; HAWES, Clement (ed.). The Cambridge History of the English novel. Cambridge: Cambridge University, 2012, p. 14-29, espcialmente p. 21.
} 
conspurcá-las. ${ }^{161}$ Encerra-se uma ideologia de estratificação social, para a qual a ascendência do indivíduo deriva mais de sua origem que, propriamente, sua trajetória. $^{162}$

Ó como é fácil avistar

O sangue gentil, por mais que esteja envolto

Em tristes infortúnios, vil deformidade ${ }^{163}$

(VI, 5, 1)

Contrariamente às narrativas épicas e romanescas, a narrativa novelística se constitui ao postular a diferença entre o narrar e o narrado, num repertório que tende à reflexividade e à ironia. ${ }^{164}$ As obras que, retrospectivamente, tomamos como os primeiros romances têm em comum problematização da distância entre a perspectiva do narrador e a das personagens, numa forma em que se enfeixam as crises social e intelectual do longo século XVIII. ${ }^{165}$ Usualmente, os protagonistas do romance setecentista começam suas aventuras ainda a crer na validade dos antigos códigos morais e (por extensão) literários, numa elaborada tematização do hiato entre o mundo e sua representação ou, para usarmos uma terminologia lockiana, entre ideia e objeto. ${ }^{166}$ Em The Female Quixote (1752), Arabella deriva suas "concepções e expectativas" de estórias romanescas, ao tomá-las como "retratos verdadeiros da vida":

Suas ideias [...] tomaram uma inclinação romântica; e, ao supor que estórias romanescas eram retratos verdadeiros da vida, deles ela tirou todas as suas concepções e expectativas. Por meio deles, ela foi ensinada a acreditar que o amor era o princípio supremo do mundo; e que cada paixão se subordinava a isso; e que ele [o amor] causava todas as alegrias e misérias da vida. ${ }^{167}$

${ }^{161}$ FRYE, Northrop. The secular scripture: a study of the structure of romance. Cambridge, MA Londres: Harvard University, 1976, p. 161 e VASCONCELOS, Sandra Guardini T. A formação do romance inglês: ensaios teóricos. São Paulo: Hucitec - Fapesp, 2007, p. 48.

162 TAYLOR, Charles. Sources of the self cit., p. 214 e 287.

163 "O what an easie thing is to descry/ The gentle bloud, how euer it be wrapt/ In sad misfortunes foule deformity" (V, 5, 1) (SPENSER, Edmund. The faerie queene cit., p. 632).

${ }^{164}$ LUKÁCS, Georg. A teoria do romance. Trad. José Marcos Mariani de Macedo. São Paulo: 34 Duas Cidades, 2000, p. 117 e ss.

${ }^{165}$ BERNSTEIN, J. M. The philosophy of the novel cit., p. xxi e p. 50-51; ISER, Wolfgang. The implied reader: patterns of communication in prose fiction from Bunyan to Beckett. Baltimore Londres: Johns Hopkins University, 1974, p. 32-35 e McKEON, Michael. The origins of the English novel cit., p. 266.

${ }^{166}$ Ver TAYLOR, Charles. Sources of the self cit., p. 198; BERNSTEIN, J. M. The philosophy of the novel cit., p. xix e p. 79-89 e McKEON, Michael. The origins of the English novel cit., p. 266.

167 "Her Ideas [...] had taken a romantic Turn; and, supposing Romances were real Pictures of Life, from them she drew all her Notions and Expectations. By them she was taught to believe, that Love was the ruling Principle of the World; that every other Passion was subordinate to this; and that it 
Trata-se de uma suposição que, obviamente, só lhe trará problemas. À custa de inúmeras desventuras, Arabella descobrirá que os tempos mudaram - que, como lhe dirá Mr Glanville, nem o amor nem a honra têm leis próprias no mundo moderno. ${ }^{168}$ O único "retrato verdadeiro da vida" seria aquele que, antiteticamente, afirma sua falsidade, porque inepto a capturar a maneira como costumeiramente nos portamos. É o que o Doutor - ensina a Arabella na admoestação que perfaz o penúltimo capítulo:

É a imperfeição das melhores ficções que elas ensinam as mentes jovens a esperar aventuras estranhas e vicissitudes repentinas, e, portanto, encorajam-nas muitas vezes a confiar no acaso. Uma longa vida pode transcorrer sem uma ocorrência sequer que cause grande surpresa, ou produzir alguma consequência de grande importância. A ordem do mundo é tão estabelecida que todos os negócios humanos procedem num método regular [...], [que] o bravo e o covarde, o vivaz e o insípido, estão todos sujeitos a serem levados pelo fluxo do costume. ${ }^{169}$

Sintomaticamente, o romance setecentista desenvolve uma tópica mais ou menos ubíqua de contrastar as convenções da epopeia e da estória romanesca à vida e aos hábitos na Grã-Bretanha moderna - àquilo que o Doutor - chama de "fluxo do costume". ${ }^{170}$ Tome-se o caso de Joseph Andrews (1742), de Henry Fielding. Afilia-se a estória das aventuras e desventuras do lacaio epônimo e de seu amigo, Abraham Adams, à tradição épica. Numa leitura um tanto liberal de Aristóteles, com a qual se divide o épico e o drama em tragédia e comédia, apresenta-se Joseph Andrews como um poema épico-cômico em prosa:

O [Épico], ${ }^{171}$ tão bem como o Drama, se divide em tragédia e comédia. Homero, que foi pai dessa espécie de poesia, legou-nos o

caused all the Happiness and Miseries of Life" (LENNOX, Charlotte. The female Quixote or the adventures of Arabella. Ed. Margaret Dalziel. Oxford - Nova Iorque: Oxford University, 1998, p. 7).

${ }^{168}$ Idem, p. 320.

${ }^{169}$ Trecho integral: "It is the Fault of the best Fictions, that they teach young Minds to expect strange Adventures and sudden Vicissitudes, and therefore encourage them often to trust to Chance. A long Life may be passed without a single Occurrence that can cause much Surprize, or produce any unexpected Consequence of great Importance; the Order of the World is so established, that all human Affairs proceed in a regular Method, and very little Opportunity is left for Sallies or Hazards, for Assault or Rescue; but the Brave and the Coward, the Sprightly and the Dull, suffer themselves to be carried alike down the Stream of Custom" (idem, p. 379).

${ }^{170}$ Ver BERNSTEIN, J. M. The philosophy of the novel cit., p. 51.

${ }^{171}$ Com certo sotaque hegelio-crociano, a tradução brasileira de Roger Maioli dos Santos adota o termo "Épica", ao invés de "Épico" ou "Epopeia" (FIELDING, Henry. A história das aventuras de Joseph Andrews e seu amigo Abraham Adams. Trad. Roger Maioli dos Santos. Cotia: Ateliê Campinas: Unicamp, 2011, p. 59 e ss.). A escolha me parece pouco apropriada. "Épica”, "dramática" e "lírica" são termos que pertencem a uma visão essencialista dos gêneros literários, completamente estranha à prática e à teoria do século XVIII e que se disseminaria na Grã-Bretanha somente no período vitoriano (ver FOWLER, Alastair. Kinds of literature: an introduction to the theory of genres and 
modelo de ambas, muito embora o do último gênero se haja inteiramente perdido, o qual, Aristóteles nos diz, tinha a mesma relação com a comédia que sua Ilíada com a tragédia. ${ }^{172}$

Por mais que a vinculação à linhagem épica possa dignificar o empreendimento literário de Fielding, o elemento nuclear da classificação genérica de Joseph Andrews é o cômico. ${ }^{173} \mathrm{O}$ que há de épico, aqui, tem função eminentemente paródica. Abraham Adams, por exemplo, encontra-se com um cavalheiro que a todo instante professa sua coragem. Diz até ter deserdado um sobrinho que desertara do exército. Adams elogia seu interlocutor, num diálogo em que se enumeram precedentes homéricos por meio de citações a Aquiles, Heitor e Páris. Entretanto, quando ouvem à distância uma súplica por socorro, o cavalheiro bate em retirada e deixa apenas o excêntrico pároco para tentar salvar a moça em apuros:

[...] eles seguiram adiante, com o cavalheiro retomando o discurso sobre a coragem e a infâmia de não se estar pronto a toda hora para sacrificar a vida pela pátria. A noite os alcançou quase no mesmo instante em que chegaram a um moitendo, do qual, subitamente, ouviram provir os mais violentos berros imagináveis numa voz feminina. Adams fez menção de tomar a espingarda das mãos do companheiro. - O que está fazendo? - disse este. - Fazendo? volveu Adams. - Estou indo ao socorro dessa pobre criatura, que alguns vilões estão assassinando. - Espero que não seja louco a esse ponto - disse o cavalheiro, tremebundo. [...] Isto não é assunto nosso; vamos dar o fora daqui o mais prontamente possível, ou poderemos cair nós mesmos nas mãos deles. ${ }^{174}$

A cena claramente transfere os predicados de que o cavalheiro se gabava para Adams. Se há alguma personagem em Joseph Andrews que tem alguma propensão ao

modes. Cambridge, MA: Harvard University, 1982, p. 235-239). Diante disso, substituí "épica" por "épico".

${ }^{172}$ FIELDING, Henry. A história das aventuras de Joseph Andrews e seu amigo Abraham Adams cit., p. 59. No original: "The EPIC as well as the DRAMA is divided into Tragedy and Comedy. Homer, who was the father of this Species of Poetry, gave us a Pattern of both these, tho' that of the latter kind is entirely lost; which Aristotle tells us, bore the same relation to Comedy which his Iliad bears to Tragedy" (FIELDING, Henry. "Joseph Andrews". The history of the adventures of Joseph Andrews and of his friend Mr. Abraham Adams and An apology for the life of Mrs. Shamela Andrews. Ed. Douglas Brooks-Davies; Martin C. Battestin. Oxford - Nova Iorque: Oxford University, 1999, p. 3).

${ }^{173}$ Sigo de muito perto: WATT, Ian. A ascensão do romance: estudos sobre Defoe, Richardson e Fielding. Trad. Hildegard Feist. São Paulo: Companhia das Letras, p. 216 e ss.

${ }^{174}$ FIELDING, Henry. A história das aventuras de Joseph Andrews e seu amigo Abraham Adams cit., p. 181. No original: "Adams accepted this Proposal, and on they travelled, the Gentleman renewing his Discourse on Courage, and the Infamy of not being ready at all times to sacrifice our Lives to our Country. Night overtook them much about the same Time as they arrived near some Bushes: whence, on a sudden, they heard the most violent Shrieks imaginable in a female Voice. Adams offered to snatch the gun out of his Companion's Hand. 'What are you doing?' said he. 'Doing!' said Adams, 'I am hastening to the Assistance of the poor Creature whom some Villains are murdering.' '[...] This is no Business of ours; let us make as much haste as possible out of the way, or we may fall into their hands ourselves"” (FIELDING, Henry. "Joseph Andrews" cit., p. 119). 
heroísmo, Adams decerto é o primeiro na lista. Suas imensas qualidades, contudo, tornam-no completamente inepto para viver neste mundo, como afirma o próprio narrador. ${ }^{175}$ Mas ao contrário de outros gêneros narrativos que descortinam a fratura entre convenção e realidade, como o poema herói-cômico, o romance setecentista muitas vezes desenvolve soluções para que, enfim, o narrar e o narrado convirjam para uma conciliação. ${ }^{176}$ Retomemos o caso de The Female Quixote. Articula-se o "aprendizado" de Arabella num enredo, ao final do qual ela se dará conta de que suas leituras desfiguram a aparência do mundo e tudo representam numa forma diferente do que tem mostrado a experiência. ${ }^{177}$ Depois de se expor o solipsismo de uma personagem destituída de seus referenciais hereditários, oferece-se-lhe um desfecho de satisfação deflacionada, em que o reconhecimento do próprio isolamento se torna uma medida de crescimento moral e intelectual. ${ }^{178}$

O desafio estético inescapável do romance é, portanto, a construção de seu enredo, de uma estrutura que engendre inteligibilidade à experiência destituída de seus referenciais inatos, para a qual nenhum enunciado em que se afirme a existência de um universo ordenado, estável e previsível pode ser tomado, a rigor, como verdadeiro. Levada às últimas consequências, a separação lockiana entre ideia e objeto implica a incognoscibilidade do mundo. ${ }^{179}$ Contudo, como observaria David Hume, ${ }^{180}$ a mente precisa atribuir coerência e continuidade ao nosso "amontoado de impressões", cuja correspondência ou compatibilidade com a natureza é impossível

\footnotetext{
${ }^{175}$ Idem, p. 19. Ver também ISER, Wolfgang. The implied reader cit., p. 34 e HUNTER, J. Paul. Occasional form: Henry Fielding and the chains of circumstance. Baltimore - Londres: Johns Hopkins University, 1975, p. 114. Para Hunter, Adams é tanto um modelo do que o indivíduo pode atingir quanto um alerta do quanto essas qualidades se encontram deslocadas no mundo moderno.

${ }^{176}$ TAYLOR, Charles. Sources of the self cit., p. 286-287 e BERNSTEIN, J. M. The philosophy of the novel cit., p. 79 e ss.

${ }^{177}$ LENNOX, Charlotte. The female Quixote cit., p. 379.

${ }^{178}$ Ver SHRODER, Maurice Z. "The novel as a genre". In: STEVICK, Philip (ed.). The theory of the novel. Nova Iorque: The Free Press - Londres: Collier Macmillan, 1967, p. 13-29.

${ }^{179}$ HUME, David. A treatise of human nature. Ed. L. A. Selby-Bigge; P. H. Nidditch. 2. ed. Oxford: Clarendon, 1979 (reimpressão, 2009), p. 193.

${ }^{180}$ Para a homologia entre a epistemologia de Hume e a ascensão do romance, ver DUNCAN, Ian. Scott's shadow: the novel in Romantic Edinburgh. Princeton - Oxford: Princeton University, 2007, p. 116-144. Ver também DUNCAN, Ian. "Hume and the Scottish Enlightenment". In: MANNING, Susan (ed.). The Edinburgh history of Scottish literature: Enlightenment, Britain and empire (1707-1918). Edimburgo: Edinburgh University, 2007, p. 71-79, especialmente p. 72-73; CRAIG, Cairns. "Coleridge, Hume, and the chains of the Romantic imagination". In: DAVIS, Leith; DUNCAN, Ian; SORENSEN, Janet (ed.). Scotland and the borders of romanticism cit., p. 20-37. Dialoga-se, também, com BERNSTEIN, J. M. The philosophy of the novel cit., p. xix e ISER, Wolfgang. The fictive and the imaginary: charting literary anthropology. Baltimore - Londres: Johns Hopkins University, 1993, p. 110-112.
} 
provar por meio da lógica ou da razão. ${ }^{181}$ Para tanto, nossas faculdades imaginativas ficcionalmente unificariam nossas percepções, fazendo com que as consideremos invariáveis e ininterruptas. ${ }^{182} \mathrm{~A}$ imaginação estabeleceria relações de causa e efeito e postularia a identidade e a continuidade de nossas impressões e de nosso próprio eu:

A passagem suave da imaginação pelas ideias das percepções semelhantes faz que atribuamos a elas uma identidade perfeita. A maneira descontínua de sua aparição nos faz considerá-las seres semelhantes, porém distintos, que aparecem em intervalos. A perplexidade resultante dessa contradição produz uma propensão a unir essas aparições fragmentadas mediante a ficção de uma existência contínua $\left[\ldots . . .{ }^{183}\right.$

O enredo no romance opera como a imaginação para Hume: amarra as "contradições" e "perplexidades" inerentes à experiência humana num arranjo aparentemente inteligível, em que a ficção é postulado epistêmico falho porém indispensável de uma mente cujo potencial cognitivo se reconhece como irremediavelmente limitado. ${ }^{184} \mathrm{O}$ engendrar do enredo é indispensável porque se rejeitam estruturas episódicas e descontínuas, como nas estórias romanescas, em que o sentido (o heroísmo do protagonista) antecede à própria narrativa. O romance precisa entrelaçar suas múltiplas partes numa estrutura identificável para que possa, ele mesmo, construir a sua inteligibilidade, já que nenhum sentido pode ser tido como dado. ${ }^{185}$ Em 1780 , Thomas Holcroft veria a "combinação de incidentes [...] para formar um todo" como o elemento definidor da narrativa novelística. $\mathrm{Na}$ estória romanesca, "as aventuras passam diante de nossos olhos [...] sem [...] afetar a estória principal":

O romance é uma outra espécie de obra. A unidade de desígnio é a sua natureza. Numa estória romanesca, se os incidentes são bem demarcados e ligados com vitalidade, satisfaz-se o propósito: e as aventuras passam diante de nossos olhos com nenhuma outra finalidade senão a de entreter por conta de sua peculiaridade, sem,

\footnotetext{
${ }^{181}$ Para Hume, a rigor, não poderíamos nem nos certificarmos da existência da natureza - só de nossas percepções (ver HUME, David. A treatise of human nature cit., p. 212).

${ }^{182}$ Ver idem, p. 255.

${ }^{183}$ Tratado da natureza humana. Trad. Débora Danowski. 2. ed. São Paulo: Unesp, 2009, p. 238. No original: "The smooth passage of the imagination along the ideas of the resembling perceptions makes us ascribe to them a perfect identity. The interrupted manner of their appearance makes us consider them as so many resembling, but still distinct beings, which appear after certain intervals. The perplexity arising from this contradiction produces a propension to unite these broken appearances by the fiction of a continu'd existence [...]" (HUME, David. A treatise of human nature cit., p. 205).

${ }^{184}$ Dialogo, novamente, com BERNSTEIN, J. M. The philosophy of the novel cit., p. xviii e 147; JAMESON, Fredric. The political unconscious cit., p. 83 e ISER, Wolfgang. The fictive and the imaginary cit., p. 111.

${ }^{185}$ VASCONCELOS, Sandra Guardini T. A formação do romance inglês cit., p. 48 e HUNTER, J. Paul. Before novels cit., p. 24.
} 
talvez, afetar a estória principal, se houver uma. Num romance, porém, uma combinação de incidentes, interessantes por si mesmos, é feita para formar um todo. E uma circunstância dispensável se torna uma mácula ao separar-se da simplicidade necessária para exibir-se vantajosamente o todo. ${ }^{186}$

Como se depreende do "Prefácio" às obras coligidas de Mary Davys, em 1725, o romance precisa ordenar os incidentes de maneira mais clara que a Fortuna, ${ }^{187}$ aproximando-se dos modelos da epopeia, da tragédia e da comédia. ${ }^{188}$ No entanto, o entremear da experiência, conforme operado pela ficção novelística, não seria visto nem por Davys nem por ninguém como substituto para a realidade. Os romancistas do século XVIII não têm nem de longe a confiança dos teóricos neoclássicos, que viam, como tantas vezes mostramos, na ordenação da ação a chave para uma verdade superior. A temporalização da experiência proporcionada pelo enredo não passa, para retomarmos o paradoxo humiano, de mera construção imaginativa. ${ }^{189}$ Qualquer tentativa de se representar com alguma fidelidade a mente humana e seu "amontoado de impressões" ${ }^{190}$ requer, como observariam Jane Collier e Sarah Fielding, uma abertura formal em que, inevitavelmente, violam-se "as regras": ${ }^{191}$

Revelar por inteiro os labirintos da mente humana é tarefa árdua e, não obstante os muitos traços habilidosos e penetrantes que se encontram nos melhores autores, parecem ainda permanecer alguns recessos intrincados e fechados no coração do homem. A fim de mergulhar nesses recessos e abri-los ao leitor de uma maneira surpreendente e inteligível, é necessário pressupor uma certa

\footnotetext{
186 "A Novel is another kind of work. Unity of design is its character. In a Romance, if the incidents be well marked and related with spirit, the intention is answered; and adventures pass before the view for no other purpose than to amuse by their peculiarity, without, perhaps, affecting the main story, if there should be one. But in a Novel, a combination of incidents, entertaining in themselves, are made to form a whole; and an unnecessary circumstance becomes a blemish, by detaching from the simplicity which is requisite to exhibit that whole to advantage" (HOLCROFT, Thomas. "Preface to Alwyn (1780)". In: NIXON, Cheryl L. Novel definitions cit., p. 94).

${ }^{187}$ No original: "[...] room to order Accidents better than Fortune will be at Pains to do" (DAVYS, Mary. "Preface to The works of Mrs. Davys (1725)". In: NIXON, Cheryl L. Novel definitions cit., p. 81-82).

${ }^{188}$ Idem, p. 83. Críticos de orientação neoclássica, como Andrew Murphy e Francis Coventry, aplicariam de maneira deliberada o receituário aristotélico na análise de romances (MURPHY, Arthur. "An essay on the life and genius of Henry Fielding, Esq.". The works of Henry Fielding, Esq.; with the life of the of the author. [Ed. Arthur Murphy] 2. ed. Londres: Arthur Millar, 1762. v. 1, p. 5-98 e [COVENTRY, Francis]. An essay on the new species of writing founded by Mr. Fielding: with a word or two upon the modern state of criticism. Londres, 1751, passim).

${ }^{189}$ Ver: KERBY, Anthony Paul. Narrative and the self. Bloomington: University of Indiana, 1991, p. 25-26.

${ }^{190}$ HUME, David. A treatise of human nature cit., p. 225.

${ }^{191}$ As regras de Aristóteles.
} 
liberdade na escrita, não estritamente talvez dentro dos limites prescritos pelas regras. ${ }^{192}$

Analogamente, William Guthrie argumentaria, no "Prefácio" a The friends: a sentimental history, que era inevitável desviar das regras dos críticos, pois "não poderia sacrificar minha veracidade ao seu decoro". ${ }^{193}$ E um resenhista anônimo da Critical review discorreria sobre como os romances não estão "confinados às unidades de espaço e tempo", não havendo por que falarmos de unidade de ação. Quando a "personagem fala em seu próprio nome, enuncia seus sentimentos e compartilha suas opiniões com o fervor do coração", ${ }^{194}$ elas inevitavelmente se detêm em circunstâncias que, noutros gêneros narrativos, seriam tidas como "frívolas e impertinentes". Não é de surpreender, portanto, que o romance setecentista trate as operações ostensivas e incontornáveis do enredo com certo embaraço, como nesta passagem de The Vicar of Wakefield (1766), de Oliver Goldsmith, em que a sucessão de coincidências é canhestramente comparada à mão invisível do mercado:

Não posso prosseguir sem uma reflexão sobre esses encontros acidentais que, embora ocorram todo dia, dificilmente excitam nossa surpresa, salvo em alguma ocasião extraordinária. Nós não devemos todos os prazeres e conveniências de nossas vidas a uma conjunção fortuita? Quantas coincidências aparentes devem convergir para que nos possamos vestir e alimentar? O camponês deve estar disposto a trabalhar, a chuva deve cair, o vento lufar as velas do mercador e as pessoas demandarem a oferta usual. ${ }^{195}$

\footnotetext{
${ }^{192}$ FIELDING, Sarah. "Prefácio a The cry (1764)". VASCONCELOS, Sandra Guardini. A formação do romance inglês cit., p. 386. No original: "Thoroughly to unfold the labyrinths of the human mind, is an arduous task; and notwithstanding the many skilful [sic] and penetrating strokes which are to be found in the best authors, there seem yet to remain some intricate and unopen'd recesses in the heart of man. In order to dive into those recesses, and lay them open to the reader in a striking and intelligible manner, 'tis necessary to assume a certain freedom in writing, not strictly perhaps within the limits prescribed by rules" ([FIELDING, Sarah]. The cry: a new dramatic fable in three volumes. Londres, 1754, v. 1, p. 14).

193 "I could not sacrifice my own Veracity to their Decorum" (GUTHRIE, William. The friends: a sentimental history: describing love as a virtue, as well as a passion. Londres: printed for T. Waller, 1754 , v. 1, s. p.).

194 " [...] character speaks in his own person, utters his feelings, and delivers his sentiments warm from the heart" (ANÔNIMO. "Review of Frances Sheridan, Memoirs of Miss Sidney Bidulph, Critical review, n. 11 (March 1761)”. In: NIXON, Cheryl L. Novel definitions cit., p. 302).

195 "Nor can I go on without a reflection on those accidental meetings which, though they happen every day, seldom excite our surprise but upon some extraordinary occasion. To what a fortuitous concurrence do we not owe every pleasure and convenience of our lives. How many seeming accidents must unite before we can be clothed or fed. The peasant must be disposed to labour, the shower must fall, the wind fill the merchant's sail, or numbers must want the usual supply" (GOLDSMITH, Oliver. "The vicar of Wakefield". Collected works of Oliver Goldsmith. Ed. Arthur Friedman. Oxford: Clarendon Press, 1966. v. 4, p. 174). Sobre o colapso da narrativa em The vicar of Wakefield, ver BROWN, Marshall. Preromanticism. Stanford: Stanford University, 1991, p. 164 e ss.
} 
Ou de maneira paródica, como em Tom Jones (1749), em que o narrador toma o desenlace como um desenvolvimento arbitrário e formular da narrativa, em que finalmente se espremem as diversas questões suscitadas até a última etapa de uma longa jornada, na qual se dá "adeus ao leitor”:

[...] se eu, de vez em quando, no decurso desta obra, me entreguei a alguma brincadeira para teu entretenimento, deixo-o aqui. De feito, a variedade de assuntos que força me será atafulhar neste livro não dará lugar a nenhuma dessas observações facetas que fiz alhures, e que talvez te impediram de cochilar quando o sono principiava, sorrateiro, a abeirar-se de ti. Neste último livro não encontrarás nada (ou quando muito, muito pouco) dessa natureza. Tudo consistirá numa simples narrativa $[\ldots] .{ }^{196}$

O enredo é um índice inegável de ficcionalidade num gênero para o qual a própria ficcionalidade é uma vexata quaestio. ${ }^{197}$ A ficcionalização do processo de reconhecimento da ilusão ficcional mobiliza estratégias complexas de legitimação, ausentes noutras paragens. Nas epopeias neoclássicas, a invocação às musas e, sobretudo, o desfile de convenções genéricas, religiosas ou prosódicas validam, de per $s e$, o discurso. No romance, narradores ou personagens precisam, ainda que pela via paródica, justificar-se narrativamente, por meio da textualização de seus condicionantes, que se estabelecem, delimitam e resolvem na e pela estrutura da obra. ${ }^{198}$ Esta fornece, ela mesma, o mapa e as instruções para se adentrar no universo que configura, tendo um quê de epistemologia. Reifica-se a maneira por que narradores e personagens veem, conhecem e interpretam a realidade, para que o leitor possa escrutinizá-la. ${ }^{199}$ Em Felicia to Charlotte (1744), de Mary Collyer, a narradora epistolar, Felicia, vê-se forçada a naturalizar sua narrativa:

De minha parte, tenciono revelar todas as dobras secretas de meu coração e abrir-me inteira para você, sem a mínima reserva, pois estou convencida de que jamais terei segredos com os quais você não terá o direito de se familiarizar - e os quais não estarei pronta para the comunicar. Por favor, siga o meu exemplo: escreva com a

\footnotetext{
196 “.... if I have now and then, in the Course of this Work, indulged any Pleasantry for thy entertainment, I shall here lay it down. The Variety of Matter, indeed, which I shall be obliged to cram into this Book, will afford no Room for any of those ludicrous Observations which I have elsewhere made, and which may sometimes, perhaps, have prevented thee from taking a Nap when it was beginning to steal upon thee. In this last Book thou wilt find nothing (or at most very little) of that Nature. All will be plain Narrative only" (The history of Tom Jones, a foundling. Ed. Thomas Keymer; Alice Wakely. Londres: Penguin, 2005, p. 812).

${ }^{197}$ Ver BERNSTEIN, J. M. The philosophy of the novel cit., p. xxi e HUNTER, J. Paul. Before novels cit., p. 24.

${ }^{198}$ Ver ISER, Wolfgang. The implied reader cit., p. xii-xiii.

${ }^{199}$ HUNTER, J. Paul. Before novels cit., p. 44-47 e BERNSTEIN, J. M. The philosophy of the novel cit., p. xxi e p. 46 e ss.
} 
mesma liberdade, sem reservas, e nunca esconda aqueles pequenos afazeres de que se ocupa seu coração $[. . .]^{200}$

A mesma tópica pode ser encontrada em Sir Charles Grandison (1753), de Samuel Richardson. Harriet Byron se compromete a revelar seus pensamentos por completo, a despeito de eventuais reproches por parte de sua prima Lucy:

Nem uma sombra de reserva eu darei ao meu coração: minha caneta será honesta com esse coração. Serei beneficiada, estou certa, pelos ferimentos fiéis de amigos tão afetuosos, tão amados quanto reverenciados. - Então, Caneta, segue teu curso. ${ }^{201}$

Os encontros, conversas, saraus e entrevistas com pretendentes se sucedem ao longo de sete volumes numa narrativa minuciosa que, todavia, não quer ser vista, para retomarmos a citação de Holcroft, como dotada de qualquer "outra finalidade senão a de entreter por conta de sua peculiaridade". Miss Byron prometera escrever sem "uma sombra de reserva" e suas muitas e muitas cartas, de certa maneira, apenas cumprem com a promessa inicial.

O romance se institucionaliza na década de 1740, com Samuel Richardson, quando se sintetizam os impulsos antitéticos de inteligibilidade, inclusividade ${ }^{202}$ e autojustificação numa narrativa heterogênea em que os referidos impulsos se determinam mutuamente. ${ }^{203}$ Ao final da década de 1740 , reconhecer-se-ia finalmente que essa tensão formal constitui o gênero. De maneira lapidar, o escocês Tobias Smollett tomaria o romance como um quadro em que se opõe a vida a um plano geral, engendrados reciprocamente. Todas as personagens do romance seriam

\footnotetext{
200 "For my part, I intend to discover all the secret folds of my heart, and to unbosom myself to you without the least reserve, as I am persuaded I shall never have any secrets which you have not a right to be acquainted with, and which I shall not be very ready to communicate. Pray do you follow my example; write with the same unreserved freedom, and never disguise those little affairs in which your heart is concerned" ([COLLYER, Mary]. Felicia to Charlotte: being letters from a young lady in the country, to her friend in town. Londres, 1744, p. 2). O romance epistolar seria repleto desse tipo de procedimento de autojustificação narrativa. De acordo com Linda Kauffman, missivas se fundam na ilusão de que o remetente de fato conversa com o destinatário, a converter o silêncio deste último numa estrutura de intimidade compartilhada (KAUFFMAN, Linda. Discourses of desire: gender, genre, and epistolary fictions. Ithaca - Londres: Cornell University, 1988, p. 19-27).

201 "Not the least shadow of reserve shall it give to my heart: My pen shall be honest to that heart; and I shall be benefited, I am sure, by the faithful wounds of such affectionate, and equally-beloved as revered friends-And so, Pen, take thy course" (RICHARDSON, Samuel. The history of Sir Charles Grandison. Ed. Jocelyn Harris. Oxford - Nova Iorque: Oxford University, 1986, v. 1, L. XXXVI, p. 179).

${ }^{202}$ Tomamos de empréstimo a expressão de J. Paul Hunter, para abarcar a liberdade formal vislumbrada por Sarah Fielding (HUNTER, J. Paul. Before novels cit., p. 24).

${ }^{203}$ Ver BARTOLOMEO, Joseph F. A new species of criticism: eighteenth-century discourse on the novel. Newark: University of Delaware; Londres - Toronto: Associated University Presses, 1994, p. 88; McKEON, Michael. The origins of the English novel cit., p. 17-18 e passim. SPACKS, Patricia Meyer. Desire and truth cit., p. 12 e 75.
} 
"subservientes" a esse plano. Por outro lado, seriam as personagens - e, mais especificamente, uma personagem principal - que desenrolam o novelo da forma. A narrativa novelística seria grande, difusa e diversa e, ao mesmo tempo, submetida a "um plano uniforme":

Um romance é um grande quadro difuso, que abrange as personagens da vida, dispostas em diferentes grupos e exibidas em diversas atitudes, segundo os propósitos de um plano uniforme e ocorrência geral, ao qual cada figura individual é subserviente. Porém, esse plano não pode ser executado com adequação, probabilidade ou sucesso, sem uma personagem principal que atraia a atenção, junte os incidentes, desemaranhe o fio do labirinto e, finalmente, feche a cena, por força de sua importância. ${ }^{204}$

A fórmula de Smollett, entretanto, não nasceu pronta. Nem tampouco "a nova espécie de escrita" ${ }^{205}$ de Samuel Richardson pode ser creditada, como faria Edward Young, em 1759, a seu gênio natural. ${ }^{206}$ A problematização da distância entre o narrador e o narrado, que redunda nos impasses da construção do enredo, pode ser detectada desde o final do século XVII. Por conseguinte, para entendermos o complexo jogo de codeterminações engendrado pela narrativa novelística, não basta analisarmos apenas romances canônicos, cujo status artístico parece claramente assegurado. ${ }^{207}$ A conciliação promovida pela narrativa novelística se sedimenta ao longo de décadas. Para que possamos entendê-la melhor, é necessário adotarmos os anos de 1740 como ponto de chegada, e não de partida. Antes de Richardson, nomes como Aphra Behn, Eliza Haywood e Daniel Defoe, dentre outros, buscaram a conciliação do inconciliável.

\footnotetext{
${ }^{204}$ SMOLLETT, Tobias. "Dedicatória em The adventures of Ferdinand Count Fathom (1753)". In: VASCONCELOS, Sandra Guardini T. A formação do romance inglês cit., p. 382. No original: "A novel a large diffused picture, comprehending the characters of life, disposed in different groups, and exhibited in various attitudes, for the purposes of an uniform plan, and general occurrence, to which every individual figure is subservient. But this plan cannot be executed with propriety, probability or success, without a principle personage to attract the attention, unite the incidents, unwind the clue of the labyrinth, and at last close the scene by virtue of his own importance" (SMOLLETT, Tobias. "Dedication". The adventures of Ferdinand Count Fathom. Ed. Jerry C. Beasley; O. M. Brack Jr. Athens, GA - Londres: University of Georgia, 1988, p. 4). Para uma discussão sobre a maneira como Smollett define o romance, ver: MacKAY, Marina. The Cambridge introduction to the novel. Cambridge: Cambridge University, 2011, p. 75-76.

${ }^{205}$ A expressão "a new species of writing" foi empregada por Richardson numa carta sua a Aaron Hill (1 de fevereiro de 1741) (GERRARD, Christine (ed.). The Cambridge edition of the correspondence of Samuel Richardson. Correspondence with Aaron Hill and the Hill family. Cambridge: Cambridge University, 2013, edição Kindle reader).

${ }^{206}$ YOUNG, Edward. Conjectures on original composition, in a letter to the author of Sir Charles Grandison. Londres, 1759, p. 36.

${ }^{207}$ Para William B. Warner, com Richardson começa o que chama de "estética do entretenimento novelístico" (WARNER, William B. Licensing entertainment: the elevation of novel reading in Britain, 1684-1750. Berkeley - Los Angeles - Londres: University of California, 1998, p. 251 e ss.).
} 


\subsection{Aphra Behn}

Qualquer que tenha sido o primeiro romance, as narrativas em prosa de Aphra Behn problematizam a distância entre a perspectiva do narrador e a das personagens. ${ }^{208}$ Em sua obra mais famosa, Oroonoko, or, The Royal Slave (1688), por exemplo, esse arranjo pressupõe o apagamento consciente dos traços identificadores de seu registro ficcional por meio da incorporação de índices da narrativa histórica. Apresenta-se Oroonoko como "uma história verdadeira" (“a true history”) logo na Dedicatória ostensivamente subscrita por “A. Behn”. Obscurecem-se os traços inequivocamente romanescos da estória por meio de uma tópica que mais ou menos parodia relatos de viagem, em que o distanciamento geográfico escusa a representação dos feitos os mais extraordinários: $:^{209}$

Se há algo que pareça romanesco, rogo a Vossa Senhoria para que se lembre que esses países, em todas as coisas, em muito diferem do nosso, de modo que exibem maravilhas inconcebíveis - ou que assim nos parecem porque novas e estranhas. ${ }^{210}$

Promete-se, com isso, que a narrativa será prefigurada exclusivamente pelas "maravilhas inconcebíveis" desempenhadas pela personagem principal, um "escravo real", sem concessões a convenções literárias. Seriam os "acidentes" que "realmente

\footnotetext{
${ }^{208}$ A postulação de um ponto de ruptura inequívoca entre o romance e outras formas de ficção mostra-se uma miragem (idem, p. 45-47 e McKEON, Michael. The origins of the English novel cit., p. 267). Já nas últimas décadas do século XVII, é possível encontrar algumas narrativas ficcionais em prosa designadas ostensivamente como "romances" (novels), bem como algumas teorizações do gênero. Por outro lado, muitas das obras em cuja página de rosto se estampava o termo novel dificilmente são contabilizadas, hoje em dia, como pertencentes a uma linhagem de narrativas novelísticas. Talvez o caso mais eloquente seja Incognita (publicada em 1713), de William Congreve, em cujo "Prefácio" se traçam elaboradas distinções entre o romance e a estória romanesca (Ver VASCONCELOS, Sandra Guardini T. A formação do romance inglês cit., p. 43; RICHETTI, John. Popular fiction before Richardson: narrative patterns, 1700-1739. Oxford: Clarendon, 1969 (introdução 1992, reimpressão 2011), p. 174 e ss.; McKEON, Michael. The origins of the English novel cit., p. 6163; e AERCKE, Kristiaan. “Congreve's Incognita: romance, novel, drama?”. Eighteenth-century fiction, v. 2, n. 4 (julho, 1990), p. 293-308). Raros são os que hoje consideram Incognita como um romance. Seu uso de convenções do drama e sua linguagem estetizada colocam-na mais próxima da ficção ornamental do Renascimento e do Barroco (Richetti diz que, aqui, devemos ler "novella" no lugar de "novel": ver RICHETTI, John. Popular fiction before Richardson cit., p. 174 e ss. Para uma discussão sobre a dificuldade em se determinar o gênero de Incognita, ver AERCKE, Kristiaan. “Congreve's Incognita: romance, novel, drama?" cit., p. 293-308). E ainda: novel estaria longe de ser uma designação de livre curso e consensual, social e culturalmente aceitável ao longo de todo o século XVIII. Dos autores setecentistas hoje tidos como canônicos, só Smollett se referiria abertamente às suas obras como romances.

${ }^{209}$ Ver McKEON, Michael. The origins of the English novel cit., p. 249-250.

210 "If there be anything that seems Romantic, I beseech your Lordship to consider these countries do, in all things, so far differ from ours, that they produce unconceivable wonders; at least they appear so to us because new and strange" (BEHN, Aphra. "Oroonoko, or, The royal slave, a true history". Oroonoko and other writings cit., p. 5).
} 
se sucederam" que, dispostos de maneira "natural", determinariam a sucessão de "intrigas", sem "acréscimo de invenção" ou de manipulações imaginativas "do poeta":

Não pretendo, ao oferecer-lhes a história desse escravo real, entreter meu leitor com aventuras de um falso herói, cuja vida e destino a imaginação pode manipular de acordo com a vontade do poeta; tampouco, ao relatar a verdade, tenciono adorná-la com quaisquer acidentes, exceto os que realmente se sucederam. E ela virá de modo simples ao mundo recomendada por seus próprios méritos e intrigas naturais; sendo a realidade suficiente para sustentá-la e torná-la divertida, sem o acréscimo de invenção. ${ }^{211}$

Logo na abertura da "história desse escravo real", correlaciona-se "relatar a verdade" à ausência de adornos composicionais. Ainda na Dedicatória, “A. Behn” ponderara que eventuais "falhas de conexão" em sua história não seriam um impeditivo para o público apreciá-la. ${ }^{212}$ Sustenta-se a "verdade" comunicada, acima de tudo, pela força de "seus próprios méritos". ${ }^{213} \mathrm{O}$ resultado dessa fórmula é uma obra intrinsecamente "divertida", mas que, ao contrário do que afirma a narradora, está longe de ser "simples".

Oroonoko mobiliza uma série de procedimentos de autenticação narrativa, com os quais se recomenda como um relato fidedigno de um evento real. ${ }^{214}$ Vai-se muito além dos lugares-comuns das asseverações de veracidade e boa-fé. A narradora se coloca como "testemunha ocular de grande parte do que encontrarás aqui registrado", mas tem o cuidado de dizer que "aquilo que não pude testemunhar eu tomei conhecimento pela boca do principal ator desta história, o próprio herói, que nos

211 BEHN, Aphra. "Prefácio a Oroonoko, or, The royal slave. A true history (1668)". In: VASCONCELOS, Sandra Guardini. A formação do romance inglês cit., p. 238-239. No original: "I do not pretend, in giving you the history of this royal slave, to entertain my reader with the adventures of a feigned hero, whose life and fortunes fancy may manage at the poet's pleasure; nor in relating the truth, design to adorn it with any accidents, but such as arrived in earnest to him: and it shall come simply into the world, recommended by its own proper merits and natural intrigues, there being enough of reality to support it, and to render it diverting, without the addition of invention" (BEHN, Aphra. "Oroonoko, or, The royal slave, a true history". Oroonoko and other writings cit., p. 6).

212 "[...] faults of connection" (idem, p. 5).

${ }^{213}$ Para Anderson, Behn apresenta uma solução literária poderosa de como se comunicar o novo sem apelar para expectativas compartilhadas, que contradiriam a busca pela novidade (ANDERSON, Emily Hodgson. "Novelty in novels: a look at what's new in Aphra Behn's Oroonoko". Studies in the novel, v. 39, n. 1 (primavera, 2007), p. 1-16).

${ }^{214}$ Sobre as estratégias narrativas de Oroonoko, ver: ROSENTHAL, Laura J. "Oroonoko: reception, ideology, and narrative strategy". In: HUGHES, Derek; TODD, Janet (ed.). The Cambridge companion to Aphra Behn. Cambridge: Cambridge University, 2004, p. 151-165, especialmente p. 156 e ss. A análise também é informada pela discussão de Ian Watt sobre o que chama de "realismo formal" (cf. WATT, Ian. A ascensão do romance cit., p. 30). Ver também: VASCONCELOS, Sandra Guardini T. "Ian Watt e a figuração do real (anotações de leitura)". Literatura e sociedade, v. 14 (2010), p. 170183. 
forneceu todos os acontecimentos de sua juventude". ${ }^{215}$ Ao estabelecer sua experiência como mediadora de nosso acesso à personagem, a narradora busca investir-se de credibilidade para que nos fiemos sem ressalvas às suas palavras. Segue-se um expediente de individuação da titular da voz narrativa, que a todo instante fala de si, de seus afazeres e de sua relação com o herói. Delineiam-se, com isso, traços identificadores com os quais o leitor pode reconhecer "a pessoa" a quem emprestará sua confiança. De saída, institui-se uma perspectiva autobiográfica. Conforme se indicou acima, confunde-se deliberadamente a narradora com a autora, cujo nome estampa as pré-textuais do livro. "A. Behn” que subscreve a Dedicatória é uma função do texto ou é um referente para a mesma mulher que se apresenta, na página de rosto da primeira edição de Oroonoko, como Mrs A. Behn? ${ }^{216}$ Seja como for, A. Behn seria uma inglesa (branca, obviamente) que passara sua juventude no domínio inglês no Suriname, antes da conquista dos holandeses, em 1667. Sua familiaridade com a terra é derivada de uma listagem interminável dos animais que os nativos capturam e comercializam com os brancos:

[...] negociando com eles pelo seu peixe; carne; peles de búfalos e pequenas raridades, como saguis, uma espécie de macaco do tamanho de um rato ou doninha, porém de figura maravilhosa e delicada, e [que] tem a face e as mãos como uma criatura humana; e cousheries, ${ }^{217}$ um pequeno animal na forma e aparência de um leão, do tamanho de um gato, mas em tudo tão exatamente parecido com aquele animal nobre, de modo que é sua miniatura. E também por pequenos periquitos, grandes papagaios, araras, e outros milhares de pássaros e animais de formas, figuras e cores surpreendentes e maravilhosas $[\ldots]^{218}$

\footnotetext{
${ }^{215}$ Trecho integral: "I was myself an eye-witness to a great part of what you will find here set down, and what I could not be witness of I received from the mouth of the chief actor in this history, the hero himself, who gave us the whole transactions of his youth" (BEHN, Aphra. "Oroonoko, or, The royal slave, a true history". Oroonoko and other writings cit., p. 6).

${ }^{216}$ Para Genette, o nome do autor teria pouco ou nenhum efeito na ficção, mas é muito forte em escritos referenciais, em que a credibilidade do testemunho se apoia na credibilidade de quem se atribui o texto (GENETTE, Gérard. Paratextos editoriais. Trad. Álvaro Faleiros. Cotia - SP: Ateliê, 2009, p. 42).

${ }^{217}$ Mico-leão?

218 “ “...] trading with 'em for their fish, venison, buffaloes' skins and little rarities, as marmosets, a sort of monkey as big as a rat or weasel, but of a marvellous and delicate shape, and has face and hands like an human creature, and cousheries, a little beast in the form and fashion of a lion, as big as a kitten, but so exactly made in all parts like that noble beast that it is it in miniature. Then for little parakeetoes, great parrots, macaws, and a thousand other birds and beasts of wonderful and surprising forms, shapes, and colours [...]" (BEHN, Aphra. "Oroonoko, or, The royal slave, a true history". Oroonoko and other writings cit., p. 6).
} 
Seriam, porém, observações minuciosas, num tom quase jornalístico, ${ }^{219}$ de como se organiza a sociedade colonial que certificariam o leitor de que a narradora "de fato" esteve no continente americano:

Aqueles que querem escravos negociam com um mestre, ou capitão, de um navio e comprometem-se a pagar uma quantia para cada peça, num montante de vinte libras a cabeça, por quantas acharem necessário, quando elas lhe forem entregues numa determinada plantação. Tanto é assim que, ao chegar um navio carregado de escravos, os contratantes sobem a bordo e recebem seu quinhão por lotes. Num lote de dez, talvez haja apenas três ou quatro homens; o resto, mulheres e crianças. Ou seja: se houver menos de qualquer um dos sexos, és obrigado a te contentares com teu quinhão. ${ }^{220}$

O preço per capita, as cláusulas de entrega e as incertezas sobre o desfecho das negociações são índices cujo acúmulo conota informações obtidas in loco, por alguém que teria visto de perto o funcionamento e os dissabores, na perspectiva dos brancos, de uma economia dependente do comércio ultramarino de escravos. São-nos fornecidas, portanto, coordenadas precisas de tempo e espaço, que tanto criam o efeito da realidade da experiência narrada quanto constituem condicionantes inafastáveis de tal experiência. Contraste-se a maneira como o aedo institui o tempo e o espaço numa epopeia. No Paraíso perdido, a Musa Celeste leva-nos ao princípio dos tempos e às profundezas do inferno:

Instrui-me porque nada se te encobre.

Desde o princípio a tudo estás presente

$[\ldots]$

Dize primeiro, tu que observas tudo

No Céu sublime, no profundo Inferno. ${ }^{221}$

A consciência de A. Behn, por seu turno, não contempla os abismos da eternidade e do infinito. É, repitamos, mera "testemunha" de um mundo sobre cujas leis não tem o controle, porque determinadas por ambiente, natureza, economia e sociedade. ${ }^{222}$ Sua

${ }^{219}$ Cf. ROSENTHAL, Laura J. “Oroonoko: reception, ideology, and narrative strategy” cit., p. 159.

220 "Those who want slaves make a bargain with a master, or captain of a ship and contract to pay him so much a piece, a matter of twenty pound a head for as many as he agrees for and to pay for 'em when they shall be delivered on such a plantation. So that when there arrives a ship laden with slaves, they who have so contracted go aboard and receive their number by lot; and perhaps in one lot that may be for ten, there may happen to be three or four men, the rest, women and children. Or, be there more or less of either sex, you are obliged to be contented with your lot" (BEHN, Aphra. "Oroonoko, or, The royal slave, a true history". Oroonoko and other writings cit., p. 9).

${ }^{221}$ MILTON, John. O paraíso perdido cit., p. 22. No original: "Instruct me, for Thou know'st; Thou from the first/ Wast present, [...]/ Heav'n hides nothing from thy view/ Nor the deep Tract of Hell" (I, 19-20, 27-28) (MILTON, John. "Paradise lost" cit., p. 211-212).

${ }^{222}$ ANDERSON, Emily Hodgson. "Novelty in novels: a look at what's new in Aphra Behn's Oroonoko" cit., p. 1-16. 
credibilidade, ao contrário do que ocorria na epopeia, não é um dado: há de ser construída, como nesta passagem, em que se arregimenta a autoridade de nomes insuspeitos para ratificar as maravilhas que a narradora fala a respeito da fauna do Suriname:

[...] peles de cobras prodigiosas, algumas das quais com até sessenta jardas de comprimento, como é a pele de uma que pode ser vista no antiquário de Sua Majestade, onde estão alguns insetos raros, de cores e formas impressionantes, doados por mim, alguns do tamanho de meu pulso, outros menores, mas todos dotados de muitas excelências, que a arte não pode imitar. ${ }^{223}$

Personificada a narradora numa mulher determinada, em cuja palavra se pode acreditar, normaliza-se o heroísmo de Oroonoko, "o escravo real". Oroonoko é uma figura extraordinária, um herói que nasce pronto, como nas estórias romanescas: "tornou-se, aos dezessete anos, um dos capitães mais expertos e um dos soldados mais bravos que jamais viram o campo de Marte". ${ }^{224}$ Derivaria seus predicados de força, beleza, coragem, fidelidade e inteligência de seu berço principesco, de sua condição de neto e herdeiro do rei de Coramantien, em Gana. São as suas origens que o diferenciam de todas as outras personagens: do mercador de escravos que o engana, dos colonos que o admiram e isentam-no do trabalho na lavoura (e, apropriadamente, dão-lhe o nome de César) e dos demais negros, que desertam a rebelião por ele iniciada. Por outro lado, a representação idealizada de Oroonoko é calibrada em toda parte pela inflexão da narrativa à primeira pessoa. Quando A. Behn decide conhecer o escravo de cujas qualidades todos falam, deflete a provável incredulidade do leitor ao confessar, ela mesma, sua surpresa:

Essa reputação grande e justa de Oroonoko me trouxe uma curiosidade extrema para vê-lo, especialmente quando eu soube que falava inglês e francês e que poderia conversar com ele. Embora ouvira falar tanto dele, fiquei tão surpresa como se nada ouvira, tão superior a qualquer relato ele era. ${ }^{225}$

\footnotetext{
223 “ $[\ldots .$.$] skins of prodigious snakes, of which there are some threescore yards in length, as is the skin$ of one that may be seen at His Majesty's antiquary's, where are also some rare flies, of amazing forms and colours, presented to 'em by myself, some as big as my fist, some less, and all of various excellencies, such as art cannot imitate" (BEHN, Aphra. "Oroonoko, or, The royal slave, a true history". Oroonoko and other writings cit., p. 6-7).

224 " [...] at the age of seventeen, one of the most expert captains and bravest soldiers that ever saw the field of Mars" (idem, p. 10).

225 "This great and just character of Oroonoko give me an extreme curiosity to see him, especially when I knew he spoke French and English and that I could talk with him. But though I had heard so much of him, I was as greatly surprised when I saw him as if I had heard nothing of him; so beyond all report I found him" (idem, p. 11).
} 
Em Oroonoko, o herói se comporta de maneira uniforme, mas a transportação da África para a América inverte a valoração de sua conduta. Suas qualidades põem-no à parte do sistema mercantilista que os europeus introduzem em suas colônias. São as virtudes do africano que fazem com que sucumba aos grilhões do navio negreiro e à tortura imposta pelos fazendeiros do Suriname. A honestidade e altivez que demonstra desde os primeiros episódios em Coramantien fazem com que jamais desconfie das intenções de seu suposto amigo, um mercador de escravos, que o convida para visitar sua embarcação, e, o que é pior, acredite nas promessas dos ingleses de que o libertarão antes que nasça seu filho com Imoinda, seu amor desde a África. Quando Oroonoko se dá conta da distância entre seus valores e a duplicidade dos ingleses, ele não se dobra à dinâmica do processo colonial. Antes, tenta impor-se pelo heroísmo. $\mathrm{O}$ problema, obviamente, é que as personagens à sua volta veem esse heroísmo como um elemento de desordem - e não medirão esforços para suprimi-lo. Ao ser tapeado e aprisionado num navio negreiro, o príncipe "ressente essa indignidade" e reage como "um leão pego numa armadilha". ${ }^{226}$ Mais tarde, ante a recusa de o alforriarem, incita os demais escravos a sublevarem-se. Seu discurso contrasta o universo regido pela “alma do soldado" àquele em que predominam as relações de compra e venda:

E por que - ele disse -, meus queridos amigos e companheiros de sofrimento, devemos ser escravos para um povo desconhecido? Eles nos derrotaram nobremente numa luta? Eles nos venceram em batalha honrosa? E nós nos tornamos escravos pelo acaso da guerra? Isso não zangaria o coração nobre; isso não incensaria a alma do soldado. Mas não: somos comprados e vendidos como símios ou macacos, para sermos o passatempo de mulheres, tolos e covardes, e o arrimo de vigaristas e renegados, que abandonaram seu próprio país por rapinagem, homicídios, furtos e vilanias. ${ }^{227}$

A rebelião falha e desmorona o sonho de fugir para o Caribe e, de lá, conseguir uma embarcação de volta para a África. Os revoltosos são logo arrestados e seu líder é chicoteado "da maneira mais deplorável e desumana". ${ }^{228}$ Heroico, não geme nem demonstra dor. Frustrados seus planos, entrega-se a um último ato de insubmissão.

\footnotetext{
${ }^{226}$ Trecho integral: "It may be easily guessed in what manner the prince resented this indignity, who may be best resembled to a lion taken in a toil" (idem, p. 34).

227 “" And why,' said he, 'my dear friends and fellow sufferers, should we be slaves to an unknown people? Have they vanquished us nobly in fight? Have they won us in honourable battle? And are we by the chance of war become their slaves? This would not anger a noble heart, this would not animate a soldier's soul; no, but we are bought and sold like apes or monkeys, to be the sport of women, fools, and cowards, and the support of rogues, runagates, that have abandoned their own countries for rapine, murders, thefts, and villainies" (idem, p. 58).

228 "[...] in a most deplorable and inhuman manner" (idem, p. 63).
} 
Com o consentimento dela, mata Imoinda e seu filho por nascer; depois, precipita-se num ataque suicida aos colonos. Preso mais uma vez, é morto e esquartejado por uma sociedade indiferente a seu heroísmo principesco. ${ }^{229}$

O rompimento com o meio que, até então, dava sentido ao heroísmo do protagonista consiste na solução fundamental para o desenvolvimento do que a narradora chama de "intrigas naturais", o equivalente estrutural de uma narrativa "sem o acréscimo de invenção". Numa obra como Oroonoko, o indivíduo insatisfeito se sente compelido a agir e acaba por isolar-se dos demais. É nesse processo de cisão com a coletividade que a intriga se cristaliza. A narrativa abandona a visão do todo e concentra-se na perspectiva de uma personagem, na maneira como ela se opõe àquele mundo com que, há pouco, encontrava-se conciliada. ${ }^{230}$

Esse processo de isolamento seria elaborado nas ditas ficções amorosas de Aphra Behn, como The history of the nun; or the fair vow breaker. Ao invés do conflito entre um herói idealizado e um mundo inapelavelmente corrupto, representa-se a tensão entre os anseios sexuais das personagens e a moral estrita de um tempo profundamente religioso. Desloca-se, com isso, a inflexibilidade de um polo para outro. A uniformidade do caráter de Oroonoko, que tem a honra como seu primeiro princípio, ${ }^{231}$ faz com que reaja sempre do mesmo jeito, sem grandes dúvidas ou remorsos quanto à sua maneira de proceder. Em The history of the nun, são os protagonistas que não estão à altura do que deles se espera. Isabella e Henault iniciam a estória em aparente harmonia com os ideais de fé, devoção, fidelidade e honra. Ela jurara castidade ao ordenar-se freira e ele dera as costas às frivolidades da nobreza, numa vida de contemplação e estudo. A paixão que nasce de seu encontro fará com que rejeitem a idealização em que viveram e, o que é mais importante, reconheçam sua própria humanidade:

Assim que ela se deitou, [...] entregou-se a deliberações profundas, e decidiu solucionar naquela noite o conflito entre seu coração e seu juramento de devoção, para que, não tendo mais o que decidir, pudesse pôr fim ao caso de maneira apropriada na primeira

\footnotetext{
${ }^{229}$ Cf. ROSENTHAL, Laura J. "Oroonoko: reception, ideology, and narrative strategy" cit., p. 161 e STARR, G. A. "Aphra Behn and the genealogy of the man of feeling". Modern Philology, v. 87, n. 4 (maio, 1990), p. 362-372, especialmente p. 367.

${ }^{230}$ Ver ARMSTRONG, Nancy. How novels think: the limits of individualism from 1719-1900. Nova Iorque: Columbia University, 2005, p. 3.

231 "To this, Caesar replied that honour was the first principle in nature that was to be obeyed" (BEHN, Aphra. "Oroonoko, or, The royal slave, a true history". Oroonoko and other writings cit., p. 58-59).
} 
oportunidade que pudesse falar com Henault, qual seja: fugir e casar-se com ele; ou permanecer para sempre atada a seu juramento de castidade. Esse era o debate. Ela reúne argumentos para os dois lados: para o primeiro, antecipa a vergonha de um juramento violado, e considera onde poderá mostrar o rosto depois de tal ato; quanto ao juramento, argumenta que nascera em pecado e que não teria como superá-lo; que era humana, e não um anjo, e que, possivelmente, esse pecado seria logo perdoado, como qualquer outro; que, já que todas as suas tentativas devotas não conseguiram defendê-la da causa, os céus deveriam executar o efeito. Quanto a mostrar seu rosto, ela sempre enxergava o de Henault (encantador como era) a olhá-la com amor: por que ela deveria se preocupar com o mundo, ou importar-se em olhar outro? ${ }^{232}$

O conflito entre Isabella e seu entorno não se materializa, como em Oroonoko, em discursos belicosos, insurgências, fugas ou batalhas. Sua insatisfação se traduz em deliberações internas e manifestações de angústia, culpa ou arrependimento. Por meio desse expediente, gera-se uma tensão com os traços de um padrão narrativo preordenado. À distância, enxerga-se em The history of the nun o enquadramento das novelas exemplares. Os infortúnios que sobrevêm a protagonista e seus dois maridos, Henault e Villenoys, podem ser lidos numa chave didática, como punições divinas por Isabella ter abjurado de seus votos. ${ }^{233}$ Pouco antes de morrer, Isabella recomenda a quem quiser ouvir para que nunca quebrem um juramento. Por outro lado, na dedicatória assinada, mais uma vez, por “A. Behn”, diz-se que "a estória é verdadeira, conforme se encontra nos arquivos da cidade em que ocorreu". ${ }^{234}$ E nada parece fazer da propositura da moral um desenvolvimento lógico da obra. Não há sequer o uso de analepses ou prolepses, com que se encadeariam os eventos numa dimensão transcendente. Aos céus, como se depreende da passagem acima, caberia somente a ratificação das decisões humanas: "já que todas as suas tentativas devotas não

\footnotetext{
232 "As soon as she was laid, [...] settled herself to profound thinking and was resolved to conclude the matter between her heart and her vow of devotion that night; that she, having no more to determine, might end the affair accordingly the first opportunity she should have to speak to Henault, which was to fly and marry him, or, to remain forever fixed to her vow of chastity. This was the debate. She brings reason on both sides; against the first, she sets the shame of a violated vow and considers where she shall show her face after such an action; to the vow, she argues that she was born in sin and could not live without it; that she was human and no angel and that, possibly, that sin might be as soon forgiven as another; that since all her devout endeavours could not defend her from the cause, Heaven ought to excuse the effect; that as to showing her face, so she saw that of Henault always turned (charming as it was) towards her with love; what had she to do with the world or cared to behold any other?" (BEHN, Aphra. "The history of the nun; or the fair vow breaker". Oroonoko and other writings cit., p. 166).

${ }^{233}$ Essa é a leitura de BOWERS, Toni O'Shaughnessy. "Sex, lies, and invisibility: amatory fiction from the restoration to mid-century". In: RICHETTI, John (ed.). The Columbia history of the British novel. Nova Iorque: Columbia University, 1994, p. 50-72, especialmente p. 65-66.

234 "[...] the story is true, as it is on the records of the town where it was transacted" (BEHN, Aphra. "The history of the nun; or the fair vow breaker". Oroonoko and other writings cit., p. 139).
} 
conseguiram defendê-la da causa, os céus deveriam executar o efeito". A narradora muitas vezes focaliza nas personagens e permite que o leitor partilhe de suas incertezas e veja-se perdido na neblina do agora. A descoberta de que Henault está vivo e que, portanto, Isabella havia cometido o crime de bigamia ao se casar com Villenoys não é acompanhada de nenhuma ponderação sobre a justiça celeste. Apenas se representam o espanto e o turbilhão emocional da protagonista:

É verdade que Isabella tentou rezar, mas, ah!, foi em vão. Estava perturbada com mil pensamentos sobre o que fazer - e quanto mais ela pensava, mais perturbada ficava. Em mil ocasiões esteve à beira de pôr fim à sua vida e, num só golpe, livrar-se da infâmia que via recair sobre ela. Mas a natureza era frágil e o temperamento, forte; e depois de mil espasmos, piores que a própria morte, decidiu-se pelo assassinato de Henault, como o único meio de remover todos os obstáculos para sua felicidade futura. Ela se decidira, mas, ao fazêlo, foi tomada por um terror tão grande, com que imaginou que enlouqueceria caso praticasse o ato. Por outro lado, se não o fizesse, também endoideceria com a vergonha e a miséria que lhe recairiam. Acreditando que o assassinato era o mal menor, pois não poderia viver com ele, resolveu levar isso a cabo. ${ }^{235}$

Se podemos deslindar retrospectivamente um embate entre o secular e o temporal em The history of the nun, a narrativa conjuga também uma luta interior entre o dever e o ser, dos ditames da fé contra os impulsos da "natureza" e do "temperamento". ${ }^{236} \mathrm{Tal}$ luta possibilita a identificação com a personagem, por meio da experiência vicariante de sua interioridade. ${ }^{237}$ Numa passagem em que se listam os devaneios sensuais de Isabella, por exemplo, apela-se à vivência de todos que um dia se desesperaram por amor a fim de dimensionar o sofrimento da protagonista. Sutilmente, os tormentos e inclinações suicidas de que trata a narradora deixam de ser só de Isabella para serem atribuídos a uma coletividade, da qual todo leitor é um membro em potencial:

Ela sempre pensava nele, em quão bonito era seu rosto, quão delicado cada traço, quão encantador seu porte, quão graciosa a sua aparência, quão doce e delicado seu temperamento e quão inteligente e divertida a sua conversa. Ela se imaginava conversando

\footnotetext{
235 "'Tis true Isabella assayed to pray, but, alas, it was in vain. She was distracted with a thousand thoughts what to do, which the more she thought, the more it distracted her. She was a thousand times about to end her life and, at one stroke, rid herself of the infamy that she saw must inevitably fall upon her. But nature was frail and the tempter strong, and after a thousand convulsions, even worse than death itself, she resolved upon the murder of Henault, as the only means of removing all obstacles to her future happiness. She resolved on this, but after she had done so, she was seized with so great horror that she imagined if she performed it she should run mad, and yet, if she did not, she should be also frantic with the shames and miseries that would befall her, and believing the murder the least evil, since she could never live with him, she fixed her heart on that [...]" (idem, p. 183).

${ }^{236}$ Dialogamos com BERNSTEIN, J. M. The philosophy of the novel cit., p. xvii.

${ }^{237}$ RICHETTI, John. "The novel before 'the novel”” cit., p. 14-29, especialmente p. 27-28.
} 
com ele da gelosia como costumava fazer, abençoava as horas felizes que passara com ele e lamentava seu infortúnio de não poder mais ser tão feliz, dando vazão, então, a seu pesar - pesares que nenhum mortal, salvo os amantes desesperados, tem como dimensionar, ou quão torturantes eles são, nos quais os momentos mais tranquilos são aqueles em que se se decide pôr fim à própria vida - e o pensamento mais feliz é a danação. ${ }^{238}$

Os sofrimentos do amor subvertem os parâmetros da moral religiosa. A bênção advém da transgressão dos votos de castidade e a danação, pela vigência do impedimento monástico. Os ideais romanescos de piedade e devoção simplesmente não lhe servem mais. ${ }^{239}$ Para usarmos o vocabulário lockiano, aquilo que os outros tomam como bom causa-lhe dor e inquietação, a impeli-la a romper com a sociedade e buscar o seu caminho sozinha. Sintomaticamente, a narradora se abstém de retificar a percepção da personagem, com que devolveria as noções de bênção e danação a seu uso socialmente aceitável. ${ }^{240}$ Pelo contrário: subscreve à perspectiva de Isabella e estendea ao leitor, ao qual pede, indiretamente, que se identifique com a personagem e imagine como seus os tormentos dela. A ficção de Behn promove, antes, a suspensão dos julgamentos morais, pela configuração de um ponto de vista a priori condenável. Oferece-se ao leitor a oportunidade de conhecer esse outro ponto de vista, ao convidálo para espiar as solidões do claustro, os delírios sensuais de uma adolescente e os diálogos amorosos que um casal trava em seu quarto de dormir. ${ }^{241}$ Nesses ambientes recônditos, obnubila-se a percepção de elementos usualmente associados à forma, como enredo, coincidências etc. Só conseguimos ouvir a verbalização do desejo de Isabella.

\subsection{Love in excess}

Nas primeiras décadas do século XVIII, as obras mais populares são aquelas em que se narra o aflorar do desejo, num contexto de esfacelamento dos valores

\footnotetext{
238 "She was eternally thinking on him, how handsome his face, how delicate every feature, how charming his air, how graceful his mien, how soft and good his disposition and how witty and entertaining his conversation. She now fancied she was at the grate talking to him as she used to be, and blessed those happy hours she passed then, and bewailed her misfortune that she is not more destined to be so happy, then gives a loose to grief; griefs at which no mortals but despairing lovers can guess, or how tormenting they are, where the most easy moments are those wherein one resolves to kill oneself, and the happiest thought is damnation" (BEHN, Aphra. "The history of the nun; or the fair vow breaker". Oroonoko and other writings cit., p. 154-155).

${ }^{239}$ Dialogamos com: SHRODER, Maurice Z. "The novel as a genre" cit., p. 13-29.

${ }^{240}$ Sobre a amoralidade da ficção amorosa de Behn, ver: BOWERS, Toni O’Shaughnessy. "Sex, lies, and invisibility: amatory fiction from the restoration to mid-century" cit., p. 52.

${ }^{241}$ Ver HUNTER, J. Paul. Before novels cit., p. 36-39.
} 
tradicionais. É o caso dos romances de Eliza Haywood (c. 1693-1756), que foi, por muito tempo, um nome virtualmente desconhecido fora dos círculos de dixhuitièmistes. E os poucos que podiam associar o nome à pessoa faziam-no por meio da menção ultrajante d'A asníada, de Pope. Aqui, "Eliza" aparece com seus dois filhos ilegítimos a tiracolo, bela como o frontispício de seus livros. É oferecida, “com úberes de vaca, e com olhos de boi", ao vencedor do campeonato de urina em distância. Um dos participantes da contenda é Curll, notório editor de "livros curiosos”. Apenas recentemente, com o renovado interesse pela ficção popular do período $^{242} \mathrm{e}$, depois, a consolidação dos estudos feministas, é que a leitura de sua prolífica obra foi admitida nos cursos de graduação da Europa e América do Norte. A caricatura machista de Pope captura a ameaça que Haywood, com sua "promiscuidade textual", consistiu para o establishment tanto literário quanto cultural. ${ }^{243}$ No entanto, o imenso sucesso editorial que alcançara logo em sua estreia, com Love in excess (1719), indica que o público se encontrava bastante receptivo a essa ameaça. ${ }^{244}$

Love in excess; or the fatal enquiry: a novel é um romance dividido em três partes, em que se representam as complicações amorosas de um aristocrata francês, Conde D'Elmont. Sua trajetória de sedutor oportunista a amante fiel e apaixonado evolve em sucessivos confrontos de sua voluptuosidade inesgotável tanto com a inocência de Amena e Melliora quanto com a extravagância passional de Alovisa e Ciamara. ${ }^{245}$ Cada uma dessas personagens arquiteta e executa planos com os quais poderá consumar seus respectivos desejos, com que a todo tempo interagem ou entram em rota de colisão, num jogo que propele a si mesmo e se desenrola pela sua própria lógica. ${ }^{246}$ Logo no início, D’Elmont chega a Paris, após destacar-se na Guerra de Sucessão Espanhola (1701-1713). “A beleza de sua pessoa, a jovialidade de seu ar e os encantos incomparáveis de sua conversação faziam-no o objeto de admiração dos

\footnotetext{
${ }^{242}$ Ver: RICHETTI, John. Popular fiction before Richardson cit., p. 168-210.

243 BALLASTER, Ros. Seductive forms: women's amatory fiction from 1684-1740. Oxford: Clarendon, 1992, p. 160-162.

${ }^{244}$ Quase cinquenta anos depois da publicação de Love in excess, Haywood ainda era uma das ficcionistas mais lidas na Grã-Bretanha. Entre 1750 e 1769, apareceram nada menos do que 31 edições de suas obras (SUAREZ, Michael J. "Publishing contemporary literature". In: SUAREZ, Michael J.; TURNER, Michael L. (ed.). The Cambridge History of the book in Britain. Cambridge: Cambridge University, 2009, v. 5, p, 649-666, especialmente p. 664).

${ }^{245}$ WARNER, William B. Licensing entertainment cit., p. 112-113.

${ }^{246}$ Idem, p. 113. Ver também ALLISTON, April. "Amor em excesso: Eliza Haywood (1719-1720)". In: MORETTI, Franco (org.). A cultura do romance. Trad. Denise Bottman. São Paulo: Cosac Naify, 2009, p. 777-785, especialmente p. 779-781.
} 
dois sexos". ${ }^{247}$ Alovisa é uma das mulheres que devotam "admiração" irrefreável a D’Elmont. Para saciar seu interesse pelo jovem, arquiteta um plano que considera infalível. Mas suas expectativas se mostram complemente equivocadas. Seus atos dão início a uma reação em cadeia, que nenhuma personagem consegue controlar. Envia um bilhete anônimo a D’Elmont, em que se confessa possuída pelo "pequeno deus" (Eros) e promete "que ele aparecerá para você amanhã à noite no baile" em homenagem ao aniversário da Duquesa da Burgúndia, "nos olhos da mais passional de suas devotas". ${ }^{248} \mathrm{O}$ plano dá fragorosamente errado. No dia seguinte, enquanto se preparava para entrar no baile, D’Elmont vê estacionar o coche de Amena. Galante, oferece a mão para ela descer. Seus olhares se cruzam:

[...] ela estava saindo de seu coche no momento em que ele descia do seu, e, ao oferecer-lhe a mão, percebeu que a dela tremia, com que, fitando-a de modo mais determinado do que costumava, imediatamente imaginou ter visto nos olhos dela algo do langor que a epístola obsequiosa descrevera. Amena era muito amável para tornar essa suposição desagradável, e ele se decidiu por dar início a um caso, sem se dar ao trabalho de pensar nas consequências [...]. ${ }^{249}$

A indiferença de D'Elmont às consequências de sua aventura pode ser lida como um comentário à estrutura narrativa que está prestes a se desdobrar. Obviamente, estamos diante de um caso paradigmático de ironia dramática. Contrapõe-se a suposição de D'Elmont acerca do langor nos olhos de Amena àquilo que já sabemos sobre o billet-doux. O equívoco do Conde "imediatamente" instaurará o triângulo amoroso em torno do qual revolverá a primeira parte da obra. Há um claro intervalo entre o campo de visão do narrador e o das personagens, mas de tal intervalo não se propõe um jogo de profecias e antecipações. Pelo contrário: em muito pontos, o narrador mantém o leitor em suspense, na medida em que concentra o foco nas personagens. Nem o leitor nem Alovisa sabem qual será o resultado de sua nova

\footnotetext{
247 "The beauty of his person, the gaity of his air, and the unequalled charms of his conversation, made him the admiration of both sexes" (HAYWOOD, Eliza. Love in excess. Ed. David Oakleaf. 2. ed. Peterborough, ON: Broadview, 2000, p. 37).

${ }^{248}$ Trecho integral: "The little god lays down his arrows at your feet, confesses your superior power, and begs friendly treatment; he will appear to you tomorrow night at the ball, in the eyes of the most passionate of his voteresses" (idem, p. 39). Abaixo, discutirei a linguagem militar que perpassa passagens como essa.

249 “" [...] she was getting out of her chariot just as he alighted from his, and offering her his hand, he perceived hers trembled, which engaging him to look upon her more earnestly than he was wont, he immediately fancied he saw something of that languishment in her eyes, which the obliging mandate had described. Amena was too lovely to make that belief disagreeable, and he resolved on the beginnings of an amour, without giving himself the trouble of considering the consequences" (idem, $p$. $42)$.
} 
tentativa de se comunicar secretamente com D’Elmont: “começou a preparar uma segunda carta, que ela esperava que teria mais sucesso que a anterior". ${ }^{250}$ Afinal, seu primeiro bilhete contribuiu "para a felicidade de [sua] rival": "Quaisquer que fossem seus desejos, ele cuidadosamente os escondia, até que minha carta maldita induziu uma revelação". ${ }^{251}$

De maneira mais sutil, expedientes como falsas esperanças, reversões de expectativas e interrupções nos momentos de maior intensidade emocional impedem ou adiam - a percepção de um fechamento narrativo, de uma sucessão ordenada de eventos. $^{252}$ Tome-se como exemplo o encontro secreto de D'Elmont e Amena no Jardim das Tulherias. Todos os planos arquitetados na primeira parte de Love in excess convergem para o corpo de Amena. "Era agora que essa moça inconsequente se encontrava na maior encruzilhada em que já estivera". ${ }^{253}$ A carta secreta de Alovisa a precipitara para os braços de D'Elmont. O Conde se valera de subterfúgios, como o suborno à criada Anaret, para ter acesso à jovem, que fora trancafiada pelo pai, Monsieur Sansevarin. Este proibira quaisquer encontros com D’Elmont, a fim de forçá-lo a buscar uma união sancionada pela lei e pela igreja.

— Oh, não me diga isso! — gritou o Conde [...]. — Tenho de vê-la, nada a afastará de mim.

- Talvez o senhor possa - respondeu Anaret -, mas isso tem de ocorrer com a aprovação de Monsieur Sansevarin. Ele ficará orgulhoso em recebê-lo na qualidade de pretendente de sua filha, e é apenas para obrigar o senhor a uma declaração pública que ele toma tais medidas. [...]

— Eu aceitaria voluntariamente - ele disse friamente —, qualquer meio adequado para a obtenção da pessoa e do coração de Amena, mas há motivos para não revelar meus desígnios a seu pai antes de ter falado com ela.

- Meu senhor - respondeu a sutil Anaret (ao adivinhar facilmente as suas intenções) - , peço aos céus para que haja possibilidade de um encontro; não há nada que eu não arriscaria para promovê-lo $[\ldots] .{ }^{254}$

\footnotetext{
250 " [...] began to prepare a second letter, which she hoped would be more lucky [sic] than the former" (HAYWOOD, Eliza. Love in excess cit., p. 44).

${ }^{251}$ Trecho integral: "I did not doubt but that I was undone, and to my other Miseries, have that of being aiding to my rival's happiness. Whatever his desires were, he carefully concealed 'em 'till my cursed Letter prompted a discovery [...]" (idem, p. 45).

${ }^{252}$ WARNER, William B. Licensing entertainment cit., p. 113-114.

253 " [....] 'twas now this inconsiderate lady found her self in the greatest strait she had ever yet been in" (HAYWOOD, Eliza. Love in excess cit., p. 58).

254 "Oh! do not talk thus," cried the Count [...]. "I must, I will see her, nothing shall hold her from me." "You may," answered Anaret, "but then it must be with the approbation of Monsieur Sansevarin, he will be proud to receive you in quality of a suitor to his daughter, and 'tis only to oblige you to a
} 
A "maior encruzilhada" da vida de Amena é, portanto, o momento em que se resolverão as maquinações de D’Elmont, Alovisa, Anaret e Monsieur Sansevarin para “a obtenção da [sua] pessoa e do [seu] coração". Se este coração, "tão disposto a ser enganado", deixar-se levar pelas desculpas esfarrapadas do Conde, os "desígnios" de D'Elmont e, subsidiariamente, de Anaret saem triunfantes. Caso Amena obedeça às ordens de seu pai, preserva a reputação da família e abre caminho para as investidas de Alovisa. Seu peito "bate em medidas de consentimento" e prepara-se para proclamar a vitória de D'Elmont. Quando se chega ao aparente desenlace do enredo, Anaret interrompe o casal:

O calor do clima e seu confinamento a impediram de se vestir aquele dia. Ela usava apenas uma camisola de seda, que esvoaçava aberta quando ele a abraçou. Encontrou o coração dela a bater medidas de consentimento; o seio palpitante avolumava-se para ser pressionado contra o dele e cada pulso confessava um desejo de ceder. O espírito dela se dissolveu numa letargia de amor, seus níveos braços envolveram, inconscientes, o pescoço dele, os lábios dela encontraram os dele no meio do caminho e tremeram ao toque. Enfim, havia apenas um momento entre ela e a ruína, quando passos vindo apressadamente pelo caminho obrigaram o casal semiabençoado a pôr um fim a outras carícias. Era Anaret [...]. .55 $^{255}$

A chegada de Anaret "um momento" antes da "ruína" de Amena não só posterga a resolução - ou consumação - da intriga. De imediato, há uma retorsão na rota esperada para a narrativa. D'Elmont tenta conduzir Amena de volta à casa de seu pai, mas o acesso às Tulherias está fechado. O Conde, então, decide levar Amena consigo, mas acaba por deixá-la com Alovisa ao passarem diante da casa dela: Amena confia que "sua querida amiga" a ajudará, pois "tem poder sobre [seu] pai". Alovisa, obviamente, trai o casal. Conta para Monsieur Sansevarin o que se passara e persuade-o a mandar a filha para um convento. A primeira parte de Love in excess termina com o casamento de D'Elmont e Alovisa.

publick declaration that he takes these measures." [...] "I would willingly," said he coldly, "come into any proper method for the obtaining the person of Amena, as well as her heart; but there are certain reasons for which I cannot make a discovery of my designs to her father, 'till I have first spoken with her." "My lord," replied the subtle Anaret (easily guessing at his meaning) "I wish to heaven there were a possibility of your meeting; there is nothing I would not risque [sic] to forward it" (idem, p. 51).

255 "The heat of the weather, and her confinement having hindred her from dressing that day, she had only a thin silk night gown on, which flying open as he caught her in his arms, he found her panting heart beat measures of consent, her heaving breast swell to be pressed by his, and every pulse confess a wish to yield; her spirits all dissolved sunk in a lethargy of love, her snowy arms unknowing grasped his neck, her lips met his half way, and trembled at the touch; in fine, there was but a moment betwixt her and ruine; when the tread of some body coming hastily down the walk, obliged the half-blessed pair to put a stop to farther endearments. It was Anaret [...]” (idem, p. 58). 
Pode-se tomar a reversão das expectativas como uma estratégia em que se facilita a inflação narrativa por meio de serializações, spin offs e todos aqueles truques, hoje tão conhecidos, para multiplicar a lucratividade de uma publicação. ${ }^{256}$ Ao se incorporar o détour à forma de Love in excess, o aparecimento de outras duas continuações (Partes II e III), em que se desfazem todos os arranjos anteriores, avulta como um desenvolvimento natural. Consegue-se, com isso, uma espécie de unidade sincrética, em que o padrão advém da desconstituição recorrente do padrão narrativo em vias de sedimentação. Equilibra-se a indeterminação presentificada da perspectiva das personagens, a todo instante surpreendidas com o rumo tomado pelos acontecimentos, com uma organização formal mais ou menos identificável, perpassada por temas como cartas interceptadas, encontros abortados etc. Permite-se, ademais, a multiplicação de episódios de alta carga emocional, sob o pretexto, quase nunca confirmado, de que pende a resolução da intriga. Do ponto de vista da economia narrativa, passagens como a transcrita acima, da "semi-bênção" de D'Elmont e Amena, mostram-se (quase) plenamente justificadas. Love in excess proporciona ao leitor a gratificação de uma cena sugestivamente erótica sem que tudo pareça (tão) gratuito ou apelativo. ${ }^{257}$ Aliás, o erotismo de passagens como essa se revestiria de um propósito informativo e, num quadro mais amplo, didático. $\mathrm{Na}$ dedicatória a Lasselia: or, the self-abandoned (1725), Haywood defenderia a suposta amoralidade de seus escritos, porque instrutiva, especialmente, para "a parte não pensante do mundo":

Meu propósito, ao escrever esse pequeno ROMANCE (bem como os que publiquei anteriormente) sendo apenas lembrar à parte não pensante do mundo quão perigoso é ceder à paixão, irá, espero, desculpar o excessivo ardor que possa talvez aparecer em algumas páginas específicas; pois sem que a EXPRESSÃO seja revigorada em alguma medida proporcional ao ASSUNTO, seria impossível para o leitor perceber quanto ele o toca ou quão provável é que esteja incorrendo nos descuidos que os exemplos que relato the aconselhariam a evitar. ${ }^{258}$

\footnotetext{
${ }^{256}$ WARNER, William B. Licensing entertainment cit., p. 114.

${ }^{257}$ Ver idem, p. 114-115. Trace-se um paralelo com as recentes discussões acerca da representação do sexo no cinema, suscitadas por ocasião do filme Azul é a cor mais quente (2013) (WILLIAMS, Linda. "Cinema's sex acts". Film Quarterly, v. 67, n. 4 (verão, 2014), p. 9-25).

${ }^{258}$ HAYWOOD, Eliza. "Dedicatória em Lasselia: or, the self-abandoned $(1724,2$. ed.)". In: VASCONCELOS, Sandra Guardini T. A formação do romance inglês cit., p. 262.
} 
A obra de Haywood seria, assim, indecorosamente decorosa. ${ }^{259}$ Demanda-se do leitor que reflita sobre as suas ações e das personagens, em troca de uma experiência quase libidinosa. Oferece-se a possibilidade de emular os prazeres que tentam Amena, para que se sinta sua força e se possa resisti-los em situações de risco. ${ }^{260}$

O artifício da cena de "excessivo ardor" se repete na Parte II, com Melliora no lugar de Amena, agora despachada para o convento de Saint Dennis. Como dito, D’Elmont se casara com Alovisa. No entanto, “era hora de a Fortuna, que há muito lhe sorria, girar a sua roda e punir a presunção" de sua mulher. ${ }^{261} \mathrm{Um}$ dia, um amigo de longa data de D’Elmont, Monsieur Frankville, cai doente. Em seu leito de morte, pede ao Conde para que seja o guardião de sua filha, enquanto o irmão dela não retorna de seu tour pela Europa. De tal maneira, Frankville pode partir em paz, sabendo que ela não arruinará sua vida atirando-se nos braços de qualquer um. D’Elmont logo se apaixona pela bela Melliora, uma moça também inteligente e sensível. D'Elmont tudo fará para despertar o desejo da Melliora. Ela intui que algo de terrível está para acontecer entre os dois e começa a evitar D’Elmont. Paralelamente a isso, Alovisa percebe a nova fonte de interesse de seu marido e começa a vigiá-los. Uma noite, D’Elmont decide visitar o quarto de Melliora. Encontra-a dormindo, descoberta, "com que todas as belezas de seu pescoço e seio ficaram à vista". Vendo-a assim tão bela e vulnerável, reuniu tudo o que havia de honrado em si e decidiu partir. Mas Melliora revela seu desejo ao falar durante o sono: $:^{262}$

A postura indefesa em que ele a encontrou incitou tudo o que nele havida de honrado. Teve dó até de acordá-la, mas mais ainda de violar tamanha inocência, e encontrava-se inclinado a sair e deixá-la como a encontrou [...]. Ele, ao abaixar-se à cama e deixar gentilmente a sua face próxima à dela (possivelmente a intentar não mais que lhe roubar um beijo despercebido), tal ação [sic], ao coincidir naquele instante com os sonhos dela, fez com que, ainda dormindo, envolvesse seu pescoço com o braço e, numa voz doce e lânguida, gritasse: - Oh, D'Elmont, deixe, deixe de ser tão encantador. A vida não pode suportar esses arrebatamentos - E,

\footnotetext{
${ }^{259}$ BARTOLOMEO, Joseph F. A new species of criticism cit., p. 34-35.

${ }^{260}$ LUBEY, Kathleen. "Eliza Haywood's amatory aesthetic”. Eighteenth-Century Studies, v. 39, n. 3 (New feminist work in epistemology and aesthetics) (primavera, 2006), p. 309-322, p. 310.

${ }^{261}$ Trecho integral: “[...] 'twas time for Fortune, who long enough had smiled, now to turn her wheel, and punish the presumption that defied her power" (HAYWOOD, Eliza. Love in excess cit., p.

${ }^{262}$ Para um comentário desta cena, ver BOWERS, Toni O'Shaughnessy. "Sex, lies, and invisibility: amatory fiction from the restoration to mid-century" cit., p. 68. Seguimos Bowers na seleção dos trechos que citamos abaixo.
} 84). 
então, abraçando-o ainda mais forte. - Oh!, meu tão adorável Conde, enlevado sedutor! ${ }^{263}$

O narrador observa que, diante disso, se ele houvesse recuado, alguns o aplaudiriam por sua "honra tão incomum". Arremata-se, contudo, que mais gente o condenaria por sua estupidez. ${ }^{264}$ D'Elmont tira seu casaco e deita sobre Melliora com a intenção de estuprá-la. Ela acorda de "uma felicidade imaginária" e, ao dar-se conta do que está prestes a ocorrer, implora ajuda aos céus, "ao perceber que ele procedia a liberdades as quais a sua modéstia não podia permitir”. ${ }^{265}$ D'Elmont ignora seus pedidos, silenciando-a com beijos. O estupro é inevitável. De repente, batem à porta. D'Elmont tem de fugir. O corpo de Melliora é preservado - e a intriga dá mais uma reviravolta.

A passagem também pode ser lida numa outra chave, com que se revela uma temática subjacente a Love in excess, porém nunca manifestamente articulada pelo narrador. As hesitações de D'Elmont opõem a conduta que se espera de um homem de sua posição e a vida levada entre quatro paredes. Na intimidade, honra é um valor risível, sem função na vida reprodutiva do indivíduo. O mundo de glória e ambição configurado por epopeia e estórias romanescas é explicitamente deixado para trás, logo nos parágrafos de abertura. Diz-se que o Conde D’Elmont granjeara "uma reputação incomum" nas Guerras de Sucessão Espanhola: “A fama dos atos corajosos do Conde o precederam, e ele teve a satisfação de ser recebido pelo rei e a corte, de uma maneira que poderia gratificar a ambição dos mais orgulhosos". ${ }^{266}$ Mas nada disso interessa às mulheres, como Alovisa, arrebatadas pela "beleza de sua pessoa" e “a jovialidade de seu ar”. ${ }^{267}$ Em sua primeira carta a D’Elmont, ela escreve: "Irresistível como você é na guerra, você o é muito mais no amor. Aqui, conquista sem atacar e nós nos rendemos ao seu comando; a lei da guerra o obriga a demonstrar

\footnotetext{
263 ، [...] the resistless posture he beheld her in, rouzed all that was honourable in him; he thought it pity even to wake her, but more to wrong such innocence, and he was sometimes prompted to return and leave her as he found her. [...] he, stooping to the bed, and gently laying his face close to her's, (possibly designing no more than to steal a kiss from her, unperceived) that action, concurring at that instant, with her dream, made her throw her arm (still slumbering) about his neck, and in a soft and languishing voice, cry out, Oh! D'elmont, cease, cease to charm, to such a height - Life cannot bear these raptures. - And then again, embracing him yet closer - O! too, too lovely Count - extatick ruiner!" (HAYWOOD, Eliza. Love in excess cit., p. 116).

${ }^{264}$ Idem, p. 116-117. 117).

265 "[...] finding he was proceeding to liberties, which her modesty could not allow of" (idem, p.

266 "The fame of the Count's brave actions arrived before him, and he had the satisfaction of being received by the King and Court, after a manner that might gratifie the ambition of the proudest" (idem, p. 37).

${ }^{267}$ Cf. supra, p. 195.
} 
piedade a seu inimigo". ${ }^{268} \mathrm{O}$ passado heroico de D'Elmont é só pretexto para aventuras de alcova. Seu pedigree aristocrático em nada contribui para sua caracterização, a não ser, talvez, de modo negativo, como provável fonte de sua libertinagem. ${ }^{269}$ Significativamente, as duas mulheres que vocalizam seus sentimentos, Alovisa e Ciamara, provêm da nobreza. Amena e Melliora, dotadas de inocência virginal, têm um status social inferior, embora não deixem de pertencer à aristocracia.

Em outro nível, os encontros notívagos de D’Elmont com Melliora e, antes, Amena condensam as experimentações de Haywood para representação da mente e da sensibilidade. Como nos lembra o narrador logo no segundo parágrafo de Love in excess, as mulheres são amaldiçoadas por "aquele costume que [as] proíbe [...] de declarar seus pensamentos" em matérias amorosas. ${ }^{270}$ Alovisa e Ciamara transgridem esse costume ao professarem abertamente seu amor por D’Elmont - e são punidas com a morte. Numa estória de intenso teor sexual, há o desafio de representar o consentimento de personagens como Melliora e Amena sem levá-las a violar, ao menos verbalmente, a sua "modéstia". ${ }^{271}$ Amena expressa sua aquiescência às investidas de D'Elmont sem proferir palavra. ${ }^{272}$ Fora tomada pela letargia. O narrador em terceira pessoa percorre um caminho de fora para dentro, do ambiente à interioridade da jovem, para descortinar, num esquema lockiano, um processo incontrolável do qual sensações subjugam a mente da personagem. O estado mental de amor e submissão, por outro lado, expressa-se somente de maneira física. É “o seio palpitante" que a "cada pulso" confessa "um desejo de ceder". São os lábios que vão ao encontro dos do Conde. E seus braços o abraçam "inconscientes". Ao converter o pensamento em ações ou gestos, Haywood obtém uma tecnologia literária em que se

\footnotetext{
268 "Resistless as you are in war, you are much more in love. Here you conquer without making an attack, and we surrender before your summons; the law of arms obliges you to show mercy to an yielding enemy" (HAYWOOD, Eliza. Love in excess cit., p. 39).

${ }^{269}$ Ver RICHETTI, John. The English novel in history cit., p. 48 e BLACK, Scott. "Trading sex for secrets in Eliza Haywood's Love in excess". Eighteenth-century fiction, v. 15, n. 2 (janeiro, 2003), $207-$ 226, especialmente p. 221.

${ }^{270}$ Trecho integral: "[...] that custom which forbids women to make a declaration of their thoughts" (HAYWOOD, Eliza. Love in excess cit., p. 37). Ver ALLISTON, April. "Amor em excesso: Eliza Haywood (1719-1720)" cit., p. 779.

${ }^{271}$ Sobre a representação do consentimento em Love in excess, ver KRAMNICK, Jonathan. Actions and objects from Hobbes to Richardson. Stanford: Stanford University, 2010, p. 151 e ss. A análise abaixo do encontro de Amena e D'Elmont é tributária da de Kramnick.

${ }^{272}$ Cf. supra, p. 198.
} 
concilia a liberdade do narrador em terceira pessoa com o interesse crescente pela maneira como o indivíduo percebia e reagia a seu entorno. ${ }^{273}$

Se a letargia de Amena não a implica no pecado da imodéstia, os sussurros sonâmbulos de Melliora ficam no limiar do aceitável. ${ }^{274}$ A enunciação do desejo, para usarmos termos do próprio narrador, é claramente associada a "vergonha" e "culpa". Por outro lado, precede-se a confissão inconsciente por uma espécie de arrazoado proto-freudiano, em que se descrevem os sonhos como a expressão de "paixões" reprimidas. À noite, esfacela-se o código de honra feminino: $:^{275}$

Qualquer que seja o domínio que honra e virtude tenham sobre nossos pensamentos despertos, é certo que desertam ao fechar dos olhos. Nossas paixões exercem seu poder vigoroso e aquela que tiver maior predominância na alma agita a fantasia e faz com que até mesmo coisas impossíveis ocorram. O desejo, repelido com diligência vigilante, retorna com violência ainda maior no sono desguarnecido e derruba os esforços vãos do dia. Melliora, contra sua vontade, era muitas vezes feliz em pensamentos e possuía uma bênção da qual vergonha e culpa a privavam na realidade. ${ }^{276}$

O desejo se impõe à mente de Melliora. Como argumentara Locke, as ideias muitas vezes vêm à mente de maneira espontânea, por meio de associações involuntárias e sensações, como prazer e inquietação, sobre as quais não temos controle. ${ }^{277}$ Em Love in excess, sonhos seriam a instância em que as constrições da educação, como "honra" e "virtude", arrefecem e as ideias brotam com maior liberdade. ${ }^{278}$ Pelo uso da primeira pessoa do plural, ademais, convida-se o leitor a se identificar com a personagem e, no limite, a procurar em seus próprios sonhos manifestações de um

${ }^{273}$ Ver KRAMNICK, Jonathan. Actions and objects from Hobbes to Richardson cit., p. 152.

${ }^{274}$ Ver BOWERS, Toni O'Shaughnessy. "Sex, lies, and invisibility: amatory fiction from the restoration to mid-century" cit., p. 68-69. Para Bowers, a verbalização do desejo torna indistinta a fronteira entre estupro e sedução.

${ }^{275}$ WARNER, William B. Licensing entertainment cit., p. 120 e LUBEY, Kathleen. "Erotic interiors in Joseph Addison's imagination". Eighteenth-century fiction, v. 20, n. 3 (primavera, 2008), p. 415 444, especialmente p. 416.

276 “ $[. .$.$] whatever dominion, honour and virtue may have over our waking thoughts, 'tis certain that$ they fly from the closed eyes; our passions then exert their forceful power, and that which is most predominant in the soul, agitates the fancy, and brings even things impossible to pass. Desire, with watchful diligence repelled, returns with greater violence in unguarded sleep, and overthrows the vain efforts of the day. Melliora in spite of her self, was often happy in idea, and possest a blessing, which shame and guilt, deterred her from in reality" (HAYWOOD, Eliza. Love in excess cit., p. 116).

${ }^{277}$ LOCKE, John. An essay concerning human understanding cit., p. 395 e ss.

${ }^{278}$ Locke, no entanto, nega que pensemos durante o sono, pois não conseguiríamos perceber o mundo nem as operações de nossa mente (idem, p. 109). 
desejo reprimido. ${ }^{279} \mathrm{O}$ ponto culminante na trajetória de Melliora é aquele em que verbaliza seus desejos inconfessáveis.

\subsection{Defoe}

Love in excess desenvolve uma fórmula narrativa com que se acomoda a representação da interioridade ao movimento do enredo. Toda a engrenagem revolve em torno do narrador em terceira pessoa, cuja flexibilidade proporciona desde a focalização numa moça prestes a ser seduzida até considerações gerais sobre a origem dos sonhos. Tamanha flexibilidade, contudo, é obtida ao custo da abdicação de uma exploração mais persistente dos mecanismos de autenticação narrativa, como em Oroonoko. ${ }^{280}$ Obviamente, o realismo professado em Oroonoko também tinha suas limitações. Os índices mobilizados para que se dê um ar de "história verdadeira" ao relato dos infortúnios do escravo real discrepam de sua caracterização uniforme e idealizada, decorrente, dentre outras coisas, da inevitável falta de acesso de "A. Behn" à mente $\mathrm{e}$ aos sentimentos de Oroonoko.

Os romances de Daniel Defoe propõem a resolução desse trade off. ${ }^{281}$ Tamanha a profundidade com que Robinson Crusoe (1719), Moll Flanders (1722), Colonel Jack (1722) e Roxana (1724) expandem e elaboram as estratégias narrativas que circulavam desde os tempos de Aphra Behn, que alguns críticos veem nessas obras uma verdadeira ruptura com tudo aquilo que as precedeu: Defoe teria escrito "o primeiro romance inglês". ${ }^{282}$ Sob a aparência de autobiografia, seu uso da narrativa em primeira pessoa costura a experiência presentificada do protagonista a uma segunda voz, atribuída a esse protagonista, agora maduro e arrependido, que periodicamente reflete sobre a estória. ${ }^{283}$

\footnotetext{
${ }^{279}$ WARNER, William B. Licensing entertainment cit., p. 119.

${ }^{280}$ Ver RICHETTI, John. Popular fiction before Richardson cit., p. 168-169. A própria narradora de The history of the nun não foi muito além de afirmar que "a história é verdadeira". O efeito de realidade advém muito mais da temática e da ambientação que, propriamente, de estratégias de validação narrativa (noutro contexto, ver WATT, Ian. A ascensão do romance cit., p. 226 e ss.).

${ }^{281}$ Tomamos o argumento central de nossa análise de Defoe de WARNER, William B. Licensing entertainment cit., p. 149 e ss.

${ }^{282}$ DAMROSCH Jr, Leopold. God's plots \& man's stories: studies in the fictional imagination from Milton to Fielding. Chicago - Londres: University of Chicago, 1985, p. 187. Paradigmaticamente, ver também WATT, Ian. A ascensão do romance cit., p. 31-33.

${ }^{283}$ Ver WARNER, William B. Licensing entertainment cit., p. 151; SPACKS, Patricia Meyer. Imagining a self: autobiography and novel in eighteenth-century England. Cambridge, MA - Londres: Harvard University, 1976, p. 21 e 28 e KONIGSBERG, Ira. Narrative technique in the English novel: Defoe to Austen. Hamden, CT: Archon Books, 1985, p. 29 e ss.
} 
O campo de experiência do protagonista se corporifica numa narrativa linear de sua trajetória, em que seus feitos se enumeram sem hierarquização imanente, porquanto apresentados de maneira escrupulosamente cronológica, ${ }^{284}$ sem inversões, com aparente coincidência entre fabula e sjužet. Atualizam-se os sucessivos estados mentais da personagem, num encadeamento em que o processo se sobrepõe à teleologia, em que a performance das dúvidas, hesitações e falsas esperanças parece ser tão importante quanto a representação de eventos nodais, dos quais usualmente se projeta a inflexão no enredo. ${ }^{285}$ Em Robinson Crusoe, por exemplo, o protagonista agradece aos céus quando se depara com uns pés de cevada inglesa em sua famosa ilha. Crê que Deus fizera com que lá crescessem, para alimentá-lo. Até que se dá conta de que a procedência do grão é bem mais trivial:

E não só acreditei que se deviam à pura obra da Providência destinada ao meu sustento como, sem dúvida, que deveria haver mais em volta, e corri toda a parte da ilha onde já tinha estado, espiando em todos os cantos e debaixo de cada pedra, para ver se achava mais, nada encontrando. Finalmente ocorreu aos meus pensamentos que tinha sido ali que eu despejei o saco de comida de galinha, e então meu pasmo começou a arrefecer. E, devo confessar, minha gratidão à Providência começou também a se atenuar quando descobri que tudo aquilo não era nada fora do comum $[\ldots]{ }^{286}$

Todas essas idas-e-vindas fundem o desenvolvimento psicológico com a percepção do mundo físico. ${ }^{287}$ Não se vincula o aflorar da religiosidade de Crusoe a encontros com os anjos, milagres ou qualquer outra intervenção em que a experiência da personagem se torne dispensável. A fé vem com a cevada e esvai-se com o saco vazio de ração.

\footnotetext{
${ }^{284}$ WARNER, William B. Licensing entertainment cit., p. 150.

${ }^{285}$ MARSHALL, David. "Autobiographical acts in Robinson Crusoe”. EHL, v. 71, n. 4 (inverno, 2004), p. 899-920, especialmente p. 901-902.

${ }^{286}$ DEFOE, Daniel. Robinson Crusoé. Trad. Sergio Flaskman. São Paulo: Penguin Classics Companhia das Letras, 2011, p. 136. No original: "I not only thought these the pure Productions of Providence for my Support, but not doubting, but that there was more in the Place, I went all over that Part of the Island, where I had been before, peering in every Corner, and under every Rock, to see for more of it, but I could not find any; at last it occur'd to my Thoughts, that I had shook a Bag of Chickens Meat out in that Place, and then the Wonder began to cease; and I must confess, my religious Thankfulness to God's Providence began to abate too upon the Discovering that all this was nothing but what was common [...]" (DEFOE, Daniel. Robinson Crusoe cit., p. 68).

${ }^{287}$ BENDER, John. Imagining the penitentiary: fiction and the architecture of mind in eighteenthcentury England. Chicago - Londres: University of Chicago, 1987, p. 43-44. Para G. A. Starr, os romances de Defoe ocupam-se especialmente da maneira como como o eu percebe e interpreta o mundo, numa relação em que nenhum dos pólos é absoluto (STARR, G. A. "Defoe's prose style 1: the language of interpretation”. Modern Philology, v. 71, n. 3 (fevereiro, 1974), p. 277-294).
} 
O mundo físico em Defoe não se resume a pés de cevada. Configura-se em coordenadas espaciais e temporais precisas. ${ }^{288}$ Os exemplos são inesgotáveis. Roxana teria nascido em "Poictiers" (Poitiers), no ano de 1673, uma década antes de os protestantes serem banidos da França "pela crueldade de seus perseguidores". ${ }^{289}$ Crusoe chegaria na ilha, situada na "Latitude de 9 graus e 22 minutos ao norte do Equador", no dia 30 de setembro de $1659 .{ }^{290}$ Lá, levaria quarenta e dois dias (três dos quais só para derrubar uma árvore) para fazer uma prancha lisa nas duas faces, com uma polegada de espessura. O marido "mercador-fidalgo" de Moll Flanders escaparia da casa do meirinho às três da manhã. Páginas depois, ela e seu novo marido, Jemmy, se hospedariam numa estalagem em West Street, perto da Catedral de Chester. E o Coronel Jack chegaria mesmo a testemunhar eventos históricos. Observaria a última campanha da Guerra da Liga de Augsburg, em 1697, e tomaria parte, em 1701 e 1702, da Guerra de Sucessão Espanhola, conflito no qual, aliás, conseguiria sua patente militar. ${ }^{291}$ Em cada um desses casos, inserem-se as personagens em circunstâncias que se querem únicas, determinadas, impossíveis de serem repetidas. ${ }^{292}$ Localizada e circunscrita a condições que se querem tangíveis, a experiência ganha um lastro material, condicionando-se pelas percepções que o entorno lhe suscita. ${ }^{293} \mathrm{Na}$ famosa cena em que Crusoe finalmente se converte, estabelece-se um continuum do mundo físico à epifania religiosa:

A estação chuvosa ou de equinócio do outono tinha chegado, e eu observei o dia 30 de setembro da mesma forma solene do ano anterior, quando completei o primeiro aniversário de meu desembarque na ilha, que agora já fazia dois anos, sem maior perspectiva de libertação que no primeiro dia em que [lá] cheguei. Passei todo o dia reconhecendo com humildade e gratidão as muitas mercês prodigiosas que socorreram minha condição solitária, e sem as quais meu sofrimento teria sido infinitamente maior. Dei graças humildes e sinceras a Deus por ter sido Sua vontade que eu

\footnotetext{
${ }^{288}$ Sobre a cronologia de Robinson Crusoe, ver o quadro em: DEFOE, Daniel. Robinson Crusoe. Ed. Thomas Keymer. Oxford - Nova Iorque: Oxford University, 2007, p. 269-270. Ver a discussão em: MÄKIKALLI, Aino. From eternity to time: conceptions of time in Daniel Defoe's novels. Oxford Berna - Berlim - Bruxelas - Frankfurt - Nova Iorque - Viena: Peter Lang, 2007, p. 129-132.

289 “[...] by the cruelty of their persecutors" (DEFOE, Daniel. Roxana. Ed. John Mullan. Oxford Nova Iorque: Oxford University, 1998, p. 5).

290 " [....] in the Latitude of 9 Degrees 22 Minutes North of the Line" (DEFOE, Daniel. Robinson Crusoe cit., p. 55).

${ }^{291}$ Cf. MACK, Ruth. "'Seeing something that was doing in the World': the form of History in Colonel Jack". Eighteenth-century fiction, v. 24, n. 2 (inverno, 2011-2012), p. 227-245.

${ }^{292}$ WATT, Ian. A ascensão do romance cit., p. 15.

${ }^{293}$ ARMSTRONG, Nancy. How novels think cit., p. 3-4 e BENDER, John. Imagining the penitentiary cit., p. 47-50.
} 
possivelmente estava mais feliz naquela condição solitária que na vida livre em sociedade, desfrutando de todos os prazeres do mundo. ${ }^{294}$

A contabilidade fria dos anos, que assinala no calendário o dia 30 de setembro, tornase indistinguível da sucessão sensorial, em que se percebe o retorno das chuvas e as variações na luminosidade solar. Mas o tempo externo e o tempo percebido confluem para a dissolução do futuro, para o temor de que cada novo dia será igual ao primeiro dia na ilha e que a "condição solitária" de Crusoe se arrastará indefinidamente. ${ }^{295}$ Absorto no agora, o aventureiro se humilha e, dentro de si e nos céus, tenta buscar o conforto que não consegue encontrar na terra.

A “condição solitária” é o requisito indispensável para que Crusoe se quede na "maneira solene" com que se reconcilia com o divino. Seu estado de introspecção permanente depende da ruptura com "a vida livre em sociedade" e com "todos os prazeres do mundo". Algumas das passagens de maior intensidade emocional da obra novelística de Defoe tematizam a conscientização do isolamento. Em Robinson Crusoe, a impossibilidade de se transporem "as grades e as trancas eternas do oceano" se traduz em acessos de choro e divagações incontroláveis, numa cena em que gestos silenciosos encenam "a angústia" da "alma":

Antes [da conversão], sempre que eu caminhava pela ilha, fosse em minhas caçadas, ou no reconhecimento do terreno, a angústia de minha alma com minha condição podia me ocorrer de um momento para o outro, e nessa hora meu coração morria dentro de mim, ao pensar nas matas, nas montanhas e nos desertos onde eu me encontrava, e como eu era um prisioneiro aferrolhado com as grades e as trancas eternas do oceano num local selvagem e desabitado, sem possibilidade de salvação. Nos momentos de maior temperança de minha mente, essa ideia irrompia em mim como uma tempestade, e me fazia torcer as mãos e chorar como uma criança. Às vezes me acometia no meio do trabalho, e na mesma hora eu me sentava e me punha a suspirar, olhando fixo para o chão por uma ou duas horas seguidas. E isso era ainda pior para mim, pois se eu conseguisse

\footnotetext{
${ }^{294}$ DEFOE, Daniel. Robinson Crusoé cit., p. 174 (com modificações). No original: "The rainy Season of the Autumnal Equinox was now come, and I kept the 30th of Sept. in the same solemn Manner as before, being the Anniversary of my Landing on the Island, having now been there two Years, and no more Prospect of being deliver'd, than the first Day I came there. I spent the whole Day in humble and thankful Acknowledgments of the many wonderful Mercies which my Solitary Condition was attended with, and without which it might have been infinitely more miserable. I gave humble and hearty Thanks that God had been pleas'd to discover to me, even that it was possible I might be more happy in this Solitary Condition, than I should have been in a Liberty of Society, and in all the Pleasures of the World" (DEFOE, Daniel. Robinson Crusoe cit., p. 96).

${ }^{295}$ Sobre a dissolução do tempo, ver DAMROSCH Jr, Leopold. God's plots \& man's stories cit., p. 191.
} 
rebentar em lágrimas ou dar vazão à minha dor com palavras, essa tristeza passaria, e a dor, esgotando-se assim, poderia se atenuar. ${ }^{296}$

Paradoxalmente, correlaciona-se a externalização do eu a exílio, silêncio e clausura. Até a chegada de Friday, o desterro secciona Crusoe de qualquer convívio ou organização social de que pudesse construir sua identidade. ${ }^{297} \mathrm{Na}$ ilha despovoada, Crusoe refere-se a si mesmo como rei, súdito, general e outra penca de títulos cuja abundância denota, antes de tudo, sua vacuidade. Para resguardar sua integridade, o eu precisa dar vazão a si mesmo, ainda que sob a forma de lágrimas e palavras que ninguém irá ver ou ouvir. ${ }^{298}$

Na solidão de Crusoe também se enfeixa a contradição que serve de premissa aos enredos dos romances de Defoe. Seus protagonistas anseiam por uma vida plena, em família e sociedade, mas é a ausência de vínculos que naturaliza e impele suas perambulações pelos mares e continentes. É a desobediência ao pai que leva Crusoe a se aventurar pela África e América do Sul. A vida pelo "caminho do meio", como mercador em York, certamente não teria o mesmo apelo. Pelo menos é o que sugere o "Editor", implicitamente, em seu "Prefácio": “As maravilhas da vida desse homem excedem tudo que [...] se pode encontrar: mal se imagina que a vida de um homem seja capaz de maior variedade". ${ }^{299}$ Configura-se aquilo que Nancy Armstrong chama de "retórica do desejo". A inquietação de Crusoe coloca-o, juntamente com o enredo, em constante movimento. Sempre insatisfeito, sente uma necessidade incontrolável de buscar algo novo, diferente. Abandona a casa paterna, deixa para trás a sua plantação no Brasil e, depois de mais de três décadas no estrangeiro, decide partir para mais uma aventura. ${ }^{300}$ Num outro nível, o isolamento de Crusoe incorpora a lógica das

\footnotetext{
${ }^{296}$ DEFOE, Daniel. Robinson Crusoé cit., p. 175. No original: "Before, as I walk'd about, either on my Hunting, or for viewing the Country, the Anguish of my Soul at my Condition, would break out upon me on a sudden, and my very Heart would die within me, to think of the Woods, the Mountains, the Desarts I was in; and how I was a Prisoner lock'd up with the Eternal Bars and Bolts of the Ocean, in an uninhabited Wilderness, without Redemption: In the midst of the greatest Composures of my Mind, this would break out upon me like a Storm, and make me wring my Hands, and weep like a Child: Sometimes it would take me in the middle of my Work, and I would immediately sit down and sigh, and look upon the Ground for an Hour or two together; and this was still worse to me; for if I could burst out into Tears, or vent my self by Words, it would go off, and the Grief having exhausted it self would abate" (DEFOE, Daniel. Robinson Crusoe cit., p. 96).

${ }^{297}$ Crusoe, é verdade, carrega algo do inglês e de sua cultura dentro de si.

${ }^{298}$ JAGER, Eric. "The parrot's voice: language and the self in Robinson Crusoe". Eighteenthcentury studies, v. 21, n. 3 (primavera, 1988), p. 316-333, especialmente p. 319.

${ }^{299}$ DEFOE, Daniel. Robinson Crusoé cit., p. 43. No original: "The Wonders of this Man's Life exceed all that [...] is to be found extant; the Life of one Man being scarce capable of a greater Variety" (DEFOE, Daniel. Robinson Crusoe cit., p. 4).

${ }^{300}$ ARMSTRONG, Nancy. How novels think cit., p. 4.
} 
relações socioeconômicas da Grã-Bretanha setecentista. ${ }^{301} \mathrm{O}$ aventureiro é "um homem privado", ${ }^{302}$ fora dos círculos da aristocracia, livre para explorar as múltiplas oportunidades de mobilidade social oferecidas pelo capitalismo mercantilista. Faz-se mercador em Portugal, traficante de escravos africanos e senhor de engenho no Nordeste brasileiro. A polimorfia de sua heráldica insular, a que aludimos há pouco, seria apenas a epítome de um movimento observável ao longo de todo o romance. De maneira semelhante, o desejo por mobilidade social fará com que Moll Flanders supere as limitações de seu nascimento e explore seus atributos em casamentos, golpes e trapaças em várias cidades da Inglaterra e também nas colônias americanas. E o anseio de Jack em regressar ao seu status original de gentleman o levará a se tornar punguista, ladrão, servo nas colônias, feitor, intendente de plantation, mercador, voluntário no exército francês e, por fìm, coronel. Para transitar em tantas esferas, a personagem deve, necessariamente, ser solitária - ainda que isso lhe cause sofrimento:

Agora, eu me via como alguém enterrado vivo, numa parte remota do mundo, onde eu não poderia ver nada, ou ouvir só rumores do que era visto - e esse pouco, não menos que meio ano depois de ter ocorrido. E, às vezes, até um ano ou mais. Em suma, defrontei-me com o velho reproche: a saber, que nem mesmo isso era, ainda, a vida de um fidalgo. ${ }^{303}$

A naturalização da intriga, a narrativa escrupulosamente linear e a atenção à maneira como se percebe o mundo perfazem uma estratégia ficcional cujo escopo é negar sua própria ficcionalidade. Para citarmos os termos empregados no "Prefácio" a Robinson Crusoe: a "seriedade" e "modéstia" com que o protagonista recontaria suas

\footnotetext{
${ }^{301}$ Paradigmaticamente, ver: WATT, Ian. A ascensão do romance cit., p. 55-83. McKeon empresta uma leitura mais weberiana ao Crusoe, associando seu empreendedorismo à ética protestante (McKEON, Michael. The origins of the English novel cit., p. 319).

302 "[...] private man” (DEFOE, Daniel. Robinson Crusoe cit., p. 4). A noção de "private man" contrapõe-se à de homem público, e esta se confunde com a de aristocracia (ver SENNETT, Richard. The fall of public man. Londres: Penguin, 2002, p. 16). A distinção fica bastante clara numa passagem de Sir Charles Grandison, de Samuel Richardson: "Minha maior glória será portar-me meritoriamente na vida privada. Não desejo ser um homem público" ("My chief glory will be, to behave commendably in the private life. I wish not to be a public man [...]") (RICHARDSON, Samuel. The history of Sir Charles Grandison cit., v. 6, L. XXV, p. 99). A tradução de Sergio Flaskman (DEFOE, Daniel. Robinson Crusoé cit., p. 43), que toma "private man" como "homem em particular", parece-me equivocada.

303 'Now, I look'd upon my self as one Buried alive, in a remote Part of the World, where I could see nothing at all, and hear but a little of what was seen, and that little, not till at least half a Year after it was done, and sometimes a Year or more; and in a Word, the old Reproach often came in my way; Namely, that even this was not yet, the Life of a Gentleman" (DEFOE, Daniel. The history and remarkable life of the truly honourable Col. Jacque. Ed. Maurice Hindle. Londres: Pickering \& Chatto, 2009, p. 161).
} 
"aventuras no mundo" dariam às múltiplas "maravilhas" que viveu um ar de "justa história factual". ${ }^{304} \mathrm{Se}$ nos fiarmos no testemunho de Theophilus Cibber, parte considerável do público setecentista parece ter acreditado nas palavras do "Editor":.305

Sua imaginação era fértil, forte e vivaz, como se pode ver em suas obras imaginativas, particularmente seu Robinson Crusoe, que foi escrito de uma maneira tão natural, e com tantos incidentes prováveis, que, por um tempo depois de sua publicação, foi tido como uma estória verdadeira. Foi, efetivamente, escrito num modelo inteiramente novo, e o sucesso e a estima com que foi recebido podem ser verificadas pelas várias edições que vendeu, e pelas somas de dinheiro que rendeu. ${ }^{306}$

Em Moll Flanders, Colonel Jack e Roxana, a proclamada veracidade factual, com que “a obra não é uma estória mas uma história", ${ }^{307}$ implica a descida sem reservas a "linhas iníquas de conduta", ${ }^{308}$ em que a personagem pode vir a percorrer "os degraus de dama, prostituta e alcoviteira; parteira e caftina, [...] [agiota], traficante de menores, [receptadora]" 309 etc. Oficialmente, cada um dos supostos "Editores" condena os atos narrados: "o vício pintado em suas cores não é para que as pessoas gostem dele, mas para expô-lo". ${ }^{310}$ À primeira vista, trata-se de uma estratégia semelhante à empregada por Eliza Haywood, discutida páginas atrás. ${ }^{311}$ Ao contrário

\footnotetext{
${ }^{304}$ Respectivamente, no original: "Seriousness", "Modesty", "Adventures in the World", "Wonders" e "just History of Fact" (DEFOE, Daniel. Robinson Crusoe cit., p. 4).

${ }^{305}$ Para uma leitura bem mais nuançada da recepção de Defoe, ver: BROWN, Homer. "The institution of the English novel: Defoe's contribution". Novel: a forum on fiction, v. 29, n. 3 (primavera, 1996), p. 299-318.

306 "His imagination was fertile, strong, and lively, as may be collected from his works of fancy, particularly his Robinson Crusoe, which was written in so natural a manner, and with so many probable incidents, that, for some time after its publication, it was judged by most people to be a true story. It was indeed written upon a model entirely new, and the success and esteem it met with, may be ascertained by the many editions it has sold, and the sums of money which have been gained by it" (ROGERS, Pat. Daniel Defoe: the critical heritage. Londres: Routledge, 2013, p. 49-50).

${ }^{307}$ DEFOE, Daniel. "Prefácio a Roxana. The fortunate Mistress (1724)". In: VASCONCELOS, Sandra Guardini T. A formação do romance inglês cit., p. 266. No original: "[...] the Work is not a Story, but a History" (DEFOE, Daniel. Roxana cit., p. 1).

${ }^{308}$ DEFOE, Daniel. "Prefácio a Roxana. The fortunate Mistress (1724)". In: VASCONCELOS, Sandra Guardini T. A formação do romance inglês cit., p. 267. No original: "[...] wicked Courses" (DEFOE, Daniel. Roxana cit., p. 2).

${ }^{309}$ DEFOE, Daniel. Moll Flanders. Trad. Donaldson M. Garschagen. São Paulo: Cosac Naify, 2015, p. 12. No original: "all the eminent degrees of a Gentlewoman, a Whore, and a Bawd; a Midwife, and a Midwife-Keeper, [...] a Pawn-broker, a Child-taker, a Receiver of Thieves" (DEFOE, Daniel. Moll Flanders cit., p. 6). Modifiquei a tradução de Garschagen quando me pareceu inconsistente com o original.

${ }^{310}$ DEFOE, Daniel. "Prefácio a Roxana. The fortunate Mistress (1724)". In: VASCONCELOS, Sandra Guardini T. A formação do romance inglês cit., p. 267. No original: "[...] when Vice is painted in its Low-priz'd Colours, 'tis not to make People in love with it [...]" (DEFOE, Daniel. Roxana cit., p. 2).

${ }^{311}$ Cf. supra, p. 199.
} 
do que se dá em Love in excess, todavia, os narradores de Defoe trazem o discurso moralizador para o entrecho narrativo, moldando-o, como se disse acima, por uma segunda voz que reflete sobre a conduta do protagonista. Em tese, são essas as intervenções nas quais o leitor deveria buscar inspiração: ${ }^{312}$

Pelo modo como ela [Roxana] contou a estória, fica evidente que ela não insiste na sua justificativa em nenhuma parte; muito menos recomenda sua conduta, ou, de fato, qualquer parte dela, exceto seu arrependimento, para nossa imitação. ${ }^{313}$

As reflexões do autor suposto resgatam o leitor da suspensão do discernimento moral, que parecia intrínseca à ficção novelística. Com efeito, Samuel Johnson, provavelmente o maior árbitro literário do século XVIII, alertaria anos depois para o estranho "poder" do romance, que "se apossa da memória com uma espécie de violência e produz efeitos quase sem intervenção da vontade". ${ }^{314}$ Em vista disso, comentários, ponderações e avaliações críticas periodicamente irrompem na narrativa, a estilhaçar uma eventual absorção vicariante na caracterização da personagem. Tomemos como exemplo uma passagem de Robinson Crusoe. Logo depois que o aventureiro se dá conta de que foi ele quem espalhou as sementes de cevada ${ }^{315}$ e sua gratidão a Deus se tornara menos fervorosa, o narrador comenta parenteticamente que:

[...] eu deve[ria] agradecer tanto por aquela estranha e imprevista Providência como se fosse um milagre: porque tinha sido realmente necessário que a Providência atuasse em meu favor para que dez ou doze sementes de cereal tivessem permanecido intactas (quando os ratos tinham destruído todo o resto), como se tivessem caído do céu; e também que eu as tivesse lançado naquele lugar em especial, onde, estando à sombra de um penedo, puderam brotar imediatamente. Se eu tivesse jogado as sementes em qualquer outro sítio, àquela altura todos os brotos já estariam secos e perdidos. ${ }^{316}$

\footnotetext{
${ }^{312}$ Seguimos de perto: WARNER, William B. Licensing entertainment cit., p. 151 e ss.

${ }^{313}$ DEFOE, Daniel. "Prefácio a Roxana. The fortunate Mistress (1724)". In: VASCONCELOS, Sandra Guardini T. A formação do romance inglês cit., p. 267. No original: "[...] In the Manner she has told the Story, it is evident she does not insist upon her Justification in any one Part of it; much less does she recommend her Conduct, or, indeed, any Part of it, except her Repentance to our Imitation [...]" (DEFOE, Daniel. Roxana cit., p. 2).

314 “[...] take possession of the memory by a kind of violence, and produce effects almost without the intervention of the will" (JOHNSON, Samuel. The Rambler. Ed. W. J. Bate; Albrecht B. Strauss. New Haven - Londres: Yale University, 1969, v. 1, p. 22 (n. 4. Saturday, 31 March 1750)).

${ }^{315}$ Ver supra, p. 205.

${ }^{316}$ DEFOE, Daniel. Robinson Crusoé cit., p. 136. No original: "I ought to have been as thankful for so strange and unforseen Providence, as if it had been miraculous; for it was really the Work of Providence as to me, that should order or appoint, that 10 or 12 Grains of Corn should remain unspoil'd, (when the Rats had destroy'd all the rest,) as if it had been dropt from Heaven; as also, that I
} 
A temporalidade do narrar se sobrepõe à do narrado, com que se almeja determinar ou clarificar o sentido da cena e da obra como um todo. No "Prefácio" a Serious reflections during the life and surprising adventures of Robinson Crusoe, cuja autoria é delegada ao próprio Crusoe, argumentar-se-ia que esse tipo de intrusão autoral daria à "história [...] histórica" uma dimensão alegórica:

[...] aqui está o único final justo e bom de toda a parábola ou história alegórica acontecida, a saber, para o aperfeiçoamento moral e religioso. Aqui se recomendam paciência invencível sob o pior sofrimento; aplicação infatigável e resolução indômita sob as maiores e mais desalentadoras circunstâncias. ${ }^{317}$

A atribuição de uma alegoria, "para o aperfeiçoamento moral e religioso", como tantas vezes já se disse aqui, presume alguma unidade de ação, em cuja paráfrase se condensaria um ensinamento. As intervenções do autor suposto costuram essa unidade. Suas reflexões não somente valoram a estória/história, mas também explicitam seu direcionamento. Vejamos uma passagem de Moll Flanders. A protagonista passara uma temporada no interior da Inglaterra. Dentre malfeitos e entreveros, afanara a bagagem de um cliente em Harwich, envolvera-se numa confusão em Ipswich e descobrira que todos seus velhos amigos de Colchester haviam morrido. De volta a Londres, Moll vai ter com uma velha confidente, a Preceptora, com quem faz a contabilidade de suas expedições. Embora tenha amealhado uma soma considerável com sua gatunagem, Moll assevera que tenciona não mais partir em expedições pelo interior. Sua amiga a reconforta e assegura que sempre terá sucesso:

[...] descrevi para minha preceptora aquelas andanças - ela apreciou bastante a história de Harwich e, enquanto discorríamos sobre as suas peripécias, ela comentou que, por ser o ladrão uma pessoa que tira partido do erro dos demais, é impossível que faltem oportunidades se ele se mostra vigilante e industrioso; por isso, acreditava que uma pessoa competente em seu ofício, como eu, não

should throw it out in that particular Place, where it being in the Shade of a high Rock, it sprang up immediately; whereas, if I had thrown it anywhere else, at that Time, it had been burnt up and destroy'd" (DEFOE, Daniel. Robinson Crusoe cit., p. 68).

${ }^{317}$ DEFOE, Daniel. "Prefácio Serious reflections during the life and surprising adventures of Robinson Crusoe (1720)". In: VASCONCELOS, Sandra Guardini T. A formação do romance inglês cit., p. 253. No original: "[...] here is the just and only good End of all Parable or Allegorick History brought to pass, viz. for moral and religious Improvement. Here is invincible Patience recommended under the worst of Misery; indefatigable Application and undaunted Resolution under the greatest and most discouraging Circumstances [...]" (DEFOE, Daniel. Robinson Crusoe cit., p. 265). 
podia deixar de topar com uma eventualidade notável, onde quer que eu estivesse. ${ }^{318}$

A passagem congloba a estreiteza da perspectiva das personagens. Ironicamente, Moll está apenas a duas tentativas de furto antes de ser pega e despachada para a prisão de Newgate, onde reencontrará um de seus muitos maridos. Juntos, serão desterrados para a Virgínia e lá recomeçarão uma vida nova. A narradora, contudo, não deixa que o leitor se iluda com as predições da amiga Preceptora. Dois parágrafos abaixo, pondera-se, prolepticamente, que uma "nova série de acontecimentos de minha vida" se aproxima:

Preparo-me agora para narrar uma nova série de acontecimentos de minha vida; ao retornar a Londres, calejada por longa carreira criminosa, coroada de êxitos sem paralelo (pelo menos segundo minhas próprias observações), eu não tinha, como já indiquei, a mínima intenção de abandonar uma profissão que, a julgar pelos exemplos de outros praticantes, estava fadada a terminar em desgraça e sofrimento. ${ }^{319}$

A intervenção da narradora sugere que a sequência de patifarias se enreda num propósito maior, em que se prenunciam "desgraça" e "sofrimento" aos que se dedicam à "profissão" de Moll. Proporciona-se uma espécie de unidade a uma narrativa de inequívocos traços episódicos, em que os trambiques da protagonista sucedem um ao outro sem que haja relação evidente de necessidade. A reversão na fortuna da ladra requalifica toda sua trajetória, retrospectivamente figurada como preparação para o momento de revelação. ${ }^{320}$ Ainda que à revelia das intenções do puritano Defoe, havia uma tensão jamais resolvida entre aquilo que professa a narradora e, para retomarmos expressões citadas há pouco, a "intenção" e a "profissão" da personagem. Ao final, Moll estaria longe de experimentar a "desgraça" e o "sofrimento". A prisão se torna a oportunidade para reaproximá-la de seu único

\footnotetext{
${ }^{318}$ DEFOE, Daniel. Moll Flanders. Trad. Donaldson M. Garschagen cit., p. 380. No original: "I gave my Governess a History of my Travels; she lik'd the Harwich journey well enough, and in Discoursing of these things between our selves she observ'd, that a Theif [sic] being a Creature that Watches the Advantages of other Peoples mistakes, 'tis impossible but that to one that is vigilant and industrious many Opportunities must happen, and therefore she thought that one so exquisitely keen in the Trade as I was would scarce fail of something wherever I went" (DEFOE, Daniel. Moll Flanders cit., p. 268).

${ }^{319}$ DEFOE, Daniel. Moll Flanders. Trad. Donaldson M. Garschagen cit., p. 381. No original: "I am drawing now towards a new Variety of the Scenes of Life: Upon my Return, being hardened by a long Race of Crime, and success unparallel'd, at least in the reach of my own Knowledge, I had, as I have said, no thoughts of laying down a Trade, which, if I was to judge by the Example of others, must however end at last in Misery and Sorrow" (DEFOE, Daniel. Moll Flanders cit., p. 269).

${ }^{320}$ WARNER, William B. Licensing entertainment cit., p. 151 e ss.
} 
amor, Jemmy, e aposentar-se como uma respeitável proprietária de terras no Novo Mundo, poeticamente perdoada por suas incursões em incesto, prostituição e criminalidade. Diante disso, alguns dos contemporâneos de Defoe tiveram imensa dificuldade em levar a sério as moralizações de seus narradores, tachando-as de palavrório hipócrita. Charles Gildon, por exemplo, diria que as passagens discursivas de Robinson Crusoe haviam sido insertas apenas para inflar a estória até que se tornasse extensa o suficiente para ser empacotada e vendida como "um livro de cinco xelins". ${ }^{321}$ Embora tenha lá a sua graça, esse tipo de simplificação ignora tanto a participação da segunda voz na economia da narrativa quanto a maneira como soluciona, ainda que precariamente, a problematização da distância entre a perspectiva do narrador e das personagens. Com sua clarividência retrospectiva, os narradores de Defoe oferecem alguma completude à carreira de um indivíduo que, isolado, vê-se condenado a prosseguir às cegas.

\subsection{Clarissa}

Com a incorporação ostensiva do didatismo à narrativa novelística de Daniel Defoe, entrevê-se a possibilidade de se conjugar o obnubilar do registro ficcional à organização unitária do enredo, pautada pelo ideal de ação parafraseável. A atribuição de uma função integradora à reflexividade do narrador, com que intervenções do autor suposto refletem na economia narrativa, trai uma busca por coesão e inteligibilidade a um gênero que, por definição, explicita a condição quimérica de qualquer forma dotada de coesão e inteligibilidade.

Em Defoe, delineia-se o que, anos mais tarde, William Godwin tomaria como o traço distintivo da ficção setecentista (noutras palavras, o romance): a dicotomia entre a tendência e a moral da narrativa. ${ }^{322}$ Como discutimos acima, aquilo que proclama o narrador de Robinson Crusoe tende a diferir daquilo que a narrativa das aventuras do protagonista nos revela. A lamentação do Crusoe velho e amargurado quanto à sua imprudência, que perpetuamente o impele a embarcar em novas viagens, é

\footnotetext{
${ }^{321}$ Trecho integral: "[...] they were put in by you to swell the Bulk of your Treatise up to a five Shilling Book" (GILDON, Charles. "From the Postscript to an Epistle to Daniel Defoe..., 1719". In: WILLIAMS, Ioan (ed.). Novel and romance: a documentary record, 1700-1800. Londres: Routledge \& Keagan Paul, 1970 (reimpressão, 2010), p. 66.

${ }^{322}$ GODWIN, William. "Of choice in reading". The enquirer: reflections on education, manners, and literature. Londres: G. G. and J. Robinson, 1797, p. 129-146. Seguimos Patricia Meyer Spacks na aplicação das observações de Godwin à análise da organização formal da ficção setecentista (SPACKS, Patricia Meyer. Desire and truth cit., p. 4-5).
} 
incompatível com a celebração do empreendedorismo que se enfeixa, ainda que de modo inconsciente, nas andanças do protagonista. A "moral" unifica, estabelece padrões, costura continuidades, num procedimento que molda a narrativa numa estrutura identificável, da qual o leitor é convidado a extrair um sentido profundo, um ensinamento. Por outro lado, a dita "tendência" se apresenta como uma força de dispersão, indeterminação e protraimento. Se o narrador consegue enxergar um padrão, este quase sempre escapa às personagens, que se veem entregues às contingências e às frustrações do ziguezague, dos becos sem saída e da tentativa-eerro.

Os leitores e, sobretudo, o mercado editorial do século XVIII frequentemente tomavam a "moral" e a "tendência" como polos mutuamente excludentes. Antologias extraíam "belezas", "lições" e arrazoados éticos de obras novelísticas, vendendo-as como coletâneas destinadas à edificação espiritual. Muitos romancistas não teriam nenhum pudor em proceder ao que hoje chamaríamos de canibalização de seus escritos. As antologias de Sterne obteriam êxito comercial comparável ao dos títulos que continham o texto integral. ${ }^{323}$ Igualmente, edições piratas de Defoe expeliam os trechos discursivos, ficando só com a narração dos feitos e eventos de que participavam as personagens. Defoe reclamaria de maneira acerba de editores inescrupulosos que eliminariam justamente as passagens que julgava as mais belas e mais importantes de sua obra:

As observações e reflexões que ocupam esse volume coroam a obra [...]. Aqueles cuja avareza, prevalecendo sobre sua honestidade, haviam invadido a propriedade desse livro por meio de uma condensação corrupta, tanto fracassaram em sua esperança quanto se envergonharam do fato: pondo a culpa tão bem quanto possível, embora debilmente, um no outro. ${ }^{324}$

Obviamente, o maior dos crimes dos piratas não é a sua "avareza" - nem tampouco a dita invasão da propriedade autoral de Defoe. O problema de qualquer "condensação corrupta" é ignorar a relação de complementariedade entre "moral" e "tendência", a maneira como se sedimentam na estrutura do texto, num processo conflituoso, do qual a narrativa novelística inexoravelmente emerge como uma totalidade complexa e

\footnotetext{
${ }^{323}$ PRICE, Leah. The anthology and the rise of the novel: from Richardson to George Eliot. Cambridge: Cambridge University, 2000, passim.

${ }^{324}$ DEFOE, Daniel. "Introdução do Editor a Serious reflections during the life and surprising adventures of Robinson Crusoe”. In: VASCONCELOS, Sandra Guardini T. A formação do romance inglês cit., p. 254.
} 
contraditória. ${ }^{325}$ É difícil imaginar, no entanto, que Defoe ou qualquer um de seus antecessores e contemporâneos imediatos operassem com esse nível de abstração conceitual ou consciência estética. A narrativa novelística ainda não gozava de prestígio ou teorização suficientes para se converter no que Jeffrey Williams chama de tecnologia literária, num conjunto mais ou menos sistematizado de procedimentos formais assimiláveis e reproduzíveis. ${ }^{326}$ Isso só ocorreria no momento em que tradicionalmente se data a institucionalização do romance, ao final da década de 1740 , com Samuel Richardson, Henry Fielding e Tobias Smollett. ${ }^{327}$

O romance se institucionaliza ao postular a indissolubilidade entre o objetivo e o subjetivo $^{328}$ e, por extensão, entre os diversos polos que vêm organizando esta exposição: "moral" e "tendência", intriga natural e enredo unitário, forma e conteúdo, indivíduo e sociedade, mercado e heroísmo, aristocracia e burguesia, perspectiva do narrador e das personagens, ficção e história verdadeira etc. ${ }^{329}$ Com aquela que é considerada a obra mais importante de Richardson, Clarissa (1748), temos uma narrativa em cujo desenvolvimento expõem-se essas múltiplas polaridades num regime de codeterminação, engendrado numa estrutura que culmina com a sugestão de um horizonte ideal, fora do narrado, em que as dicotomias que condicionam a narrativa estariam superadas.

Resumir a estória de Clarissa é algo enganosamente simples e descomplicado. ${ }^{330}$ As qualidades da jovem Clarissa Harlowe distinguem-na de seu irmão e irmã, James e Arabella, o que compele seu avô a legar-lhe o título exclusivo de uma propriedade no interior da Inglaterra. Embora Clarissa seja um exemplo de abnegação e devoção familiar, sua independência financeira gera descontentamento entre aqueles que foram preteridos pelo testamento do avô. A crise se instaura com a chegada de Sir Robert Lovelace, um aristocrata devasso, definido nas pré-textuais como "um homem de nascimento e fortuna, arrogante, vingativo, de humor vaidoso, igualmente intrépido e

\footnotetext{
${ }^{325}$ Ver SPACKS, Patricia Meyer. Desire and truth cit., p. 235 e McKEON, Michael. The origins of the English novel cit., p. 266.

${ }^{326}$ WILLIAMS, Jeffrey. Theory and the novel: narrative reflexitivity in the British tradition. Cambridge: Cambridge University, 1998, p. 8 e ss.

${ }^{327}$ Cf. McKEON, Michael. The origins of the English novel cit., p. 266 e BEASLEY, Jerry C. Novels of the 1740s. Athens, GA: University of Georgia, 1982, p. 1-22.

${ }^{328}$ Cf. RICHETTI, John. The English novel in History cit., p. 115-116.

${ }^{329}$ McKEON, Michael. The origins of the English novel cit., p. 265-270.

${ }^{330}$ Sigo não só o argumento, como a maneira de argumentar, de Damrosch, que contrapõe a singeleza da estória de Clarissa à sua complexidade formal (DAMROSCH Jr, Leopold. God's plots \& man's stories cit., p. 213-214).
} 
incansável na busca de seus prazeres". ${ }^{331}$ Inicialmente, cortejara Arabella, mas logo dirige suas atenções a Clarissa. James intervém para impedir a união e acaba provocando Lovelace para um duelo. Apesar de James sobreviver, sua derrota convence os demais familiares a afastarem Clarissa de Lovelace e casarem-na com um outro pretendente, o vil mas riquíssimo Solmes. Ela se recusa e, como consequência, é trancafiada em seu quarto. Mantendo correspondência secreta com Lovelace, Clarissa é enganada e foge com ele. Embora logo perceba a perversidade de seu salvador, nada tem a fazer senão prosseguir com ele, cujas vagas insinuações de casamento poderiam restaurar sua reputação, destruída pela fuga. Lovelace, entretanto, explora a inexperiência de Clarissa e leva-a para um prostíbulo em Londres. Diante das reiteradas recusas de Clarissa em entregar-se de maneira incondicional, Lovelace droga-a e estupra-a. Quando ela volta a si, consegue fugir de sua prisão. Acaba por rejeitar não só os pedidos de desculpa de Lovelace, que agora quer desposá-la, como o próprio o mundo em que vivera. Com o coração partido, sua saúde se deteriora e ela vem a morrer de maneira santificada, trazendo culpa e arrependimento a todos que a conheceram.

Na edição da Peguin, a mais acessível e consultada, essa estória que resumi em poucas linhas se estende por cerca de 1500 páginas. ${ }^{332}$ Narrada numa série de epístolas trocadas sobretudo entre a protagonista e Lovelace e entre os dois e seus respectivos confidentes, Anna Howe e John Belford, Clarissa representa o longo e potencialmente inesgotável processo de reconhecimento das contradições da realidade, ${ }^{333}$ articulado numa narrativa facilmente parafraseável, explicitamente derivada da tragédia. ${ }^{334}$ Como o próprio Richardson argumentaria: “[...] ainda que

\footnotetext{
331 " [...] a man of birth and fortune, haughty, vindictive, humourously vain, equally intrepid and indefatigable in the pursuit of his pleasures" (RICHARDSON, Samuel. Clarissa, or the history of a young lady. Ed. Agus Ross. Londres: Penguin, 2004, p. 37).

${ }^{332}$ Encontra-se no prelo a edição de Thomas Keymer, para a coleção que edita em conjunto com Peter Sabor, a "Cambridge Edition of the Works of Samuel Richardson".

${ }^{333}$ Para Damrsoch, Richardson inaugura a preocupação com a durée, a completude psicológica do tempo vivido (DAMROSCH Jr, Leopold. God's plots \& man's stories cit., p. 213).

${ }^{334}$ A relação entre Clarissa e a forma clássica da tragédia é feita pelo próprio Richardson, no posfácio ao romance: RICHARDSON, Samuel. Clarissa cit., p. 1495-1499. Sobre a inteligibilidade do enredo, ver BRISSENDEN, R. F. Virtue in distress: studies in the novel of sentiment from Richardson to Sade. London - Basingstoke: Macmillan, 1974, p. 160 e ss. O paradoxo da dilação narrativa numa estrutura inteligível também é apontado no famoso diálogo ficcional de Sarah Fielding, Remarks on Clarissa, em que personagens debatem o romance de Richardson ([FIELDING, Sarah]. Remarks on Clarissa, addressed to the Author. Occasioned by some critical conversations on the characters and conduct of that work. With some reflections on the character and behaviour of Prior's Emma. Londres, 1749, p. 4-5).
} 
essa obra seja extensa, não há uma digressão, um episódio, uma reflexão, que não advenha naturalmente do assunto, contribua para ele e o leve adiante". 335

As digressões e reflexões a que alude Richardson decorrem da forma epistolar, que se apresenta como o registro dos eventos tão logo vivenciados, num expediente que proporciona um preciso enquadramento temporal e espacial à experiência relatada. As cartas se sucedem num ritmo quase diário, do dia 10 de janeiro até a primeira semana de outubro, cerca de um mês depois da morte da protagonista, que se dá no dia sete de setembro. ${ }^{336}$ Em certo sentido, trata-se de uma elaboração da técnica já encontrada em Defoe, em que a circunscrição da experiência a condições que se querem tangíveis outorga-lhe um lastro material, uma vez que condicionada pelas percepções que o entorno lhe suscita. ${ }^{337}$ Significativamente, a vinculação da narração a um suporte fático é explicitada no subtítulo da obra: uma "história". Não se trata, para citarmos o "Posfácio" assinado pelo "Editor", de "um mero romance ou estória romanesca". 338

A narrativa epistolar sugere o pleno envolvimento emocional da personagem encarregada de proceder à redação da carta. 339 "Descrições e reflexões" "que podem ser chamadas de instantâneas" 340 compõem, com isso, uma (famosa) técnica de "escrita para o momento", 341 para a qual as reações das personagens no ato da escrita

${ }^{335}$ RICHARDSON, Samuel. "Sugestões de prefácios para Clarissa". In: VASCONCELOS, Sandra Guardini T. A formação do romance inglês cit., p. 290. Trecho integral, no original: "Judges will see, that, long as the Work is, there is not one Digression, not one Episode, not one Reflection, but what arises naturally from the Subject, and makes for it, and to carry it on" (RICHARDSON, Samuel. Clarissa: Preface, hints of prefaces, and Postscript. Ed. R. F. Brissenden. Los Angeles: University of California - The Augustan Reprint Society, 1964, p. 4, n. 4). Ver o comentário de Watt sobre essa passagem (WATT, Ian. A ascensão do romance cit., p. 181).

${ }^{336} \mathrm{Em}$ verdade, a narrativa segue mais espaçada até meados de dezembro, quando sobrevém a justiça poética contra Lovelace.

337 ARMSTRONG, Nancy. How novels think cit., p. 3-4 e BENDER, John. Imagining the penitentiary cit., p. 47-50.

338 "[...] a mere novel or romance" (RICHARDSON, Samuel. "Postcript". Clarissa cit., p. 1498).

${ }^{339}$ Thomas Keymer, no entanto, demole a noção de que a carta e, por extensão, a narrativa epistolar sejam formas transparentes, em que o eu apareceria de maneira não mediada. Antes de tudo, Clarissa é uma narrativa sobre escrever, sobre o ato e o produto da escrita. Os narradores epistolares não descrevem a si mesmos por meio da carta. Eles se constituem por meio da escrita (KEYMER, Thomas. Richardson's Clarissa and the eighteenth-century reader. Cambridge: Cambridge University, 1992, $\mathrm{p}$. 6-11 e passim). Contudo, não há como ignorar o efeito de imediatez proporcionado pela narrativa epistolar, bem como toda a retórica desenvolvida para a produção desse efeito. São estratégias com as quais se criava a ilusão de realidade do romance e obscurecia-se seu registro ficcional.

340 "[...] what may be called instantaneous descriptions and reflections" (RICHARDSON, Samuel. "Preface". Clarissa cit., p. 35).

${ }^{341}$ A expressão é de Lovelace: "I love to write to the moment" (idem, L. 224, p. 721). 
são tão importantes quanto o estado mental e emocional em face das situações com que se defrontam. ${ }^{342}$ É o que se depreende desta carta de Clarissa:

Perdoe-me, minha querida amiga, por quebrar minha estória com essas reflexões. Se eu fosse seguir rapidamente com minha narrativa, sem pensar, sem refletir, creio que dificilmente conseguiria manter-me sã, pois a veemência e a paixão sempre estariam a ponto de rebentar. Porém, se eu penso enquanto escrevo, acalmo-me, e a inquietação de meu espírito arrefece. ${ }^{343}$

Delineiam-se três tempos nesta passagem: dos eventos narrados, da mente da narradora e da escrita. É sintomático da narrativa epistolar, no entanto, que essas três instâncias temporais se confundam. No último período do trecho em epígrafe, pensar e escrever se refletem, sem distinção, no "espírito" da personagem. Analogamente, o curto intervalo com que se sucede a troca de cartas faz com que o passado recentíssimo se presentifique. ${ }^{344}$ Como Lovelace observaria na carta de número 127 , "ela escreve a cada hora toda a sua mente". ${ }^{345} \mathrm{E}$, noutro lugar, Clarissa ponderaria que a rememoração da escrita faz com que a tensão que sentira há pouco volte com a mesma intensidade. As lágrimas vêm a seus olhos e embotam-lhe a vista. ${ }^{346} \mathrm{O}$ eixo temporal colapsa num presente de "nebulosidade". ${ }^{347}$

Privado tanto da retrospecção quanto do distanciamento, o narrador epistolar tende a não ter clareza quanto ao teor e aos desdobramentos dos atos praticados por outras personagens. Na transcrição de seus corações e mentes - e aqui fazemos uma paráfrase oblíqua do "Prefácio" a Sir Charles Grandison -, expressam-se sobretudo temores e esperanças. ${ }^{348}$ Perguntam-se o que lhes sobrevirá; perscrutam, sondam e conjecturam sobre quais serão os movimentos umas das outras. Crucialmente, a vocalização das indeterminações do agora aproxima-se em muitos pontos da performance, a comunicar o que seria o devir da escrita epistolar. Um exemplo

\footnotetext{
${ }^{342}$ KONIGSBERG, Ira. Narrative technique in the English novel cit., p. 95.

343 "Forgive me, my dear friend, for breaking into my story by these reflections. Were I rapidly to pursue my narration, without thinking, without reflecting, I believe I should hardly be able to keep in my right mind, since vehemence and passion would then be always uppermost; but while I think as I write, I cool, and my hurry of spirits is allayed" (RICHARDSON, Samuel. Clarissa cit., L. 78, p. 310).

${ }^{344}$ KONIGSBERG, Ira. Narrative technique in the English novel cit., p. 95.

345 "[...] she is hourly writing her whole mind" (RICHARDSON, Samuel. Clarissa cit., L. 127, p. 463).

346 "The very repetition of this fills me with almost equal concern to that which I felt at the time. I can write no more; mistinesses of all the colours in the rainbow twinkling upon my deluged eye" (idem, L. 45, p. 205)

347 "Mistiness" (ver nota acima).

${ }^{348}$ RICHARDSON, Samuel. The history of Sir Charles Grandison cit., v. 1, p. 3-4.
} 
sobremodo ilustrativo desse procedimento pode ser encontrado na "Carta 376", na qual as oscilações da caneta da mãe de Clarissa, Mrs Harlowe, fazem com que convirjam as noções lockiana e newtoniana do tempo: ${ }^{349}$

— Não a envie - Eu lhe ordeno para que não — Não ouso ver Mas - Ai de mim! - Oh! Perdoe os pensamentos tão confusos de uma mãe! Você pode — você saberia como aceitar tudo isso então eu vou deixar que a entregue - Não reescreverei esta parte da minha carta. ${ }^{350}$

Em Shamela, Fielding parodiaria essa técnica, tachando-a, nas entrelinhas, de inverossímil:

Mrs Jervis eu acabamos de nos deitar, e a porta está trancada, caso meu Mestre queira entrar - Com a breca! Eu o escuto entrar pela porta. Você pode notar que escrevo no presente, como diz o Pastor Williams. Bem, ele está na cama entre nós, as duas fingindo que dormimos. Ele desliza sua mão para meu peito e eu, como se dormisse, pressiono-a contra mim. Então finjo acordar. ${ }^{351}$

Note-se, no entanto, que a pseudo-performance de Shamela não captura a falência comunicativa da carta de Mrs Harlowe. Em Clarissa, a alta carga emocional muitas vezes solapa o modo narrativo e dilata os limites da linguagem. ${ }^{352}$ Sugere-se que a redação epistolar é muitas vezes obstada ou pelo choro ou por uma sensação de que a linguagem é meio inepto para a expressão da subjetividade, para a transmissão dos verdadeiros sentimentos que acometem o ser humano. No primeiro caso, explora-se um topos com que o narrador se vê impossibilitado de continuar e vê-se forçado a deitar sua pena. Assim, Lovelace, transtornado pelo remorso, já não consegue prosseguir: “Que demônio me aflige? — Não posso pensar ou escrever! — Descansa,

\footnotetext{
${ }^{349}$ Ver supra, p. 173.

350 “-Don't send it - I charge you don't—I dare not see it-Yet-But, alas! - Oh forgive the distracted-thoughted mother! You can-you know how to allow for all this—so I will let it go-I will not write again this part of my letter" (RICHARDSON, Samuel. Clarissa cit., L. 376, p. 1158).

351 "Mrs. Jervis and I are just in Bed, and the Door unlocked; if my Master should come-Odsbobs! I hear him just coming in at the Door. You see I write in the present tense, as Parson Williams says. Well, he is in Bed between us, we are both shamming a Sleep, he steals his Hand into my Bosom, which I, as if in my Sleep, press closer to me with mine, and then pretend to awake" (FIELDING, Henry. "An apology for the life of Mrs. Shamela Andrews". The history of the adventures of Joseph Andrews and of his friend Mr. Abraham Adams; and An apology for the life of Mrs. Shamela Andrews cit., p. 318). Ver: EAGLETON, Terry. The English novel: an introduction. Oxford: Blackwell, 2005, p.

${ }^{352}$ KAUFFMAN, Linda. Discourses of desire cit., p. 26 e VAN SANT, Ann Jessie. Eighteenthcentury sensibility and the novel: the senses in social context. Cambridge: Cambridge University, 1993, p. 116-125.
} 34. 
pena, por um momento! _-". ${ }^{353}$ No segundo caso, elabora-se uma retórica de inefabilidade. $\mathrm{Na}$ busca pelo registro dos mais ínfimos estados emocionais, narradores e personagens muitas vezes tomam a escrita como um meio insuficiente para comunicar tudo o que se passa no interior do eu. Basta olhar os papéis avulsos de Clarissa, escritos após seu estupro: providenciam os exemplos mais lapidares dessa falência comunicativa. ${ }^{354}$ Ela quer contar a Miss Howe "coisas muito, muito terríveis", mas é impedida por choro, pensamentos, pesar e confusão, com que se perde num "absurdo eloquente" 355 de frases incompletas, parágrafos entrecortados por travessões e, o que é mais perturbador, palavras, versos e estrofes de ponta cabeça.

Sentei-me para falar muitas coisas - mas meu coração estava cheio - não sabia como começar - e pensamentos, e pesar, e confusão, e (Oh, minha pobre cabeça!) e não sei mais o quê - E pensamentos, e pesar, e confusão amontoam-se de maneira indistinta sobre mim: um seria o primeiro, outro seria o primeiro, todos seriam o primeiro; e então eu nada consigo escrever - apenas que, o que quer que tenham feito comigo, não posso [sei?] dizer; mas em nada eu sou o que era. ${ }^{356}$

Fragmentária, a narrativa abdica ostensivamente da narração para, no silêncio da disposição gráfica, obter uma "representação do real" inacessível à linguagem corrente. $^{357}$

Noutro nível, a escrita epistolar é o meio por que se caracterizam as personagens. A imediatez com se registram ideias e acontecimentos presume a dispensa de convenções literárias, porquanto o estilo ornamental tende à uniformidade e à monologia. Reconhece-se uma dimensão estética peculiar a cada personagem, tomada como um indivíduo dotado de voz única, ainda que tido a priori como simplório e

\footnotetext{
353 "What a devil ails me! - I can neither think nor write! — Lie down, pen, for a moment! -" (RICHARDSON, Samuel. Clarissa cit., L. 266, p. 911).

${ }^{354}$ HARRIES, Elizabeth Wanning. The unfinished manner: essays on the fragment in the later eighteenth century. Charlottesville - Londres: University Press of Virginia, 1994, p. 128-129.

355 “[...] dreadful, dreadful things [...] thought, and grief, and confusion [...] eloquent nonsense" (RICHARDSON, Samuel. Clarissa cit., L. 261, p. 890).

356 "I sat down to say a great deal-my heart was full-I did not know what to say first-and thought, and grief, and confusion, and (Oh my poor head!) I cannot tell what-And thought, and grief, and confusion, came crowding so thick upon me; one would be first, another would be first, all would be first; so I can write nothing at all —only that, whatever they have done to me, I cannot tell; but I am no longer what I was in any one thing" (idem, L. 261, p. 890).

${ }^{357}$ BARCHAS, Janine. Graphic design, print culture, and the eighteenth-century novel. Cambridge: Cambridge University, 2003, p. 118 e ss. e VAN SANT, Ann Jessie. Eighteenth-century sensibility and the novel cit., p. 117. De acordo com M. B. Parkes, Richardson empregara esse sinal de pontuação para registrar hesitação (PARKES, M. B. Pause and effect: an introduction to the history of punctuation in the West. Londres: Scolar, 1992, p. 94).
} 
vulgar. ${ }^{358}$ Em Clarissa, parece haver um despertar generalizado para as potencialidades do que Bakhtin chamou de heteroglóssia, a estratificação linguística inerente às formas novelísticas. ${ }^{359}$ De fato, Richardson já havia atribuído à criada Pamela, em seu romance de estreia, um estilo permeado por deslizes gramaticais. E, antes dele, Defoe buscara capturar o pidgin de escravos e nativos, especialmente em Colonel Jack. Mas a multiplicidade de personagens e, por extensão, narradores epistolares em Clarissa permite uma orquestração ventríloqua bem mais complexa. ${ }^{360}$ Solmes, o pérfido pretendente de Clarissa, mostra-se, por exemplo, semiletrado, como se seu caráter transbordasse na ortografia viciosa. Num bilhete que envia a Clarissa, troca your por youre, concern por concerne, said por sed, value por valew etc. ${ }^{361}$ De igual maneira, o lacaio Joseph Leman mostra-se incapaz de soletrar corretamente três palavras em sequência. ${ }^{362}$ Outra vez, materializa-se graficamente a baixeza da personagem, pois Leman colabora com Lovelace em seu plano para enganar Clarissa a fugir. Degraus acima de Leman na escala social, o Reverendo Mr Brand faz transparecer a sua índole servil e adulatória em floreios, brocardos e expressões em latim, francês e italiano. ${ }^{363}$ Enviado pela família de Clarissa para investigar a situação dela em Londres, Brand falsamente a acusa de viver em concubinato com Belford. Bem mais sintomática, entretanto, é maneira como se contrapõe o estilo de Clarissa ao de seu pai e irmão, de um lado, e ao de Lovelace, de outro.

O "Editor" de Clarissa define a protagonista como uma moça detentora de muitos predicados. ${ }^{364}$ Há que se dizer, contudo, que as noções setecentistas de feminilidade jamais fariam de Clarissa alguém dotada de erudição. Basta lembrar a maneira caricatural como a historiadora diletante Miss Barnevelt seria, anos mais tarde, representada em Sir Charles Grandison. Ou do ridículo que a latinista Mrs Atkinson seria coberta em Amelia (1751), de Henry Fielding. É óbvio, porém, que o intelecto de Clarissa a coloca à parte tanto de personagens masculinas quanto femininas. De qualquer modo, ela domina plenamente o jargão constitucionalista do Estado liberal

\footnotetext{
${ }^{358}$ DOODY, Margaret Anne. A natural passion: a study of the novels of Samuel Richardson. Oxford: Clarendon, 1974, p. 32-34.

${ }^{359}$ Ver McKEON, Michael. The origins of the English novel cit., p. 11-14 e BAKHTIN, Mikhail M. "Discourse in the novel". The dialogic imagination cit., p. 262 e ss.

${ }^{360}$ Sobre orquestração e ventriloquismo no romance, ver idem, p. 299.

${ }^{361}$ RICHARDSON, Samuel. Clarissa cit., L. 51.9, p. 250.

${ }^{362}$ Ver idem, L. 96, p. 385.

${ }^{363}$ Ver idem, L. 444, p. 1292-1295.

${ }^{364}$ Idem, p. 37.
} 
erigido depois da Revolução Gloriosa. Em carta a seu irmão, reclama do tratamento pouco fraterno que lhe tem dispensado, como se ela fosse sua "serva". ${ }^{365}$ Páginas adiante, pede que Lovelace a liberte em respeito aos direitos hereditários de qualquer súdito inglês. ${ }^{366}$ Implacavelmente perseguida por sua família e por Lovelace, Clarissa anseia pela morte. Sua escrita, no entanto, transpira um desejo de libertação, ou mesmo transcendência. Sua correspondência com Anna Howe afasta-se do ideal augustano de concisão e sobriedade. Como em grade parte já se mostrou acima, sua sintaxe por vezes é abstrusa, paratática e permeada por anacolutos. A dor e o desespero a afastam de um estilo comedido e decoroso: $:^{367}$

Meu coração está cheio demais - tão cheio, que talvez pusesse meus deveres a perigo se eu fosse aliviá-lo para você nesta ocasião: assim, vou deitar minha pena - Mas posso - Mesmo assim, com certeza, deitarei a minha pena! _ 368

Com o estupro, pode-se dizer que muitas das cartas de Clarissa se convertem num "monstro de Horácio", abolindo-se qualquer barreira entre os modos líricos, dramático e narrativo.

Então baixei minha cabeça,

Baixei à terra fria, por um tempo eu morri;

E minha alma livre fugiu para um lugar estranho!

Ah! embriagada alma!, eu disse,

Quando a vi fugir de volta para sua jaula.

Tola! restaurar as correntes que partira

E outra vez remar as galés!

Tola! retornar para que corpo,

Onde é condenada e destinada a lamentar. ${ }^{369}$

À beira da morte, afirma numa missiva a Anna Howe que tem coisas mais importantes que narrar a sua "estória". ${ }^{370}$ Nalguns pontos, passa a ignorar as fronteiras entre prosa e poesia, a entregar-se à transcrição de versos e poemas inteiros e à

\footnotetext{
${ }^{365}$ Trecho integral: "And permit me [...] to remind you that I am your sister, and not your servant" (RICHARDSON, Samuel. Clarissa cit., L. 29.1, p. 137).

366 "[...] permit me the freedom which is my birthright as an English subject" (idem, L. 276, p. 934).

${ }^{367}$ KAUFFMAN, Linda. Discourses of desire cit., p. 141.

368 "My heart is too full-so full, that it may endanger my duty, were I to try to unburden it to you on this occasion: so I will lay down my pen-But can-Yet, positively, I will lay down my pen!-” (RICHARDSON, Samuel. Clarissa cit., L 9, p. 65).

369 "Then down I laid my head,/ Down on cold earth, and for a while was dead;/ And my freed soul to a strange somewhere fled! Ah! sottish soul! said I,/ When back to its cage again I saw it fly,/ Fool, to resume her broken chain,/ And row her galley here again!/ Fool! to that body to return,/ Where it condemned and destined is to mourn" (idem, L. 261, paper X, p. 893). Trata-se de uma variação de The despair, de William Cowper.

${ }^{370}$ Idem, L. 379, p. 1163.
} 
composição de "Meditações", derivadas de colações do salmista, dos Eclesiastes, dos Apócrifos e, em especial, do Livro de Jó. ${ }^{371}$

O pai e o irmão de Clarissa compartilham um nome associado ao absolutismo dos Stuarts: James. Em 1748, três anos depois do segundo Levante Jacobita, poucos leitores deixariam de ligar seu despotismo ao do rei deposto. ${ }^{372} \mathrm{E}$ Richardson não deixaria margem para que ninguém julgasse a associação como infundada. James Harlowe é uma figura inacessível, um monarca que se recusa a ouvir as súplicas de seus súditos. Proíbe Clarissa de escrever-lhe e dirigir-lhe a palavra. Toda vez que ela entra num aposento, ele se retira. Ainda assim, assina alguns bilhetes imperiosos, a demandar obediência e a condicionar seu "perdão" à aquiescência de Clarissa às pretensões matrimoniais de Solmes:

Escrevo, garota perversa, com toda a indignação que a sua desobediência merece. Desejar ser perdoada de uma falta que reconhece, mas ainda assim nela persiste, é de uma ousadia inigualável e insuperável. É a minha a autoridade que você desafia. [...] Continue banida de minha presença, desobediente como você é, até que aprenda a se sujeitar à minha vontade. ${ }^{373}$

Nas cartas de James Jr transparece uma emulação do estilo imperial do pai, ainda que numa versão um tanto mitigada. Muitas vezes, é verdade, James Jr se apresenta como procurador da vontade paterna, baixando em seu nome constrições e interditos à livre circulação de Clarissa. É de sua pena que se estipula expressamente a proibição de comparecer à presença de seus pais, "exceto sob particular licença ou comando". ${ }^{374}$

Lovelace está longe de se apresentar epistolarmente como um déspota. ${ }^{375}$ Suas afiliações e referências, todavia, provêm primordialmente da Restauração, numa

\footnotetext{
${ }^{371}$ STARR, G. Gabrielle. Lyric generations: poetry and the novel in the long eighteenth century. Baltimore - Londres: Johns Hopkins University, 2004, p. 15-46 e KEYMER, Thomas. "Richardson's Meditations: Clarissa's Clarissa”. In: DOODY, Margaret Anne; SABOR, Peter (ed.). Samuel Richardson: tercentenary essays. Cambridge: Cambridge University, 1989, p. 89-109, especialmente p. 90.

${ }^{372}$ Para o subtexto político de Clarissa, ver McGIRR, Elaine. "Why Lovelace must die". Novel: a forum on fiction, v. 37, n. 1/2 (outono, 2003 - primavera, 2004), p. 5-23. Sintomaticamente, o "Editor" chama James Harlowe Sor. de "despótico" (RICHARDSON, Samuel. Clarissa cit., p. 37).

373 "I write, perverse girl, but with all the indignation that your disobedience deserves. To desire to be forgiven a fault you own, and yet resolve to persevere in, is a boldness, no more to be equalled than passed over. It is $m y$ authority you defy. [...] Continue banished from my presence, undutiful as you are, till you know how to conform to my will" (idem, L. 25.4, p. 125).

374 “[...] except by particular license or command" (idem, L. 24.1, p. 120-121).

375 "Lovelace" era o nome de uma proeminente família partidária da Coroa na época das guerras civis e de um famoso poeta da Restauração. Ademais, era um nome comumente associado a Lothario, o personagem sedutor do Dom Quixote (ver WATT, Ian. "The naming of characters in Defoe,
} 
aliança estilística que o coloca em choque com o vocabulário constitucionalista de Clarissa. ${ }^{376}$ Antes de Lovelace ser acometido pelo remorso, sua prosa é linear, ordenada e despida dos travessões que traem o turbilhão emocional da protagonista. É, em suma, aristocrática. Nas missivas a Belford, trata-o como "thou", um pronome em desuso na linguagem corrente, mas ainda dotado de circulação literária. Clarissa, ao contrário, interpela sua amiga Anna Howe como "you". De maneira mais interessante, as cartas de Lovelace contêm alusões recorrentes a autores clássicos e neoclássicos, como Terêncio, Dryden e Boileau, e a heróis e monarcas, quase sempre acompanhadas de termos de origem marcial. Proclama-se "general" e "o maior conquistador do mundo". Teria angariado "ouro" em "batalha obstinada", ao final da qual tomaria como "ornamento" a sua "prisioneira". Argumenta que sua "vitória" contra o "mérito" de alguém como Clarissa é "mais nobre". Prevê que seu "triunfo" será tão "glorioso" quanto inigualável. ${ }^{377}$ Apropriadamente, acomodar-se-iam à sua retórica bélica menções a heróis épicos. Lovelace se compararia a Heitor, Aquiles, $\mathrm{Ajax}^{378}$ e, de maneira mais demorada, a Enéas. Perguntaria a Belford se ele não acha que mereça ser perdoado, como fora "o herói de Virgílio" pelo que fizera com Dido. Afinal, "tenho metade da obrigação para com ela [Clarissa] do que tinha Enéas para com a Rainha de Cartago?". ${ }^{379}$ De maneira semelhante, apresentar-se-ia como um herói romanesco submetido aos mais terríveis desafios: "houve alguma vez um herói

Richardson, and Fielding". The review of English studies, v. 25, n. 100 (outubro, 1949), p. 322-338, especialmente p. 331 e ss.).

${ }^{376}$ Cf. EAGLETON, Terry. The rape of Clarissa: writing, sexuality and class struggle in Samuel Richardson. Minneapolis: University of Minnesota, 1982, p. 89. Para um mapeamento da linguagem militar e política empregada na caracterização de Lovelace, ver: CADWELL, M. John. "The rake as military strategist: Clarissa and eighteenth-century warfare". Eighteenth-century fiction, v. 19, n. 1 \& 2 (outono, 2006), p. 153-180. Lovelace, obviamente, assume múltiplas máscaras. Jocelyn Harris, no entanto, associa a natureza proteiforme da personagem a concepções hobbesianas acerca do estado da natureza (HARRIS, Jocelyn. "Protean Lovelace". Eighteenth-century fiction, v. 2, n. 4 (julho, 1990), p. 327-346).

${ }^{377}$ Até aqui, todos os termos citados neste parágrafo provêm da Carta de n. 171 (RICHARDSON, Samuel. Clarissa cit., L. 171, p. 471-472).

${ }^{378}$ Idem, L. 209, p. 672. Deve-se dizer, no entanto, que a citação dos heróis homéricos é mediada por Troilus and Cressida, de William Shakespeare (ver KONIGSBERG, Ira. Samuel Richardson \& the dramatic novel. Lexington: University of Kentucky, 1968, p. 9-10).

${ }^{379}$ Trecho integral: "Dost thou not think that I am as much entitled to forgiveness on Miss Harlowe's account, as Virgil's hero was on Queen Dido's? [...] And have I half the obligation to her that Aeneas had to the Queen of Carthage?" (RICHARDSON, Samuel. Clarissa cit., L. 370, p. 1142). Para uma discussão dessa passagem, ver: WATT, Ian. A ascensão do romance cit., p. 215. 
de estória romanesca (salvo a lutar contra gigantes e dragões) submetido a provações mais difíceis?".380

A estratificação linguística consubstancia os múltiplos embates que constituem Clarissa. ${ }^{381} \mathrm{~A}$ justaposição da retórica liberal da protagonista às referências da Restauração de Lovelace ilumina o conflito de classes que perpassa o romance. De família aristocrática, o libertino desdenha das aspirações sociais dos Harlowes, ${ }^{382}$ uma família que ascendeu à condição de proprietária de terras por meio do comércio: “Todos conhecem a Casa Harlowe, pois [...] brotou de uma esterqueira num período ao alcance da memória de qualquer pessoa mais velha". ${ }^{383}$ Clarissa, por sua vez, é uma paragona da moral burguesa, cada vez mais reticente ante o código de honra aristocrático. Para ela, Lovelace "tem noções elevadas de honra, uma palavra que dificilmente sai de sua boca, mas parece não ter muito apreço à moral". 384 Paralelamente a isso, a impessoalidade dos comandos dos Harlowes, permeados de abstrações como "dever" e "obediência", contrasta com o tom passional e rogatório de Clarissa, que implora por companheirismo, piedade e compreensão. Separa-se o domínio público, da autoridade que encarcera e aliena, de um ideal de convivência doméstica, em que predominariam relações mais horizontais, entre indivíduos, reguladas pelo afeto. A vinculação do discurso patético à esfera doméstica torna-o, também, elemento definidor da expressão feminina, pois a casa era tida como o domínio par excellence das mulheres. ${ }^{385}$ Tal expressão é tida como natural, inacabada, fragmentária e desarticulada, porque alheia aos critérios masculinos de poder e controle, que demandariam uma escrita racional, comedida e ordenada. ${ }^{386} \mathrm{Sem}$ acesso à educação formal e aos escritos citados por Lovelace, as mulheres passariam ao largo da rejeição neoclássica ao "caos de pensamento e paixão", para citarmos a formulação

\footnotetext{
380 "[...] was ever hero in romance (opposing giants and dragons excepted) called upon to harder trials!" (RICHARDSON, Samuel. Clarissa cit., L. 31, p. 146).

${ }^{381}$ Sobre os conflitos em Clarissa, ver: EAGLETON, Terry. The rape of Clarissa cit., p. 4 e ss.

382 "Harlowe" é quase um homófono de "harlot", meretriz (WATT, Ian. "The naming of characters in Defoe, Richardson, and Fielding" cit., p. 333).

383 "Everybody knows Harlowe-Place - for [...] it is sprung up from a dunghill within every elderly person's remembrance” (RICHARDSON, Samuel. Clarissa cit., L. 34, p. 161).

384 ، [...] has high notions of honour, a word hardly ever out of his mouth; but seems to have no great regard to morals" (idem, L. 161, p. 543).

${ }^{385}$ MULLAN, John. Sentiment and sociability: the language of feeling in the eighteenth century. Oxford: Clarendon, 1988, p. 57-113 e ARMSTRONG, Nancy. Desire and domestic fiction: a political history of the novel. Oxford - Nova Iorque: Oxford University, 1987, p. 59 e ss.

${ }^{386}$ HARRIES, Elizabeth Wanning. The unfinished manner cit., p. 122-150.
} 
de Pope, no Essay on man. ${ }^{387}$ Os guias femininos de conduta e, por extensão, estilo seriam, como afirma o Coronel Morden, um primo de Clarissa, "romances inflamados e ociosas estórias romanescas". 388

A correlação das tensões que perpassam a sociedade e a cultura do século XVIII aos desníveis linguísticos das personagens é apenas o aspecto mais visível da síntese do heterogêneo promovida pelo romance richardsoniano. A oposição do comedimento augustano, masculino e aristocrático, à desarticulação novelística do discurso feminino e burguês constitui-se como princípio estruturante de Clarissa. Vincula-se a forma e o direcionamento da narrativa à ação das personagens masculinas, ao passo que os momentos de aparente quebra do modo narrativo, para a performance da interioridade, creditam-se, sobretudo, às mulheres. ${ }^{389} \mathrm{~A}$ carta de abertura do romance, assinada por Anna Howe, delineia Clarissa como inequivocamente passiva. Anna pergunta sobre a maneira como tem sido tratada e pede informações quanto ao "acidente" (o duelo entre James e Lovelace) que não pôde evitar. ${ }^{390} \mathrm{O}$ início in medias res já insere a protagonista num enredo que a antecede, numa trama para cujo controle dois homens se digladiam. Lovelace, por sua vez, é deliberada e explicitamente tecedor de intrigas. Apresenta-se como um criador de plots (tramas, enredos, intrigas). Sente-se - atenção para o adjetivo - "honrado" quando Belford toma seu "coração" como "o mais intrigante [plotting] do mundo". ${ }^{391}$ Arquitetar

\footnotetext{
387 "Chaos of Thought and Passion" (POPE, Alexander. "Essay on man". Poetry and prose of Alexander Pope cit., p. 131).

388 “[...] inflaming novels, and idle romances" (RICHARDSON, Samuel. Clarissa cit., L. 442, p. 1279-1280). O Coronel Morden afirma, é verdade, que Clarissa seria um tipo diferente de mulher. Prudente, não se interessaria por esse tipo de coisa. Contudo, ela mesma admite, ainda que por vias indiretas, que sua correspondência com Anna Howe seria permeada por "imaginação e fantasia" ("imagination and fancy"). Talvez a experiência, pondera, torne as suas cartas recomendáveis aos olhares mais judiciosos (idem, L. 69, p. 283). A experiência, entretanto, parece apenas ter acentuado a instabilidade estilística demonstrada já no início do romance.

${ }^{389}$ SPACKS, Patricia Meyer. Desire and truth cit., p. 63 e ss. Trata-se de uma dinâmica que pode ser lida numa chave marxista, em que o enredo tende a corporificar a ideologia dominante ou residual, ao passo que os trechos discursivos tendem a ser o lugar em que se realizam os elementos mais progressistas da obra, onde se localizam seus pronunciamentos políticos (WILLIAMS, Raymond. Marxism and literature cit., p. 121-127 e LANSER, Susan S. "The novel body politic". In: BACKSCHEIDER, Paula R.; INGRASSIA, Catherine (ed.). A companion to the eighteenth-century English novel and culture. Oxford: Blackwell, 2005, p. 481-503, especialmente p. 494). Para Brissenden, a vocalização do sentimento, associada em Clarissa ao discurso feminino, implica abdicação de agência e do poder de influir nos rumos da narrativa (BRISSENDEN, R. F. Virtue in distress cit., p. 8).

${ }^{390}$ Trecho integral: "I long to have the particulars from yourself, and of the usage I am told you receive upon an accident you could not help" (RICHARDSON, Samuel. Clarissa cit., L. 1, p. 39).

${ }^{391}$ Trecho integral: "Well sayest thou, that mine is the most plotting heart in the world. Thou dost me honour” (idem, L. 171, p. 558).
} 
intrigas é, para esse aristocrata, parte integral de sua masculinidade. De maneira significativa, chama seus planos de estuprar Clarissa e Anna Howe (este último nunca realizado) de "plots". ${ }^{392}$ No caso específico de Clarissa, o objetivo do estupro é humilhá-la, forçando-a a aceitá-lo como marido. Crucialmente, dada a organização, depois do início in medias res, quase que inteiramente linear e cronológica da narrativa, o enredo de Clarissa parece ser, até o momento do estupro, em grande parte enredado pelo próprio Lovelace. Tapeia Clarissa para fugir com ele, leva-a para Londres, disfarça as prostitutas de senhoras respeitáveis, põe fogo na casa, intercepta e falsifica cartas, espiona pela fechadura, diz a terceiros que a protagonista é sua esposa louca que fugiu etc. ${ }^{393}$ Quando está perto de consumar seu maior plano, o estupro, o controle da intriga parece tamanho que consegue até transcender a forma epistolar:

Agora, Belford, passemos à narrativa das narrativas. Eu a continuarei conforme tiver oportunidade; e o farei tão destramente que, se eu parar vinte vezes, não saberás discernir onde entrelaço a minha linha. 394

É o fio da sua intriga que amarra as vocalizações da interioridade de Clarissa. Fórmulas literárias que remontam a Aristóteles engendram uma subjetividade singularizada, que não se toma como plenamente comunicável. É o enredo de Lovelace que leva Clarissa ao isolamento, ao conflito com sua família e, por fím, à redação de suas cartas perpassadas por travessões. É nesta personagem aristocrática, tão claramente vinculada ao universo literário augustano, que se enfeixa a unidade de uma narrativa que tantas vezes chega às portas da fragmentação. Ao se creditar a uma personagem o controle sobre todas as outras, tematiza-se um problema da forma e naturaliza-se a organização ostensivamente ficcional da narrativa. Até ser estuprada, Clarissa ignorava a onisciência do libertino. Julgava que a interioridade dela era insondável. À beira da morte, no entanto, ela olha retrospectivamente para sua trajetória e enxerga Lovelace quase como um agente desavisado da Providência. Escreve-lhe em sua epístola derradeira:

\footnotetext{
${ }^{392}$ Ver SPACKS, Patricia Meyer. Desire and truth cit., p. 64.

${ }^{393}$ Ver KEYMER, Thomas. Richardson's Clarissa and the eighteenth-century reader cit., p. 157 e Ss.

394 "Now, Belford, for the narrative of narratives. I will continue it as I have opportunity; and that so dextrously, that if I break off twenty times, thou shalt not discern where I pierce my thread" (RICHARDSON, Samuel. Clarissa cit., L. 233, p. 767).
} 
Repito, portanto, que o perdoo. E que o Altíssimo o perdoe também! Também não tenho [...] nenhuma outra mágoa essencial senão aquela causada pelo pesar que dei aos pais que, até conhecê-lo, eram dos mais complacentes; pelo escândalo trazido aos outros ramos da minha família; pela infâmia trazida para meu sexo; e pela ofensa dada à virtude em minha queda.

Quanto a mim, você apenas me roubou aquelas que eram as minhas esperanças favoritas nesta vida transitória, que já terei deixado quando você receber esta. Você apenas foi a causa de eu ser colhida na flor da juventude, e por reduzir uma vida que era agradável para mim, [...] conforme aprouveram os desígnios e as finalidades da Providência. [...] E sou (de fato, por aflições agudas e angustiantes) grata a você [...], como humildemente espero, por muitos anos de glória, que poderiam ter sido anos de perigo, tentação e angústia, caso eles houvessem sido adicionados à minha vida mortal.

Portanto, senhor, embora contra a sua intenção, prestou-me um imenso serviço $[\ldots] .{ }^{395}$

Contrapõem-se a família burguesa, o gênero feminino e suas noções de virtude ao enredo entretecido por Lovelace. Sua recusa em se submeter aos planos de Lovelace e seu sacrifício refiguram a lógica da narrativa. Clarissa desconstitui o enredo de Lovelace (e de sua família), pelo triunfo de seu eu, que tantas vezes se aproxima da desintegração. Ao final, já longe do alcance do libertino, Clarissa vislumbra um mundo em que o termo "glória" será ressignificado.

Richardson demonstrava ter plena consciência do tênue e conflituoso equilíbrio que organizava sua obra. No "Prefácio do Editor" a Clarissa, diz-se ter submetido a leitura da coleção de cartas a vários cavalheiros. De um lado, defende-se a necessidade de delinear o enredo com mais clareza, o que tornaria necessário cortar "os incidentes colaterais e tudo que se relacionasse a caracteres secundários". 396 Outros, por sua vez, "insistiriam que a estória não poderia ser reduzida à unidade dramática", ${ }^{397}$ pois isso implicaria cortar as partes e personagens que "eram algumas

\footnotetext{
395 "I repeat, therefore, that I do forgive you. And may the Almighty forgive you too! Nor have I [...] any other essential regrets than what are occasioned by the grief I have given to parents who till I knew you were the most indulgent of parents; by the scandal given tothe other branches of my family; by the disreputation brought upon my sex; and by the offence given to virtue in my fall. As to myself, you have only robbed me of what once were my favourite expectations in the transient life I shall have quitted when you receive this. You have only been the cause that I have been cut off in the bloom of youth, and of curtailing a life that might have been agreeable to myself, [...] as had suited the designs and ends of Providence. [...] And I am (indeed through sharp afflictions and distresses) indebted to you [...] for so many years of glory, as might have proved years of danger, temptation, and anguish, had they been added to my mortal life. So, Sir, though no thanks to your intention, you have done me real service [...]" (idem, L. 510.4, p. 1426).

396 " [...] the collateral incidents and all that related to the second characters" (idem, p. 34).

397 "[...] insisted that the story could not be reduced to dramatic unity" (idem, p. 34-35).
} 
das mais naturais na coleção inteira”. ${ }^{398}$ Aparentemente, Richardson jamais conseguiria determinar qual desses polos estaria correto. O dito Editor recusa-se a arbitrar. Ao final, diz ter-se decidido pela publicação apenas da primeira parte da coleção. Caso fosse bem recebida pelo público, publicaria o resto.

\section{Sir Fingal Grandison}

Ossian é um nome recorrente em estudos sobre o desenvolvimento da narrativa novelística nas últimas quatro décadas do século XVIII e no arborescer do romantismo. Em sua totalidade, os Poemas de Ossian providenciam um repertório de temas lacrimosos a boa parte da ficção sentimental das décadas de 1760 e 1770 . É impossível não associar a ubiquidade do Tio Toby nos volumes finais de Tristram Shandy (1759-1767), de Laurence Sterne, e o estilhaçamento de The Man of Feeling (1771), de Henry Mackenzie, à imensa ressonância das traduções de Macpherson. ${ }^{399}$ Da mesma maneira, há inequívoca presença do bardo ossiânico no registro das vozes da periferia escocesa e irlandesa, que define a national tale e os romances regional e histórico. ${ }^{400}$ No entanto, há uma relação pouco estudada entre a configuração dos ditos épicos ossiânicos, Fingal e Temora, e a ascensão do romance, do fim do século XVII em diante. ${ }^{401}$

James Macpherson publicaria Fingal e sua estranha conciliação entre o primitivo e o neoclássico em 1761, poucos meses após a morte de Samuel Richardson e quatorze anos depois de Clarissa vir à luz. À primeira vista, os dois homens e suas respectivas chefs d'œuvre não parecem ter nada em comum. Macpherson era escocês, frequentara a universidade e era versado nos clássicos, ao passo que Richardson conduzira quase que toda a sua vida profissional em Londres, mal se beneficiara de

\footnotetext{
398 “[...] were some of the most natural in the whole collection" (idem, p. 35).

${ }^{399}$ KEYMER, Thomas. Sterne, the Moderns, and the novel. Oxford - Nova Iorque: Oxford University, 1992, p. 166 e ss.; MANNING, Susan. "Henry Mackenzie and Ossian or, the emotional value of asterisks". In: GASKILL, Howard; STAFFORD, Fiona J. (ed.). From Gaelic to romantic: Ossianic translations. Amsterdã - Atlanta, GA: Rodopi, 1998, p. 136-152.

${ }^{400}$ SHIELDS, Juliet. Sentimental literature and Anglo-Scottish identity, 1745-1820. Cambridge: Cambridge University, 2010, p. 114; TRUMPENER, Katie. Bardic nationalism: the romantic novel and the British empire. Princeton, NJ: Princeton University, 1997, p. 115 e ss.; LAUGHLIN, Corinna. The Ossianic novel cit., passim; PITTOCK, Murray. Scottish and Irish romanticism cit., p. 27.

${ }^{401}$ Ver TEMPLE, Kathryn. Scandal nation: law and authorship in Britain, 1750-1832. Ithaca, NY: Cornell University, 2003, p. 73 e ss. Outras referências quanto à proximidade dos épicos ossiânicos e o romance serão fornecidas ao longo deste item. Como pano de fundo da análise das próximas páginas, está a observação (quase de passagem), feita por Bakhtin, de que o advento do romance implicou a novelização dos demais gêneros literários (BAKHTIN, Mikhail M. "Epic and the novel". The dialogic imagination cit., p. 33).
} 
uma educação formal e seus interesses intelectuais, afora a produção de "uma nova espécie de escrita", eram estritamente ligados a questões práticas de seu ofício como tipógrafo. Fingal seria embrulhado em roupagens épicas; suas extensas anotações o vinculavam aos modelos de Homero, Virgílio e Milton. Em nenhum poema ossiânico há referências, por mais remotas que sejam, a uma narrativa novelística. Os romances richardsonianos, por seu turno, rejeitam o heroísmo ínsito à epopeia. Em Clarissa, é o vilão Lovelace quem se compara a Aquiles, Heitor, Ajax e Enéas. Em Sir Charles Grandison, representa-se Homero como um poeta que interessa apenas aos pedantes, como Mr Walden e Miss Barnevelt. ${ }^{402}$ Ademais, trata-se o herói da Ilíada como "Aquiles, o selvagem Aquiles". ${ }^{403}$ A despeito dessas diferenças intransponíveis, observadores argutos, como Sir Walter Scott, diriam que Fingal "tem toda força e bravura de Aquiles com a cortesia, sentimentos [opiniões?] e boa educação de Sir Charles Grandison". 404

A observação de Scott está longe de ser casual. É possível traçar algumas coincidências bastante interessantes entre a caracterização do guerreiro ossiânico e o protagonista do último romance de Richardson. Ambos choram com certa profusão. Sir Charles chora ao reencontrar as irmãs, ao olhar o retrato da mãe que morrera, ao contar para Harriet a sua história com Clementina e ao leito de morte de Sir Hargrave Pollexfen. E Fingal se comove ao pensar no pai de Orla, ao saber da morte de seu filho Ryno, ao testemunhar o assassinato de Agandecca etc. Ademais, tanto Sir Charles quanto o rei de Morven têm uma certa tendência a escusar seus atos de violência em prol de causas maiores. Apesar de excelente espadachim, Sir Charles Grandison mostra-se reticente em bater-se num duelo. Faz isso apenas como último recurso, como no caso em que se vira forçado a intervir para salvar Harriet Byron de Sir Hargrave Pollexfen, que tentava abduzi-la. E, mesmo assim, almeja converter a

\footnotetext{
${ }^{402}$ WATT, Ian. "Defoe and Richardson on Homer: a study of the relation of novel and epic in the early eighteenth century". The review of English studies, v. 3, n. 12 (outubro, 1952), p. 325-340, especialmente p. 334.

403 "[...] Achilles, the savage Achilles" (RICHARDSON, Samuel. The history of Sir Charles Grandison cit., v. 1, L. XIII, p. 60).

${ }^{404}$ Trecho integral: "[...] as to Fingal himself, he has all the strength and bravery of Achilles, with the courtesy, sentiment, and high-breeding of Sir Charles Grandison" ([SCOTT, Walter]. "Art. XV. Report of the Committee of the Highland Society of Scotland, appointed to inquire into the nature and authenticity of the Poems of Ossian: drawn up according to the directions of the Committee, by Henry Mackensie, Esquire, its convener or chairman. With a copious Appendix, containing some of the principal documents on which the account is founded". The Edinburgh review, v. 6, n. 12 (julho, 1805), p. 429-462, especialmente p. 446). Ver: SHIELDS, Juliet. Sentimental literature and Anglo-Scottish identity, 1745-1820 cit., p. 25.
} 
presente rusga numa futura amizade, conforme ele mesmo declararia ao próprio Sir Hargrave: ${ }^{405}$

Eu já me defrontei antes com um desafiante, mas foi quando não pude evitá-lo, e mediante a resolução de postar-me apenas em autodefesa, e na esperança de tornar um inimigo um amigo. ${ }^{406}$

Fingal aspira à glória do herói épico. No entanto, ao contrário do "Aquiles, o selvagem Aquiles", para o qual a busca pelo renome é um fim em si mesmo, os feitos militares do rei de Morven são muitas vezes cautelosamente dignificados por uma finalidade elevada:

Meus pais, Ossian, acompanham meus passos. Meus feitos são agradáveis a seus olhos. Toda vez que rumo à batalha [...] lá estão as suas colunas de névoa. - Mas meu braço resgatou o fraco; o soberbo descobriu que minha ira era fogo. ${ }^{407}$

E, como sabemos, Fingal também teria certa inclinação a entabular amizades com antigos oponentes. Magnânimo, libertaria Swaran mediante a tênue promessa de jamais regressar à Irlanda com hostilidades. O perdão estendido ao rei de Lochlin seria visto com aprovação por Hugh Blair. O retor proporia - transcrevemos mais uma vez - uma alegoria para Fingal nos seguintes termos: “a vitória mais completa sobre um inimigo é obtida por aquela moderação e generosidade que o convertem num amigo". 408

O interesse em comum pela dignificação da peleja e pela aproximação de dois inimigos vai muito além da - para usarmos uma expressão fora de moda - eventual influência de Richardson sobre Macpherson. Estudos sobre a história do livro na Escócia, somados ao que se sabe sobre a vida do tradutor de Ossian, permitem-nos especular com alguma segurança sobre a possibilidade de Macpherson ter lido Sir Charles Grandison ou qualquer outro romance richardsoniano. Antes da publicação dos Fragmentos, em 1759, Macpherson trabalhou como copidesque na tipografia de

\footnotetext{
${ }^{405}$ Sobre os duelos em Sir Charles Grandison, ver DOODY, Margaret Anne. A natural passion cit., p. 261.

406 "I have before now met a challenger; but it was when I could not avoid it; and with the resolution of standing only on my own defence, and in the hope of making an enemy a friend" (RICHARDSON, Samuel. The history of Sir Charles Grandison cit., v. 2, L. II, p. 255).

407 "My fathers, Ossian, trace my steps; my deeds are pleasant to their eyes. Wherever I come forth to battle [...] are their columns of mist.-But mine arm rescued the feeble; the haughty found my rage was fire" (MACPHERSON, James. "Temora: an epic poem". The poems of Ossian and related works cit., p. 290).

408 " [...] the most compleat victory over an enemy is obtained by that moderation and generosity which convert him into a friend" (BLAIR, Hugh. "A critical dissertation on the poems of Ossian". In: MACPHERSON, James. The Poems of Ossian and related works cit., p. 359-360). Ver supra, p. 120.
} 
Neill, em Edimburgo. ${ }^{409}$ Conquanto tal casa tivesse grande ligação com a Universidade, seu emprego decerto o colocava na condição de espectador privilegiado da cena editorial da cidade. Ao final da década de 1750, parte expressiva do mercado livreiro se encontrava inundada de romances ingleses, reproduzidos tanto de maneira legítima quanto pirata. ${ }^{410}$ Mas Macpherson não precisaria esperar até a fase adulta para se familiarizar com as novas tendências literárias. Anos antes, de 1752 a 1755 , estudara em Aberdeen, onde frequentou o King's e o Marischal College. ${ }^{411}$ Integrada ao mercado livreiro nacional, Aberdeen distribuía para o norte da Escócia publicações provenientes de todas as partes da Ilha. ${ }^{412}$ Professores, gente do clero, profissionais liberais e membros dos setores médios da população, mostram-nos os arquivos e os catálogos dos gabinetes de leitura, eram consumidores de romances. ${ }^{413}$ Não por acaso, a Universidade de Aberdeen, junto com outras universidades escocesas, seria uma das primeiras a introduzir, a partir da década de 1750, a leitura de romances no currículo acadêmico. $^{414}$

Dignos de nota como são todos os estudos sobre influência e recepção, o objetivo desta pesquisa não é comprovar empréstimos sub-reptícios feitos por Macpherson de uma matriz richardsoniana - ou de qualquer outra matriz novelística. Interessa-me,

${ }^{409}$ McDOUGALL, Warren. "Edinburgh”. In: BROWN, Stephen W.; McDOUGALL, Warren (ed.). The Edinburgh history of the book in Scotland. Edimburgo: Edinburgh University, 2012. v. 2 (Enlightenment and expansion, 1707-1800), p. 118-131, especialmente p. 122.

${ }^{410}$ OVENDEN, Richard. "Selling books in early eighteenth-century Edinburgh: a case study". In: BROWN, Stephen W.; McDOUGALL, Warren (ed.). The Edinburgh history of the book in Scotland cit., p. 132-142.

${ }^{411}$ Sobre os estudos de Macpherson em Aberdeen, ver STAFFORD, Fiona J. The sublime savage cit., p. 24-37.

${ }^{412}$ BEAVAN, Ian. "Aberdeen and the North-East". In: BROWN, Stephen W.; McDOUGALL, Warren (ed.). The Edinburgh history of the book in Scotland cit., p. 166-176.

${ }^{413}$ Ver McDONALD, William. "Book-auctions and book-sales in the Aberdeen area, 1749-1800". The Aberdeen University Review, v. 42, n. 138 (outono, 1967), p. 114-132. Os gabinetes de leitura de Aberdeen começaram a se organizar em meados da década de 1760, dando amplo destaque a obras novelísticas. Isso indica a sedimentação do interesse pelo gênero antes mesmo da instalação dos gabinetes (ver McDONALD, William R. "Circulating libraries in the north-east of Scotland". Bibliotheck, v. 5, n. 4 (1968), p. 119-137, especialmente p. 120-124).

${ }^{414}$ De maneira pioneira, o romance foi admitido como matéria de estudo universitário em Aberdeen, Saint Andrews, Glasgow e Edimburgo (cf. BATOR, Paul G. "The entrance of the novel into Scottish universities". In: CRAWFORD, Robert (ed.). The Scottish invention of English literature. Cambridge: Cambridge University, 1998, p. 89-102). A ubiquidade do romance na vida cultural escocesa pode ser atestada por um pequeno estudo de Vivienne S. Dunstan sobre a Gray Library, em Haddington. Mesmo essa biblioteca modesta, ligada a uma ordem religiosa (que, portanto, não incentivava a aquisição de obras ficcionais) e localizada numa parte relativamente remota do país, contava com um exemplar de Tom Jones desde a década de 1750. Anos mais tarde, quando as obras completas de Fielding foram adquiridas, tornou-se um dos títulos mais emprestados: era o preferido das mulheres e o terceiro mais lido pelos homens (DUNSTAN, Vivienne S. "Glimpses into a town's reading habits in enlightenment Scotland: analysing the borrowings of Gray Library, Haddington, 1732-1816". Journal of Scottish Historical Studies, v. 26, n. $1+2$ (2006), p. 42-59, especialmente p. 50-51). 
isso sim, a estranha proximidade temática e estrutural de Fingal e Temora, composições que mobilizam um duplo referencial épico, com uma obra que tão explicitamente rejeita a Weltanschauung da epopeia. Miss Charlotte Grandison (depois, Lady G.) diria em termos inequívocos:

[...] homens e mulheres são uma fraude uns para os outros. Mas podemos, em larga medida, agradecer à tribo poética pela fascinação. Eu os odeio todos. Não são eles os atiçadores das piores paixões? Quanto aos épicos, Alexandre, louco como era, teria sido tão louco, não fosse por Homero? Por quanta violência, mortes e depredações os poetas épicos não são responsáveis, por propagarem a falsa honra, a falsa glória e a falsa religião? ${ }^{415}$

E Harriet Byron, agora tornada Mrs Grandison, pondera em sua última carta sobre a incompatibilidade do que tradicionalmente se entende por heroísmo com as qualidades que seus contemporâneos atribuíam a "um Homem Verdadeiramente Bom":

O que é, minha querida vovó, o jactado caráter da maioria desses ditos Heróis diante do mérito despretensioso de um Homem Verdadeiramente Bom? Em quantas circunstâncias cordiais ele se manifesta? Quantas vezes ele é uma bênção e uma alegria para seus companheiros? $?^{416}$

Ao contrário de Lady G., Ossian decerto subscreveria às noções homéricas de honra e glória. Parece claro, porém, que tanto Fingal quanto Temora partilham da dúvida de Mrs Grandison, tipicamente novelística, quanto à permanência desses valores no mundo moderno. Parte considerável das intervenções paratextuais assinadas pelo tradutor acusa, ainda que com certo pesar, a completa superação da ética marcial dos antigos no século XVIII. Com efeito, os comentários à margem dos épicos ossiânicos endossam o argumento primitivista de que o heroísmo do "selvagem Aquiles" (ou de Fingal) só poderia ser recriado por um procedimento quase exumatório, em que a

\footnotetext{
415 “[...] men and women are cheats to one another. But we may, in a great measure, thank the poetical tribe for the fascination. I hate them all. Are they not inflamers of the worst passions? With regard to the Epics, would Alexander, madman as he was, have been so much a madman, had it not been for Homer? Of what violences, murders, depredations, have not the Epic poets been the occasion, by propagating false honour, false glory, and false religion?" (RICHARDSON, Samuel. The history of Sir Charles Grandison cit., v. 6, L. XLV, p. 197-198). Ver também: WATT, Ian. "Defoe and Richardson on Homer: a study of the relation of novel and epic in the early eighteenth century"cit., $p$. 334.

416 "What, my dear grandmamma, is the boasted character of most of those who are called Heroes, to the un-ostentatious merit of a Truly Good Man? In what a variety of amiable lights does such a one appear? In how many ways is he a blessing and a joy to his fellow creatures?" (RICHARDSON, Samuel. The history of Sir Charles Grandison cit., v. 7, L. LXI, p. 462).
} 
“invenção" traria de volta os "sentimentos e cenários de uma idade remota". ${ }^{417} \mathrm{Em}$ "Uma dissertação", que antecede Temora, afirmar-se-ia que "as paixões mais nobres da mente" brotam "livres e irrestritas [...] naqueles tempos que chamamos de bárbaros", ao passo que "os caracteres humanos são uniformes e encobertos" "numa sociedade avançada". 418

A "sociedade avançada" a que Macpherson se referia chegara às Terras Altas escocesas em 1746, com o malogro do Levante Jacobita iniciado no ano anterior. Whitehall buscaria integrar a porção norte da Escócia ao arranjo político, econômico e institucional desenhado pela Revolução Gloriosa, por meio da eliminação do sistema de clãs e da supressão da cultura highlander. Muitos dos chefes, como Ewan Macpherson de Cluny, ${ }^{419}$ seriam presos, perseguidos e executados. Outros veriam erodir sua autoridade pela ocupação permanente do Exército e pela transferência de sua jurisdição para juízes de paz, ministros da igreja e oficiais militares ali instalados. De igual modo, proscreveu-se a identidade highlander, sobretudo pelo banimento do uso do tartan e da língua gaélica. ${ }^{420}$ Num movimento concertado, abriram-se os Highlands à circulação de pessoas, bens e mercadorias. Pavimentaram-se estradas, erigiram-se pontes e pôs-se um serviço de correios para funcionar. Como consequência, relações capitalistas de trabalho rapidamente substituiriam relações tradicionais, baseadas na lealdade intra-clã. ${ }^{421}$ Para servir a um mercado nacional, a produção agrícola seria redirecionada à criação de gado ovino, no lugar da agricultura de subsistência e dos pequenos rebanhos de gado bovino, num roteiro que culminaria

\footnotetext{
417 " [...] the sentiments or scenery of an age remote from his own [...]" (An essay on the history of civil society. Ed. Fania Oz-Salzberger. Cambridge: Cambridge University, 1995, p. 166). Trecho citado supra, p. 63.

418 Trecho integral: "The nobler passions of the mind never shoot forth more free and unrestrained than in these times we call barbarous. [...] In advanced society the characters of men are more uniform and disguised" (MACPHERSON, James. "A dissertation". The poems of Ossian and related works cit., p. 205). Esta passagem foi discutida supra, p. 70.

${ }^{419}$ Líder do clã a que pertencia o tradutor do Ossian.

${ }^{420}$ TREVOR-ROPER, Hugh. "The invention of tradition: the Highland tradition of Scotland". In: HOBSBAWM, Eric; RANGER, Terence (ed.). The invention of tradition. Cambridge: Cambridge University, 2005, p. 15-42, especialmente p. 23-24.

${ }^{421}$ Vejam-se os artigos de Neil Davidson sobre as transformações ocorridas na economia da Escócia: DAVIDSON, Neil. "The Scottish path to capitalist agriculture 1: from the crisis of feudalism to the origins of agrarian transformation (1688 - 1746)". Journal of Agrarian Change, v. 4, n. 3 (julho, 2004), p. 227-268 e DAVIDSON, Neil. "The Scottish path to capitalist agriculture 2: the capitalist offensive (1747 - 1815)”. Journal of Agrarian Change, v. 4, n. 4 (outubro, 2004), p. 411-460.
} 
com a explosão dos alugueres, a expulsão dos inquilinos hereditários e o cercamento da terra para o pastoreio. ${ }^{422}$

O tradutor de Ossian explicitamente ligaria todas essas transformações ao fim de qualquer possibilidade de se reviverem ou mesmo rememorarem os feitos dos antigos caledônios. Na dissertação sobre a antiguidade da poesia ossiânica, Macpherson escreveria que sua expedição pelas montanhas salvara Fingal do completo esquecimento. O "mérito poético" de Ossian "tornara seus heróis famosos num país em que o heroísmo era tão estimado e admirado". ${ }^{423}$ Famílias empregavam bardos para que repetissem os poemas ossiânicos. ${ }^{424}$ Essa situação, entretanto, já não existiria mais. "O gênio dos highlanders", observa, "sofreu uma grande mudança nos últimos anos", por conta da abertura da "comunicação com o resto do mundo" e da "introdução do comércio e manufaturas". Confinados aos "prazeres" que "a propriedade" "proporciona", os habitantes das Terras Altas não mais se dedicam "a escutar e repetir os poemas de outrora". Muitos "aprenderam a deixar suas montanhas" e "a desprezar os costumes de seus ancestrais". Os bardos já não cantam e o "espírito da genealogia arrefeceu enormemente". Menos "devotados a seus chefes", os highlanders já não estimam a consanguinidade. ${ }^{425}$ Politicamente, e aqui cito "Uma dissertação" a Temora, a idealização do governo unipessoal, exercido por comandos "absolutos e supremos" -

Aqui vivia o chefe, o juiz supremo e legislador de seu próprio povo; mas seu poder não era nem severo nem injusto. Como a população o tomava como um líder de seu sangue, ele, em contrapartida, considerava-a como membros de sua família. Seus comandos,

\footnotetext{
${ }^{422}$ YOUNGSON, A. J. After the Forty-Five cit., p. 84-89 e 170-175.

423 "His poetical merit made his heroes famous in a country where heroism was much esteemed and admired" (MACPHERSON, James. "A dissertation concerning the antiquity, \&c. of the poems of Ossian the son of Fingal". The poems of Ossian and related works cit., p. 49).

${ }^{424}$ Idem, ibidem.

${ }^{425}$ Trecho integral: "The complete work, now printed, would, in a short time, have shared the fate of the rest. The genius of the highlanders has suffered a great change within these few years. The communication with the rest of the island is open, and the introduction of trade and manufactures has destroyed that leisure which was formerly dedicated to hearing and repeating the poems of ancient times. Many have now learned to leave their mountains, and seek their fortunes in a milder climate; and though a certain amor patrio may sometimes bring them back, they have, during their absence, imbibed enough of foreign manners to despise the customs of their ancestors. Bards have been long disused, and the spirit of genealogy has greatly subsided. Men begin to be less devoted to their chiefs, and consanguinity is not so much regarded. When property is established, the human mind confines its views to the pleasure it procures" (idem, p. 51).
} 
embora absolutos e supremos, pareciam mais o exercício da autoridade de um pai que do rigor de um juiz. ${ }^{426}$

—, é substituída pela desconfiança a uma sociedade em que um "evento fortuito é capaz de levar os tímidos e covardes ao poder". ${ }^{427}$ Como em Oroonoko, a "alma do soldado" já não tem lugar num mundo em que predominam relações de compra e venda. $^{428}$

Se os bardos e suas composições davam sinais claros de desaparecimento, narrativas novelísticas começavam a tematizar o desarranjo social e econômico do país. Três anos depois do Levante Jacobita, Smollett publicaria seu romance de estreia, The adventures of Roderick Random. Ele já havia se ocupado da desolação causada em sua Escócia pelo conflito. Na elegia "Tears of Scotland", dá-se forma ao "Ressentimento quanto ao destino de meu país", ${ }^{429}$ num lamento pelo jugo imposto ao "espírito altaneiro" da antropomorfizada Caledônia:

Teu espírito altaneiro agora está partido,

Teu pescoço se curva ao jugo:

O que tropas estrangeiras jamais dominaram

Tombou pelo ódio e rancor intestino. ${ }^{430}$

No entanto, o romance parece ser a forma que captura com mais clareza o esgarçamento do tecido social no país. ${ }^{431}$ A própria personagem epônima já prenuncia a desconstrução de um universo heroico. Roderick Random, ou Rodrigo Randômico, une o nome do último rei dos godos, que teria perecido na invasão árabe à Península Ibérica, à aleatoriedade de alguém que, despejado de sua propriedade hereditária, perambula pelo mundo. De fato: após ser expulso das terras de sua família na Escócia, Roderick vê-se obrigado a tentar a sorte como médico, marujo, soldado e mercador de

\footnotetext{
426 "Here the chief lived, the supreme judge and law-giver of his own people; but his sway was neither severe nor unjust. As the populace regarded him as the chief of their blood, so he, in return, considered them as members of his family. His commands therefore, though absolute and decisive, partook more of the authority of a father, than of the rigor of a judge" (MACPHERSON, James. "A dissertation". The poems of Ossian and related works cit., p. 213).

427 “[...] event can raise the timid and mean into power" (idem, p. 205).

${ }^{428}$ Ver supra, p. 190. Para a relação entre Ossian e o quadro escocês depois do Levante de 1745 , ver DAVIS, Leith. Acts of Union: Scotland and the literary negotiation of the British nation, 1707-1830. Stanford : Stanford University, 1998, p. 74-106.

429 "Resentment of my country's fate" (51) (SMOLLETT, Tobias. "The tears of Scotland". Poems, plays, and The Briton. Ed. Byron Gassman; O. M. Brack Jr. Athens, GA - Londres: University of Georgia, 1993, p. 23-26, especialmente p. 26).

430 "Thy tow'ring spirit now is broke,/ Thy neck is bended to the yoke./ What foreign arms could never quell,/ By civil rage, and rancor fell" (21-24) (idem, p. 24)

${ }^{431}$ DAVIS, Leith. Acts of Union cit., p. 64 e ss.
} 
escravos em vários cantos do globo: Continente, Caribe, África Ocidental, Argentina, Londres e Bath. Já no "Prefácio", Smollett associaria, de uma maneira um tanto irônica, o desterro permanente à condição de escocês: "a disposição dos escoceses, viciados em viajar, justifica a minha conduta em derivar um aventureiro daquele país". 432

As andanças de Roderick pelo mundo têm feições picarescas, porquanto o narrador em primeira pessoa rememora sua descida ao submundo da sociedade, num périplo em que deixa sua condição fidalga para lidar com uma infinidade de trapaceiros, aproveitadores, corruptos, prostitutas etc. ${ }^{433}$ A sucessão de desventuras que acometem Roderick traz a narrativa perigosamente próxima do episódico, em que a ausência de perspectivas do protagonista se traduz na inflação inesgotável de incidentes. Se Lovelace demonstrara que o controle do enredo é parte inextrincável tanto de sua masculinidade quanto da sua condição de aristocrata, a sujeição de Roderick ao "capricho da fortuna" $" 434$ afasta-o do código de honra de sua classe original e submete-o ao risco de efeminação. No ponto mais baixo de sua trajetória, depois de ser acossado para fora das terras de sua amada, Narcissa, Roderick é instado por um velho francês a "honrá-lo" com um duelo, "como um fidalgo":.435

Segui seu conselho e acompanhei-o a um campo ao lado, onde, de fato, envergonhei-me da figura deplorável de meu antagonista, que era uma criatura pobre, diminuta e trêmula, decrépita pela idade e cega de um olho. - Mas logo me dei conta da tolice de julgar pelas aparências, sendo no segundo golpe ferido na mão que empunhava a espada e imediatamente desarmado por um solavanco tão grande, que pensei ter deslocado a junta. ${ }^{436}$

\footnotetext{
432 "[...] the disposition of the Scots, addicted to travelling, justifies my conduct in deriving an adventurer from that country" (SMOLLETT, Tobias. The adventures of Roderick Random. Ed. James G. Basker, Paul-Gabriel Boucé; Nicole A. Seary. Athens, GA - Londres: University of Georgia, 2012, p. 5). Ver também LUTZ, Alfred. "Representing Scotland in Roderick Random and Humphry Clinker: Smollett's development as a novelist". Studies in the novel, v. 33, n. 1 (primavera, 2001), p. 1-17, especialmente p. 3-4 e DAVIS, Leith. Acts of Union cit., p. 68.

${ }^{433}$ BEASLEY, Jerry C. "Roderick Randam: the picaresque transformed". College literature v. 6, n. 3 (The Picaresque Tradition) (outubro, 1979), p. 211-220.

434 “[...] caprice of fortune" (SMOLLETT, Tobias. The adventures of Roderick Random cit., p. 39). A "Fortuna", entendida como acaso, é um termo ubiquamente empregado ao longo da obra. Sobre a relação de Roderick com a fortuna, ver BEASLEY, Jerry C. "Roderick Randam: the picaresque transformed" cit., p. 216.

${ }^{435}$ Trecho integral: "[...] do him the honour of measuring his sword with mine, like a gentleman" (SMOLLETT, Tobias. The adventures of Roderick Random cit., p. 223).

436 "I took his advice, and followed him to a field hard by, where indeed I was ashamed at the pitiful figure of my antagonist, who was a poor, little, shivering creature decrepit with age, and blind of one eye.-But I soon found the folly of judging from appearances; being at the second pass wounded in the
} 
Ferido e humilhado, mas já de volta à Grã-Bretanha, Roderick vê falharem seus esquemas para ascender socialmente. Convencido por um espertalhão que faz as vezes de amigo, Straddle, visita Lorde Strutwell para pedir-lhe que exerça sua suposta influência junto à corte e consiga-lhe um emprego. Strutwell mostra-se afável e promete intervir junto ao gabinete do primeiro-ministro em nome de Roderick. Diz haver grande possibilidade de obter-lhe um posto como secretário de um embaixador. Roderick regozija-se ante sua "boa fortuna" e ajoelha-se para beijar a mão de seu benfeitor. Strutwell então muda a conversa para temas literários e pergunta a Roderick sua opinião sobre Petrônio. O protagonista condena a "indecência" do romano, ao passo que Strutwell tece considerações sobre "seu gosto no amor", ${ }^{437}$ que, "em nosso país, ganha terreno rapidamente e, decerto, se tornará em breve um vício mais na moda que a mera fornicação". ${ }^{438}$ Roderick toma as observações de seu patrono putativo como irônicas e nega ter sido "infectado com esse desejo espúrio e sórdido" em suas viagens pelo mundo, para aparente satisfação de Strutwell. ${ }^{439}$ Os dois homens se despedem professando amabilidades. Roderick presenteia Strutwell com seu relógio, mediante acenos de reencontro. Pouco depois, para desespero de Roderick, contam-lhe que o Lorde costuma entreter forasteiros trazidos por seus rufiões com "promessas" e "carícias", "até rapiná-los de seu dinheiro e de qualquer outro bem que tragam consigo - frequentemente, de sua própria castidade. E então os deixa vulneráveis à necessidade e à infâmia". ${ }^{440}$ Roderick busca vingança, mas a falta de dinheiro leva-o a "empenhar a [sua] melhor espada". 441

Assim, no romance em questão, a pobreza e a dependência do escocês dos favores ingleses privam-no de sua dignidade nativa, numa espiral em que a capitis diminutio e a emasculação se confundem. Símbolo de classe e de gênero, a espada se torna um bem dispensável numa realidade em que as relações intersubjetivas são, cada vez mais, mediadas pelo dinheiro. Roderick só retorna à sua condição de fidalgo quando

sword hand, and immediately disarmed with such a jerk, that I thought the joint was dislocated" (idem, ibidem).

437 “[...] his taste in love" (idem, p. 270)

438 "....] in our own country it gains ground apace, and in all probability will become in a short time a more fashionable vice than simple fornication" (idem, ibidem).

439 "[...] infected with this spurius and sordid desire" (idem, p. 271).

${ }^{440}$ Trecho integral: "[...] it was a common thing for him to amuse strangers whom his jack-calls ran down, with such assurances and caresses as he had bestowed on me, until he had stripped them of their cash and everything valuable about them;- - very often of their chastity, and then leave them a prey to want and infamy" (idem, p. 272).

441 “[...] pawn my best sword" (idem, p. 273). 
deixa de ser um caçador de fortunas e torna-se um empreendedor capitalista, juntando-se a uma expedição para comprar escravos na África e vendê-los na Argentina. Com isso, obtém meios suficientes para casar-se com a inglesa Narcissa e recomprar as terras de seus antepassados. Rompe-se com o vagar sem rumo da picaresca, passando-se de um enredo episódico ao fechamento narrativo, no momento em que o protagonista converte a indiferença da sociedade capitalista em oportunidade e, à custa da exploração colonial, propõe um novo casamento entre Inglaterra e Escócia ${ }^{442} \mathrm{e}$ pode pagar por seu retorno à classe dominante.

$\mathrm{O}$ movimento de The adventures of Roderick Random expõe a situação social escocesa e oferece uma solução, consubstanciada na forma, à instabilidade que perpassava o país. Se os escoceses se dedicassem à construção do império britânico talvez pudessem reconquistar - ou recomprar - a sua antiga glória, na medida em que glória é um bem disponível no mercado. ${ }^{443} \mathrm{E}$, assim como os romances analisados acima, The adventures of Roderick Random corporifica um modelo narrativo de tensão e coexistência de princípios construtivos antitéticos, num tecido cuja dissonância textualiza o quadro social do qual a obra emerge. ${ }^{444}$ É esse modelo que nos permite ressignificar a aporia decorrente da conciliação do primitivo ao neoclássico em Fingal e Temora, num procedimento em que o domínio da contingência (a Fortuna blackwelliana) e a obtenção da inteligibilidade por meio da ação una se refiguram numa síntese do heterogêneo, própria da narrativa novelística.

Os ditos épicos ossiânicos constituem uma incongruência tipicamente novelística entre o narrar e o narrado, entre o presente isolado e supranumerário do narrador e o passado gregário e heroico das personagens. Apresentando-se como alguém "cego e choroso e esquecido", ${ }^{445}$ Ossian se encontra temporal e ideologicamente apartado do universo habitado por Fingal, Swaran, Cathmor e seus companheiros. Leia-se a abertura do "Livro Quinto" de Temora:

Tu que habitas entre os escudos dependurados no alto do salão de Ossian, desça de teu lugar, ó harpa, e deixa-me escutar tua voz. Filho de Alpin, tange as cordas; deves despertar a alma do bardo. $\mathrm{O}$ murmúrio das corredeiras de Lora levou a estória embora. - Posto-

\footnotetext{
${ }^{442}$ DAVIS, Leith. Acts of Union cit., p. 69.

${ }^{443}$ Cf. SHIELDS, Juliet. Sentimental literature and Anglo-Scottish identity cit., p. 69.

${ }^{444}$ Dialoga-se com JAMESON, Fredric. The political unconscious cit., p. 141 e CANDIDO, Antonio. "Crítica e sociologia". Literatura e sociedade. São Paulo: TAQ, 2000, p. 6.

445 "“...] blind, and tearful, and forlon" (MACPHERSON, James. "Fingal: an epic poem". The poems of Ossian and related works cit., p. 79).
} 
me no nevoeiro dos anos: poucas são as aberturas em direção ao passado; quando vem a visão, ela é turva e escura. - Eu te ouço, harpa de Cona. Minha alma regressa, como uma brisa, que o sol traz de volta ao vale, onde morava a preguiçosa neblina.

Lubar é nítida para mim, na sinuosidade de seu vale. Em cada extremo, em suas colinas, erguem-se as altas formas dos reis [...]. ${ }^{446}$

As "altas formas dos reis" podem ser divisadas apenas ocasionalmente, quando se dissipa o nevoeiro. Sua “estória” já não pertence a este mundo, mas a um passado quase inacessível, silenciado pelo curso dos anos. Como diria em outro lugar, "as corças selvagens se alimentam sobre o túmulo do poderoso rei de Morven". ${ }^{44}$ Reviver esse passado deixou de ser uma possibilidade. Ossian já não pode brandir os escudos que pendem em seu salão. Seu instrumento, agora, é a harpa; seu meio de reconstituir os dias de Fingal, o canto - ou melhor, a ficção.

A recuperação da "estória" tragada pelo "murmúrio das corredeiras de Lora" depende de um apagamento consciente das condicionantes materiais da experiência. É preciso desconsiderar a paisagem marcada por ruínas, tumbas cobertas pela relva, armas enferrujadas e fantasmas solitários que uivam pelo vento - e sobrepujar o sentimento de que se caminha "entre homens inferiores". ${ }^{448}$ Mas como fazê-lo, se a configuração de Ossian é tão ostensivamente inserta no tempo e no espaço condicionada, para retomarmos um termo de Blackwell, pela Fortuna? ${ }^{449}$ Em certa medida, Ossian se individua como um narrador novelístico: singulariza-se por meio da atribuição de um lastro material à sua experiência, que, localizada e circunscrita, apresenta-se como única, determinada e, por isso mesmo, verdadeira. ${ }^{450}$ Fingal e Temora, significativamente, compartilham da insistência novelística de negar a sua

\footnotetext{
446 "Thou dweller between the shields that hang on high in Ossian's hall, descend from thy place, $\mathrm{O}$ harp, and let me hear thy voice.- - Son of Alpin, strike the string; thou must awake the soul of the bard. The murmur of Lora's stream has rolled the tale away.-I stand in the cloud of years: few are its openings towards the past, and when the vision comes it is but dim and dark.-I hear thee, harp of Cona; my soul returns, like a breeze, which the sun brings back to the vale, where dwelt the lazy mist. Lubar is bright before me, in the windings of its vale. On either side, on their hills, rise the tall forms of the kings" (MACPHERSON, James. "Temora: an epic poem". The poems of Ossian and related works cit., p. 263).

447 "The wild roes feed upon the green romb of the mighty king of Morven" (MACPHERSON, James. "Fingal: an epic poem". The poems of Ossian and related works cit., p. 79).

448 "But blind, and tearful, and forlorn now I walk with little men" (idem, p. 75). Ver supra, p. 142.

${ }^{449}$ Ver supra, p. 56.

${ }^{450}$ WATT, Ian. $A$ ascensão do romance cit., p. 30 e ss.
} 
própria ficcionalidade, rejeitando o status de "fábula". ${ }^{451}$ Diante disso, a reconstituição do passado, para Ossian, é algo muito próximo da alucinação:

Não mais escuto a tua voz em Cona. Meus olhos não te veem. Muitas vezes, sombrio e esquecido, sento-me em teu túmulo e sintoo com minhas mãos. Quando penso que ouço tua voz, é apenas o vento do deserto. ${ }^{452}$

Abstrai-se de uma realidade prosaica e inglória, do vento que sopra no ermo, por meio da conversão dos vestígios dos dias em que Ossian "não era tão sombrio nem tão esquecido" 453 num universo que se quer uno, pleno e investido de transcendência. Sintomaticamente, a relação do narrador ossiânico com essa empreitada é de ambivalência. ${ }^{454}$

As intervenções em primeira pessoa de Ossian indicam, de modo reiterado, que os princípios construtivos da ação épica são ineptos para a expressão de sua experiência presente. Ossian interpõe o que seria a sua interioridade ao domínio do narrado, ${ }^{455}$ num expediente em que demanda a empatia do público para si, em detrimento de seus heróis. No "Livro V" de Fingal, susta um solilóquio do rei de Morven diante do corpo de seu filho mais novo, Ryno, ${ }^{456}$ para comparar a dor de Fingal à dor que ele, Ossian, sentia por conta de sua morte:

- Descansa, meu caçula, descansa, ó Ryno, em Lena. Nós também morreremos, pois o guerreiro há de tombar um dia.

Tal foi o teu pesar, rei das colinas, quando Ryno jazia sobre a terra. Qual não deve ser o pesar de Ossian, pois também te foste. [...] Fingal há muito foi dormir, o senhor da guerra. ${ }^{457}$

Enquanto Fingal chora pelo "caçula" que se foi, Ossian lamenta a morte do "senhor da guerra", o desaparecimento de um tipo humano que se identificava como "guerreiro". De maneira mais interessante, o narrador apostrofa Malvina, sua nora, para que não desperdiçasse suas lágrimas com Oscar, pois ele sairia triunfante do

\footnotetext{
451 “[...] fable" (MACPHERSON, James. "Preface to $1^{\text {st }}$ edition of Fingal". The poems of Ossian and related works cit., p. 37).

452 "I hear not thy distant voice on Cona. My eyes perceive thee not. Often forlorn and dark I sit at thy tomb; and feel it with my hands. When I think I hear thy voice; it is but the blast of the desart" (MACPHERSON, James. "Fingal: an epic poem". The poems of Ossian and related works cit., p. 95).

${ }^{453}$ Trecho integral: "I was not so dark and forlorn" (idem, p. 83).

${ }^{454}$ KEYMER, Thomas. Sterne, the Moderns, and the novel cit., p. 178.

${ }^{455}$ Ver TRUMPENER, Katie. Bardic nationalism cit., p. 75.

${ }^{456}$ Ver supra, p. 69.

457 "Rest, youngest of my sons, rest, O Ryno, on Lena. We too shall be no more; for the warrior one day must fall. Such was thy grief, thou king of hills, when Ryno lay on earth. What must the grief of Ossian be, for thou thyself art gone. [...] __ Fingal has long since fallen asleep, the ruler of the war" (MACPHERSON, James. "Fingal: an epic poem". The poems of Ossian and related works cit., p. 95).
} 
conflito. Implora para que chore pelo bardo, que é "triste, cego e esquecido - não mais o companheiro de heróis": "Dá, amável donzela, dá as tuas lágrimas para mim, pois eu vi o túmulo de todos os meus amigos". 458

A sobreposição do eu ossiânico à representação literária manifesta-se, também, em questionamentos quanto ao processo de ficcionalização do passado, num expediente em que a suposta rememoração é entrecortada pela performance presentificada do narrador, como nesta passagem do "Livro Terceiro" de Temora:

Não é pacífica a mão de Foldath: do sangue ele fareja seu caminho. Connal o encontrou na luta. Fundiram seu aço estridente. - Por que meus olhos os contemplam? Connal, tuas madeixas são grisalhas. - Eras o amigo dos forasteiros, nas escarpas de Dunlora cobertas pelo musgo. Quando os céus fluíam em conjunto, então se instalavam teus banquetes. $\mathrm{O}$ forasteiro ouvia os ventos do lado de fora e rejubilava-se diante de teu carvalho crepitante. - Por que, filho de Duth-caron, jazes coberto de sangue? A árvore podre se dobra sobre ti: ao lado, teus escudos jazem partidos. Teu sangue mistura-se ao riacho, ó destruidor de escudos! $!^{49}$

No trecho citado, existem três eixos temporais. O primeiro e mais evidente é o perfeito (inicialmente travestido de presente histórico) da ação épica: quando Foldath e Connal se encontram em batalha, com a derrota desse último. O segundo cristalizase no uso do imperfeito, relativo a acontecimentos anteriores ao embate fatal. Ambos os eixos pertencem ao campo de experiência das personagens, que ordena os eventos vivenciados pelos heróis. ${ }^{460}$ Contudo, insinua-se um terceiro eixo temporal, presentificado, que irrompe em meio à narrativa do passado. ${ }^{461}$ Seu referente é o narrador de Temora. Incapaz de conter as emoções que lhe vêm à mente, hesita em dar continuidade ao seu projeto de rememoração e formula a indagação: "Por que meus olhos os contemplam?". O deslocamento do campo de experiência resulta num estilo paratático, marcado pelo uso de travessões, em que a reflexividade do narrador torna-se tão ou mais importante que a caracterização das personagens ou a

\footnotetext{
458 "I am sad, forlorn, and blind; and no more the companion of heroes. Give, lovely maid, to me thy tears, for I have seen the tombs of all my friends" (idem, p. 87).

459 "Not peaceful is the hand of Foldath: he winds his course in blood. Connal met him in fight; they mixed their clanging steel.-Why should mine eyes behold them! Connal, thy locks are gray.-Thou wert the friend of strangers, at the moss-covered rock of Dunlora. When the skies were rolled together; then thy feast was spread. The stranger heard the winds without; and rejoiced at thy burning oak. Why, son of Duth-caron, art thou laid in blood! The blasted tree bends above thee: thy shield lies broken near. Thy blood mixes with the stream; thou breaker of the shields!" (MACPHERSON, James. "Temora: an epic poem". The poems of Ossian and related works cit., p. 247).

${ }^{460}$ Cf. HAMBURGER, Käte. A lógica da criação literária cit., p. 44-57.

${ }^{461}$ Ver DUNCAN, Ian. "The pathos of abstraction: Adam Smith, Ossian, and Samuel Johnson" cit., p. 47.
} 
representação da ação.

A subjetivação do bardo ou aedo na narrativa épica, todavia, não é exatamente nova ou original. Ocorre com alguma frequência na Eneida, como nesta apóstrofe a Eurialo e Niso, logo após a sua morte prematura:

Par ditoso! terás, se em verso eu valho,

Perpétua fama, enquanto o Pai de Roma

O orbe domine, e a geração de Enéias

Do capitólio habite a rocha imóvel. ${ }^{462}$

(IX, 437-440)

E, de maneira ainda mais evidente, no Paraíso perdido. Na abertura do "Livro III", o aedo ostensivamente se apresenta como John Milton, a implorar para que a luz divina transponha a escuridão de seus olhos:

Salve, ó luz, primogênita do Empíreo,

Ou coeterno fulgor do eterno Nume!

Como te hei de nomear sem que te ofenda?

É Deus a luz, - e, em luz inacessível

Tendo estado por toda a Eternidade,

Esteve em ti, emanação brilhante

Da brilhante incriada essência pura.

[...] a ti volvo, e já me anima

De tua essência o sacrossanto influxo:

Mas tu não entras mais nestes meus olhos:

Por invencível sufusão tapados

Rolam ansiosos com baldado anelo

Procurando teus raios penetrantes,

E nem sequer lhes acham o vislumbre!

[...] tu, eterna luz, porção divina,

Com tanta mais razão me acode e vale:

Brilha em minha alma, nela olhos acende

As faculdades todas the ilumina,

E de nuvens quaisquer a desassombra,

A fim que eu livremente veja e narre

Cenas que à vista dos mortais se escondem. ${ }^{463}$

${ }^{462}$ VIRGÍlLIO. Eneida. 2. ed. Trad. Odorico Mendes. Cotia: Ateliê, 2010, p. 207. Na versão de Dryden da Eneida, lê-se: "O happy Friends! for if my Verse can give/ Immortal Life, your Fame shall ever live:/ Fix'd as the Capitol's Foundation lies;/ And spread, where e're the Roman Eagle flies!” (IX, 597-600) (VIRGÍLIO. "Virgil's AEneis". Trad. John Dryden. In: KINSLEY, James (ed.). The poems of John Dryden cit., v. 3, p. 1307). Sobre a voz do narrador na Eneida, ver: BEHR, Francesca D'Allesandro. "The narrator's voice: a narratological reappraisal of apostrophe in Virgil's Aeneid". Arethusa v. 38, n. 2 (junho, 2005), p. 189-221.

${ }^{463}$ MILTON, John. O paraíso perdido cit., p. 100-102. No original: "Hail holy light, offspring of Heav'n first-born, / Or of th' Eternal Coeternal beam / May I express thee unblam'd? since God is light, /And never but in unapproached Light / Dwelt from Eternity, dwelt then in thee,/ Bright effluence 
Entretanto, a interrupção da mimese pela hipertrofia do sujeito narrativo é um expediente comum à narrativa novelística, porquanto decorre da reflexividade que lhe é intrínseca. Como vimos, os romances de Defoe talvez proporcionem os exemplos mais evidentes de narradores cuja avaliação retrospectiva se intromete de maneira recorrente no desenrolar da intriga. ${ }^{464}$ Tal avaliação brota até mesmo em circunstâncias aparentemente banais. Em Robinson Crusoe, o narrador não se contenta em deixar sua personagem se aventurar pelos mares, numa jangada precária, a fim de escapar do confinamento da ilha. Observa, em tom sentencioso, que "de novo sirvo de mau exemplo, a ser evitado por todos os pilotos atrevidos e ignorantes". 465 De fato: seu barquinho mal deixa a praia e começa a ser tragado pela correnteza, a colocar, com o perdão do trocadilho, seus planos de fuga por água abaixo. Na mesma linha, escritores como Henry Fielding ${ }^{466}$ e Laurence Sterne ${ }^{467}$ explorariam essas intromissões discursivas para produzir efeitos cômicos e paródicos. Vejamos o caso de Fielding: ele as sistematizaria em Tom Jones, reservando sempre o capítulo inaugural de cada um dos "Livros" a um "ensaio". Aqui, algumas vezes se discorre sobre as ideias imanentes à "matéria histórica" dos capítulos subsequentes. Noutros casos, oferece-se o que seria uma posição autoral sobre a poética neoclássica. E, por fim, para citarmos um dos títulos desses ensaios, há instâncias que parecem conter "pouco ou nada". Ainda assim, o narrador assevera que não se julga no dever de

of bright essence increate./ [...] thee I revisit safe, / And feel thy sovran vital Lamp; but thou/ Revisit'st not these eyes, that rowle in vain/ To find thy piercing ray, and find no dawn; / So thick a drop serene hath quencht thir Orbs,/ Or dim suffusion veild./ [...] thou Celestial Light / Shine inward, and the mind through all her powers / Irradiate, there plant eyes, all mist from thence / Purge and disperse, that I may see and tell / Of things invisible to mortal sight" (III, 1-55) (MILTON, John. "Paradise lost" cit., p. 257-259).

${ }^{464}$ Como vimos, alguns editores piratas tinham a tendência de expelir as intervenções do narrador. Ver supra, p. 214-215.

${ }^{465}$ DEFOE, Daniel. Robinson Crusoé cit., p. 208. No original: "I am a warning Piece again, to all rash and ignorant Pilots" (DEFOE, Daniel. Robinson Crusoe cit., p. 118).

${ }^{466}$ A partir de Bakhtin, Fiona Stafford sugere que os épicos ossiânicos seriam uma paródia do épico, semelhante àquela de Fielding. Stafford associa a "reconstrução pouco usual" do épico empreendida por Macpherson aos "romances explicitamente paródicos" de Fielding, com seu "uso espirituoso das convenções épicas, justaposições do elevado e do baixo, estórias enxertadas e narração autoconsciente" (Trecho integral: "[...] Macpherson's unusual reconstructions of epic next to Henry Fielding's explicitly parodic novels, with their playful use of epic conventions, juxtapositions of high and low, imbedded tales and self-conscious narration"). Embora muito estimulante, seu diagnóstico apenas tangencia as questões formais e epistêmicas implicadas na transição do mundo da epopeia para o do romance. Ver: STAFFORD, Fiona J. "Romantic Macpherson". In: PITTOCK, Murray (ed.). The Edinburgh companion to Scottish Romanticism. Edimburgo: Edinburgh University, 2011, p. 27-38, especialmente p. 36-37 e BAKHTIN, Mikhail M. "Epic and the novel". The dialogic imagination cit., p. 5 e ss.

${ }^{467}$ Para Fiona Stafford, Fingal e Tristram Shandy são narrativas informes, que obtêm coerência pela focalização no narrador (STAFFORD, Fiona J. The sublime savage cit., p. 141). 
prestar explicações do porquê desses ensaios. Seria uma "norma que há de ser compulsoriamente seguida em todos os escritos prosai-comi-épicos". 468

Mas as interposições do eu ossiânico à continuidade da narrativa não tomam corpo apenas como comentários e digressões. Em Temora, o narrador abstém-se de dar prosseguimento à representação do encontro de Sul-malla com o fantasma de Cathmor, no momento em que ela finalmente se daria conta de que seu amado perecera em combate. Faz-se brusca inflexão no foco narrativo, demarcada pelo uso do segundo travessão, com que se aborta a cena - e eclode a amargura de Ossian:

Seus olhos voltaram-se para a colina. A forma imponente descia mais uma vez. Ela se ergueu, tomada pela alegria. Ele partiu em névoa. Gradualmente, desaparecem seus membros de fumaça e misturam-se ao vento da montanha. - Então ela entendeu que o rei tombara. "Rei de Erin, estás morto!" - Deixai que Ossian esqueça seu pesar; ele exaure a alma dos velhos. ${ }^{469}$

O desalinho pode ser creditado à suposta espontaneidade da elocução primitiva, cuja incapacidade para refrear a vocalização dos sentimentos muitas vezes solaparia o modo narrativo. No entanto, esse traço de reflexividade na representação literária encontra o máximo de sua elaboração formal, como discutimos acima, num gênero novelístico em que se apreende a narração como se se desdobrasse do presente para o futuro: o romance epistolar. ${ }^{470}$ De Pamela em diante, deparamo-nos com narradores (na maioria dos casos, narradoras) que não conseguem continuar, num expediente cujo acúmulo constitui uma retórica do inefável. ${ }^{471} \mathrm{Um}$ dos topoi mais comuns dessa retórica é o deitar da pena. A primeira parte de Pamela in her exalted condition (Pamela 2) abunda em trechos em que se dramatiza o ato de narrar. Assim, quando Mr Andrews, o pai da protagonista, examina sua condição atual, a alegria arrebenta em seu coração e ele se vê forçado a recuperar o fôlego:

\footnotetext{
${ }^{468}$ FIELDING, Henry. Tom Jones, um enjeitado cit., v. 1, p. 155. No original: "we have laid it down as a Rule necessary to be observed in all prosai-comic-epic Writing" (FIELDING, Henry. Tom Jones cit., p. 187). Sobre os capítulos introdutórios de Tom Jones, ver: CHIBKA, Robert L. "Taking "the serious' seriously: the introductory chapters of Tom Jones". The eighteenth century, v. 31, n. 1 (primavera, 1990), p. 23-45; VASCONCELOS, Sandra Guardini T. "Ensaios teóricos: os capítulos introdutórios de Henry Fielding". Psicologia USP, v. 11, n. 2 (2000), p. 171-185; e BOOTH, Wayne C. The rhetoric of fiction. 2. ed. Chicago - Londres: University of Chicago, 1983, p. 215-218. Sobre "os escritos prosai-comi-épicos", ver supra 176.

469 "Her eyes are turned to the hill; again the stately form came down. She rose, in the midst of joy. $\mathrm{He}$ retired in mist. Gradual vanish his limbs of smoak, and mix with the mountain-wind.-Then she knew that he fell! 'King of Erin art thou low!'-Let Ossian forget her grief; it wastes the soul of age" (MACPHERSON, James. "Temora: an epic poem". The poems of Ossian and related works cit., p. 292).

${ }^{470}$ KONIGSBERG, Ira. Narrative technique in the English novel cit., p. 93-94.

${ }^{471}$ Ver supra, p. 221.
} 
Oh, minha querida filha, quem pode suportar tudo isso? - Desculpeme! - preciso parar um pouco, pois meus olhos estão tão cheios quanto meu coração. Retirar-me-ei para abençoar a Deus e teu honrado esposo! ${ }^{472}$

De modo semelhante, em The history of Lady Julia of Mandeville (1763), de Frances Brooke, quando Anne vai relatar o duelo que leva Mandeville à morte, a caneta vacila: "Bellville! Seus ferimentos são mortais - a caneta cai de minha mão!". ${ }^{473}$ Além de largarem a pena quando a emoção se mostra incontrolável, narradores e narradoras epistolares abdicam de sua função, deixando para que terceiros (amigos ou editores) completem a empreitada. Em The memoirs of Miss Sidney Bidulph (1761), a narradora epônima simplesmente abandona o registro de seu sofrimento ao descobrir que incorrera em bigamia ao se casar com Mr Faukland, pois, ao contrário do que se suspeitava, a esposa dele não havia morrido: “Adeus, minha Cecília, adeus; nada senão a minha morte pode fechar uma cena como esta". ${ }^{474} \mathrm{Em}$ meados do século XVIII, tratava-se de uma técnica narrativa tão consolidada que pode ser encontrada, como paródia, até mesmo em escritos pornográficos. Em Fanny Hill (1748), de John Cleland, o rememorar da noite de núpcias infecta a narradora do antigo prazer e impede-a de seguir narrando:

[...] Vejo! Sinto! a deliciosa ponta aveludada! - ele me penetra forte e poderoso, com - oh! - minha caneta cai aqui por conta do êxtase agora recuperado por minha memória fiel! A descrição também me abandona e renuncia a tarefa, acima de suas forças, à imaginação $[\ldots] .{ }^{475}$

Paralelamente às manifestações explícitas de reflexividade narrativa, eleva-se ao nível da forma a distância de Ossian ao universo configurado pela ação épica. Assim como a incompatibilidade de Clarissa com a trama enredada por Lovelace satura sua narrativa epistolar de travessões, fragmentos, poemas líricos e meditações, demarca-se

\footnotetext{
472 "O my dear Daughter, who can bear these Things! - Excuse me-I must break off a little, for my Eyes are as full as my Heart; and I will retire to bless God and your honoured Husband" (RICHARDSON, Samuel. Pamela in her exalted condition. Ed. Albert J. Rivero. Cambridge: Cambridge University, 2012, p. 9).

473 "Bellville! his wounds are mortal - the pen drops from my hand" (BROOKE, Frances. The history of Lady Julia of Mandeville. By the Translator of Lady Catesby's letters. Londres, 1763, v. 2, p. 149).

${ }^{474}$ SHERIDAN, Frances. The memoirs of Miss Sidney Bidulph. Ed. Heidi Hunter; Nicole Garret. Peterborough, ON: Broadview, 2011, p. 459.

475 “'... I see! I feel! the delicious velvet tip! — he enters me might and main, with—oh!—my pen drops from me here in the extasy now present to my faithful memory! Description too deserts me, and delivers over a task, above its strength of Wing, to the imagination [...]" (CLELAND, John. Memoirs of a woman of pleasure. Ed. Peter Sabor. Oxford: Oxford University, 1999, p. 183).
} 
a fratura entre o narrador e o narrado em modulações ao registro da epopeia. De fato: em Fingal e Temora também se entabula um jogo em que o adensamento do enredo engendra instâncias que rompem com a lógica da forma. Nos momentos em que Ossian está para se consagrar, de acordo com a doutrina neoclássica, como um artífice do gênero épico, aparece uma rachadura no edifício, a indicar a irrealizabilidade de sua empreitada. ${ }^{476}$ Tomemos como exemplo a abertura do "Livro IV" de Fingal. Até aqui, é verdade, a voz do narrador se havia subjetivado nalgumas oportunidades. ${ }^{477}$ Mesmo assim, isso sempre se dera por meio de pequenos excursos performáticos, geralmente de algumas linhas. Algo diferente acontece neste ponto, no entanto. Quando caledônios e os escandinavos se preparam para sua grande batalha, introduzse um longo episódio sobre o encontro de Ossian com sua amada Everallin.

Inicialmente, desloca-se o eixo temporal do passado para o momento da narração, no qual se apostrofa, pela primeira em todos os Poemas de Ossian, Malvina, a "filha de Toscar". Pergunta-se a ela se vem "para as batalhas do teu povo, e para ouvir as ações de Oscar?". ${ }^{478}$ Malvina não responde. Mas também não se dá prosseguimento ao que seria a rememoração das batalhas do povo de Malvina. Pelo contrário: o narrador parece mais interessado em falar de si e de suas próprias ações:

Quando deixarei de lamentar às margens da ecoante Cona? Meus anos se passaram na batalha, e minha velhice é escurecida pelo pesar. [...] Eu não era tão triste e cego; não era tão sombrio e esquecido quando Everallin me amava. ${ }^{479}$

Everallin seria uma donzela irlandesa, por quem Cormac se apaixonara. Ela, no entanto, rejeita o pretendente, "pois gracioso aos seus olhos era Ossian". ${ }^{480}$ Quando estavam prestes a se casar, "na colina, apareceu a gente do imponente Cormac". ${ }^{481}$ Trava-se uma luta pela moça, mas ao final Ossian decapita seu oponente. O episódio pouco contribui para o desenvolvimento do enredo, embora o fantasma de Everallin acabe por visitar o Ossian-personagem, para avisá-lo de que Oscar corre perigo. Sua

\footnotetext{
${ }^{476}$ Sobre a inserção de episódios em Fingal, ver STAFFORD, Fiona J. The sublime savage cit., p. 140.

${ }^{477}$ Ver supra, p. 142.

${ }^{478}$ Trecho integral: "Dost thou come to the battles of thy people, and to hear the actions of Oscar?" (MACPHERSON, James. "Fingal: an epic poem". The poems of Ossian and related works cit., p. 83).

479 "When shall I cease to mourn by the streams of the echoing Cona? My years have passed away in battle, and my age is darkened with sorrow. [...] I was not so mournful and blind; I was not so dark and forlorn when Everallin loved me" (idem, ibidem).

480 “[...] for graceful in her eyes was Ossian" (idem, ibidem).

481 "[.... on the hill appeared the people of stately Cormac" (idem, ibidem).
} 
função na economia da obra, entretanto, é personificar um narrador cuja individuação só pode ser obtida fora do universo narrado:

Quem me houvesse dito, amável donzela, quando eu lutava na batalha, que, cego, desamparado e esquecido, hoje eu passaria a noite, firme precisaria ser a sua armadura e inigualável o seu braço na batalha. ${ }^{482}$

Essa separação entre o "quando eu lutava na batalha" e o "hoje" em que "passaria a noite" é comunicada pela ausência de conexão entre o episódio de Everallin e as guerras do povo de Malvina.

Caso semelhante a este pode ser encontrado ao final do "Livro Sétimo" de Temora, logo depois que Cathmor e Fingal convocam suas tropas para o confronto final. Pende a resolução do conflito ancestral entre os Fir-bolg e os caledônios, conforme discutimos no item 4.3.2 do capítulo anterior. Um bardo realça a dimensão transcendente desse embate, ao celebrar os feitos de Larthon, um antepassado de Cathmor, que "marchou rumo às corças de Erin". ${ }^{483}$ Terminado o curto episódio, Cathmor e seus homens partem em direção ao exército de Fingal. Sul-malla, a amada do irlandês, despede-se com olhos marejados. A caminhada para o encontro climático, contudo, é interrompida - e aqui cito o próprio tradutor e editor - por "uma canção lírica". Interpela-se o "filho de Alpin" e pede-se-lhe que tanja sua harpa, para trazer um pouco de alegria a Ossian: "Filho de Alpin, tange a corda. Há uma réstia de alegria nessa harpa? Verte-a, então, sobre a alma de Ossian: está envolta pela névoa". ${ }^{484}$ A melodia, no entanto, não o reconforta. Pede para que se ponha a harpa de lado: "Ouço-te, ó bardo, em minha escuridão. Mas cessa com essa toada trêmula. A alegria do sofrimento pertence a Ossian, em seus anos castanho-escuros". ${ }^{485}$ A canção do bardo explicita o silêncio que envolve o narrador: ${ }^{486}$

\footnotetext{
482 "Whoever would have told me, lovely maid, when then I strove in battle; that blind, forsaken, and forlorn I now should pass the night; firm ought his mail to have been, and unmatched his arm in battle" (idem, p. 84).

483 "He went forth to the roes of Erin" (MACPHERSON, James. "Temora: an epic poem". The poems of Ossian and related works cit., p. 283).

484 "Son of Alpin, strike the string. Is there ought of joy in the harp? Pour it then, on the soul of Ossian: it is folded in mist" (idem, ibidem).

485 "I hear thee, O bard, in my night. But cease the lightly-trembling sound. The joy of grief belongs to Ossian, amidst his dark-brown years" (idem, ibidem).

${ }^{486}$ Ver KEYMER, Thomas. "Narratives of loss: The poems of Ossian and Tristram Shandy". In: GASKILL, Howard; STAFFORD, Fiona J. (ed.). From Gaelic to romantic cit., p. 94; KEYMER, Thomas. Sterne, the Moderns, and the novel cit., p. 172 e ss.; WEINBROT, Howard D. Britannia's issue cit., p. 530; e STAFFORD, Fiona J. The last of the race: the growth of a myth from Milton to Darwin. Oxford: Clarendon, 1994, p. 105.
} 
Espinho verde da colina dos fantasmas, que se verga aos ventos noturnos! Não ouço som de ti. $\mathrm{O}$ traje aéreo dos espíritos não farfalha as tuas folhas? Muitos sãos os passos dos mortos, no negro vórtice da borrasca, quando a lua, um escudo opaco, ${ }^{487}$ desliza pelo céu. $^{488}$

E a mudez das "vozes de outrora":

Ullin, Carril e Ryno, as vozes de outrora. Quero ouvi-los, na escuridão de Selma, e despertar a alma das canções. - Não vos ouço, criaturas musicais! Em que nuvem repousais? Tocais a harpa umbral, trajados na névoa da manhã, onde mergulha o sol vindo das verdes vagas?

Finda "a canção lírica", passa-se ao combate entre os irlandeses e escoceses. A celebração dos feitos de Fingal e Cathmor, no entanto, não dissolve a "escuridão de Selma". Nem a sua harpa nem a de seus contemporâneos, como o filho de Alpin, conseguem "despertar a alma" de Ossian. Para tanto, as "vozes de outrora" precisariam fazer-se ouvir na "colina dos fantasmas". Ossian, contudo, não pode mais escutá-las.

Modulações à narrativa - e à narração! - épica como as que analisamos acabam por refigurá-la. As fraturas na forma explicitam, como em Clarissa ou mesmo Oroonoko, que a persistência de uma estrutura proveniente das "vozes do passado", para que se lhe possa atribuir sentido, requer a mediação de um repertório discursivo que a deslegitima, que expõe a sua extemporaneidade. ${ }^{490}$ Ossian só consegue celebrar feitos heroicos na medida em que consigna o esgotamento e - por que não? - a artificialidade do objeto de sua celebração. Trata-se de uma dialética que não se esgota na relação entre o narrador e o narrado, mas que perpassa as relações entre as próprias personagens.

${ }^{487}$ Lua nova?

488 "Green thorn of the hill of ghosts, that shakest thy head to nightly winds! I hear no sound in thee; is there no spirit's windy skirt now rustling in thy leaves? Often are the steps of the dead, in the darkeddying blasts; when the moon, a dun shield, from the east, is rolled along the sky" (MACPHERSON, James. "Temora: an epic poem". The poems of Ossian and related works cit., p. 283).

489 "Ullin, Carril and Ryno, voices of the days of old! Let me hear you, in the darkness of Selma, and awake the soul of songs._ I hear you not, ye children of music, in what hall of the clouds is your rest? Do you touch the shadowy harp, robed with morning mist, where the sun comes sounding forth from his green-headed waves?" (idem, ibidem).

${ }^{490}$ Veja-se a discussão de Raymond Williams sobre o residual e o emergente (WILLIAMS, Raymond. Marxism and literature cit., p. 121-127). No enredo, sedimentar-se-ia a ideologia residual, ao passo que os trechos discursivos vocalizam os elementos mais progressistas da obra, onde se localizam seus pronunciamentos políticos. 
O movimento da ação ostensivamente se enfeixa nas figuras de Swaran e Fingal, no primeiro épico ossiânico, e de Fingal e Cathmor, no segundo. Crucialmente, esses três heróis são dotados de plena agência. Indiferentes às determinações do espaço e do tempo, seus movimentos não são constritos por montanhas, rios e mares. No confronto entre os soberanos de Morven e Lochlin, em Fingal, desenraizam-se montanhas e obstrui-se o fluxo dos rios. ${ }^{491}$ Em Temora, nas lanças de Cathmor e Fingal se enfeixa um conflito secular entre os caledônios e os irlandeses do sul, ao final do qual se vislumbra a transcendência do processo histórico. ${ }^{492}$ Mais especificamente, correlaciona-se a compressão temporal e espacial, derivada do receituário neoclássico, ao controle heroico da ação sob a qual se unificam todos os eventos narrados. Vinculam-se o movimento e a organização da ação às intervenções de suas majestades, num procedimento que é explicitado pelo manejo de profecias e antecipações. ${ }^{493}$ Numa imagem recorrente, aqueles "dotados de consequência política" ${ }^{494}$ contemplam os outros como uma massa indistinta. Frequentemente, reforça-se esse contraste pela desumanização dos demais, a enfatizar a transcendência do herói. Quando Swaran vai ao encontro dos navios de Morven, representam-se seus soldados anônimos "como as marés do mar ressoante pelas centenas de ilhas de Inistore". ${ }^{495}$ De maneira semelhante, "Fingal, ardendo em sua ira, consumiu os filhos de Lochlin" como se eles fossem folhas secas de relva. "Gemidos se sobrepunham a gemidos, de colina a colina, até que a noite os engolfou. Pálidos, assustados como um rebanho de cervos, os filhos de Lochlin reúnem-se em Lena". ${ }^{496} \mathrm{Na}$ mesma toada, em Temora, as tropas de Cathmor vêm ao seu chamado, "como um mar agitado, ao sentir as asas do vento. As ondas não sabem para onde fluir; levantam suas cristas revoltas". 497

\footnotetext{
${ }^{491}$ Ver supra, p. 82.

${ }^{492}$ Ver supra, p. 129 e ss.

${ }^{493}$ Ver supra, p. 116.

${ }^{494}$ LE BOSSU, René. Traité du poëme épique cit., p. 113.
}

495 "As ebbs the resounding sea through the hundred isles of Inis-tore" (MACPHERSON, James. "Fingal: an epic poem". The poems of Ossian and related works cit., p. 75).

${ }^{496}$ Trecho integral: "Who can relate the deaths of the people; or the deeds of mighty heroes; when Fingal, burning in his wrath, consumed the sons of Lochlin? Groans swelled on groans from hill to hill, till night had covered all. Pale, staring like a herd of deer, the sons of Lochlin convene on Lena" (idem, p. 77).

${ }^{497}$ Trecho integral: "His host heard the shield of Cathmor: at once they rose around; like a crowded sea, when first it feels the wings of the wind. The waves know not whither to roll; they lift their troubled heads" (MACPHERSON, James. "Temora: an epic poem". The poems of Ossian and related works cit., p. 283). 
Em Fingal, Swaran desponta no horizonte para enredar os irlandeses numa guerra suicida, num desastre antecipado desde o princípio. Moran, a sentinela, exorta Cuchullin logo na abertura da narrativa a evitar o pior. Ouvira Swaran dizer: "Que o sombrio Cuchullin se renda àquele que é forte como as tempestades de Malmor". ${ }^{498}$ Igualmente, o fantasma de Crugal aparece no "Livro II" para profetizar a queda dos irlandeses. Aconselha-os a implorar por clemência. Mas não há como se opor ao rei de Lochlin:

[...] Swaran avançava como uma corredeira que irrompe do deserto. As pequenas colinas estão revolvidas em seu curso e as rochas, quase submersas às suas margens [...].

— Ó, filhos de Innis-fail — disse Grumal, — Lochlin conquista o campo. Para que lutarmos como o junco contra o vento? Fujamos para as colinas das corças castanhas! - Fugiu como um cervo de Morven. Sua lança é um feixe trêmulo de luz atrás de si. ${ }^{499}$

Será a Fingal que se atribuirão a retorsão do enredo e a consequente libertação dos irlandeses. Efetivamente, Fingal enreda o rei de Lochlin numa nova intriga: "Swaran os viu do alto de uma colina e retornou dos filhos de Erin". ${ }^{500}$ Os contornos que a ação assumirá já haviam sido prefigurados por Carril, a quem se delega a narrativa, discutida páginas atrás, da expedição de Fingal à Escandinávia. ${ }^{501}$ Ao ouvir o relato de Carril, Cuchullin antecipa os desdobramentos dos três últimos "Livros" de Fingal: "Forte era a juventude de Fingal, e forte é seu braço maduro. Lochlin tombará outra vez diante do rei da ecoante Morven". ${ }^{502}$ E é literalmente o braço de Fingal que fecha a ação. Num expediente que se repetiria em Temora, o rei de Morven de início se abstém da luta, para que seus guerreiros conquistem a fama. Ryno e Gaul, contudo, não conseguem repelir o ímpeto de Lochlin e o chefe escocês acaba por intervir. Rapidamente, triunfa sobre os escandinavos e vence Swaran num combate singular. ${ }^{503}$

\footnotetext{
498 "Let dark Cuchullin yield to him that is strong as the storms of Malmor" (MACPHERSON, James. "Fingal: an epic poem". The poems of Ossian and related works cit., p. 55).

499 " [...] Swaran advanced, as a stream that bursts from the desart. The little hills are rolled in its course; and the rocks half-sunk by its side. [...] O sons of Innis-fail, said Grumal, Lochlin conquers on the field. Why strive we as reeds against the wind? Fly to the hill of dark-brown hinds. He fled like the stag of Morven, and his spear is a trembling beam of light behind him" (idem, p. 68).

500 "Swaran saw them from the hill, and returned from the sons of Erin" (idem, p. 75).

${ }^{501}$ Vide supra, p. 121.

502 "Strong was the youth of Fingal, and strong is his arm of age. Lochlin shall fall again before the king of echoing Morven" (MACPHERSON, James. "Fingal: an epic poem". The poems of Ossian and related works cit., p. 75).

${ }^{503}$ Dafydd Moore compara a ausência de Fingal à de Charles Grandison, no romance epônimo, como uma estratégia narrativa para conciliar força e sensibilidade (MOORE, Dafydd. Enlightenment
} 
Decisivamente, deriva-se o controle que Swaran e Fingal exercem sobre a ação à sua masculinidade. Os heróis entrariam em cena de arma em punho, a conferir uma dimensão fálica à sua proeza marcial. Ao avistar a chegada dos escandinavos às praias de Erin, Moran, a sentinela, diz aterrorizado: "Eu vi seu chefe [...] alto como uma rocha de gelo. Sua lança é como o abeto queimado. Seu escudo, como a lua nascente". ${ }^{504}$ E quando o rei de Lochlin divisa a nau de Fingal, será ele a reparar que seu oponente "estendia sua lança luminosa diante de si". ${ }^{505}$ A simetria evidente entre as imagens expõe a centralidade dada ao armamento, que emerge como extensão do herói. De maneira mais específica, as armas são cuidadosamente associadas à ascendência de Swaran e Fingal sobre os demais. No ataque inaugural aos irlandeses, Swaran ordena aos escandinavos para que se reúnam "em volta do aço luminoso de seu rei". ${ }^{506}$ Em sua primeira marcha à batalha, Fingal brande não só a sua "lança luminosa", mas outra também, e depois uma espada.

Terrível é a luz de sua armadura, e duas lanças estão em suas mãos. - Seus cabelos cendrados esvoaçam ao vento. - Várias vezes olha para trás, para a guerra. Três bardos acompanham o filho da glória, para levar suas palavras a seus heróis. - No alto, ao sopé de Cromla ele se sentou, a brandir o relâmpago de sua espada e, conforme ele brandia, nós seguíamos. ${ }^{507}$

Em Temora, fecha-se o enredo ancestral da luta entre os caledônios e os Fir-bolg por meio do manejo da tópica da lança. No "Livro Sétimo", Fingal marcha para sua batalha final, em sua última expedição. Convoca seus homens mediante um alarme produzido por sua "lança mortal", que golpeia contra seu escudo. ${ }^{508}$ Cathmor responde da mesma maneira: "Sob a lança de Cathmor, despertou-se aquela voz que desperta os bardos". ${ }^{509}$ No "Livro Oitavo", Fingal adentra o campo de batalha. Sua lança o antecede e sobressai-se no nevoeiro: “Agora avança o rei. — Primeiro

and romance in James Macpherson's The Poems of Ossian cit., p. 132). Pessoalmente, creio que o precedente seja efetivamente épico. Basta pensarmos nos exemplos de Aquiles e Rinaldo.

504 "I saw their chief, says Moran, tall as a rock of ice. His spear is like that blasted fir. His shield like the rising moon" (MACPHERSON, James. "Fingal: an epic poem". The poems of Ossian and related works cit., p. 55).

${ }^{505}$ Trecho integral: "Fingal, tall in his ship, stretched his bright lance before him" (idem, p. 76).

${ }^{506}$ Trecho integral: "Gather round the bright steel of your king" (idem, p. 59).

507 "Terrible is the light of his armour, and two spears are in his hand.-His gray hair falls on the wind.-He often looks back on the war. Three bards attend the son of fame, to carry his words to the heroes.-High on Cromla's side he sat, waving the lightning of his sword, and as he waved we moved" (idem, p. 85).

508 “[...] deathful spear" (MACPHERSON, James. "Temora: an epic poem". The poems of Ossian and related works cit., p. 278). Ver supra, p. 134.

509 "Beneath the spear of Cathmor, awaked that voice which awakes the bards" (idem, p. 282). 
apareceu a espada de Luno; a lança em parte a emergir das nuvens, o escudo ainda oculto pela névoa". ${ }^{510}$ Do lado oposto, desponta Cathmor. Sua lança também o precede: "Devagar, detrás de uma rocha, ergueu-se a luminosa forma de Atha. Primeiro apareceram as duas pontas de suas lanças, depois parte de seu escudo lustroso". 511 O duelo final não é representado. Uma névoa envolve os combatentes. Quando ela se dissipa, o irlandês está recostado contra uma rocha, agonizante. Sua derrota, o expirar de sua potência, é indicada pela pergunta do escocês: "Rende-se a raça de Borbar-duthul? Ou ele ainda levanta sua lança?". 512

Sob o enredo que se enfeixa na ponta das lanças de Swaran, Fingal e Cathmor, há uma multidão de personagens vitimadas pela fortuna. ${ }^{513}$ Guerreiros derrotados como Cuchullin, que, "curvado, choroso, triste e vagaroso", arrasta sua "longa lança atrás" de si. ${ }^{514}$ Mulheres como Sul-malla, que se disfarça de soldado para seguir seu amado no combate, ou como Inibaca, que tenta defender seu pai, mas não tem força para empunhar uma arma. Fantasmas como os de Crugal e Cairbar, cujas palavras se dissipam no vento. Velhos como Cormac, que vê estrangeiros invadirem suas terras, enquanto caminha com "seus passos idosos", apoiado numa "lança sem ponta". 515 Jovens como Orla, que anseia pela glória e mete-se num confronto desigual, ou como Fillan, que morre em sua primeira expedição, sem alcançar renome. Ou até mesmo o cão Bran, que uiva sobre o escudo bipartido de seu dono. E mais uma infinidade de esposas que pranteiam sobre a espada de seu marido, soldados que morrem anônimos, crianças que não podem brandir a alabarda do pai etc. Irmanadas em sua tristeza, essas personagens têm uma similaridade que acaba por dissolver a rígida distinção social e de gênero que heróis como Fingal parecem impor. Tome-se o caso de Cuchullin. A perda de sua masculinidade torna-se patente no primeiro de seus muitos

\footnotetext{
510 "Now is the coming forth of the king.-First appeared the sword of Luno; the spear half issuing from a cloud, the shield still dim in mist" (idem, p. 286).

511 "Slowly, from behind a rock, rose the bright form of Atha. First appeared his two pointed spears, then the half of his burnished shield" (idem, p. 289).

512 "Yields the race of Borbar-duthul? Or still does he lift the spear?" (idem, p. 290). Ver supra, p. 135.

${ }^{513}$ MOORE, Dafydd. "Heroic incoherence in James Macpherson's The Poems of Ossian" cit., p. 51.

514 "[...] bending, weeping, sad, and slow, and dragging his long spear behind [...]" (MACPHERSON, James. "Fingal: an epic poem". The poems of Ossian and related works cit., p. 75).

515 Trecho integral: "[...] on his pointless spear, came forth the aged steps of Cormac" (MACPHERSON, James. "Temora: an epic poem". The poems of Ossian and related works cit., p. 255).
} 
lamentos. Significativamente, atribui sua derrota para Swaran ao fato de ter matado Ferda, um amigo com o qual partilhava o leito na charneca:

Infeliz é a mão de Cuchullin — disse o filho de Semo —, infeliz é a mão de Cuchullin desde que matou seu amigo! Ferda, filho de Damman, eu te amava como a mim mesmo.

[...] De Albion veio Ferda, o chefe de centenas de colinas. No salão de Muri ele aprendeu a usar a espada e conquistou a amizade de Cuchullin. Íamos caçar juntos, e uma só era a nossa cama na charneca. ${ }^{516}$

Personagens como Cuchullin são marcadas pela impotência, pela incapacidade de moldar ou influir nos desdobramentos da ação épica. Com suas lanças sem ponta, são vítimas do enredo, do destino de grandeza e transcendência reservado aos heróis. Algumas das manifestações mais recorrentes desse sentimento de impotência, como em Clarissa, são as lágrimas:

Seus pensamentos estão na batalha que ele [Cuchullin] perdeu; e a lágrima está em sua bochecha. Ele lamentava a partida da fama, como a névoa de Cona. ${ }^{517}$

Mesmo os fantasmas não conseguem impedir o desastre. Em Fingal, Crugal até avisa os irlandeses do massacre iminente. Mas os fantasmas de Ossian não são como os deuses homéricos, cuja intervenção efetivamente tem influência nos desdobramentos da ação. Nas epopeias ossiânicas, ninguém dá ouvidos a essas criaturas diáfanas. ${ }^{518} \mathrm{E}$,

\footnotetext{
516 "Unhappy is the hand of Cuchullin, said the son of Semo, unhappy is the hand of Cuchullin since he slew his friend. - Ferda, thou son of Damman, I loved thee as myself. [...] Ferda from Albion came, the chief of a hundred hills. In Muri's hall he learned the sword, and won the friendship of Cuchullin. We moved to the chace together; and one was our bed in the heath" (MACPHERSON, James. "Fingal: an epic poem". The poems of Ossian and related works cit., p. 69). Para um estudo sobre as identidades de gênero nos Poemas de Ossian, ver: KOZLOWSKI, Lisa. "Terrible women and tender men: a study of gender in Macpherson's Ossian”. In: GASKILL, Howard; STAFFORD, Fiona J. (ed.). From Gaelic to romantic cit., p. 119-135.

517 "His thoughts are on the battle he lost; and the tear is on his cheek. He mourned the departure of his fame that fled like the mist of Cona" (MACPHERSON, James. "Fingal: an epic poem". The poems of Ossian and related works cit., p. 95).

${ }^{518}$ Malcolm Laing, com a mordacidade costumeira, diz que Machperson "[...] criou uma sociedade selvagem de ateus refinados, que acreditam em fantasmas, mas não em divindades" ("[...] created a savage society of refined atheists, who believe in ghots but not in deities") (LAING, Malcolm. The history of Scotland, from the Union of the Crowns on the accession of James VI to the throne of England, to the Union of the Kingdoms in the reign of Queen Anne. Londres: I. Cadwell Jr and W. Davies, 1800, v. 2, p. 396). Num estudo sobre as leituras de Werther aos Poemas de Ossian, F. J. Lamport associa o mundo sem Deus da personagem goethiana ao universo ossiânico do qual divindade desertou (LAMPORT, F. J. "Goethe, Ossian, and Werther". In: GASKILL, Howard; STAFFORD, Fiona J. (ed.). From Gaelic to romantic cit., p. 97-106, especialmente p. 101). Para Stafford, o sobrenatural e as concepções de vida e morte têm uma conformação não cristã nas composições ossiânicas (STAFFORD, Fiona J. The last of the race cit., p. 105). Cabe acrescentar, por fim, que Lukács toma a ausência de divindade como um dos elementos definidores do romance (LUKÁCS, Georg. A teoria do romance cit., p. 89).
} 
entre os vivos, o rei infante Cormac II se desespera ao saber que o ataque de Cairbar se aproxima e que Cuchullin, seu protetor, não poderá acudi-lo:

Filho de Conachan! Morreu o rei de Tura? Por que suspiras em segredo? Por que cai essa lágrima? - Aproxima-se o aurígico Torlath? Ou o som do ruivo Cairbar? - Eles vêm! — pois vejo teu pesar. O rei da musgosa Tura está morto! - Eu não deveria correr para a batalha? - Mas não consigo levantar a lança! — Oh! Se meu braço tivesse a força do de Cuchullin, logo Cairbar fugiria; a glória de meus pais seria renovada; e os feitos de outrora! ${ }^{519}$

Indefeso, o rei se dá conta de seu isolamento, de que ninguém virá ao seu socorro, de que nenhuma tropa se reunirá sob sua lança. Sua condição de monarca não serve de anteparo à fúria dos acontecimentos. Como Oroonoko, descobre que há forças maiores e mais incontroláveis que sua linhagem. A ruptura do tecido social, como transparece em sua ansiedade por renovar a glória de seus antepassados, transforma-o numa personagem vulneravelmente comum. Se a narrativa novelística lida, como é o caso explícito de Robinson Crusoe, ${ }^{520} \mathrm{com}$ "homens privados", os ditos épicos ossiânicos tematizam extensivamente o ocaso do que o século XVIII chamaria de "homem público". Tais "homens públicos", sejam da realeza ou da aristocracia, projetam uma noção de continuidade, ${ }^{521}$ na qual seu poder, seu nome e sua propriedade atravessam gerações. Trata-se, obviamente, de uma noção relacional, inscrita no papel reservado ao indivíduo na sociedade. Em Fingal e Temora, correlaciona-se a derrocada de inúmeras personagens imediatamente associáveis aos estamentos superiores à perda de sua função social hereditária, numa sequência marcada, primeiro, pelo isolamento e, depois, pelo oblívio ou esquecimento. ${ }^{522}$ Leiase esta passagem em que Cuchullin, escondido numa caverna depois de sua derrota para Swaran, exorta fantasmas para que venham visitá-lo:

Ó fantasmas da solitária Cromla! Espíritos dos chefes que se foram! Sede os companheiros de Cuchullin e conversai com ele em sua caverna de pesar, pois nunca serei renomado entre os grandes de minha terra. Sou como o raio de luz que brilhou, como uma neblina

\footnotetext{
519 "Son of Conachar! he said, is the king of Tura low? Why bursts thy sigh in secret? And why descends the tear? - Comes the car-borne Torlath? Or the sound of the red-haired Cairbar? —-They come! - for I behold thy grief. Mossy Tura's king is low! - Shall I not rush to battle? - But I cannot lift the spear! - O had mine arm the strength of Cuchullin, soon would Cairbar fly; the fame of my fathers would be renewed; and the deeds of other times!" (MACPHERSON, James. "Temora: an epic poem". The poems of Ossian and related works cit., p. 232).

${ }^{520}$ Vide supra, p. 209.

${ }^{521}$ Dialogamos com SENNETT, Richard. The fall of public man cit., p. 38.

${ }^{522}$ Ver STAFFORD, Fiona J. The last of the race cit., p. 104.
} 
soprada para longe, quando chegou a borrasca da manhã e ilumina a face escarpada da colina. ${ }^{523}$

Por meio da comparação ao evanescente feixe de luz, Cuchullin contrapõe a efemeridade dos derrotados à glória eterna atribuída aos vencedores. Ao final de Temora, Fingal brada que seu nome - atente-se para a imagem - "será trajado pela fama, um raio de luz para outros tempos". ${ }^{524}$ Cuchullin e seus semelhantes, por seu turno, são constantemente associados a imagens de transitoriedade, como túmulos cobertos pela grama, ruínas tomadas pelo líquen ou armas quebradas ao meio. Assim, "o escudo partido" de Fillan torna-se não apenas um símbolo de sua morte, mas uma metáfora metonímica do processo histórico, em que um povo sucede a outro:

Cathmor viu o cão de peito branco; ele viu o escudo partido. A escuridão é soprada de volta à sua alma. Ele se lembra da gente caída. Eles vêm, um córrego; são repelidos; outra raça os sucede. "Mas alguns marcam os campos, quando passam, com seus nomes poderosos. A charneca, através dos anos castanho-escuros, é sua; algum córrego azul uiva para sua fama $[\ldots]$ ".. ${ }^{525}$

Numa relação de complementariedade aos que se foram, estão os resquícios supérstites de uma ordem tragada pelo tempo. São os pais que choram os filhos que os precederam, as esposas que esperam inutilmente o regresso dos maridos e os epígonos que não conseguem vergar os arcos de seus antepassados:

Os filhos dos fracos encontrarão seu arco em casa, mas não conseguirão dobrá-lo. Seus leais cães uivam em suas colinas; e seus javalis, que ele costumava perseguir, regozijam-se. Caído está o braço da batalha. ${ }^{526}$

A incongruência entre aqueles para os quais as armas são um fardo e os heróis que conduzem multidões na ponta de suas lanças também se manifesta, conforme nossa análise do narrador ossiânico, no nível da forma. Em Fingal e Temora, as

\footnotetext{
523 "O ye ghosts of the lonely Cromla! ye souls of chiefs that are no more! be ye the companions of Cuchullin, and talk to him in the cave of his sorrow. For never more shall I be renowned among the mighty in the land. I am like a beam that has shone; like a mist that fled away, when the blast of the morning came, and brightened the shaggy side of the hill" (MACPHERSON, James. "Fingal: an epic poem". The poems of Ossian and related works cit., p. 88).

524 Trecho integral: "Fingal shall be clothed with fame, a beam of light to other times" (MACPHERSON, James. "Temora: an epic poem". The poems of Ossian and related works cit., p. 291).

525 "Cathmor saw the white-breasted dog; he saw the broken shield. Darkness is blown back on his soul; he remembers the falling away of the people. They came, a stream; are rolled away; another race succeeds. - 'But some mark the fields, as they pass, with their own mighty names. The heath, thro' dark-brown years, is theirs; some blue stream winds to their fame [...]"' (idem, p. 274).

526 "The sons of the feeble will find his bow at home, but will not be able to bend it. His faithful dogs howl on his hills; and his boars, which he used to pursue, rejoice. Fallen is the arm of battle!" (MACPHERSON, James. "Fingal: an epic poem". The Poems of Ossian and related works cit., p. 93).
} 
instâncias nas quais personagens vocalizam sofrimento muitas vezes tendem à fragmentação e modulação lírica. Em tais instâncias, mobilizam-se algumas das técnicas literárias mais intimamente associadas à elocução primitiva, para a qual a expressão não mediada das emoções sugeriria o descontrole formal. ${ }^{527}$ Por outro lado, tais técnicas, como se verá, aproximam a fala dos antigos celtas da escrita desarticulada que, em Richardson, atribuía-se às mulheres. ${ }^{528}$ De fato: assim como em Clarissa, os momentos de maior intensidade emocional são demarcados pelo uso desmesurado de travessões. É o caso da passagem do rei Cormac II, citada acima, em que o medo da morte dissolve a linguagem nesses sinais gráficos silenciosos. Ou, em Fingal, do relato que Connal faz a Cuchullin de seu encontro com o fantasma de Crugal. A gravidade do teor da profecia fragmenta sua fala:

Filho de Semo [...], o fantasma de Crugal veio da caverna da colina. - As estrelas brilhavam opacas através de sua forma; e sua voz era como o som de um córrego distante. - Ele é um mensageiro da morte. - Ele fala da casa sombria e escura. Implora pela paz, ó chefe de Dunscaich, ou foge pela charneca de Lena. ${ }^{529}$

Em meados do século XVIII, o emprego desses recursos paralinguísticos como meio de comunicar as contradições da vida dos sentimentos e emoções se tornara bastante disseminado, mormente por conta da ressonância do romance richardsoniano. ${ }^{530} \mathrm{E}$ possível argumentar, aliás, que os travessões se haviam convertido num idioma próprio, como mostram Tristram Shandy (1759-1767), de Laurence Sterne, e David Simple (1744), de Sarah Fielding, romance no qual o número e o tamanho desse tipo de intervenção gráfica se adensam conforme a narrativa caminha para a conclusão. No caso das personagens femininas, sua presença é ainda mais visível: substituem plenamente a fala de um gênero constrito a não expressar publicamente seus pensamentos. ${ }^{531}$ Leia-se uma fala de Juliè, em que a modulação da pontuação é bem mais expressiva que as palavras e frases efetivamente ditas:

\footnotetext{
${ }^{527}$ Ver supra, p. 82 e ss.

${ }^{528}$ Ver supra, p. 226 e 227.

529 "Son of Semo, replied the chief, the ghost of Crugal came from the cave of his hill.-The stars dim-twinkled through his form; and his voice was like the sound of a distant stream.- $\mathrm{He}$ is a messenger of death.-He speaks of the dark and narrow house. Sue for peace, O chief of Dunscaich; or fly over the heath of Lena" (MACPHERSON, James. "Fingal: an epic poem". The Poems of Ossian and related works cit., p. 64).

${ }^{530}$ PARKES, M. B. Pause and effect cit., p. 94.

${ }^{531}$ BARCHAS, Janine. Graphic design, print culture, and the eighteenth-century novel cit., p. 153172.
} 
Em que condição eu estava - o que eu poderia pensar! - - Meu irmão - - Dorimene - - Dumont - - - tudo parecia envolto por uma loucura comum, e eu não sabia a quem revelar meu pesar [...]. ${ }^{532}$

De modo decisivo, o emprego de travessões também se faria presente na recriação daquele que seria a elocução indígena. Em Lydia, or filial piety (1755), de John Shebbeare, a intensa vida emocional atribuída aos índios norte-americanos se converte numa fala às margens da desintegração. Uma jovem índia da tribo Onnondagan, Yarico, desespera-se ante a iminente partida de seu amado, Cannassatego, rumo à Europa, para reclamar junto à metrópole do tratamento que os colonos dispensam aos nativos:

Ser separada de tudo que amo por mundos intervenientes - Nunca ouvir a tua voz doce para me dizer que estás bem. - Temer mil perigos, e não provar nenhum consolo. - Quem pode tolerar isso? - Oh, Cannassatego, ensina-me como suportar esta angústia! ${ }^{533}$

Condensam-se a parataxe atribuída à elocução primitiva e a desarticulação que se vislumbra na escrita feminina. ${ }^{534}$ Além da emotividade, o índio e as mulheres teriam em comum um modo de escrever ou falar que fugiria do decoro augustano, que prescrevia simplicidade, elevação e nobreza. De certa maneira, o desenvolvimento de suas vozes se dá como um exercício de desconstrução de um estilo tido como belo e correto, em que se sacrifica um ideal estético para a incorporação da alteridade. ${ }^{535}$

Ao lado da fragmentação paralinguística, modulações líricas à narrativa constituem momentos privilegiados nas epopeias ossiânicas para a expressão de sentimentos. Quase sempre indicados pelo próprio tradutor em suas notas de rodapé,

\footnotetext{
532 "What a Condition was I in - what could I think! - - -My Brother- - Dorimene- - Dumont - - -all seemed involved in one common Madness; and I knew not to whom to go to disclose my Griefs [...]" (FIELDING, Sarah. The adventures of David simple and Volume the last. Ed. Peter Sabor. Lexington: The University Press of Kentucky, 1998, p. 189).

533 “To be divided from all I love by interposing Worlds - Never to hear one sweet accent which may tell me thou art well.-To dread a thousand Dangers, and to taste no Relief-Can I bear this?Oh! Cannassatego, teach me to support this anguish!” ([SHEBBEARE, John]. Lydia, or filial piety. A novel. Londres: Printed for J. Scott, at the Black Swan, in Pater-noster-row, 1755, v. 1, p. 47).

${ }^{534}$ Em sua Dissertação, Blair estenderia suas considerações sobre a elocução primitiva aos índios americanos: "Um cacique americano, hoje em dia, perora defronte de sua tribo num estilo muito mais arrojado e metafórico que um europeu moderno se aventuraria a usar num poema épico" ("An American chief, at this day, harangues at the head of his tribe, in a more bold and metaphorical style, than a modern European would adventure to use in an Epic poem") (BLAIR, Hugh. A critical dissertation on the poems of Ossian cit., p. 346). Ver supra, p. 15.

${ }^{535}$ Ver BAKHTIN, Mikhail M. "Discourse in the novel" cit., p. 324 e PITTOCK, Murray. Scottish and Irish romanticism cit., p. 7. Sobre as semelhanças entre Ossian e o dito romance indianista, gênero que se consolidaria no século XIX, ver: FRIDÉN, Georg. James Fenimore Cooper and Ossian. Upsala: A.-B. Lundequistska Bokhanden, 1949, passim; AGUIAR, Ofir Bergemann de. Ossian no Brasil. Goiânia: UFG, 1999, p. 83-93; BÄR, Gerald. "A recepção dos textos ossiânicos". Poesias de Ossian: antologia das traduções em português cit., p. 57-152, especialmente p. 67-69.
} 
em tais trechos personagens tendem a "derramar a sua própria canção triste". 536 Significativamente, tais "canções" demarcam, com sua ruptura no ritmo e no modo presentacional, o isolamento da personagem que se converte em sujeito poético. Em Temora, Sul-malla, a amada de Cathmor, ao ver o rei dos irlandeses reunir as suas tropas para a guerra, "ergue a voz da canção, enquanto toca a harpa" ${ }^{537}$ Entoa o que seria um diálogo lírico entre a própria Sul-malla e sua mãe, Clun-galo. Dramatiza-se a busca da mãe por sua filha, que desapareceu para fugir com seu namorado. $O$ desespero da mãe se corporifica num ritmo instável, ${ }^{538}$ cujas variações são sinalizadas por travessões. Ao dar por falta de Sul-malla, Clun-galo pergunta:

— Onde estás, raio de luz?

- Where art thou, beam of light?

Inquire alguns caçadores para saber se a viram. Pergunta a si mesma se ela saíra para caçar:

[...] vistes a bela de olhos azuis? - Estão seus passos na relvosa Lumon, perto do leito das corças?

[...] saw you the blue-eyed fair? - Are her steps on grassy Lumon; near the bed of roes?

Mas Sul-malla partiu. E Clun-galo pergunta outra vez:

— Onde estás, raio de luz?

—Where art thou, beam of light?

A jovem não voltará. Deixara Lumon para trás para, disfarçada de soldado, seguir Cathmor, cujo

[...] caminho é terrível na guerra.

$[\ldots]$ whose path is terrible in war.

O rei, no entanto, é como um sol no alto dos céus e não consegue divisar a jovem em meio à multidão:

Por que, sol de Sul-malla, não olhas adiante? - Vivo aqui na escuridão [...].

Why sun of Sul-malla, dost thou not look forth? - I dwell in darkness here $[\ldots] .{ }^{539}$

\footnotetext{
${ }^{536}$ Trecho integral: "[...] she longed, in secret, to pour her own sad song" (MACPHERSON, James. "Temora: an epic poem". The Poems of Ossian and related works cit., p. 275).

${ }^{537}$ Trecho integral: "She raised the voice of the song, and touched the harp between" (idem, p. 275).

${ }^{538}$ Assinalado pelo próprio Macpherson (idem, p. 514, nota 38).

${ }^{539}$ Idem, p. 275. Como o ritmo é elemento central da discussão, transcrevi o trecho em inglês no corpo da tese.
} 
A luz do herói e a noite da donzela projetam domínios imiscíveis, em que o rei precisa seguir seu "caminho [...] terrível na guerra", dando as costas à sua amada e seus passeios "perto do leito das corças". Ou ainda: a trilha de glória de Cathmor passa ao largo do isolamento obscuro de Sul-malla. Com efeito, o controle masculino da ação depende da recusa à possibilidade oferecida pela personagem feminina de se abandonar o conflito e, como consequência, deixar o enredo sem solução. Sul-malla é a Dido ou a Armida de Temora. Mas assim como Enéas e Rinaldo (e Lovelace) tiveram de romper com suas respectivas amadas, Cathmor escolhe cumprir com o papel que lhe foi reservado. Quando Cathmor finalmente descobre que Sul-malla o seguira, nada faz: "Não é hora, rei de Atha, para despertar a alma secreta. A batalha se estende diante de ti, como uma agitada corredeira" ${ }^{540}$ Por outro lado, a presença dispersiva da jovem, com suas ameaças à concretização do enredo, deflaciona o heroísmo de Cathmor, ao expor a arbitrariedade e a violência da ação épica de que toma parte. Suas efusões sentimentais, excursos discursivos e declamações líricas vocalizam o desejo por uma comunhão que o heroísmo atribuído ao irlandês não tem como oferecer, em que a experiência caótica (e, por isso mesmo, inenarrável) de Sulmalla se fundiria com a conduta ordenada do guerreiro. ${ }^{541}$ Até o último momento, ela espera o retorno de Cathmor na caverna, onde parece ansiar por um futuro de felicidade conjugal: "Venha para a caverna de Clonmal, ó meu bem-amado!". 542 Cathmor, obviamente, não volta. Fingal o matara.

Ao final, a incongruência que perpassa as epopeias ossiânicas se submete à lança do rei de Morven. Suas vitórias constituem o coroamento de uma trajetória heroica, a proporcionar o que seria o fechamento da narrativa, numa operação em que se correlaciona a conquista militar à configuração da forma. Fingal, entretanto, não emerge incólume desse processo: matiza-se a culminância do enredo pela vocalização, por parte do rei, do discurso até aqui associado aos derrotados - aos velhos, aos infantes, às mulheres. Tanto ao cabo de Fingal quanto de Temora, o chefe dos escoceses mostra-se ambivalente quanto ao valor de seus feitos. No primeiro

\footnotetext{
540 "This is no time, king of Atha, to wake thy secret soul. The battle is rolled before thee, like a troubled stream" (idem, p. 259). O casal se reúne novamente, agora no penúltimo "Livro" de Temora, no momento em Fingal chama seus homens para a batalha final. Sul-malla implora para que Cathmor se renda, ao ouvir o clangor do escudo de Morven (ver supra, p. 134-135). O irlandês desdenha da possibilidade e caminha para a morte.

${ }^{541}$ Dialoga-se com SPACKS, Patricia Meyer. Desire and truth cit., p. 55-56.

542 "Come to the cave Clonmal, O my best beloved!" (MACPHERSON, James. "Temora: an epic poem". The poems of Ossian and related works cit., p. 291).
} 
épico, Fingal se condói com a esposa e o pai de Orla, um jovem guerreiro de Lochlin, que debalde esperarão por seu retorno. ${ }^{543} \mathrm{E}$, o que é mais importante, enxerga Swaran não mais como um inimigo, mas como aquele que também chorou por Agandecca. ${ }^{54}$ A guerra irmana a todos pelas lágrimas que suscita. Ao término do conflito, homens, mulheres, reis e soldados se quedam - evoquemos a imagem de Agandecca mais uma vez - "com os olhos vermelhos de lágrimas". ${ }^{545}$ A identidade entre o vencedor e o derrotado se manifesta pela recusa do primeiro em converter seu triunfo numa conquista imperial, em concretizar o movimento estruturante da narrativa épica. ${ }^{546}$ Fingal não aceita tributos nem terras dos escandinavos. "O deserto é suficiente para mim", 547 ele diz. Swaran pode partir em paz:

Iça, amanhã, as tuas velas para o vento, ó irmão de Agandecca. Clara como a luz do meio-dia ela vem à minha alma lamentosa. Eu vi as tuas lágrimas por aquela mulher e te poupei nos salões de Starno, quando minha espada estava vermelha de sangue e meus olhos, cheios de lágrimas pela donzela. ${ }^{548}$

A recusa em desempenhar o papel de conquistador é, de maneira significativa, acompanhada de uma profunda reavaliação do que seria a glória de um herói:

Swaran - disse o rei das montanhas - hoje nossa fama é imensa. Passaremos como um sonho. Som nenhum permanecerá no campo de batalha. Nossos túmulos se perderão na charneca. O caçador não reconhecerá o local de nosso repouso. Nossos nomes poderão até ser ouvidos na canção, mas cessará a força de nossos braços. ${ }^{549}$

Trata-se de uma imagem que se repete duas páginas depois, assim que os barcos de Swaran somem no horizonte. Fingal convoca uma caçada em celebração a seu triunfo, mas se dá conta de que Ryno, seu filho, morrera. Ao lado do túmulo de Ryno, ergue

\footnotetext{
${ }^{543}$ Sobre o duelo entre Orla e Fingal, ver WEINBROT, Howard D. Britannia's issue cit., p. 551.

${ }^{544}$ Ver supra, p. 122.

545 "[...] with the red eye of tears" (MACPHERSON, James. "Fingal: an epic poem". The poems of Ossian and related works cit., p. 74). Trecho citado supra, p. 74.

${ }^{546}$ Ver QUINT, David. Epic and empire cit., p. 30 e ss. Ver discussão supra, p. 111 e ss.

547 "The desart is enough to me" (MACPHERSON, James. "Fingal: an epic poem". The poems of Ossian and related works cit., p. 101).

548 "Raise, to-morrow, thy white sails to the wind, thou brother of Agandecca. Bright as the beam of noon she comes on my mournful soul. I have seen thy tears for the fair one, and spared thee in the halls of Starno; when my sword was red with slaughter, and my eye full of tears for the maid" (idem, ibidem).

549 "Swaran, said the king of hills, to-day our fame is greatest. We shall pass away like a dream. No sound will remain in the fields of battle. Our tombs will be lost in the heath. The hunter shall not know the place of our rest. Our names may be heard in song, but the strength of our arms will cease" (idem, ibidem). Trecho citado supra, p. 76.
} 
um monumento em sua homenagem, mas parece duvidar que isso preservará a memória do guerreiro caído:

Logo teu túmulo será escondido e a grama crescerá alta em tua cova. Os filhos dos fracos passarão por ela e não saberão que os fortes jazem aqui. ${ }^{550}$

Em Temora, intervenções desse tipo não estão reservadas exclusivamente para o final. Podem ser rastreadas no no "Livro Sexto", ao saber que Cathmor matara Fillan, seu caçula. E de maneira mais eloquente, logo no "Livro Primeiro", quando o velho rei pranteia a morte de seu neto Oscar, assassinado à traição por Cairbar. Seus descendentes, diz, tombam "um a um". Teme que seu futuro seja solitário, na escuridão de Selma, onde viverá como "o último de sua raça". ${ }^{551}$ Associa-se o fím de Oscar à extinção de uma linhagem de heróis:

Os bravos devem tombar um dia, e não mais serem conhecidos em suas colinas. - Onde estão nossos pais, ó guerreiros, os chefes de antanho? Eles se puseram como as estrelas que brilharam [...]. ${ }^{552}$

Latente, esse contra-discurso acaba por embotar a consagração da campanha de Fingal na Irlanda. Reversamente do que se dá no primeiro épico ossiânico, o rei de Morven declara de maneira expressa que sua vitória (sobre os Fir-bolg) lhe trará glória imorredoura. ${ }^{553}$ Entretanto, pergunta-se em meio à celebração: a que preço ${ }^{554}$ Sua celebração é entrecortada por manifestações inequívocas de arrependimento: "Fingal não se regozija com o sangue. Lágrimas são córregos invernais que exaurem a minha alma". ${ }^{555}$ Dizendo-se velho e cansado, anuncia que não mais dará ouvidos ao chamado da guerra. E, renunciando à condição de herói, entrega sua lança a Ossian, o

\footnotetext{
550 "Soon will thy tomb be hid, and the grass grow rank on thy grave. The sons of the feeble shall pass over it, and shall not know that the mighty lie there" (idem, p. 103).

${ }^{551}$ Trecho integral: "My sons fall by degrees: Fingal shall be the last of his race" (MACPHERSON, James. "Temora: an epic poem". The poems of Ossian and related works cit., p. 230). Ver também STAFFORD, Fiona J. The last of the race cit., p. 105. A passagem foi citada supra, p. 78.

552 "The valiant must fall one day, and be no more known on his hills.-Where are our fathers, $\mathrm{O}$ warriors! the chiefs of the times of old? They have set like stars that have shone [...]" (MACPHERSON, James. "Temora: an epic poem". The poems of Ossian and related works cit., p. 231).

${ }^{553}$ Ver supra, p. 256.

${ }^{554}$ Ver MOORE, Dafydd. "Heroic incoherence in James Macpherson's The Poems of Ossian" cit., p. 46.

555 "Fingal delights not in blood. Tears are wintry streams that waste away my soul" (MACPHERSON, James. "Temora: an epic poem". The poems of Ossian and related works cit., p. 290).
} 
único filho que the sobreviveu. ${ }^{556}$ Admoesta-o a jamais se esquecer de seus antepassados ao empunhar a arma na guerra:

Ossian, tens a lança de teu pai: não é o bastão de um menino com que esparge o cardo [...]. - Não: é a lança dos poderosos, com que empunhavam suas mãos para a morte. Olha para os teus pais, meu filho; eles são feixes veneráveis de luz. ${ }^{557}$

Com esse gesto, a ação épica não apenas se completa: para usarmos uma expressão do próprio Fingal, ela se exaure. Nas mãos de Ossian, a lança enferrujará nos salões de Selma e os "feixes veneráveis de luz" serão envoltos pela escuridão.

${ }^{556}$ Ver também STAFFORD, Fiona J. The last of the race cit., p. 105. Ver também WEINBROT, Howard D. Britannia's issue cit., p. 530-531.

557 "Ossian, thou hast the spear of Fingal: it is not the staff of a boy with which he strews the thistle round, young wanderer of the field.--No: it is the lance of the mighty [...]. Look to thy fathers, my son; they are awful beams" (MACPHERSON, James. "Temora: an epic poem". The poems of Ossian and related works cit., p. 292). 


\section{REFERÊNCIAS BIBLIOGRÁFICAS}

\section{Bibliografia primária}

ADDISON, Joseph; STEELE, Richard. The Spectator. Ed. Gregory Smith. Londres - Nova Iorque: Everyman, 1958. 4 vols.

AKENSIDE, Mark. The poetical works of Mark Akenside. Ed. Robin Dix. Cranbury, NJ Londres - Mississauga, ON: Associated University Presses, 1996.

ANÔNIMO. The life and memoirs of Mr. Ephraim Tristram Bates, commonly called Corporal Bates, a broaken-hearted soldier. Londres: Printed by Malachi $* * * *$, for Edith Bates ... and sold by W. Owen, 1756.

ARISTÓTELES. "Poetics". Trad. Stephen Halliwell. In: HENDERSON, Jeffrey (ed.). The Loeb Classical Library: Aristotle XXIII. 2. ed. Cambridge, MA - Londres: Harvard University, 1995, p. 3-142.

ARNOLD, Matthew. On the study of Celtic literature. Nova Iorque: Macmillan, 1904.

BEHN, Aphra. "Oroonoko". The works of Aphra Behn. Ed. Janet Todd. Londres: William Pickering, 1995. v. 3.

Oroonoko and other writings. Ed. Paul Salzman. Oxford - Nova Iorque: Oxford University, 1994.

BLACKWELL, Thomas. An enquiry into the life and writings of Homer. Londres, 1735.

BLAIR, Hugh. A critical dissertation on the poems of Ossian, the son of Fingal. Londres, 1763.

"A critical dissertation on the poems of Ossian, the son of Fingal". In: MACPHERSON, James. The poems of Ossian and related works. Ed. Howard Gaskill. Edimburgo: Edinburgh University, 1996, p. 343-408.

Lectures on rhetoric and belles lettres. Ed. Linda Ferreira-Buckley; S. Michael Halloran. Carbondale: Southern Illinois University, 2005.

BOSWELL, James. Life of Johnson. Ed. R. W. Chapman. Oxford - Nova Iorque: Oxford University, 1980.

BROOKE, Frances. The history of Lady Julia of Mandeville. By the Translator of Lady Catesby's letters. Londres, 1763. 2 vols. 
[BURKE, Edmund]. "An account of books for 1761". The annual register, or a view of the history, politicks, and literature of the year 1761. Londres, 1762, p. 276-286.

CHAMBERS, Ephraim. Cyclopcedia, or, An universal dictionary of arts and sciences: containing the definitions of the terms, and accounts of the things signify'd thereby, in the several arts, both liberal and mechanical, and the several sciences, human and divine: the figures, kinds, properties, productions, preparations, and uses, of things natural and artificial: the rise, progress, and state of things ecclesiastical, civil, military, and commercial: with the several systems, sects, opinions, \&c: among philosophers, divines, mathematicians, physicians, antiquaries, criticks, \&c: the whole intended as a course of antient and modern learning. Londres, 1728. 2 vols.

CLELAND, John. Memoirs of a woman of pleasure. Ed. Peter Sabor. Oxford: Oxford University, 1999.

[COLLYER, Mary]. Felicia to Charlotte: being letters from a young lady in the country, to her friend in town. Londres, 1744.

[COVENTRY, Francis]. An essay on the new species of writing founded by Mr. Fielding: with a word or two upon the modern state of criticism. Londres, 1751.

DEFOE, Daniel. Moll Flanders. Ed. G. A. Starr. Oxford: Oxford University, 1978.

. Moll Flanders. Trad. Donaldson M. Garschagen. São Paulo: Cosac Naify, 2015. 2007.

Robinson Crusoe. Ed. Thomas Keymer. Oxford - Nova Iorque: Oxford University,

Robinson Crusoé. Trad. Sergio Flaskman. São Paulo: Penguin Classics - Companhia das Letras, 2011.

Roxana. Ed. John Mullan. Oxford - Nova Iorque: Oxford University, 1998.

The history and remarkable life of the truly honourable Col. Jaque. Ed. Maurice Hindle. Londres: Pickering \& Chatto, 2009.

DENNIS, John. An essay upon publick spirit; being a satyr in prose upon the manners and luxury of the times, the chief sources of our present parties and divisions. Londres, 1711.

DUFF, William. An essay on original genius, and its various modes of exertion in Philosophy and the fine arts, particularly in poetry. 2. ed. Londres, 1767.

Critical observations on the writings of the most celebrated original geniuses in poetry. Being a sequel to the Essay on original genius. Londres, 1770.

ELLEDGE, Scott. Eighteenth-century critical essays. Ithaca, NY: Cornell University, 1961. 2 vols.

; SCHIER, Donald (ed.). The continental model: selected French critical essays of the seventeenth century, in English translation. Ithaca, NY: Cornell University, 1970.

FERGUSON, Adam. An essay on the history of civil society. Ed. Fania Oz-Salzberger. Cambridge: Cambridge University, 1995.

FIELDING, Henry. A história das aventuras de Joseph Andrews e seu amigo Abraham Adams. Trad. Roger Maioli dos Santos. Cotia: Ateliê - Campinas: Unicamp, 2011. 
. A história de Tom Jones, um enjeitado. Trad. Octavio Mendes Cajado. Rio de Janeiro - Porto Alegre - São Paulo: Globo, 1949. 2 vols.

The history of the adventures of Joseph Andrews and of his friend Mr. Abraham Adams and An apology for the life of Mrs. Shamela Andrews. Ed. Douglas Brooks-Davies; Martin C. Battestin. Oxford - Nova Iorque: Oxford University, 1999.

. The history of Tom Jones, a foundling. Ed. Thomas Keymer; Alice Wakely. Londres: Penguin, 2005.

[FIELDING, Sarah]. Remarks on Clarissa, addressed to the Author. Occasioned by some critical conversations on the characters and conduct of that work. With some reflections on the character and behaviour of Prior's Emma. Londres, 1749.

. The adventures of David simple and Volume the last. Ed. Peter Sabor. Lexington: The University Press of Kentucky, 1998.

The cry: a new dramatic fable in three volumes. Londres, 1754. 3 vols.

GENG, Li-Ping (ed.). A critical edition of the novels of Scottish writer Henry Mackenzie (17451831). Lewiston - Queenston - Lampeter: Edwin Mellen, 2011.

GODWIN, William. "Of choice in reading". The enquirer: reflections on education, manners, and literature. Londres: G. G. and J. Robinson, 1797, p. 129-146.

GOLDSMITH, Oliver. "The vicar of Wakefield". Collected works of Oliver Goldsmith. Ed. Arthur Friedman. Oxford: Clarendon Press, 1966. v. 4, p. 3-185.

GUTHRIE, William. The friends: a sentimental history: describing love as a virtue, as well as a passion. Londres: printed for T. Waller, 1754. 2 vols.

HARRINGTON, John. “An apology for Ariosto: poetry, epic, morality”. In: VICKERS, Brian (ed.). English Renaissance literary criticism. Oxford: Clarendon, 1999, p. 302-324.

HAYWOOD, Eliza. Love in excess. Ed. David Oakleaf. 2. ed. Peterborough, ON: Broadview, 2000.

HEGEL, Georg Wilhelm. Cursos de estética. Trad. Marco A. Werle. São Paulo: Edusp, 2004. v. 4.

HOBBES, Thomas. Leviatã ou matéria, forma e poder do Estado eclesiástico e civil. Trad. João Paulo Monteiro; Maria Beatriz Nizza da Silva. São Paulo: Abril Cultural, 1974.

Leviathan. Revised Student Edition. Ed. Richard Tuck. Cambridge: Cambridge University, 1996.

HOME, Henry (Lord Kames). Elements of criticism. Ed. Peter Jones. Indianápolis, IN: Liberty Fund, 2005. 2 vols.

HOME, John. The history of the rebellion in the year 1745. Londres, 1802.

HOMERO. Ilíada. Trad. Carlos Alberto Nunes. Rio de Janeiro: Ediouro, 2004.

HOOKER, Edward Niles (ed.). The critical works of John Dennis. Baltimore: Johns Hopkins University, 1939. 2 vols. 
HUME, David. A treatise of human nature. Ed. L. A. Selby-Bigge; P. H. Nidditch. 2. ed. Oxford: Clarendon, 1979 (reimpressão, 2009).

Tratado da natureza humana. Trad. Débora Danowski. 2. ed. São Paulo: Unesp, 2009.

HURD, Richard. Letters on chivalry and romance: with the Third Elizabethan dialogue. Ed. Edith J. Morley. Londres: Henry Frowde, 1911.

HUTCHESON, Francis. An inquiry into the original of our ideas of beauty and virtue. Ed. Wolfgang Leidhold. Indianápolis: Liberty Fund, 2008.

JACKSON, Kenneth. A Celtic miscellany. Harmondsworth: Penguin, 1971.

JOHNSON, Samuel. The lives of the poets. Ed. John H. Minddendorf. New Haven - Londres: Yale University, 2010. 3 vols.

The Rambler. Ed. W. J. Bate; Albrecht B. Strauss. New Haven - Londres: Yale University, 1969. 3 vols.

KER, W. P. (ed.). Essays of John Dryden. Oxford: Clarendon, 1900. 2 vols.

KINSLEY, James (ed.). The poems of John Dryden. Londres: Oxford University, 1958. 3 vols.

LAING, Malcolm. The history of Scotland, from the Union of the Crowns on the accession of James VI to the throne of England, to the Union of the Kingdoms in the reign of Queen Anne. Londres: I. Cadwell Jr and W. Davies, 1800. 2 vols.

The poems of Ossian \&c., containing the poetical works of James Macpherson, Esq. in prose and rhyme: with notes and illustrations. Edimburgo, 1805. 2 vols.

LE BOSSU, René. Monsieur Bossu's treatise of the epick poem: containing many curious reflexions, very useful and necessary, for the right understanding and judging of the excellencies of Homer and Vergil. Trad. W. J. Londres, 1719. 2 vols.

. Traité du poëme épique. Paris, 1705.

LENNOX, Charlotte. The female Quixote: or the adventures of Arabella. Oxford: Oxford University, 1998.

LOCKE, John. An essay concerning human understanding. Ed. Peter H. Nidditch. Oxford Nova Iorque: Clarendon, 1972 (reimpressão, 2011).

. Two treatises of government and A letter concerning toleration. Ed. Ian Shapiro. New Haven - Londres: Yale University, 2003.

LOWTH, Robert. Lectures on the sacred poetry of the Hebrews. Trad. G. Gregory, Londres, 1787.

MACDONALD, Donald. Three beautiful and important passages omitted by the translator of Fingal. Londres, 1762.

[MACPHERSON, James]. The Highlander: a poem: in six cantos. Edimburgo: Printed by Wal. Ruddiman jun. and Company, 1758.

The poems of Ossian and related works. Ed. Howard Gaskill. Edimburgo: Edinburgh University, 1996. 
MILTON, John. Complete poems and major prose. Ed. Merritt Y. Hughes. Indianápolis Cambridge: Hackett, 1957 (reimpressão, 2003).

O paraíso perdido. Trad. António José Lima Leitão. Belo Horizonte - Rio de Janeiro: Villa Rica, 1994.

MURPHY, Arthur. "An essay on the life and genius of Henry Fielding, Esq.". The works of Henry Fielding, Esq.; with the life of the of the author. [Ed. Arthur Murphy] 2. ed. Londres: Arthur Millar, 1762. v. 1, p. 5-98.

OSSIAN. Fingal, an ancient epic poem in six books, together with several other poems. Trad. James Macpherson. Londres, 1762.

Fingal: poema em seis cantos. Seguido de duas cartas dos poetas Pinto Ribeiro e Sousa Viterbo. Trad. Maria Adelaide Fernandes Prata. Porto: Typographia Commercial, 1867.

. Temora an ancient epic poem in eight books, together with several other poems. Trad. James Macpherson. Londres, 1763.

POPE, Alexander. Poemas. Trad. Paulo Vizioli. São Paulo: Nova Alexandria, 1994.

Poetry and prose of Alexander Pope. Ed. Aubrey Williams. Boston: Riverside, 1969.

"Peri Bathous: of the art of sinking in poetry". In: GOLDGAR, Bertand A. (ed.). Literary criticism of Alexander Pope. Lincoln: University of Nebraska, 1965, p. 43-90.

The Iliad of Homer. Ed. Maynard Mack. Londres: Metheun - New Haven: Yale University, 1967. 2 vols.

RAPIN. "Reflections on Aristotle's Treatise of poesie". Trad. Thomas Rymer. The whole critical works of Monsieur Rapin. Vários tradutores. Londres, 1706. v. 2, p. 135-244.

[REEVE, Clara]. The Progress of romance, through times, countries, and manners; with remarks on the good and bad effects of it, on them respectively: in a course of evening conversations. Colchester, 1785. 2 vols.

RICHARDSON, Samuel. Clarissa, or the history of a young lady. Ed. Angus Ross. Londres: Penguin, 2004.

Clarissa: Preface, hints of prefaces, and Postscript. Ed. R. F. Brissenden. Los Angeles: University of California - The Augustan Reprint Society, 1964.

Pamela in her exalted condition. Ed. Albert J. Rivero. Cambridge: Cambridge University, 2012.

. Pamela; or virtue rewarded. Ed. Peter Sabor. Londres: Penguin, 1980.

. The history of Sir Charles Grandison. Ed. Jocelyn Harris. Oxford - Nova Iorque: Oxford University, 1986. 7 vols.

SAINT-EVREMOND. The works of Monsieur de St. Evremond, made English from the French original: with the Life of the author, by Mr. des Maizeaux, to which are added the memoirs of the Dutchess of Mazarin, \&c. 2. ed. Londres, 1728. 3 vols. 
[SCOTT, Walter]. "Art. XV. Report of the Committee of the Highland Society of Scotland, appointed to inquire into the nature and authenticity of the Poems of Ossian: drawn up according to the directions of the Committee, by Henry Mackensie, Esquire, its convener or chairman. With a copious Appendix, containing some of the principal documents on which the account is founded". The Edinburgh review, v. 6, n. 12 (julho, 1805), p. 429-462.

Waverley; or, 'tis sixty years since. Ed. Claire Lamont. Oxford - Nova Iorque: Oxford University, 1998.

[SHEBBEARE, John]. Lydia, or filial piety. A novel. Londres: Printed for J. Scott, at the Black Swan, in Pater-noster-row, 1755. 4 vols.

SHERIDAN, Frances. The memoirs of Miss Sidney Bidulph. Ed. Heidi Hunter; Nicole Garret. Peterborough, ON: Broadview, 2011.

[SMOLLETT, Tobias]. "Article I". "The critical review for the month of December, 1761". The critical review: or, Annals of literature. Londres, 1762. v. 12, p. 405-418.

"Article VII". "The critical review for the month of January, 1762". The critical review: or, Annals of literature. Londres, 1762, v. 13, p. 45-53.

. Poems, plays, and The Briton. Ed. Byron Gassman; O. M. Brack Jr. Athens, GA Londres: University of Georgia, 1993.

. The adventures of Ferdinand Count Fathom. Ed. Jerry C. Beasley; O. M. Brack Jr. Athens, GA - Londres: University of Georgia, 1988.

The adventures of Roderick Random. Ed. James G. Basker; Nicole Seary; PaulGabriel Boucé. Athens, GA: University of Georgia, 2012.

SPENSER, Edmund. The Faerie Queene. Ed. A. C. Hamilton. 2. ed. Harlow: Pearson Longman, 2007.

SPINGARN, J. E. (ed.). Critical essays of the seventeenth century. Oxford: Clarendon, 1908. 3 vols.

(ed.). Sir William Temple's essays On ancient and modern learning and On poetry. Oxford: Clarendon, 1909.

SWIFT, Jonathan. "No 14". The Examiner (1710-11). Ed. Herbert Davis. Oxford: Blackwell, 1959.

THOMSON, James. The seasons and The castle of indolence. Ed. James Sambrook. Oxford: Clarendon, 1972.

TRAPP, Joseph. Lectures on poetry: read in the School of Natural Philosophy at Oxford. Londres, 1742.

VICO, Giambattista. Ciência nova. Trad. Jorge Vaz de Carvalho. Lisboa: Calouste Gulbekian, 2005.

VIRGÍLIO. Eneida. 2. ed. Trad. Odorico Mendes. Cotia: Ateliê, 2010.

WODROW, John. Fingal: an ancient epic poem. In six books. Translated into English heroic rhyme. Edimburgo, 1771. 2 vols. 
WOLLSTONECRAFT, Mary. "A vindication of the rights of women". A vindication of the rights of women and $A$ vindication of the rights of men. Ed. Janet Todd. Oxford - Nova Iorque: Oxford University, 1993.

WOOD, Robert. An essay on the original genius of Homer. Londres, 1769.

WOTTON, William. Reflections upon ancient and modern learning. Londres, 1694.

YOUNG, Edward. Conjectures on original composition, in a letter to the author of Sir Charles Grandison. Londres, 1759.

ZIMANSKI, Curt A. (ed.). The critical works of Thomas Rymer. New Haven: Yale - Londres: Geoffrey Cumberlege - Oxford University, 1956.

\section{Bibliografia secundária}

ABRAMS, M. H. The mirror and the lamp: romantic theory and critical tradition. Londres Oxford - Nova Iorque: Oxford University, 1953.

ADORNO, Theodor. "Palestra sobre lírica e sociedade". Notas de literatura I. Trad. Jorge de Almeida. São Paulo: 34, 2003, p. 65-89.

AERCKE, Kristiaan. "Congreve's Incognita: romance, novel, drama?". Eighteenth-century fiction, v. 2, n. 4 (julho, 1990), p. 293-308.

AGUIAR, Ofir Bergemann. Ossian no Brasil. Goiânia: UFG, 1999.

ANCEKEWICZ, E. M. "De la poétisation de l'histoire à la politisation de la poétique: histoire et poésie dans le Traité du poème épique (1675) du Père Le Bossu". MLN, v. 107, n. 4, (setembro, 1992), p. 698-729

ANDERSON, Emily Hodgson. "Novelty in novels: a look at what's new in Aphra Behn's Oroonoko". Studies in the novel, v. 39, n. 1 (primavera, 2007), p. 1-16.

ANDREW, Donna T. "The code of honour and its critics: the opposition to duelling in England, 1700-1850". Social History, v. 5, n. 3 (outubro, 1980), p. 409-434.

ARMINTAGE, David. "Making the Empire British: Scotland in the Atlantic World, 15421707”. Past \& Present, n. 155 (maio, 1997), p. 34-63.

ARMSTRONG, Nancy. Desire and domestic fiction: a political history of the novel. Oxford Nova Iorque: Oxford University, 1987.

How novels think: the limits of individualism from 1719-1900. Nova Iorque: Columbia University, 2005.

AUERBACH, Erich. Mimesis: the representation of reality in Western literature. Trad. Willard R. Trask. Princeton, NJ: Princeton University, 1953.

BACKSCHEIDER, Paula R.; INGRASSIA, Catherine (ed.). A companion to the eighteenthcentury English novel and culture. Oxford: Blackwell, 2005.

BAKHTIN, Mikhail M. The dialogic imagination. Trad. Michael Holquist; Caryl Emerson. Austin: University of Texas, 1981 (reimpressão, 2008). 
BALLASTER, Ros. Seductive forms: women's amatory fiction from 1684-1740. Oxford: Clarendon, 1992.

BARCHAS, Janine. Graphic design, print culture, and the eighteenth-century novel. Cambridge: Cambridge University, 2003.

BÄR, Gerald (ed.). "Ossian in Portugal”. In: GASKILL, Howard (ed.). The reception of Ossian in Europe. Londres: Continuum, 2004, p. 351-374.

Poesias de Ossian: antologia da poesia ossiânica traduzida em português. Lisboa: Universidade Católica, 2010.

; GASKILL, Howard (ed.). Ossian and national epic. Oxford - Berna - Berlim Bruxelas - Frankfurt - Nova Iorque - Viena: Peter Lang, 2012.

BARNEY, Richard A. Plots of enlightenment: education and the novel in eighteenth-century England. Stanford: Stanford University, 1999.

BARTOLOMEO, Joseph F. A new species of criticism: eighteenth-century discourse on the novel. Newark: University of Delaware; Londres - Toronto: Associated University Presses, 1994.

BATE, Walter Jackson. From classic to romantic: premises of taste in eighteenth-century England. Cambridge, MA: Harvard University, 1949.

BEASLEY, Jerry C. A check-list of prose fiction in England, 1740-1749. Charlottesville: University of Virginia, 1972.

Novels of the 1740s. Athens, GA: University of Georgia, 1982.

. "Roderick Randam: the picaresque transformed". College literature v. 6, n. 3 (The Picaresque Tradition) (outubro, 1979), p. 211-220.

BEHR, Francesca D'Allesandro. “The narrator's voice: a narratological reappraisal of apostrophe in Virgil's Aeneid". Arethusa, v. 38, n. 2 (junho, 2005), p. 189-221.

BENDER, John. Imagining the penitentiary: fiction and the architecture of mind in eighteenthcentury England. Chicago - Londres: University of Chicago, 1987.

BENNETT, Tony. "The sociology of genres: a critique". Outside literature. Londres - Nova Iorque: Routledge, 1990, p. 78-114.

BENVENISTE, Émile. "Les relations de temps dans le verbe français". Problèmes de linguistique générale. Paris: Gallimard, 1966, t. I, p. 237-250.

BERRY, Christopher J. Social theory of the Scottish Enlightenment. Edimburgo: Edinburgh University, 1997.

BERNSTEIN, J. M. The philosophy of the novel: Lukács, marxism, and the dialectic of form. Brighton: Harvester, 1984.

BLACK, Scott. "Trading sex for secrets in Eliza Haywood's Love in excess". Eighteenthcentury fiction, v. 15, n. 2 (janeiro, 2003), 207-226.

BOOTH, Wayne C. The rhetoric of fiction. 2. ed. Chicago - Londres: University of Chicago, 1983. 
BOWRA, C. M. From Virgil to Milton. Londres: Macmillan, 1945.

BRAY, René. La formation de la doctrine classique en France. Paris: A. G. Nizet, 1966.

BREWER, John. "Sentiment and sensibility". In: CHANDLER, James (ed.). The Cambridge history of English Romantic literature. Cambridge: Cambridge University, 2009, p. 21-44.

BREWER, John. The sinews of power: war, money and the English state, 1688-1783. Cambridge, MA: Harvard University, 1988.

BRISSENDEN, R. F. Virtue in distress: studies in the novel of sentiment from Richardson to Sade. Londres - Basingstoke: Macmillan, 1974.

BROICH, Ulrich. The eighteenth-century mock-heroic poem. Trad. David Henry Wilson. Cambridge: Cambridge University, 1990.

BROOKS, Peter. Reading for the plot: design and intention in narrative. Nova Iorque: Alfred A. Knopf, 1984.

BROWN, Homer. "The institution of the English novel: Defoe's contribution". Novel: a forum on fiction, v. 29, n. 3 (primavera, 1996), p. 299-318.

BROWN, Marshall. "Poetry and the novel". In: MAXWELL, Richard; TRUMPNER, Katie (ed.). The Cambridge companion to fiction in the Romantic period. Cambridge: Cambridge University, 2008, p. 107-128.

Preromanticism. Stanford: Stanford University, 1991.

BROWN, Stephen W.; McDOUGALL, Warren (ed.). The Edinburgh history of the book in Scotland. Edimburgo: Edinburgh University, 2012. v. 2 ("Enlightenment and expansion, 1707-1800”).

BROWN, Terence (ed.). Celticism: studia imagologica. Amsterdã - Atlanta, GA: Rodopi, 1996.

BUELER, Lois E. Clarissa's plots. Newark, DE: University of Delaware, 1994.

BUESCU, Maria Gabriela Carvalhão. Macpherson e o Ossian em Portugal: estudo comparativo-translatológico. Lisboa: Colibri, 2001.

BUTT, John; CARNALL, Geoffrey. The mid-eighteenth century. Oxford: Clarendon, 1979.

BYSVEEN, Josef. Epic tradition and innovation in James Macpherson's Fingal. Uppsala: Acta Universitatis Upsaliensis, 1982.

CADWELL, M. John. "The rake as military strategist: Clarissa and eighteenth-century warfare". Eighteenth-century fiction, v. 19, n. 1 \& 2 (outono, 2006), p. 153-180.

CANDIDO, Antonio. Formação da literatura brasileira. 9. ed. Belo Horizonte - Rio de Janeiro: Itatiaia, 2000. 2 vols.

. Literatura e sociedade. 8. ed. São Paulo: TAQ, 2000.

CARBONI, Pierre. "Ossian and belles lettres: Scottish influence on J.-B.-A. Suard and lateeighteenth-century French taste and criticism". In: DAWSON, Deidre; MORERE, Pierre (ed.). Scotland and France in the Enlightenment. Lewisburg: Bucknell University Londres: Associated University Presses, 2004, p. 74-89. 
CARPEAUX, Otto Maria. História da literatura ocidental. São Paulo: Leya, 2011. v. 3.

CARPENTER, Frederic. "The vogue of Ossian in America". American literature, v. 2, n. 4 (janeiro, 1931), p. 405-417.

CHIBKA, Robert L. "Taking 'the serious' seriously: the introductory chapters of Tom Jones". The eighteenth century, v. 31, n. 1 (primavera, 1990), p. 23-45.

CLARK, A. F. B. Boileau and the French classical critics in England (1660-1830). Nova Iorque: Russell \& Russell, 1965.

COOK, Patrick J. Milton, Spenser and the epic tradition. Aldershot: Ashgate, 1999.

COOKE, Anthony et al (ed.). Modern Scottish history: 1707 to the present. Phantassie: Tuckwell, 2001. v. 1.

COOPER, Lane. The Poetics of Aristotle: its meaning and influence. Boston: Marshall Jones, 1923.

COSTA, Leila de Aguiar. Antigos e modernos: a cena literária na França do século XVII. Nankin: São Paulo, 2010.

CRAIG, Cairns. Out of history: narrative paradigms in Scottish and English Culture. Edimburgo: Polygon, 1996.

CRAWFORD, Robert (ed.). The Scottish invention of English literature. Cambridge: Cambridge University, 1998.

CURLEY, Thomas M. Samuel Johnson, the Ossian fraud and the Celtic revival in Great Britain and Ireland. Cambridge: Cambridge University, 2009.

CURTIUS, Ernst Robert. European literature and the Latin Middle Ages. Trad. William Trask. Princeton, NJ: Princeton University, 1990.

DAMROSCH Jr, Leopold. God's plots \& man's stories: studies in the fictional imagination from Milton to Fielding. Chicago - Londres: University of Chicago, 1985.

. "The significance of Addison's criticism". Studies in English Literature, 1500-1900, v. 19, n. 3 (Restoration and Eighteenth Century) (verão, 1979), p. 421-430.

DAVIDSON, Neil. "The Scottish path to capitalist agriculture 1: from the crisis of feudalism to the origins of agrarian transformation (1688-1746)". Journal of Agrarian Change, v. 4, n. 3 (julho, 2004), p. 227-268.

"The Scottish path to capitalist agriculture 2: the capitalist offensive $(1747-1815)$ ". Journal of Agrarian Change, v. 4, n. 4 (outubro, 2004), p. 411-460.

DAVIS, Leith. Acts of Union: Scotland and the literary negotiation of the British nation, 17071830. Stanford : Stanford University, 1998.

; DUNCAN, Ian; SORENSEN, Janet (ed.). Scotland and the borders of romanticism. Cambridge: Cambridge University, 2004.

DENTITH, Simon. Epic and empire in nineteenth-century Britain. Cambridge: Cambridge University, 2006. 
DELASANTA, Rodney. The epic voice. Haia - Paris: Mouton, 1967.

DIPIERO, Thomas. "Unreadable novels: toward a theory of seventeenth-century aritocratic fiction". Novel: a forum on fiction, v. 38, n. 2/3 (primavera-verão, 2005), p. 129-146.

DOODY, Margaret Anne. A natural passion: a study of the novels of Samuel Richardson. Oxford: Clarendon, 1974.

; SABOR, Peter (ed.). Samuel Richardson: tercentenary essays. Cambridge: Cambridge University, 1989.

DOUGLAS, Loyd. "A severe animadversion on Bossu”. PMLA, v. 62, n. 3 (setembro, 1947), p. 690-706.

DUBOIS, J. et al (Grupo $\mu$ ). Retórica geral. Trad. Carlos Felipe Moisés; Dúlio Colombini; Elenir de Barros. São Paulo: Cultrix - USP, 1974.

DUFF, David. Romanticism and the uses of genre. Oxford: Oxford University, 2009.

DUNCAN, Ian. Scott's shadow: the novel in Romantic Edinburgh. Princeton - Oxford: Princeton University, 2007.

DUNSTAN, Vivienne S. "Glimpses into a town's reading habits in Enlightenment Scotland: analysing the borrowings of Gray Library, Haddington, 1732-1816". Journal of Scottish Historical Studies, v. 26, n. $1+2$ (2006), p. 42-59.

EADE, J. C. Aristotle anatomised: the Poetics in England, 1674-1781. Oxford - Berna - Berlim - Bruxelas - Frankfurt - Nova Iorque - Viena: Peter Lang, 1988.

EAGLETON, Terry. The English novel: an introduction. Oxford: Blackwell, 2005.

The rape of Clarissa: writing, sexuality and class struggle in Samuel Richardson. Minneapolis: University of Minnesota, 1982.

EPSTEIN, Julia L.; GREENBERG, Mark L. "Decomposing Newton's Rainbow”. Journal of the History of Ideas, v. 45, n. 1 (janeiro - março, 1984), p. 115-140.

FEATHER, John. A history of British publishing. Londres - Nova Iorque: Routledge, 1988.

FOERSTER, Donald M. Homer in English criticism: the historical approach in the eighteenth century. New Haven: Yale University, 1947.

The fortunes of epic poetry: a study in English and American criticism, 1750-1950. Washington, DC: The Catholic University of America, 1962.

FOSTER, James R. "Smollett's pamphleteering foe Shebbeare”. PMLA, v. 57, n. 4 (dezembro, 1942), p. 1053-1100.

FOLKENFLIK, Robert. "Folklore, antiquarianism, scholarship and high literary culture". In: RICHETTI, John (ed.). The Cambridge History of English Literature, 1660-1780. Cambridge: Cambridge University, 2005, p. 602-622.

"Tristram Shandy and eighteenth-century narrative". In: KEYMER, Thomas (ed.). The Cambridge companion to Laurence Sterne. Cambridge: Cambridge University, 2009, p. 49-63. 
FOWLER, Alastair. Kinds of literature: an introduction to the theory of genres and modes. Cambridge, MA: Harvard University, 1982.

FRIDÉN, Georg. James Fenimore Cooper and Ossian. Upsala: A.-B. Lundequistska Bokhanden, 1949.

FRYE, Northrop. FRYE, Northrop. Anatomy of criticism. Londres: Penguin, 1990.

. The secular scripture: a study of the structure of romance. Cambridge, MA - Londres: Harvard University, 1976.

. "Towards defining an age of sensibility". English Literary History, v. 23, n. 2 (jun. 1956), p. 144-152.

GASKILL, Howard. "Ossian in Europe". Canadian review of Comparative Literature, v. 21, n. 4 (dezembro, 1994), p. 643-675.

(ed.). Ossian revisited. Edimburgo: Edinburgh University, 1991.

(ed.). The reception of Ossian in Europe. Londres: Continuum, 2004.

. "What did James Macpherson really leave on display at his publisher's shop in 1762?". Scottish Gaelic Studies, v. 16 (1990), p. 67-89.

; STAFFORD, Fiona (ed.). From Gaelic to romantic: Ossianic translations. Amsterdã Atlanta, GA: Rodopi, 1998.

GENETTE, Gérard. Discurso da narrativa. Trad. Fernando Cabral Martins. 3. ed. Lisboa: Vega, 1995.

Paratextos editoriais. Trad. Álvaro Faleiros. Cotia, SP: Ateliê, 2009.

GERRARD, Christine (ed.). The Cambridge edition of the correspondence of Samuel Richardson. Correspondence with Aaron Hill and the Hill family. Cambridge: Cambridge University, 2013 (Kindle Edition).

GILLIES, John. "Space and place in Paradise lost". ELH, v. 74, n. 1 (primavera, 2007), p. $27-$ 57.

GOODY, Jack; WATT, Ian. "The consequences of literacy". Comparative studies in society and history, v. 5, n. 3 (abril, 1963), p. 304-345.

GUILLÉN, Claudio. Literature as a system: essays toward the theory of literary history. Princeton, NJ: Princeton University, 1971.

HALL, Stuart. "Marx's notes on method: a 'reading' of the '1857 Introduction"”. Cultural Studies, v. 17, n. 2 (2003), p. 113-149.

HALLIWELL, Stephen. "The importance of Plato and Aristotle for Aesthetics". In: GERSON, Lloyd P. (ed.). Aristotle: critical assessments. Routledge: Londres: Nova Iorque, 1999. v. 4, p. 289-312.

HAMBURGER, Käte. A lógica da criação literária. Trad. Margot P. Malnic. 2. ed. São Paulo: Perspectiva, 1986. 
HANSEN, João Adolfo. "Notas sobre o gênero épico". In: TEIXEIRA, Ivan (org.). Épicos. São Paulo: Universidade de São Paulo - Imprensa Oficial do Estado de São Paulo, 2008, p. 1591.

HARRIES, Elizabeth Wanning. The unfinished manner: essays on the fragment in the later eighteenth century. Charlottesville - Londres: University Press of Virginia, 1994.

HARRIS, Jocelyn. "Protean Lovelace". Eighteenth-century fiction, v. 2, n. 4 (julho, 1990), p. 327-346.

HATCH, Gary Lane. "Sudent Notes on Hugh Blair's lectures on Rhetoric". In: GAILLET, Lynee Lewis (ed.). Scottish Rhetoric and its influences. Mahwah, NJ: Hermagoras, 1998, p. 79-94.

HAYWOOD, Ian. The making of history: a study of the literary forgeries of James Macpherson and Thomas Chatterton in relation to eighteenth-century ideas of history and fiction. Londres - Toronto: Associated University Presses, 1986.

HAUGEN, Kristine Louise. "Ossian and the invention of textual history". Journal of the History of Ideas, v. 59, n. 2 (abril, 1998), p. 309-327.

HENRIQUES, Ana Lucia de Souza. "Machado de Assis, leitor de Ossian". In: JOBIM, José Luís (org.). A biblioteca de Machado de Assis. Rio de Janeiro: Academia Brasileira de Letras - Topbooks, 2001, p. 277-287.

HILL, Christopher. A century of revolution, 1603-1714. Londres - Nova Iorque: Routledge, 1991.

The English Bible and 17th century Revolution. Harmonsworth: Penguin, 1993.

HOUSTON, Rab. "The literacy myth?: Illiteracy in Scotland 1630-1760". Past \& Present, n. 96 (agosto, 1982), p. 81-102.

HUNTER, J. PAUL. Before novels: the cultural contexts of eighteenth-century English fictions. Nova Iorque - Londres: Norton, 1990.

IMMERWAHR, Raymond. "'Romantic' and its cognates in England, Germany, and France in 1790”. In: EICHNER, Hans (ed.). 'Romantic' and its cognates: the European history of a word. Manchester: University of Manchester, 1972, p. 17-97.

ISER, Wolfgang. The implied reader: patterns of communication in prose fiction from Bunyan to Beckett. Baltimore - Londres: Johns Hopkins University, 1974.

JAGER, Eric. "The parrot's voice: language and the self in Robinson Crusoe". Eighteenthcentury studies, v. 21, n. 3 (primavera, 1988), p. 316-333.

JAMESON, Frederic. Marxism and form: twentieth-century dialectical theories of literature. Princeton, NJ: Princeton University, 1974.

The political unconscious: narrative as a socially simbolic act. Ithaca, NY: Cornell University, 1981.

JONES, Hester. "Restoration poetry: Behn, Dryden and their contemporaries". In: RICHETTI, John (ed.). The Cambridge history of English literature, 1660-1780. Cambridge: Cambridge University, 2005, p. 281-298. 
KAUFFMAN, Linda. Discourses of desire: gender, genre, and epistolary fictions. Ithaca Londres: Cornell University, 1988.

KERBY, Anthony Paul. Narrative and the self. Bloomington: University of Indiana, 1991.

KERSEY, Mel. “Addison's Indian, Blackwell's bard and the voice of Ossian". History of European Ideas, v. 31, n. 2 (setembro, 2005), p. 265-275.

KEYMER, Thomas. "Obscenity and the erotics of fiction". In: CASERIO, Robert L.; HAWES, Clement (ed.). The Cambridge History of the English novel. Cambridge: Cambridge University, 2012, p. 131-146.

. "Sentimental fiction: ethics, social critique and philantropy". In: RICHETTI, John. (ed.). The Cambridge history of English literature, 1680-1780. Cambridge: Cambridge University, 2005, p. 572-601.

Richardson's Clarissa and the eighteenth-century reader. Cambridge: Cambridge University, 1992. . Sterne, the Moderns, and the novel. Oxford - Nova Iorque: Oxford University, 2002.

KONIGSBERG, Ira. Narrative technique in the English novel: Defoe to Austen. Hamden, CT: Archon Books, 1985.

. Samuel Richardson \& the dramatic novel. Lexington: University of Kentucky, 1968.

KRAMNICK, Jonathan. Actions and objects from Hobbes to Richardson. Stanford: Stanford University, 2010.

LACERDA, Sonia. Metamorfoses de Homero: história e antropologia na crítica setecentista da poesia épica. Brasília: UnB, 2003.

LAUGHLIN, Corinna. “The lawless language of Macpherson's Ossian”. SEL, v. 40, n. 3 (verão, 2000), p. 511-537.

The Ossianic novel. Tese de Doutorado (PhD Dissertation). Seattle, WA: Washington University, 1998.

LEERSEN, Joep. "Ossian and the rise of literary historicism". GASKILL, Howard (ed.). The reception of Ossian in Europe. Londres: Continuum, 2004, p. 109-125.

LEME LOPES, André. O poeta que não existiu: James Macpherson e os poemas de Ossian. Tese de Doutorado. Brasília: Universidade de Brasília, 2009.

LENNARD, John. But I digress: the exploitation of parentheses in English printed verse. Oxford: Clarendon, 1991.

LEVINE, Joseph M. The battle of the books: history and literature in the Augustan age. Ithaca, NY - Londres: Cornell University, 1991.

LEWIS, C. S. Um experimento na crítica literária. Trad. João Luís Ceccantini. São Paulo: Unesp, 2009.

LINDFIELD-OTT, Kristin. 'See Scot and Saxon coalesc'd in one': James Macpherson's The Highlander in its intellectual and cultural contexts, with an annotated text of the poem. Tese de Doutorado (PhD Dissertation). Saint Andrews: University of Saint Andrews, 2011. 
LUBEY, Kathleen. "Eliza Haywood's amatory aesthetic". Eighteenth-Century Studies, vl. 39, n. 3 (New feminist work in epistemology and aesthetics) (primavera, 2006), p. 309-322.

. "Erotic interiors in Joseph Addison's imagination". Eighteenth-century fiction, v. 20, n. 3 (primavera, 2008), p. 415-444.

LUKÁCS, Georg. Teoria do romance. Trad. José Macedo. São Paulo: 34 - Duas Cidades, 2000.

LUTZ, Alfred. "Representing Scotland in Roderick Random and Humphry Clinker: Smollett's development as a novelist". Studies in the novel, v. 33, n. 1 (primavera, 2001), p. 1-17.

MACK, Ruth. "'Seeing something that was doing in the World': the form of History in Colonel Jack". Eighteenth-century fiction, v. 24, n. 2 (inverno, 2011-2012), p. 227-245.

MacKAY, Marina. The Cambridge introduction to the novel. Cambridge: Cambridge University, 2011.

MADELÉNAT, Daniel. L'épopée. Paris: PUF, 1986.

MÄKIKALLI, Aino. From eternity to time: conceptions of time in Daniel Defoe's novels. Oxford - Berna - Berlim - Bruxelas - Frankfurt - Nova Iorque - Viena: Peter Lang, 2007.

MALM, Mats. "The role of emotions in the development of artistic theory and the system of literary genres". In: BOD, Rens; MAAT, Jaap; WESTSTEIJN, Thijs (ed.). The making of the humanities. Amsterdã: Amsterdam University, 2012. v. 2, p. 267-281.

MANNING, Susan. "Ossian, Scott, and nineteenth-century Scottish nationalism". Studies in Scottish Literature, v. 17 (1982), p. 39-54.

(ed.). The Edinburgh history of Scottish literature: Enlightenment, Britain and empire (1707-1918). Edimburgo: Edinburgh University, 2007.

MARESCA, Thomas E. Epic to novel. Columbus: Ohio State University, 1974.

MARQUES, Mariana Teixeira. Fanny e Margot, libertinas: o aprendizado do corpo e do mundo em dois romances eróticos setecentistas. Tese de Doutorado. São Paulo: Universidade de São Paulo, 2011.

MARSHALL, David. "Autobiographical acts in Robinson Crusoe". EHL, v. 71, n. 4 (inverno, 2004), p. 899-920.

MARTIN, Catherine Gimelli. “'What if the sun be centre to the world?': Milton's epistemology, cosmology, and Paradise of Fools reconsidered”. Modern Philology, v. 99, n. 2 (novembro, 2001), p. 231-265.

MARTINS, Eduardo Vieira. A fonte subterrânea: José de Alencar e a retórica oitocentista. Londrina: Eduel - São Paulo: Edusp, 2005.

MARX, Karl. Grundrisse. Trad. Mario Duayer; Nélio Schneider. São Paulo: Boitempo - Rio de Janeiro: UFRJ.

McDONALD, William R. "Book-auctions and book-sales in the Aberdeen area, 1749-1800". The Aberdeen University Review, v. 42, n. 138 (outono, 1967), p. 114-132. 119-137.

. "Circulating libraries in the north-east of Scotland". Bibliotheck, v. 5, n. 4 (1968), p. 
McGANN, Jerome. The poetics of sensibility: a revolution in literary style. Oxford: Clarendon, 1998.

McGIRR, Elaine. "Why Lovelace must die". Novel: a forum on fiction, v. 37, n. 1/2 (outono, 2003 - primavera, 2004), p. 5-23.

McKEON, Michael. "Generic transformation and social change: rethinking the rise of the novel". In: DAMROSCH Jr., Leopold (ed.). Modern essays on eighteenth-century literature. Nova Iorque - Oxford: Oxford University, 1988, p. 159-180.

"The origins of aesthetic value". Telos v. 1983, n. 57 (setembro, 1983), p. 63-82. 1987.

MEEK, Donald E. "The Gaelic ballads of Scotland: creativity and adaptation". In: GASKILL, Howard (ed.). Ossian revisited. Edimburgo: Edinburgh University, 1991, p. 19-48.

MOORE, Dafydd. Enlightenment and romance in James Macpherson's The Poems of Ossian: myth, genre and cultural change. Aldershot: Ashgate, 2003.

"Heroic incoherence in James Macpherson's The Poems of Ossian". Eighteenthcentury studies, v. 34, n. 1 (outono, 2000), p. 43-59.

"James Macpherson and Adam Ferguson: an Enlightenment encounter". Scottish Literary Journal, v. 24, n. 2 (novembro, 1997), p. 5-23.

"The critical response to Ossian's Romantic bequest". In: CARRUTHERS, Gerard; RAWES, Alan (ed.). English Romanticism and the Celtic world. Cambridge: Cambridge University, 2003, p. 38-53.

"The reception of The Poems of Ossian in England and Scotland". In: GASKILL, Howard (ed.). The reception of Ossian in Europe. London: Continuum, 2004, p. 21-39.

MOORE, James. "Montesquieu and the Scottish Enlightenment". In: KINGSTON, Rebecca E. (ed.). Montesquieu and his legacy. Albany, NY: State University of New York, 2009, p. 179-195.

MORETTI, Franco (org.). A cultura do romance. Trad. Denise Bottman. São Paulo: Cosac Naify, 2009.

MONTIEL, Isidoro. Ossián en España. Barcelona: Planeta, 1974.

"Ossián en la literatura argentina". Revista interamericana de bibliografía, v. 19, n. 2 (abril - junho, 1969), p. 146-179.

MUDGE, Bradford K (ed.). When flesh becomes word: an anthology of early eighteenth-century libertine literature. Oxford: Oxford University, 2004.

MULLAN, John. Sentiment and sociability: the language of feeling in the eighteenth century. Oxford: Clarendon, 1988.

MURPHY, Andrew. "Britain, c. 1475-1800". In: SUAREZ, Michael J.; WOOUDHUYSEN, H. R. (ed.). The book: a global History. Oxford: Oxford University, 2013, p. 287-299. 
MURPHY, Peter T. "Fool's gold: the Highland treasures of Macpherson's Ossian". ELH, v. 53, n. 3 (outono, 1986), p. 567-591.

MUSTO, Marcello. "History, production and method in the 1857 'Introduction'". In: MUSTO, Marcello (ed.) Karl Marx's Grundrisse: foundations of the critique of political economy 150 years later. Londres - Nova Iorque, 2008, p. 3-32.

NIXON, Cheryl L. Novel definitions: an anthology on the novel (1688-1815). Peterborough, ON: Broadview, 2008.

NOVAK, Maximillian E. "Primitivism". In: NISBET, H. B.; RAWSON, Claude (ed.) The Cambridge History of Literary Criticism: the eighteenth century. Cambridge: Cambridge University, 2005, p. 456-469.

O'HALLORAN, Clare. "Irish re-creations of the Gaelic Past: the Challenge of Macpherson's Ossian". Past and Present, n. 124 (agosto, 1989), p. 69-95

PARKES, M. B. Pause and effect: an introduction to the history of punctuation in the West. Londres: Scolar, 1992.

PATEY, Douglas Lane. "The institution of criticism in the eighteenth century". In: NISBET, H. B.; RAWSON, Claude (ed.) The Cambridge History of Literary Criticism: the eighteenth century. Cambridge: Cambridge University, 2005, p. 3-31.

PEARCE, Roy Harvey. "The eighteenth-century Scottish primitivists: some reconsiderations". $E L H$, v. 12, n. 3, (setembro, 1945), p. 203-220.

PITTOCK, Murray. "Historiography". In: BROADIE, Alexander (ed.). The Cambridge companion to the Scottish Enlightenment. Cambridge: Cambridge University, 2003, p. 258279.

Scottish and Irish romanticism. Oxford: Oxford University, 2008.

(ed.). The Edinburgh companion to Scottish Romanticism. Edimburgo: Edinburgh University, 2011.

POCOCK, J. G. A. "The classical theory of deference". The American Historical Review, v. 81, n. 3 (junho, 1976), p. 516-523.

POST, Jonathan. "Substance and style: an introduction to The temple". George Herbert Journal, v. 18, n. $1 \& 2$ (outono, 1994 - primavera, 1995), p. 1-28.

QUINT, David. Epic and empire. Princeton, NJ: Princeton University, 1993.

RAVEN, James. British fiction, 1750-1770: a chronological check-list of prose fiction in Britain and Ireland. Newark, DE: University of Delaware, 1987.

Publishing business in eighteenth-century England. Woodbridge: Boydell, 2014.

RICHETTI, John (ed.). The Columbia history of the British novel. Nova Iorque: Columbia University, 1994.

. The English novel in History, 1700-1780. Londres: Routledge, 1999. 
. "The novel before "the novel"”. In: CASERIO, Robert L.; HAWES, Clement (ed.). The Cambridge History of the English novel. Cambridge: Cambridge University, 2012, p. 14-29.

RICOEUR, Paul. Tempo e narrativa. Trad. Claudia Berliner e Márcia Valéria Martinez de Aguiar. São Paulo: Martins Fontes, 2012. 3 vols.

RIZZA, Steve. "A bulky and foolish treatise? Hugh Blair's Critical dissertation reconsidered". In: GASKILL, Howard (ed.). Ossian revisited. Edimburgo: Edinburgh University, 1991, p. 129-146.

ROGERS, Pat. Daniel Defoe: the critical heritage. Londres: Routledge, 2013.

RORTY, Amélie Oskenberg (ed.). Essays on Aristotle's Poetics. Princeton, NJ: Princeton University, 1992.

ROSENTHAL, Laura J. "Oroonoko: reception, ideology, and narrative strategy". In: HUGHES, Derek; TODD, Janet (ed.). The Cambridge companion to Aphra Behn. Cambridge: Cambridge University, 2004, p. 151-165.

RUBEL, Margaret Mary. Savage and barbarian: historical attitudes in the criticism of Homer and Ossian in Britain, 1760-1800. Amsterdã - Oxford - Nova Iorque: North Holland, 1978.

SAUNDERS, Bailey. The life and letters of James Macpherson: containing a particular account of his famous quarrel with Dr. Johnson, and a sketch of the origin and influence of the Ossianic poems. Nova Iorque: Haskell House, 1968.

SEIDEL, Michael. "Systems satire: Swift.com". In: RICHETTI, John (ed.). The Cambridge history of English literature, 1660-1780 cit., p. 235-258.

SENNETT, Richard. The fall of public man. Londres: Penguin, 2002.

SCHMITT, Arbogast. "Mímesis em Aristóteles e nos comentários da Poética no Renascimento: da mudança do pensamento sobre a imitação no começo dos tempos modernos". Trad. Luiz Costa Lima. In: COSTA LIMA, Luiz (org.). Mímesis e a reflexão contemporânea. Rio de Janeiro: Uerj, 2010, p. 137-189.

SCHMITZ, Robert Morell. Hugh Blair. Morningside Heights, NY: King’s Crown, 1948.

SCHOLES, Robert; KELLOGG, Robert. The nature of narrative. Londres - Oxford - Nova Iorque: Oxford University, 1968.

SCHULTZ, Dieter. "'Novel', 'romance', and popular fiction in the first half of the eighteenth century". Studies in philology, v. 70, n. 1 (janeiro, 1973), p. 77-91.

SHARP, Andrew (ed.). The English Levellers. Cambridge: Cambridge University, 1998.

SHELL, Alison. "Seventeenth-century poetry 2: Herbert, Vaughan, Philips, Cowley, Crashaw, Marvell”. In: O'NEILL, Michael (ed.). The Cambridge history of English poetry. Cambridge: Cambridge University, 2010, p. 211-230.

SHER, Richard B. "From Troglodytes to Americans: Montesquieu and the Scottish Enlightenment on liberty, virtue, and commerce". In: WOOTTON, David (ed.). Republicanism, liberty, and commercial society, 1649-1776. Stanford, CA: Stanford University, 1994, p. 368-402. 
SHIELDS, Juliet. Sentimental literature and Anglo-Scottish identity, 1745-1820. Cambridge: Cambridge University, 2010.

SHRODER, Maurice Z. "The novel as a genre". In: STEVICK, Philip. The theory of the novel. Nova Iorque: The Free Press - Londres: Collier Macmillan, 1967, p. 13-29.

SIMONSUURI, Kirsti. Homer's original genius: eighteenth-century notions of the early Greek epic. Cambridge: Cambridge University, 1979.

SPACKS, Patricia Meyer. Desire and truth: functions of plot in eighteenth-century English novels. Chicago - Londres: University of Chicago, 1990.

Imagining a self: autobiography and novel in eighteenth-century England. Cambridge, MA - Londres: Harvard University, 1976.

STAFFORD, Fiona. "Blair's Ossian, romanticism, and the teaching of literature". In: CRAWFORD, Robert (ed.). The Scottish invention of English literature. Cambridge: Cambridge University, 1998, p. 68-88.

"Dr. Johnson and the Ruffian: new evidence in the dispute between Samuel Johnson and James Macpherson". Notes and Queries, n. 36 (1989), p. 70-77.

. "Primitivism and the 'primitive' poet: a cultural context for Macpherson's Ossian". In: BROWN, Terence (ed.). Celticism: studia imagologica. Amsterdã - Atlanta, GA: Rodopi, 1996, p. 79-96.

"Romantic Macpherson". In: PITTOCK, Murray (ed.). The Edinburgh companion to Scottish Romanticism. Edimburgo: Edinburgh University, 2011, p. 27-37. 1994.

The last of the race: the growth of a myth from Milton to Darwin. Oxford: Clarendon,

The sublime savage: a study of James Macpherson and The Poems of Ossian. Edimburgo: Edinburgh University, 1988.

STARR, G. A. "Aphra Behn and the genealogy of the man of feeling". Modern Philology, v. 87, n. 4 (maio, 1990), p. 362-372.

"Defoe's prose style 1: the language of interpretation". Modern Philology, v. 71, n. 3 (fevereiro, 1974), p. 277-294. 501-527.

STARR, G. Gabrielle. Lyric generations: poetry and the novel in the Long Eighteenth Century. Baltimore - Londres: Johns Hopkins University, 2004.

STEPHENS, W. B. "Literacy in England, Scotland, and Wales, 1500-1900". History of Education Quarterly, v. 30, n. 4 (Special Issue on the History of Literacy) (inverno, 1990), p. 545-571.

STEWART, Keith. "The ballad and the genres in the 18h century". English Literary History, v. 24, n. 2 (jun. 1957), p. 120-137.

STEWART, Susan. "Notes on distressed genres". The Journal of American Folklore, v. 104, n. 411 (inverno, 1991), p. 5-31. 
SUAREZ, Michael J. "Publishing contemporary literature". In: SUAREZ, Michael J.; TURNER, Michael L (ed.). The Cambridge History of the book in Britain. Cambridge: Cambridge University, 2009, v. 5, p, 649-666.

SUDO, Yoshiaki. "An unpublished lecture of Hugh Blair on the Poems of Ossian". The Hiyoshi review of English studies, v. 25 (março, 1995), p. 160-94.

SWEDENBERG JR., H. T. The theory of the epic in England: 1650-1800. Berkeley - Los Angeles: University of California, 1944.

SZONDI, Peter. Poésie et poétique de l'idéalisme allemand. Trad. Jean Bollack. Paris: Gallimard, 1975.

. Teoria do drama moderno. Trad. Raquel Rodrigues. Cosac Naify: São Paulo, 2001.

TAYLOR, Charles. Sources of the self: the making of the modern identity. Cambridge, MA: Harvard University, 1989.

THIESSE, Anne-Marie. La création des identités nationales: Europe XVIIIe-XXe siècle. Paris : Seuil, 1999.

THOMSON, Derick S. "James Macpherson: the Gaelic dimension”. In: GASKILL, Howard; STAFFORD, Fiona (ed.). From Gaelic to romantic: Ossianic translations. Amsterdã Atlanta, GA: Rodopi, 1998, p. 17-26.

. The Gaelic sources of Macpherson's 'Ossian'. Edimburgo - Londres: Oliver and Boyd (published for the University of Aberdeen), 1951.

THOMAS, Richard F. Virgil and the Augustan reception. Cambridge: Cambridge University, 2004.

THORNBURY, Ethel Margaret. Henry Fielding's theory of the comic prose epic. Madison: Wisconsin, 1931.

TILLYARD, E. M. W. The English epic and its background. Nova Iorque: Oxford University, 1966.

TODD, Janet. Sensibility. Londres: Methuen, 1986.

TODOROV, Tzvetan; GENETTE, Gérard (org.). Théorie des genres. Paris: Seuil, 1986.

TORCHIANA, Donald T. "Brutus: Pope's last hero". The journal of English and Germanic Philology, v. 61, n. 4 (outubro, 1962), p. 853-867.

TREVOR-ROPER, Hugh. "The invention of tradition: the Highland tradition of Scotland". In: HOBSBAWM, Eric; RANGER, Terence (ed.). The invention of tradition. Cambridge: Cambridge University, 2005, p. 15-42.

TRUMPENER, Katie. Bardic nationalism: the romantic novel and the British Empire. Princeton, NJ: Princeton University, 1997.

VAN SANT, Ann Jessie. Eighteenth-century sensibility and the novel: the senses in social context. Cambridge: Cambridge University, 1993.

VAN TIEGHEM, Paul. Ossian en France. Paris : F. Rieder, 1917. 2 t. 
Ossian et l'ossianisme dans la littérature européenne aux XVIII ${ }^{E}$ siècle. Haia: J. B. Wolters, 1920

VASCONCELOS, Sandra Guardini T. A formação do romance inglês: ensaios teóricos. São Paulo: Hucitec - Fapesp, 2007.

. Dez lições sobre o romance inglês do século XVIII. Rio de Janeiro: Boitempo, 2002.

"Ensaios teóricos: os capítulos introdutórios de Henry Fielding". Psicologia USP, v. 11, n. 2 (2000), p. 171-185.

. "Ian Watt e a figuração do real (anotações de leitura)". Literatura e sociedade, v. 14 (2010), p. 170-183.

VENTURO, David. "Understanding genre: epic, mock epic, and some versions of heroism, from Milton to Pope". In: DeMARIA, Robert; CHANG, Heesok; ZACHER, Samantha (ed.). A companion to British Literature: the Long Eighteenth Century, 1660 - 1830. Chinchester: Wiley-Blackwell, 2014, p. 1-18.

VITO, George V. "A note on the population of seventeenth-century London". Demography, v. 9, n. 3 (agosto, 1972), p. 511-514.

WAHRMAN, Dror. The making of the modern self: identity and culture in eighteenth-century England. New Haven - Londres: Yale University, 2004.

WARNER, William B. Licensing entertainment: the elevation of novel reading in Britain, 16841750. Berkeley - Los Angeles - Londres: University of California, 1998.

WATT, Ian. A ascensão do romance. Trad. Hildegard Feist. São Paulo: Companhia das Letras, 2007.

"Defoe and Richardson on Homer: a study of the relation of novel and epic in the early eighteenth century". The review of English studies, v. 3, n. 12 (outubro, 1952), p. 325340 .

"The naming of characters in Defoe, Richardson, and Fielding". The review of English studies, v. 25, n. 100 (outubro, 1949), p. 322-338.

WEINBERG, Bernard. "From Aristotle to pseudo-Aristotle". Comparative literature, v. 5, n. 2 (primavera, 1953), p. 97-104.

WEINBROT, Howard D. Britannia's issue: the rise of British literature from Dryden to Ossian. Cambridge: Cambridge University, 1993.

WELLEK. René. A history of modern criticism: 1750-1950. New Haven: Yale University, 1955. V. 1.

WHITNEY, Lois. "English primitivistic theories of epic origins". Modern philology, v. 21, n. 4 (maio, 1924), p. 337-378.

WILLIAMS, Ioan (ed.). Novel and romance: a documentary record, 1700-1800. Londres: Routledge \& Keagan Paul, 1970 (reimpressão, 2010).

WILLIAMS, Jeffrey. Theory and the novel: narrative reflexitivity in the British tradition. Cambridge: Cambridge University, 1998. 
WILLIAMS, Linda. “Cinema's sex acts”. Film Quarterly, v. 67, n. 4 (verão, 2014), p. 9-25.

WILLIAMS, Ralph C. "Two studies in epic theory". Modern philology, v. 22, n. 2 (novembro, 1924), p. 133-158.

WILLIAMS, Raymond. Marxism and literature. Oxford - Nova Iorque: Oxford University, 1977 (reimpr. 2009).

YOUNGSON, A. J. After the Forty-Five: the economic impact on the Scottish Highlands. Edimburgo: Edinburgh University, 1972. 